\title{
THE MECHANICS OF A STRONG EURO AREA
}

IMF Policy Analysis
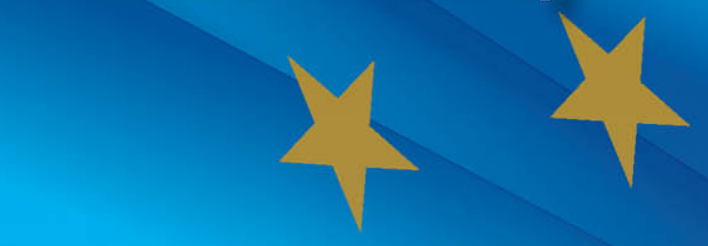

Editors
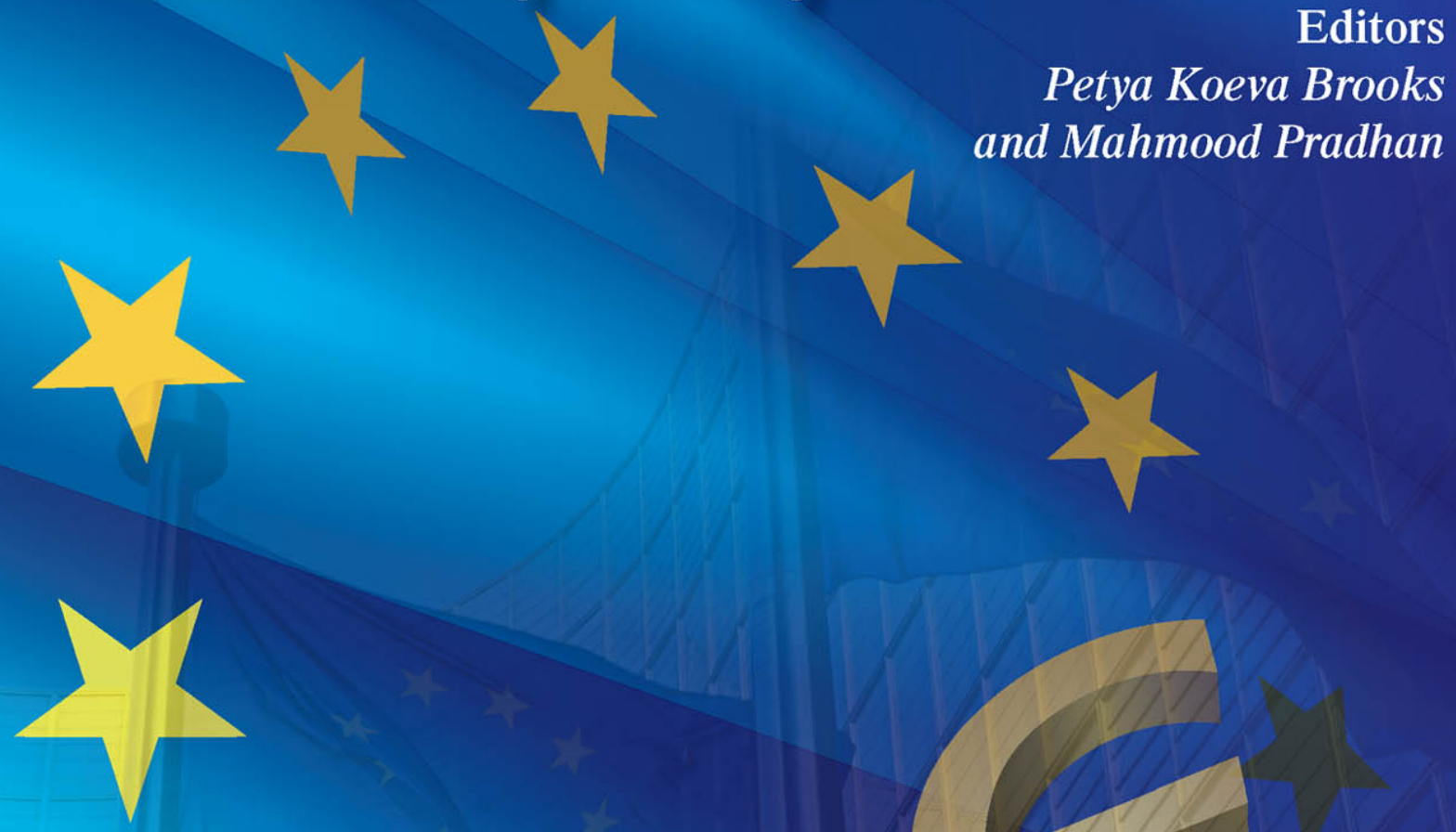

and Mahmood Pradhan
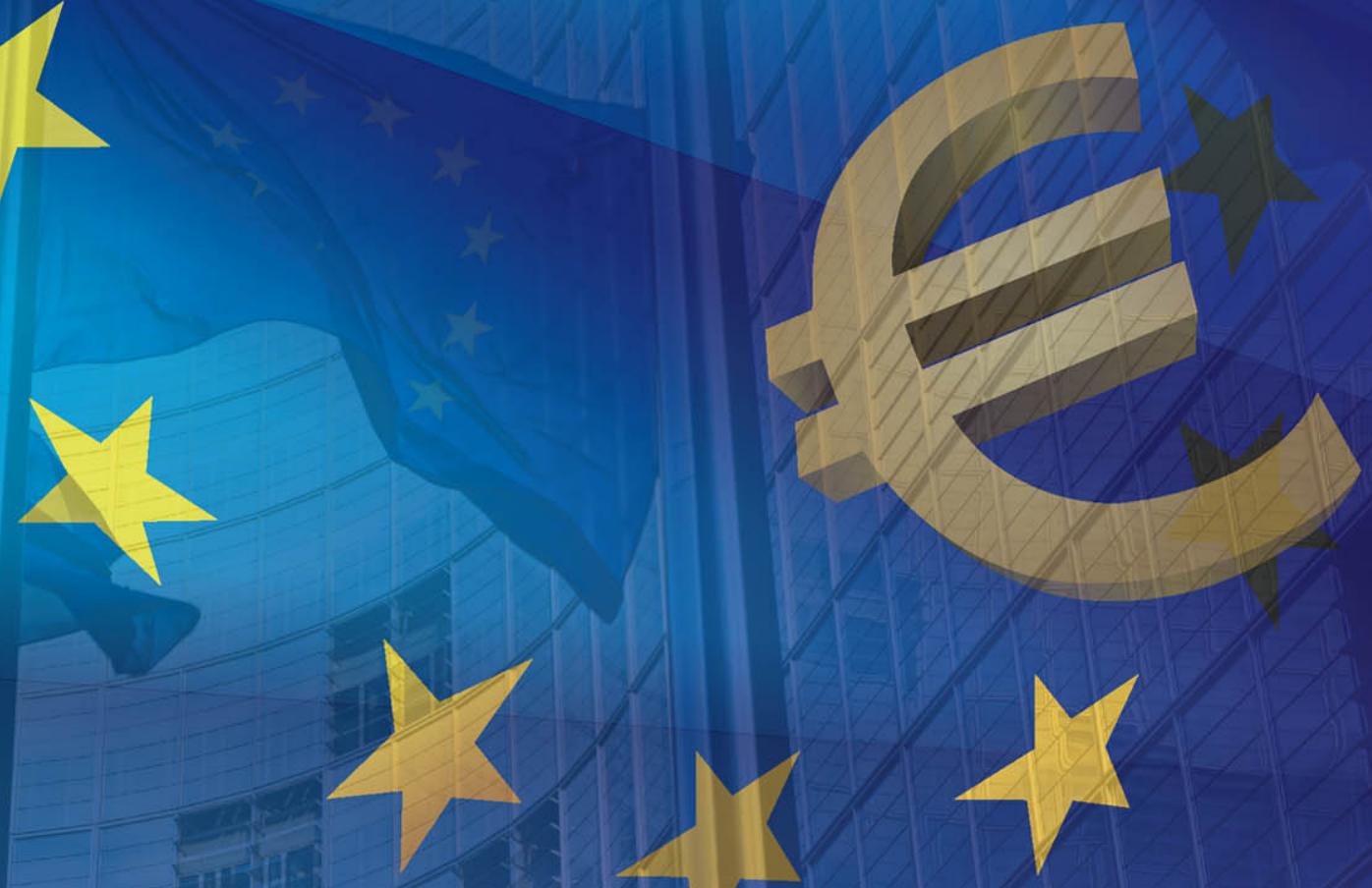

I N T E R N A T I O N A L M O N E T A R Y F U N D 


\section{THE MECHANICS OF A STRONG EURO AREA IMF Policy Analysis}

Editors

Petya Koeva Brooks

and Mahmood Pradhan

I N T E R N A T I O N A L M O N E T A R Y F U N D 
(C) 2015 International Monetary Fund

Cover design: IMF Multimedia Services Division

\section{Cataloging-in-Publication Data \\ Joint Bank-Fund Library}

The mechanics of a strong Euro area / editors: Petya Koeva Brooks and Mahmood Pradhan. Washington, D.C. : International Monetary Fund, 2015.

pages; $\mathrm{cm}$.

Includes bibliographical references and index.

ISBN 978-1-49830-553-2 (paper)

ISBN 978-1-51356-676-4 (ePub)

ISBN 978-1-51357-943-6 (Mobipocket)

ISBN 978-1-51357-224-6 (PDF)

1. Euro. 2. Monetary policy - European Economic Community countries. 3. Currency question - European Economic Community countries. 4. Global Financial Crisis, 2008-2009. I. Koeva, Petya. II, Pradhan, Mahmood, 1957- III. International Monetary Fund.

HG930.5.M43 2015

Disclaimer: The views expressed in this book are those of the authors and do not necessarily represent the views of the International Monetary Fund, its Executive Board, or management.

Please send orders to:

International Monetary Fund, Publication Services

P.O. Box 92780, Washington, DC 20090, U.S.A.

Tel.: (202) 623-7430 Fax: (202) 623-7201

E-mail: publications@imf.org

Internet: www.elibrary.imf.org

www.imfbookstore.org 


\section{Contents}

Foreword $\underline{v}$

Acknowledgments vii

Preface $\underline{i x}$

Contributors xiii

Abbreviations and Acronyms $\underline{x v i i}$

PART I THE LEGACIES OF THE CRISIS

1 Investment in the Euro Area: Why Has It Been Weak? $\underline{3}$ Bergljot Barkbu, S. Pelin Berkmen, Pavel Lukyantsau, Sergejs Saksonovs, and Hanni Schoelermann

2 Indebtedness and Deleveraging in the Euro Area $\underline{25}$ Fabian Bornhorst and Marta Ruiz-Arranz

3 Rebalancing: Where Do We Stand and Where to Go? .49 Thierry Tressel and Shengzu Wang

PART II I THE ROLE OF MONETARY POLICY AND THE FISCAL FRAMEWORK

4 Fragmentation, the Monetary Transmission Mechanism, and Monetary Policy in the Euro Area Ali Al-Eyd and S. Pelin Berkmen

5 Possible Subordination Effects of Eurosystem Bond Purchases $\underline{95}$ Nico Valckx, Kenichi Ueda, and Manmohan Singh

6 An Early Assessment of Quantitative Easing S. Pelin Berkmen and Andreas (Andy) Jobst

7 Fiscal Consolidation under the Stability and Growth Pact: Some Illustrative Simulations Derek Anderson, Marialuz Moreno Badia, Esther Perez Ruiz, Stephen Snudden, and Francis Vitek

8 Fiscal Governance in the Euro Area: Progress and Challenges. $\underline{149}$ Luc Eyraud and Tao Wu

PART III COMPLETING THE ECONOMIC AND MONETARY UNION (EMU)

9 A Banking Union for the Euro Area $\underline{173}$ Rishi Goyal, Petya Koeva Brooks, Mahmood Pradhan, Thierry Tressel, Giovanni Dell'Ariccia, Ross Leckow, and Ceyla Pazarbasioglu

10 Toward a Fiscal Union for the Euro Area IMF Staff Team Led By Céline Allard 
PART IV | THE ROLE OF STRUCTURAL POLICIES AT THE EURO AREA LEVEL

11 Capital Market Development: Financing of Small and Medium-Sized Enterprises in the Euro Area Ali Al-Eyd, Bergljot Barkbu, S. Pelin Berkmen, John Bluedorn, Andreas (Andy) Jobst, and Alexander Tieman

12 Youth Unemployment in Europe: Okun's Law and Beyond... $\underline{239}$ Angana Banerji, Huidan Lin, Sergejs Saksonovs, and Rodolphe Blavy

Index $\underline{259}$ 


\section{Foreword}

In line with its mandate, the International Monetary Fund has over the years been reviewing the design of and developments in the Economic and Monetary Union (EMU) in Europe. With the introduction of the euro as the single currency in 11 European Union member states at the beginning of 1999, the IMF faced the new challenge of having to conduct surveillance for a systemically important monetary union. It has addressed this situation by pursuing a dual-track approach: conducting a surveillance exercise of the euro area's policies that provides an adequate context for national Article IV consultations with the now 19 members of the euro area. Furthermore, with the introduction of the euro and the single monetary and exchange rate policy conducted by the European Central Bank (ECB), the bilateral relationship with the ECB has been reinforced, as reflected in the granting of IMF observer status to the ECB in 1998.

The ECB, the European Commission, and other European institutions and bodies responsible for policies falling within the purview of the IMF participate in regular consultations with Fund staff as part of the IMF's surveillance for the annual report on euro area policies. As such, the IMF is an important counterpart on macroeconomic, macro-financial, and macro-critical structural policy issues that are crucial to the functioning of the euro area as a whole and of its member states. The Fund has also given increased attention to further improvements to the institutional framework governing the euro area.

Following the global financial crisis in 2008, IMF surveillance of the euro area has been especially useful in the challenging environment facing the euro area. The subsequent euro area sovereign debt crisis added to the challenges the EMU had to cope with. In this more recent period, the Fund has significantly intensified its surveillance, including of the euro area and its constituent countries. It has responded to the shortcomings exposed by the crisis with new initiatives and a strengthening of practices in key areas, for example, with better analysis of spillovers, macrofinancial linkages, and risk assessment. In addressing the imperfections of the euro area governance framework as designed at the outset of the EMU, a shift from national toward more coordinated or centralized policymaking has been taking place. The Fund has actively made suggestions about how to reinforce the institutional architecture of the EMU, advocating in particular more financial and fiscal integration. This book presents a vivid example of Fund staff contributions of pertinent advice to euro area policymakers based on sound analytical underpinnings reflecting broad cross-country experiences.

Looking to the future, IMF surveillance of the euro area will inevitably adjust in light of strengthened EMU architecture. The main elements of a banking union have already been put in place, most notably the Single Supervisory Mechanism and the Single Resolution Mechanism. The recent Five Presidents' Report on Completing Europe's Economic and Monetary Union sets out various ideas for a further deepening of the EMU. Based on the experience of the past few years, as illustrated in this book, I have no doubt that the assessments and advice provided by Fund staff will continue to be highly appreciated by euro area policymakers as they strive toward a more complete EMU. 
This page intentionally left blank

CInternational Monetary Fund. Not for Redistribution 


\section{Acknowledgments}

This book is the product of a long period of collaboration among many departments at the IMF. In addition to numerous colleagues in the European Department, including our Director Poul Thomsen and his predecessor Reza Moghadam, we are extremely grateful to our colleagues in the Fiscal Affairs Department; the Legal Department; the Monetary and Capital Markets Department; the Research Department; and the Strategy, Policy, and Review Department. All these departments have played an active role not only in reviewing the chapters in this volume, but also as energetic participants in the policy discussions at the Fund that have ultimately shaped the agenda for the annual Article IV consultations with the euro area institutions. Many of our colleagues worked very closely with us and are authors of some of the chapters in this volume.

We are also extremely grateful to numerous officials - certainly way too many to mention individually here-in Europe. During the past four years we have benefited from extensive discussions on all of the topics covered here with officials at the European Commission, the European Central Bank, the European Stability Mechanism, the European Investment Bank, and the European Banking Authority. They have all been exceptionally generous with their time and, without assigning any responsibility, their detailed comments have undoubtedly improved all of the chapters herein. 
This page intentionally left blank

CInternational Monetary Fund. Not for Redistribution 


\section{Preface}

The euro area has experienced an unprecedented economic downturn and exceptional financial market turmoil in the past few years. Policymakers have faced the twin challenge of addressing cyclical economic weakness - not unlike other industrial countries following the global economic crisis - and the underlying weaknesses in the architecture of the currency union, weaknesses that appear to have been masked during the first relatively calm years of the Economic and Monetary Union (EMU). Among member states, many structural weaknesses were exposed when economic performance declined significantly and financial markets became more discerning.

It would be an understatement to say euro area policymakers have been busy addressing these challenges. Demand support in response to the pervasive weakness throughout the region has necessarily relied heavily on monetary accommodation given the constraints of the Stability and Growth Pact (SGP), including the need to balance growth and debt stability objectives in some countries. At the same time, the euro area has embarked on fundamental changes in its financial and economic architecture, such as the Banking Union, a much stronger and clearer bail-in mechanism for resolution of banks, and more centralized supervision of banks at the European Central Bank (ECB) under the Single Supervisory Mechanism.

Much has been done, yet important concerns linger. Unemployment, especially among the young, is still stubbornly and unacceptably high, posing the risk of a lost generation. Debt levels — both public and private-remain elevated. Capital markets have become more fragmented as cross-border flows have declined and banks have become more national. The impact of these reversals of trends toward more integration has been felt particularly in the small and mediumsized enterprise (SME) sector, where borrowing rates remain too high in some countries and credit flows too weak. Very low inflation is a worrying sign of the anemic recovery. It signals stillsubstantial slack in the euro area, and complicates the task of reducing debt and unemployment. And persistently low investment and high unemployment threaten the long-term productive capacity of the euro area economy.

A strong and sustained recovery is needed to repair the damage from the crisis. Because many factors are weighing on growth, no single action can address its revitalization. Instead, reviving growth requires complementary policy actions to (1) support demand (by undertaking monetary policy measures and pacing fiscal adjustment while preserving the integrity of the SGP), (2) make more progress on EMU architecture (by repairing bank balance sheets and advancing and consolidating the banking union agenda), and (3) boost trend growth and foster rebalancing (by implementing structural policies).

This book focuses on the analytical underpinnings of real-time policy advice given to euro area policymakers during four cycles of the IMF's annual Article IV consultations (2012-15) with euro area authorities. The papers in this collection are part of the background analysis for the IMF's policy perspectives on the euro area. They are presented here in their original form (many of these were published as "Selected Issues Papers" supporting the "Staff Reports" of the Article IV consultations during 2012 to 2015, while some were published as "Staff Discussion Notes"). The book does not cover some important policy developments since July 2014. In particular, it does not assess the Bank Recovery and Resolution Directive, and some of the recent changes in the Stability and Growth Pact. 
The first section of the book examines the legacies for the euro area of the crisis: low investment, high debt, and external imbalances. Chapter 1 analyzes the behavior of private investment, which fell substantially during the crisis and has remained subdued since. What does low private investment portend for economic recovery? The analysis here provides firm evidence that low growth is integral to the story. But in some countries, high corporate leverage, policy uncertainty, and financial constraints are also holding back investment. These factors highlight the role of banks, and their health, given the heavy reliance on bank financing in the euro area.

Public and private debt levels in the euro area rose to unprecedented levels in some countries during the crisis. This debt overhang has undoubtedly added to deleveraging pressures both in the public sector and in the private sector. But it could also be weighing on growth, even though aggregate public debt for the euro area as a whole compares favorably with that of other large industrial countries. Chapter 2 establishes that high private and public sector debt is restraining growth in the euro area. It argues that simultaneous deleveraging across all sectors is unique to the euro area when compared with other deleveraging episodes in many industrial countries, and represents a significant challenge. And negative feedback loops between high debt and a weak financial sector are exacerbating the constraints on economic growth and credit conditions.

In an environment of much lower cross-border capital flows, large internal imbalances of member states vis-à-vis other member states have become external imbalances, necessitating policy adjustments and relative price changes within the euro area. Chapter 3 finds that relative price adjustments and current account improvements are taking place. Although exports have rebounded, slumping internal demand (and imports) accounts for much of the reduction in current account deficits in debtor countries. This trend has not been matched by stronger demand and narrower current account surpluses in creditor countries. Thus the current account balance of the euro area as a whole has shifted from deficit to surplus, and internal rebalancing has been accompanied by subdued activity, notably very high unemployment in the deficit economies, contributing to a more painful adjustment.

The second section of the book turns to the role of macroeconomic policies in supporting the recovery. Starting with monetary policy, Chapter $\mathbf{4}$ illustrates that despite important actions by the ECB, fragmented financial markets, particularly banking systems, along national borders led to substantially higher interest rates for borrowers in stressed markets-far above those in the core. The analysis shows that the credit channel was impaired during the crisis particularly in stressed markets, and that SMEs in hard-hit economies appear to be most affected. Given these stresses, the authors argue that the ECB can undertake additional targeted policy measures, including through various forms of term funding, looser collateral policies, and direct asset purchases. These actions would relieve funding constraints on banks and should, in principle, cause ECB monetary policy to have a more uniform impact across the region.

The ECB's quantitative easing efforts under the Securities Markets Program raised occasional market concerns about private holders of sovereign being subordinated, and may have reduced the impact of the program on sovereign borrowing costs. Chapter 5 looks at various ways-both empirical and theoretical - to quantify the extent of subordination arising from ECB debt purchases in some countries. The main finding is that the impact of ECB seniority is primarily related to the perceived probability of default and the proportion of outstanding debt already in the hands of the central bank.

Despite substantial monetary accommodation, by December 2014 euro area inflation had been falling for 17 months, and 12 out of 18 countries in the common currency area were in the grip 
of deflation. The ECB had already lowered interest rates to zero and introduced various unconventional policies such as private asset purchases and very cheap funding for banks. The ECB's expanded asset purchase program (announced in January 2015), to include sovereign assets, was larger and more open ended than markets had anticipated. Chapter $\mathbf{6}$ assesses this program and compares it with quantitative easing in other industrial countries-Japan, the United Kingdom, and the United States. Its findings are encouraging. In Europe, quantitative easing has had a stronger initial impact on term premiums and other asset prices than it has elsewhere, and it has been particularly successful in arresting the decline in inflation expectations. The experience of other countries also shows that the impact on bank lending, and on the real economy, typically takes longer to materialize.

Turning to fiscal policy, Chapter 7 assesses the pace of consolidation driven by the SGP, particularly whether it is appropriate in the face of an extremely weak economic environment. It quantifies the output effects from fiscal consolidation implied by the SGP and illustrates that multipliers are likely to be larger than normal (given negative output gaps, joint consolidation efforts, and monetary policy constraints). This outcome suggests that, while preserving its integrity, SGP rules should be applied more flexibly to accommodate unexpected events, and that where financing conditions permit, the pace of fiscal consolidation should take into account the adverse economic conditions.

Looking beyond the crisis, Chapter 8 contributes to the discussion on fiscal governance in Europe. Despite recent improvements, the European fiscal governance system faces a number of challenges. The remaining gaps are most apparent in the complex design of fiscal rules and their poor enforcement mechanisms. Given that public debt is approaching unsafe territory in several member states, the fiscal framework has a key role to play in putting public finances back on a sound footing. In this context, the authors take stock of recent reforms; identify areas for further progress; and examine a menu of policy options for making the fiscal governance framework simpler, more transparent, and more robust in the medium term.

The third section of the book discusses the importance of completing the EMU architecture-by moving toward a banking union and greater fiscal integration. Chapter 9 discusses how a banking union will help end the adverse downward spirals between sovereigns, banks, and the real economy. The interconnection between sovereigns and banks is also the underlying reason for the marked financial fragmentation in the euro area, which has resulted in the vastly uneven impact of monetary policy across the area. It argues that a banking union-comprising a single supervisory and regulatory framework, single resolution mechanism, and common safety net-for the euro area is the logical conclusion of the idea that integrated banking systems require integrated prudential oversight. The case for a banking union for the euro area is both immediate and longer term. Moving responsibility for potential financial support and bank supervision to a shared level can reduce financial market fragmentation, stem deposit flight, and weaken the vicious loop of rising sovereign and bank borrowing costs. A single framework should bring about a uniformly high standard of confidence and oversight, reduce national distortions, and mitigate the buildup of concentrated risk that compromises systemic stability.

The euro area crisis exposed a critical gap in the economic architecture of the EMU: the capacity for country-level shocks, whether exogenous or home grown, to spread across the euro area, calling into question the viability of the common currency. The European Union's fiscal governance framework — centered around the SGP — is designed to address fiscal discipline in member states, but it cannot deal with economic shocks that become pervasive across the region. Chapter $\mathbf{1 0}$ explores the role that deeper fiscal integration can play in correcting these architectural weaknesses in the

\section{CInternational Monetary Fund. Not for Redistribution}


system, to reduce the incidence and severity of future crises and lend long-term credibility to the crisis measures in progress. The chapter argues that a clearer ex ante approach to fiscal discipline and transfers will further strengthen the architecture of EMU, ensuring the stability of the euro area.

The final two chapters focus on two structural challenges for the euro area: developing capital markets and tackling youth unemployment. Overcoming these structural problems would ensure that the long-term productive capacity of the economy is not permanently impaired. Chapter $\mathbf{1 1}$ assesses the structure of private capital markets in the euro area, their role in financing growth, and prospects and policies for further development, at both the national and the euro area levels. It explores the potential for reducing the excessive dependence of SMEs on banks and expanding direct access to capital markets, particularly through securitization. More capital market finance for firms and households would, in principle, make the real economy more resilient to the travails of the banking system.

Chapter 12 delves into explanations for the extraordinarily high youth unemployment rate, especially in comparison with adult workers. Can these youth unemployment rates be explained simply by the extent of the economic downturn, or are other institutional factors at work? Cyclical weakness explains much of the increase in youth unemployment, but it also masks institutional and structural rigidities that reduce the incentives for firms to hire young people. The chapter discusses policy initiatives both in individual member states and at the euro area levelactive labor market policies such as more training and the use of tax policies and more flexible labor contracts - that could help increase youth employment and reduce the risk of a much more permanent decline in the productive capacity of the many member states in which this problem is particularly acute.

Petya Koeva Brooks and Mahmood Pradhan 


\section{Contributors}

\section{EDITORS}

Petya Koeva Brooks is Assistant Director in the IMF's European Department and the mission chief for Italy. She was previously in charge of the unit responsible for euro area surveillance (2012-14), and the World Economic Studies division in the Research Department that produces the IMF's flagship publication, the World Economic Outlook (2009-12).

Mahmood Pradhan is Deputy Director in the European Department at the IMF and mission chief for the euro area since 2011. He was earlier a senior advisor in the Asia Pacific Department and mission chief for Japan. Mr. Pradhan has previously worked at the Bank of England and in the private financial sector as a fund manager.

\section{AUTHORS}

Ali Al-Eyd is a Deputy Division Chief in the IMF's Monetary and Capital Markets Department. He was previously a senior economist covering euro area surveillance in the European Department (2012-14), and was also in the Middle East and Central Asia Department (2009-12). Prior to joining the IMF, he held positions in London with Citigroup and Dresdner Kleinwort Investment Bank.

Céline Allard heads the Regional Studies Division in the IMF's African Department, where she oversees the publication of the semiannual Regional Economic Outlook for Sub-Saharan Africa. She was previously deputy division chief in the unit responsible for euro area surveillance in the European Department (2010-14) and before that worked on a number of advanced, transition, and low-income economies at the IMF.

Derek Anderson is a graduate student at the University of Virginia in the department of Systems and Information Engineering. He holds a master's degree in economics and worked in the Economic Modeling Division at the IMF for four years, participating in development and production work for various models employed by the division.

Angana Banerji is a Senior Economist in the IMF's European Department. She was previously a lead evaluator in the IMF's Independent Evaluation Office (2009-13), participating in the evaluation of the IMF's performance in the run-up to the global financial crisis. Prior to that, she was the IMF's mission chief for Cyprus, Netherlands Antilles, and San Marino.

Bergljot Barkbu is the IMF's Deputy Resident Representative to the European Union. She previously worked on Italy and Ireland in the IMF's European Department and has also held positions in the Strategy and Policy Review Department, working on crisis cases, debt sustainability, and IMF lending facilities.

S. Pelin Berkmen is a Senior Economist in the Advanced Economies Unit of the European Department. Her research has focused on a range of international macroeconomic and financial policy issues. She has worked on a wide set of countries and regions, including the euro area, Japan, and Argentina. 
Rodolphe Blavy is currently Deputy Director of the European Offices of the IMF. Since 2001, as desk economist, he covered key policy issues for emerging markets, in particular related to macrofinancial linkages, and has been involved in the negotiation and monitoring of IMFsupported programs. In the context of the crisis, he joined the Strategy Unit, a group instrumental in recent IMF reforms. He read doctoral studies at Cambridge University and is a graduate of Sciences Po in Paris and ESSEC Business School.

John Bluedorn is a Senior Economist in the Advanced Economies Unit of the European Department. He joined the IMF in 2010, working in the Research Department's World Economic Studies Division on the World Economic Outlook (2010-14). Prior to joining the IMF, he was a postdoctoral research fellow at the University of Oxford and a professor at the University of Southampton in the United Kingdom. He holds a Ph.D. in economics from the University of California, Berkeley.

Fabian Bornhorst is the IMF's Resident Representative to Brazil and to Bolivia. He was previously senior economist in the European Department (2011-14), working in the Advanced Economies Unit covering the euro area and Germany.

Giovanni Dell'Ariccia is Assistant Director in the Research Department of the IMF, where he coordinates the activities of the Macro-Financial Division. Previously, he worked in the Asia and Pacific Department on the Thailand, Singapore, and Hong Kong desks. He received a Ph.D. from the Massachusetts Institute of Technology and a Laurea (summa cum laude) in economics and statistics from the University of Rome. He is a CEPR Research Fellow. His papers have been published in several major economics and finance journals.

Luc Eyraud is a Senior Economist in the IMF's Western Hemisphere Department. He worked previously in the IMF Fiscal Affairs Department and at the French Treasury.

Rishi Goyal is the Mission Chief for Greece and head of the Southern 4 Unit in the IMF's European Department. He was previously the deputy in the unit responsible for euro area surveillance (2012-13), leading a project on the banking union. Prior to that, he was deputy in the Strategy Unit of the IMF's Strategy, Policy, and Review Department, working on the IMF's spillover reports (2008-12).

Andreas (Andy) Jobst is Senior Economist in the IMF's European Department, where he covers the financial sector, monetary policy, and macroprudential surveillance for the euro area. Previously, he spent three years as chief economist and deputy director at the Bermuda Monetary Authority after having worked on the Global Financial Stability Report (2005-11).

Ross Leckow is Deputy General Counsel in the IMF Legal Department. A national of Canada, he has extensive experience in the IMF's regulatory and financial operations and currently leads the work of IMF lawyers on issues of financial sector law reform in member countries. He has also contributed to the IMF's efforts to develop an international legal framework for the resolution of cross-border financial institutions. Before joining the IMF in 1990, Mr. Leckow practiced law in the private and public sectors in Canada.

Huidan Lin is an Economist in the unit responsible for euro area surveillance in IMF's European Department. She previously worked on Portugal (2012-14), on Korea in the Asia and Pacific Department (2010-12), and in the General Resources and SDR Policy Division of the Finance Department (2009-10).

Pavel Lukyantsau is a Research Officer in the IMF's Monetary and Capital Markets Department. Previously, he was a research analyst in the Advanced Economies division (at the European Department), which is involved in euro area surveillance. 
Marialuz Moreno Badia is Deputy Division Chief at the Fiscal Affairs Department, where she is coordinating the work on developing economies. Prior to this assignment, she led the team producing the Fiscal Monitor. Her country work experience includes a broad range of advanced and emerging economies such as Brazil, Greece, Ireland, and Spain.

Ceyla Pazarbasioglu was a Deputy Director in the IMF Monetary and Capital Markets Department, where she was in charge of the work on financial sector oversight and crisis management. She managed the IMF's work on the global regulatory reform agenda and its implementation in member countries, and led the Financial Sector Assessment Programs for the United Kingdom (2011) and Spain (2012). She represented the IMF at the Financial Stability Board Resolution Steering Group and World Economic Forum Global Agenda Council on Global Financial Systems. She holds a Ph.D. in economics from Georgetown University.

Esther Pérez Ruiz is a Senior Economist in the IMF's European Department and desk for France. Since she joined the IMF in 2009, she has worked on Greece, Advanced Economies, and France. She was previously a policy analyst at the European Commission (2006-09). Prior to this post, she was advisor to the central government at the Spanish Ministry of Economy and Finance (2002-06).

Marta Ruiz-Arranz is Deputy Division Chief in the IMF's Fiscal Affairs Department. She coordinates the work of the Fiscal Monitor, an IMF flagship publication. Previously, she held positions in the IMF's European and Asia-Pacific Departments.

Sergejs Saksonovs is an Economist in the IMF's European Department. He has worked in the unit responsible for euro area surveillance since 2012, focusing primarily on structural reform, unemployment, and the macroeconomic outlook. He previously worked in the structural reform area on Belarus.

Hanni Schoelermann is an Economist at the IMF Europe Office in Brussels. Prior to joining the IMF, she worked at the Directorate-General International and European Relations of the European Central Bank. She holds a first degree in economics from the University of London and a master's degree in public policy from the Hertie School of Governance in Berlin.

Manmohan Singh is a Senior Economist in the IMF's Monetary and Capital Markets Department. He has written extensively on rehypothecation of collateral, collateral velocity, shadow banking, deleveraging in financial markets, and counterparty risk in OTC derivatives market. He recently published a book, Collateral and Financial Plumbing. He has also worked on several countries, including Chile, Japan, India, the United States, the United Kingdom, Argentina, Kazakhstan, and the United Arab Emirates. Mr. Singh holds a Ph.D., and an MBA from the University of Illinois at Urbana-Champaign, and a B.S. from Allegheny College.

Stephen Snudden is a Project Officer in the IMF's Research Department Economic Modeling Unit, where he develops and applies macroeconomic policy models. He held a similar position in the International Department of the Bank of Canada (2008-10). He is pursuing a Ph.D. in economics at Queen's University in Kingston, Ontario.

Alexander Tieman is a Senior Economist in the IMF's European Department. He covers Turkey and is mission chief for San Marino. Previously, Mr. Tieman worked on financial sector issues and stress testing in the IMF's Monetary and Capital Markets Department and headed the IMF office in Skopje, Macedonia.

Thierry Tressel is a Lead Economist and Task Leader for the Global Financial Development Report at the World Bank. He was previously a senior economist on the euro area in the IMF's European Department (2011-14) and also worked in the IMF's Research Department (2004-10). 
Kenichi Ueda is an Associate Professor at the Faculty of Economics, The University of Tokyo. His research focuses on linkages between financial systems and macroeconomic activities. His research papers have been published in leading academic journals, including the Review of Economic Studies and the Journal of Economic Theory. Until 2014, he worked for the IMF for 14 years, mostly in the Research Department. He also held a visiting position at the Economics Department of the Massachusetts Institute of Technology (2011-12). He obtained his Ph.D. in economics from the University of Chicago in 2000. Prior to this, he worked at the Ministry of Finance, Japan, after obtaining a B.A. in economics from the University of Tokyo.

Nico Valckx is a Senior Economist in the IMF's Monetary and Capital Markets Department, where he focuses on structural financial sector developments. Previously, he worked on euro area monetary and financial sector policies in the IMF's European Department, and in Financial Stability and Research Departments at the European Central Bank, De Nederlandsche Bank, and the Bank of Finland.

Francis Vitek is an Economist in the IMF's Monetary and Capital Markets Department. He is a global macrofinancial modeling expert and has contributed scenario analysis to many IMF surveillance products. He formerly served in the Strategy, Policy, and Review Department (200914) and in the Asia and Pacific Department (2007-09).

Shengzu Wang is currently a Vice President and China Economist at Barclays Capital Asia, based in Hong Kong. He was previously an economist in the IMF's European Department, covering the euro area and Greece. Since joining the IMF in 2009, he has also worked on economic surveillance and lending programs on a variety of advanced and emerging market economies in Asia and Africa.

Tao Wu is a Senior Economist in the Advanced Economies unit in IMF's European Department. Previously, he worked on U.S. monetary policy and financial market in the IMF's Western Hemisphere Department, as well as the IMF Institute, where he was responsible for economic policy training in Asian countries. Prior to joining the IMF in 2010, he worked as a policy advisor for the U.S. Federal Reserve, where he was responsible for analyzing the U.S. economy and global financial market, and providing policy recommendations. 


\section{Abbreviations and Acronyms}

\begin{tabular}{|c|c|}
\hline $\mathrm{ABCP}$ & asset-backed commercial paper \\
\hline ABS & asset-backed securities \\
\hline ABSGS & Asset-backed Securities Guarantee Scheme \\
\hline ACC & additional credit claim \\
\hline ALMPs & active labor market policies \\
\hline AMC & asset management company \\
\hline AMECO & Annual Microeconomic (database) \\
\hline $\mathrm{BdF}$ & Banque de France \\
\hline BIS & Bank for International Settlements \\
\hline BoJ & Bank of Japan \\
\hline BRRD & Bank Resolution and Recovery Directive \\
\hline CAPB & cyclically adjusted primary balance \\
\hline $\mathrm{CDO}$ & collateralized debt obligation \\
\hline CDS & credit default swap \\
\hline CMBS & commercial mortgage-backed securities \\
\hline CPI & consumer price index \\
\hline CRR & Capital Requirements Regulation \\
\hline CRR/CRD IV & Capital Requirements Regulation/Capital Requirements Directive IV \\
\hline EA11 & $\begin{array}{l}\text { Austria, Belgium, Finland, France, Germany, Ireland, Italy, Luxembourg, } \\
\text { Netherlands, Portugal, Spain }\end{array}$ \\
\hline EA12 & $\begin{array}{l}\text { Austria, Belgium, Finland, France, Germany, Greece, Ireland, Italy, } \\
\text { Luxembourg, Netherlands, Portugal, Spain }\end{array}$ \\
\hline EA17 & $\begin{array}{l}\text { Austria, Belgium, Cyprus, Estonia, Finland, France, Germany, Greece, } \\
\text { Ireland, Italy, Luxembourg, Malta, Netherlands, Portugal, Slovak Republic, } \\
\text { Slovenia, Spain }\end{array}$ \\
\hline EA18 & $\begin{array}{l}\text { Austria, Belgium, Cyprus, Estonia, Finland, France, Germany, Greece, } \\
\text { Ireland, Italy, Latvia, Luxembourg, Malta, Netherlands, Portugal, Slovak } \\
\text { Republic, Slovenia, Spain }\end{array}$ \\
\hline EBA & European Banking Authority \\
\hline ECB & European Central Bank \\
\hline ECJ & European Court of Justice \\
\hline EDP & Excessive Deficit Procedure \\
\hline EFSF & European Financial Stability Facility \\
\hline EIB & European Investment Bank \\
\hline EIF & European Investment Fund \\
\hline ELA & emergency liquidity assistance \\
\hline EMU & Economic and Monetary Union \\
\hline EONIA & Euro OverNight Index Average \\
\hline EPL & employment protection legislation \\
\hline ESFS & European System of Financial Supervisors \\
\hline ESM & European Stability Mechanism \\
\hline ESRB & European Systemic Risk Board \\
\hline EU & European Union \\
\hline Euribor & Euro Interbank Offered Rate \\
\hline
\end{tabular}


EU15

EU27

FDIC

FLS

FTPYME

GDP

GIMF

HD

HQLA

HQS

IMF

ISO

KfW

LCR

LD

LGD

LOLR

LSDV

LTRO

MFF

MTO

NCA

NFA

NFC

NPL

OECD

OMT

PD

PROMISE

PSI

REER

RMBS

RoE

SAFE

SBA

SGP

SLS

SME

SMP

SPV

SSM

TFEU

TSI

ULC

VECM

WEO
Austria, Belgium, Denmark, Finland, France, Germany, Greece, Ireland, Italy, Luxembourg, Netherlands, Portugal, Spain, Sweden, United Kingdom Austria, Belgium, Bulgaria, Cyprus, Czech Republic, Denmark, Estonia, Finland, France, Germany, Greece, Hungary, Ireland, Italy, Latvia, Lithuania, Luxembourg, Malta, Netherlands, Poland, Portugal, Romania, Slovak Republic, Slovenia, Spain, Sweden, United Kingdom

Federal Deposit Insurance Corporation

Funding for Lending Scheme

Fondos de Titulización de Activos para Pymes

gross domestic product

Global Integrated Monetary and Fiscal model

high debt

high-quality, liquid assets

high-quality securitization

International Monetary Fund

International Organization for Standardization

Kreditanstalt für Wiederaufbau

liquidity coverage ratio

low debt

loss given default

lender of last resort

least squares dummy variable

Long-Term Refinancing Operation

Multiannual Financial Framework

medium-term objective

national competent authority

net foreign asset

nonfinancial corporation

nonperforming loan

Organisation for Economic Co-operation and Development

Outright Monetary Transactions

probability of default

Programme for Mittelstand-loan Securitisation

private sector involvement

real effective exchange rate

residential mortgage-backed securities

return on equity

Survey on the Access to Finance of Enterprises in the Euro Area

Small Business Administration

Stability and Growth Pact

Special Liquidity Scheme

small and medium-sized enterprise

Securities Markets Program

special purpose vehicle

single supervisory mechanism

Treaty on the Functioning of the European Union

True Sale International

unit labor cost

vector error correction model

World Economic Outlook 


\section{The Legacies of the Crisis}


This page intentionally left blank

CInternational Monetary Fund. Not for Redistribution 


\title{
Investment in the Euro Area: Why Has It Been Weak?
}

\author{
Bergljot Barkbu, S. Pelin Berkmen, Pavel lukyantsau, \\ SeRGeJs SaKsonovs, and HanNi SCHOEleRmanN
}

Investment across the euro area — both in real terms and as a percentage of GDP—remains below its precrisis level. Investment performance has been weaker than in most previous recessions and financial crises. IMF staff analysis shows that much of this weakness can be explained by output dynamics, although a high cost of capital, financial constraints, high corporate leverage, and uncertainty have also inhibited investment in parts of the euro area. Investment is expected to pick up as the recovery strengthens and uncertainty declines. However, financial fragmentation and high corporate leverage in some countries will likely continue to weigh on investment.

\section{INVESTMENT IN THE EURO AREA: POSTCRISIS TRENDS}

Investment has been hit hard since the onset of the global economic and financial crisis. It has not recovered since, including in many of the core economies. Total real investment remains below its precrisis level across the euro area. ${ }^{1}$ Part of this decline reflects reductions in public investment and in investment in housing in certain countries. For example, housing investment declined from about 12-13 percent of GDP before the crisis to 6 percent of GDP in Spain and to 2-3 percent of GDP in Greece and Ireland after the crisis. Similarly, following the sovereign debt crisis, both public investment and private nonresidential investment remain well below their precrisis levels in most of the euro area, particularly in stressed countries (Figures 1.1 and 1.2). ${ }^{2}$

Overall, the behavior of investment and its determinants has varied widely across the euro area. Stressed countries have suffered more than core countries. Small and medium-sized enterprises have suffered more than larger corporations. And the services sector has suffered substantially.

Weak investment performance is associated with weak aggregate demand. Real GDP in the euro area remains below its precrisis level and is more sluggish than in typical recessions (panel 1 of Figure 1.3). Although the recovery is gaining momentum, domestic demand growth is still

\footnotetext{
This chapter is based on Euro Area Policies: Article IV 2014 Consultation-Selected Issues, "Investment in the Euro Area: Why Has It Been Weak?” IMF Country Report 14/199, 2014, and the IMF Working Paper 15/32 of the same title, 2015. The authors are grateful for the comments provided by Philip Vermeulen and other participants at the European Central Bank seminar, as well as the European Commission staff.

${ }^{1}$ Investment as a percentage of GDP remains below its precrisis long-term (1995-2007) level, particularly for stressed countries.

${ }^{2}$ For the figures and regressions in this chapter, private nonresidential investment data are obtained from Eurostat to ensure consistency and comparability across countries. Other data sources also show weak investment dynamics. For example, real fixed investment in equipment in Germany and real investment by nonfinancial corporations (NFCs) in France, and equipment and transportation machinery investment in the euro area are also weaker than their precrisis levels. Stressed countries refer to debtor countries who have experienced high funding costs (public and private) and suffered from financial fragmentation during the period covered.
} 
fragile, and the output gap for the euro area is still negative and large. Given subdued aggregate demand, it is not surprising that investment has also lagged behind the trends observed in most previous recessions (panel 2 of Figure 1.3). Indeed, investment growth is still lower than real GDP growth in the euro area, unlike in the recovery in the United States (Figure 1.4).

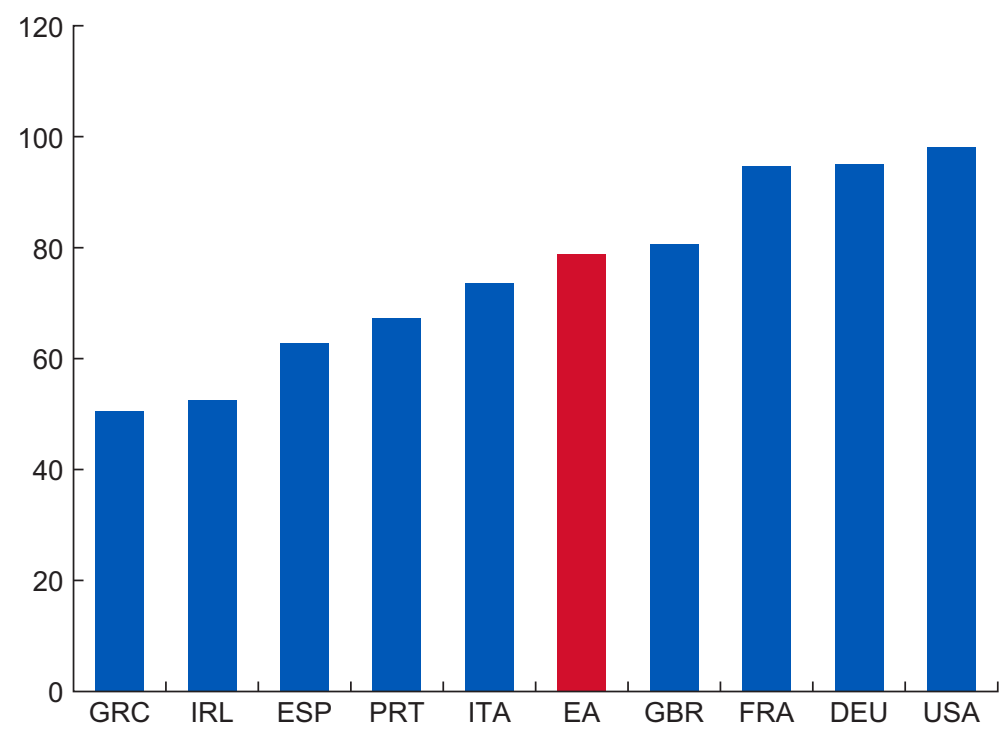

Sources: Eurostat; Haver Analytics; and IMF staff calculations.

Note: $E A=$ Euro area. Data labels in the figure use International Organization for Standardization (ISO) country codes.

Figure 1.1 Investment Recovery to Date: 2013:Q4 (Percent; 2007 quarterly average $=100$ )

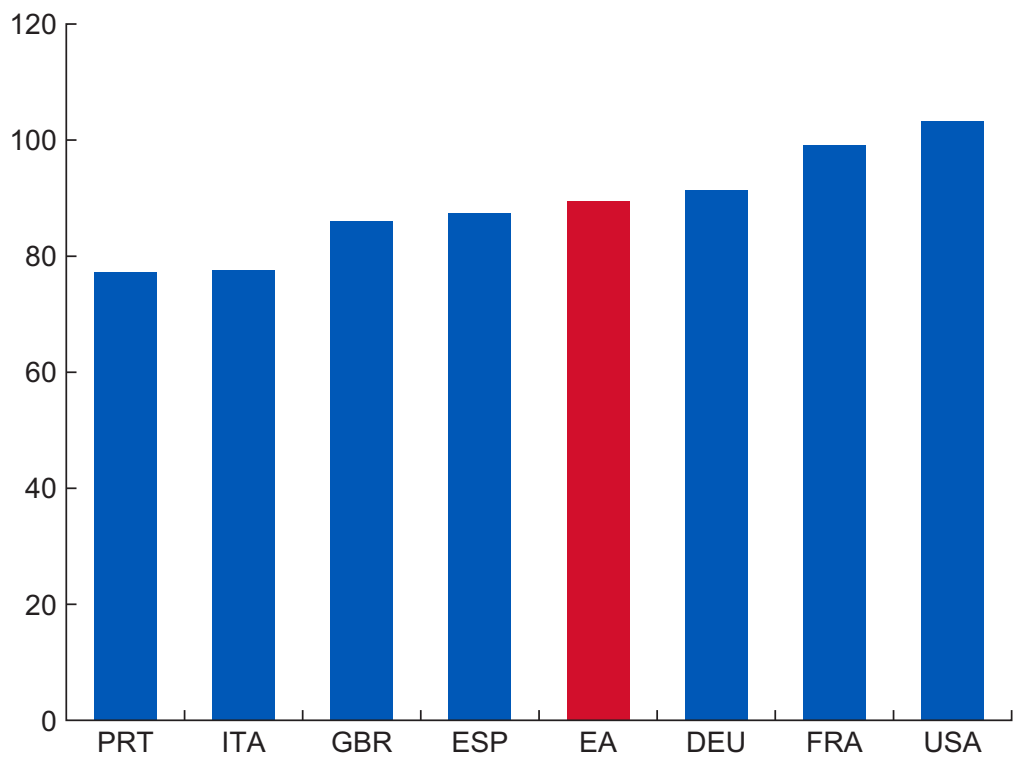

Sources: Eurostat; and IMF staff calculations.

Note: Last available data point is 2013:Q3 for PRT and 2012:Q4 for DEU. EA = Euro area. Data labels in the figure use International Organization for Standardization (ISO) country codes.

Figure 1.2 Private Nonresidential Investment Recovery through 2013:Q4 (Percent; 2007 quarterly average $=100$ ) 

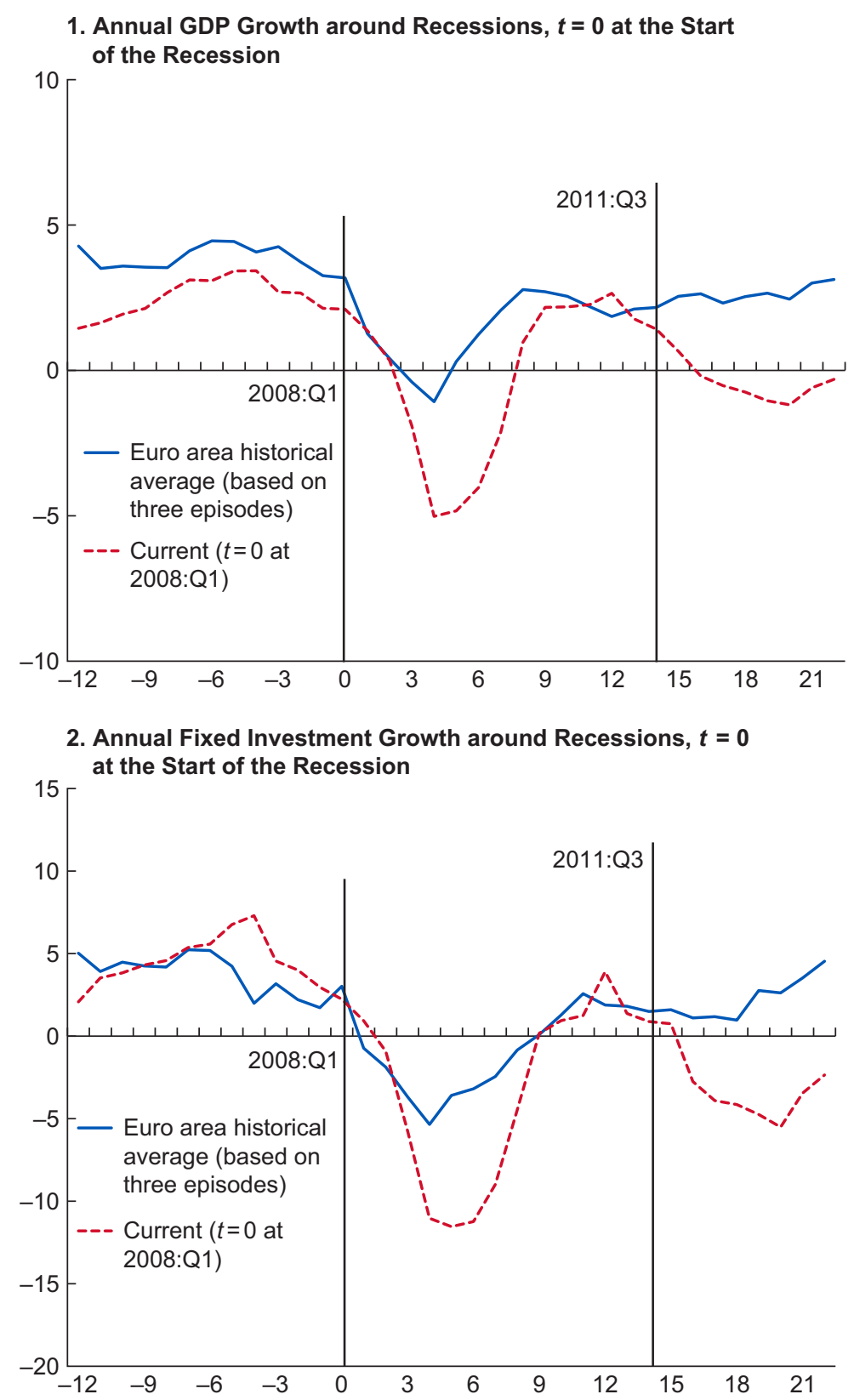

Sources: Eurostat; Organisation for Economic Co-operation and Development; and IMF staff calculations. Note: Quarterly data and year-over-year changes. $t=0$ at 2008:Q1; the second line starts from 2011:Q3 ( $t=15)$ to indicate the back-to-back recessions in the euro area; historical episodes are based on CEPR-dated recessions: 1974:Q3 to 1975:Q1, 1980:Q1 to 1982:Q3, and 1992:Q1 to 1993:Q3. CEPR = Centre for Economic Policy Research.

Figure 1.3 GDP Growth and Investment around Recessions

In addition, financial crises tend to have durable effects on investment, reflecting credit supply constraints, balance sheet problems, and other supply-side factors. Previous experience with financial crises shows that the decline in the investment-to-GDP ratio could be long lasting, with a peak impact of 3 to $3 \frac{1}{2}$ percentage points three years after the crisis (IMF 2014a). 


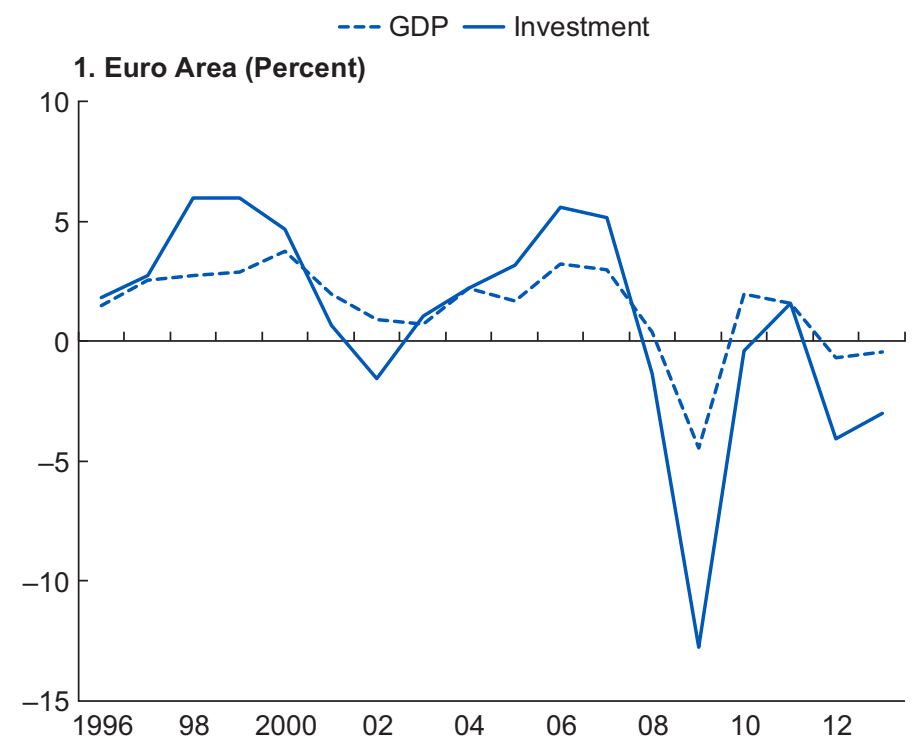

\section{United States (Percent)}

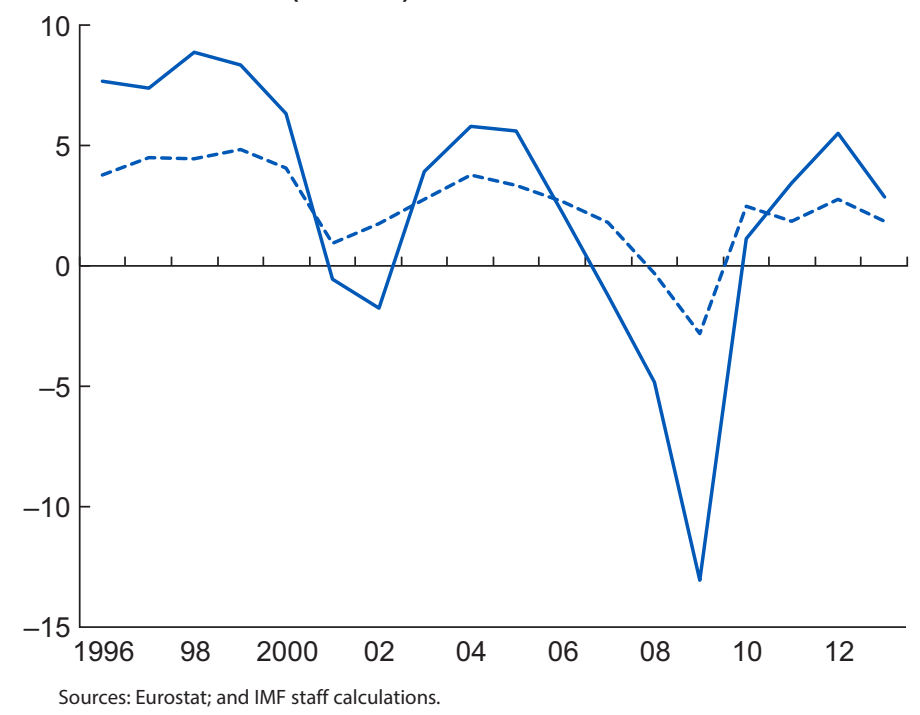

Figure 1.4 GDP and Investment Growth in the Euro Area and the United States

In the euro area, the observed decline in the investment-to-GDP ratio since the beginning of the crisis is more severe than the standard financial crisis but is in line with the decline observed in the most severe crises-with the ratio standing at $41 / 4$ percentage points below the precrisis level (Figure 1.5).

In the euro area, the high cost of capital and limited access to funding could pose additional impediments to investment in certain countries. Even though the European Central Bank's (ECB's) policy rate is close to zero, lending rates remain elevated in some countries as financial fragmentation persists (Figure 1.6). Debt financing in the euro area is mostly bank based (about 90 percent), which increases the cost of capital, particularly for smaller firms. In addition, many smaller companies have difficulty accessing credit (European Central Bank 2014) (Figure 1.7). Improvements in corporate bond and stock markets since 2012 are likely to benefit only larger corporations. 
— Investment-to-GDP ratio-crisis episodes

--- 90 percent confidence interval

— Euro area: Investment-to-GDP ratio, 2007-13 (index, $2007=0$ )

1. Advanced Economy Crises, 1970-2007

(Percent of GDP)

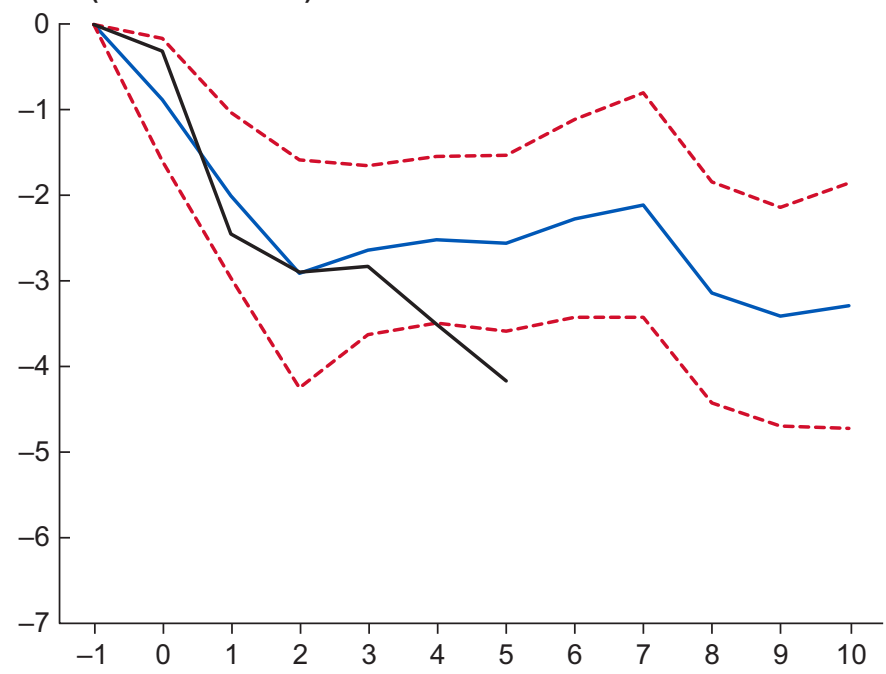

2. Big Five Crises (Percent of GDP)

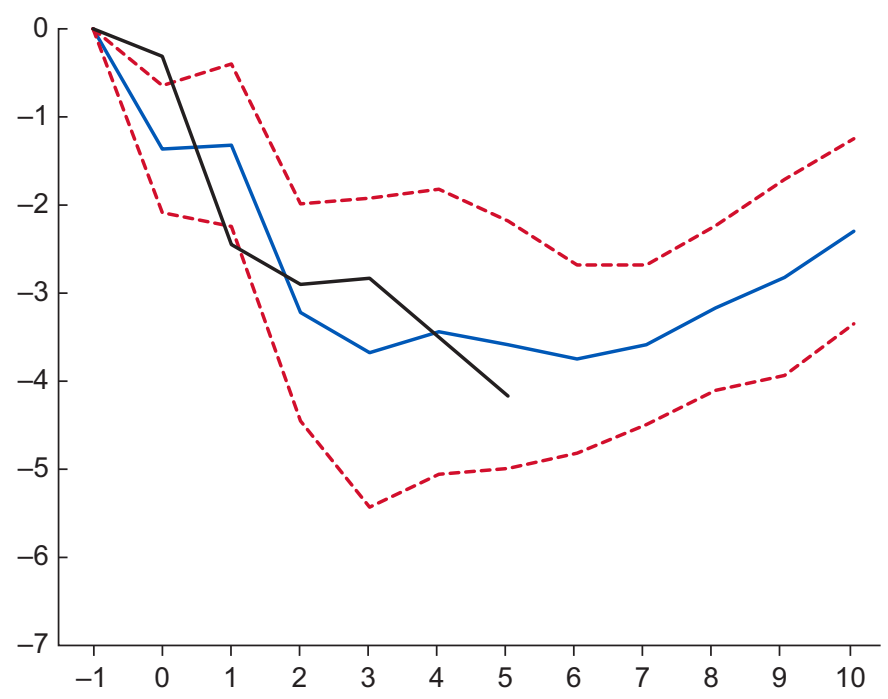

Sources: IMF 2014b; and IMF staff calculations.

Note: Gross fixed capital formation in percent of GDP. The entire sample of advanced economy financial crises between 1970 and 2007 identified by Laeven and Valencia (2012). Big five financial crises are those in Spain, 1977; Norway, 1987; Finland, 1991; Sweden, 1991; and Japan, 1992. Dashed red lines denote 90 percent confidence bands; black line denotes the actual evolution of the investment-to-GDP ratio in the euro area from 2007 to 2013. Units on the $x$-axis are years; $t=0$ denotes the year of the financial crisis.

Figure 1.5 Euro Area versus Other Financial Crisis Episodes 


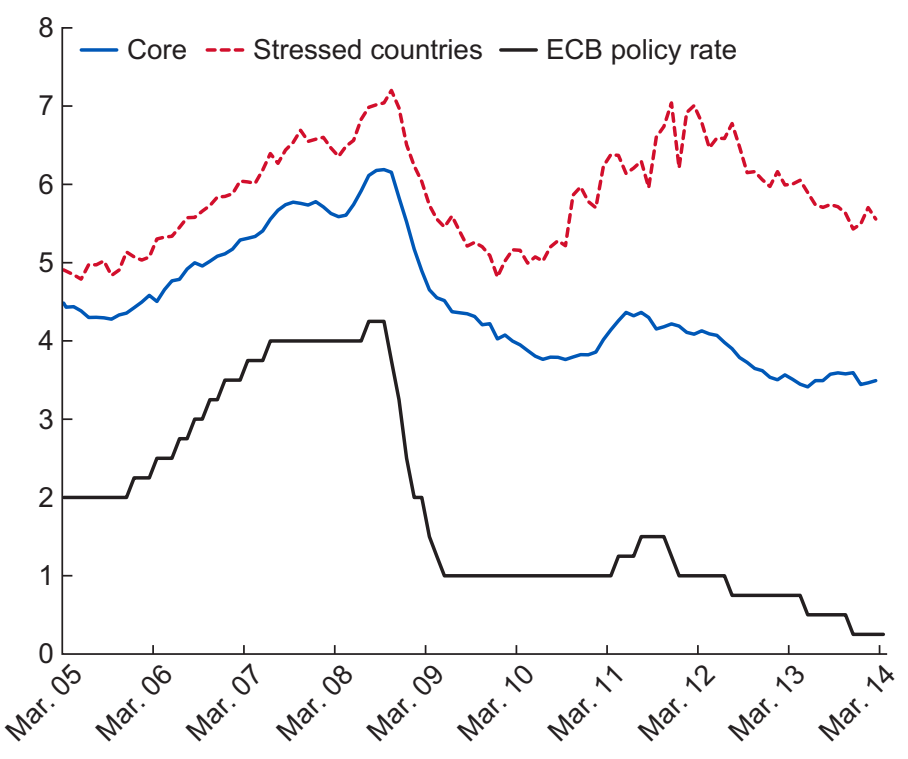

Sources: European Central Bank (ECB); Haver Analytics; and IMF staff calculations.

Note: Unweighted average; MFI lending to corporations under $€ 1$ million, 1-5 years maturity. Core = Belgium, France, Germany, Netherlands. Stressed countries = Greece, Ireland, Italy, Portugal, Spain. In the sample, Ireland is excluded from May 2011 and Greece from September 2012.

Figure 1.6 Euro Area Corporate Lending Rates (Percent)

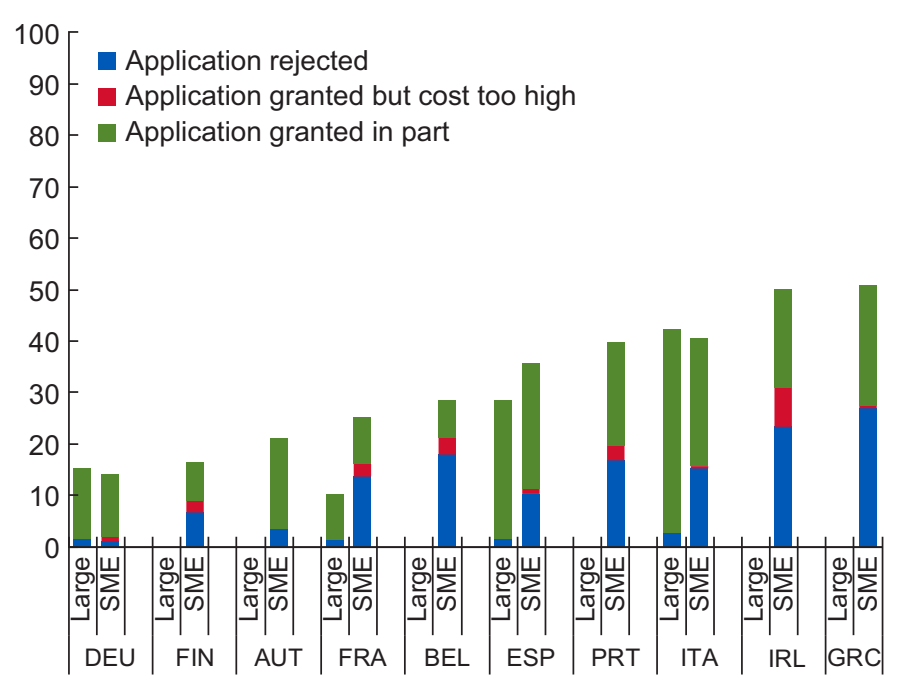

Sources: Survey on the access to finance of enterprises (SAFE), European Central Bank; and IMF staff calculations.

Note: SME = small and medium-sized enterprises. Among firms that applied within the past six months. Data labels in the figure use International Organization for Standardization (ISO) country codes.

Figure 1.7 Outcome of Loan Application by Euro Area Firms, 2013:H2 (Weighted percentages of responses) 


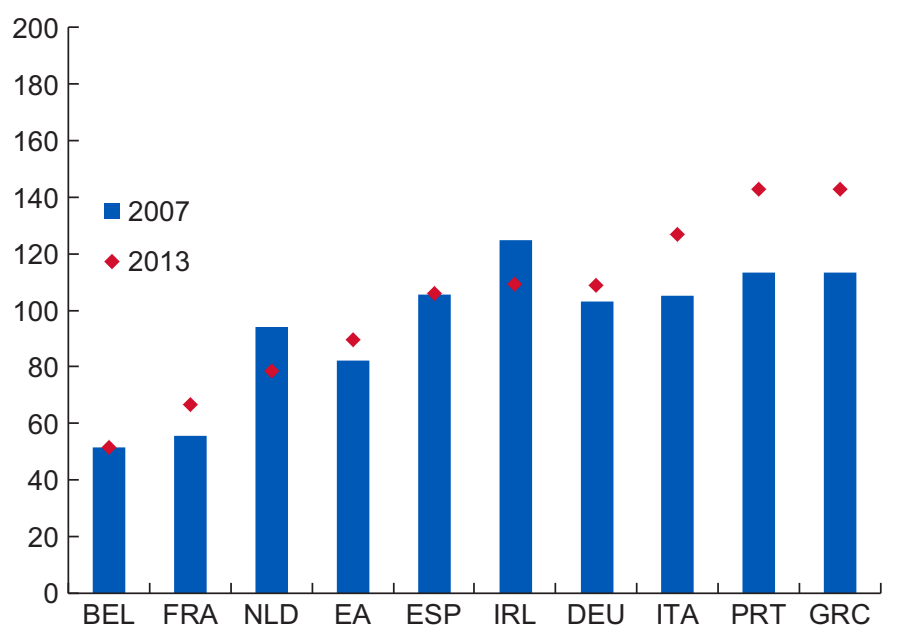

Source: European Central Bank.

Note: Debt at euro area level is nonconsolidated. EA = Euro area. Data labels in the figure use International Organization for Standardization (ISO) country codes.

Figure 1.8 Euro Area: Nonfinancial Corporation Debt-to-Equity Ratio (Percent)

Moreover, the corporate sector is highly leveraged in some countries, further depressing credit flows to the private sector. ${ }^{3}$ Corporate debt-to-equity ratios remain elevated in some stressed countries (Figure 1.8), and the deleveraging process is still at an early stage. As companies repair their balance sheets and reduce debt, the effects feed back into the banking sector through low demand for credit and higher nonperforming loans. As a result of both corporate and banking sector deleveraging, credit to the private sector continues to shrink (Figure 1.9).

Investment in the euro area could recover without credit, but creditless recoveries are associated with lower investment and GDP growth. Empirically, creditless recoveries are rare, especially in advanced economies, which suggests risks to recovery unless credit growth resumes (IMF 2014b). In addition, such recoveries are associated with lower investment and output growth than in recoveries with credit. A creditless recovery could, in turn, have long-term consequences through lower potential output.

Against this backdrop, this chapter explores to what extent output dynamics and other factors can explain private nonresidential investment across the euro area. First, to analyze the impact of the output dynamics, an accelerator model is estimated for the euro area and selected euro area countries. ${ }^{4}$ Although this model tracks investment closely, actual postcrisis investment has remained below its model-implied value for most countries. Second, to explore the impact of the cost of capital and financial constraints, the model is augmented with the real cost of capital and a proxy for financial constraints (European Commission 2014). These additional factors are significant for some of the countries; however, actual investment continues to remain below its estimated level for most countries. Finally, to explore the effects stemming from uncertainty, corporate leverage, and cash flow, a more eclectic (bond market) model is estimated. Controlling for these factors, changes in output are more representative of demand factors. Accordingly,

\footnotetext{
${ }^{3}$ In addition to these standard factors, investment in many smaller European countries has been affected by availability of the EU Structural Funds. For instance, there are indications that investment in Portugal was too high before the crisis (Pina and Abreu 2012).

${ }^{4}$ Selected countries are Germany, France, Greece, Ireland, Italy, Portugal, and Spain. Quarterly data between 1990 and 2013 are used (depending on data availability).
} 


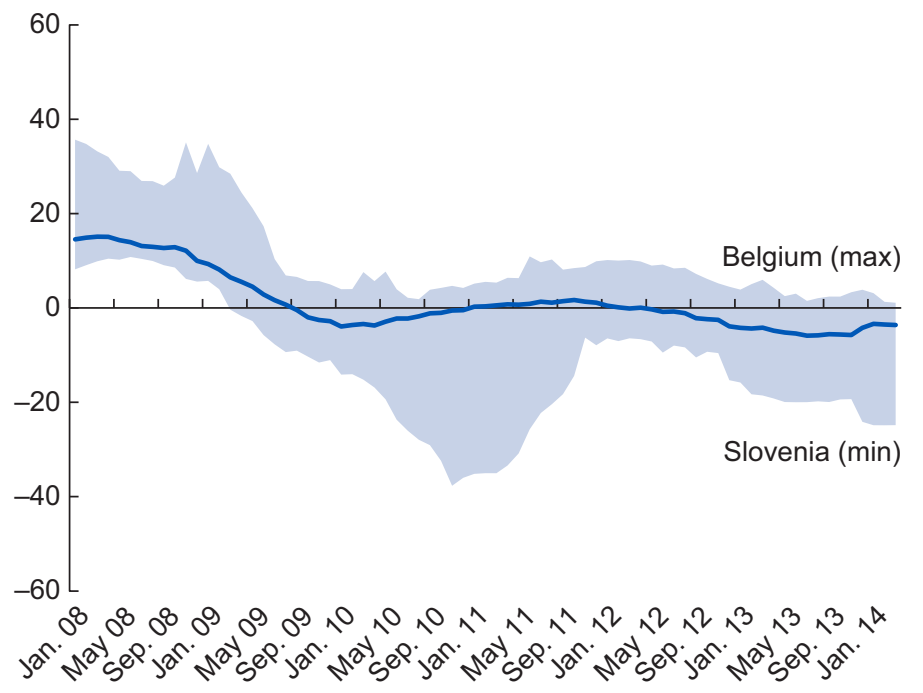

Source: Haver Analytics.

Note: The stock of credit for Slovenia includes the December 2013 transfer of nonperforming loans to Bank Asset Management Company (BAMC).

Figure 1.9 Euro Area: Growth of Nominal Credit to Firms (Year-over-year percent change)

uncertainty is associated with low investment in most countries. In addition, high corporate leverage is associated with subdued investment in Italy and Portugal, and to a lesser extent in Spain and France. Overall, this model seems to be a better fit for stressed countries, with the residuals substantially smaller than in the previous two models.

\section{DRIVERS OF INVESTMENT: OUTPUT CHANGES VERSUS OTHER FACTORS}

Three types of investment models are used to explain the dynamics of private nonresidential investment, following Lee and Rabanal (2010): (1) an accelerator model (Clark 1917; Jorgenson 1971); (2) a neoclassical model (Jorgenson 1971; Caballero 1994); and (3) a bond market model (Philippon 2009; Bloom 2009; Lee and Rabanal 2010). ${ }^{5}$ Annex 1.1 presents data sources and definitions.

\section{Are Output Changes Sufficient to Explain the Decline in Investment (Accelerator Model)?}

The first step is to explore whether changes in output are sufficient to explain investment dynamics in the euro area. The accelerator model relates real investment to past changes in real output,

\footnotetext{
${ }^{5} \mathrm{~A}$ model based on Tobin's Q was also estimated. This model relates the real-investment-to-capital ratio to the ratio of firm value to the replacement cost of the existing capital stock (Tobin 1969; Hayashi 1982). Alternative definitions of Tobin's Q (for NFCs) are used: (1) interpolated from annual Tobin's Q (CVU, Worldscope); (2) price-to-book ratio; and (3) stock prices deflated by GDP deflator. The model also controls for firms' leverage (debt-to-asset ratio) and cash flow (CVU, Worldscope). Among the Tobin's Q proxies used, only price-to-book ratio appears to be significant in a few specifications for France, Germany, and Portugal. Controlling for endogeneity (by two-stage least squares) and running the regressions for the precrisis period, the significance of the results increases: price-to-book ratio and leverage are significant and correctly signed for Germany, Greece, Portugal, and the euro area. Overall, however, model performance remains weak.
} 


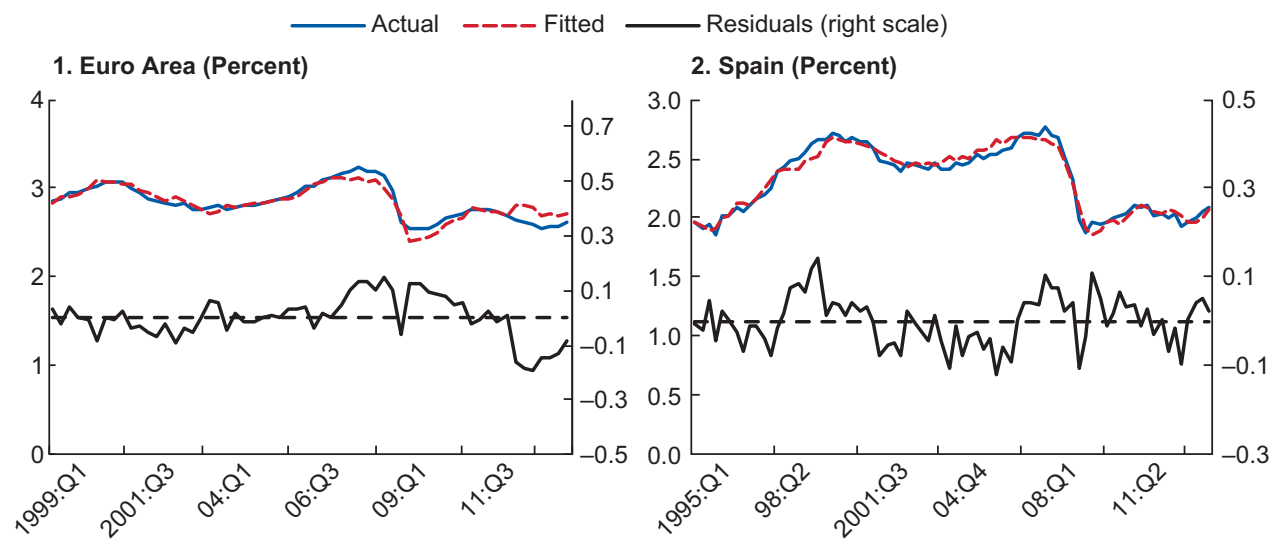

Source: IMF staff estimates.

Figure 1.10 Accelerator Model: Euro Area and Spain

taken to be the primary determinants of the changes in the desired capital stock. A common approach is to run these regressions on the investment-to-capital stock ratio:

$$
\frac{I_{t}}{K_{t-1}}=\frac{\alpha}{K_{t-1}}+\sum_{i=1}^{N} \beta_{i} \frac{\Delta Y_{t-i}}{K_{t-1}}+\delta+e_{t},
$$

in which $I$ is real private nonresidential investment, $K$ is the total capital stock, and $\Delta Y$ is the change in real GDP. ${ }^{6}$

The results indicate that changes in output can capture broad changes in investment but cannot fully account for the decline in investment after the crisis in most cases (Annex 1.2). Lags of changes in real GDP (up to 12) are correctly signed and significant. Although the model provides a good fit for overall trends, real nonresidential private investment, particularly during the second phase of the crisis, is lower than in-sample fitted values, with the exception of Spain (Figure 1.10). The model seems to track Spain's investment closely, implying that output has played an important role in investment dynamics. For most countries, underinvestment becomes smaller toward the end of the sample. The model does not seem to explain the behavior of total investment in Greece and Ireland well. As a robustness check, the regressions are run for machinery and equipment investment in Ireland and Germany (with data up to 2013:Q4). For both cases, the results are broadly the same.

\section{Do Cost of Capital and Financial Constraints Matter for Investment (Neoclassical Model)?}

Because output developments cannot fully explain the decline in investment after the crisis, whether the cost of capital and financial constraints are additional impediments is explored. In the neoclassical model, current investment is a function of the lags of changes in desired capital stock, which, in turn, is determined by the cost of capital. Under the additional assumption that the cost of capital is equal to its marginal product, investment can be related to past changes in output and changes in the real cost of capital (Oliner, Rudebusch, and Sichel 1995). This baseline

\footnotetext{
${ }^{6}$ For Ireland and Greece, total real investment is used. Because the residuals are highly correlated—a common result in the literature-Newey-West standard errors are reported. Note that the constant $\delta$ can be interpreted as an indirect estimate of the depreciation rate.
} 


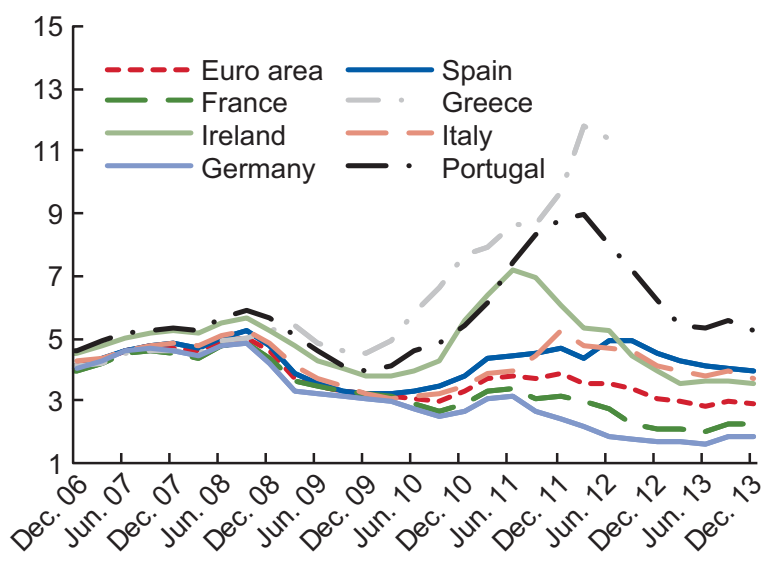

Sources: Eurostat; Haver Analytics; and IMF staff calculations.

Figure 1.11 Euro Area: Nominal Cost of Capital (Percentage points)

specification is then augmented with a variable to capture credit rationing (based on a question on financial constraints from the European Commission consumer and business survey).

$$
\frac{I_{t}}{K_{t-1}}=\frac{\alpha}{K_{t-1}}+\sum_{i=1}^{N} \beta_{i} \frac{\Delta\left(\frac{Y_{t-i}}{r_{i-i}}\right)}{K_{t-1}}+\sum_{i=0}^{N} \gamma_{i} f c_{t-i}+\delta+\varepsilon_{t}
$$

Both nominal and real costs of capital are elevated for the stressed countries. (See Annex 1.1 for definition of the cost of capital.) Although reduced policy rates have translated into lower costs of borrowing in the core countries, these rates have remained elevated in the stressed countries (Figures 1.11 and 1.12) — a sign of continued fragmentation.

While financial constraints are generally significant, the coefficients on a proxy for lagged desired changes in capital stock are generally not statistically significant, with the exception of Greece. The lack of significance of coefficients in the neoclassical model has been encountered in the literature before, for example, in Oliner, Rudebusch, and Sichel (1995). On the other hand, financial constraints, in line with expectations, have a significant negative effect on investment in the euro area, Germany, Spain, and Portugal. Overall, actual investment remains below the predicted level for other countries throughout the duration of the European debt crisis, with the exception of Spain. ${ }^{7}$ The gap between the actual and fitted investment in the euro area and Italy closes toward the end of the estimation period (Figure 1.13). The robustness checks using alternative lag selection strategies, and narrower measures of nonresidential investment in Germany and Ireland produce broadly similar results. ${ }^{8}$

\footnotetext{
${ }^{7}$ Similar to the accelerator model, the residuals are serially correlated. Annex 1.3 presents the results for the extended model; the results for the baseline model without financial constraints are available upon request.

${ }^{8}$ We have also modeled the short- and long-term investment dynamics using a vector error correction model (VECM), controlling for cost of capital, output, and labor costs. We did not obtain consistently significant coefficients for the cost of capital measure, but output and labor costs were significant, showing that higher labor costs dampen investment growth. Augmenting the VECM with indicators of capacity utilization and uncertainty generally failed to establish significant results.
} 


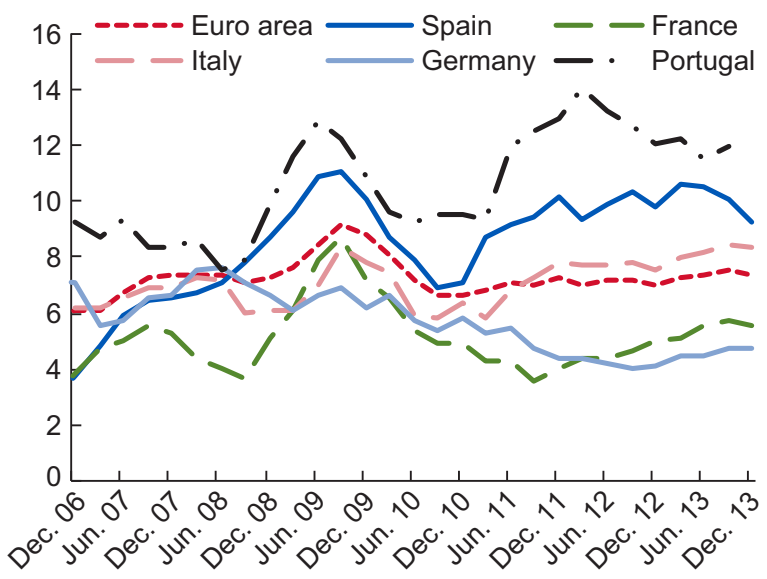

Sources: Eurostat; Haver Analytics; and IMF staff calculations.

Figure 1.12 Euro Area: Real Cost of Capital (Percentage points)

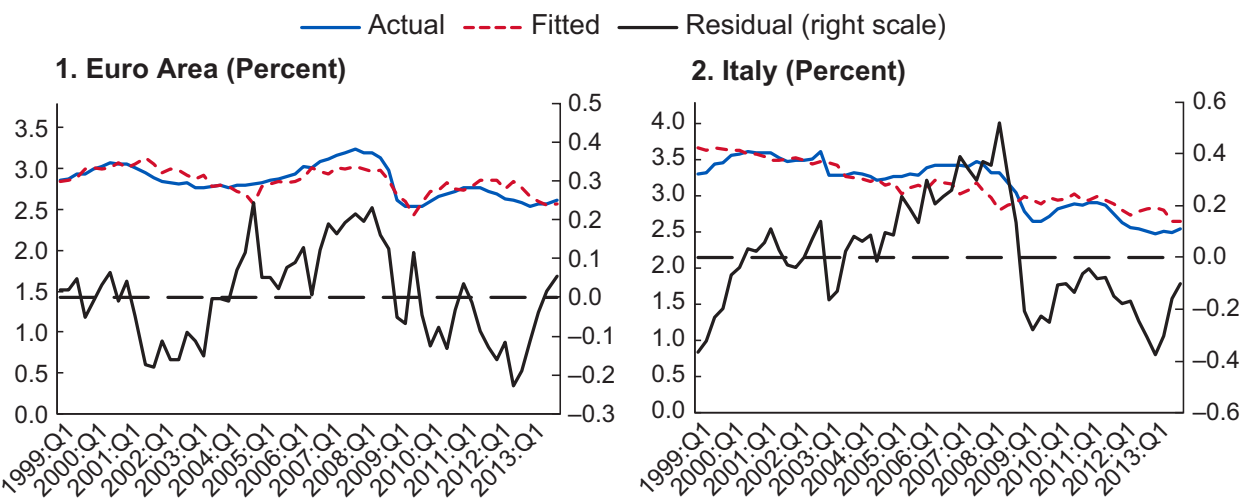

Source: IMF staff estimates.

Figure 1.13 Neoclassical Model: Euro Area and Italy

Out-of-sample projections also suggest underinvestment. For all countries, one-step-ahead forecasts from 2008:Q3 onward produce projected investment levels that are higher than realized investment levels, particularly during the second phase of the crisis. For Germany, during the first phase of the crisis, the decline in projected investment was deeper than the actual decline. This reversed during the second phase of the crisis. To test whether the crisis has changed investment dynamics, intercept and interaction dummies are added to the specification. Although the intercept terms are generally significant, the results are mixed for the interaction terms. (All results are available upon request.)

\section{Do Other Factors (Uncertainty, Leverage, and Cash Flow) Play a Role in Investment Dynamics?}

To account for other factors that could potentially weigh on investment, a more eclectic model is used. Philippon (2009) suggests using bond prices instead of equity prices to estimate the value of Tobin's Q. The proposed measure, called "Bond Market's Q," is a function of the real risk-free 
rate, the spread between bond yields and government bonds, leverage, and uncertainty. The real lending rate for nonfinancial corporations (NFCs) is substituted for the real rate in the baseline model, and following Lee and Rabanal (2010), the model includes a measure of cash flow.

The model captures any additional impact on investment from uncertainty and corporate leverage. The ratio of private nonresidential investment to total capital stock is modeled as a function of overall real lending rates to NFCs, corporate bond spreads, uncertainty, corporate leverage, and the cash-flow-to-sales ratio. To account for demand effects, the baseline model is augmented with changes in real output over total capital stock. This augmentation also allows this model to be compared with the accelerator and neoclassical models. Finally, similar to the neoclassical model, financial constraints are controlled for to account for possible credit rationing (Annex 1.4): ${ }^{?}$

$$
\begin{aligned}
\frac{I_{t}}{K_{t-1}}= & \alpha+\beta_{1} \text { cbond }_{i-1}+\beta_{2} \text { rlrate }_{i-1}+\beta_{3} \text {.nuncer }_{i-1}+\beta_{4} \text { leverage }_{t-1}+\beta_{5} \text { cash flow }_{t-1} \\
& +\sum_{i=1}^{N} \gamma_{i} \frac{\Delta Y_{t-i}}{K_{t-1}}+\beta_{6} f c_{t}+\varepsilon_{t} .
\end{aligned}
$$

High uncertainty is associated with low investment, particularly for the stressed countries. In the baseline model (without controlling for output changes and financial constraints), uncertainty reduces investment in most countries and in the euro area as a whole, though the effects are fairly small. A one standard deviation increase in uncertainty reduces the investment-tocapital-stock ratio by about $0.03-0.1$ percentage point. The results remain broadly unchanged when output changes and financial constraints are controlled for.

Higher corporate leverage is associated with weak investment in some countries. In the baseline model (without controlling for output changes), corporate leverage reduces investment in France, Italy, Portugal, and Spain by between 0.1 and 0.4 percentage point for every 10 percentage point increase in the debt-to-equity ratio. Controlling for output changes and financial constraints, leverage is still important for France, Italy, and Portugal. Cash flow is significant for a few countries in the baseline model, but only has the expected positive sign for Germany, Greece, and, after controlling for changes in output, Spain.

Corporate bond spreads and real lending rates are significant and correctly signed for only a few countries. The former are significant for Ireland, as well as for Germany and Spain once output changes and financial constraints are controlled for. A 100 basis point increase in the spread of corporate over government bond yields decreases investment by about $0.1-0.8$ percentage point. Real lending rates (deflated by the GDP deflator) are correctly signed and significant for determining investment in Italy once output changes and financial constraints are controlled for. ${ }^{10}$ The financial constraints variable is significant for Italy and Portugal.

Overall, the model seems to work better for stressed countries, in particular for Italy and Spain, and to a lesser extent for Portugal and the euro area as a whole (Figure 1.14). It performs comparatively poorly for France and Germany. ${ }^{11}$ The robustness checks using the series for machinery and equipment investment in Ireland and Germany (with data up to 2013:Q4) produce broadly similar results.

\footnotetext{
${ }^{9}$ Annex 1.4 presents the results for the extended model. The results for the baseline and other steps are available upon request.

${ }^{10}$ The coefficients for the euro area, Germany, and Spain have the reverse sign, which is a common finding in the literature, possibly reflecting difficulties in identifying credit demand and supply.

${ }^{11}$ Pérez Ruiz (2014) uses a broader set of determinants to explain the level of business investment in France. That model provides a good fit for France.
}

\section{CInternational Monetary Fund. Not for Redistribution}




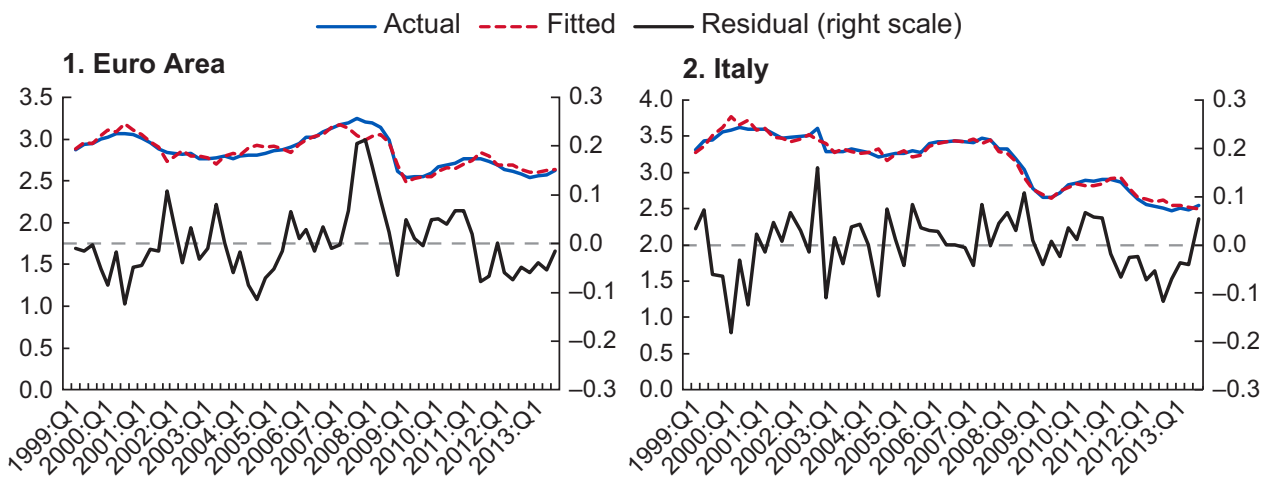

Source: IMF staff estimates.

Figure 1.14 Bond Market Model

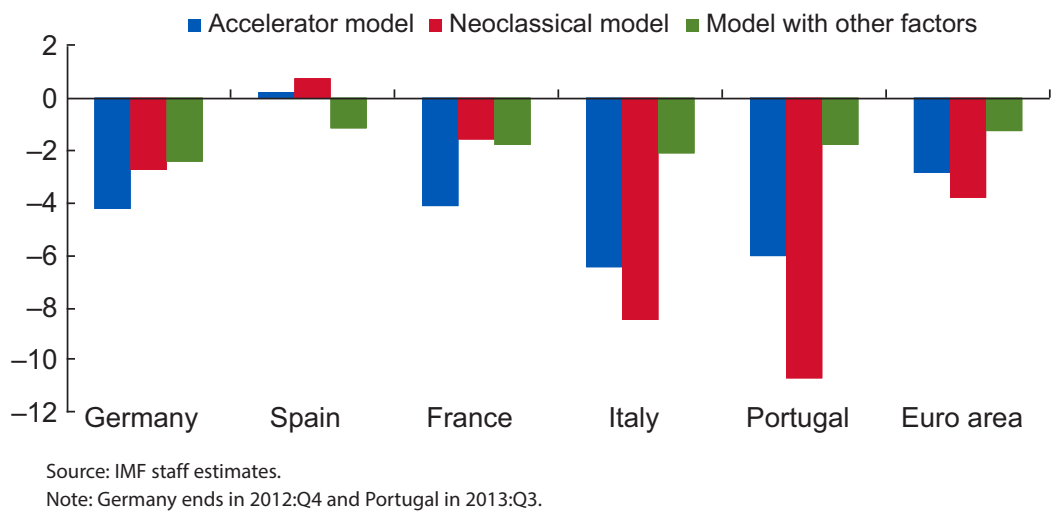

Figure 1.15 Cumulative Underinvestment (Since 2010:Q2, percent of GDP)

\section{The Magnitude of Missing Investment}

Since the European debt crisis, investment has been systematically lower than its estimated level, except in Spain. To better gauge how much investment has been missing since the start of the European sovereign crisis, the cumulative underinvestment since then is examined. Overall, controlling only for output, the cumulative underinvestment is about 3-6 percent of GDP (excluding Spain) (Figure 1.15). Once other determinants are also controlled for, the cumulative underinvestment declines substantially to about $1 / 2-2$ percent. In Spain, output changes alone are enough to explain much of the decline in investment. However, other factors such as cost of capital, financial constraints, and uncertainty are also important elements affecting investment in Spain, implying that these factors may affect investment through their impact on output.

\section{CONCLUSION}

Investment has been weak across the euro area. Empirical evidence suggests that output dynamics can explain the broad trends in investment, including its collapse after the financial crisis. In particular, output accounts for the behavior of investment in Spain. In other countries (including France and Germany), private nonresidential investment has been lower than suggested by output developments only since the onset of the crisis. 
In addition to output dynamics, financial constraints affect investment, particularly for Italy, Portugal, and Spain. The neoclassical model that seeks to proxy desired capital stock with a measure based on the real cost of capital generally does not produce significant results, except for Greece. Nevertheless, investment continues to remain below its model implied value for most of the countries.

High uncertainty and corporate sector leverage are additional impediments to investment, particularly in France, Italy, Portugal, and Spain. After controlling for these two factors, investment (in cumulative terms) is lower than its estimated level by up to about 2 percent of GDP since the beginning of the European debt crisis.

Investment is expected to pick up as the recovery strengthens and uncertainty declines. However, a sustained recovery in investment will require that the corporate debt overhang and financial fragmentation be dealt with. Corporate debt-to-equity ratios remain elevated in some stressed countries, and the deleveraging process is still at an early stage. At the same time, borrowing costs need to be substantially lower, particularly for smaller firms.

Future work will focus on firm-level investment, particularly for small and medium-sized enterprises. Firm-level analysis will supplement macro-level regressions. The use of microeconomic data will allow differentiation between the investment patterns of large and small corporations, as well as a determination of the impact of firm-specific variables, such as cash flow, leverage, and Tobin's Q.

\section{ANNEX 1.1. DATA SOURCES AND DEFINITIONS}

Real investment. Investment data are downloaded from Eurostat. Private nonresidential investment is the sum of investment in transport and other machinery and equipment, cultivated assets, and intangible fixed assets.

Capital stock series are from the European Commission Annual Macroeconomic (AMECO) database-the annual series were linearly interpolated so that the stock of capital in the last quarter would match the corresponding annual figure. Alternative measures of capital stock are also calculated using the perpetual inventory method. The initial capital stock values from the AMECO capital stock were scaled by applying appropriate investment subcomponent ratios. Depreciation rates are assumed to be constant and equal to average rates implied by the AMECO series.

Real GDP on a quarterly basis was obtained from the IMF World Economic Outlook database.

Real cost of capital. The correct measure of the cost of capital depends on the structure of financing of the firm. The flow-of-funds data suggest that liabilities of NFCs consist primarily of loans and equity, with the share of bond financing being less than 10 percent in most periods and countries. The following formula is used for the real cost of capital:

$$
\begin{aligned}
r_{i, t}= & {\left[\left(\frac{D_{i, t}}{D_{i, t}+B_{i, t}+E_{i, t}}\right) l_{i, t}+\left(\frac{B_{i, t}}{D_{i, t}+B_{i, t}+E_{i, t}}\right) i_{t}\right.} \\
& \left.+\left(\frac{E_{i, t}}{D_{i, t}+B_{i, t}+E_{i, t}}\right) c_{i, t}-\pi_{i, t}+\delta_{i}\right] \times \frac{P_{i, t}^{I}}{P_{i, t}},
\end{aligned}
$$

in which $D_{i, t}, B_{i, t}$ and $E_{i, t}$ are the amounts of bank loans, bonds (securities other than shares), and equity in the liabilities of NFCs. For the nominal costs of different kinds of capital, we use monetary financial institution lending rates in a given country for new business at all maturities, $l_{i, t}$, for bank loan liabilities; yield on the euro area-wide corporate bond index, $i_{t}$, for bond 
liabilities; and the yield on 10-year government bonds, $c_{i, t}$, to price equity liabilities. ${ }^{12}$ In line with the literature, from the nominal rate, we subtract the year-over-year change in the investment deflator $\pi_{i, t}$; add the depreciation rate, which is assumed to be constant but different across countries $\delta_{i}$; and multiply the result by the relative price of investment goods (investment deflator) and output $P_{i, \downarrow}^{I} / P_{i, t}$. We also report the "nominal cost of capital," which is simply the first three terms in equation (1.1.1). In addition, we also use a measure of the real cost of capital for debt financing, composed of bond and bank lending (available upon request).

In most countries the real cost of capital has been declining throughout the 2000s; however, after the crisis, southern European countries diverged from France and Germany. Annex Figure 1.1.1 shows the nominal and real costs of capital for the countries considered. As of June 2014 moment, the lowest real cost of capital is in Germany ( 5 percent), while Italy has the highest cost (12.1 percent). The volatility of the real cost of capital in Greece (for which only a shorter sample is available) is driven by the volatility of the investment deflator.

Financial constraints. This variable is from the quarterly European Commission Business and Consumer Survey. Seasonally adjusted series are from the survey of the manufacturing industry: percentage of correspondents listing financial constraints as the factor limiting production.

Corporate bond prices. We use the average spread of corporate over government bonds with maturity of one to five years for the euro area as a whole for all countries in the sample, to proxy corporate bond market conditions. This measure inherently gives more weight to large euro area economies and applies to large firms. (These are Merrill-Lynch indices, from Bloomberg.) This variable is in basis points.

Uncertainty index. Bloom (2009). Natural log of uncertainty index $\times 100$.

Corporate sector leverage. Debt-to-equity ratio from the European Central Bank (in percent).

Cash flow to sales. Worldscope and IMF Corporate Vulnerability Unit database (median).

Crisis dummy. Crisis = 1 from 2008:Q3 (used only for robustness checks).

\footnotetext{
${ }^{12}$ We have experimented with alternative approaches to pricing equity capital, such as variations on the dividend growth model; however, they tend to produce counterintuitive implications for the ranking of the cost of capital across different countries. Using a 10-year government bond establishes a sensible lower bound for the cost of equity and, assuming that the risk premium is constant, is not expected to affect the results. For the euro area, we use the simple average of the 10 -year bond yields in France, Germany, Italy, and Spain.
} 

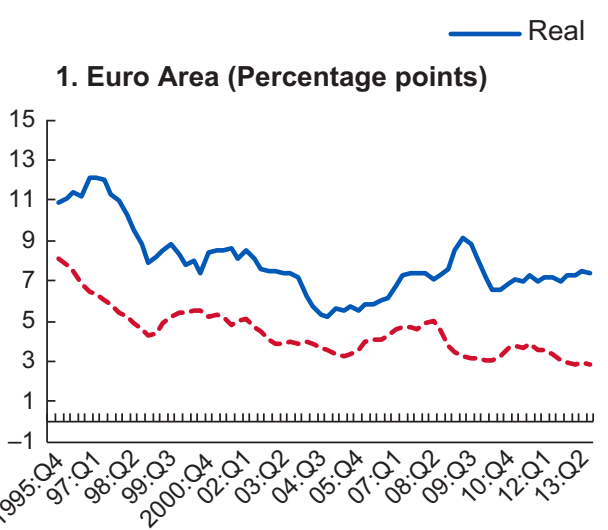

3. Spain (Percentage points)

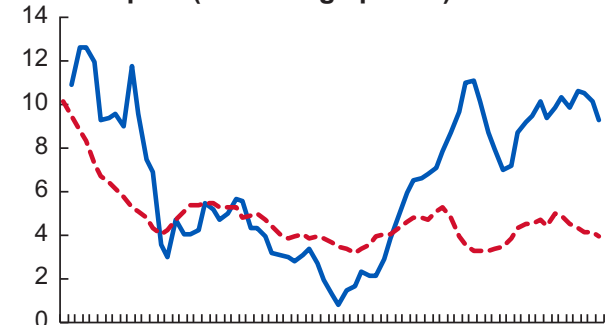

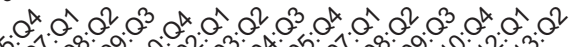

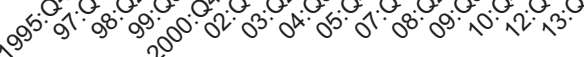

\section{Greece (Percentage points)}

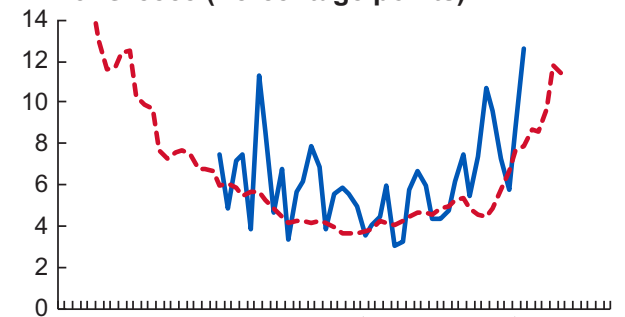

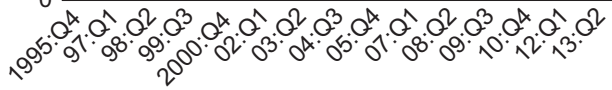

7. Italy (Percentage points)

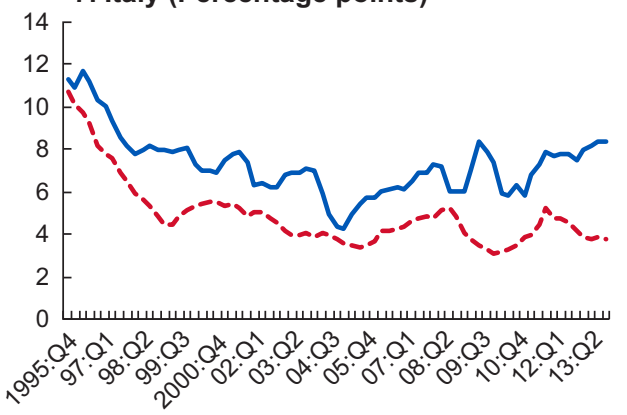

Sources: Haver Analytics; and IMF staff estimates.

Figure 1.1.1 Cost of Capital Calculations
Nominal

2. Germany (Percentage points)

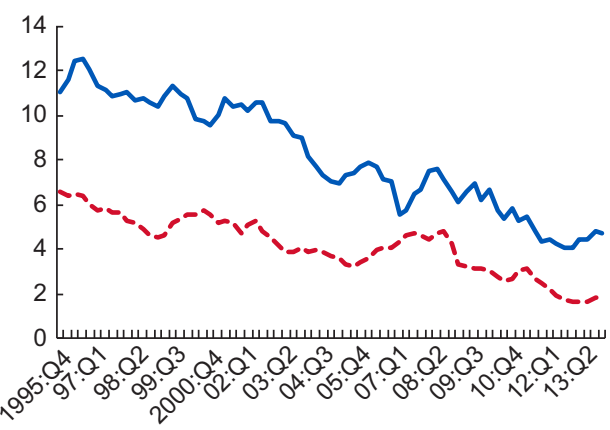

4. France (Percentage points)

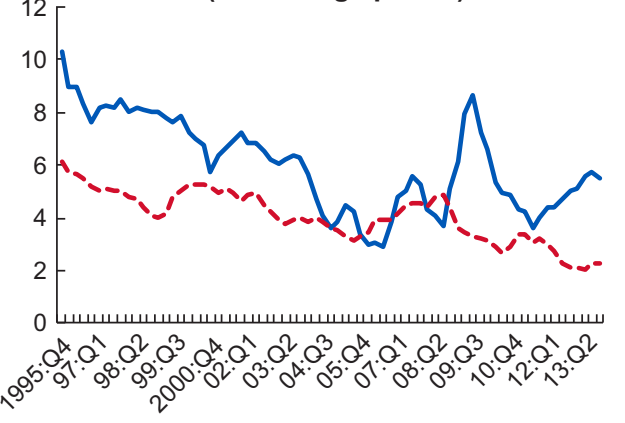

6. Ireland (Percentage points)

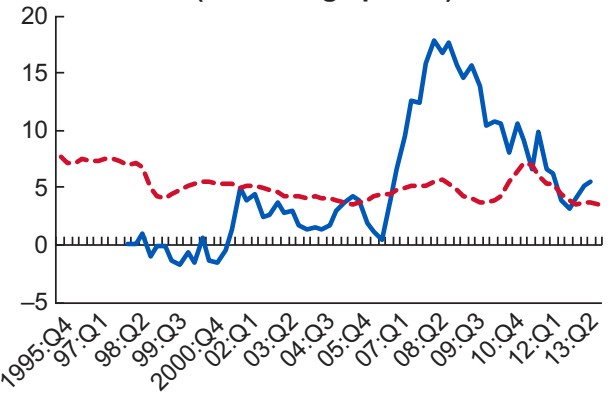

8. Portugal (Percentage points)

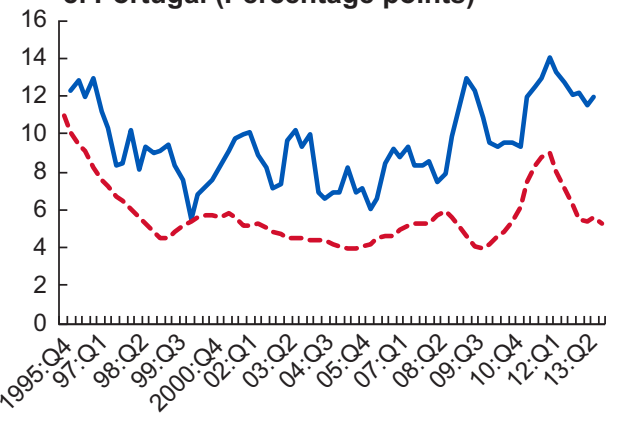


ANNEX 1.2. RESULTS OF THE ACCELERATOR MODEL ${ }^{13}$

$$
\frac{I_{t}}{K_{t-1}}=\frac{\alpha}{K_{t-1}}+\sum_{i=0}^{N} \beta_{i} \frac{\Delta Y_{t-i}}{K_{t-1}}+\delta+e_{t}
$$

ANNEX TABLE 1.2.1

\begin{tabular}{|c|c|c|c|c|c|c|c|c|}
\hline \multicolumn{9}{|c|}{ Accelerator Model-Total Investments (Newey-West HAC Standard Error Estimates) } \\
\hline & Euro Area & Germany & France & Italy & Spain & Greece & Ireland & Portugal \\
\hline \multirow[t]{2}{*}{$\beta 1$} & $0.32^{* * *}$ & $0.21^{* * *}$ & $0.26^{* * *}$ & $0.47^{* * *}$ & $0.41^{* * *}$ & $0.38^{* *}$ & $0.75^{* *}$ & $0.29^{* * *}$ \\
\hline & $(0.06)$ & $(0.06)$ & $(0.06)$ & $(0.08)$ & $(0.09)$ & $(0.17)$ & $(0.28)$ & $(0.08)$ \\
\hline \multirow[t]{2}{*}{$\beta 2$} & $0.21^{* *}$ & $0.23^{* * *}$ & $0.23^{* * *}$ & $0.39^{* * *}$ & $0.49^{* * *}$ & $0.70^{* * *}$ & $0.99^{* *}$ & $0.26^{* *}$ \\
\hline & $(0.1)$ & $(0.07)$ & $(0.05)$ & $(0.09)$ & $(0.06)$ & $(0.15)$ & $(0.42)$ & $(0.1)$ \\
\hline \multirow[t]{2}{*}{$\beta 3$} & $0.25^{* * *}$ & $0.25^{* * *}$ & $0.23^{* * *}$ & $0.37^{* * *}$ & $0.23^{* * *}$ & $1.10^{* * *}$ & $0.92^{* *}$ & $0.26^{* * *}$ \\
\hline & $(0.06)$ & $(0.06)$ & $(0.05)$ & $(0.07)$ & $(0.07)$ & $(0.1)$ & $(0.38)$ & $(0.06)$ \\
\hline \multirow[t]{2}{*}{$\beta 4$} & $0.22^{* * *}$ & $0.18^{* * *}$ & $0.20^{* * *}$ & $0.19^{* *}$ & -0.05 & $0.71^{* * *}$ & $0.76^{* *}$ & $0.24^{* * *}$ \\
\hline & $(0.07)$ & $(0.04)$ & $(0.05)$ & $(0.08)$ & $(0.08)$ & $(0.12)$ & $(0.29)$ & $(0.07)$ \\
\hline \multirow[t]{2}{*}{$\beta 5$} & $0.13^{*}$ & $0.13^{* * *}$ & $0.20^{* * * *}$ & $0.27^{* * *}$ & $0.12^{*}$ & $1.04^{* * *}$ & 0.37 & $0.21^{* *}$ \\
\hline & $(0.07)$ & $(0.04)$ & $(0.05)$ & $(0.09)$ & $(0.07)$ & $(0.12)$ & $(0.35)$ & $(0.08)$ \\
\hline \multirow[t]{2}{*}{$\beta 6$} & $0.16^{* * *}$ & $0.10^{* *}$ & $0.17^{* * *}$ & $0.18^{* * *}$ & $0.39^{* * *}$ & $1.12^{* * *}$ & 0.30 & $0.19^{* *}$ \\
\hline & $(0.05)$ & $(0.04)$ & $(0.06)$ & $(0.07)$ & $(0.06)$ & $(0.16)$ & $(0.39)$ & $(0.08)$ \\
\hline \multirow[t]{2}{*}{$\beta 7$} & $0.17^{* *}$ & 0.07 & $0.09^{*}$ & $0.28^{* * *}$ & 0.09 & $0.82^{* * *}$ & 0.28 & $0.22^{* * *}$ \\
\hline & $(0.07)$ & $(0.05)$ & $(0.06)$ & $(0.07)$ & $(0.06)$ & $(0.18)$ & $(0.33)$ & $(0.07)$ \\
\hline \multirow[t]{2}{*}{$\beta 8$} & 0.06 & $0.09^{*}$ & $0.12^{* *}$ & $0.24^{* * *}$ & 0.00 & & $0.57^{* *}$ & 0.10 \\
\hline & $(0.04)$ & $(0.05)$ & $(0.05)$ & $(0.07)$ & $(0.05)$ & & $(0.25)$ & $(0.07)$ \\
\hline \multirow[t]{2}{*}{$\beta 9$} & $0.10^{* *}$ & $0.12^{* *}$ & $0.11^{* *}$ & 0.09 & 0.05 & & 0.55 & $0.16^{* *}$ \\
\hline & $(0.05)$ & $(0.06)$ & $(0.05)$ & $(0.07)$ & $(0.04)$ & & $(0.34)$ & $(0.08)$ \\
\hline \multirow[t]{2}{*}{$\beta 10$} & $0.09^{*}$ & 0.07 & $0.10^{* *}$ & $0.18^{* * *}$ & $0.15^{* * *}$ & & $0.71^{*}$ & $0.16^{*}$ \\
\hline & $(0.05)$ & $(0.05)$ & $(0.05)$ & $(0.06)$ & $(0.03)$ & & $(0.39)$ & $(0.09)$ \\
\hline \multirow[t]{2}{*}{$\beta 11$} & 0.05 & $0.10^{*}$ & 0.08 & $0.26^{* * *}$ & $0.06^{*}$ & & $1.04 * * *$ & $0.17^{*}$ \\
\hline & $(0.04)$ & $(0.05)$ & $(0.05)$ & $(0.07)$ & $(0.03)$ & & $(0.35)$ & $(0.09)$ \\
\hline \multirow[t]{2}{*}{$\beta 12$} & $0.18^{* * *}$ & & $0.20^{* * *}$ & $0.38^{* * *}$ & & & $0.75^{* *}$ & $0.16^{*}$ \\
\hline & $(0.05)$ & & $(0.06)$ & $(0.08)$ & & & $(0.3)$ & $(0.08)$ \\
\hline \multirow[t]{2}{*}{$\delta$} & $3.43^{* * *}$ & $5.99^{* * *}$ & $3.98^{* * *}$ & $4.29^{* * *}$ & $2.76^{* * *}$ & $10.65^{* * *}$ & $8.92^{* * *}$ & $3.81^{* * *}$ \\
\hline & $(0.38)$ & $(0.35)$ & $(0.16)$ & $(0.3)$ & $(0.05)$ & $(0.48)$ & $(2.75)$ & $(0.66)$ \\
\hline Observations & 60 & 76 & 96 & 92 & 76 & 76 & 54 & 62 \\
\hline$R$-squared & 0.84 & 0.82 & 0.87 & 0.75 & 0.95 & 0.39 & 0.75 & 0.86 \\
\hline Akaike info criterion & 0.50 & -0.88 & 0.33 & 0.35 & 0.99 & 0.69 & 0.50 & 0.80 \\
\hline $\begin{array}{l}\text { Schwarz Bayesian } \\
\text { criterion }\end{array}$ & -1.31 & -0.48 & -1.57 & -0.05 & -2.21 & 1.33 & 4.40 & 0.11 \\
\hline $\begin{array}{l}\text { Standard error of } \\
\text { regression }\end{array}$ & 0.09 & 0.14 & 0.10 & 0.18 & 0.06 & 0.39 & 1.52 & 0.18 \\
\hline
\end{tabular}

Notes: $\mathrm{HAC}=$ heteroscedasticity and autocorrelation consistent.

${ }^{*}$ significant at 10 percent; ${ }^{* *}$ significant at 5 percent; ${ }^{* * *}$ significant at 1 percent.

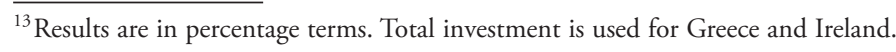




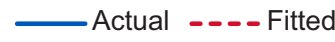

1. Euro Area (Percent)

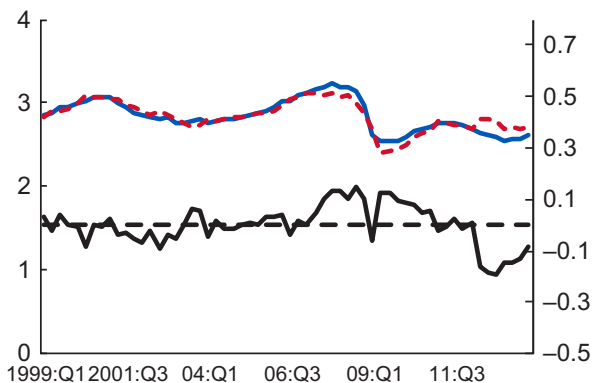

3. Spain (Percent)

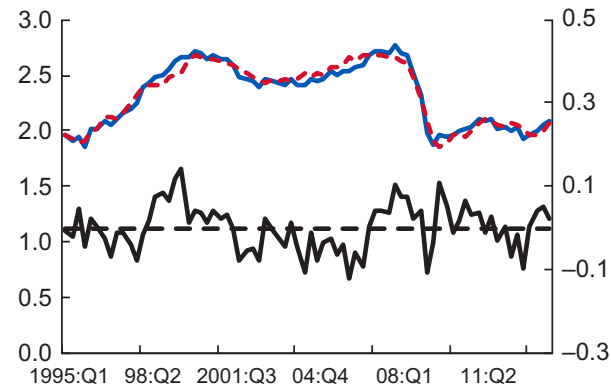

5. Greece (Percent)

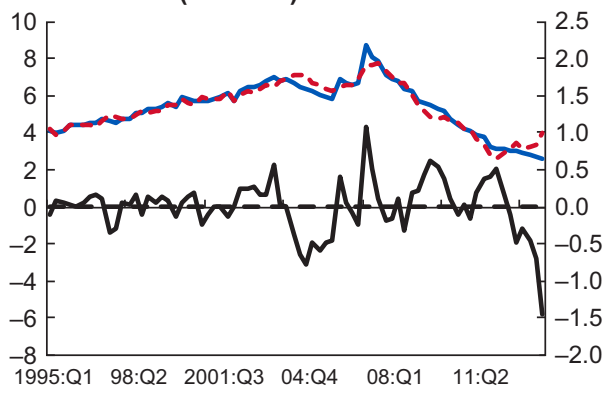

7. Italy (Percent)

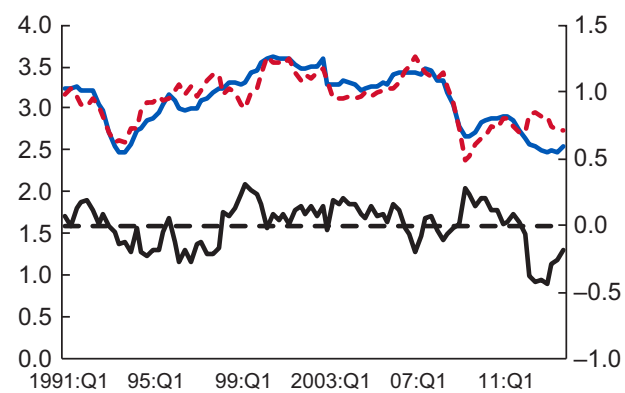

Residuals (right scale)

2. Germany (Percent)

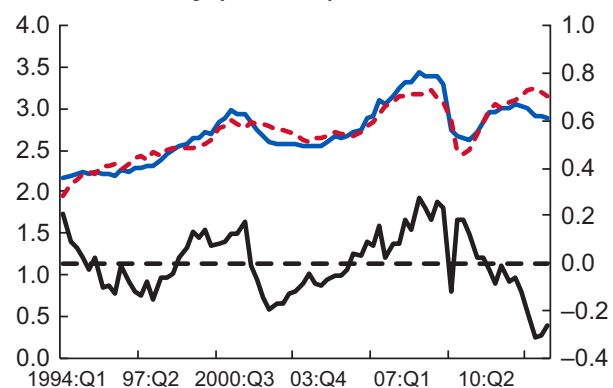

4. France (Percent)

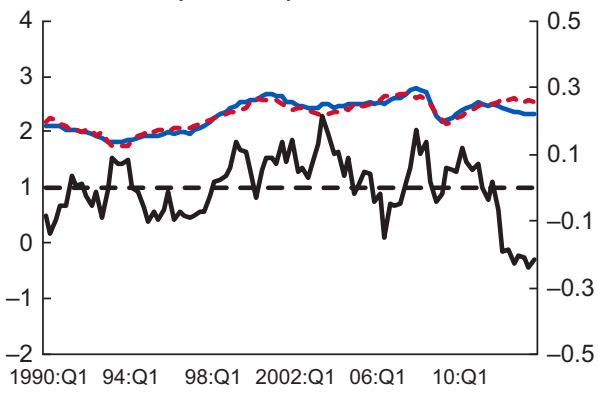

6. Ireland (Percent)

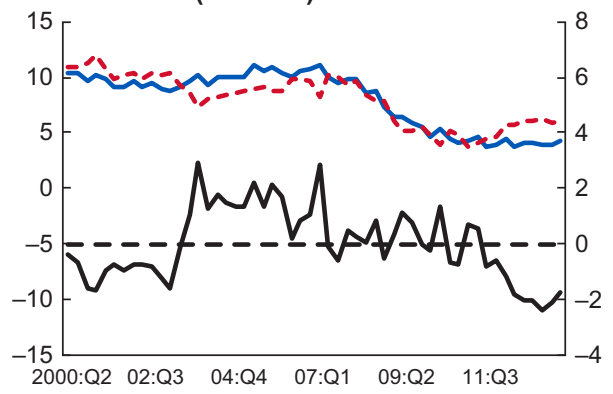

8. Portugal (Percent)

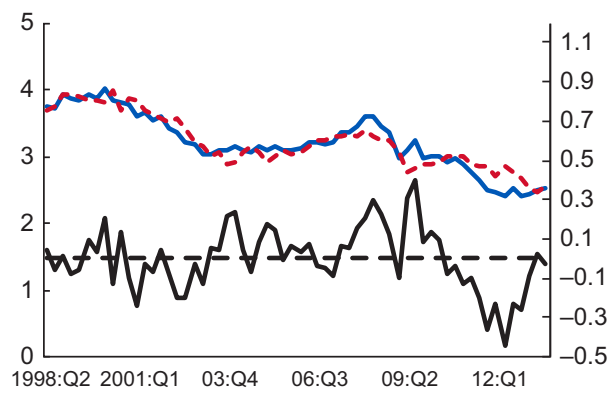

Sources: Eurostat; IMF, World Economic Outlook database; OECD, Analytical database; European Commission, Annual Macroeconomic Database; and IMF staff calculations.

Note: Total investment for Greece and Ireland.

Annex Figure 1.2.1 Accelerator Model: Private Nonresidential Investment/Capital Ratio 


\section{ANNEX 1.3. RESULTS OF THE NEOCLASSICAL MODEL}

$$
\frac{I_{t}}{K_{t-1}}=\frac{\alpha}{K_{t-1}}+\sum_{i=0}^{N} \beta_{i} \frac{\Delta\left(\frac{Y_{i-i}}{r_{t-i}}\right)}{K_{t-1}}+\sum_{i=0}^{N} \gamma_{i} f c_{t-i}+\delta+\varepsilon_{t}
$$

ANNEX TABLE 1.3.1

\begin{tabular}{|c|c|c|c|c|c|c|c|c|}
\hline \multicolumn{9}{|c|}{$\begin{array}{l}\text { Neoclassical Model Augmented with Financial Constraints: Estimates with Newey-West } \\
\text { Standard Errors }\end{array}$} \\
\hline & Euro Area & Germany & Spain & France & Greece & Ireland & Italy & Portugal \\
\hline \multirow[t]{2}{*}{$\alpha$} & $-507,279^{* * *}$ & $-450,609^{* * *}$ & 9,752 & 6,546 & $-44,545^{* *}$ & $92,896^{* * *}$ & $100,171^{*}$ & $24,477^{* * *}$ \\
\hline & $(186,844)$ & $(65,147)$ & $(6,595)$ & $(18,503)$ & $(17,547)$ & $(17,731)$ & $(55,275)$ & $(5,235)$ \\
\hline \multirow[t]{2}{*}{$\beta 1$} & -0.0960 & -0.104 & -0.00578 & 0.0222 & $0.270^{* * * *}$ & -0.0401 & 0.0314 & $-0.141^{* *}$ \\
\hline & $(0.0750)$ & $(0.0889)$ & $(0.00419)$ & $(0.0179)$ & $(0.0846)$ & $(0.0417)$ & $(0.0894)$ & $(0.0516)$ \\
\hline \multirow[t]{2}{*}{$\beta 2$} & -0.0820 & -0.0665 & $-0.00884^{*}$ & 0.00497 & $0.244^{*}$ & -0.0452 & -0.0220 & $-0.205^{* * *}$ \\
\hline & $(0.0780)$ & (0.0998) & $(0.00466)$ & $(0.0203)$ & $(0.125)$ & $(0.0524)$ & $(0.0836)$ & (0.0724) \\
\hline \multirow[t]{2}{*}{$\beta 3$} & 0.0197 & -0.00688 & -0.00616 & 0.00221 & $0.482^{* * *}$ & -0.0451 & 0.0284 & $-0.250^{* *}$ \\
\hline & $(0.0503)$ & $(0.0809)$ & $(0.00468)$ & $(0.0174)$ & $(0.0934)$ & $(0.0497)$ & $(0.0862)$ & $(0.0913)$ \\
\hline \multirow[t]{2}{*}{$\beta 4$} & 0.00570 & -0.0400 & -0.00671 & -0.00585 & $0.591 * * *$ & -0.0619 & 0.00272 & -0.109 \\
\hline & $(0.0583)$ & $(0.0712)$ & $(0.00523)$ & $(0.0215)$ & $(0.104)$ & $(0.0408)$ & $(0.101)$ & $(0.0873)$ \\
\hline \multirow[t]{2}{*}{$\beta 5$} & -0.0628 & & -0.00780 & 0.00159 & $0.729 * * *$ & $-0.0814^{* * *}$ & 0.0256 & -0.0608 \\
\hline & $(0.0772)$ & & $(0.00566)$ & $(0.0271)$ & $(0.105)$ & $(0.0256)$ & $(0.106)$ & $(0.0449)$ \\
\hline \multirow[t]{2}{*}{$\beta 6$} & 0.0191 & & -0.00728 & 0.00753 & $0.820^{* * *}$ & $-0.0613^{* * *}$ & 0.0352 & $-0.127^{* *}$ \\
\hline & $(0.0684)$ & & $(0.00473)$ & $(0.0222)$ & $(0.125)$ & (0.0209) & $(0.117)$ & $(0.0582)$ \\
\hline \multirow[t]{2}{*}{$\beta 7$} & 0.0610 & & -0.00419 & 0.00722 & $0.866^{* * *}$ & $-0.0426^{* * *}$ & 0.0458 & $-0.0978^{*}$ \\
\hline & $(0.0636)$ & & $(0.00399)$ & $(0.0186)$ & $(0.169)$ & $(0.0147)$ & $(0.130)$ & $(0.0553)$ \\
\hline \multirow[t]{2}{*}{$\beta 8$} & -0.0186 & & -0.00121 & 0.0235 & $0.714^{* * *}$ & $-0.0319 * * *$ & 0.0889 & 0.0551 \\
\hline & $(0.0844)$ & & $(0.00472)$ & (0.0169) & $(0.125)$ & $(0.00932)$ & $(0.141)$ & $(0.0922)$ \\
\hline \multirow[t]{2}{*}{$\beta 9$} & 0.0613 & & 0.00213 & 0.0171 & $0.598^{* * *}$ & $-0.0195^{* *}$ & 0.0224 & \\
\hline & $(0.0807)$ & & $(0.00589)$ & $(0.0169)$ & $(0.120)$ & (0.00939) & $(0.105)$ & \\
\hline \multirow[t]{2}{*}{$\beta 10$} & 0.121 & & & 0.0235 & $0.441^{* * *}$ & $-0.0180^{*}$ & 0.0471 & \\
\hline & $(0.0982)$ & & & $(0.0232)$ & $(0.102)$ & $(0.00972)$ & $(0.124)$ & \\
\hline \multirow[t]{2}{*}{$\beta 11$} & & & & 0.0209 & $0.235^{* * *}$ & $-0.0129^{*}$ & 0.0579 & \\
\hline & & & & $(0.0211)$ & $(0.0681)$ & $(0.00740)$ & $(0.120)$ & \\
\hline \multirow[t]{2}{*}{$\beta 12$} & & & & 0.0306 & $0.139^{*}$ & -0.00697 & 0.129 & \\
\hline & & & & $(0.0296)$ & $(0.0685)$ & $(0.00585)$ & $(0.152)$ & \\
\hline \multirow[t]{2}{*}{$\gamma 0$} & $-0.141^{* * *}$ & $-0.0807^{* * *}$ & $-0.0681^{* * *}$ & -0.00961 & -0.0579 & & -0.0593 & $-0.0889^{* * *}$ \\
\hline & $(0.0363)$ & $(0.0237)$ & $(0.0161)$ & $(0.00917)$ & $(0.0411)$ & & $(0.0363)$ & $(0.0133)$ \\
\hline \multirow[t]{2}{*}{$\gamma 1$} & & $-0.0532^{* *}$ & & & -0.0465 & & & $-0.0936^{* * *}$ \\
\hline & & $(0.0264)$ & & & $(0.0638)$ & & & $(0.0228)$ \\
\hline \multirow[t]{2}{*}{$\delta$} & $5.394 * * *$ & $9.977^{* * *}$ & $2.273^{* * *}$ & $2.395^{* * *}$ & $12.94 * * *$ & $-12.42^{* * *}$ & 0.979 & -0.343 \\
\hline & $(0.900)$ & $(1.073)$ & $(0.265)$ & $(0.400)$ & $(2.215)$ & (3.869) & (1.304) & (1.123) \\
\hline Observations & 61 & 64 & 62 & 60 & 29 & 50 & 60 & 42 \\
\hline$R$-squared & 0.628 & 0.702 & 0.787 & 0.330 & 0.921 & 0.690 & 0.659 & 0.747 \\
\hline $\begin{array}{l}\text { Adjusted } \\
R \text {-squared }\end{array}$ & 0.535 & 0.665 & 0.740 & 0.122 & 0.829 & 0.578 & 0.553 & 0.654 \\
\hline $\begin{array}{l}\text { Root-mean- } \\
\text { square error }\end{array}$ & 0.131 & 0.165 & 0.141 & 0.119 & 0.481 & 1.709 & 0.242 & 0.193 \\
\hline $\begin{array}{l}\text { Durbin-Watson } \\
\text { statistic }\end{array}$ & 0.380 & 0.376 & 0.488 & 0.180 & 1.017 & 0.112 & 0.602 & 0.767 \\
\hline
\end{tabular}

Note: ${ }^{*}$ significant at 10 percent; ${ }^{* *}$ significant at 5 percent; ${ }^{* * *}$ significant at 1 percent. 


\section{ANNEX 1.4. RESULTS OF THE BOND MARKET MODEL}

$$
\begin{aligned}
\frac{I_{t}}{K_{t-1}}= & \alpha+\beta_{1} \text { cbond }_{t-1}+\beta_{2} \text { rlrate }_{t-1}+\beta_{3} \text { Inuncer }_{t-1}+\beta_{4} \text { leverage }_{t-1}+\beta_{5} \text { cash flow }_{t-1} \\
& +\sum_{i=1}^{N} \gamma_{i} \frac{\Delta Y_{t-i}}{K_{t-1}}+\beta_{6} f_{t}+\varepsilon_{t}
\end{aligned}
$$

\begin{tabular}{|c|c|c|c|c|c|c|c|c|}
\hline \multicolumn{9}{|c|}{ Bond Market Model (Controlling for Output Changes and Financial Constraints) } \\
\hline & Euro Area & Germany & Spain & France & Greece & Ireland & Italy & Portugal \\
\hline \multirow[t]{2}{*}{$\alpha$} & $3.554^{* * *}$ & $2.014^{* * *}$ & $1.956^{* * *}$ & $2.674^{* * *}$ & $10.102^{* * *}$ & $15.715^{* * *}$ & $4.692^{* * *}$ & $7.379^{* * *}$ \\
\hline & $(0.577)$ & $(0.578)$ & (0.226) & $(0.443)$ & $(1.205)$ & (3.069) & $(0.382)$ & $(0.732)$ \\
\hline \multirow[t]{2}{*}{$\beta 1$} & -0.0004 & $-0.001^{*}$ & $-0.002^{* * *}$ & -0.0004 & 0.0002 & $-0.008^{* * *}$ & 0.0003 & -0.001 \\
\hline & $(0.0005)$ & $(0.0004)$ & $(0.0003)$ & $(0.0005)$ & $(0.001)$ & $(0.003)$ & $(0.0004)$ & $(0.001)$ \\
\hline \multirow[t]{2}{*}{$\beta 2$} & $0.089^{* *}$ & $0.067^{* *}$ & $0.038^{* * *}$ & 0.013 & -0.012 & 0.094 & $-0.07^{* * *}$ & 0.06 \\
\hline & $(0.036)$ & $(0.025)$ & $(0.013)$ & $(0.032)$ & $(0.031)$ & $(0.056)$ & $(0.015)$ & $(0.036)$ \\
\hline \multirow[t]{2}{*}{$\beta 3$} & $-0.003^{* * *}$ & -0.0003 & $-0.001^{*}$ & 0.0004 & $-0.012^{* * *}$ & $-0.027^{* * *}$ & $-0.003^{* * *}$ & 0.0001 \\
\hline & $(0.001)$ & $(0.001)$ & $(0.0004)$ & $(0.0004)$ & $(0.002)$ & $(0.005)$ & $(0.0005)$ & $(0.001)$ \\
\hline \multirow[t]{2}{*}{$\beta 4$} & 0.005 & -0.003 & $0.006^{* * *}$ & $-0.007^{* *}$ & $0.01^{* * *}$ & $0.033^{* * *}$ & $-0.005^{*}$ & $-0.043^{* * *}$ \\
\hline & $(0.004)$ & $(0.002)$ & $(0.002)$ & $(0.003)$ & $(0.003)$ & $(0.006)$ & $(0.003)$ & $(0.013)$ \\
\hline \multirow[t]{2}{*}{$\beta 5$} & -0.019 & $0.077^{* *}$ & $0.01^{* * *}$ & -0.01 & -0.065 & -0.15 & 0.018 & $-0.047^{*}$ \\
\hline & $(0.03)$ & $(0.036)$ & $(0.003)$ & $(0.06)$ & $(0.053)$ & $(0.189)$ & $(0.018)$ & $(0.025)$ \\
\hline \multirow[t]{2}{*}{$\beta 6$} & $0.203^{* * *}$ & $0.109^{* *}$ & $0.293^{* * *}$ & -0.115 & $0.72^{* * *}$ & 0.008 & $0.333^{* * *}$ & $-0.215^{*}$ \\
\hline & $(0.065)$ & $(0.045)$ & $(0.094)$ & $(0.092)$ & $(0.216)$ & $(0.198)$ & $(0.065)$ & $(0.117)$ \\
\hline \multirow[t]{2}{*}{$\beta 7$} & $0.091^{* *}$ & $0.165^{* *}$ & $0.308^{* *}$ & -0.008 & $0.814^{* * *}$ & 0.362 & $0.194^{* * *}$ & $-0.277^{*}$ \\
\hline & $(0.043)$ & $(0.073)$ & $(0.115)$ & $(0.071)$ & $(0.209)$ & $(0.225)$ & $(0.065)$ & $(0.159)$ \\
\hline \multirow[t]{2}{*}{$\beta 8$} & $0.182^{* * * *}$ & $0.385^{* * *}$ & $0.209^{* * *}$ & $0.205^{* * *}$ & $1.012^{* * *}$ & $0.502^{* *}$ & $0.26^{* * *}$ & -0.237 \\
\hline & $(0.064)$ & $(0.076)$ & $(0.076)$ & $(0.063)$ & $(0.206)$ & $(0.231)$ & $(0.073)$ & $(0.139)$ \\
\hline \multirow[t]{2}{*}{$\beta 9$} & $0.203^{* * *}$ & $0.302^{* * *}$ & -0.044 & $0.205^{* *}$ & $0.751 * * *$ & $0.871^{* * *}$ & $0.137^{* *}$ & -0.145 \\
\hline & $(0.058)$ & $(0.063)$ & $(0.076)$ & $(0.082)$ & $(0.152)$ & $(0.228)$ & $(0.058)$ & $(0.092)$ \\
\hline \multirow[t]{2}{*}{$\beta 10$} & $0.118^{*}$ & $0.184^{* * *}$ & $0.327^{* * *}$ & & $1.171^{* * *}$ & $0.608^{*}$ & $0.138^{* *}$ & -0.09 \\
\hline & $(0.061)$ & $(0.054)$ & $(0.096)$ & & $(0.142)$ & $(0.327)$ & $(0.054)$ & $(0.074)$ \\
\hline \multirow[t]{2}{*}{$\beta 11$} & 0.047 & 0.148 & $0.345^{* * *}$ & & $0.965^{* * *}$ & 0.445 & $0.116^{*}$ & -0.147 \\
\hline & $(0.071)$ & $(0.091)$ & $(0.102)$ & & $(0.225)$ & $(0.32)$ & $(0.059)$ & $(0.104)$ \\
\hline \multirow[t]{2}{*}{$\beta 12$} & 0.041 & 0.115 & 0.093 & & $0.549^{* * *}$ & 0.446 & $0.132^{* *}$ & $-0.206^{*}$ \\
\hline & $(0.051)$ & $(0.09)$ & $(0.065)$ & & $(0.168)$ & $(0.315)$ & $(0.063)$ & $(0.116)$ \\
\hline \multirow[t]{2}{*}{$\beta 13$} & 0.047 & $0.199^{* *}$ & -0.048 & & & $0.493^{*}$ & 0.105 & $-0.186^{*}$ \\
\hline & $(0.073)$ & $(0.077)$ & $(0.064)$ & & & $(0.263)$ & $(0.075)$ & $(0.102)$ \\
\hline \multirow[t]{2}{*}{$\beta 14$} & $0.165^{* * *}$ & $0.215^{* *}$ & $0.153^{*}$ & & & 0.185 & $0.107^{*}$ & 0.099 \\
\hline & $(0.056)$ & $(0.1)$ & $(0.087)$ & & & $(0.182)$ & $(0.058)$ & $(0.088)$ \\
\hline \multirow[t]{2}{*}{$\beta 15$} & & $0.218^{* * *}$ & $0.176^{* * *}$ & & & 0.34 & 0.092 & $0.184^{* *}$ \\
\hline & & $(0.07)$ & $(0.057)$ & & & $(0.389)$ & $(0.06)$ & $(0.065)$ \\
\hline \multirow[t]{2}{*}{$\beta 16$} & & 0.112 & & & & 0.408 & 0.107 & $0.214^{* * *}$ \\
\hline & & $(0.08)$ & & & & $(0.339)$ & $(0.067)$ & $(0.065)$ \\
\hline \multirow[t]{2}{*}{$\beta 17$} & & & & & & & $0.1^{*}$ & $0.131^{* *}$ \\
\hline & & & & & & & $(0.058)$ & $(0.06)$ \\
\hline \multirow[t]{2}{*}{$\beta 18$} & 0.029 & $0.137^{* * *}$ & -0.011 & -0.005 & -0.005 & & $-0.034^{* * *}$ & $-0.07^{* * *}$ \\
\hline & $(0.017)$ & $(0.024)$ & $(0.012)$ & $(0.005)$ & $(0.022)$ & & $(0.007)$ & $(0.015)$ \\
\hline Observations & 59 & 55 & 59 & 59 & 54 & 46 & 59 & 40 \\
\hline$R$-squared & 0.88 & 0.84 & 0.98 & 0.68 & 0.94 & 0.93 & 0.97 & 0.94 \\
\hline $\begin{array}{l}\text { Durbin-Watson } \\
\text { statistic }\end{array}$ & 0.71 & 1.26 & 1.55 & 0.5 & 1.57 & 1.09 & 1.71 & 1.19 \\
\hline
\end{tabular}

ANNEX TABLE 1.4.1

Note: ${ }^{*}$ significant at 10 percent; ${ }^{* *}$ significant at 5 percent; ${ }^{* * *}$ significant at 1 percent. 

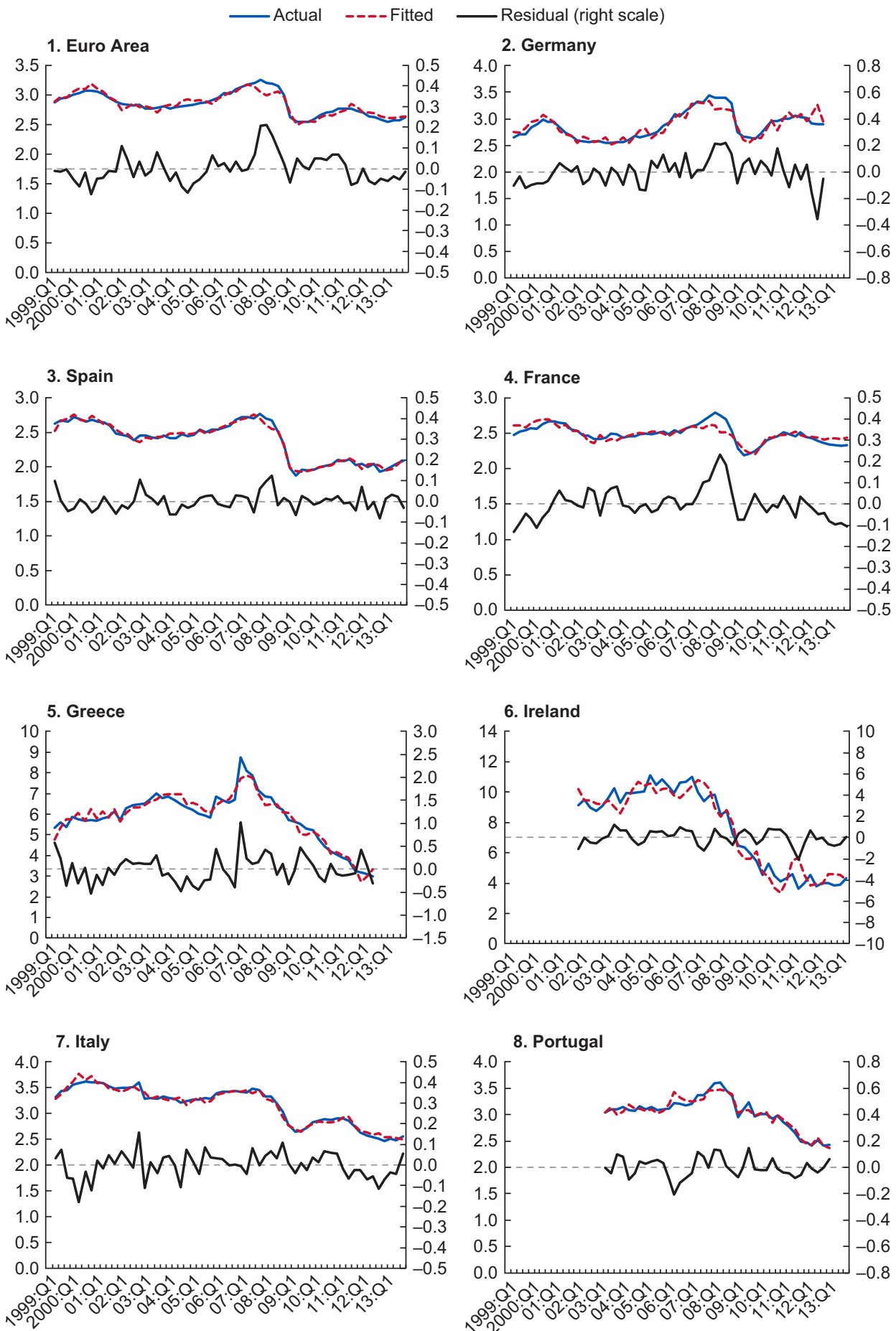

Sources: Annual Macroeconomic Database; Eurostat; Haver Analytics; and IMF staff estimates.

Annex Figure 1.4.1 Bond Market Model (Controlling For Output Changes and Financial Constraints) 


\section{REFERENCES}

Bloom, Nick. 2009. “The Impact of Uncertainty Shocks.” Econometrica 77 (3): 623-85.

Caballero, Ricardo. 1994. "Small Sample Bias and Adjustment Costs." Review of Economics and Statistics 76 (1): 52-58.

Clark, J. M. 1917. "Business Acceleration and the Law of Demand: A Technical Factor in Economic Cycles." Journal of Political Economy 25 (3): 217-35.

European Central Bank. 2014. "Data of Survey on the Access to Finance of Enterprises in the Euro Area (SAFE)." Available at: https://www.ecb.europa.eu/stats/money/surveys/sme/html/index.en.html. Accessed June 2014.

European Commission. 2014. "EC Business and Consumer Survey." Available via HAVER Analytics. Accessed June 2014.

Hayashi, Fumio. 1982. “Tobin's Marginal q and Average q: A Neoclassical Interpretation.” Econometrica 50 (1): 213-24.

International Monetary Fund (IMF). 2014a. "Perspectives on Global Real Interest Rates." In World Economic Outlook: Recovery Strengthens, Remains Uneven. Washington, DC: International Monetary Fund. DC.

Jorgenson, D. W. 1971. “Econometric Studies of Investment Behavior: A Survey.” Journal of Economic Literature 9 (4): 1111-47.

Laeven, Luc, and Fabian Valencia. 2012. “Systemic Banking Crises Database: An Update.” Working Paper 12/63, International Monetary Fund, Washington, DC.

Lee, Jaewoo, and Pau Rabanal. 2010. "Forecasting U.S. Investment.” Working Paper 10/246, International Monetary Fund, Washington, DC.

Oliner, Stephen, Glenn Rudebusch, and Daniel Sichel. 1995. "New and Old Models of Business Investment: A Comparison of Forecasting Performance." Journal of Money, Credit, and Banking 27 (3): 806-26.

Pérez Ruiz, Esther. 2014. "France, Selected Issues_-The Drivers of Business Investment in France: Reasons for Recent Weakness.” Country Report No. 14/183, International Monetary Fund, Washington, DC.

Philippon, Thomas. 2009. “The Bond Market's Q.” Quarterly Journal of Economics 124 (3): 1011-56.

Pina, Alvaro, and Ildeberta Abreu. 2012. "Portugal: Rebalancing the Economy and Returning to Growth through Job Creation and Better Capital Allocation.” Economics Department Working Paper 994, Organisation for Economic Co-operation and Development, Paris.

Tobin, James. 1969. "A General Equilibrium Approach to Monetary Theory." Journal of Money, Credit and Banking 1 (1): 15-29. 


\title{
Indebtedness and Deleveraging in the Euro Area
}

\author{
FABIAN BORNHORST AND MARTA RUIZ-ARRANZ
}

High debt in the euro area is weighing on growth. Countries that experienced a rapid increase in private sector debt in the run-up to the global financial crisis of 2008-09 have had worse economic outcomes - some are still in the middle of deep recessions, and their medium-term growth outlooks are weak.

Balance sheet adjustment in the euro area at the current juncture may prove more challenging than in other regions or in other episodes in the past. The simultaneous deleveraging of the public and private sectors in some countries appears increasingly daunting. And a fragmented financial sector with its own balance sheet problems amplifies the effect of private sector balance sheet stress on economic outcomes. Furthermore, the significant heterogeneity across countries in the euro area suggests that a one-size policy mix is unlikely to fit all. Countries in need of adjustment may be constrained by a common monetary and exchange rate policy, leaving them little space to maneuver. Finally, simultaneous deleveraging in several euro area members can lead to negative spillover effects, further amplifying the negative impact of country-specific deleveraging on economic activity.

This chapter evaluates indebtedness in the euro area and its implications for growth. It asks the following questions: Why does private sector indebtedness matter for growth? In which euro area countries is private sector indebtedness and leverage high? What do we know from past deleveraging experiences and what lessons can be drawn for the euro area? The next section of this chapter outlines how balance sheet stress can arise from high indebtedness and discusses the feedback loops at play across sectors. The third section takes stock of indebtedness across the euro area, identifying vulnerabilities across sectors and countries. The fourth section looks at historical episodes to gauge the extent of deleveraging that can be expected and the macroeconomic environment that supported previous deleveraging episodes. It also presents econometric evidence linking high debt in the private and public sector to growth outcomes. The fifth section offers policy considerations for the euro area.

\section{WHY DEBT MATTERS}

This section discusses balance sheet stress analysis and diagnosis.

\section{Balance Sheet Stress}

Indebted private sector agents are more susceptible to reacting to sudden asset price shocks or increased volatility. Large and sudden drops or swings in asset prices (for example, houses or equities) can cause balance sheet stress in an environment of high debt, because liabilities remain unchanged as the valuation of assets falls or fluctuates. High debt makes agents more vulnerable to sudden changes in macroeconomic conditions (interest rates and growth), while changing

This chapter is based on Euro Area Policies: Article IV 2013 Consultation-Selected Issues, "Indebtedness and Deleveraging in the Euro Area," IMF Country Report 13/232, 2013. 


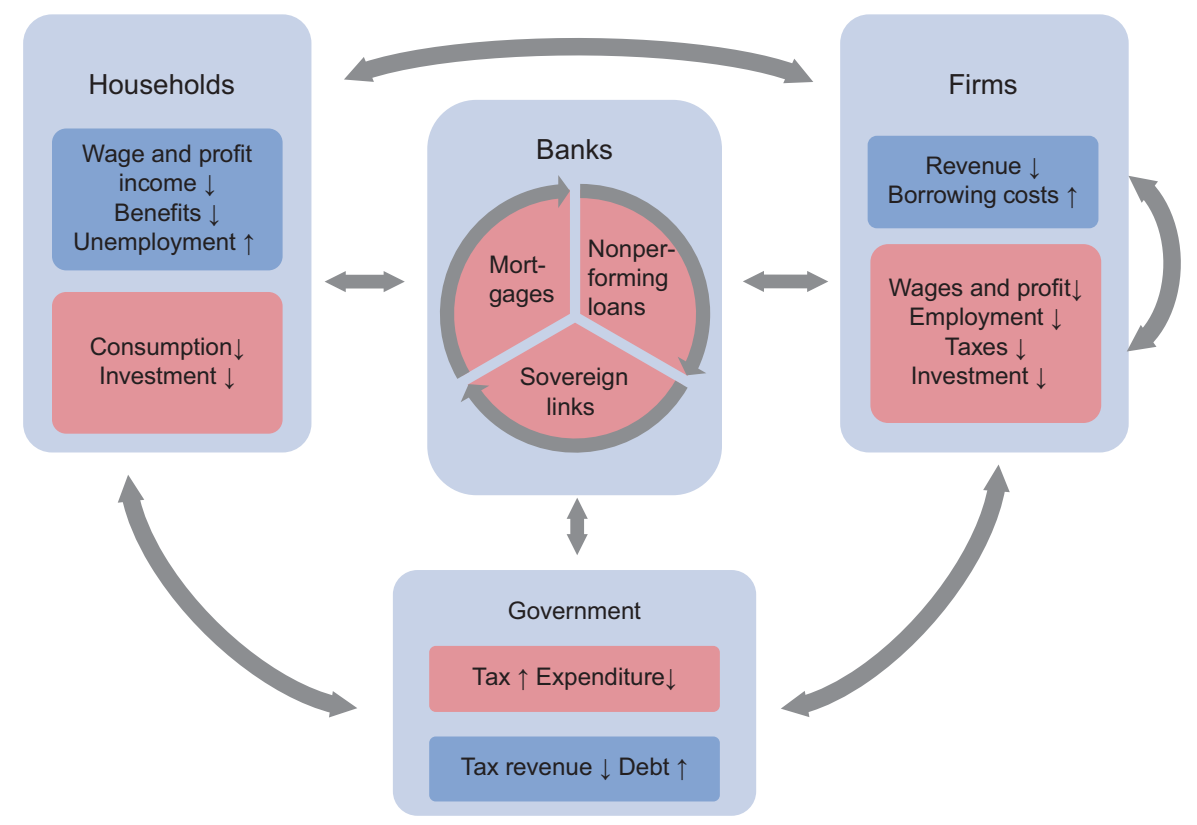

Note: NPLs = nonperforming loans.

Figure 2.1 Feedback Loops from Balance Sheet Effects

financing conditions make debt more difficult to roll over. Households and firms start focusing on repaying debt and strengthening their balance sheets (for example, by improving equity ratios or building liquidity buffers), while life-cycle consumption smoothing or expected returns on investment become secondary. This shift in behavior depresses demand and creates selfreinforcing feedback loops across sectors.

Thus, declines in asset prices have economy-wide consequences. Falling asset prices go beyond one sector of the economy because they affect both borrowers and creditors. For example, falling house prices reduce household wealth, decrease the value of collateral held by banks, increase nonperforming loans, and, when weak banks require public support, ultimately affect the public sector's balance sheet. Public finances are also affected by lower tax revenue derived from transactions in this asset (for example, stamp duties). Likewise, equity prices not only determine a firm's valuation (raising the cost of capital) and increase financial vulnerabilities such as the debt-toequity ratio, but they also determine the value of households' financial assets.

Feedback loops exacerbate downturns, particularly in cases of simultaneous deleveraging of the private, financial, and public sectors (Figure 2.1). The impact of asset price shocks has secondary effects. Faced with the need to repair balance sheets, agents give more importance to debt reduction than to profit maximization, which reduces economic activity and, in turn, exacerbates the initial drop in asset prices. Managing deleveraging becomes particularly challenging when all sectors of the economy, including the public and the financial sectors, deleverage simultaneously. This deleveraging can depress activity further because no sector is able to expand its balance sheet, even temporarily. The following feedback loops can be at play in a balance sheet recession with a weak financial sector:

- Indebted households that need to repair their balance sheets consume and invest less, reducing firms' profitability and the public sector's tax revenue.

- Firms faced with a slump in household demand begin to reduce their debt burdens by increasing margins, reducing wage costs, and scaling back investment. These actions, in turn, feed into lower household income through lower wages and higher unemployment, and into lower tax revenues. 
- The government's own consolidation effort requires higher taxes and lower spending, which reduces households' disposable income-exacerbating households' debt-servicing capacity and firm profitability. In turn, public balance sheet weakness limits the scope for further assistance to the financial sector (for example, through bank recapitalizations).

- The banking sector-faced with increasing nonperforming loans from households and firms and high exposure to a potentially weak sovereign—sees its capital being eroded. To rebuild its capital position, it tightens lending standards and increases lending rates, thereby depressing demand for investment and consumption loans.

\section{Diagnosing Balance Sheet Stress}

Gross debt matters, but so do other indicators. A sector's indebtedness is a key variable driving balance sheet stress and the ability of the sector to absorb shocks. However, focusing exclusively on gross debt is not sufficient. The level of indebtedness a sector can sustain varies across countries according to initial conditions, including the characteristics of the housing market or the degree of intermediation provided by the banking sector. Although scaling debt to income is useful for gauging a sector's capacity to service debt obligations, leverage ratios that link debt to assets are relevant for assessing debt in relation to a sector's own balance sheet. Assets, including housing and financial wealth, can also be important buffers because they allow agents to draw down savings and they are relevant in assessing debt sustainability. More important, because debt stocks tend to change slowly, financial flows can be useful for detecting changes in behavior that signal balance sheet stress. Such signals would happen, for example, when agents revert to financial surplus and when their debt-service burdens become too high relative to income. Other considerations that may alter the implications of the debt overhang include the characteristics of the debt profile, such as the composition, redemption profile, and structure of the investor base.

Analysis of aggregate balance sheet data has its limitations. It cannot identify pockets of vulnerability that may exist within sectors, and abstracts from distributional aspects. For example, assets and liabilities could be concentrated in different subsets of the population, and conclusions from an aggregate perspective can be misleading. This chapter provides an overview of indebtedness in the euro area, but it also takes into account more detailed country- and sector-specific analyses made available in other studies (IMF 2012a, 2012c, 2013c, 2013f; ECB 2013a).

\section{INDEBTEDNESS AND DELEVERAGING IN THE EURO AREA: STYLIZED FACTS}

This section discusses the debt levels for the euro area, the variation across countries, nonfinancial firms, households, financial sector, public debt, and economic outcomes of high debt.

\section{The Euro Area Debt Level}

Debt levels for the euro area as a whole are on par with those in the United States or the United Kingdom, but the deleveraging process has yet to translate into debt reduction (Figure 2.2). In the aggregate, household debt is lower than in the United States or the United Kingdom. Corporate debt appears to be higher in the euro area and the United Kingdom than in the United States, though important differences in the size of intercompany loans and trade credit complicate comparisons in levels. ${ }^{1}$ Government debt in the euro area is also at comparable levels, and increased less since 2003 than in the United States or the United Kingdom. The euro area also enjoys a comfortable net international investment position. Yet since 2009, the United States and the United Kingdom have seen reductions in household debt, and the United Kingdom has also

\footnotetext{
${ }^{1}$ See Cussen and O'Leary (2013) for a discussion of consolidated versus nonconsolidated corporate debt in the euro area.
} 


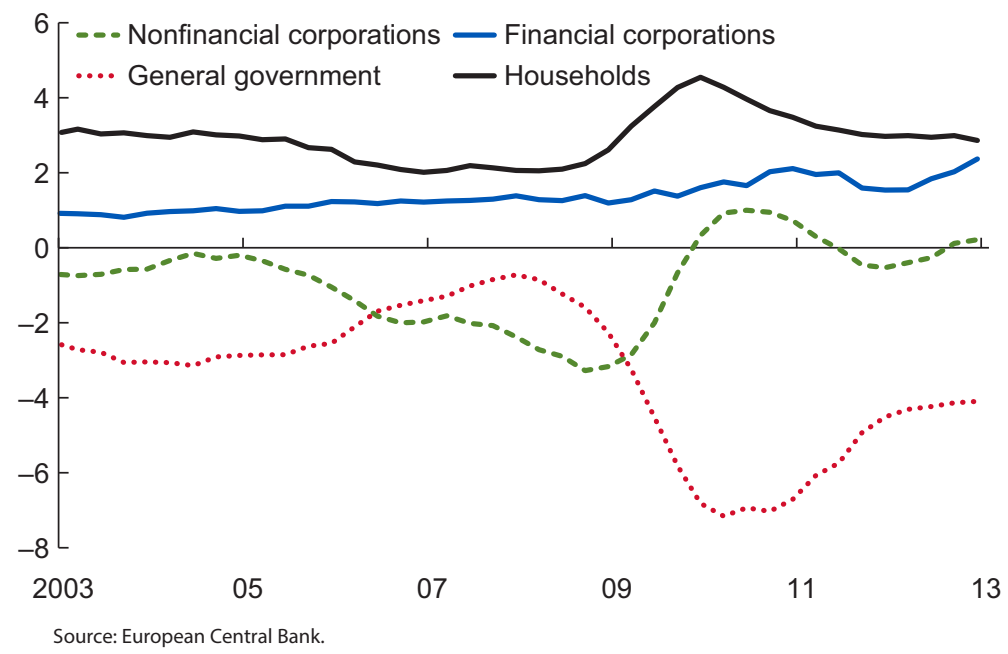

Figure 2.2 Euro Area: Net Lending/Borrowing (By sector, percent of GDP)

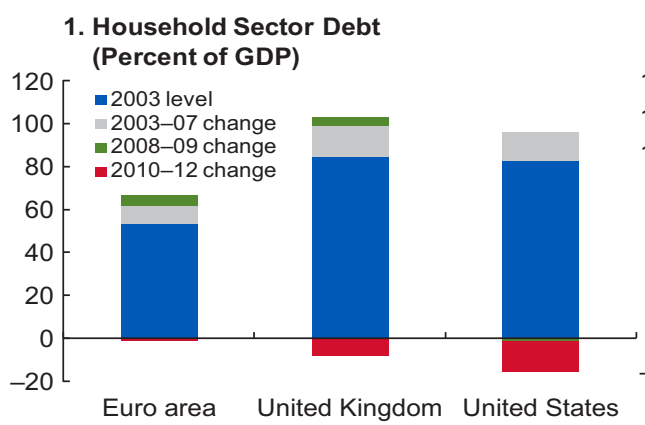

3. General Government Debt (Percent of GDP)

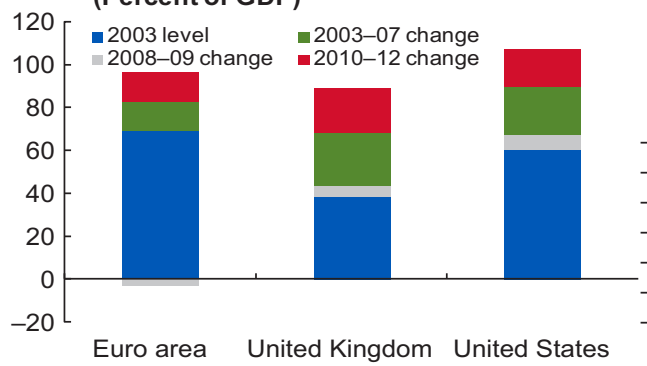

2. Nonfinancial Corporate Sector Debt (Percent of GDP)

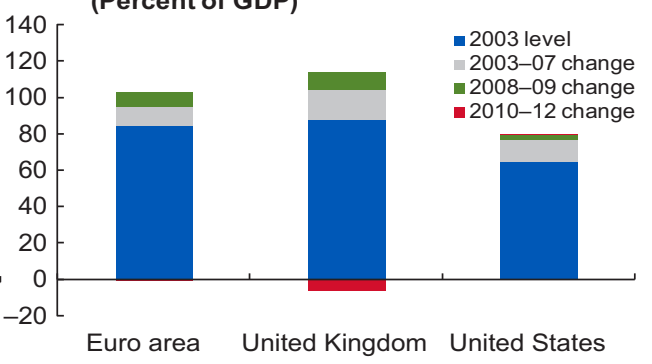

4. Net International Investment Position

(Percent of GDP)

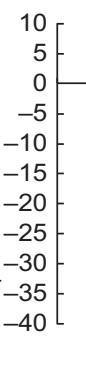

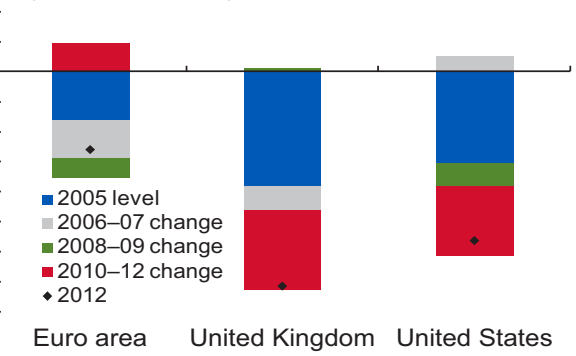

Sources: European Central Bank; Haver Analytics; IMF International Financial Statistics; and IMF World Economic Outlook. Note: Includes intercompany loans and trade credit, which can differ significantly across countries.

Figure 2.3 Indebtedness in the Euro Area, the United States, and the United Kingdom

experienced a reduction in corporate debt, whereas the deleveraging process in the euro area has not yet translated into an area-wide reduction in debt. Looking at flows in the euro area shows the private sector's deleveraging effort, with firms and households in a contractionary net lending position vis-à-vis other sectors (Figure 2.3; ECB 2013a).

\section{Variation across Countries}

Indebtedness varies across countries and sectors (Figure 2.4). Since early in the first decade of the 2000s, private and public debt have increased most sharply in countries now under stress. Debt 


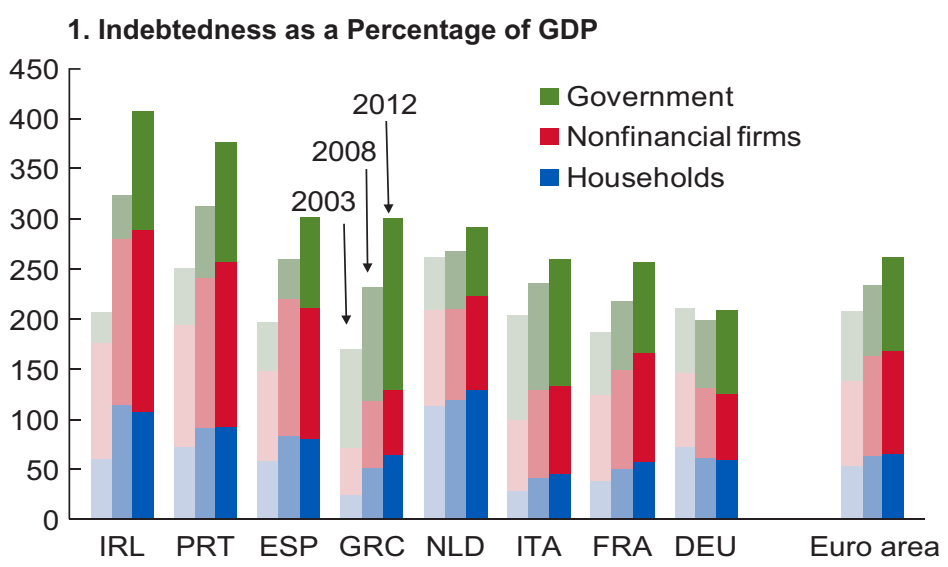

\section{Indebtedness above 60th Percentile (By country and sector, in sphere if debt higher than 60th percentile)}

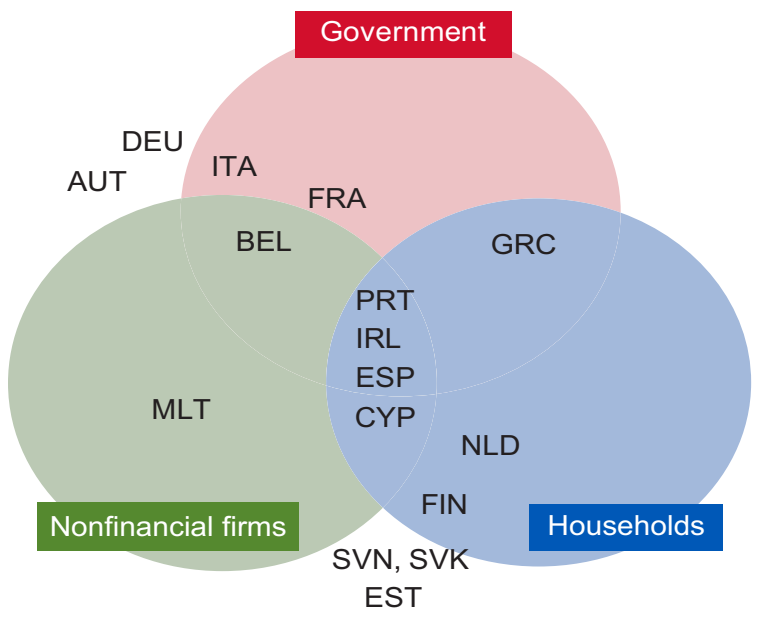

Sources: European Central Bank; Haver Analytics; and IMF staff estimates.

Note: Data labels in the figure use International Organization for Standardization (ISO) country codes.

Figure 2.4 Indebtedness across the Euro Area

is particularly high in Ireland, Portugal, and Spain, where households, the nonfinancial corporate sector, and the government are all highly indebted compared with their euro area peers. In addition, a number of other countries have high debt in one or two sectors. ${ }^{2}$ And when all sectors are highly indebted, sizable net external liabilities have accumulated.

\section{Nonfinancial Firms}

This section focuses on the corporate debt and leverage, as well as corporate insolvencies and vulnerabilities.

\section{Corporate debt and leverage}

Corporate indebtedness and leverage have increased. Indebtedness of euro area firms increased substantially in the first decade of the Economic and Monetary Union (EMU), as a consequence

\footnotetext{
${ }^{2}$ See Cuerpo and others (2013) for an identification of countries currently facing private sector deleveraging pressures based on various indebtedness indicators. For an overview, see Buiter and Rahbari (2012) and McKinsey (2012).
} 
1. Nonfinancial Corporate Sector Debt (Percent of GDP)

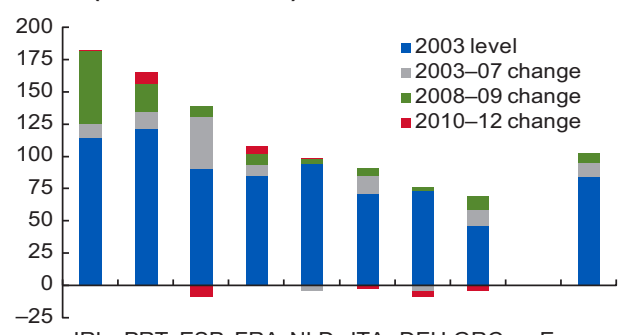

IRL PRT ESP FRA NLD ITA DEU GRC Euro area

\section{Corporate Leverage in the Euro Area} (Nonfinancial firms, debt-to-equity ratio, percent)

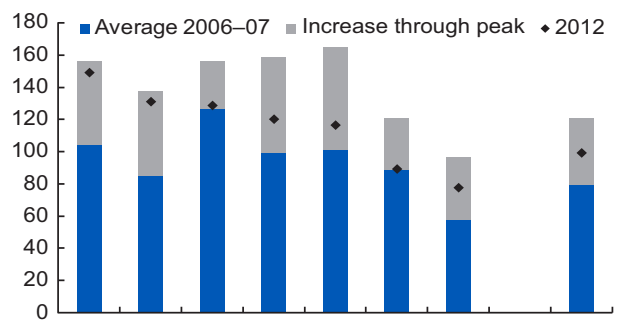

PRT ITA IRL ESP DEU NLD FRA Euro area

\section{Increase in Corporate Insolvencies} (2008-12 growth, in percent, by sector)

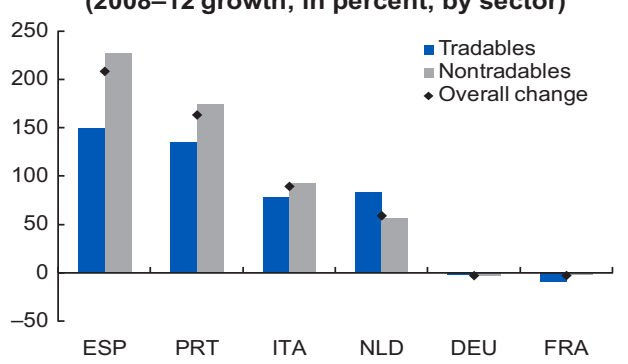

Sources: European Central Bank; Haver Analytics; IMF staff calculations; Creditreform 2012; and IMF staff estimates.

Note: First observations for the Netherlands are 2005. Data labels in the figure use International Organization for Standardization (ISO) country codes.

Figure 2.5 Corporate Debt

of low real interest rates and prospects of high growth. Higher bank debt, combined with falling equity valuations, has boosted corporate leverage during the crisis, threatening debt sustainability. Although firms' leverage ratios have more recently fallen, they remain elevated in a number of countries (Figure 2.5, panels 1 and 2). Firm-level data suggest that in some euro area economies up to 20 percent of corporate debt may not be sustainable (IMF 2013e).

Procyclical financial conditions are weighing on corporate balance sheets. Higher bank lending rates resulting from financial fragmentation are felt strongly in the bank-dependent small and medium-sized enterprise (SME) segment, which has a large share in value added. Lending conditions are tight, further reducing available financing for solvent firms.

\section{Corporate insolvencies and vulnerabilities}

Insolvencies have increased markedly where corporate debt is high (Figure 2.5, panels 3 and 4). In most crisis economies, the increase in insolvencies in the nontradables sector is somewhat higher than in the tradables sector, indicative of initial stages of economic rebalancing. This increase is noteworthy in view of the fact that, despite recent reforms, insolvency regimes in many euro area countries are generally lengthy and costly, and the recovery rate of claims is very low (Figure 2.6; World Bank 2013).

Pockets of vulnerability remain in the corporate sector. Although the overall level of indebtedness in some countries may not be alarmingly high, high debt increases the vulnerability of firms to changes in the business cycle, including interest rate fluctuations (ECB 2012). In addition, a confluence of other factors can make indebted firms more vulnerable. In Spain, corporate indebtedness problems are concentrated in the real estate and construction sectors, where firms are highly leveraged and very reliant on bank financing. However, firms in other sectors are also highly leveraged, making them vulnerable to interest rate and earnings shocks. In 2010, about a quarter of a sample of 7,000 firms were financially distressed (IMF 2012c). In Portugal, firm 

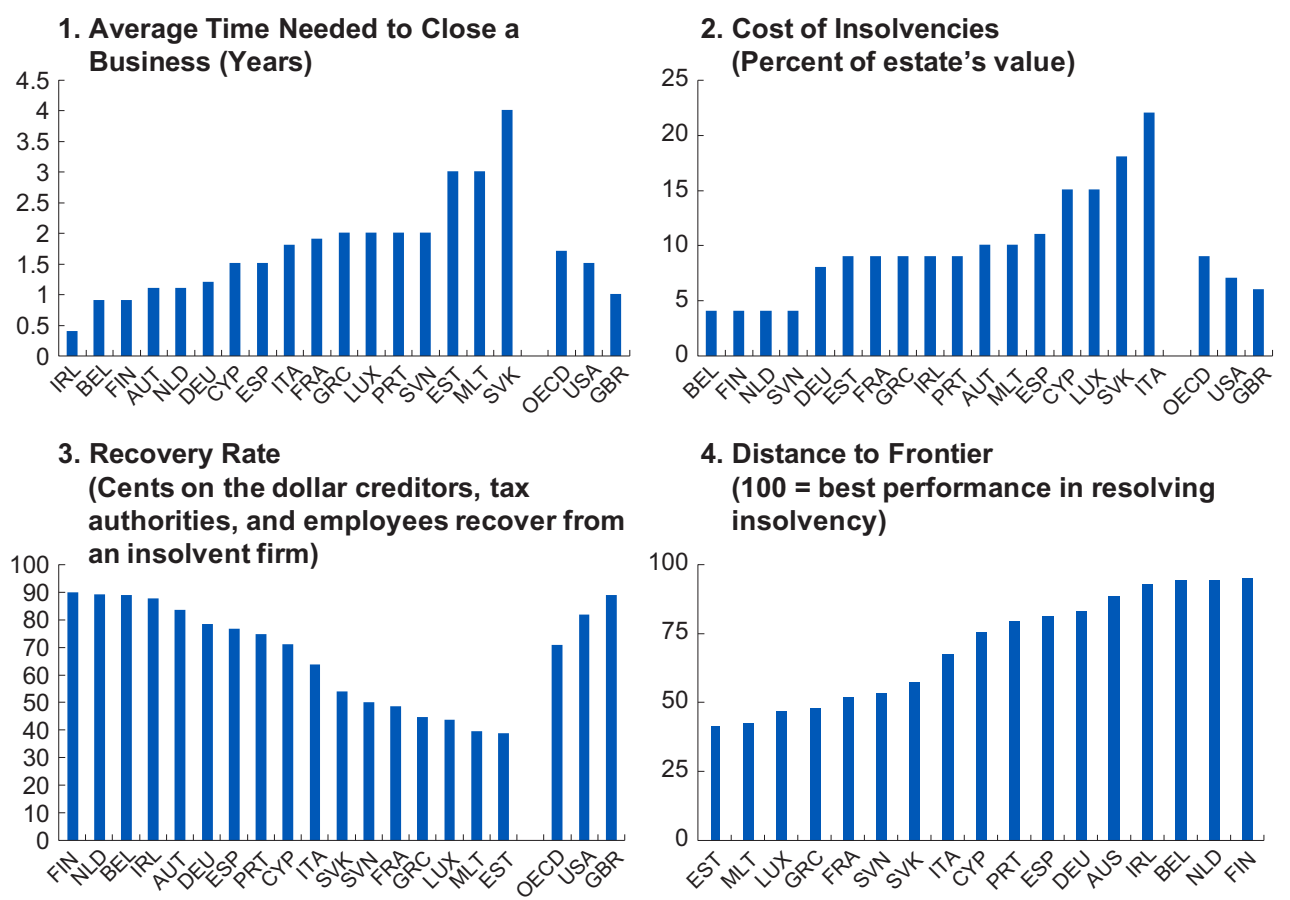
(100 $=$ best performance in resolving insolvency)

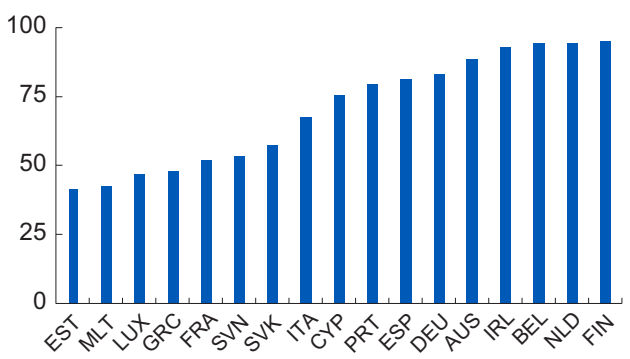

Source: World Bank 2013.

Note: Data labels in the figure use International Organization for Standardization (ISO) country codes.

Figure 2.6 Insolvency Regimes

profitability is low, particularly for SMEs and micro-firms, which account for nearly two-thirds of corporate value added. As a result, the share of debt at risk is increasing, with 20 percent of firms in financial distress, concentrated in the nontradables sector (IMF 2013f). In Italy, the corporate debt-to-income burden is not particularly high, but leverage is high and the sector relies heavily on short-term bank financing, in particular in the important SME sector (IMF 2013c).

\section{Households}

This section focuses on the household debt and the housing boom including the buffers and vulnerabilities.

\section{Household debt and the housing boom}

The turn of the housing cycle triggered sector-wide deleveraging where real estate bubbles had driven debt up (Figure 2.7), especially in those countries where declining real interest rates and rapidly rising incomes encouraged households to contract debt. Mortgages represent the largest share of household debt in euro area countries (Cussen, O'Leary, and Smith 2012), and they have been the most significant drivers in the increase of household debt since the start of the euro. When the housing boom burst in 2007-08, households were left with high debt and overvalued assets, in particular in Ireland and Spain. Although the price adjustment has gone far in some countries (for example, Ireland), house prices remain high in some others (Spain, France, and the Netherlands). ${ }^{3}$ As house prices began to adjust, households moved from a financial deficit to a financial surplus position. In Ireland and Spain, for example, households

\footnotetext{
${ }^{3} \mathrm{~A}$ full assessment of house prices would have to go beyond affordability ratios (price-to-income and price-to-rent ratios) and include other fundamentals, including supply constraints (IMF 2012c, 2013d, 2013e).
} 


\section{Household Sector Debt (Percent of GDP)}

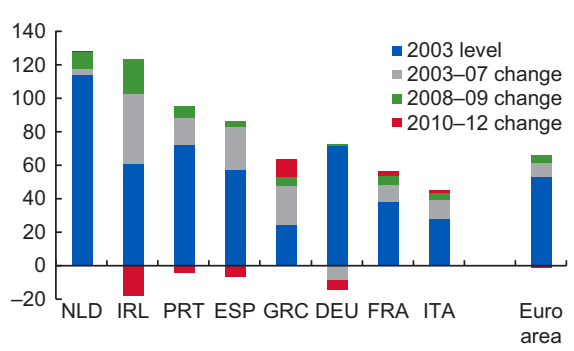

3. House Prices: Boom and Bust (Distance from long-term average of price-to-rent and price-to-income ratios)

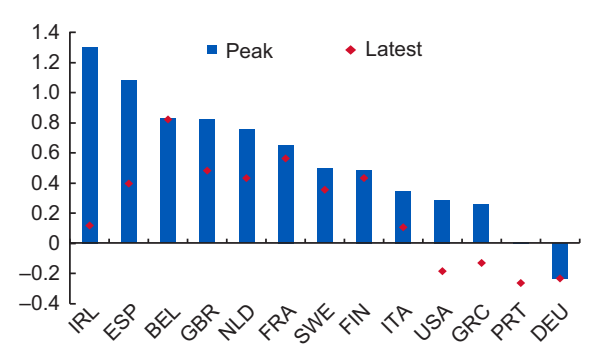

\section{Household Debt}

(Percent of GDP, long-term average $=100$, peak at $t=0$, quarters)

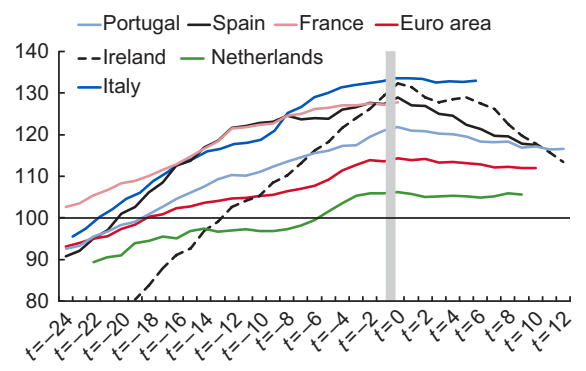

\section{House Price Adjustment and Household Net Borrowing}

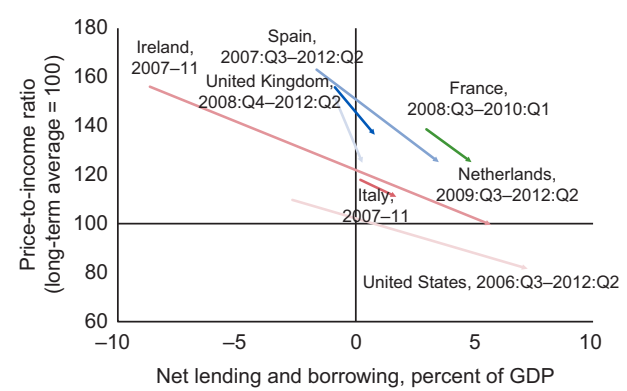

Sources: European Central Bank; and IMF staff estimates. Organisation for Economic Co-operation and Development; and IMF staff estimates. Note: First observations for the Netherlands are 2005. Data labels in the figure use International Organization for Standardization (ISO) country codes. Long-term average since 2000 but varies with data availability.

Figure 2.7 Household Debt

have now begun to dispose of financial assets and repay debt, and have slashed the acquisition of nonfinancial assets (Box 2.1). Despite these efforts to repair balance sheets, household debt continued to increase until 2009. It has since started to decline in Ireland and, to a lesser extent, in Portugal and Spain.

\section{Buffers and vulnerabilities}

Household assets are important buffers, but often illiquid. In Spain, for example, high levels of assets and low wealth dispersion - a result of high ownership rates-have been important mitigating factors, because households can dispose of assets to smooth consumption. However, in a depressed housing market with high owner-occupancy rates, disposing of housing wealth is often difficult. Indebted households have fewer liquid financial assets in countries such as Portugal, Spain, and Greece (Figure 2.8; ECB 2013b), although the sector as a whole has in many countries moved toward safe and liquid financial assets since the crisis (Cussen, O'Leary, and Smith 2012).

Household balance sheets are vulnerable to income uncertainty, further asset price corrections, and, down the road, interest rate increases. In most countries with high household debt, sustainability indicators such as debt-to-income ratios or debt-service-to-income ratios have deteriorated (Figure 2.8), owing to falling incomes, with young and low-income households particularly vulnerable. For example, in Spain, 22 percent of households are estimated to be vulnerable to stress, but the shares are much higher among poor and young households, where debt-service-to- 


\section{BOX 2.1. The Savings Rate and Household Balance Sheets}

The rise in the household saving rate during 2007-09 in many advanced economies can be explained by the sharp decline in asset prices and increase in fiscal deficits (Figure 2.1.1). ${ }^{1}$ The decrease in wealth associated with the decline in house and asset prices prompted households to decrease consumption and increase savings. In turn, the deterioration in the fiscal position had a strong positive impact on savings-partly reflecting Ricardian equivalence where the expectation of future tax increases drives households' savings relative to their income today.

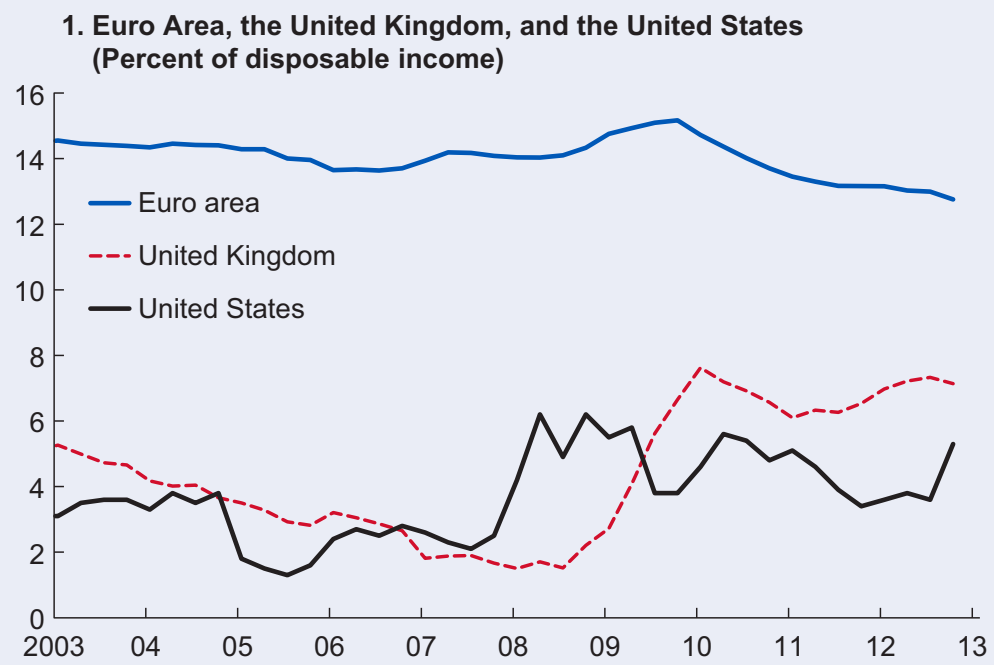

2. Select Euro Area Countries (Percent of disposable income)

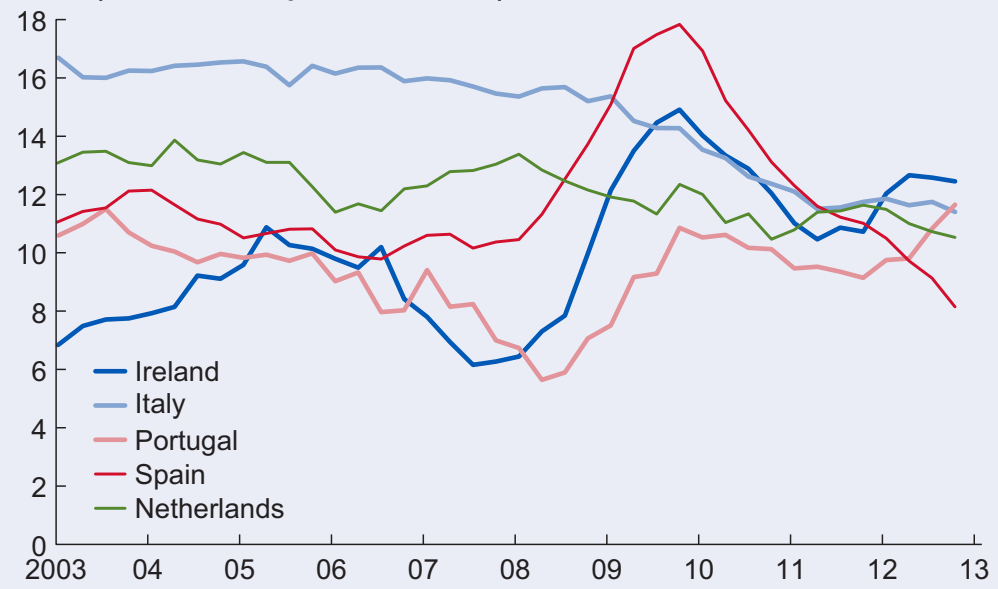

Sources: European Central Bank; and Haver Analytics.

Figure 2.1.1 Household Saving Rate

${ }^{1}$ Econometric results are based on a sample comprising Canada, France, Germany, Ireland, Italy, Japan, Spain, the United States, and the United Kingdom from 1980 through 2012. The correlates to explain household saving behavior include wealth, fiscal policy, interest rates, cyclical factors, and demographic factors (see IMF 2013b). 


\section{BOX 2.1. (continued)}

Since 2009, the deteriorating macroeconomic environment, lower disposable incomes, and higher unemployment have caused a decline in household savings (Figure 2.1.2). Cyclical factors such as higher unemployment lowered the household saving rate as households ran down accumulated assets to smooth consumption. In fact, before the crisis, households were acquiring financial and nonfinancial assets, and at the same time incurring debt. Since the crisis, households have slashed their acquisition of nonfinancial assets and are repaying debt by disposing of financial assets. In sum, households may still be saving a similar fraction of their incomes, but they are doing so by reducing their wealth and investing less, with negative consequences for the broader economy.

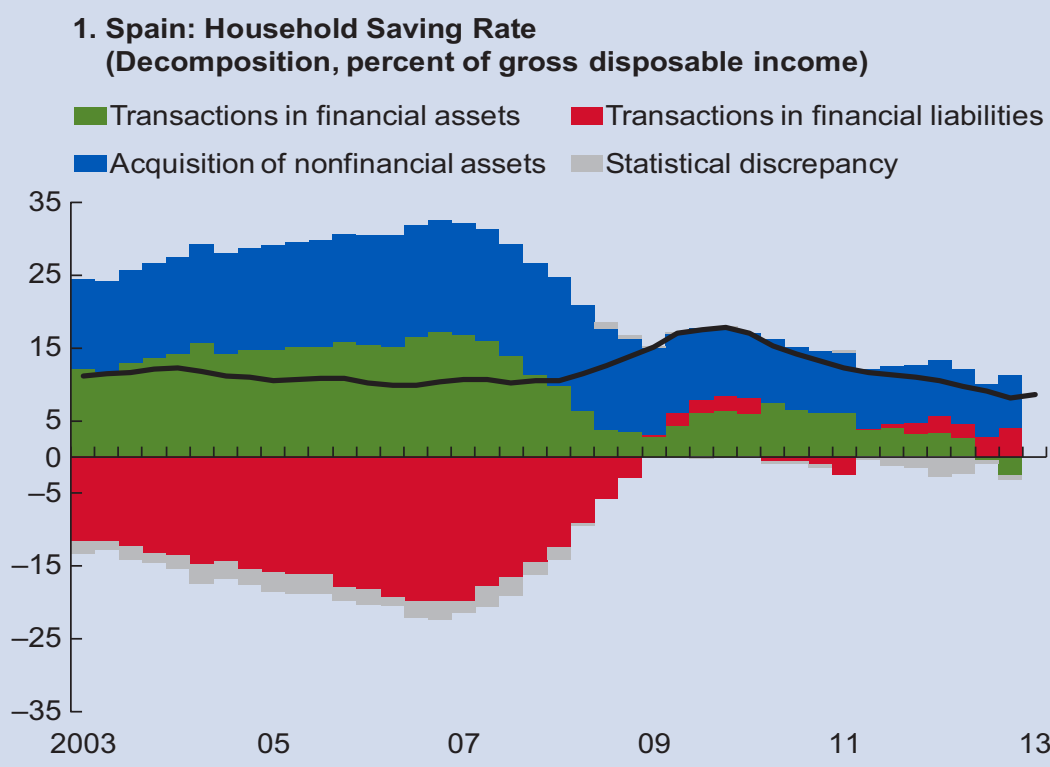

\section{Ireland: Household Saving Rate}

(Decomposition, percent of gross disposable income)

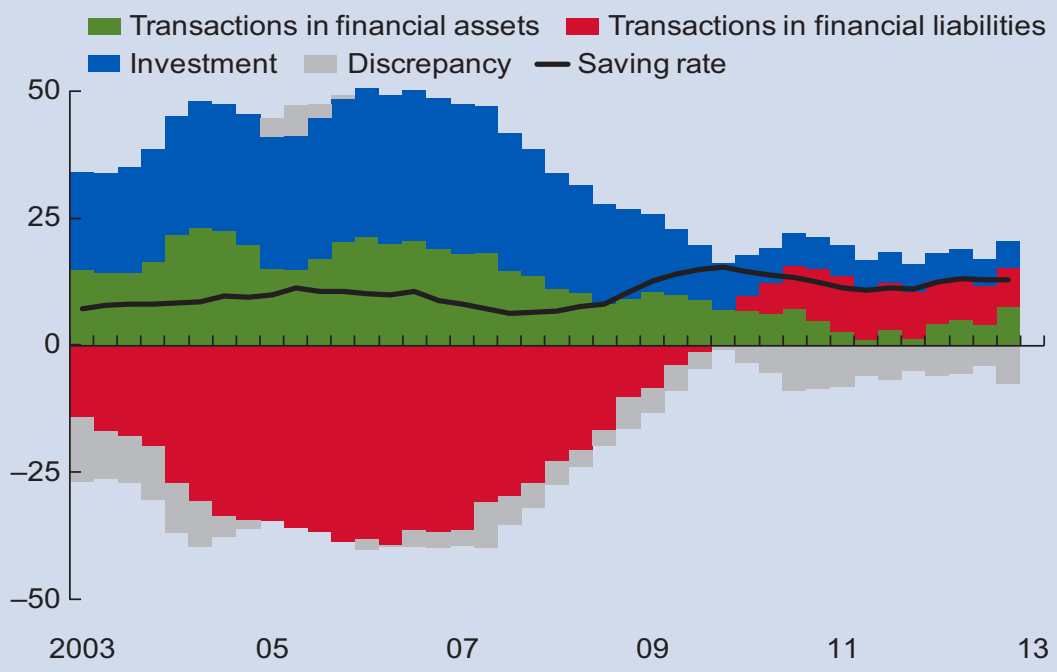

Sources: European Central Bank; Haver Analytics; and IMF staff estimates.

Figure 2.1.2 Financial Account Decomposition of the Household Saving Rate

\section{CInternational Monetary Fund. Not for Redistribution}



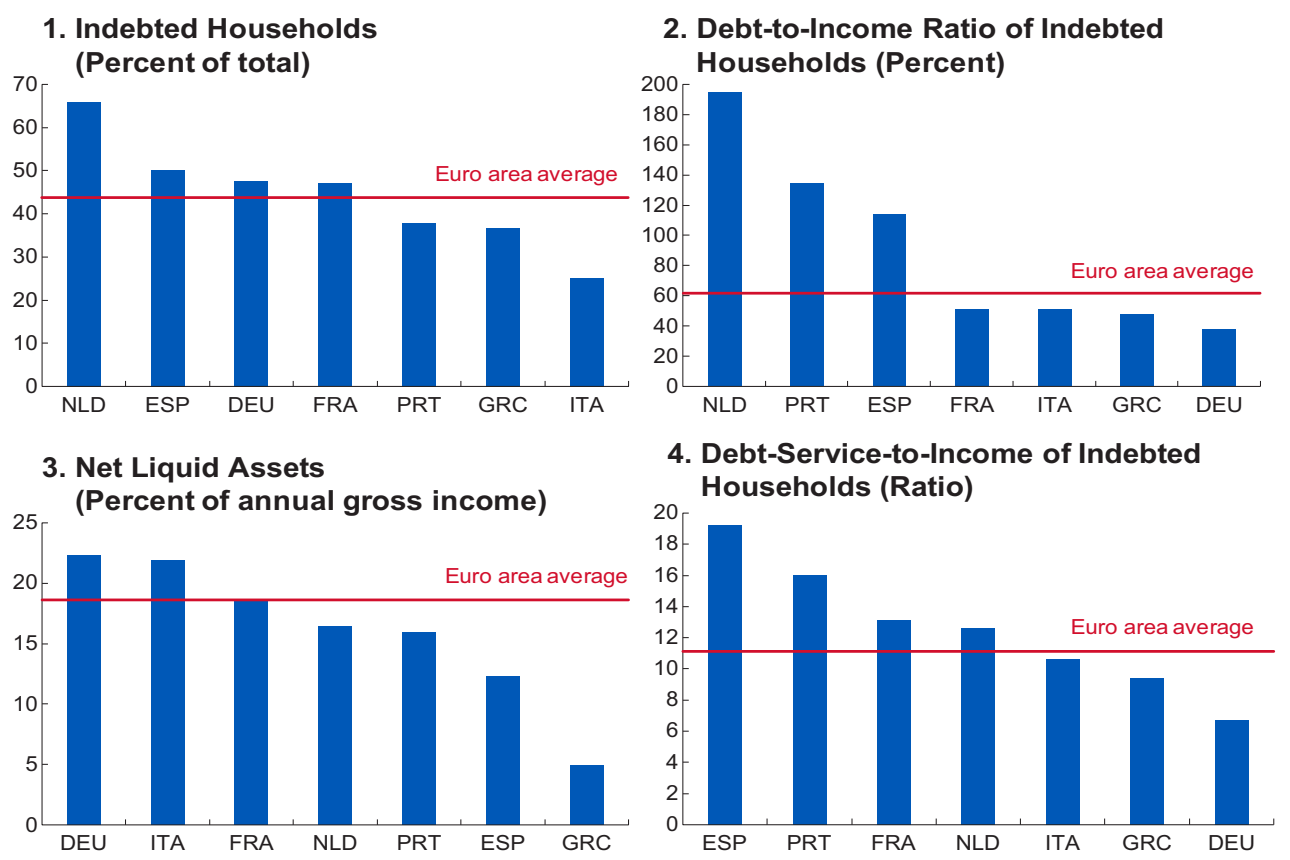

Source: European Central Bank.

Note: Data labels in the figure use International Organization for Standardization (ISO) country codes.

Figure 2.8 Household Balance Sheets: Survey Results

income ratios can reach 80 percent. The main risk for Spain arises from a further adjustment of house prices and an increase in interest rates given that most mortgages are indexed to the Euro Interbank Offered Rate (IMF 2012c). In the Netherlands, house prices are still overvalued based on a range of metrics, and young cohorts would be especially vulnerable to a further drop in prices (IMF 2013d).

\section{Financial Sector}

In many euro area countries, highly leveraged financial sectors impair intermediation and burden the sovereign. In several economies banks had traditionally relied on wholesale funding, and built large exposures to sovereigns and the real estate market (IMF 2013a). The share of nonperforming loans (NPLs) - both from households and firms — has risen rapidly, increasing uncertainty about the quality of banks' assets, and in turn increasing funding costs and driving share prices down (Figure 2.9). In a fragmented European financial market, such banks face an uphill battle to strengthen their capital positions so as to provision for NPLs, buffer their sovereign exposure, and meet new regulatory requirements.

\section{Public Debt and the Migration of Debt}

Debt migration from the private to the public sector has played an important buffer role in the euro area. In the boom phase, the private sector, in particular financial firms, increased their indebtedness while governments were able to reduce debt. As the private sector entered the deleveraging cycle, debt migrated to the public sector-through bank recapitalization or debtfinanced fiscal demand support-while other sectors moved to reduce their debt burdens 


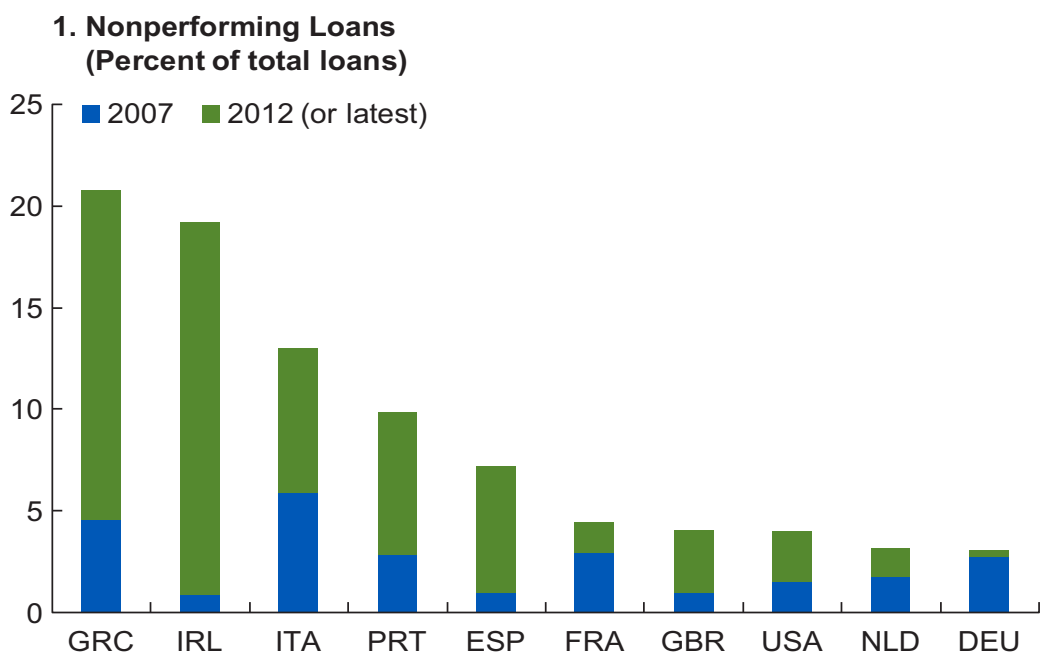

2. Return on Equity (Percent)

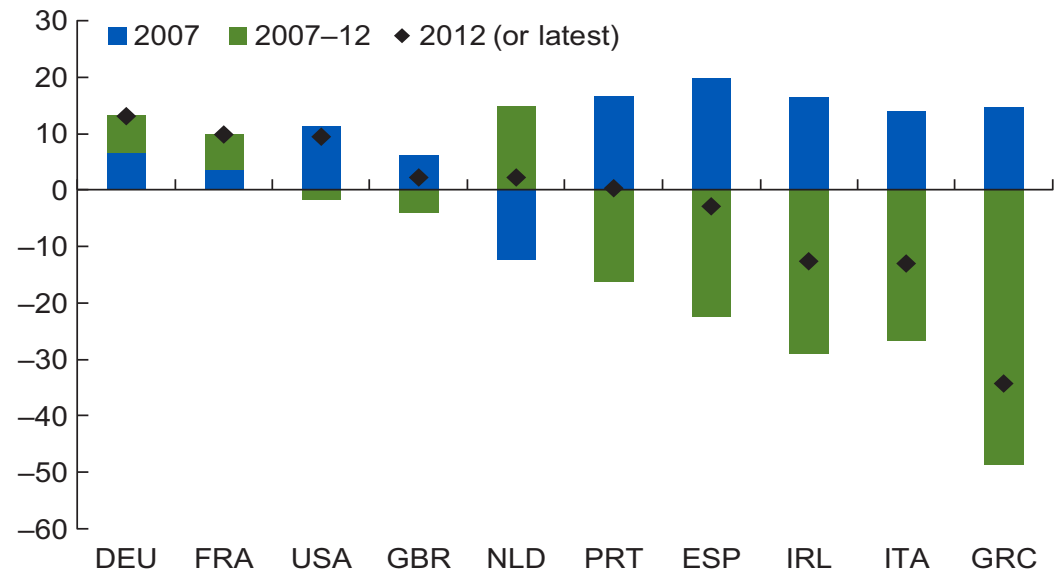

Sources: IMF Financial Soundness Indicators.

Note: Data labels in the figure use International Organization for Standardization (ISO) country codes.

Figure 2.9 A Weak Financial Sector

(Figures 2.10 and 2.11). However, with savings being lower than investment across all sectors for a number of years, many economies accumulated sizable external debt (Figure 2.12).

\section{High Debt and Economic Outcomes}

Balance sheet stress has been associated with weaker economic outcomes (Figure 2.13). In countries where private sector debt increased rapidly to a high level until 2007, growth outcomes have since been weaker. This association also holds for household debt and consumption, as well as for corporate debt and investment. Moreover, where the corporate sector was highly leveraged in 2007, the increase in unemployment since the crisis has been higher. ${ }^{4}$ Finally, a highly leveraged financial sector precrisis has also been associated with higher lending rates postcrisis, creating procyclical financial conditions. Looking ahead, fiscal policy is tightening most where private sector balance sheet stress was the highest, also creating procyclical fiscal conditions.

\footnotetext{
${ }^{4}$ In the euro area, high corporate debt is also associated with lower per capita GDP growth during the period 1999-2011
} (ECB 2012). 


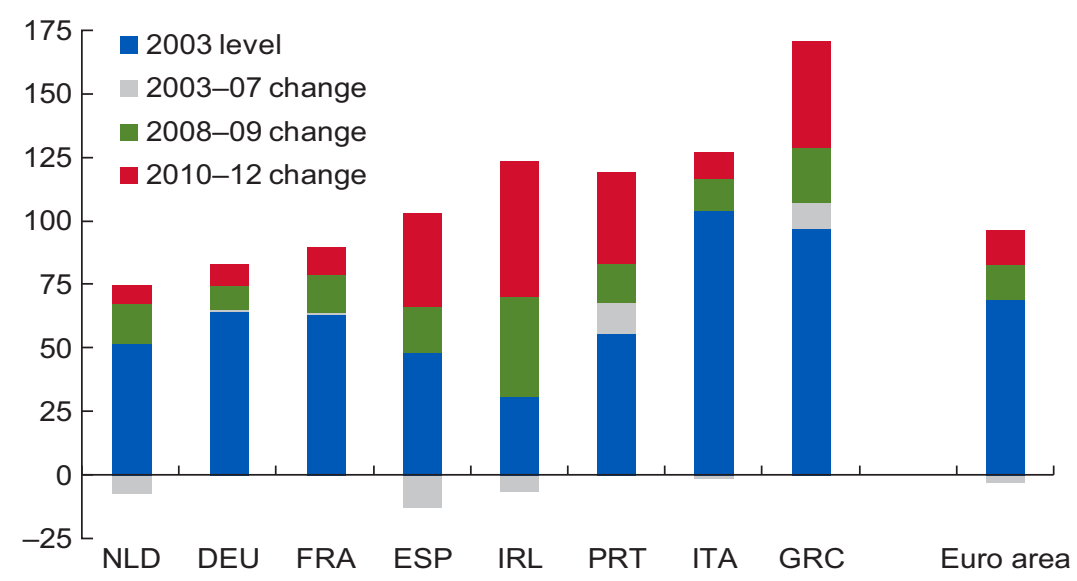

Source: IMF World Economic Outlook.

Note: Data labels in the figure use International Organization for Standardization (ISO) country codes.

Figure 2.10 General Government Debt (Percent of GDP)

\section{Domestic Debt Shares, 2000-07}

(Change of each sector's share in total debt, percent)

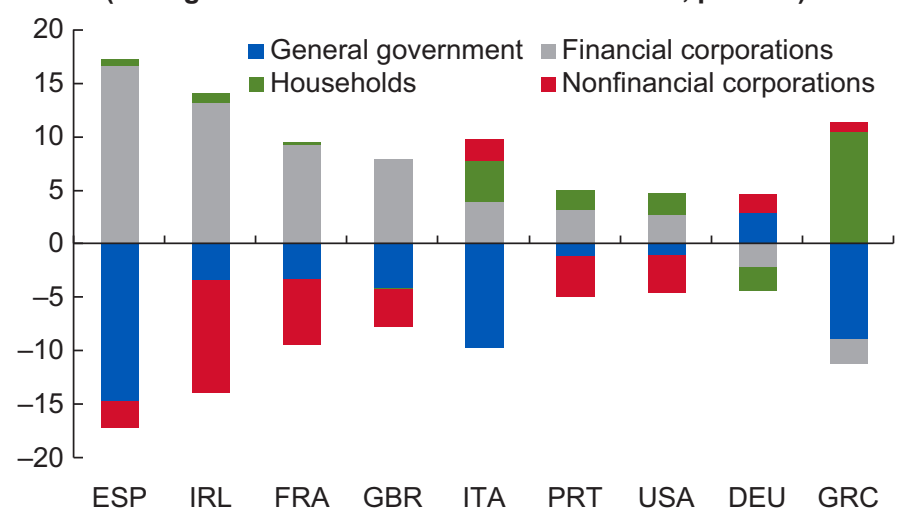

2. Domestic Debt Shares, 2008-12

(Change of each sector's share in total debt, percent)

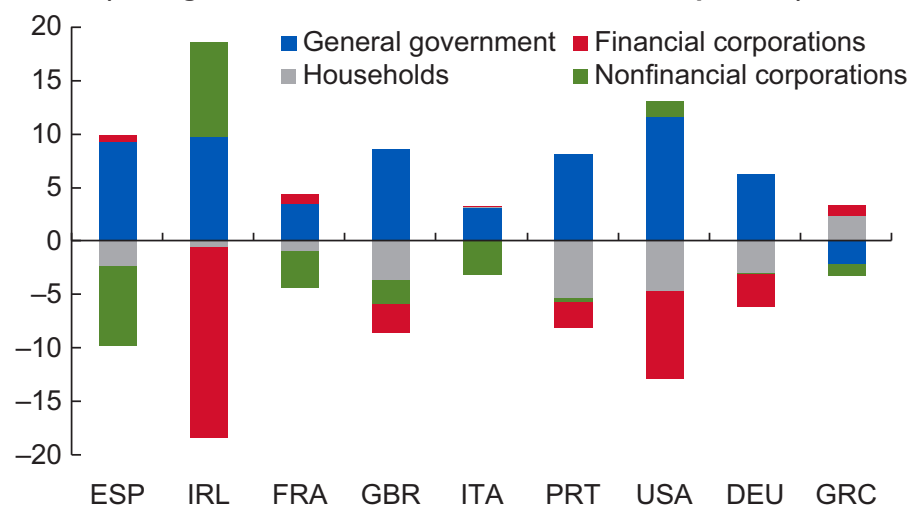

Source: Haver Analytics.

Note: Data labels in the figure use International Organization for Standardization (ISO) country codes.

Figure 2.11 Debt Migration 


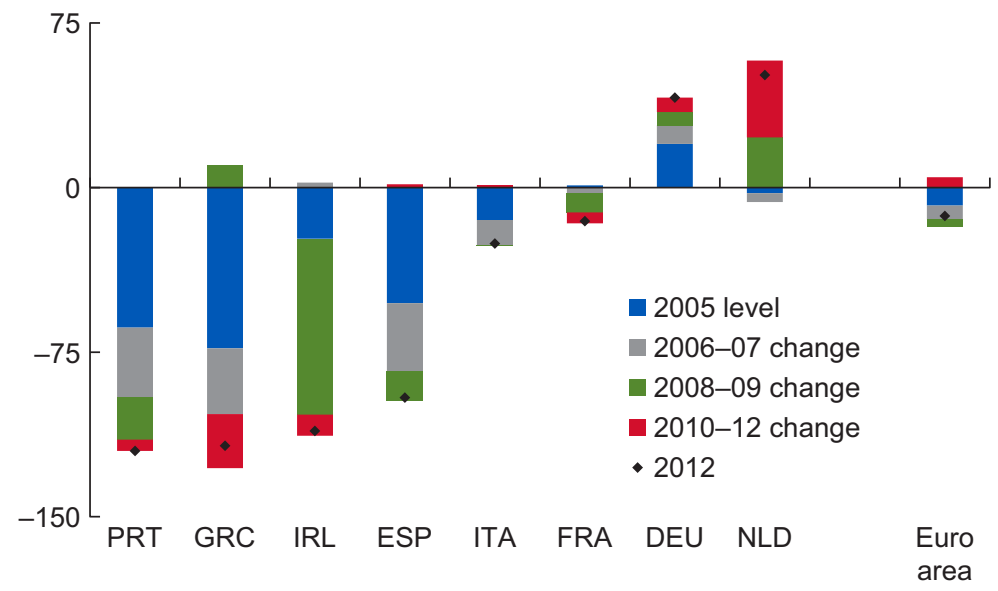

Source: IMF International Financial Statistics.

Note: Data for France are for 2011. Data labels in the figure use International Organization for Standardization (ISO) country codes.

Figure 2.12 External Indebtedness: Net International Investment Position (Percent of GDP)

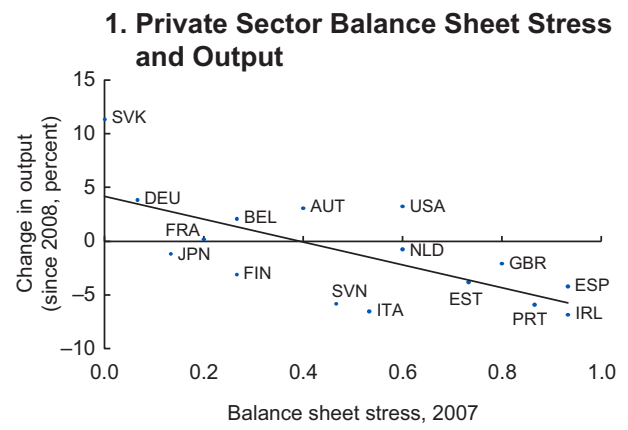

3. Private Sector Balance Sheet Stress and Planned Fiscal Tightening

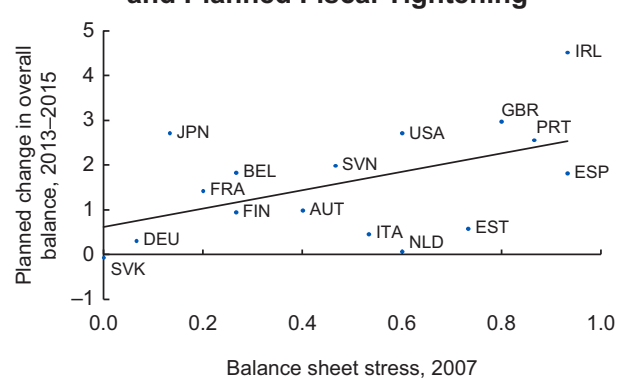

2. Nonfinancial Corporations' Balance Sheet Stress and Unemployment

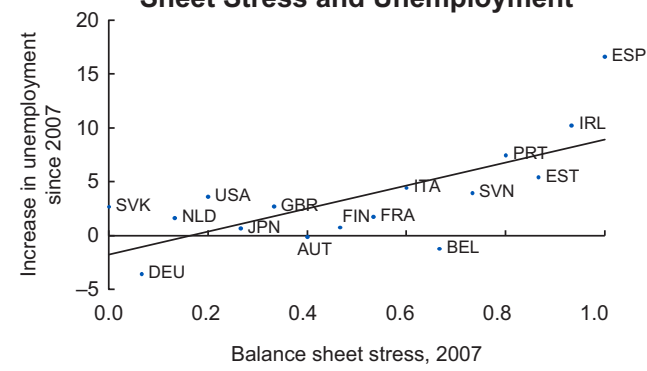

4. Precrisis Leverage and Current Lending Rates

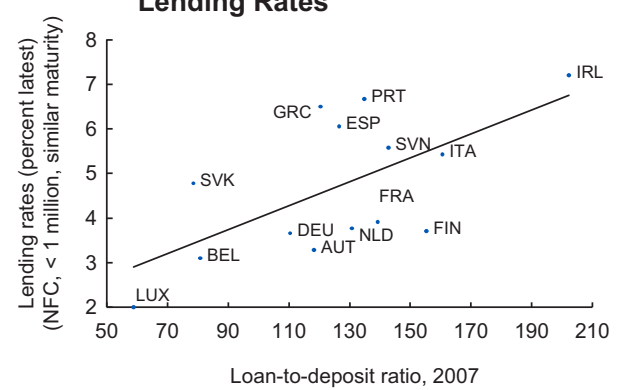

Sources: Organisation for Economic Co-operation and Development; IMF World Economic Outlook; IMF staff estimates; European Central Bank; and Haver Analytics.

Note: NFC = Nonfinancial corporation. Data labels in the figure use International Organization for Standardization (ISO) country codes.

Figure 2.13 Balance Sheet Stress and Economic Activity 


\section{EXPERIENCE WITH PREVIOUS DELEVERAGING EPISODES}

This section discusses household deleveraging, corporate deleveraging, and the debt and growth nexus, including an econometric analysis.

\section{Household Deleveraging}

The magnitude of the post-2000 credit boom was unprecedented. A look at historical episodes can illustrate the scale of the present challenge. In the run-up to the crisis, the increase in household indebtedness in many advanced economies was, on average, 20 percentage points of GDP higher than in past credit cycles. ${ }^{5}$ As a result, the level of household debt and the need to deleverage became exceptionally large, compared with historical episodes. ${ }^{6}$

Household debt reduction has barely started (Figure 2.14). Most banking crises preceded by rapid credit expansions are followed by a protracted period of debt reduction (Tang and Upper 2010). Historical episodes suggest that the extent of deleveraging after the bust matches almost one-to-one the size of the debt built up during the boom period. That is, in most cases, household debt returned to the precredit boom level after a protracted period of deleveraging (lasting between 5 and 10 years). With household debt barely off its peak levels, the deleveraging process in euro area countries is expected to take many more years if debt is to return to the 2000 level. A notable contrast is the United States, which is two-thirds of the way back to the precrisis level (Figure 2.14).

In most historical episodes, household deleveraging was facilitated by higher inflation and an expansionary fiscal policy:

- Most deleveraging episodes in the past were passive, in the sense that households did not actively pay down debt; instead, debt was eroded by inflation and income growth. The median contribution of inflation to the reduction in debt to disposable income was almost 70 percent in episodes associated with banking crises. The contribution of real income growth was about 25 percent, while the reduction in the stock of debt was small, except in Japan. In episodes without a banking crisis, the stock of debt even increased during the deleveraging period (Figure 2.14).

- Fiscal policy was expansionary during the deleveraging period, supporting growth. The magnitude of the fiscal impulse varied across countries, but the cumulative impact was more than 10 percentage points in Sweden and almost 8 percentage points in Finland. The fiscal support was generally larger where deleveraging was the result of a banking crisis.

Projections suggest that the macroeconomic context this time will be more challenging. Euro area inflation is expected to undershoot the price stability objective. Therefore, the role of inflation in assisting the deleveraging process will be much more limited than in the past. ${ }^{7}$ Similarly, the contribution of growth in real disposable income is expected to be small, implying that deleveraging will have to rely more on paying down debt and, therefore, is likely to put additional

\footnotetext{
${ }^{5}$ Historical episodes include Canada (1979-84), Denmark (1987-94), Norway (1988-95), Sweden (1989-95), Finland (1989-97), the United Kingdom (1990-96), Germany (2000-11), and Japan (2001-11). In Finland, Japan, Norway, and Sweden, household deleveraging was associated with a banking crisis. These episodes were selected from among advanced economies that experienced a reduction in the household-debt-to-disposable-income ratio of more than 10 percentage points. ${ }^{6}$ Historical experience offers one possible benchmark. Model-based approaches can also be used to derive optimal levels of leverage or indebtedness to gauge deleveraging needs (for example, Cuerpo and others 2013).

${ }^{7}$ For a discussion of the role of inflation in assisting the deleveraging process, including its costs, see IMF Fiscal Monitor (April 2013).
} 

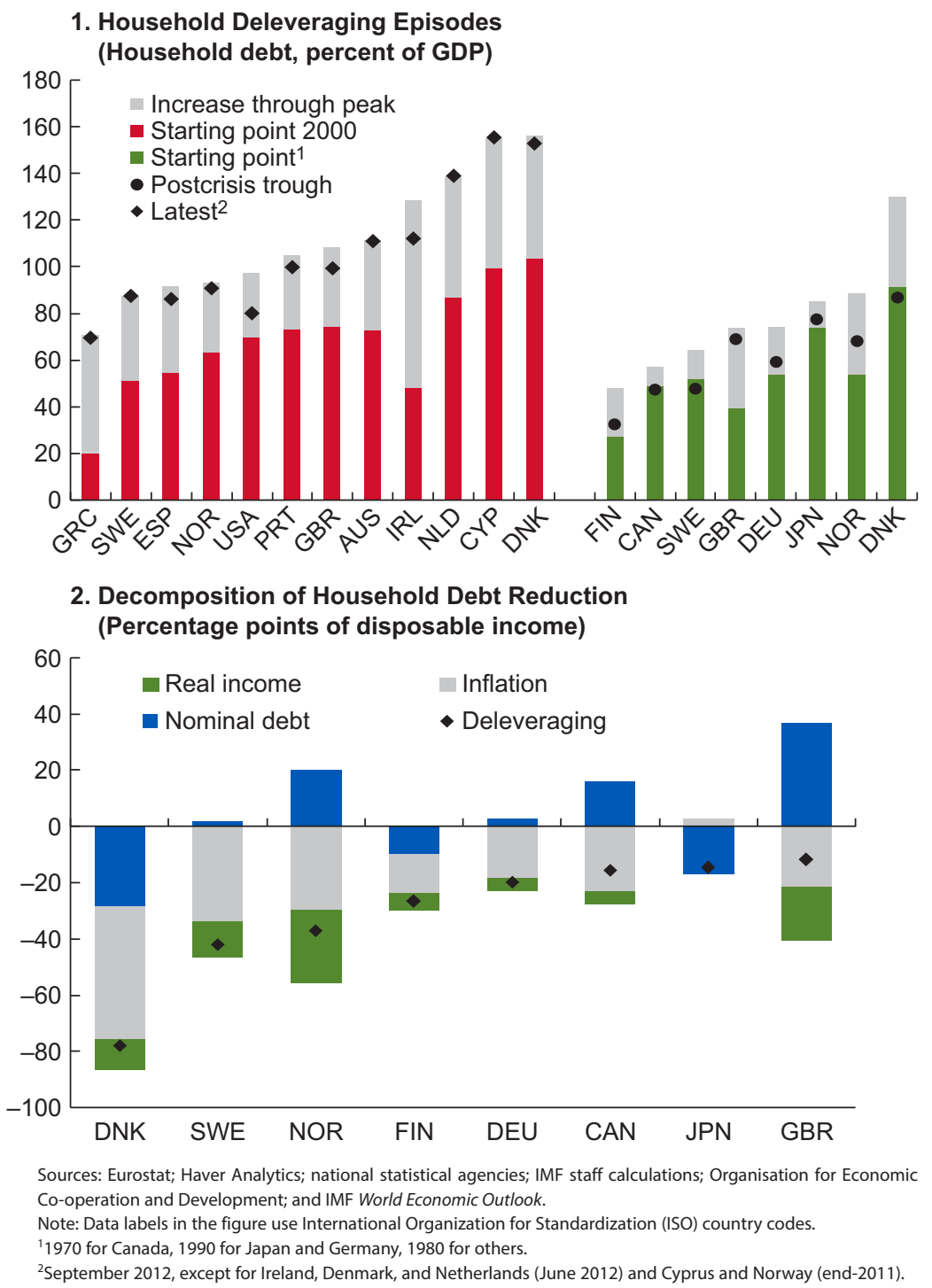

Figure 2.14 Household Deleveraging Episodes and Debt Reduction

stress on households. Likewise, fiscal policy will be less supportive of private sector deleveraging than in past episodes because public debt levels are significantly higher in most countries now than in the past. At the current juncture, market pressures and institutional factors constrain fiscal policy; the countercyclical role of public debt is projected to end in 2014 with a turn to primary surpluses in many countries (Figure 2.15).

\section{Corporate Deleveraging}

Corporate debt levels are not much higher compared with the beginning of historical episodes of corporate deleveraging, but debt reduction has barely started. Although the levels of debt are comparable to previous episodes, the increase in corporate debt in the boom cycle was particu- 
1. Overall Fiscal Balance during Household Deleveraging (Change in overall fiscal balance, percent of GDP)

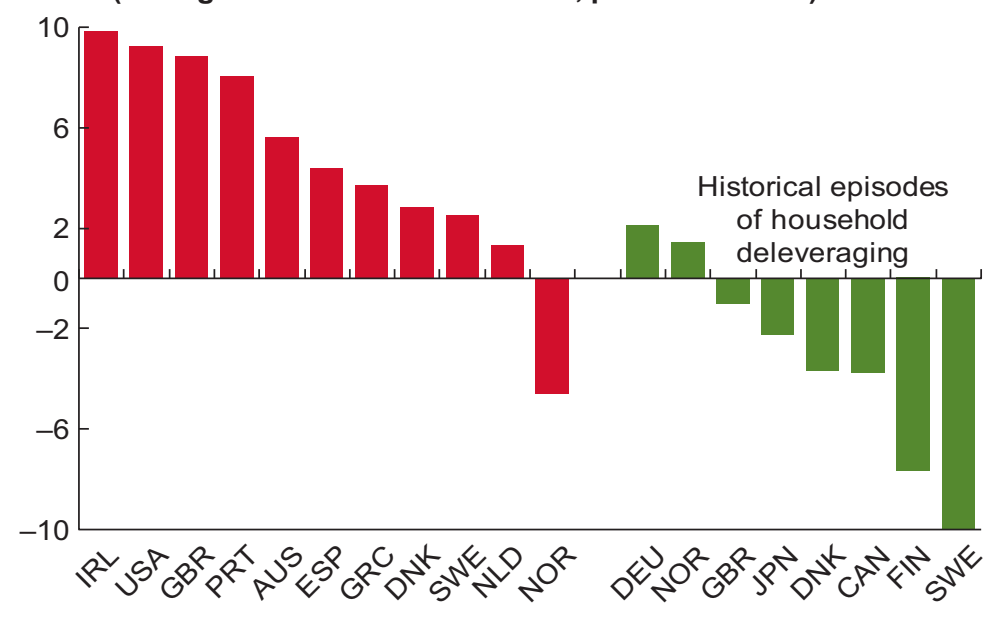

2. Government Debt during Household Deleveraging (Percent of GDP)

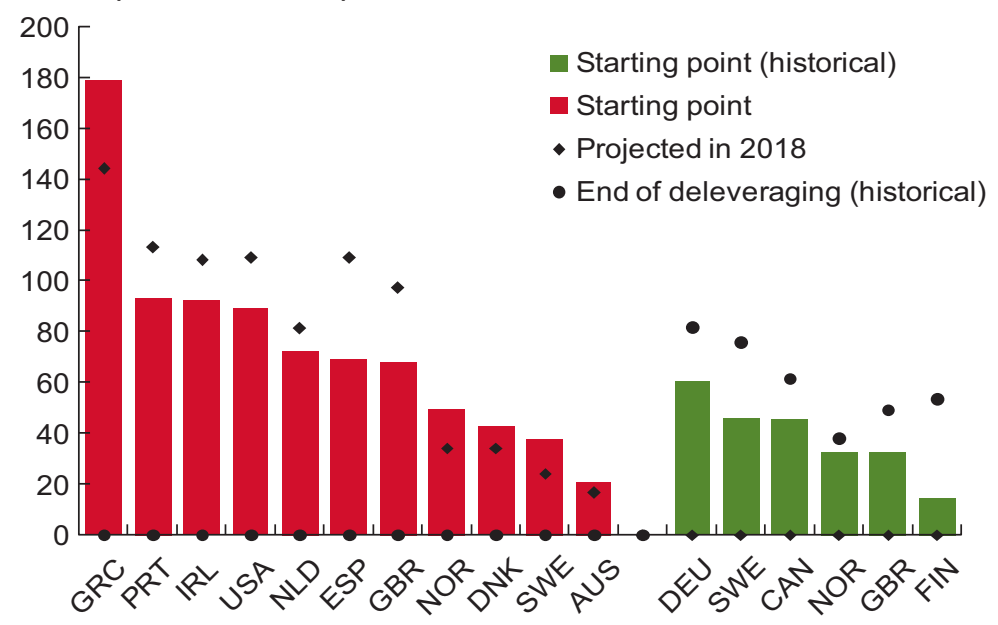

Sources: Eurostat; Haver Analytics; national statistical agencies; and IMF staff calculations. Note: Data labels in the figure use International Organization for Standardization (ISO) country codes.

Figure 2.15 Fiscal Policy during Deleveraging Episodes

larly large in Ireland and Spain, compared with historical episodes (Figure 2.16). ${ }^{8}$ Episodes of significant corporate deleveraging suggest that after large booms, an average of two-thirds of the increase in debt is subsequently reduced. In the euro area, corporate leverage has receded from the crisis peak in some countries, but debt-to-income ratios remain high.

\footnotetext{
${ }^{8}$ Identification of historical corporate deleveraging episodes is based on Ruscher and Wolff (2012), who use the sector's net lending and borrowing data as a marker, combined with indebtedness data from Cecchetti, Mohanty, and Zampolli (2011). The latter paper comprises episodes with significant debt reductions (10 percent of GDP or more), which, on average, lasted six years. A number of shorter episodes of corporate deleveraging identified by Ruscher and Wolff (2012) did not result in significant debt reductions.
} 


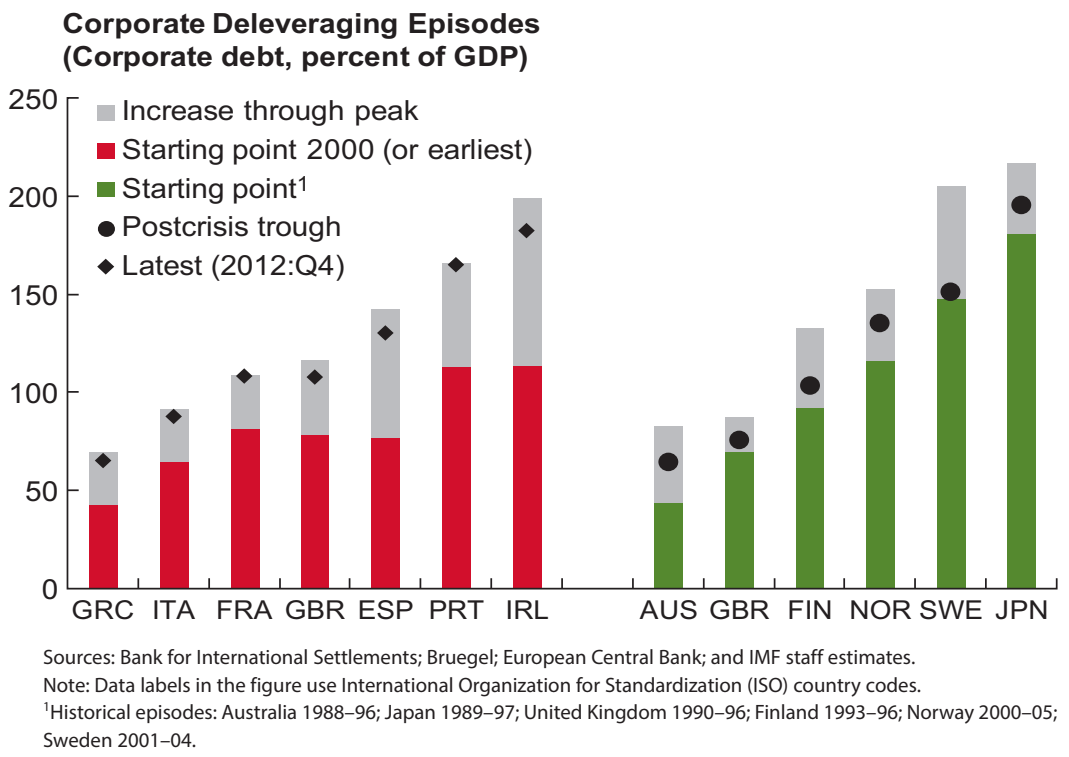

Figure 2.16 Corporate Deleveraging Episodes

\section{The Debt and Growth Nexus}

The debate about the relationship between high public debt and growth remains open. A large body of research concludes that high public debt leads to higher interest rates and slower growth (among others, Kumar and Woo 2010; Reinhart and Rogoff 2010; Reinhart, Reinhart, and Rogoff 2012; Cecchetti, Mohanty, and Zampolli 2011; Baum, Checherita-Westphal, and Rother 2012). Some of these studies find that high debt levels (greater than 80-90 percent of GDP) have a negative effect on growth. High debt also makes public finances more vulnerable because it constrains government's ability to engage in countercyclical policies. An opposing school of thought argues that weak growth causes high debt and not the other way around. Panizza and Presbitero (2012) reject the hypothesis that high debt causes lower growth. Herdon, Ash, and Pollin (2013) challenge the findings of the influential papers by Reinhart and Rogoff, which argue that there is a threshold effect whereby debt greater than 90 percent of GDP leads to dramatically worse growth outcomes.

Fewer studies have attempted to quantify the impact of private sector debt on growth. A notable exception is Cecchetti, Mohanty, and Zampolli (2011), who find that corporate debt greater than 90 percent of GDP and household debt greater than 85 percent of GDP become a drag on growth. IMF (2012b) concludes that recessions that are preceded by a run-up in household debt tend to be more severe and protracted. This section looks at growth performance in previous household deleveraging episodes and presents econometric evidence of the way in which high private sector debt hampers growth.

Historical experience suggests that household deleveraging in the euro area will continue to weigh on growth. Average annual real GDP and consumption growth were about 1.5 percent lower during the deleveraging period than in the preceding period. The growth underperformance is not found to be higher in those countries where household deleveraging was also associated with a banking crisis (Figure 2.17). Although history is not destiny and the number of historical episodes to draw lessons from is limited, the analysis above suggests that headwinds from high debt and deleveraging are likely to persist. 

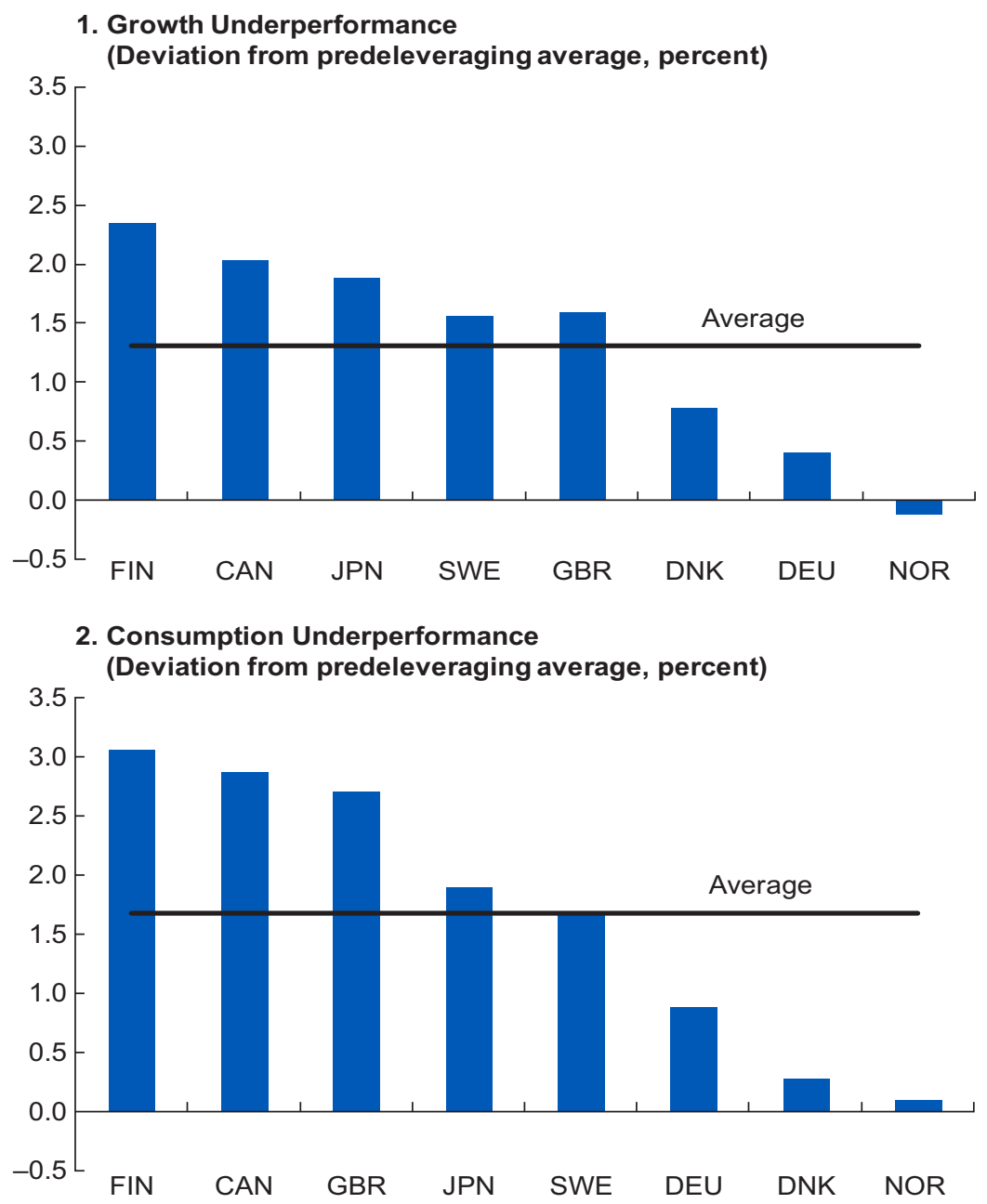

Sources: Haver Analytics; and IMF staff calculations.

Note: Data labels in the figure use International Organization for Standardization (ISO) country codes.

Figure 2.17 Historical Growth and Consumption Underperformance

\section{Econometric Analysis}

An econometric analysis suggests that the negative growth impact of debt in one sector depends on the level of indebtedness in the other sectors (Figure 2.18). ${ }^{9}$ When the three sectors-government, households, and firms - have above-average debt levels, the negative growth impact of debt is highest. Results support the hypothesis that the confluence of debt in more than one sector exacerbates the negative feedback loops that arise in times of crisis. Therefore, headwinds are likely to be particularly strong in countries where all sectors are highly indebted.

\footnotetext{
${ }^{9}$ See Annex 2.1 for details on the econometric analysis. Debt is considered to be "high" if it is greater than the mean value in the sample. The mean values are 73 percent of GDP for government debt, 48 percent of GDP for household debt, and 98 percent of GDP for corporate debt. The thresholds identified in Cecchetti, Mohanty, and Zampolli (2011) are also used as a robustness test. The main results hold, but the higher thresholds relative to the mean, particularly for household debt, imply that there are very few observations for which debt is high in all sectors at the same time.
} 


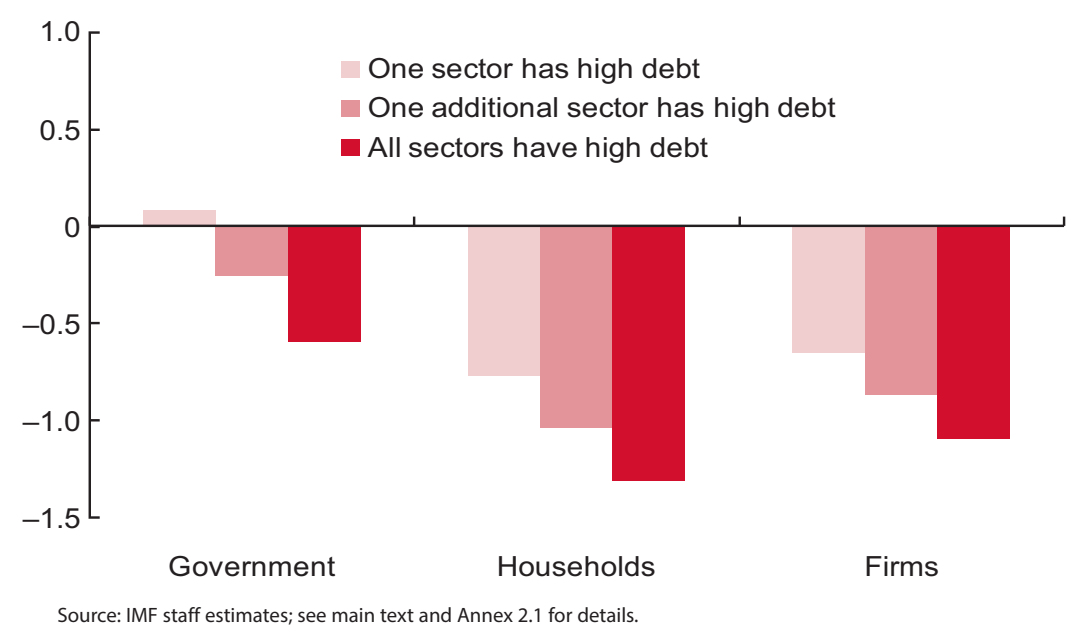

Figure 2.18 The Impact of High Debt on Growth

The analysis also suggests that private sector debt may be more detrimental to growth than public sector debt. Regressions identify a stronger and more statistically significant association between private sector debt and growth than between government debt and growth.

- High corporate debt and household debt are associated with negative growth even if either one is the only sector indebted in the economy. The negative impact becomes larger the higher the number of sectors with high debt. In particular, a 10 percentage point increase in the corporate debt-to-GDP ratio beyond the 98 percent average level is associated with a subsequent reduction in average annual growth of between 7 and 11 basis points, depending on whether the other sectors are highly indebted. Similarly, a 10 percentage point increase in the household debt-to-GDP ratio beyond the 48 percent average level is associated with a subsequent reduction in average annual growth of between 8 and 13 basis points.

- High public debt is negatively associated with growth only when both the household and corporate sectors are also indebted. In this case, a 10 percentage point increase in the government debt-to-GDP ratio beyond the 73 percent of GDP average level is associated with a 6 basis point reduction in subsequent average annual growth. In contrast, when only the government is indebted or only one additional sector has high debt, the relationship becomes not statistically significant.

\section{POLICY OPTIONS}

This section focuses on dealing with high debt in the euro area, targeted policies, and how policy mix and structural policies help support private sector deleveraging.

\section{Dealing with High Debt in the Euro Area}

Experience suggests that decisive and properly sequenced policy actions can support deleveraging. Where private sector deleveraging is more advanced (for example, in the United States), measures were taken early on to strengthen the balance sheets of financial institutions. Bank and private debt-restructuring mechanisms have been used more widely, facilitating the workout of nonperforming loans and dispelling doubts about asset quality. These processes were supported 
by appropriate legislation and institutions. Historical debt-restructuring episodes also show that policies can help facilitate the deleveraging process, including through government-sponsored programs, direct government purchases of distressed assets, and the use of asset management companies to resolve distressed assets. In all such cases, the sequencing and country-specific circumstances are important (Laryea 2010). Two successful cases of household debt restructuring are the U.S. Home Owners Loan Corporation Program in 1933 and the experience in Iceland in the recent crisis.

\section{Targeted Policies}

Progress toward improving insolvency frameworks in the euro area could help, but it has so far been uneven. Reforming insolvency frameworks takes time, and effective implementation is often most difficult but key to success. A number of countries have moved to strengthen insolvency frameworks and institutions (Liu and Rosenberg 2013) including Austria, Germany, Greece, Ireland, Italy, Portugal, and Spain. Despite this progress, however, procedures are not widely used and the insolvency regimes remain inefficient and costly in many countries (Figure 2.6). National insolvency regimes may need to be made more effective by, for example, facilitating out-of-court settlements, reducing time for insolvency proceedings, and providing more flexibility to deal with personal or corporate bankruptcy. Stronger institutions-experienced judges and insolvency administrators-would also help support insolvency processes. In many cases, the stigma associated with bankruptcy also needs to be overcome.

Debt restructuring comes at high costs. Debt reprofiling, debt restructuring, or debt default in the private sector and financial sector can reduce private sector indebtedness, with overall macroeconomic benefits. Indeed, when creditor seniority is respected and common principles are applied, the workout of bad debt can catalyze new economic activity. But debt restructuring also comes at the cost of damaging creditor-debtor relations, imposing losses on other agents, and creating moral hazard.

Policies can help guide this restructuring process, thereby mitigating its costs. Repairing the financial sector is, however, essential to addressing the balance sheet problems in the corporate and household sectors.

- Strengthening bank balance sheets and working out NPLs is a precondition to policy effectiveness. The workout of private debt requires adequate provisioning and capital buffers in the banking system to absorb losses. Only then will banks have incentives to restructure their exposures to distressed borrowers. This process could further be helped by providing tax incentives (or removing tax disincentives) for debt write-offs. Policies to encourage debt write-offs and help facilitate the transfer of nonperforming assets to new owners would also support the repair of bank balance sheets. A pan-European backstop for solvent banks would help break the negative feedback loop between banks and sovereigns and reduce fragmentation. Overall, a cleanup of banks' balance sheets would strengthen the banking system and help credit flow.

- Debt restructuring in the corporate sector could further be supported by making more use of debt-equity swaps and out-of-court procedures to support the early rescue of viable firms. Asset management companies, either private or with some government participation, could help accelerate the restructuring of corporate debt, while taking weak assets off banks' balance sheets (Laryea 2010).

- In the household sector, direct debt-service support (for example, through guarantees or deferred interest) can help vulnerable households avoid bankruptcy in the face of unemployment while minimizing moral hazard. Government-sponsored programs can also encourage banks to reschedule household debt (Laeven and Laryea 2009). Wealth

\section{CInternational Monetary Fund. Not for Redistribution}


encumbrance could be modified where needed by, for example, easing mortgage payments for highly indebted, low-income households whose property has been foreclosed. Personal insolvency frameworks should be geared toward facilitating a fresh start for financially responsible individuals.

\section{Policy Mix and Structural Policies}

A measured pace of fiscal adjustment and monetary policy actions to reduce fragmentation would further facilitate balance sheet adjustment. Countercyclical fiscal policy is effective in balance sheet recessions, but debt sustainability and market access considerations constrain its use. However, getting the pace of consolidation right is essential. Monetary policy should aim to address the impairments to the normal transmission of the monetary policy stance, which would help reduce corporate and household borrowing costs, especially in countries with a large debt overhang.

Structural policies could also help support private sector deleveraging or mitigate its impact. For example, facilitating the substitution away from bank to nonbank financing by developing capital markets could reduce the reliance of firms on bank financing. And labor market reforms could increase firms' flexibility to absorb demand shocks, through an adjustment in working hours and pay rather than through labor shedding.

\section{CONCLUSION}

Balance sheet adjustment in the euro area is an uphill battle at the current juncture. In other deleveraging episodes, high nominal and real growth, exchange rate depreciation, and monetary easing have supported balance sheet adjustments. For many euro area economies, however, the policy space is much more constrained: exchange rate devaluations can only happen internally, and if successful, will put downward pressure on prices. The real growth outlook is weak throughout the region and beyond. Finally, because the monetary transmission mechanism is impaired, monetary easing is not effective in lowering interest rates, and a fragmented financial sector amplifies the negative effects of protracted private sector deleveraging.

An accelerated cleanup of private and financial sector balance sheets can help avoid a protracted period of stagnation. Delays and resistance to working out nonperforming loans in the banking system and lengthy procedures for personal and corporate bankruptcies increase uncertainty about the extent of the problem and put further downward pressure on asset prices and firm performance. At the aggregate level, such feedback loops can trigger debt deflation dynamics. Therefore, in addition to providing a supportive macroeconomic environment, targeted policies to support the debt workout should be considered.

\section{ANNEX 2.1. ECONOMETRIC ANALYSIS}

The econometric analysis in this chapter builds on Cecchetti, Mohanty, and Zampolli (2011), who use a data set on debt levels for a group of 18 OECD countries, based primarily on flow-offunds data. The paper uses data for the period 1980-2006; however, since the authors had compiled data through 2009, this analysis uses the full sample.

The empirical specification is derived from Solow's neoclassical growth model, in which per capita income growth depends on the initial level of physical and human capital, the saving rate, the population growth rate, and technology. In addition to these standard regressors in the growth literature, measures of public and private sector debt are added to the specification to see whether they have an impact on growth independent of other determinants. Panel data 
regressions are estimated using country-specific and time-specific time effects as in the following equation:

$$
g_{i, t+1, t+k}=\phi y_{i, t}+\beta^{\prime} X_{i, t}+\alpha^{\prime} D_{i, t}+\mu_{i}+\gamma_{t}+\varepsilon_{i, t, t+k},
$$

in which

- $g_{i, t+1, t+k}$ is the $k$-year forward average of annual real GDP per capita growth between years $t+1$ and $t+k$. The analysis uses $k=5$.

- $y_{i, t}$ is the log of real per capital GDP at time $t$.

- $\mu_{i}$ and $\gamma_{t}$ are country-specific and time-specific dummies.

- $X_{i, t}$ includes gross saving as a share of GDP; population growth, number of years spent in secondary education as a proxy for the level of human capital, the age-dependency ratio, openness to trade measured by the sum of exports and imports to GDP, consumer price index inflation as a measure of macroeconomic stability, the ratio of liquid liabilities to GDP as a measure of financial development, and a dummy to control for banking crises.

- $D_{i, t}$ includes, depending on the specification, the ratio of debt to GDP of the public sector, the private sector (household and corporate sector), or both, as well as interactions with dummy variables indicating whether the debt ratios are greater than a threshold level.

Least squares dummy variable (LSDV) estimation is used. The presence of a lagged dependent variable in the right-hand side (dynamic panel) implies that the estimates may be biased. However, it has not been proved that generalized method of moments or instrumental variables outperforms LSDV in small panels, such as the one this analysis uses $(\mathrm{N}=18)$.

The analysis assesses whether the growth impact of high debt in one sector depends on the level of indebtedness in other sectors. Debt is considered to be "high" if it is above a certain threshold identified as the sample mean. The thresholds are 73 percent of GDP for public debt, 98 percent of GDP for corporate debt, and 48 percent of GDP for household debt. For instance, in the specification to estimate the impact of public debt on growth and its differential impact depending on the level of indebtedness in the private sector, the regressor $\alpha^{\prime} D_{i, t}$ becomes

$$
\alpha_{1} D_{i, t}^{P}+\alpha_{2} D_{i, t}^{P} H^{P}+\alpha_{3} D_{i, t}^{P} H^{H}+\alpha_{4} D_{i, t}^{P} H^{C}
$$

in which $D_{i, t}^{P}$ is the ratio of public debt to GDP, $H^{P}$ is a dummy variable taking the value of 1 if public debt is greater than the sample mean, $H^{H}$ is a dummy variable taking the value of 1 if household debt is greater than the sample mean, and $H^{C}$ is a dummy variable taking the value of 1 if corporate debt is greater than the sample mean. Given the above specification, $\alpha_{1}+\alpha_{2}$ is the estimated impact of high public debt on growth when the household and corporate sectors are not highly indebted. Similarly, $\alpha_{1}+\alpha_{2}+\alpha_{3}$ is the estimated impact when the household sector, in addition to the public sector, is highly indebted. When all sectors are highly indebted, the estimated impact of government debt on growth is given by $\alpha_{1}+\alpha_{2}+\alpha_{3}+\alpha_{4}$.

\section{REFERENCES}

Baum, Anja, Cristina Checherita-Westphal, and Philipp Rother. 2012. "Debt and Growth: New Evidence for the Euro Area.” Working Paper No. 1450, European Central Bank, Frankfurt.

Buiter, Willem, and Ebrahim Rahbari. 2012. "Debt of Nations: Mr. Micawber's Vindication: Causes and Consequences of Excessive Debt." Citigroup, London.

Cecchetti, Stephen G., M. S. Mohanty, and Fabrizio Zampolli. 2011. "The Real Effects of Debt.” Working Paper No. 352, Bank for International Settlements, Basel.

Creditrefom. 2012. "Insolvencies in Europe 2011/12.” Frankfurt.

\section{CInternational Monetary Fund. Not for Redistribution}


Cuerpo, Carlos, Inês Drumond, Julia Lendvai, Peter Pontuch, and Rafal Raciborski. 2013. "Indebtedness, Deleveraging Dynamics and Macroeconomic Adjustment.” European Economy, Economic Papers 477. Brussels: European Commission.

Cussen, Mary, and Bridin O'Leary. 2013. “Why Are Irish Non-financial Corporations So Indebted?” In Quarterly Bulletin 01/13, Central Bank of Ireland, Dublin.

—, and Donal Smith. 2012. "The Impact of the Financial Turmoil on Households: A Cross Country Comparison.” Quarterly Bulletin 02/12, Central Bank of Ireland, Dublin.

European Central Bank (ECB). 2012. "Corporate Indebtedness in the Euro Area." Monthly Bulletin, February (Frankfurt), 87-103.

_. 2013a. "The Eurosystem Household Finance and Consumption Survey: Results from the First Wave." Statistics Paper Series 2/13, Frankfurt.

- 2013b. “Integrated Euro Area Accounts for the Fourth Quarter of 2012.” Box 4 in Monthly Bulletin, May (Frankfurt), 46-50.

Herdon, Thomas, Michael Ash, and Robert Pollin. 2013. "Does High Public Debt Consistently Stifle Economic Growth? A Critique of Reinhart and Rogoff." Working Paper No. 322, Political Economy Research Institute, Amherst, Massachusetts.

International Monetary Fund. 2012a. "Access to Credit, Debt Overhang, and Economic Recovery: The Irish Case." Chapter 2 in "Ireland: Selected Issues Paper." Country Report No. 12/265, Washington, DC.

. 2012b. "Dealing with Household Debt." Chapter 3 in World Economic Outlook, April, Washington, DC. . 2012c. "Spain: Vulnerabilities of Private Sector Balance Sheets and Risks to the Financial Sector." Technical Note, Financial Sector Assessment Program, Washington, DC.

. 2013a. "European Union: Financial System Stability Assessment." Country Report No. 13/75, Washington, DC.

- 2013b. "Household Savings Ratio in Spain-How Low Can It Go?” In "Spain: Selected Issues Paper." Country Report No. 13/245, Washington, DC.

. 2013c. "Italy: The Financial Situation of Italian Households and Non-financial Corporations and Risks to the Banking System." Technical Note, Financial Sector Assessment Program, Washington, DC.

- 2013d. "The Kingdom of the Netherlands: Staff Report of the 2013 Article IV Consultation." Country Report No. 13/48, Washington, DC.

- 2013e. Old Risks, New Challenges: Global Financial Stability Report. Washington, DC.

. 2013f. "Portugal's Corporate (De) Leveraging." Chapter 3 in "Portugal: Selected Issues Paper." Country Report No. 13/19, Washington, DC.

Kumar, Manmohan S., and Jaejoon Woo. 2010. "Public Debt and Growth.” Working Paper No. 10/174, International Monetary Fund, Washington, DC.

Laeven, Luc, and Thomas Laryea. 2009. "Principles of Household Debt Restructuring." Staff Discussion Note No. 09/15, International Monetary Fund, Washington, DC.

Laryea, Thomas. 2010. "Approaches to Corporate Debt Restructuring in the Wake of the Financial Crisis." Staff Discussion Note No. 10/02, International Monetary Fund, Washington, DC.

Liu, Yan, and Christoph B. Rosenberg. 2013. "Dealing with Private Debt Distress in the Wake of the European Financial Crisis: A Review of the Economics and Legal Toolbox.” Working Paper No. 13/44, International Monetary Fund, Washington, DC.

McKinsey Global Institute. 2012. Debt and Deleveraging: Uneven Progress on the Path to Growth. New York: McKinsey and Company.

Panizza, Ugo, and Andrea Filippo Presbitero. 2012. "Public Debt and Economic Growth: Is There a Causal Effect?” Working Paper No. 65, Money and Finance Research Group, Ancona, Italy.

Reinhart, Carmen M., Vincent R. Reinhart, and Kenneth Rogoff. 2012. "Debt Overhangs Past and Present." Working Paper No. 18015, National Bureau of Economic Research, Cambridge, Massachusetts.

Reinhart, Carmen M., and Kenneth Rogoff. 2010. "Growth in a Time of Debt." American Economic Review: Papers and Proceedings 100: 573-78.

Ruscher, Eric, and Guntram B. Wolff. 2012. "Corporate Balance Sheet Adjustment: Stylized Facts, Causes and Consequences.” Bruegel Working Paper 2012/03, Brussels.

Tang, Garry, and Christian Upper. 2010. "Debt Reduction after Crises.” BIS Quarterly Review September: 25-38. World Bank. 2013. Doing Business 2013. Washington, DC. http://www.doingbusiness.org/. 


\title{
Rebalancing: Where Do We Stand and Where to Go?
}

\author{
THIERRY TRESSEL AND SHENGZU WANG
}

Although relative price adjustments and current account improvements are taking place, more needs to be achieved to correct the imbalances within the euro area. Improvements in export performance remain dependent on external demand, including from within the euro area. Moreover, ongoing adjustment in current account balances is partly driven by cyclical factors, which suggests that more needs to be done to make the adjustment sustainable. Converging to net foreign asset positions considered safe elsewhere will prove challenging in the future.

Intra-euro area imbalances have been a key feature of the euro area, reflecting deteriorating competitiveness and domestic demand booms in selected euro area debtor economies (Greece, Ireland, Portugal, and Spain) and rising external surpluses in export-oriented core economies (Germany, the Netherlands) in the run-up to the crisis. ${ }^{1}$ Extensive collective efforts—such as the European Stability Mechanism, Outright Monetary Transactions, and banking union-have helped restore the stability of the common currency area. However, given downward pressures on demand (due to the need to achieve internal devaluations associated with public and private deleveraging) and the limited policy space, the challenge now for many euro area economies is to rebalance across domestic and external sources of growth (Figure 3.1).

What does rebalancing mean? Even before the crisis, significant structural differences among Economic and Monetary Union members were apparent, including in labor markets, productivity, production structure, competitiveness, and specialization (Eichengreen 2007). Although few signs of convergence in the structure and performance of euro area economies were visible, demand booms associated with intra-euro area capital inflows and the loss of export competitiveness in selected economies contributed to their accumulation of very large net foreign asset (NFA) liabilities (Greece, Ireland, Portugal, Spain). Meanwhile, core economies accumulated sizable surpluses. Those surpluses have largely remained since the crisis, while current account deficits in the selected debtor economies have narrowed significantly. However, to what extent the narrowing of current accounts in selected debtor countries reflects depressed demand domestically or more structural developments remains an open question. Indeed, internal imbalances could still persist among euro area countries even if the euro area is broadly in balance with the rest of the world.

This chapter takes stock of the extent of the external adjustment in euro area countries, examines a battery of price and nonprice indicators, analyzes the determinants of recent export performance and current account adjustments, and discusses the remaining gaps and expected path of future adjustment, as well as some policy implications.

\footnotetext{
This chapter is based on Euro Area Policies: 2013 Article IV Consultation-Selected Issues, "Rebalancing the Euro Area: Where Do We Stand and Where to Go," IMF Country Report 13/232, 2013.

${ }^{1}$ France and Italy are also included in the analysis for the sake of comparison. While Italy also suffered severe market pressure and an erosion of external competitiveness, its current account deficit and net external liability position in percent of GDP were much smaller than those of the debtor countries.
} 


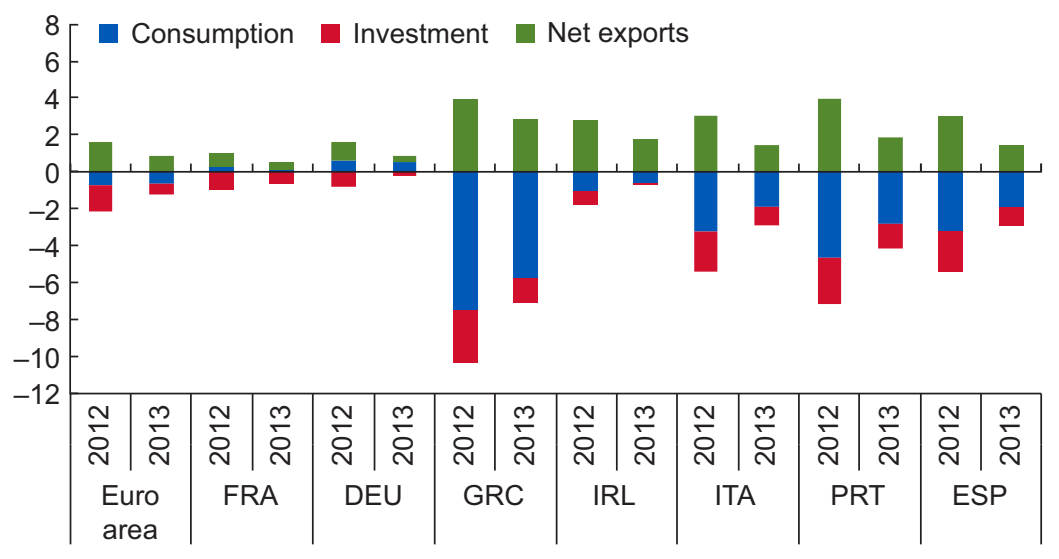

Sources: IMF World Economic Outlook; and IMF staff calculations.

Note: Data labels in the figure use International Organization for Standardization (ISO) country codes.

Figure 3.1 Contributions to Growth in the Euro Area (Percent)

Current account reversals and unit labor cost (ULC) adjustments have been significant in euro area debtors since the crisis, owing to both cyclical and structural factors. However, evidence of resource reallocation from the nontradable to the tradable sectors is limited. Export performance is very dependent on external demand, which remains weak within the euro area. Looking ahead, relying only on relative price adjustments (which adversely affect households and firms) for convergence to sustainable levels of net foreign liabilities could prove to be challenging. Structural reforms will play an important role in the reallocation of resources to the tradable sector and associated relative price adjustment, while boosting nonprice and price competitiveness. By focusing also on nonprice competitiveness, structural reforms would improve overall productivity and trend growth without unduly weighing on domestic demand.

\section{HOW MUCH ADJUSTMENT HAS OCCURRED?}

Euro area selected debtor countries have experienced large current account adjustments since the crisis (Figures 3.2 and 3.3). Between 2008 and 2012, the current account balances of Greece, Ireland, Portugal, and Spain improved by 11.6 percent of GDP, 10.6 percent, 11.1 percent, and 8.5 percent, respectively. These adjustments have contributed significantly to the reversal of the euro area current account balance, which reached 1.2 percent of GDP in 2012, the largest surplus since 2000.

The current account reversals in debtor countries reflect a combination of lower imports and higher exports, as well as improved income balances in some economies. In Greece, the decline in imports was the main contributor to the current account improvement. In Spain and Portugal, the contribution of exports to the current account improvement was larger than the decline in imports. In Ireland, the rebound of exports was associated with a rise in imports, likely as a result of the large import content of exports.

The adjustment in relative prices has proceeded, although to varying degrees across different measures of cost competitiveness (Figure 3.4).

- Real effective exchange rates (REERs). Most debtor countries have experienced large ULC-based REER depreciations since 2008. Whereas Germany's REER has remained on a downward trend since the inception of the euro, REERs of euro area debtor countries are now close to their long-term average or back to the level that prevailed at the inception of the euro, mostly as a result of large declines of ULCs. Consumer Price Index-based REERs, however, have generally adjusted less since the start of the crisis (Figure 3.5, panel 1). 


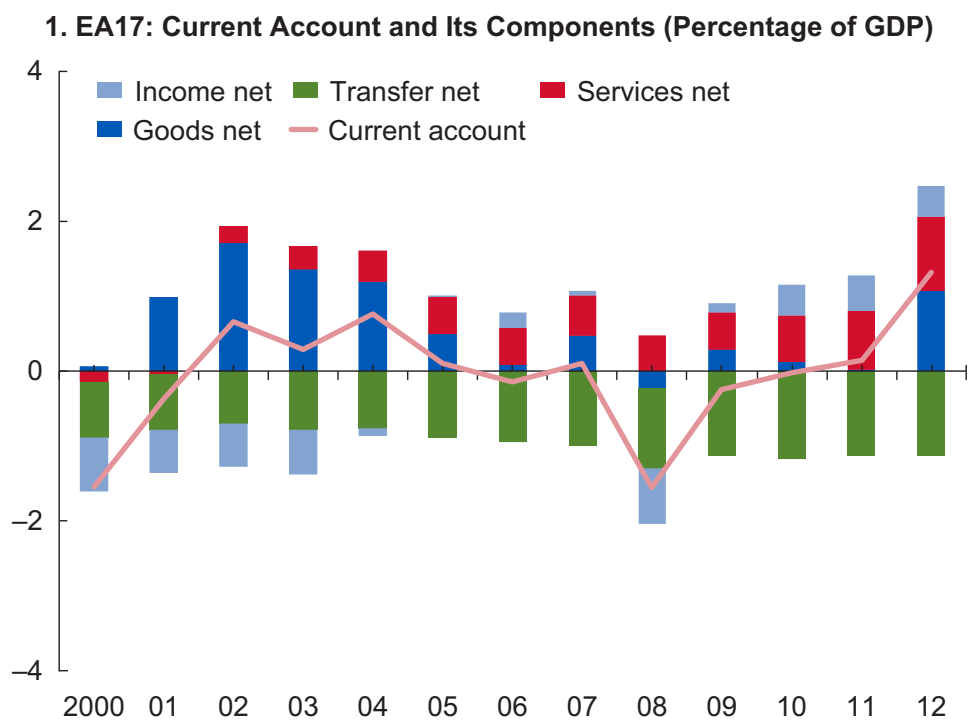

2. Contributions to Change in Current Account (2008-12, percentage of GDP)

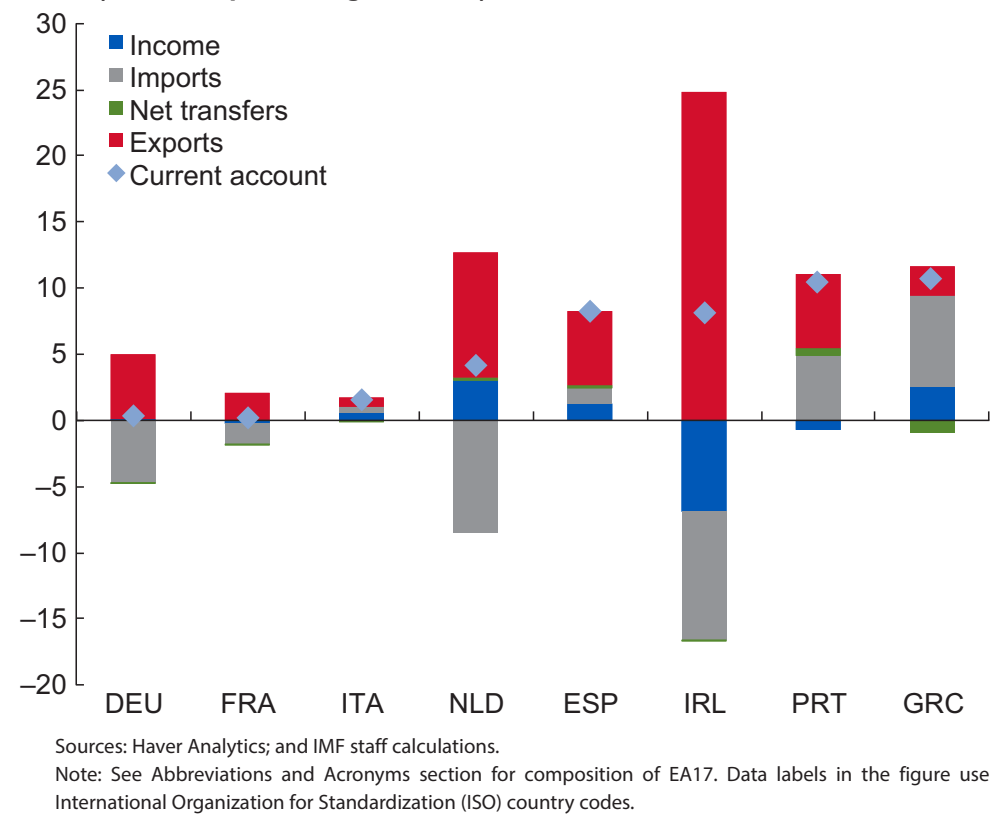

Figure 3.2 Euro Area Current Account

- Unit labor costs. Since 2008 there have been large corrections of ULCs in selected debtor economies (Ireland, Spain, Greece, and Portugal), while ULCs have started to increase in Germany (ECB 2012). In France and Italy, ULCs have continued to rise on their precrisis trend. Sectoral evidence suggests that ULCs have fallen across sectors, and the decline has often been larger in tradable sectors than in nontradable sectors, except in France, Germany, and Italy (Box 3.1, Figure 3.1.1).

- Relative price adjustments compared with euro area trading partners and the rest of the world. Consumer price adjustments have been relatively modest, perhaps as a result of 
Income net Services net $\_$Current account $\quad$ Transfers net Goods net
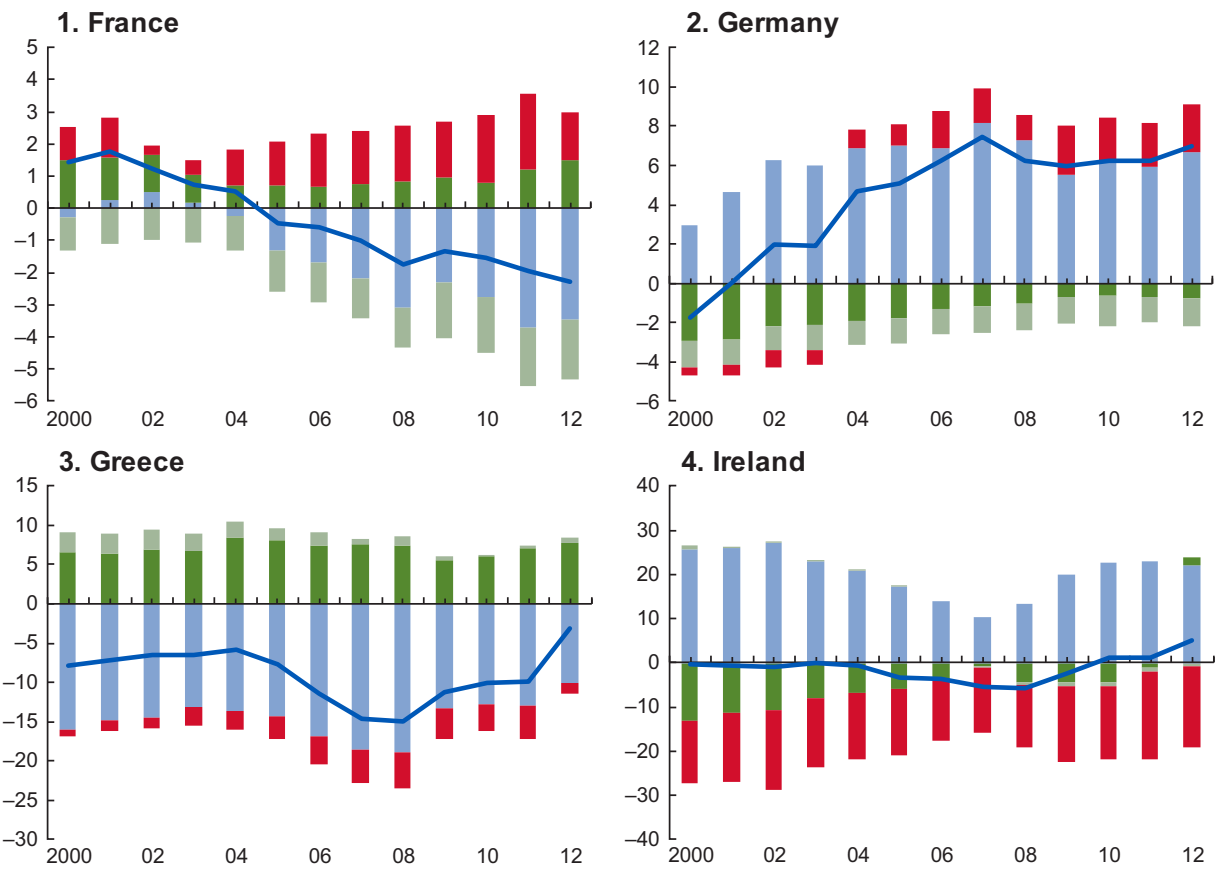

5. Italy

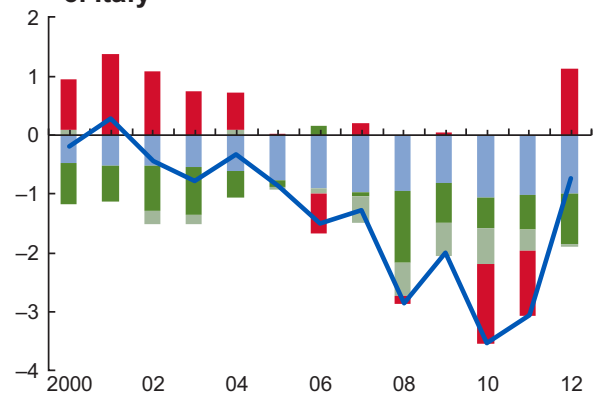

6. Netherlands

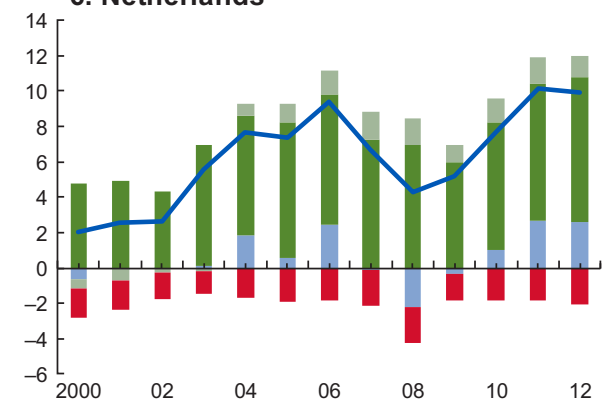

7. Portugal
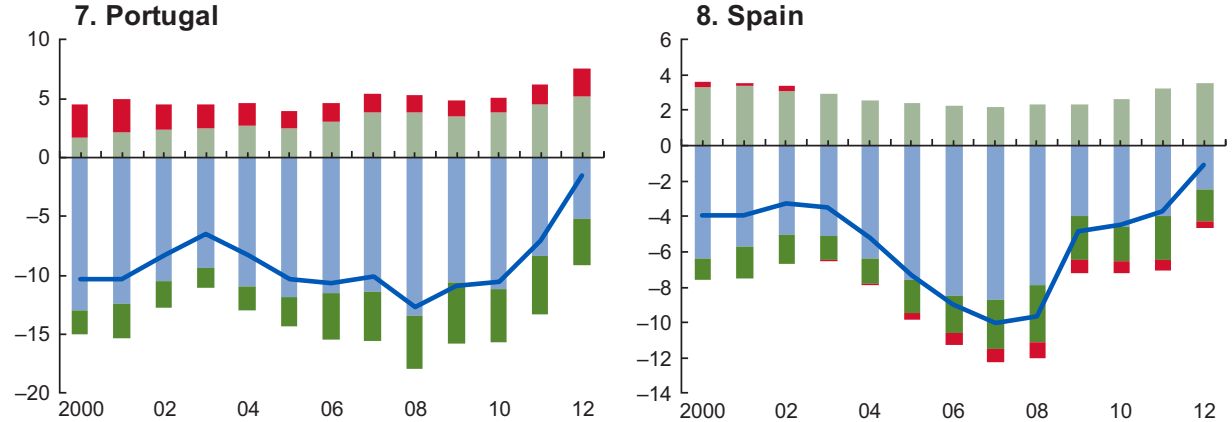

Sources: Eurostat; Haver Analytics; and IMF World Economic Outlook.

Figure 3.3 Euro Area: Current Account and Its Components (Percentage of GDP) 
REERs have declined substantially in selected debtor economies, largely because of changesin ULCs and nominal adjustment...

\section{ULC-Based REER Changes and Its Components: 2008-12 (Relative to 36 trading partners)}

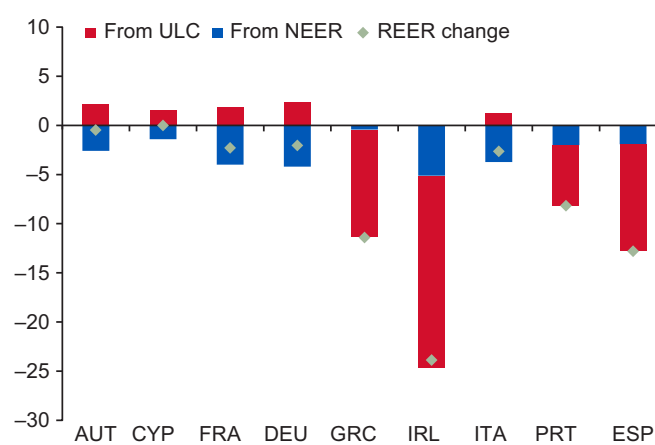

The ULC gap between the core and selected debtor economies is closing..

3. Total Economy ULC Developments: 2000-12 (Index 2000 = 100)

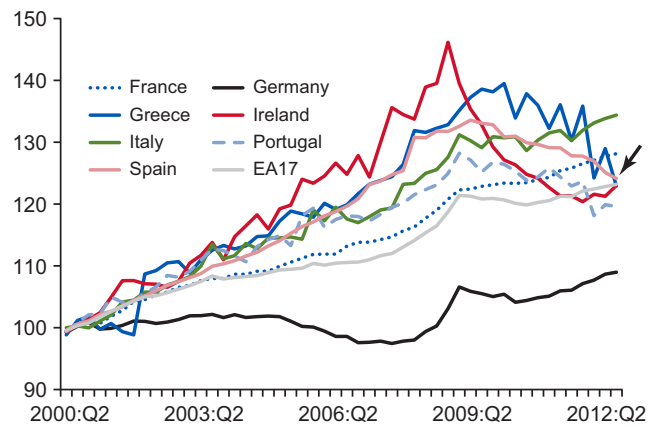

...but more modest contributions from CPI, except in Ireland.

2. CPI-Based REER Changes and Its Components: 2008-12 (Relative to 36 trading partners)

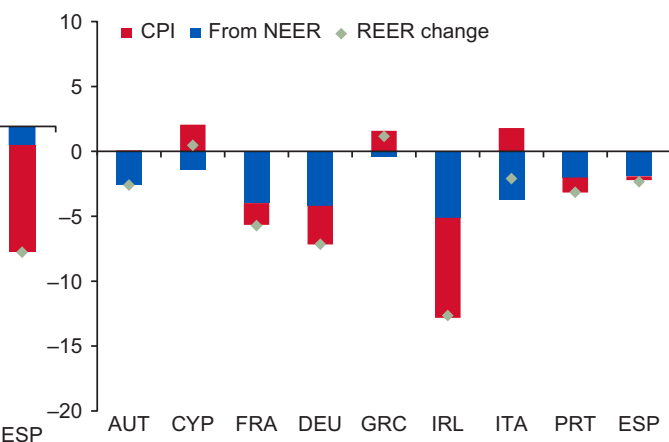

...with France and Italy still trending upward.

\section{Total Economy ULC Developments:} 2000-12 (Index: Ireland in $2000=100$ )

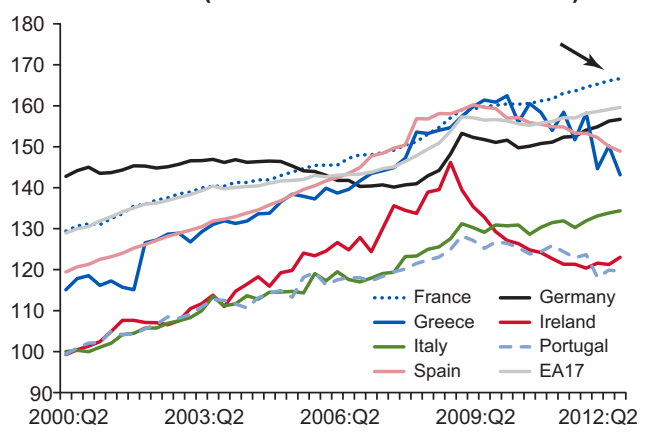

Sources: Eurostat; Haver Analytics; and IMF staff calculations.

Note: $\mathrm{CPI}=$ consumer price index; NEER = nominal effective exchange rate; REER = real effective exchange rate; ULC = unit labor cost. See Abbreviations and Acronyms section for composition of EA17. Data labels in the figure use International Organization for Standardization (ISO) country codes.

Figure 3.4 Euro Area: Real Effective Exchange Rate and Unit Labor Cost Developments

\section{Based on Consumer Price Index (CPI)}

- Relative CPI (intra-euro area)

- Relative CPI (non-euro area)

5 Nominal effective exchange rate

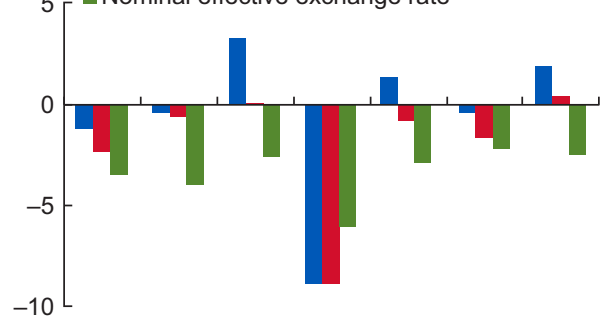

\section{Based on GDP Deflators}

nelative GDP deflator euro area

- Relative GDP deflator non-euro area

2 Nominal effective exchange rate

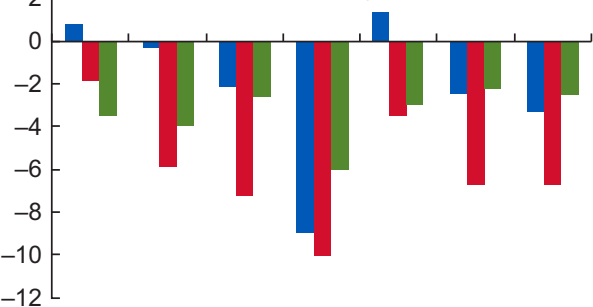

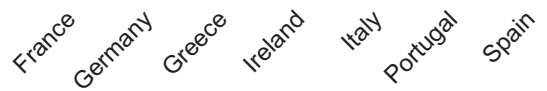

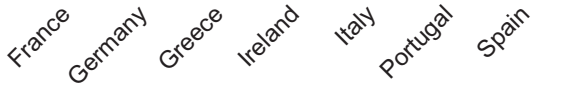

Sources: IMF Direction of Trade Statistics, Effective Exchange Rate Facility, and World Economic Outlook.

Figure 3.5 Relative Price Adjustments, 2008:Q3-2012:Q4 (Percent) 


\section{BOX 3.1. Unit Labor Cost (ULC) Developments in Tradable} and Nontradable Sectors ${ }^{1}$

Relative price adjustments are taking place in both the tradable and nontradable sectors, although quite unevenly at the national level:

- Several external debtor countries (Greece, Ireland, and Portugal) experienced larger reversals of ULCs in the tradable goods sector than in the nontradable sectors. However, saving in ULCs is sometimes achieved by large-scale labor shedding, as in Greece and Portugal.

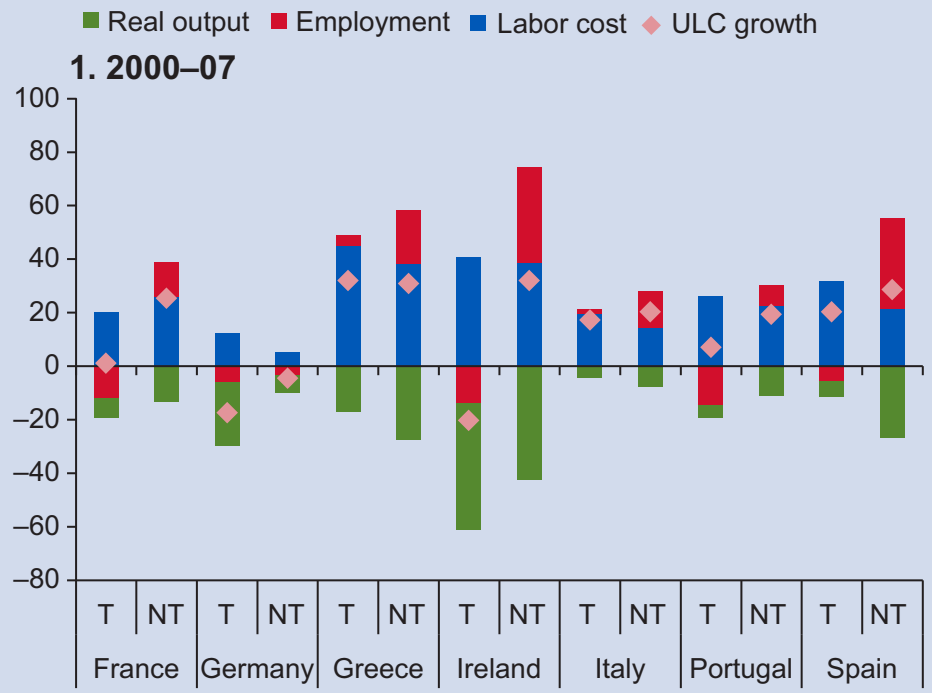

2. 2008-12

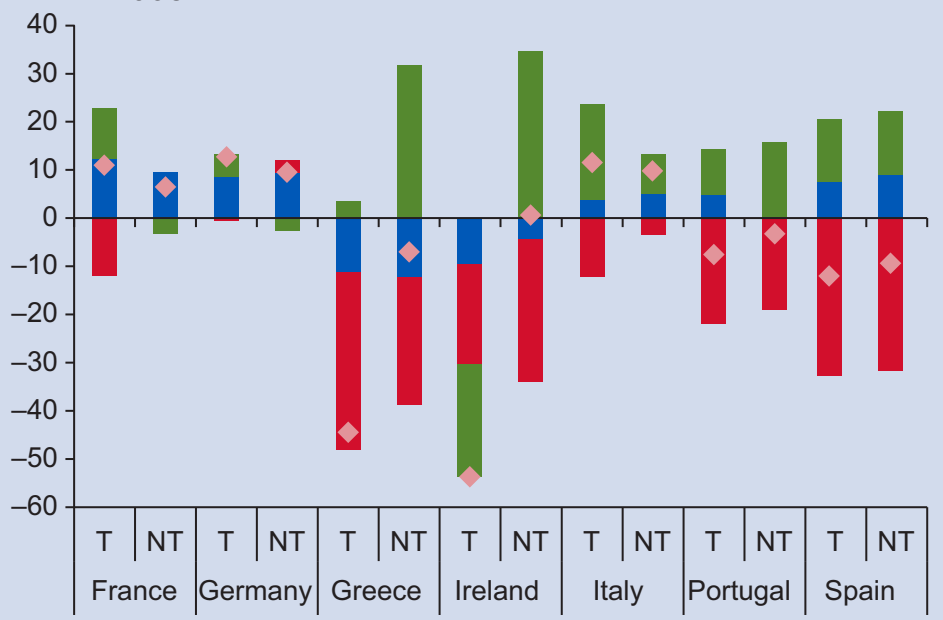

Sources: Eurostat; Haver Analytics; and IMF staff calculations.

Note: NT = nontradable; $\mathrm{T}=$ tradable; ULC = unit labor cost.

Figure 3.1.1 Contributions to Unit Labor Cost Changes (Percent)

${ }^{1}$ Tradable sector comprises manufacturing. Nontradable sector comprises construction, wholesale and retail, hotel, and transportation (ECB 2012). 


\section{BOX 3.1. (continued)}

- Ireland has been a good example of external adjustment, for example, output in the tradable sector began recovering in 2011, supporting growth.

- Spain experienced a larger drop in ULCs in its nontradable goods sector and has relatively sticky labor costs. Most of the adjustment has been through output loss and unemployment.

- Competitiveness in the large economies has diverged: France's and Italy's ULCs of tradables have continued to rise since the crisis, reflecting deterioration of external competitiveness.

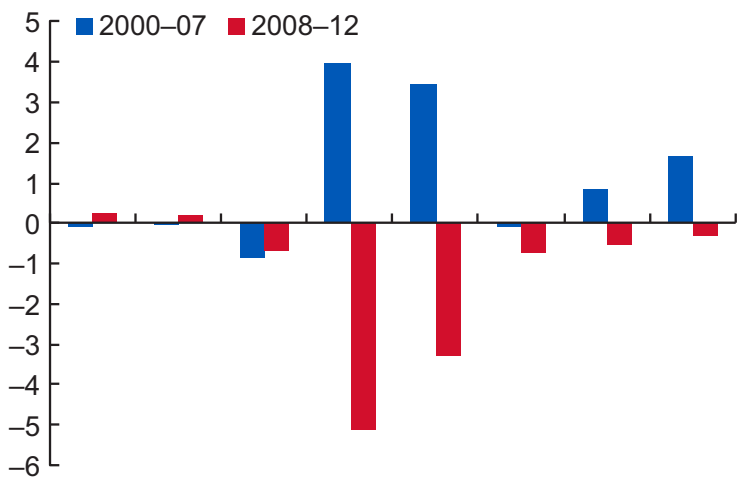

AUT FRA DEU GRC IRL ITA PRT ESP

Sources: Eurostat; and IMF staff calculations.

Note: See Abbreviations and Acronyms section for composition of EA17. Data labels in the figure use International Organization for Standardization (ISO) country codes.

Figure 3.6 Annual Wage Inflation: Manufacturing Relative to EA17

value-added tax hikes. They were mostly achieved vis-à-vis non-euro area trading partners (with the exception of Ireland, which exhibited large consumer price adjustments). Greece, Italy, and Spain experienced increases in consumer prices relative to their euro area trading partners. However, since the consumer price index (CPI) is not always a good measure of relative production costs, this analysis also considers a GDP deflator-based REER (Figure 3.5, panel 2). ${ }^{2}$ In contrast to the CPI, relative GDP deflators have declined substantially in Greece, Ireland, Portugal, and Spain, in particular in comparison with non-euro area trading partners.

- Wages. Since 2008, wages have declined in many external debtor countries relative to the euro area average. The adjustments have been particularly important in Greece, Ireland, and Portugal. Manufacturing wages declined the most in Ireland and Greece and grew at a similar pace as the euro area average in other debtor countries (Figure 3.6).

The evolution of ULC can be broken down into contributions from labor costs and from labor productivity. Labor productivity reflects changes in employment (a positive value means increasing ULC), and in output (a negative value means increasing output and negative contribution to ULCs). Figure 3.7 also shows the contribution to declining ULCs from their

\footnotetext{
${ }^{2}$ GDP-deflator-based REERs are good proxies for value-added REERs that reflect the vertical integration of trade (for
} example, Bems and Johnson 2012).

\section{(C) International Monetary Fund. Not for Redistribution}




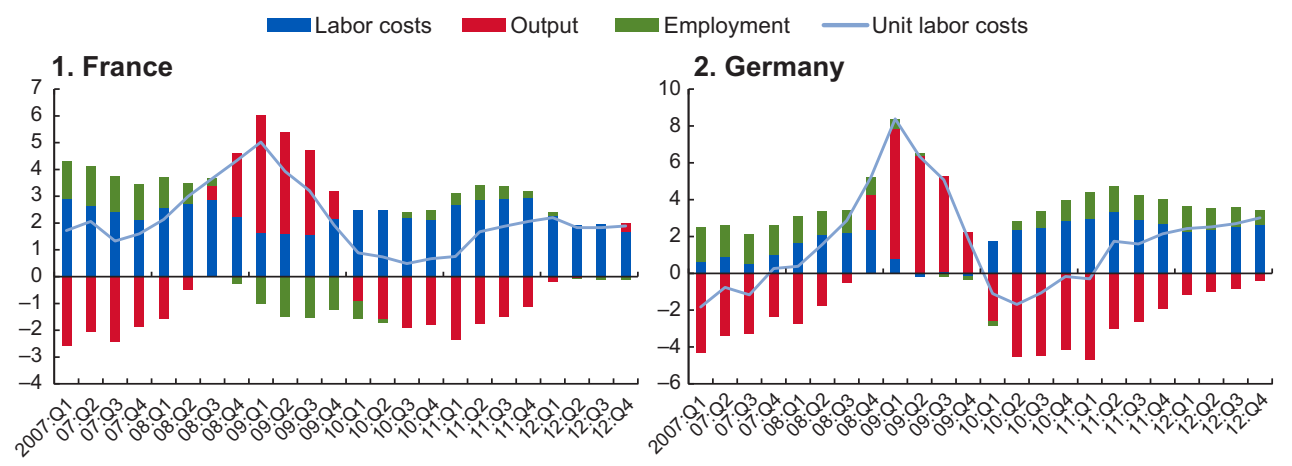

3. Greece

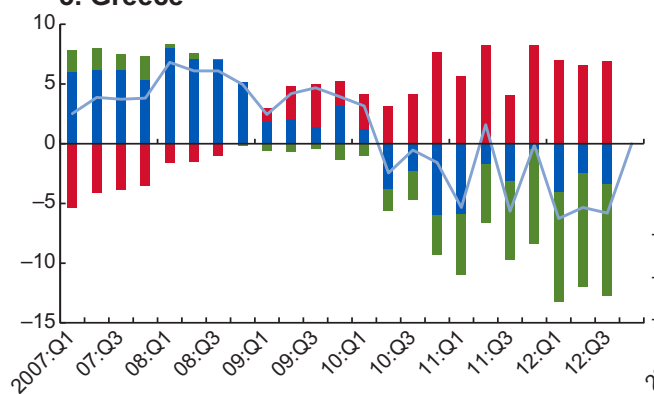

\section{Ireland}

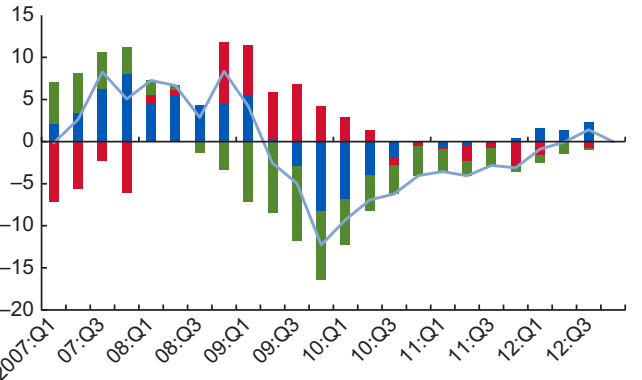

5. Italy

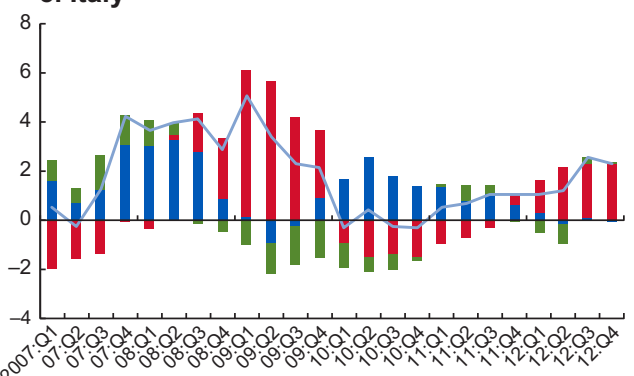

6. Netherlands

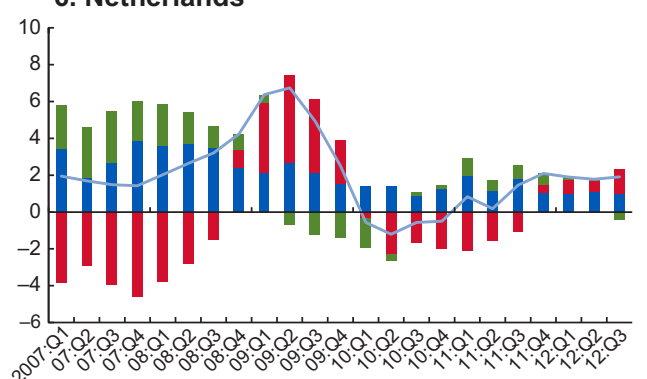

7. Portugal

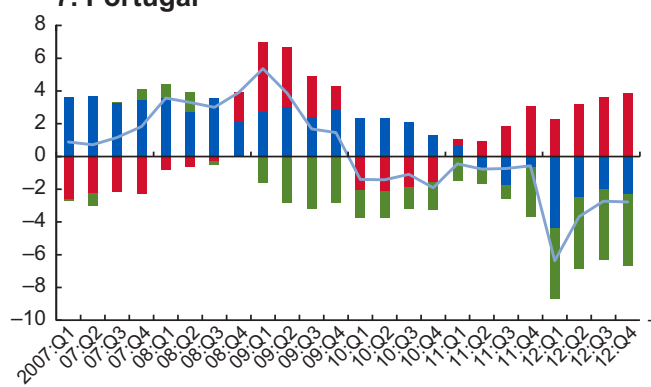

8. Spain

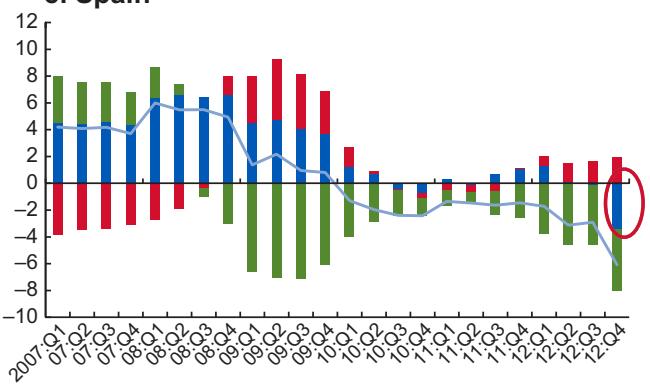

Sources: Eurostat; and IMF staff calculations.

Figure 3.7 Contributions to Changes in Unit Labor Cost (Percentage change, year over year) 


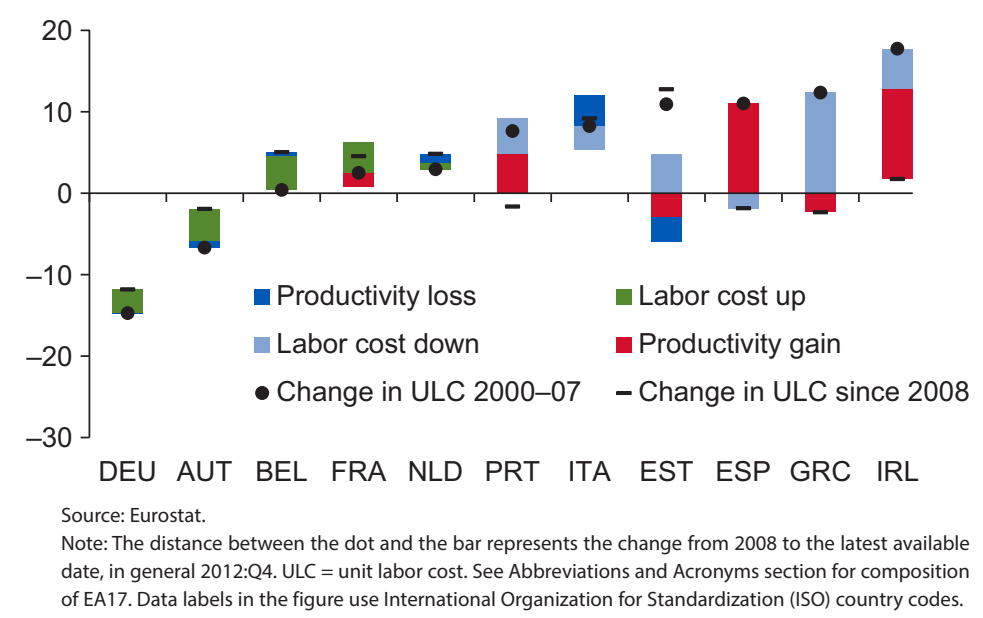

Figure 3.8 Unit Labor Cost Total Economy Growth Relative to EA17

peak for several euro area external debtor economies. ULCs have corrected in many debtor countries since 2008, although the sources of reversals have varied across countries (Figure 3.8).

- In Spain, productivity gains were achieved largely because labor shedding exceeded the decline in output, and the decline in wages relative to the euro area average was small.

- In Italy, the poor performance of labor productivity is explained by labor hoarding in a period of output decline.

- Ireland shows evidence of good relative price adjustment, for example, labor costs and labor shedding came down, in the context of a moderate growth recovery.

- In Greece and Portugal, a combination of declining wages and large labor shedding was the main driver of ULC adjustments.

- Meanwhile, in Germany, labor costs rose mainly because of higher wages, but the effect on ULC was mitigated by relatively strong output growth.

- At the sectoral level, debtor countries experienced large declines in tradable sector ULC, with the exception of Italy. However, the declines were mostly driven by large labor productivity gains, given that reductions in employment exceeded the decline in output. Ireland is the exception, as tradable output also expanded (Box 3.1).

Evidence suggests that labor cost adjustments have modestly improved the price competitiveness of exports.

- Volumes. Export growth picked up significantly after the crisis, mostly as a result of a rebound in external demand. Germany, Ireland, and Spain experienced relatively solid export recoveries, but export recoveries have been (and are forecasted to remain) weak in France, Greece, Italy, and Portugal (Figure 3.9).

- Export prices. Substantial ULC and wage adjustments have not been followed by gains in price competitiveness. ${ }^{3}$ In Greece, Ireland, Portugal, and, to some extent, Spain, exporters' margins have risen since the crisis. This increase could have occurred because exporters have attempted to increase profitability, reversing the precrisis trends of margin erosion.

\footnotetext{
${ }^{3}$ Some measurement errors could exist because the proxy for export prices is the unit export value for goods actually sold, which may not fully capture pricing-to-market behaviors nor cover transaction prices.
} 


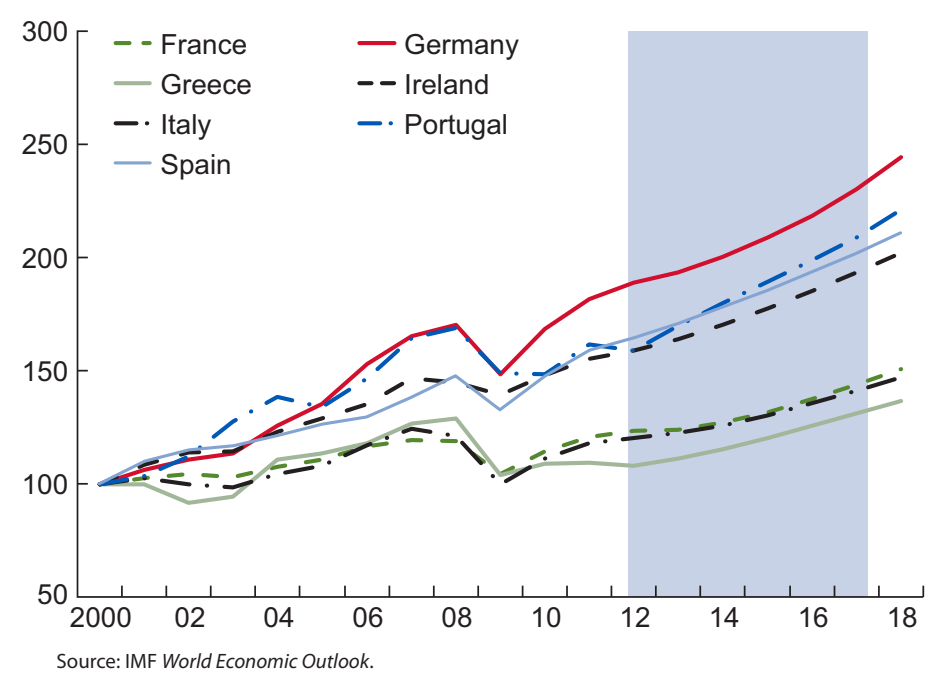

Figure 3.9 Real Exports (Index, 2000 = 100)

By contrast, the erosion of exporters' margins in France and Italy has continued since the crisis. In Germany, exporters increased their price margins before the crisis, perhaps to reverse previous trends, but margins seem to have declined somewhat in recent years. Price competitiveness (relative to production costs in export markets) has improved in Ireland and Spain, and to some extent in Germany, but it has declined in Greece and Portugal, and has remained stable in France and Italy.

Nonprice competitiveness. Indicators of market shares suggest that in general, competitiveness has not improved since the crisis. Most euro area countries (both external debtors and creditors) have lost market share in the world market. This loss could be explained by unrelated global developments in world trade, such as growing trade among emerging markets. However, several euro area countries, including France, Germany, Ireland, and Italy, have also lost market shares within the euro area since the crisis. By contrast, the market shares of Greece, Portugal, and Spain have remained stable (Figure 3.10).

The evidence suggests that although ULC adjustments have had large impacts on real disposable income, gains in price competitiveness have played a more limited role in supporting net exports. Although wages (relative to the euro area average), GDP deflators, and employment have declined in selected debtor countries, consumer prices have remained sticky, adjusting much more slowly (with the exception of Ireland), and even in the opposite direction (as in Greece). Hence, rising unemployment and wage adjustments are causing significant reductions in households' real disposable income, dampening domestic demand in the selected debtor countries. At the same time, the wage and employment adjustments have not clearly resulted in price or nonprice competitiveness gains because exporters have used part of the wage moderation to reconstitute their profit margins in Greece, Ireland, and Portugal.

Only limited evidence suggests that adjustment between the tradable and nontradable sectors has so far taken place. ${ }^{4}$

- Both price and quantity adjustments are needed. To rebalance, debtor countries must reallocate resources from nontradable sectors to tradable sectors; such a reallocation must be

\footnotetext{
${ }^{4}$ See Annex 3.1 for a definition of the tradable and nontradable sectors.
} 
1. Change in Ratio of Export Deflator to Tradable Unit Labor Cost (Percent)

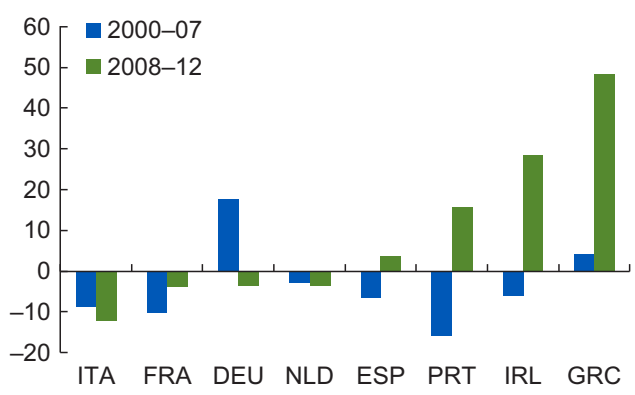

3. Change in Share of Exports to World (Percentage points)

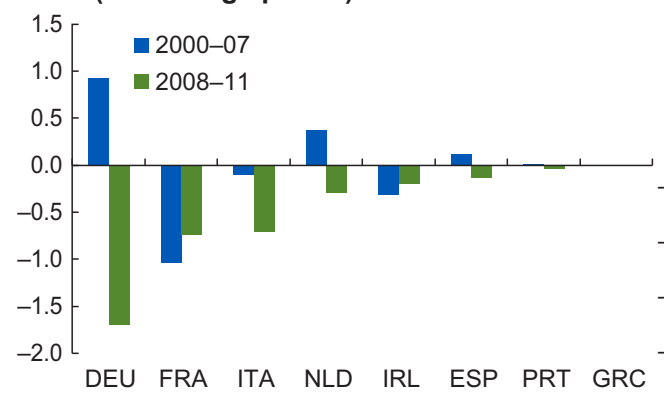

2. Export Prices Divided by GDP Deflators of Trading Partners

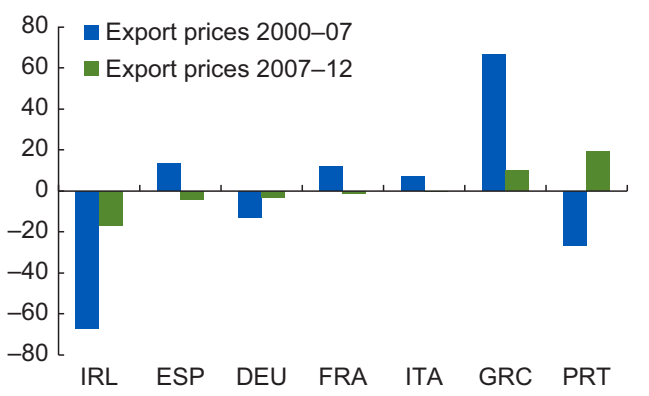

4. Change in Share of World Exports to Euro Area (Percentage points)

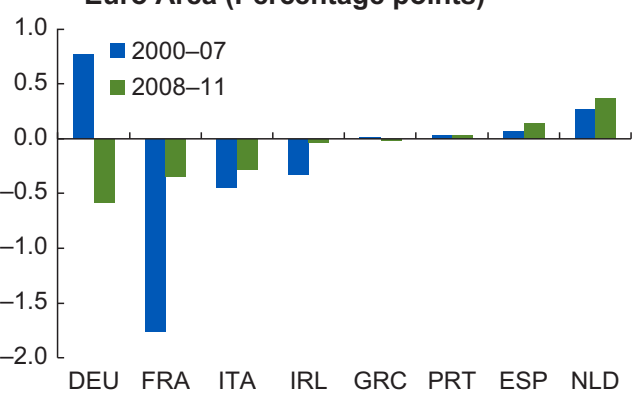

Sources: IMF Direction of Trade Statistics and World Economic Outlook.

Note: Data labels in the figure use International Organization for Standardization (ISO) country codes.

Figure 3.10 Evolution of Price and Nonprice Competitiveness: 2000-07 and 2008-12

associated with a decline in the price of nontradable goods relative to tradable goods. But external adjustment also requires a drop in tradable prices to improve external competitiveness. Sectoral labor reallocation to tradable sectors would then respond to improved profitability (resulting from cuts in costs and improvement in relative prices of tradable versus nontradable products), along with higher export demand (resulting from the absolute decline in tradable prices). This will ensure a structural change in the external balance, associated with lower imports and higher exports, but such reallocation could take time and be impeded by rigidities.

Adjustments have yet to take hold in the tradable sector. ULCs have declined in both tradable and nontradable sectors. In addition, export margins have increased in several countries with declining labor shares, ${ }^{5}$ making these sectors, in principle, more attractive for producers. As a result, however, export prices have not adjusted much compared with trade partners, which could prevent export demand from picking up. Indeed, evidence from sectoral labor flows and value-added growth show that labor (and output) have declined across sectors (both tradable and nontradable), and that the decline has often been more pronounced in the tradable sector (with the exception of Ireland), reflecting the general collapse in domestic demand (Figure 3.11, panels 1 and 2). Evidence from bank credit in Ireland and Spain suggests, however, a sharper decline in nontradable sectors and recent data point to a pickup of credit in the tradable sector (Figure 3.11, panels 3 and 4).

\footnotetext{
${ }^{5}$ Labor shares in gross value added have been declining in the past decade in the euro area, with sharp spikes during the 2008-09 crisis period when output and trade collapsed. In external debtor countries such as Spain, labor share has been declining since the crisis, reflecting both labor shedding and rising profit margins in the tradable sectors.
} 


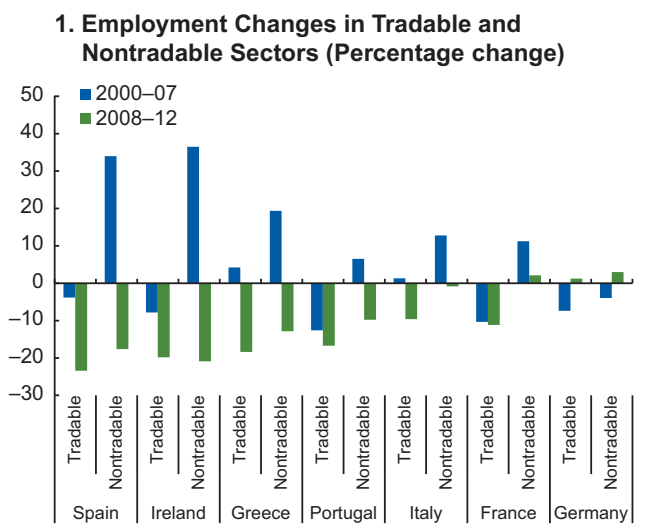

2. Gross Value Added Changes in Tradable and Nontradable Sectors (Percentage change)

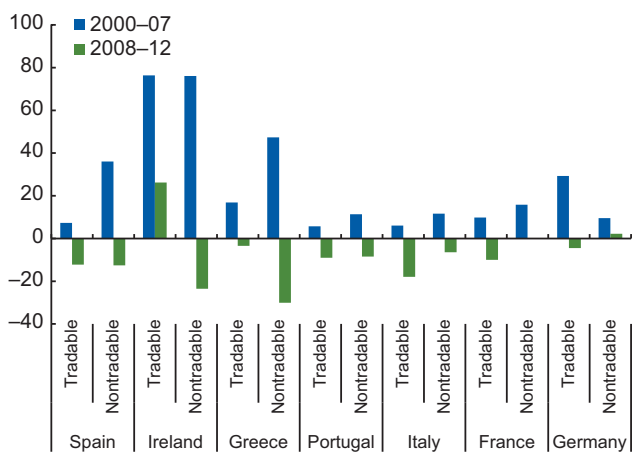

4. Spain (Credit to nonfinancial corporations, index; 2010:Q2 = 100)

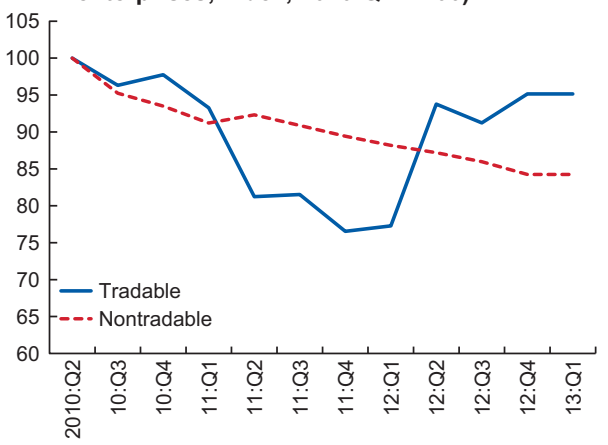

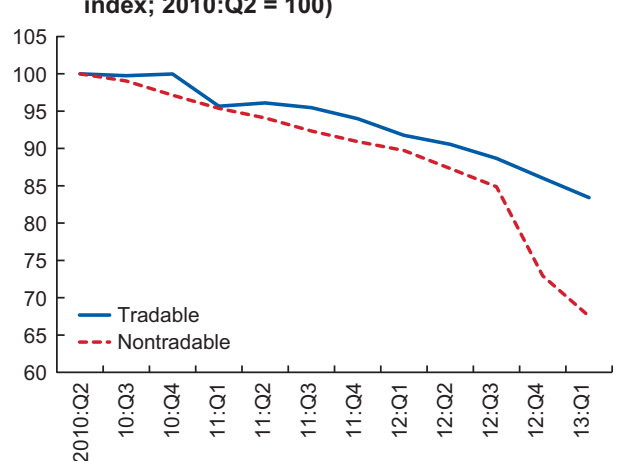

Sources: Eurostat; Central Bank of Ireland; Bank of Spain; and IMF staff calculations.

Note: Index of national stocks constructed from transactions. Tradable sector comprises manufacturing; nontradable sectors comprise construction, trade, travel and food, and real estate.

Figure 3.11 Adjustment in the Tradable and Nontradable Sectors

\section{WHAT EXPLAINS THE PERFORMANCE OF EXPORTS SINCE THE START OF THE CRISIS?}

This section analyzes the determinants of export performance in the euro area using standard panel export regressions. The sample comprises 11 euro area countries during the period 19902010. The export regressions are estimated in levels to capture a stable, long-term relationship between real exports and a set of determinants. Specifically, the following regression is estimated for bilateral exports of goods vis-à-vis the top 20 export partners:

$$
\begin{aligned}
\log _{E} \text { xport }_{i j t}= & \alpha \times \log \text { Demand }_{j t}+\beta_{n o n E A} \times \log N E R_{i j t} \\
& +\gamma \times \operatorname{logRel.CPI} i j t+\varepsilon_{i j t .}
\end{aligned}
$$

In equation (3.1) the dependent variable is the log of real exports of goods from country $i$ to country $j$ during year $t$ (converted into real values using the aggregate export price deflator); the determinants are, respectively, the log of real domestic demand (total volume of domestic demand) in country $j$ during year $t$; the log of the bilateral euro nominal exchange rate for non-euro area trading partner $j$; and the $\log$ of the relative consumer price index between euro area country $i$ and trading partner $j{ }^{6}$

\footnotetext{
${ }^{6}$ An alternative analysis uses relative GDP deflators as indicators of relative price adjustment.
} 
The regression coefficients are used to decompose the quarterly performance of real exports of goods and services as follows:

$$
\begin{aligned}
& \Delta \log E_{\text {xport }} \& \& S_{i t}=\alpha^{1} \times\left(\text { Share }_{E A}\right) \times \Delta \log \left(\text { Demand }_{E A_{t i}}\right) \\
& +\alpha^{2} \times\left(\text { Share }_{\text {nonEA }}\right) \times \Delta \log \left(\text { Demand }_{\text {nonEA }_{t i}}\right) \\
& +\beta_{\text {nonEA }} \times\left(\text { Share }_{n o n E A}\right) \times \log N E E R_{i j t} \\
& +\gamma^{1} \times\left(\text { Share }_{\text {nonEA }}\right) \times \text { lognonEARel.CPI }{ }_{i j t} \\
& +\gamma^{2} \times\left(\text { Share }_{E A}\right) \times \log \text { EARel.CPI }_{i j t}+\text { RES. }
\end{aligned}
$$

In equation (3.2)

- $\operatorname{Share}_{E A}$ is the share of euro area countries in total exports of goods.

- Share nonEA is the share of non-euro area countries in total exports of goods.

- Demand ${ }_{E A_{t}}$ is a quarterly weighted average of euro area trading partners' domestic demand; trade weights are the shares of bilateral exports to country $I$ in total exports of goods to the euro area.

- Demand ${ }_{n o n E A_{t}}$ is a quarterly weighted average of non-euro area trading partner domestic demand; trade weights are the shares of bilateral exports to country $i$ in total exports of goods to the euro area.

- $N E E R_{i j t}$ is the nominal effective exchange rate.

- EA and nonEARel.CPI are the relative prices of euro area and non-euro area countries.

- RES is the residual.

Since the start of the crisis, euro area countries have experienced significant differences in the demand for their exports. For example, between 2008 and 2012, total trading partners' demand for Germany's exports grew by 4.7 percent, compared with 2.8 percent for France, 1.8 percent for Spain, 1.7 percent for Italy, 0.5 percent for Greece, and -0.3 percent for Portugal (Figure 3.12). These differences reflect each country's initial geographic specialization. Germany's relatively large share of exports outside the euro area and to fast-growing emerging markets contributed to a relatively stronger rebound in exports. In contrast, export demand growth was more sluggish in external debtor countries as a result of either specialization in slower-growing markets outside the euro area (Italy and especially Greece) or lower shares of exports to non-euro area countries (Spain, Portugal). In all countries, demand from other euro area countries has been declining during the period, contributing to slower export growth (Figure 3.13).

Export demand from the rest of the world and changes in nominal effective exchange rates provided the strongest contributions to export performance, while weak demand from within the euro area dampened exports (Figure 3.14).

- Initial trade specialization is important: It helps explain the extent to which euro area countries' exports have rebounded. Germany's relatively large share of exports outside the euro area and in growing markets contributed to its relatively stronger rebound in exports, and made its export performance less dependent on intra-euro area demand than that of southern euro area countries. For Greece, specialization in slow-growing markets (Figure 3.15) has constrained export growth.

- Demand from the rest of the world is the main pull factor: It contributed to 47 percent and 42 percent, respectively, of the relatively strong rebound of Germany's and Spain's exports, and to 80 percent of France's exports rebound. It cushioned the headwinds on Italy's exports and was the main driver of Portuguese exports (including to fast-growing African countries).

\section{CInternational Monetary Fund. Not for Redistribution}




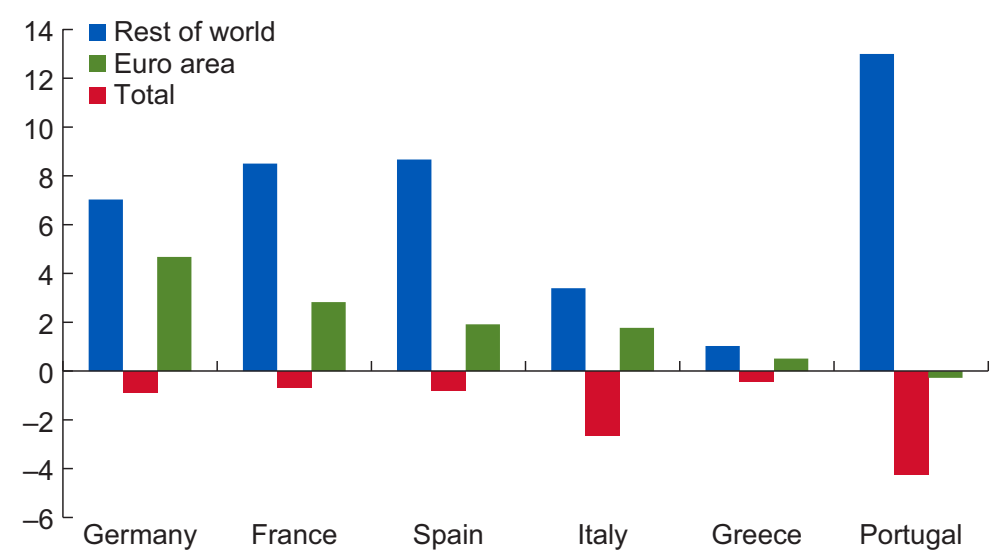

Sources: IMF, Direction of Trade Statistics database; IMF, World Economic Outlook database; and IMF staff calculations.

Figure 3.12 Export Demand Growth, 2008-12 (Percent)

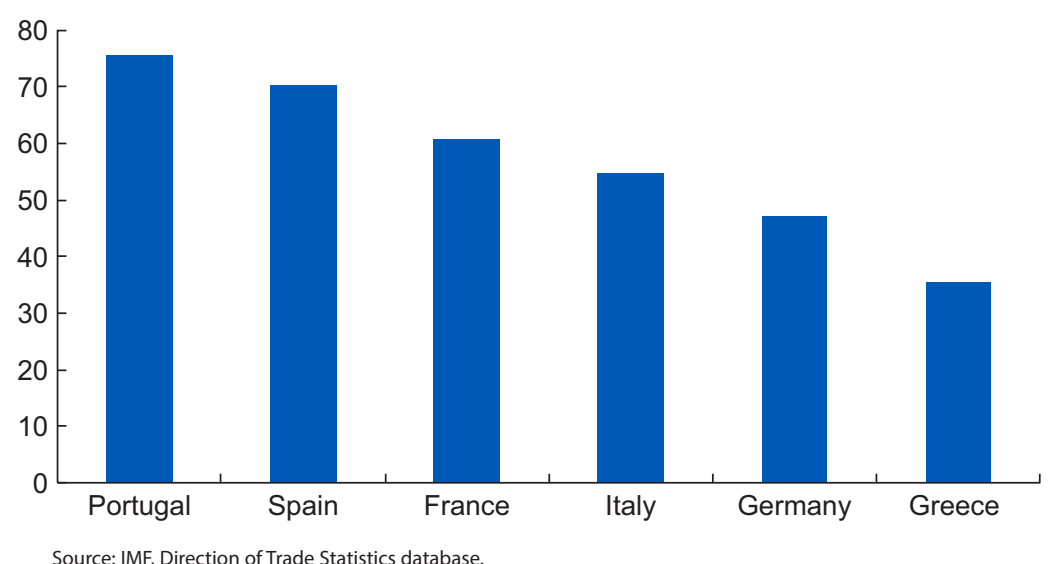

Figure 3.13 Share of Euro Area in Total Exports of Goods (Percent)

- Relative price adjustments also matter, although the precise effect is uncertain: When measured using the CPI, relative price adjustments (vis-à-vis euro area trading partners or others) appear to have had a small effect on the exports of the debtor countries, Italy, France, and Germany. Although the small contributions of relative prices are partly a result of the small elasticity of exports to relative prices, the impact also depends on the relative price considered. As demonstrated in the earlier section "How Much Adjustment Has Occurred?" CPI adjustments have been relatively small (either compared with euro area trading partners or non-euro area trading partners), although relative price adjustments as measured by GDP deflators have been more substantial (Figure 3.16). ${ }^{7}$ In this case, the contribution to export performance of GDP deflator adjustments was large for Germany, Portugal, and Spain. For the latter two countries, the changes in relative prices account for 20 percent and 35 percent of real export growth, respectively, between 2008:Q3 and 2012:Q4.

\footnotetext{
${ }^{7}$ We replicate the analysis, using the same relative price elasticities, but with GDP deflators instead of the CPI as measures of relative prices. Using the same elasticities allows us to assess the impact of using GDP deflators instead of the CPI on the contribution of each variable to export performance.
} 

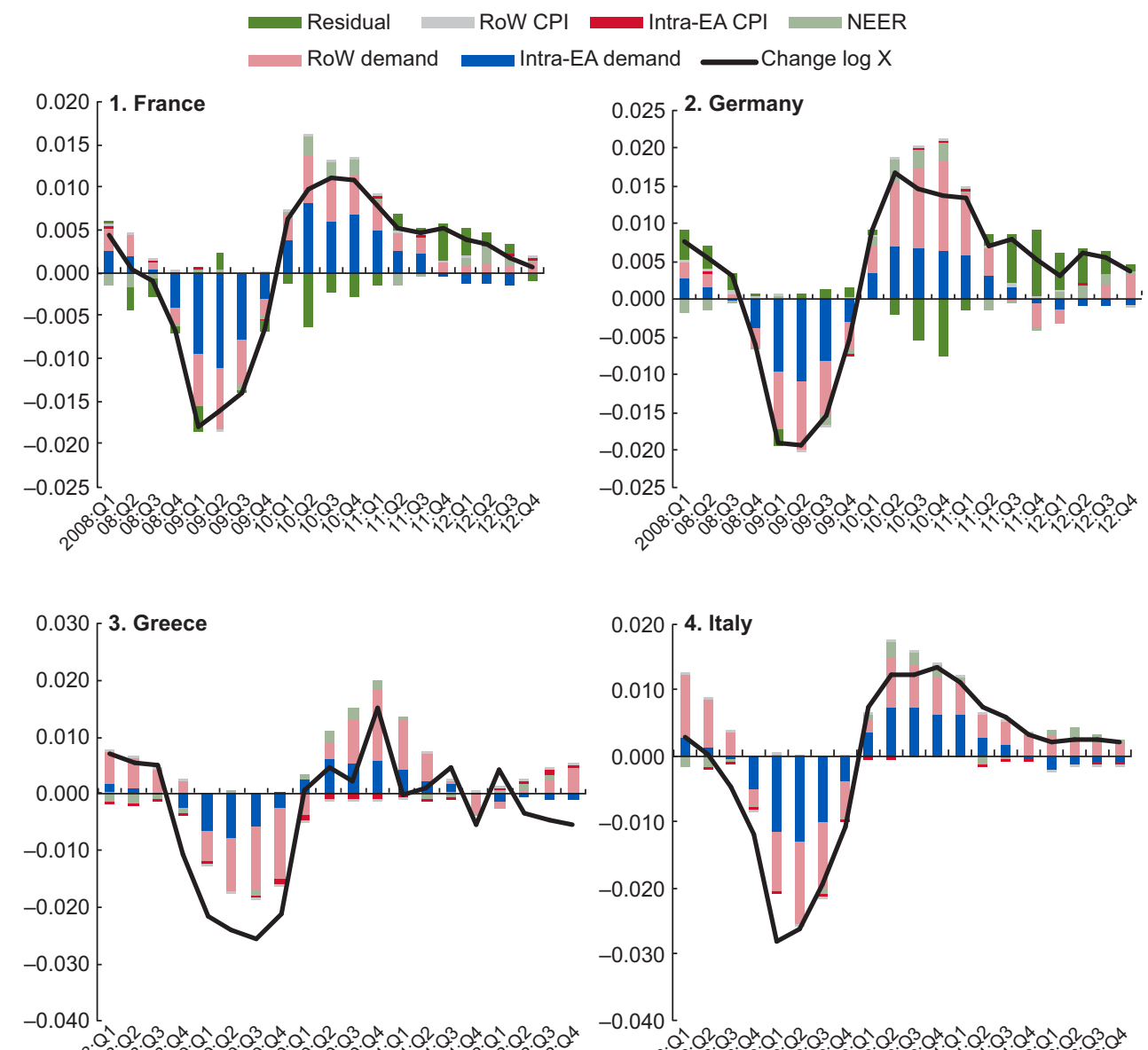

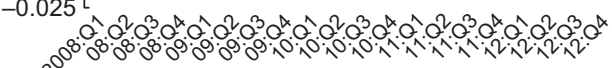
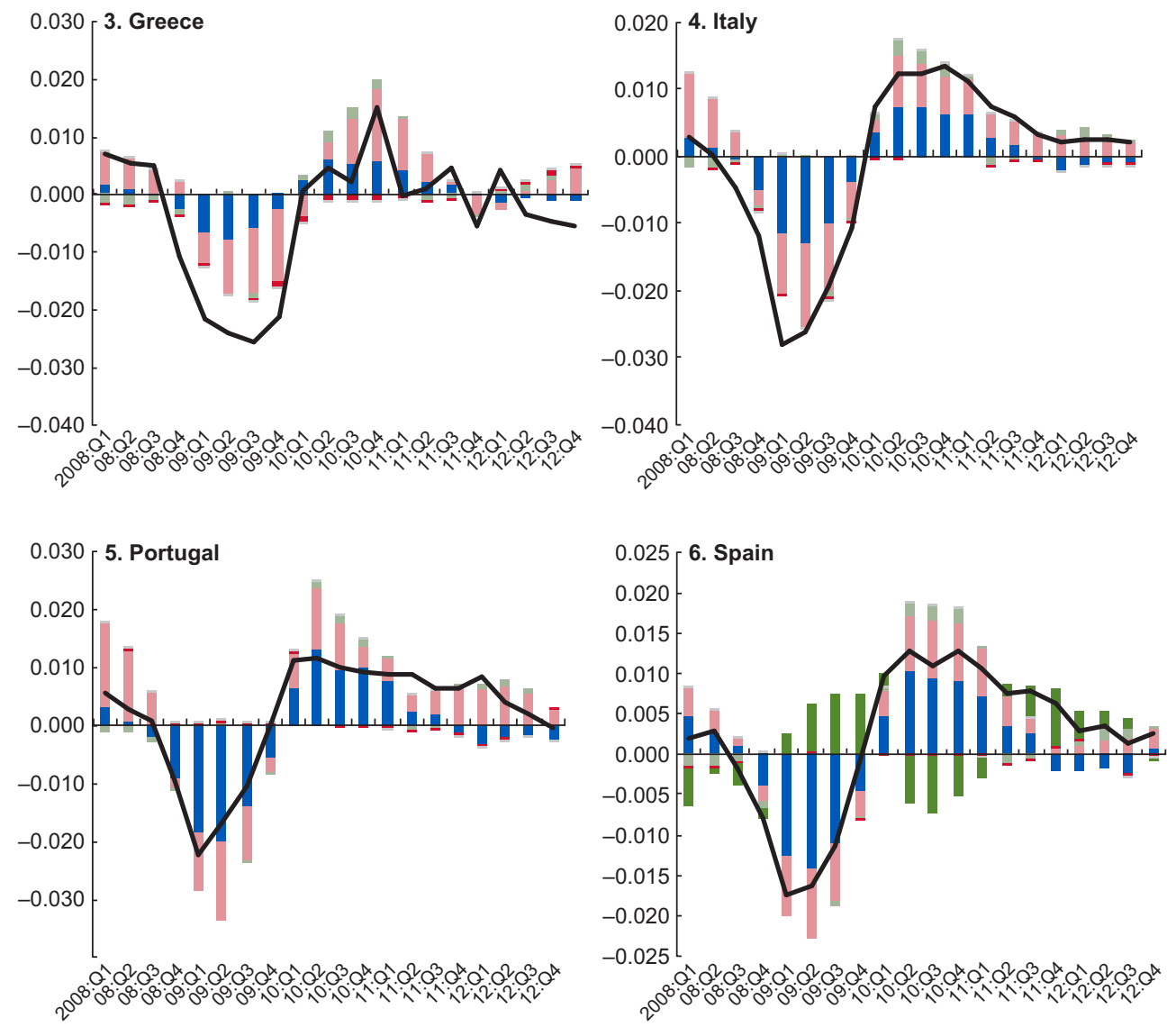

Sources: IMF Direction of Trade Statistics, Effective Exchange Rate Facility, and World Economic Outlook; and IMF staff calculations.

Note: $\mathrm{CPI}$ = consumer price index; $\mathrm{EA}=$ euro area; NEER = nominal effective exchange rate; RoW = rest of world. Contributions to quarterly real export growth of intra-euro area demand, demand from the rest of the world, the nominal effective exchange rate, and relative price adjustments (based on CPIs) vis-à-vis euro area trading partners and non-euro area trading partners. Demand and price elasticities are those estimated in regression (1), as shown in equation (3.1). Moving averages of each variable over four quarters are considered.

Figure 3.14 Determinants of Quarterly Export Performance 

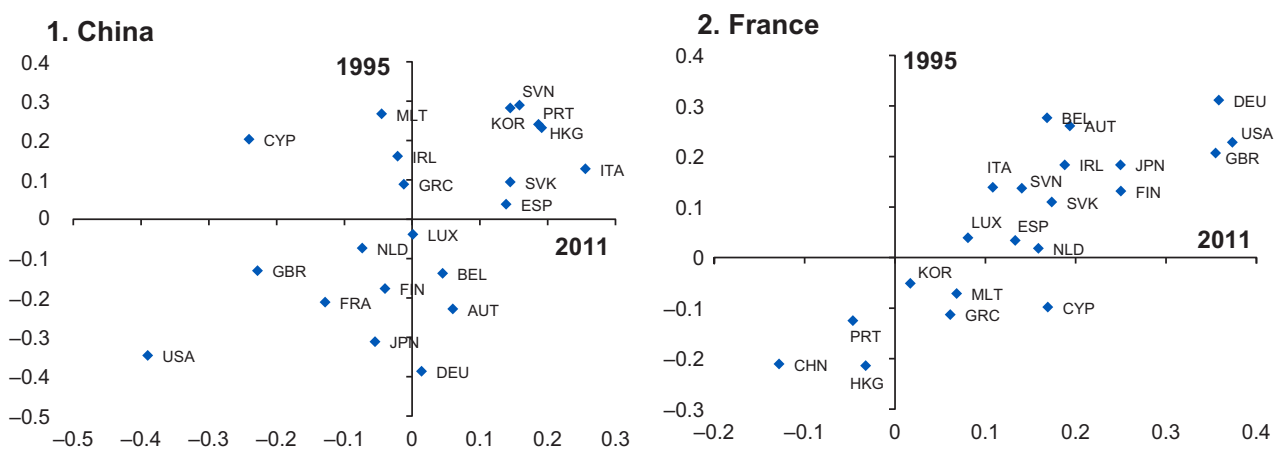

3. Germany
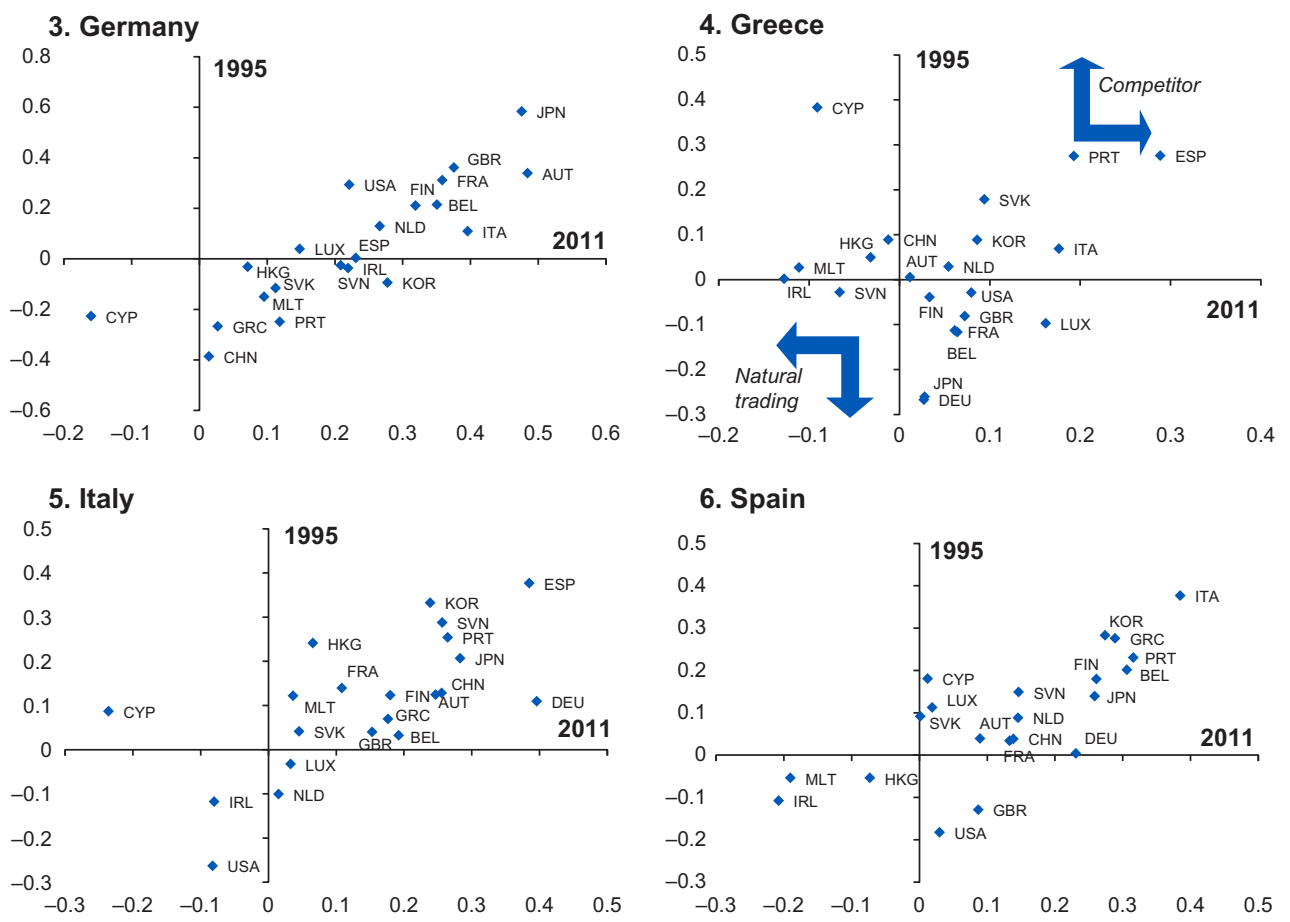

\section{Spain}

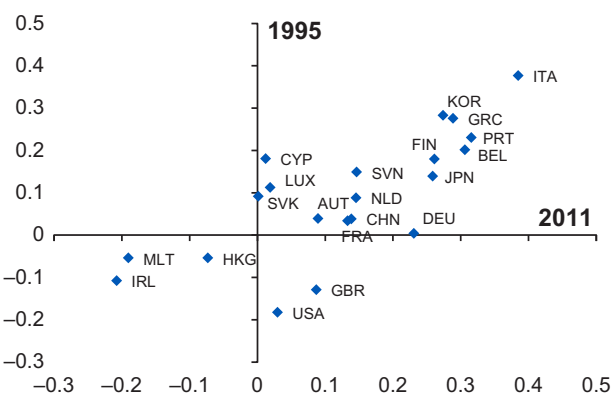

Sources: United Nations Conference on Trade and Development; and IMF staff calculations.

Note: The Trade Correlation Index is a simple correlation coefficient between economy A's and economy B's trade specialization index. The resulting coefficient can take a value from -1 to 1 . A positive value indicates that the economies are competitors in the global market because both countries are net exporters of the same set of products. Consequently, a negative value suggests that the economies do not specialize in the production or consumption of the same goods, and are therefore natural trading partners. See Abbreviations and Acronyms section for country abbreviations.

Figure 3.15 Trade Correlation Index: 1995 and 2011

- The nominal exchange rate also played a role: The nominal effective exchange rate contributed as much as external demand to France's exports, and to 30 percent, 28 percent, and 17 percent of the exports of Germany, Portugal, and Spain, respectively.

- Weak euro area demand was a drag: The euro area crisis had a direct impact on the export performance of euro area countries because demand from euro area trading partners declined during the early phase of the crisis in 2008-09 but also more recently. The impact was particularly large for Italy and Portugal.

- Unexplained factors: Greece's export performance was significantly weaker than predicted by the developments in external demand and relative price adjustments. There could be various explanations, such as lower-than-average demand or relative price elasticities (which could 


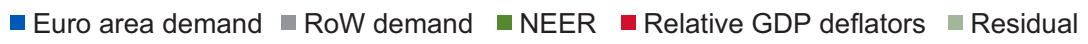
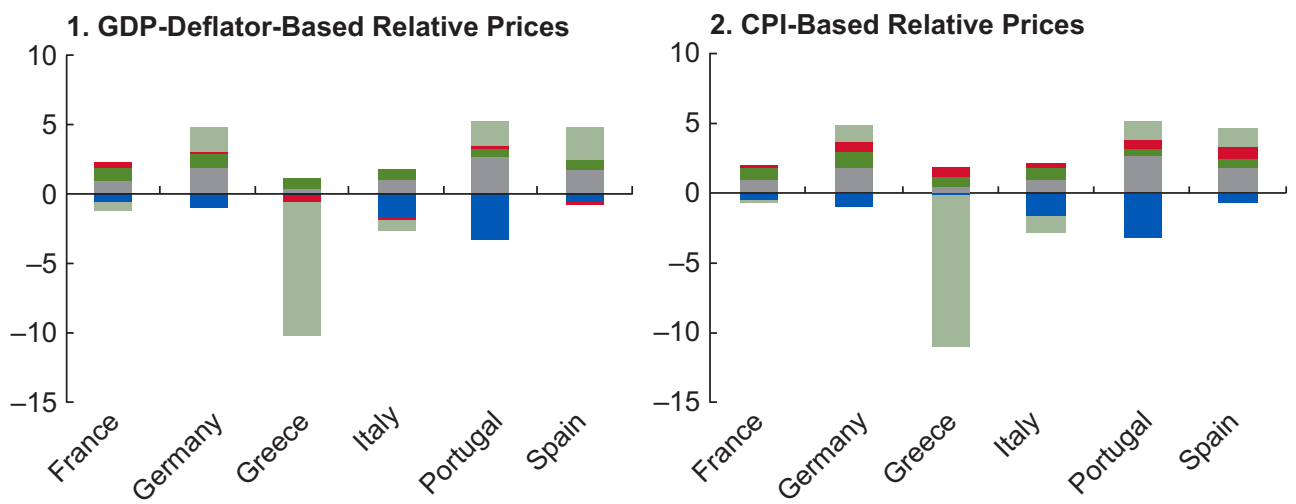

Source: IMF staff calculations.

Note: $\mathrm{CPI}$ = consumer price index; $\mathrm{NEER}=$ nominal effective exchange rate; RoW = rest of world.

Figure 3.16 Cumulative Contributions to Export Performance, 2008:Q3-2012:Q4 (Percentage points)

be related to structural impediments and nonprice competitiveness) or a substantial loss in nonprice competitiveness. In contrast, in Germany, Portugal, and Spain, the unexplained residual is relatively large and positive, suggesting that nonprice factors could have helped support export performance.

\section{EXTERNAL ADJUSTMENT: CYCLICAL OR STRUCTURAL?}

A key remaining question is whether recent current account adjustments reflect cyclical or structural factors, or a mixture of the two.

Panel regression analysis allows the contribution of structural and cyclical factors to the evolution of current accounts to be assessed. The approach builds on the existing literature, based on the standard intertemporal approach to the current account emphasizing saving and investment decisions (Chinn and Prasad 2003; Lee and others 2008; Christiansen and others 2009). In particular, this analysis follows the method used in the IMF's 2013 External Balance Assessment analysis of 50 advanced and emerging market economies, with the coverage period extended to 1986-2012. The standard fundamental determinants of saving and investment decisions include (1) demographics (population growth, old-age-dependency ratio, and aging speed); (2) initial wealth (lagged NFA); (3) long-term growth and neoclassical catch-up (five-year-ahead real GDP growth and gap to U.S. GDP per capita); (4) other structural factors (cyclically adjusted fiscal balance, public health spending); ${ }^{8}$ and cyclical factors (output gap, global capital market conditions, commodity terms of trade).

The standard regression is augmented to capture the impact of changes in potential output on the current account. An unanticipated and permanent decline in the level of potential output should cause a decline in consumption and investment, thereby resulting in an improved current account balance. Indeed, consumption adjusts immediately by the permanent amount of the decline in productivity, also reflecting lower investment in the future (and thus exceeding the initial decline in output), causing a temporary increase in saving, while investment also declines.

\footnotetext{
${ }^{8}$ Other factors considered structural but of little relevance for this analysis include capital controls, reserves accumulation, and whether the country is a financial center. The regression also includes the oil trade balance for a few countries in which it exceeds 10 percent of GDP.
} 


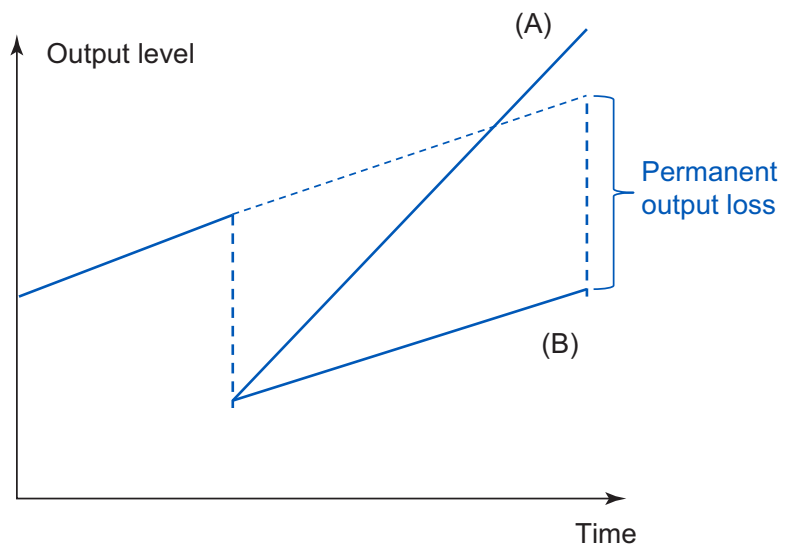

Figure 3.17 Permanent and Temporary Output Losses

The standard current account regression does not capture this effect well. The expected growth term captures the intertemporal effect of changes in productivity growth (case (A) in Figure 3.17), but not the effect of changes in productivity levels (case (B) in Figure 3.17). The gap relative to the level of U.S. GDP per capita captures the neoclassical convergence term, which has the opposite effect on the current account (for example, a lower GDP per capita relative to the United States results in a lower current account balance). Therefore, it is not well suited to capturing the impact of an unexpected drop in potential output. The purchasing-power-parity potential output level per capita relative to the world average is included as an additional explanatory variable to account for this effect.

The analysis also accounts for common factors underlying the evolution of external balances in the euro area external debtors that are over and above the impact of observed cyclical and structural determinants. These common patterns could be structural or cyclical in nature. The literature has shown that euro area external debtors experienced common current account patterns related to the reduction in risk premiums, the removal of exchange rate risks, overly optimistic convergence expectations, and regulatory factors after the creation of the Economic and Monetary Union (for instance, Blanchard and Giavazzi 2002; Blanchard, Giavazzi, and Sa 2005; Chen, Milesi-Ferretti, and Tressel 2012). These factors led to a surge of intra-euro area capital flows, contributing to domestic asset bubbles and worsening external positions (IMF 2011). In the aftermath of the crisis (and particularly since 2011), the euro area debtor countries have experienced sharp reversals of these private capital flows (Laeven and Tressel 2013). To control for these unobserved (and difficult to measure) determinants of the current account, time effects that are common to all debtor countries are included in the regression.

The empirical results suggest that both cyclical and structural factors have contributed to the recent improvement in current account balances (Table 3.1 and Figure 3.18). ${ }^{9}$ Cyclical factors have played a significant role in the current account reversals of Greece, Ireland, and Spain. The impact of measured structural factors (potential output, demographics, and others) has generally been more modest. ${ }^{10}$ However, "other debtor factors" — which arguably reflect both structural and

\footnotetext{
${ }^{9}$ The assessment is based on the output gap and potential output estimates of each World Economic Outlook vintage. There is an ongoing debate about how potential output and the output gap should be estimated in real time, including to better capture financial cycles. See, for instance, Borio, Disyatat, and Juselius (2013). The analysis in this chapter does not include those considerations.

${ }^{10}$ The impact of a decline in the output level on the current account is theoretically and empirically ambiguous as noted above: while the neoclassical effect tends to lower the current account balance (as the distance to the total factor productivity frontier increases), the decline in potential output has the opposite effect (because consumption falls by the
} 
TABLE 3.1

\begin{tabular}{lrcccccccr}
\hline \multicolumn{1}{l}{ Contributions to Current Account Adjustment: 2007-2012 } \\
\hline \multicolumn{10}{c}{ (Percentage of GDP) } \\
\cline { 2 - 10 } & CA & Cyclical & Demography & $\begin{array}{c}\text { LT Development } \\
\text { and Growth }\end{array}$ & NFA & $\begin{array}{c}\text { Other } \\
\text { Structural }\end{array}$ & $\begin{array}{c}\text { Potential } \\
\text { Output }\end{array}$ & $\begin{array}{c}\text { 0ther Debtor } \\
\text { Effect }\end{array}$ & Unexplained \\
\hline Greece & 10.19 & 5.13 & 0.43 & -0.11 & -0.02 & 0.25 & 0.45 & 3.38 & 0.69 \\
Ireland & 7.63 & 2.48 & 0.19 & -0.19 & -1.49 & -0.76 & 0.58 & 3.38 & 3.43 \\
Italy & -0.23 & 1.48 & 0.61 & 0.07 & -0.03 & 0.98 & 0.45 & - & -3.79 \\
Portugal & 7.60 & 0.70 & 0.33 & 0.38 & 0.04 & 0.15 & 0.31 & 3.38 & 2.31 \\
Spain & 8.02 & 2.14 & 1.02 & 0.58 & 0.04 & -0.66 & 0.33 & 3.38 & 1.20 \\
France & -0.73 & 0.02 & -0.17 & 0.46 & -0.61 & -0.06 & 0.36 & - & -0.74 \\
Germany & -2.02 & -0.53 & 0.57 & 0.76 & -0.05 & 0.17 & 0.19 & - & -3.13 \\
\hline
\end{tabular}

Note: Cyclical includes contribution of output gap, financial conditions, and commodity terms of trade. Potential growth includes the contributions of neoclassical catch up term and expected medium-term growth. Other structural include contributions of the fiscal balance, capital controls, and social spending. $\mathrm{CA}=$ current account; NFA = net foreign assets.

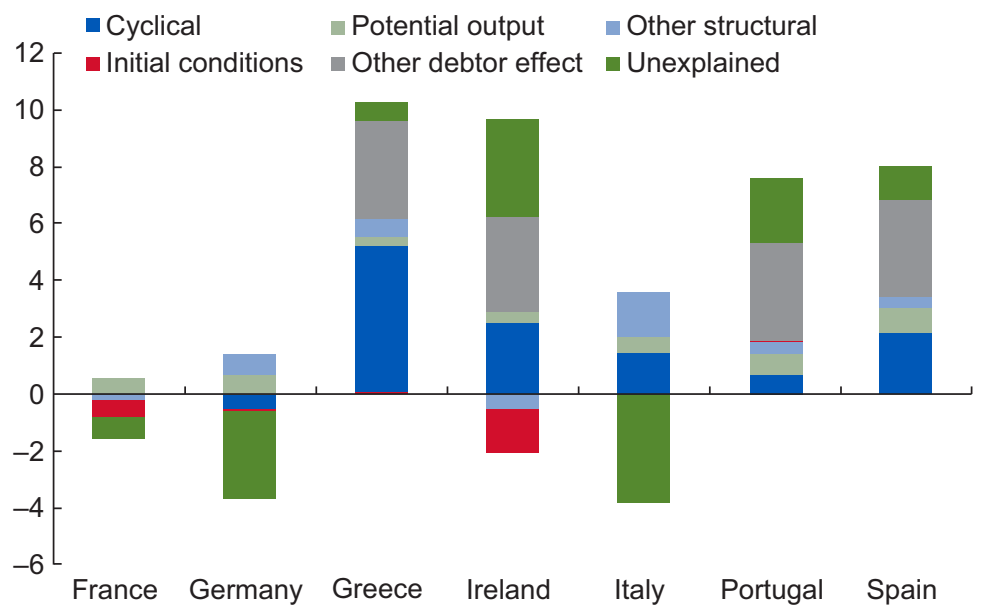

Sources: IMF Direction of Trade Statistics, Effective Exchange Rate Facility, and World Economic Outlook; and IMF staff calculations.

Figure 3.18 External Adjustment: Contribution to Change of Current Account, 2007-12 (Percent of GDP)

cyclical underlying forces-account for a significant portion of the external adjustments. The unexplained part of the adjustment remains large in some cases (for example, Italy).

\section{THE ADJUSTMENT GOING FORWARD}

Further adjustment in relative prices would be needed to complete the euro area rebalancing (based on current account or REER targets). According to the IMF "2013 Pilot External Sector Report" (IMF 2013), additional adjustment of real exchange rates by 5-10 percent is desirable for selected debtor countries (Greece, Ireland, Italy, Portugal, and Spain).

permanent component of the reduction in income). For Greece, the first effect decreases the current-account-to-GDP ratio by 0.11 percentage point, while the second effect increases the current-account-to-GDP ratio by 0.45 percentage point. See Table 3.1 for details.

\section{CInternational Monetary Fund. Not for Redistribution}




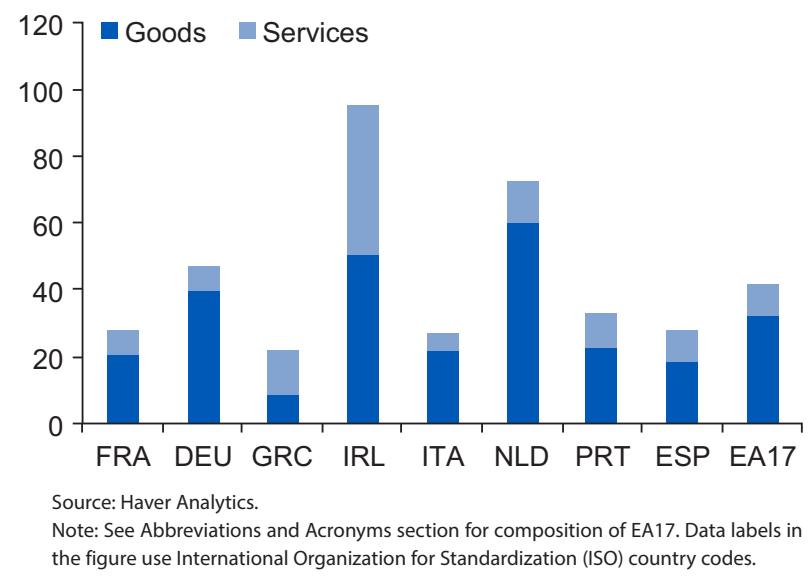

Figure 3.19 Export Shares as Percentage of GDP: 2008-12

To improve competitiveness, resources need to be reallocated to more productive sectors, countries need to move up in the value chain, and labor markets need to become more flexible:

- Reallocation of labor to traded sectors - The reallocation of labor from nontradable to tradable sectors has not occurred as of end-2012 (see section "How Much Adjustment Has Occurred?"). As the recession lingers in the selected debtor economies, human capital and potential output are lost, making structural adjustment even more difficult to achieve when relative prices begin to adjust.

- Moving up the value chain-Many debtor countries produce goods that are close substitutes for goods produced by fast-growing emerging market economies (such as China), hence facing additional structural challenges to their external rebalancing (Figure 3.15). Evidence from the Trade Correlation Index suggests that this is the case for several euro area members (Italy, Portugal, the Slovak Republic, Slovenia, and Spain), for example, a relatively high correlation of the composition of a country's merchandise exports with China. ${ }^{11}$ This means that internal devaluation in these countries (relative to other euro area countries) would help export competitiveness to a limited extent, given that competitiveness gains to help the adjustment may have to be vis-à-vis emerging markets.

- The role of service exports - The euro area is the largest service exporter in the world (one-third of world market share), and most euro area members have relatively high services export ratios, in particular Greece (tourism and transport) and Ireland (insurance and communications and information technology) (Figure 3.19). Some services exports (such as tourism) have stronger links within the euro area and may benefit more from internal devaluation through ULC improvements and wage cuts. Other services exports are more sensitive to nonprice factors (labor and product market regulations or other regulations such as taxes) (Figure 3.20).

- Structural reforms-While relative price adjustment is important to rebalancing and enhancing competitiveness, it may be insufficient to fully eliminate external deficits and reverse the net external position, given weak demand in the euro area. Therefore, pursuing structural reforms effectively at the national level would not only help in the long term, but can also help maximize the benefits of recent policy actions in the euro area to spur growth. Indeed, IMF staff analysis of the impact of nonprice indicators on export performance since the crisis suggests that, after accounting for external demand and REERs, lower business costs or lower employment protection are associated with stronger export growth (Box 3.2).

\footnotetext{
${ }^{11}$ It is also interesting to see that Greece's top three competitors in the world market are Italy, Portugal, and Spain (Figure 3.15), with very low correlations of trade specialization with China or Hong Kong SAR.
} 


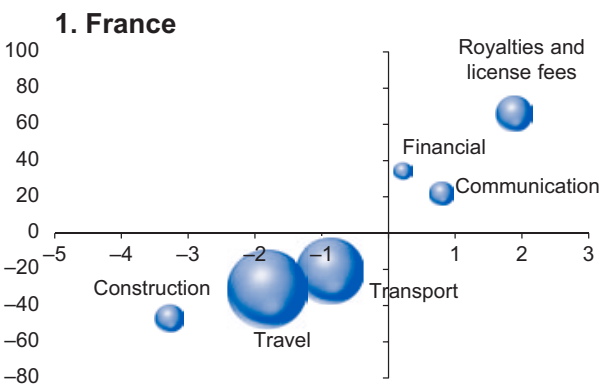

3. Greece

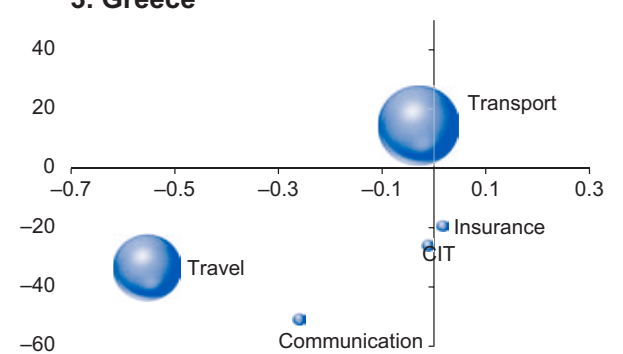

5. Italy
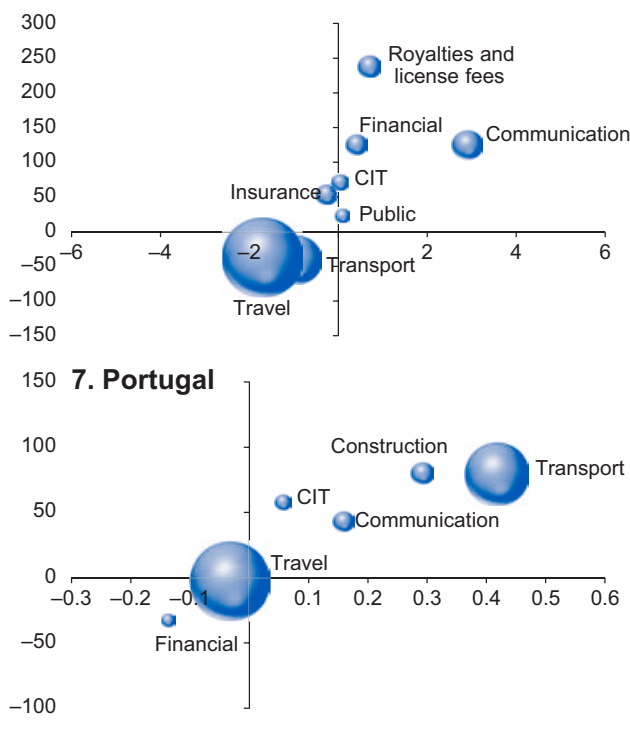

\section{Germany}

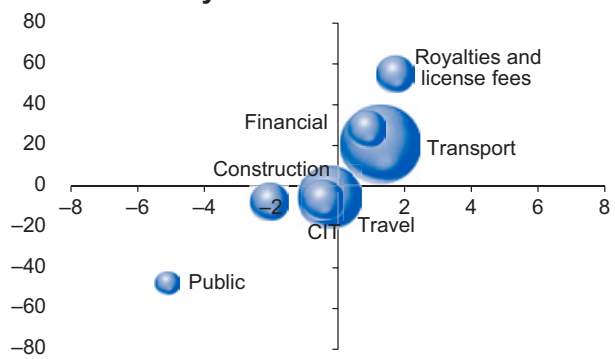

4. Ireland

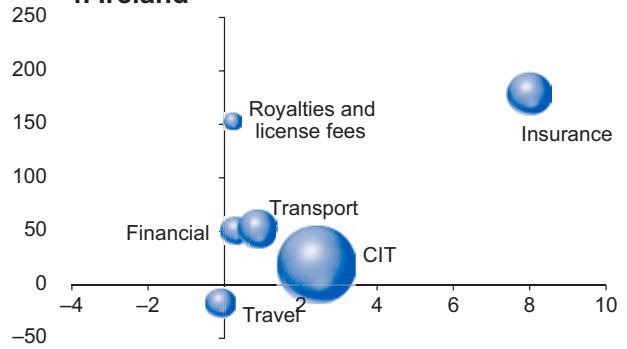

6. Netherlands

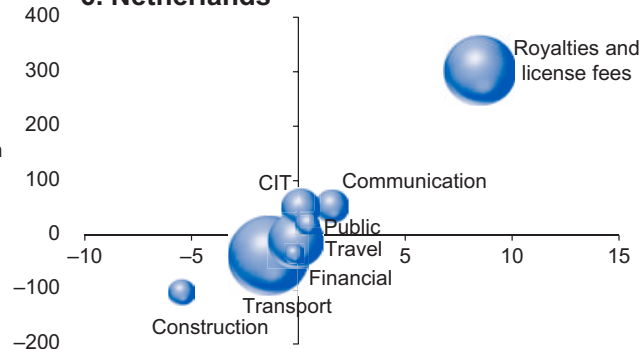

\section{Spain}

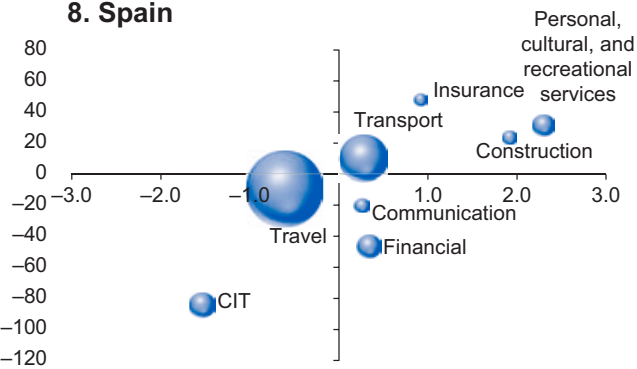

Sources: United Nations Conference on Trade and Development; and IMF staff calculations.

Note: Bubble size represents the share of each sector in total services exports.

$X$-axis: Change in country's world market share of a specific market from 2000 to 2011.

$Y$-axis: Relative growth rate of sector exports to total world growth in exports of that sector from 2000 to 2011 (in percentage points).

$\mathrm{CIT}=$ communications and information technology.

Figure 3.20 Service Exports 2000-11: Trends and Shares

Meanwhile, increasing productivity in nontradable sectors in creditor economies would improve disposable incomes and consumption in these economies and lead to higher external demand, which could support the rebalancing efforts of the debtor countries.

In the future, achieving convergence of NFAs to more stable levels to reduce external vulnerabilities will prove very challenging. Reducing net external liabilities to levels considered healthy elsewhere would likely require much larger relative price adjustments than implied by the need to reverse ULC appreciations or to achieve current account surpluses.

\section{(C) International Monetary Fund. Not for Redistribution}




\section{BOX 3.2. The Role of Nonprice Factors}

A simple approach is applied to assess export growth performance beyond the effect of world demand and relative price changes.

Model: The underlying panel regression takes the form

$$
\Delta x_{t}=\alpha \mu_{t}+\beta \Delta\left(P_{t} / P_{t}^{*}\right)+\delta y_{t}+\varepsilon,
$$

in which export growth is a function of relative prices (expect $\beta$ to be negative) and external demand $y_{t}$, with $\mu_{t}$ capturing nonprice factors such as costs of doing business, regulatory compliance, and so forth.

Panel regressions are performed over 2008-12 for 13 euro area economies using a combination of 23 measures of nonprice indicators chosen from the World Bank (costs of starting a business, costs of enforcing contracts, and costs of insolvency) and the OECD (levels of regulation [product market regulation index], employment protection [employment protection legislation index], state control, barriers to entry and entrepreneurship, and barriers to trade and investment index).

Results: The largest elasticity is attributed to external demand. Relative price matters, with the relative price elasticity ranging from 0.3 to 0.5 across various specifications (also confirmed by quantile regression on medians). Among the noncost indicators, two stand out: lower business cost and lower employment protection are positive factors explaining export growth (Table 3.2.1). Other nonprice costs are generally less significant, but their importance for long-term adjustment may not be well captured given the postcrisis period considered.

\section{TABLE 3.2.1}

\begin{tabular}{|c|c|c|c|c|c|}
\hline \multicolumn{6}{|c|}{ Euro Area Economies Export Regressions: Selected Results } \\
\hline \multirow{3}{*}{$\begin{array}{l}\text { Dependent Variable: Real Export } \\
\text { Growth Specification' }\end{array}$} & \multicolumn{4}{|c|}{ Unrestricted Panel } & \multirow{2}{*}{$\begin{array}{r}\text { Quantile } \\
1.01\end{array}$} \\
\hline & 0.97 & 0.94 & 0.98 & 1.01 & \\
\hline & (13.76) & (23.36) & $(14.43)$ & (20.78) & $(12.50)$ \\
\hline \multirow{2}{*}{ ULC-REER change } & -0.40 & & -0.47 & -0.41 & -0.42 \\
\hline & $(-2.73)$ & & $(-3.21)$ & $(-4.26)$ & $(-2.38)$ \\
\hline CPI REER change & & -0.32 & & & \\
\hline$\ldots$ & & $(-3.27)$ & & & \\
\hline Cost to start a business (WB) & & & -0.26 & & \\
\hline - & & & $(-2.36)$ & & \\
\hline Employment protection (OECD) & & & & -2.66 & \\
\hline$\ldots$ & & & & $(-1.75)$ & \\
\hline$R^{2}$ & 0.79 & 0.77 & 0.82 & 0.80 & 0.56 \\
\hline Obs & 70 & 70 & 70 & 126 & 70 \\
\hline
\end{tabular}

Source: IMF staff estimations.

'Selected variables are listed.

- Outlook. Under the baseline World Economic Outlook projections, and assuming no valuation effects, the NFA positions of Greece, Ireland, Portugal, and Spain will still be below -80 percent by 2018 (Figure 3.21). Moreover, to undo half of the deterioration of the NFA position that occurred during 2000-12 will take 15 years for Greece, 11 years for Ireland, 37 years for Portugal, and 12 years for Spain under the current baseline (Table 3.2). Reaching the European Commission scoreboard threshold ( -35 percent of GDP) will take even longer. In contrast, for Germany, the NFA is expected to continue growing under the current baseline.

\section{CONCLUSION}

Relative price adjustments and current account improvements are taking place, but improvements in export performance remain very dependent on external demand, including from within the euro area. Moreover, ongoing adjustment in current account balances is partly driven by cyclical 


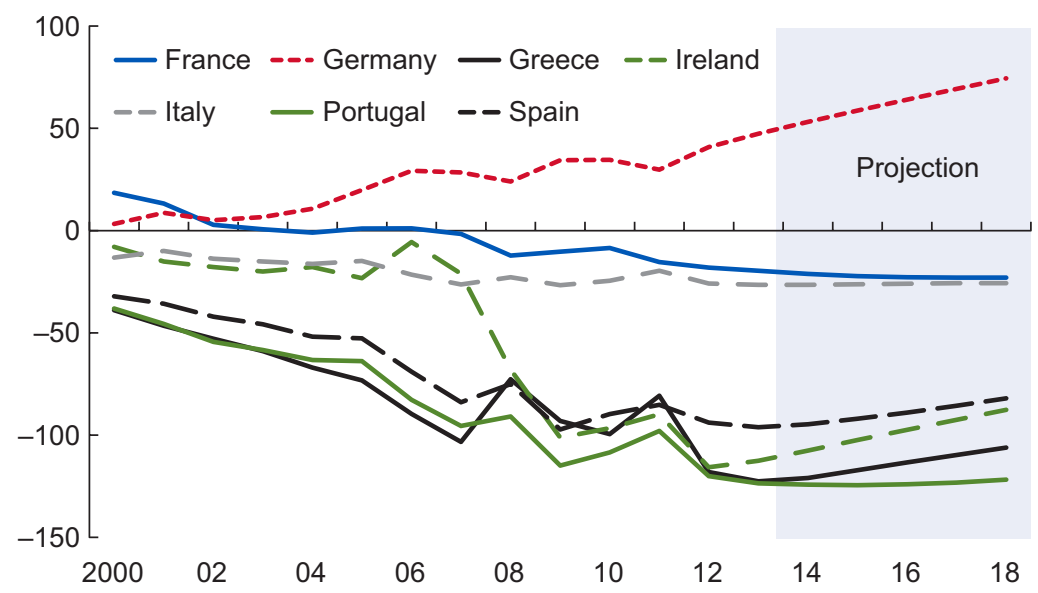

Note: Net foreign assets as a ratio of GDP implied by IMF World Economic Outlook projections, assuming no valuation effects in the future.

Figure 3.21 Net Foreign Asset Position (Percent of GDP)

\begin{tabular}{|c|c|c|c|c|c|}
\hline \multicolumn{6}{|c|}{ NFA Positions: Projected Adjustments } \\
\hline & \multirow[b]{2}{*}{$\begin{array}{c}\text { NFA/GDP } \\
2000\end{array}$} & \multirow[b]{2}{*}{$\begin{array}{c}\text { NFA/GDP } \\
2012\end{array}$} & \multirow[b]{2}{*}{$\begin{array}{c}\mathrm{NFA} / \mathrm{GDP} \\
2018^{2}\end{array}$} & \multicolumn{2}{|c|}{ Numbers of Years to: } \\
\hline & & & & $\begin{array}{l}\text { Reverse Half of } 2000-12 \\
\text { Decline of the NFA/GDP }\end{array}$ & $\begin{array}{c}\text { Reach EC Scoreboard } \\
\text { Threshold }^{3,4}\end{array}$ \\
\hline France $^{1}$ & 18 & -15 & -20 & - & - \\
\hline Germany & 3 & 42 & 75 & - & - \\
\hline Greece & -39 & -117 & -105 & 15 & 32 \\
\hline Ireland & -8 & -98 & -71 & 11 & 18 \\
\hline Italy & -13 & -25 & -25 & - & - \\
\hline Portugal & -38 & -120 & -121 & 37 & 73 \\
\hline Spain & -32 & -95 & -83 & 12 & 20 \\
\hline
\end{tabular}

Note: $\mathrm{EC}=$ European Commission; NFA = net foreign assets.

${ }^{1} 2011$ instead of 2012.

${ }^{2}$ Implied by WEO projections, assuming no valuation effects.

${ }^{3}$ Assuming constant real GDP growth, inflation, and current account balance from 2018 onward.

${ }^{4}$ European Commission Macroeconomic Imbalance Procedure scoreboard target of -35 percent of GDP.

factors, which suggests that more needs to be done to make it sustainable. From here on, converging to NFA positions considered safe elsewhere will prove challenging.

Further policy actions in both creditor and debtor economies are necessary to rebalance debtor countries internally and externally. Structural policies will improve flexibility and smooth the adjustment process across sectors, including by fostering job creation and access to credit, boosting competitiveness, and enhancing regional integration (by, for instance, introducing a single labor contract across countries and portable unemployment benefits and pensions).

- In creditor economies, increasing productivity in nontradable sectors would improve disposable incomes and consumption in these economies and lead to higher external demand, which could support the rebalancing efforts of the deficit countries. In addition, reducing euro area uncertainty would support a recovery in private investment, which would help narrow current account surpluses (notably in Germany).

- In debtor economies, where consumption booms had led to excessive growth in nontradable sectors in the run-up to the crisis, continuing structural adjustment would shift resources to tradable sectors.

\section{(C) International Monetary Fund. Not for Redistribution}


- At the euro area level, repair of bank balance sheets and implementation of the banking union will enhance the allocation of credit to more productive sectors and firms, and thereby help support the internal reallocation of resources.

\section{ANNEX 3.1. TECHNICAL NOTES Decomposition of ULC Changes}

$\mathrm{ULC}=$ labor cost/labor productivity, where labor cost $=$ compensation per employee/total employees (in persons), and productivity = real output (or gross value added)/total employment. See ECB Directorate General Statistics (http://sdw.ecb.europa.eu/browseExplanation.do ?node $=2120786$ ).

\section{Tradable and Nontradable Sectors}

No standard definition can be derived from NACE2 (European Classification of Economic Activities, rev. 2) to have a clear cutoff line between the tradable and nontradable sectors. This chapter uses the definition in ECB (2012) as follows:

Tradable sector: Manufacturing.

Nontradable sectors: Construction; Wholesale and retail trade; Travel and food service; Financial and insurance; Real estate.

\section{REFERENCES}

Bems, Rudolfs, and Robert C. Johnson. 2012. "Value-Added Exchange Rates." Working Paper No. 18498, National Bureau of Economic Research, Cambridge, Massachusetts.

Blanchard, Olivier, and Francesco Giavazzi. 2002. "Current Account Deficits in the Euro Area: The End of the Feldstein-Horioka Puzzle?” Brookings Papers on Economic Activity 2: 147-86.

Blanchard, Oliver, Francesco Giavazzi, and Filipa Sa. 2005. "International Investors, the U.S. Current Account, and the Dollar." Brookings Papers on Economic Activity 1: 1-49.

Borio, Claudio, Piti Disyatat, and Mikael Juselius. 2013. "Rethinking Potential Output: Embedding Information about the Financial Cycle.” Working Paper No. 404, Bank for International Settlements, Basel.

Chen, Ruo, Gian-Maria Milesi-Ferretti, and Thierry Tressel. 2012. "External Imbalances in the Euro Area." Working Paper No. 12/236, International Monetary Fund, Washington, DC.

Chinn, Menzie D., and Eswar S. Prasad. 2003. "Medium-Term Determinants of Current Accounts in Industrial and Developing Countries: An Empirical Exploration.” Journal of International Economics 59(1), 47-76, January.

Christiansen, Lone, Alessandro Prati, Luca Antonio Ricci, and Thierry Tressel. 2009. "External Balance in Low Income Countries.” WP/09/221, International Monetary Fund, Washington, DC.

Eichengreen, Barry. 2007. "The Breakup of the Euro Area." Working Paper No. 13393, National Bureau of Economic Research, Cambridge, Massachusetts.

European Central Bank. 2012. "Competitiveness and External Imbalances within the Euro Area." Occasional Paper No. 139, European Central Bank, Frankfurt.

International Monetary Fund (IMF). 2011. Regional Economic Outlook: Europe. May, Washington, DC. 2013. "2013 Pilot External Sector Report." Washington, DC.

Laeven, Luc, and Thierry Tressel. 2013. "The European Union: Financial Integration and Fragmentation in the European Union.” European Union Financial Sector Assessment Program Technical Note, Country Report No. 13/71, International Monetary Fund, Washington, DC.

Lee, Jaewoo, Gian-Maria Milesi-Ferretti, Jonathan Ostry, Alessandro Prati, and Luca A. Ricci. 2008. "Exchange Rate Assessments: CGER Methodologies.” IMF Occasional Paper No. 261, International Monetary Fund, Washington, DC.

Phillips, Steven, Luis A.V. Catão, Luca Antonio Ricci, Rudolfs Bems, Mitali Das, Julian di Giovanni, D. Filiz Unsal, Marola Castillo, Jungjin Lee, Jair Rodriguez, and Jose P. Mauricio Vargas. 2013. "The External Balance Assessment (EBA) Methodology," No 13/272, IMF Working Papers, International Monetary Fund. 


\section{The Role of Monetary Policy and the Fiscal Framework}


This page intentionally left blank

CInternational Monetary Fund. Not for Redistribution 


\title{
Fragmentation, the Monetary Transmission Mechanism, and Monetary Policy in the Euro Area
}

\author{
Ali Al-Eyd and S. Pelin Berkmen
}

The European Central Bank (ECB) has taken a range of actions to address bank funding problems, eliminate excessive risk in sovereign markets, and safeguard monetary transmission. As a result, the situation across the euro area financial system has improved since the summer of 2012; however, the degree of fragmentation remains high, with retail interest rates in stressed markets far higher than those in the core. These high rates have impeded the flow of credit and undermined the transmission of monetary policy. Analysis presented in this chapter indicates that the credit channel has been broken during the crisis, particularly in stressed markets, and that small and medium-sized enterprises (SMEs) in hard-hit economies appear to be most affected. Given these stresses, the ECB can undertake additional targeted policy measures, including through various forms of term funding, looser collateral policies, and direct asset purchases.

\section{HAS THE OUTRIGHT MONETARY TRANSACTIONS PROGRAM DELIVERED?}

In mid-2012, the ECB announced the Outright Monetary Transactions (OMT) framework to address severe distortions in sovereign bond markets and to safeguard monetary transmission.

Since the announcement, excessive risk in stressed sovereign markets has been reduced and confidence in the euro restored. Spreads on Italian and Spanish government bonds have declined from unsustainable levels to those last seen in late 2010, before the deepening of the sovereign crisis. At the same time, market indicators suggest that euro redenomination risks have been taken off the table, if not completely eliminated (see Box 4.1).

Firms and banks have also benefited from the OMT announcement. Credit default swap (CDS) spreads for firms and banks in stressed economies have narrowed sharply in tandem with falling sovereign risks, leading to an improvement in bond issuance, particularly by firms. However, the impact on banks appears to be less pronounced, with issuance fading relative to the post-Long-Term Refinancing Operation (LTRO) period, and CDS spreads creeping up in 2013. In any event, both bank and corporate risks remain substantially below pre-OMT peaks.

Despite improved financial conditions, monetary transmission in stressed markets remains impaired. ${ }^{1}$ In particular, private interest rates — both deposit and lending rates—in these economies have increased relative to corresponding rates in the core and the ECB's policy rates (Figure 4.1). This divergence began in 2011, and has since worsened, with Spanish and Italian firms in 2013 facing borrowing rates anywhere from 300 to 400 basis points higher than their counterparts in Germany.

\footnotetext{
This chapter is based on "Fragmentation and Monetary Policy in the Euro Area," IMF Working Paper 13/208, 2013.

${ }^{1}$ Stressed countries refer to debtor countries that have experienced high funding costs (public and private) and suffered from financial fragmentation during the period covered.
} 
BOX 4.1. Assessing Outright Monetary Transactions (OMT) and Redenomination Risks

The European Central Bank (ECB) introduced the OMT framework in response to "exceptionally high" risk premiums in sovereign bond markets related to fears of the reversibility of the euro. ${ }^{1}$ Sovereign yields in stressed countries have narrowed substantially, suggesting a decline in redenomination risk. However, isolating these risks from other market forces is difficult. In this regard, a few indicators can help shed light on the extent to which these risks have been removed. Two are considered here:

- Speculative activity in euro currency contracts - In the wake of President Draghi's "London Speech" in July 2012, the number of speculative short futures contracts in euros dropped markedly, reaching levels last seen before the crisis escalated in late 2010 (Figure 4.1.1). This drop was followed by a modest rise in long contracts. Although both contracts were volatile in 2013, and represent only a very limited slice of the overall euro currency market, they are often taken to be an indicator of broad market sentiment and tend to be well correlated with the euro exchange rate. ${ }^{1}$ The marked shift in positions thus suggests a distinct change in sentiment.

- Legal jurisdiction of obligations-Similar bonds issued by the same large bank in a stressed country could be expected to trade somewhat differently if one (governed by local law) is considered to carry higher redenomination risk than the other (governed by international law). A rise in yields and widening of their relative spread could indicate the buildup of such risks, among others, before the London Speech. However, the ensuing improvement in their yields has been significant, and the stabilization of their spread largely sustained (beyond periods of broad market stress) (Figure 4.1.2).

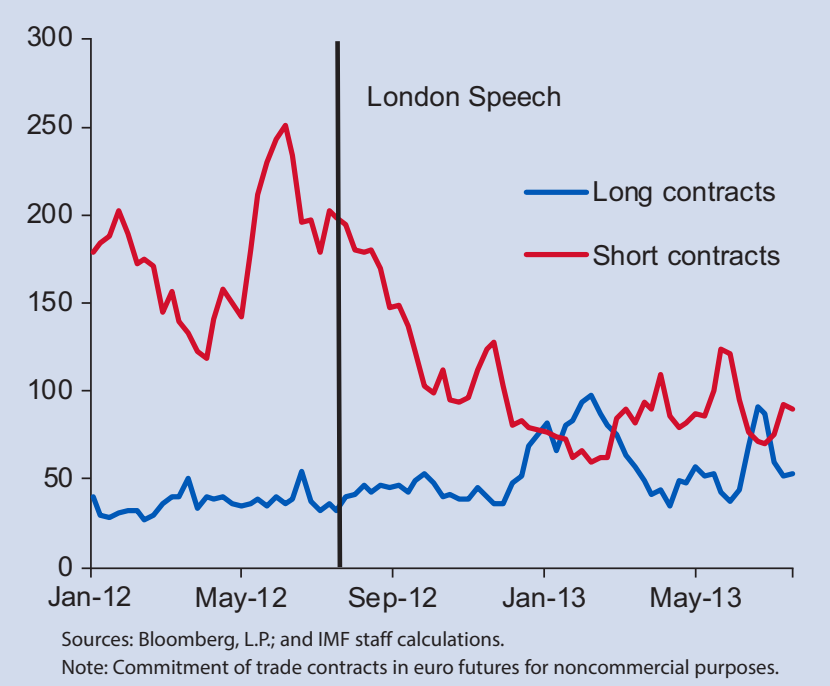

Figure 4.1.1 Euro Foreign Exchange Speculative Futures Contracts (Thousands)

Assessing the impact of OMT on euro redenomination risk is complex. However, notwithstanding this complexity, or the difficulty of disentangling factors driving market dynamics through the crisis, the indicators considered here display a marked shift in the period following the London Speech. A decline in speculative short euro currency positions and the improvement in the performance of stressed country bank (and sovereign) bonds is consistent with the decline, if not removal, of euro redenomination risks.

$\overline{1}$ ECB Annual Report (2012). 


\section{BOX 4.1. (continued)}

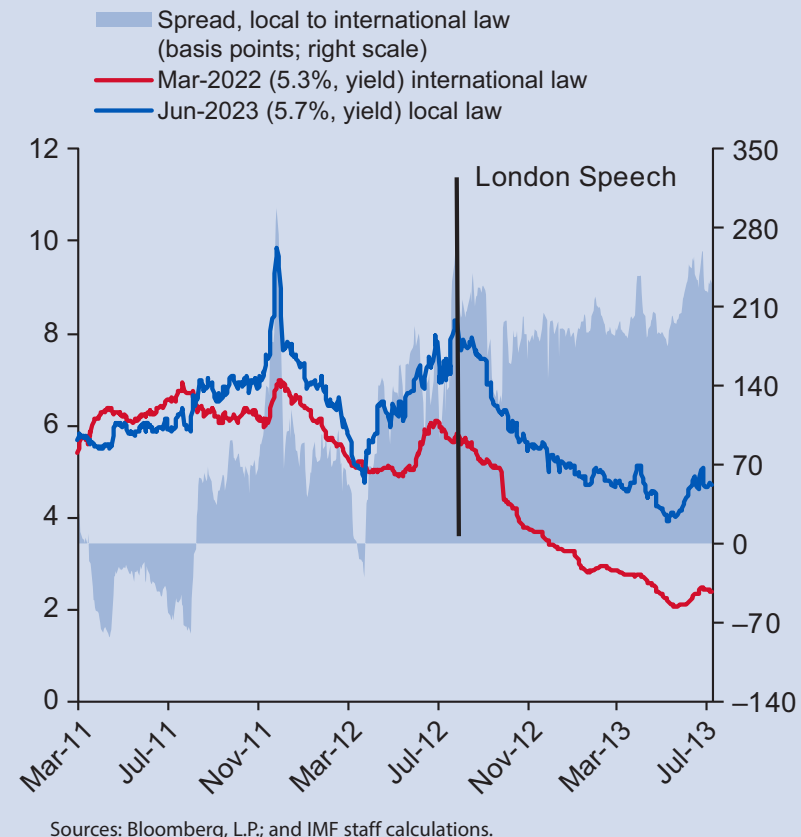

Figure 4.1.2 Bonds of a Stressed Country Bank: Local versus International Law (Percent)

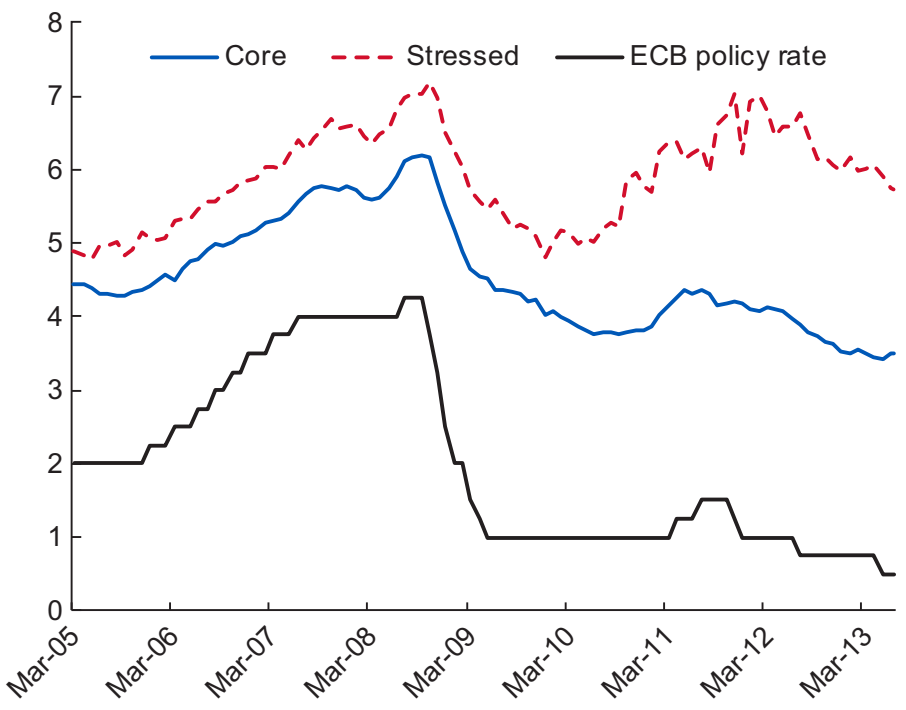

Source: European Central Bank.

Note: Unweighted average. Monetary financial institution lending to corporations valued under $€ 1$ million, one to five years' maturity. Core = Belgium, France, Germany, the Netherlands. Stressed country = Greece, Ireland, Italy, Portugal, Spain. In the sample, Ireland is excluded from May 2011 and Greece from September 2012.

Figure 4.1 Euro Area Corporate Lending Rates (Percent) 


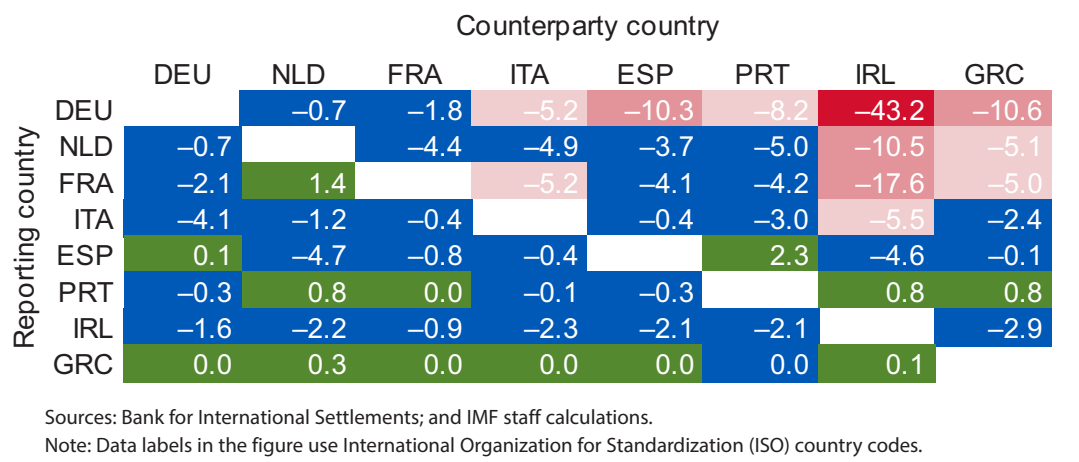

Figure 4.2 Change in Cross-Border Bank Holdings, 2008:Q1-2012:Q4

(Percent of counterparty country GDP)

\section{WHY HAVE INTEREST RATES DIVERGED?}

The divergence in interest rates reflects the elevated fragmentation of financial markets. A combination of factors - including higher counterparty risks, regulatory hurdles (higher liquidity ratios and bail-in prospects), and the increased subsidiarization of banks' business models (partly related to the rise of regulatory ring-fencing in some countries) — has undermined cross-border bank flows, particularly to the stressed countries, and contributed to diverging term funding costs with the core. At the same time, dampened growth prospects and, for certain countries, the prolonged period of low policy rates (with large mortgage books tied to the low Euro Interbank Offered Rate [Euribor]) have been weighing on banks' profitability and capital positions, reinforcing the need to deleverage and derisk their balance sheets.

- Cross-border banking flows have declined: Both core and stressed country banks have retrenched throughout the crisis, withdrawing capital to domestic markets and reducing their foreign lending. The departure of capital from the stressed countries is most pronounced, with core banks, including those in France and Germany, substantially reducing their exposure to these economies since the start of the crisis (amounting, for each of the French and German banks, to some 5-10 percent of GDP in Italy and Spain, and even higher in Ireland; see Figure 4.2). ${ }^{2}$ Most stressed country banks have also scaled back their lending to each other, while the volume of euro area unsecured interbank activity has declined by more than half.

- Term funding costs have increased: The cost of unsecured bond issuance remains elevated for both core and stressed country banks, but there is a growing divergence between the two, driven mainly by rising spreads in stressed countries (Figure 4.3, second chart). The average spread (to benchmark rates) for stressed country banks at issuance was more than 430 basis points in March 2013, down only modestly from peak levels seen in early 2012, whereas that for core banks was about 180 basis points. Before the crisis, the spread between core and stressed country banks was negligible. Similar developments are evident in secured funding markets, with spreads on covered bond issuance in stressed countries rising throughout the crisis, even as banks have become more reliant on secured forms of borrowing.

- Banks' assets have become increasingly encumbered: This encumbrance reflects the shift toward secured funding, increased bank reliance on official liquidity facilities, and pressures from credit ratings downgrades on both private and public securities. However, secured funding costs have increased, further limiting banks' ability to access this type of funding. Outside

\footnotetext{
${ }^{2}$ According to the Bank for International Settlements' statistics on banks' consolidated international claims, ultimate risk basis.
} 
Euro area sovereign and corporate risk has declined markedly post-OMT announcement, but bank risk remains elevated.

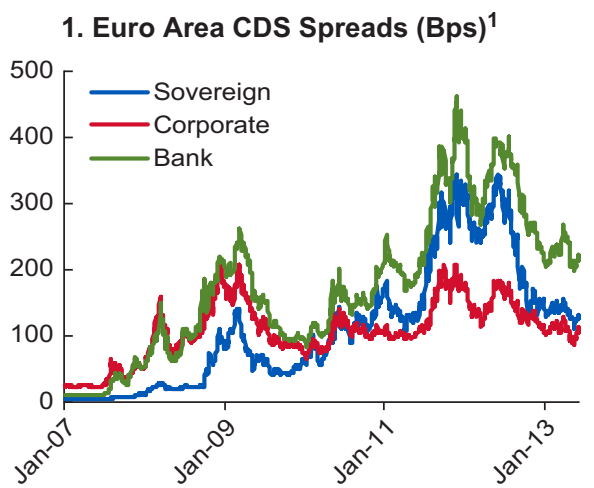

But firms have benefited from the post-OMT decline in risk, boosting their relative issuance compared with banks.

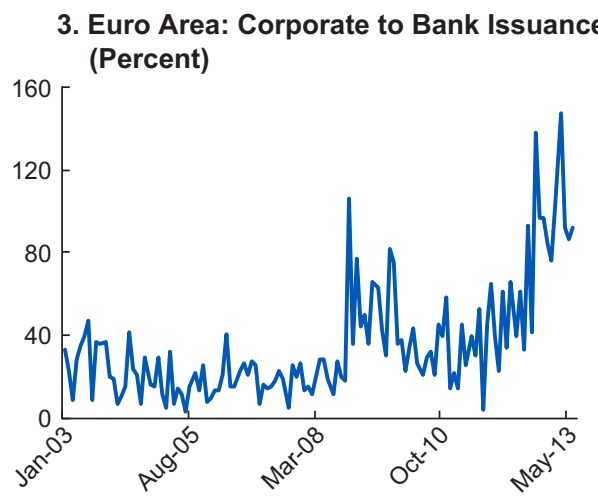

As a result, lending rates, particularly for SMEs, in the stressed markets have been driven substantially above those in the core countries.

\section{SME Loan Rates, Spread to Germany (Percent)}

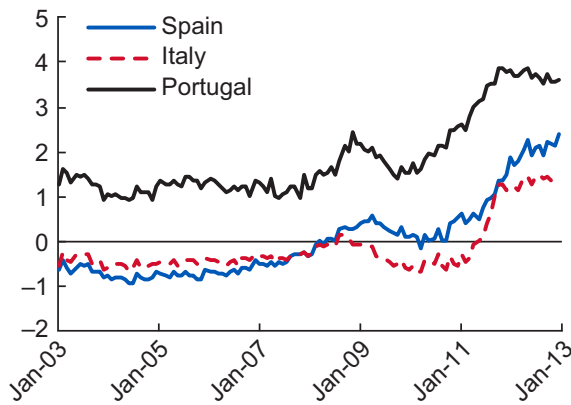

As a result, bank term funding costs have surged, particularly in the stressed countries relative to the core, driving stressed countries issuance volumes down.

\section{Stressed Countries: Cost and Volume} of Bank Issuance ${ }^{2}$

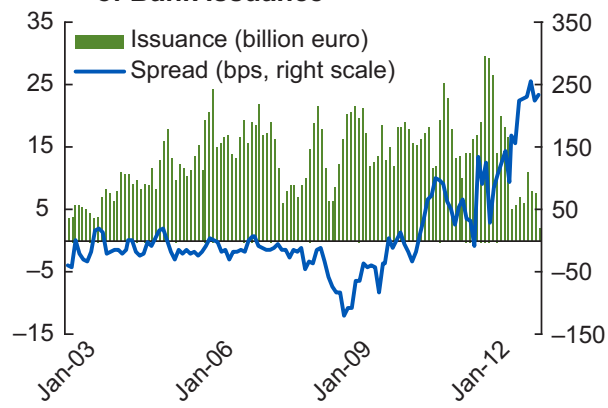

At the same time, banks in hard-hit countries are heavily dependent on Eurosystem facilities,

raising concerns about rising asset encumbrance.

\section{Bank Borrowing from the ECB (Percent of bank assets) $^{3}$}

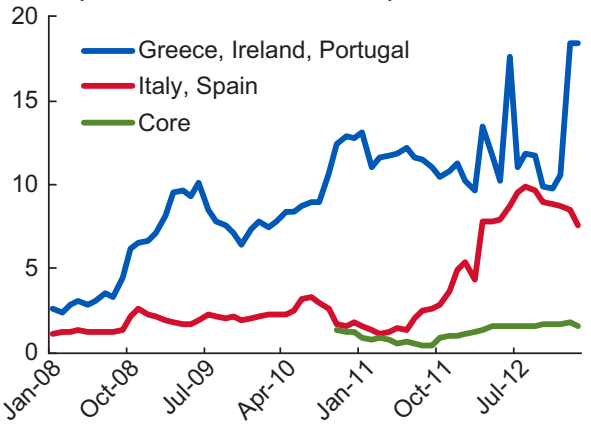

With SMEs playing an important role in both employment and value added, addressing fragmentation is key to supporting growth in the stressed markets.

6. SMEs' Share in the Economy, 2010-11 (Percent)

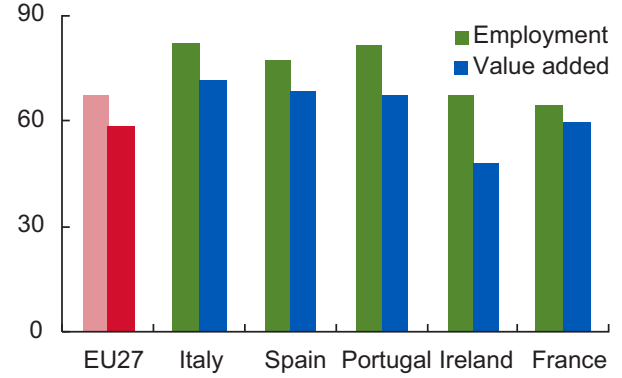

Sources: Bloomberg, L.P.; Dealogic; European Central Bank; Eurostat; Haver Analytics; and IMF staff calculations.

Note: bps = basis points; $\mathrm{CDS}=$ credit default swap; $\mathrm{ECB}=$ European Central Bank; OMT = Outright Monetary Transactions; SME = small and medium-sized enterprises. See Abbreviations section for composition of EU27.

${ }^{1}$ Sovereign and bank CDS exclude Greece and are weighted by total debt.

${ }^{2}$ Stressed countries = Italy, Ireland, Portugal, and Spain. The spread is that of stressed countries bank issuance costs over those of the core banks. The bonds are $1-10$ years in tenor.

${ }^{3}$ Banks are first averaged within own country, and then added across country groupings.

Figure 4.3 Euro Area: Financial Market Fragmentation 


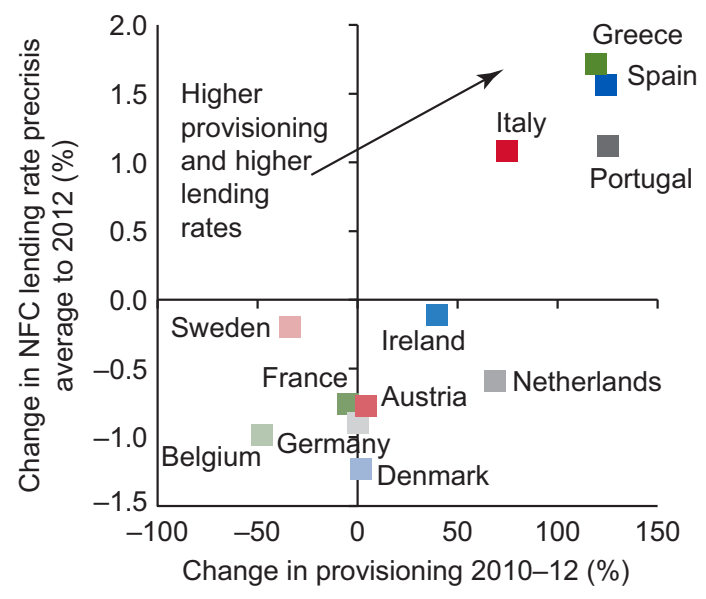

Sources: Bloomberg, L.P.; and IMF staff calculations.

Note: NFC = nonfinancial corporation. Data labels in the figure use International Organization for Standardization (ISO) country codes.

Figure 4.4 Bank Provisioning and Lending Rates, 20092011 (Percent)

of the IMF program countries, encumbrance has increased markedly in Spain and Italy, and it has also increased in France, though the overall level is relatively low.

- Pressures on banks' balance sheets, including on profitability, have increased: Weak growth and high levels of private balance sheet debt in stressed countries are weighing on the health of bank balance sheets. Asset quality is declining, with nonperforming loans (NPLs) in Spain rising to 10.4 percent in February 2012 and those in Italy hitting 13.4 in December 2012. ${ }^{3}$ In addition, there are signs that bank profitability in both stressed countries and the core has been under pressure as firms and households deleverage. Net interest margins have moderated, while provisioning as a share of income has increased, notably for both Italian and Spanish banks (Figure 4.4) despite the support to profitability from increased holdings of own-sovereign debt, facilitated in particular by the three LTRO facilities. At the same time, pressures from the low policy rate environment can also weigh on banks' profitability-for example, Spanish banks are unable to reprice large mortgage books tied to low Euribor rates.

- Stressed country banks have increased their reliance on deposits: In particular, the spreads against Germany have increased substantially for term deposits (more than two years), reflecting the squeeze in term funding and further pressuring profitability.

These risks and challenges are increasingly reflected in stressed country bank CDS spreads (Figure 4.5). After showing some improvement subsequent to OMT, spreads reached 430 basis points at the end of March 2013 (about 375 basis points higher than early 2008 levels). In fact, they have traded wider to those of core banks since the turn of 2013, following the turbulence in the wake of the Italian elections and events in Cyprus. This rise in spreads has coincided with lower bond issuances for both core and stressed country banks. At the same time, the relative volume of euro area corporate bond issuance has increased, pointing to a degree of disintermediation and unmet demand by banks for corporate borrowing.

\footnotetext{
${ }^{3}$ Cross-country comparisons of NPLs are complicated by differences in definitions. For example, Italy's impairment categories are broadly defined, capturing a wider class of impaired assets than in other countries.
} 


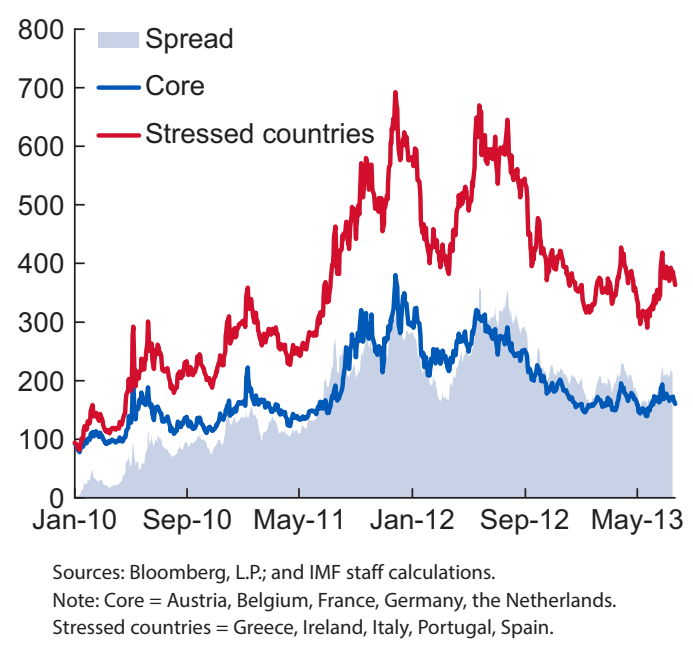

Figure 4.5 Spread between Core and Stressed Country Bank Credit Default Swaps (Basis points)

\section{FRAGMENTATION FEEDING INTO THE BROKEN MONETARY TRANSMISSION MECHANISM}

Together, pressures from fragmentation and weak balance sheets have contributed to elevated lending and deposit rates in stressed countries. A main consequence has been a breakdown in the monetary transmission mechanism in these economies (Annex 4.1). Despite lower policy rates, private interest rates remain high, reflecting a combination of factors, including lack of term funding for some banks, and weak bank and corporate balance sheets. As borrowing costs have risen, access to credit has been further reduced, particularly for SMEs, and Economic and Monetary Union deintegration forces have strengthened.

The European intermediation system is mainly bank based, with about 90 percent of nonfinancial corporation (NFC) debt financing intermediated through the banking sector (Figure 4.6). Although reliance on bond financing has been gradually increasing since the start of the crisisbecause larger firms have turned to markets-it still remains low (about 11 percent).

The interest rate channel has been hampered by the decline in interbank activity. As the volume of interbank activity declined through the crisis, so did the effectiveness of the transmission of policy rate changes to money market rates. A number of factors, including counterparty risks and the rise in excess system liquidity-partly reflecting supportive ECB measures and the general decline in economic activity, among others— have weighed on interbank activity, despite the reduced volatility of money market interest rates since early $2012 .{ }^{4}$

At the same time, weaknesses in both bank and corporate balance sheets undermined the credit channel. In addition to the decline in wholesale funding and rise in borrowing costsforcing banks to deleverage, including by reducing their loan-to-deposit ratios through a combination of reduced assets and higher deposit rates - the stress in sovereign bond markets has also led to problems in the functioning of the monetary transmission mechanism. Government bonds not only serve as a benchmark (floor), but also are the prime source of collateral in the interbank

\footnotetext{
${ }^{4}$ As noted in ECB (2012), the decline in turnover of euro area money market instruments in the first half of 2012 was attributable to both the debt crisis—and the related impairment of the interbank market—and to the high excess liquidity environment that prevailed in the euro interbank market as a result of the two three-year LTROs conducted in December 2011 and February 2012.
} 


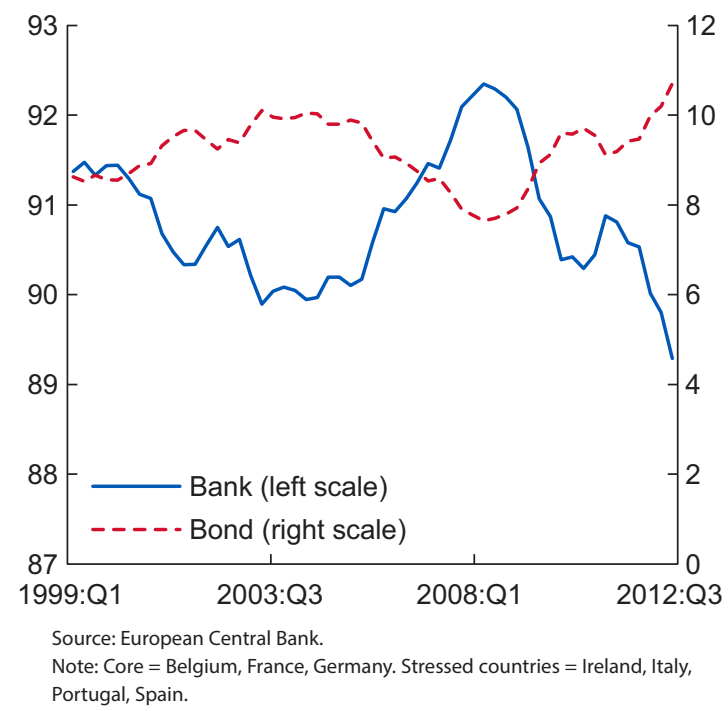

Figure 4.6 Euro Area: Nonfinancial Corporation Borrowing Breakdown (Percent)

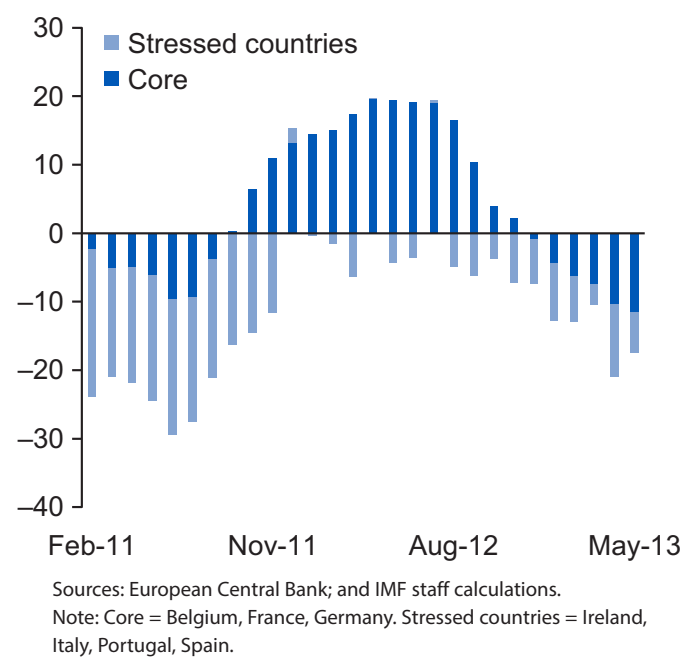

Figure 4.7 Bank Lending to Interbank Market (Percent change, year over year)

markets, reinforcing the decline in activity there (Figure 4.7). Although the ECB's unconventional policies have mainly aimed to restore this channel, the substitution of official funding for the missing market funding has caused lending rates to remain high since mid-2010, and overall credit growth is still subdued.

The remaining obstacles for the proper functioning of the credit channel include (1) the lack of term funding in some stressed countries, with deposit rates and the cost of unsecured bond issuance remaining persistently high; (2) ongoing weaknesses in banks' balances sheets—including from reduced profitability and declining asset quality in the low-growth environment—and the consequent strengthening of sovereign-bank links, given that banks have purchased sovereign debt with official liquidity (these factors limit credit supply); and (3) weak firm balance sheets, particularly in Italy, Portugal, and Spain, where corporate and household sector deleveraging is 


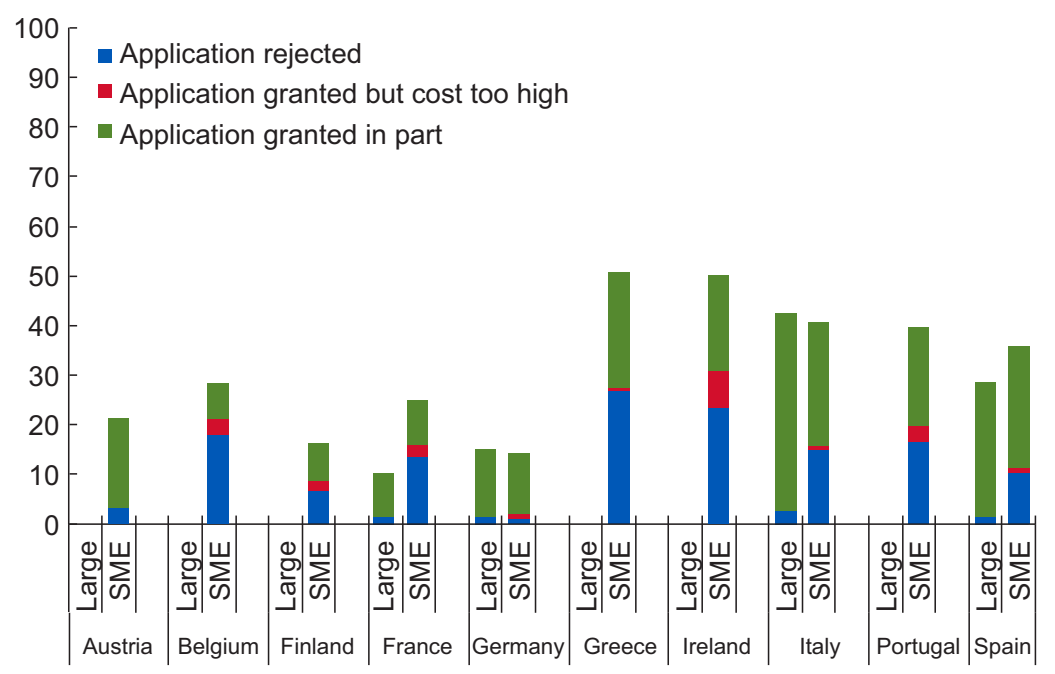

Source: European Central Bank Survey on the Access to Finance of Enterprises.

Note: $\mathrm{SME}=$ small and medium-sized enterprise. Among those firms that applied within the last six months.

Figure 4.8 Outcome of Loan Application by EA Firms (Average, April 2012-March 2013)

still ongoing (Bornhorst and Ruiz-Arranz 2013). While these headwinds limit credit demand, banks are also facing increasing NPLs and are unwilling to provide credit at the rates prevailing in the core European countries given reduced net worth and cash flow of NFCs and the decline in the creditworthiness of households.

Fragmentation and the broken monetary transmission mechanism affect SMEs disproportionately. Interest rates charged for small loans in stressed countries are higher than those charged for larger loans, but also higher than those charged for similar loans in core countries (Figure 4.3, panel 5). While the ECB's bank lending survey indicates that demand for loans has been weak, its Survey on the Access to Finance of Enterprises shows that SMEs applying for loans are experiencing difficulties in obtaining credit from banks, particularly in Italy, Portugal, and Spain (Figure 4.8). ${ }^{5}$ SMEs listed "finding customers" and "access to finance" as their largest concerns. Although the availability of external financing (including bank loans, bank overdrafts, and trade credit) has improved in early 2013 , as have the associated terms and conditions, the climate has been worse for SMEs than for larger companies (see Box 3 of ECB 2013).

Ensuring credit availability to viable SMEs is essential to supporting the recovery in the euro area, given that SMEs are about 80 percent of employment and 70 percent of value added in Italy, Portugal, and Spain (Figure 4.3, panel 6). In addition, the SME sectors in those three countries are dominated by micro-firms with fewer than 10 employees (about 94-95 percent of total firms).

\section{ASSESSING THE PASS-THROUGH OF ECB POLICY RATES TO LENDING RATES}

A simple model is used to assess the pass-through of policy rates to bank lending rates, controlling for factors capturing both the interest rate and credit channels. An error correction model is employed similar to those found in the ECB's Monthly Bulletins of August 2009 and

\footnotetext{
${ }^{5}$ Survey on the Access to Finance of Enterprises in the Euro Area (SAFE) (October 2012-March 2013). The survey covers about 7,500 firms, 93 percent of which are SMEs.
} 
May 2010. The ECB focuses on quarterly interest rates at the euro area level, and explains various retail rates through money market rates, the capital-to-asset ratio, and credit risk. ECB (2010) concludes that credit risk was an important factor contributing to the widening of short-term lending spreads between 2008:Q3 and 2010:Q1. The study described here analyzes both euro area and country-level lending rates, covering France, Germany, Italy, Portugal, and Spain for January 2003 through February 2013. In particular, the changes in bank lending rates $\left(\Delta L R_{t}\right)$ for small and large loans are regressed on simultaneous and lagged changes of market rates $\left(\Delta M R_{t}\right)$, lagged changes of the bank interest rate, and on other measures of the credit channel, including bank funding, leverage, credit risk, and economic uncertainty $\left(\Delta X_{t}\right)$. An error correction term is also included, to capture deviations from the long-term relationship. See equation (4.1).

$$
\begin{aligned}
\Delta L R_{i}= & \varphi+\gamma\left(L R_{i-1}-\beta_{1} M R_{t-1}-\beta_{2} X_{t-1}+\kappa\right)+\alpha_{1 i} \Delta M R_{t}+\sum_{1}^{i} \alpha_{2 i} \Delta M R_{t-i} \\
& +\sum_{1}^{i} \alpha_{3 i} \Delta L R_{t-i}+\sum_{1}^{i} \alpha_{4 i} \Delta X_{t-i}
\end{aligned}
$$

Various specifications are examined to capture the range of effects on lending rates. Baseline regressions are run using monthly lending rates (on loans both less than and more than $€ 1$ million for all maturities), three-month Euribor, senior financial CDS to capture credit risk, bank bond spreads at issuance (for both stressed countries and core) to capture funding costs, asset-tocapital ratios to capture leverage, and Purchasing Managers Index to capture the overall economic outlook affecting firms' balance sheets. Additional variables include lending rates to NFCs with maturities between one and five years, other money market rates (Euro OverNight Index Average [EONIA], three-month EONIA, three- and seven-year swap rates), other measures of credit risk (sovereign yields, subordinated financial CDS), other measures of cost of funding (bank equity prices, stock market indices, term deposit rates), other measures of leverage (loan-to-deposit ratio), and an economic policy uncertainty index to capture overall weak and uncertain economic activity. ${ }^{6}$ Baseline regressions are also run for the period 2003 through August 2008 to see how the pass-through changed after the crisis. ${ }^{7}$

The regression results support the notion that funding costs, credit risk, and leverage have become important determinants of lending rates since the onset of the crisis, particularly for stressed countries. These factors appear to be more relevant for small loans, such as are typically associated with SMEs. ${ }^{8}$ Detailed results are as follows:

- Without controlling for other factors, the long-term pass-through from the Euribor to lending rates has declined since the crisis for the euro area as a whole and for stressed countries, but not for core countries (Figure 4.9). This outcome reflects the importance of other factors in determining lending rates in stressed countries.

- Once other factors are controlled for, the long-term pass-through from the Euribor to lending rates is close to precrisis levels (Figure 4.10), implying that the postcrisis divergence in lending rates is explained by these other factors (cost of funding, credit risk, and leverage).

- The immediate pass-through is broadly similar across countries, and larger for large loans (Figure 4.11).

\footnotetext{
${ }^{6}$ The Economic Policy Uncertainty Index is constructed from two types of underlying components (see PolicyUncertainty. com). One component quantifies newspaper coverage of policy-related economic uncertainty. A second component uses disagreement among economic forecasters as a proxy for uncertainty.

${ }^{7}$ Because of the short sample period, the results are only indicative.

${ }^{8}$ See Al-Eyd and Berkmen 2013 for further details.
} 


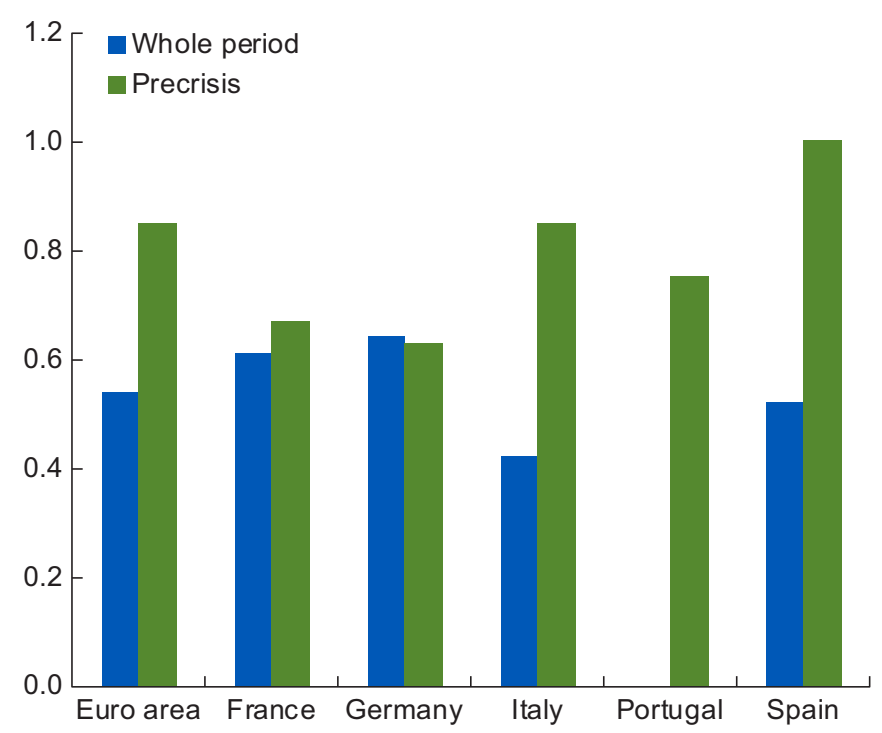

Sources: Bloomberg, L.P.; European Central Bank; and IMF staff calculations.

Figure 4.9 Interest Rate Pass-Through (Long-term coefficients, not controlling for other factors)

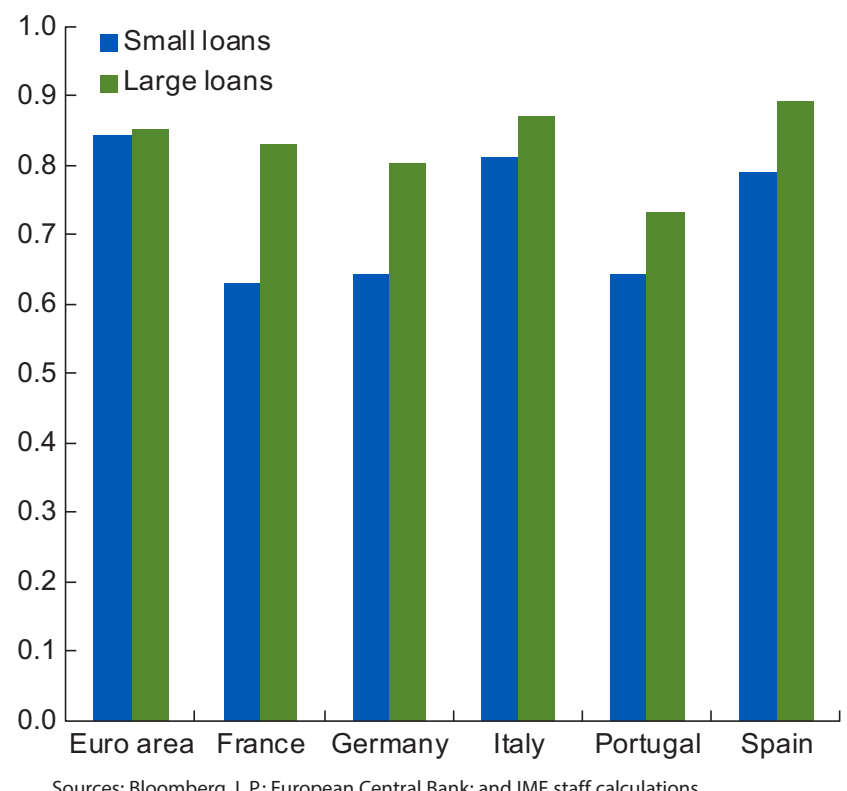

Figure 4.10 Long-Term Pass-Through

- Both the cost of funding and credit risk are significant factors in explaining lending rates for the euro area and the stressed countries, but not for the core countries. Similarly, assetto-capital ratios (capturing banks' leverage) are significant for Italy and Spain, implying that banks with weak capital positions cannot (or do not) lower their lending rates. Broadly speaking, the long-term coefficients for the cost of funding, credit risk, and leverage are higher for small loans than for larger loans (except for Portugal, for which the coefficients are very close) (Figure 4.12). 


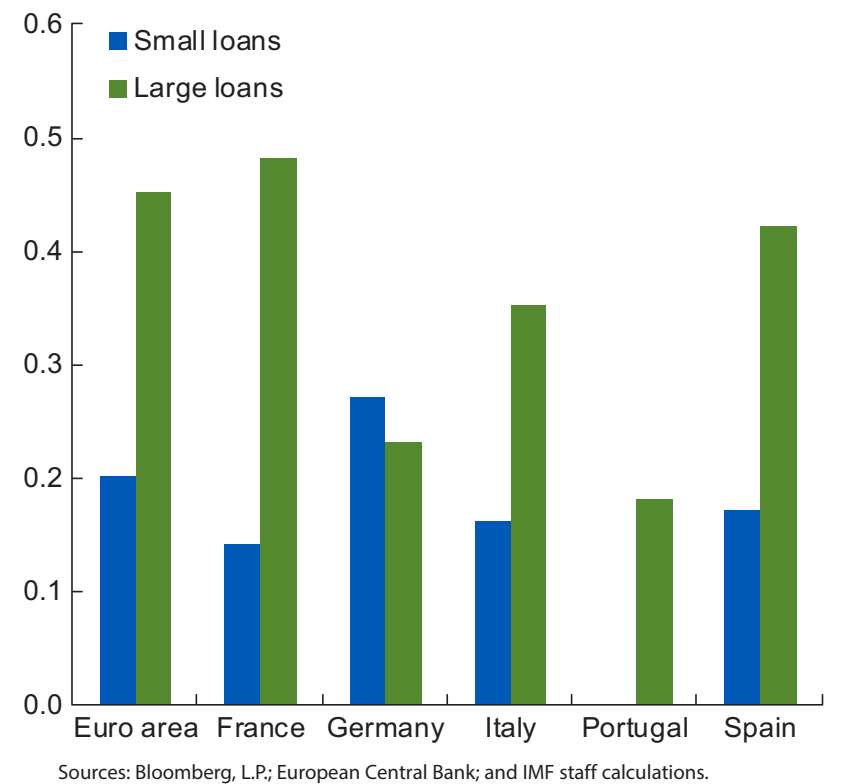

Figure 4.11 Immediate Pass-Through

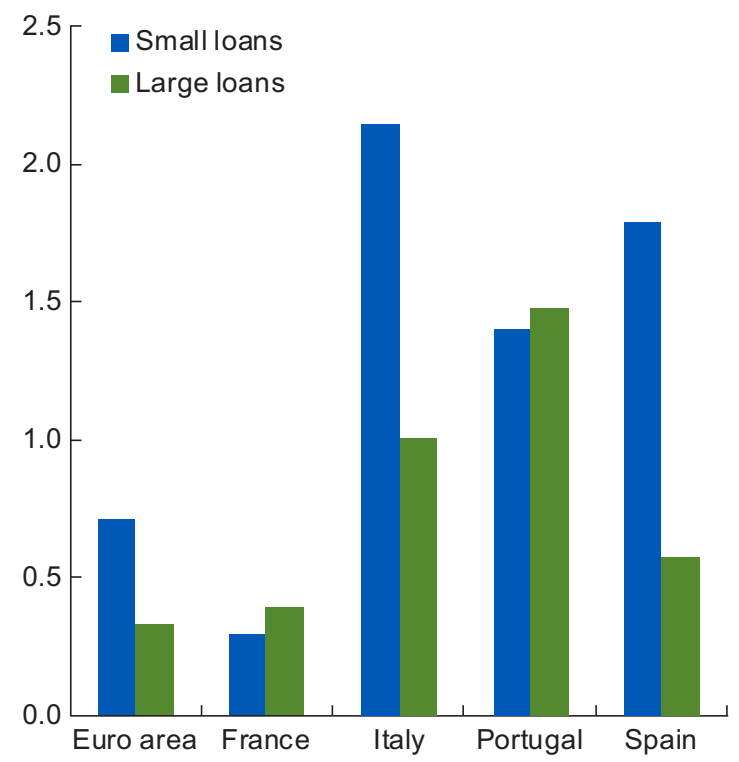

Sources: Bloomberg, L.P.; European Central Bank; and IMF staff calculations.

Figure 4.12 Financial Credit Default Swap (Long-term coefficient)

- The information in sovereign risk appears to be captured in financial sector risk and bank bond spreads (Figure 4.13). Although sovereign yields are significant when they are included in the regressions together with money market rates, they lose significance when the other cost-of-funding and risk variables are included in the regression. However, sovereign yields are significant in the term deposit rate regressions (particularly 


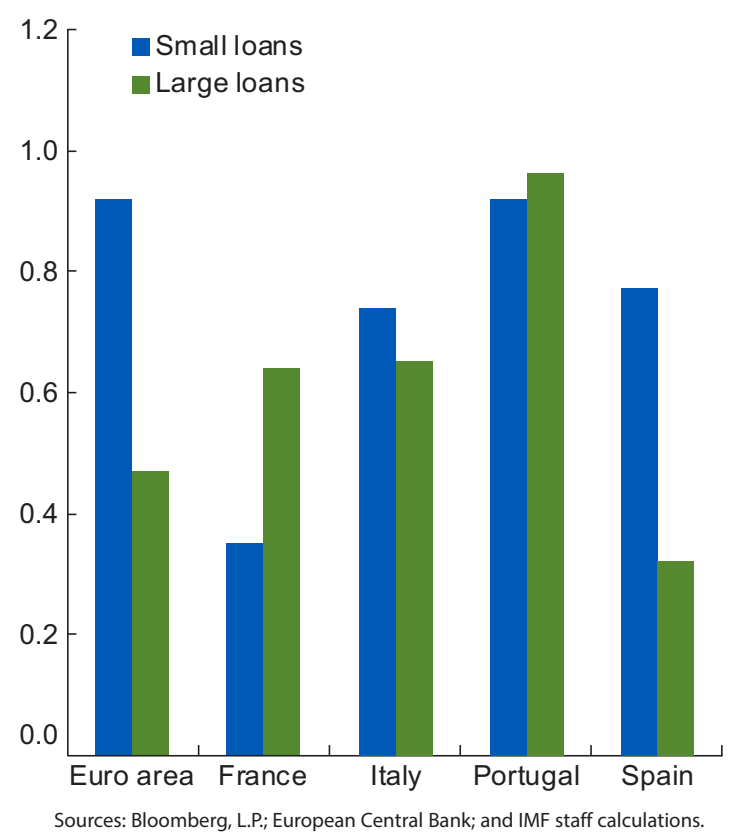

Figure 4.13 Bank Bond Spreads (Long-term coefficient)

for Italy), possibly reflecting that banks and the sovereign are competing in the same funding market.

- Although economic policy uncertainty and PMIs are significant in certain regressions, they lose their significance when other control variables are included. The significance of these variables could increase with additional data, reflecting the emergence of demand factors, as evidenced in survey data.

- Term deposits appear to be an important factor for lending rates in Italy. The coefficient on the Euribor in the lending regressions is smaller because it also affects deposit rates.

- Using alternative money market rates yields qualitatively similar results. Stock market indices (an alternative measure of the cost of funding) and the loan-to-deposit ratio (an alternative measure of leverage) are not robustly significant. The importance of the latter could be better captured in a panel regression framework (capturing countries with high dependence on wholesale funding), but homogeneity assumptions for other coefficients would be too restrictive. Regressions using lending rates for maturities of one to five years do not yield consistently significant results. ${ }^{9}$

Other studies have also found that credit risk, funding constraints, and weak firm balance sheets have affected the transmission mechanism during the crisis. Goretti (2013) examines the determinants of NFC lending rates in a panel regression framework. The paper regresses NFC lending rates on the Euribor, sovereign yields, and unemployment and finds that lending rates are determined more by sovereign yields and unemployment than by the Euribor after 2010 . Ciccarelli, Maddaloni, and Peydro (2013) study the functioning of the credit channel to

\footnotetext{
${ }^{9}$ During 2012, about 5 percent of new loans were in this category (8 percent for small loans and 3-4 percent for large loans). About 90 percent of the loans had maturities of less than one year.
} 
identify both bank lending and firm balance sheet channels using a panel vector autoregression framework, broadly differentiating the coefficients for stressed countries and others. The paper finds that the problems in the bank lending channel (caused by funding constraints) have been mitigated by the ECB's unconventional monetary policy instruments, but that the transmission mechanism through the firm balance sheet channel remains impaired (as of end-2011) and appears more prevalent in small banks (which tend to lend primarily to SMEs). Zoli (2013) focuses on the Italian financial system and finds that sovereign spreads have transmitted to bank CDS spreads and bond yields, which were transmitted to firm lending rates. In addition, banks with lower capital ratios and higher NPLs were found to be more sensitive to sovereign spreads.

\section{HOW CAN THE ECB ADDRESS THE BROKEN TRANSMISSION MECHANISM?}

The ECB has deployed both conventional and unconventional policies to combat the crisis. ${ }^{10}$ Together, these actions have alleviated some funding problems for banks, reduced sovereign and private risk, removed tail risks related to the euro, and kept monetary conditions accommodative, particularly for the core countries. However, financial markets remained fragmented, and weak growth has reinforced balance sheet stresses and credit risks. These pressures have pushed up retail interest rates in stressed countries and restrained the flow of credit, undermining the transmission of monetary policy to stressed economies.

The evidence above highlights the importance of cleaning up bank balance sheets and implementing other measures to increase access to credit for SMEs. Repairing bank balance sheets and making further progress on banking union are essential to restoring confidence in the financial system, weakening bank-sovereign links, reducing fragmentation, and supporting credit and growth (see IMF 2013b). But because these actions will take time, it is important to stem the decline in real activity through various measures to support credit supply.

In this regard, the ECB should consider targeted policies to help reduce fragmentation and further improve monetary transmission. Monetary policy alone cannot address underlying weaknesses in banks' balance sheets, but by supporting demand to the fullest extent, it can provide breathing space for this to occur. In most cases, policies would entail additional ECB balance sheet risks, but this alone should not inhibit further needed action. Such risks could either be addressed through offsetting measures, including a backstop provided by the European Investment Bank (EIB) (discussed later in this chapter), or sustained through gains to financial stability or the ECB's ability to maintain a protracted investment horizon.

\section{Ensure Term Funding Needs Are Met}

At a minimum, the ECB should continue to support liquidity to weak banks. In line with the ECB's current approach, this action could include (1) additional LTROs of considerable tenor (for example, three to five years) to ensure term funding for weak banks, and (2) a targeted review of existing collateral policies, including to lower haircuts on certain assets (for example, additional credit claims [ACCs] and asset-backed securities [ABS]). In combination, the result could be akin to credit easing. Although about a third of the three-year LTROs have been repaid, repayments have been largely driven by core banks with ample liquidity, and weaker

\footnotetext{
${ }^{10}$ In particular, policy interest rates have been lowered to historic levels, special liquidity facilities implemented, collateral policies relaxed, and OMT announced. In addition, the ECB and national central banks have made limited, direct interventions in selected securities markets through the Securities Markets Program and the Covered Bond Purchase Program.
} 
banks in stressed countries remain reliant on official liquidity, given their high-term funding costs.

The provision of additional liquidity should at least cover any current funding shortfalls. As an example, based on 2013 loan-to-deposit ratios, the combined funding gap for Spanish and Italian banks is about $€ 600$ billion. ${ }^{11}$ Moreover, although the ECB's full allotment policy ensures that there is sufficient liquidity in the system, the maturity of lending operations is limited to only three months, which is not conducive to term lending given the need to roll over frequently. It also prevents banks from matching new liabilities with existing longer-term assets, thus increasing incentives to deleverage. Therefore, additional LTROs of a scale similar to those already implemented could be useful, with additional amounts provided to promote further lending activity.

A targeted review of existing collateral policies is an integral part of this option, particularly given the pressures on system collateral and the encumbrance of banks' balance sheets. Such a review would increase liquidity for weak banks and promote the flow of credit to SMEs without further broadening the pool of eligible collateral.

- The ECB could reduce haircuts on certain assets, namely ACCs (linked to SME loans and ABS). This reduction would directly increase the availability of collateral for weaker banks and SMEs in stressed economies, and encourage greater securitization activity. Indeed, for a given collateral category, the ECB's haircuts are larger than what is imposed by some other major central banks to limit risks to its balance sheet. ${ }^{12}$ At the same time, however, haircuts have become more binding as the quality of collateral has declined (see Box 4.2).

- National central banks could be less conservative in assessing the quality of ACCs used as collateral and held on their balance sheets. National central banks may be too conservative in assessing credit risk-as a deviation from ECB criteria. ${ }^{13}$

\section{Target Liquidity to SMEs}

The ECB could also take actions to ensure that liquidity is directly targeted to SMEs. In particular, the ECB could consider a targeted lending scheme, similar to the U.K. Funding for Lending Scheme (see Box 4.3). Although LTROs together with relaxed collateral requirements function in a way similar to this program in providing funding for banks, they do not change incentives for banks to lend. Therefore, a new LTRO could be contingent on the provision of new lending to SMEs, directly supporting credit to this sector. For such an LTRO to prove effective, however, the costs to access the scheme must be less than alternative funding costs. Therefore, lower haircuts (as described above) should be considered in tandem.

\section{Direct Private Asset Purchases}

The ECB could circumvent weak banking systems through targeted asset purchases. Direct ECB purchases of private assets would support market-based credit to households and corporations while bank balance sheets are repaired. Program design could limit ECB balance sheet risks, though private assets could include securitized assets (supporting SME financing), corporate

\footnotetext{
${ }^{11}$ This funding gap represents the difference between loans outstanding and deposits held, which is about $€ 200$ billion for Italy and $€ 400$ billion for Spain.

${ }^{12}$ For example, the haircut imposed by the ECB on ABS (up to five-year tenor) is 16 percent, more than three times that imposed by the U.S. Federal Reserve on comparable assets.

${ }^{13}$ In 2013, national central banks have the ability to accept ACCs that do not meet the ECB's minimum eligibility criteria, but they must bear any associated risk on their own balance sheets. By setting their own criteria and risk-mitigation measures for ACCs—as "deviations" from those of the ECB (though approved by the ECB)—national central banks are able to ensure a greater provision of liquidity to weaker banks.
} 


\section{BOX 4.2. Eurosystem Collateral}

Throughout the crisis, the European Central Bank has drawn upon the flexibility of the Eurosystem's collateral framework to provide increasing liquidity support to banks. Collateral policies have been relaxed on several occasions, including by broadening the base of eligible instruments to include additional credit claims and other nonmarketable assets. ${ }^{1}$ Along with the introduction of the three-year Long-Term Refinancing Operations (LTROs), ${ }^{2}$ the amounts of eligible collateral and average outstanding $\mathrm{credit}^{3}$ have increased substantially through the crisis (Figure 4.2.1).

Despite these accommodative actions, however, there were signs of increased strains on system-wide collateral in 2013, particularly in stressed countries. Against higher unsecured funding costs, banks have become heavily reliant on secured borrowing, particularly through official facilities. The pressures on funding are evident at both the Eurosystem and private bank funding levels, and are transmitted through several channels.

- The composition of pledged Eurosystem collateral has changed throughout the crisis, with a marked rise in the share of government securities and nonmarketable assets (about three-quarters of which are additional credit claims) and a drop in corporate and bank bonds. In addition, the pool of higher-quality government securities has decreased with ratings downgrades, and there has been a trend away from the use of cross-border assets toward domestic collateral, reflecting increased financial market fragmentation and regulatory "home bias."

- In addition, collateral in private funding markets appears increasingly encumbered for some. Apart from a few opportunistic periods following key euro area policy initiatives, the issuance of covered bonds and other asset-backed securities declined in 2012, while banks in stressed countries have seen a marked rise

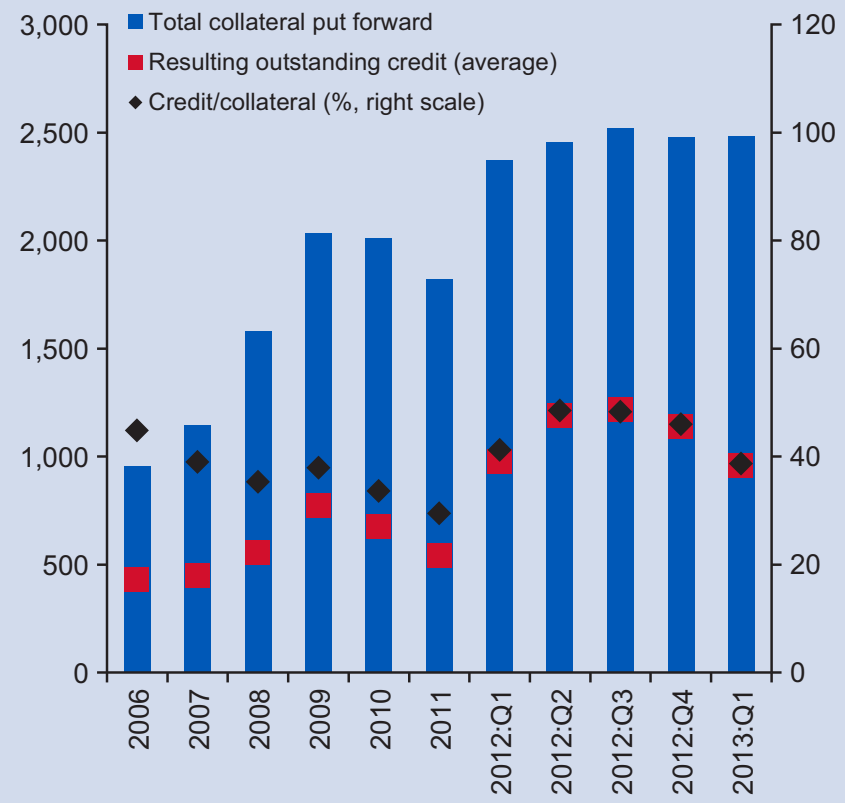

Source: European Central Bank.

Figure 4.2.1 Collateral Pledged with the Eurosystem (Billion euro)

\footnotetext{
${ }^{1}$ According to the European Central Bank, the eligibility of additional credit claims increased the collateral pool by approximately $€ 600$ billion to $€ 700$ billion, but this was only expected to result in about $€ 200$ billion of acceptable collateral because of stringent overcollateralization requirements.

${ }^{2}$ The ongoing repayment of three-year LTROs since the start of 2013 suggests that collateral will be released back into the system. However, the repayments also imply a reduction in excess system liquidity.

${ }^{3}$ Banks can and do prepledge collateral with the Eurosystem. Therefore, the rise in credit to collateral shown here is likely understated, suggesting more credit became available for the given pool of collateral.
} 


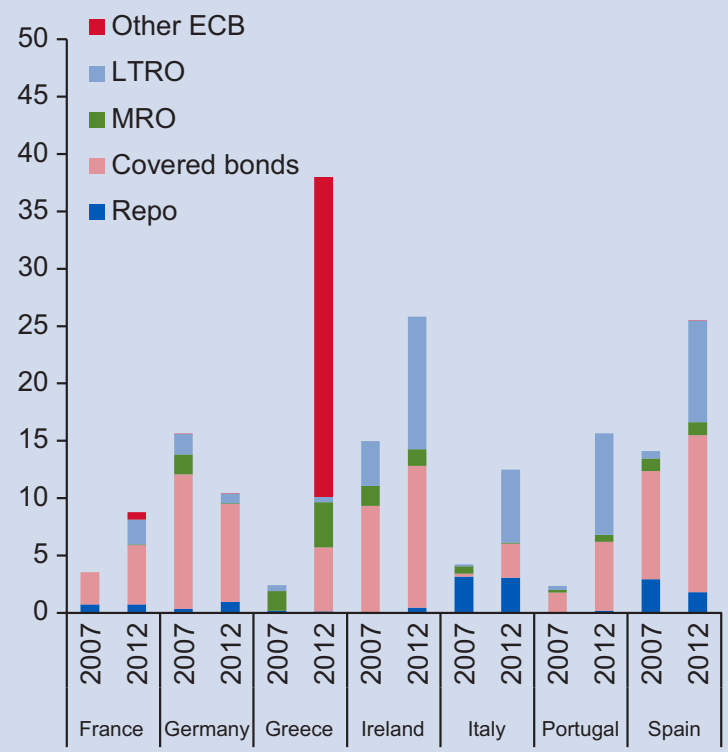

Source: European Central Bank.

Note: $E C B$ = European Central Bank; $L T R O=$ long-term refinancing operation; $\mathrm{MRO}=$ main refinancing operations.

Figure 4.2.2 Proportion of System Balance Sheets Encumbered (Percent of banks' assets)

in associated bond spreads. In addition, the euro-denominated securitization market has declined by more than $€ 250$ billion to about $€ 1$ trillion since 2009, and the euro-denominated commercial paper market has dried up. Taken alongside the strains from official borrowing, the share of encumbered assets has increased during the crisis, notably for stressed economies (Figure 4.2.2).

- Systemic factors are also contributing to strains on collateral. In particular, the move to central counterparty clearing systems for over-the-counter derivatives, and larger recourse to central bank liquidity (including through asset purchase programs by major central banks), add to the overall demand for highquality collateral.

bonds, commercial paper (NFC financing), and covered bonds (bank funding), while mortgagebacked securities could be encouraged and accepted for collateral at Eurosystem liquidity facilities. Although the purchases could be small (to limit the balance sheet risks), official participation could boost confidence and thus act as a catalyst to further market activity. Depending on the nature of the program - that is, whether it targets existing loans - the impact could be timely, but may still be hampered by regulatory changes, including higher risk weights on securitized assets.

\section{Backstop from the EIB}

The EIB could provide a backstop to contain the balance sheet risks. The EIB currently has paid-in capital of $€ 55$ billion (after a $€ 10$ billion increase). As an illustration, $€ 10$ billion provided 


\section{BOX 4.3. The Bank of England's Funding for Lending Scheme (FLS)}

The FLS was designed as a four-year collateral swap. Participating banks would place their lower-quality collateral with the Bank of England (with the usual haircuts and margins) in exchange for higher-quality gilts, which they could then use to obtain market funding at close to the policy rate. The initial FLS allowance was set at 5 percent of banks' loan books, but the allowance increased pound-for-pound with net lending (that is, there was no ceiling on the scheme size). A built-in pricing incentive-an access fee that varied inversely with the volume of net credit extended-encouraged banks to lend (or minimize deleveraging).

Although the scheme has improved funding conditions, take-up has remained limited. The scheme has contributed to easing funding pressures on U.K. banks, with credit default swap spreads and deposit rates falling sharply since mid-2012. Some of this reduction has also translated into lower lending rates, particularly for mortgages. However, take-up of the scheme has been limited and banks have not made full use of the program, even to draw down up to 5 percent of their existing loans. Overall private sector lending has not picked up. But there was a net increase in lending if banks facing deleveraging pressures (Royal Bank of Scotland, Lloyds Banking Group, and Santander UK) are excluded, and FLS drawings contributed about twothirds of that increase.

The program's limited impact could be explained by the following factors:

- Low cost advantage of accessing the scheme-Drawing down from the FLS conferred no big cost advantage. Banks face three costs: an access fee (25-150 basis points, depending on the bank's net lending position), a Bank of England haircut on the collateral swapped to obtain the gilts, and the cost of market financing obtained using the gilts (essentially close to the policy rate). In 2013, these combined costs are not lower than what most banks would pay on wholesale or deposit funding raised directly, thus reducing the incentive to access the scheme. This lack of competitiveness with the market, however, could also reflect the scheme's success in reducing banks' funding costs.

- Abundant liquidity and weak or low-quality demand for credit-With households deleveraging and bigger corporations able to borrow directly from markets at cheap rates, demand for bank credit is weak. Moreover, banks' perceived credit risk, especially on lending to SMEs and unsecured credit to households, is likely to have been elevated, given weak aggregate demand and earnings prospects.

- Health of U.K. banks-There were lingering concerns about the health of U.K. banks, especially their asset quality and the adequacy of existing capital buffers. As a result, despite being flush with liquidity, some banks have eschewed credit origination, persisting with previous deleveraging plans and using the cheaper funding to boost net interest margins instead.

- Design of capital charge on FLS lending-The scheme initially allowed banks to offset under Pillar II the regulatory capital charge in respect of FLS-funded loans. However, the offset was done on the basis of average risk weight, which constituted a de facto incentive for banks to substitute increased secured lending but reduce SME lending. This is unlikely to be a significant factor, and the April 2013 modification to the FLS has addressed this by significantly improving the attractiveness of SME lending.

Note: See Annex 5 of IMF (2013a) for further details.

as a backstop, or first-loss guarantee, to ECB private asset purchases could be leveraged to support a much larger pool of securitization activity. The amount of leverage would depend on several factors, including the amount of risk pooled among member states and the impact on EIB financial ratios.

Nevertheless, even modest leverage could have a sizable impact on SME-backed securities. The euro area securitized bond market reached $€ 1.03$ trillion at end-2012, of which approximately $€ 140$ billion was collateral backed by SME loans (Figure 4.14). The current stock of SME loans by banks is estimated to be approximately $€ 1.5$ trillion. However, beyond SMEs, further support to market development could be achieved by including assets securitized by mortgages and by enhancing the commercial paper market infrastructure.

\section{CInternational Monetary Fund. Not for Redistribution}




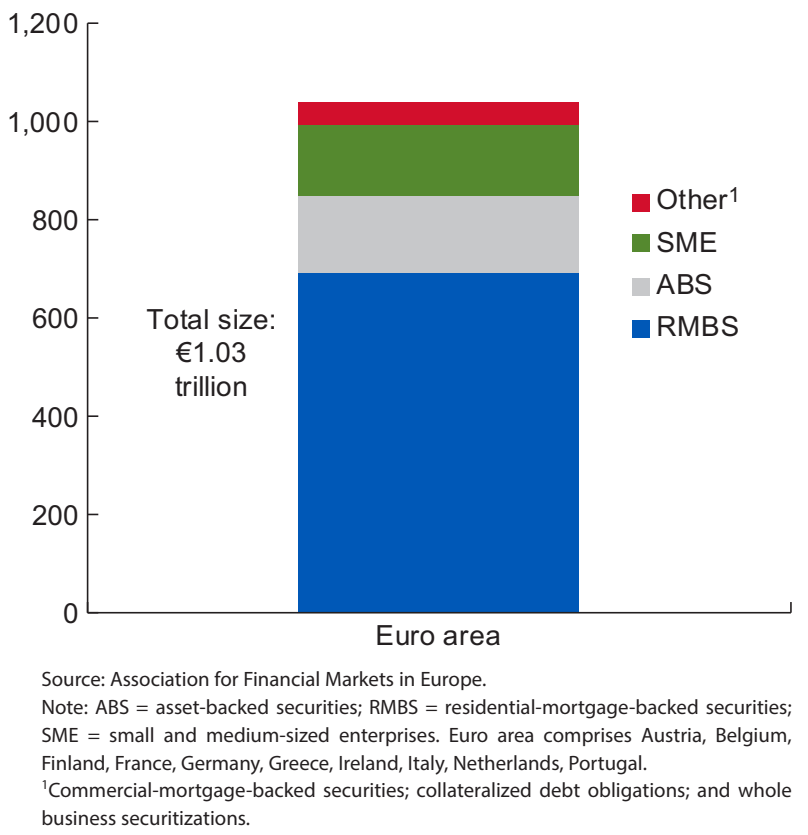

Figure 4.14 Euro Area Securitized Bond Market as of End-2012 (Billion euro)

ANNEX 4.1. MONETARY POLICY TRANSMISSION CHANNELS

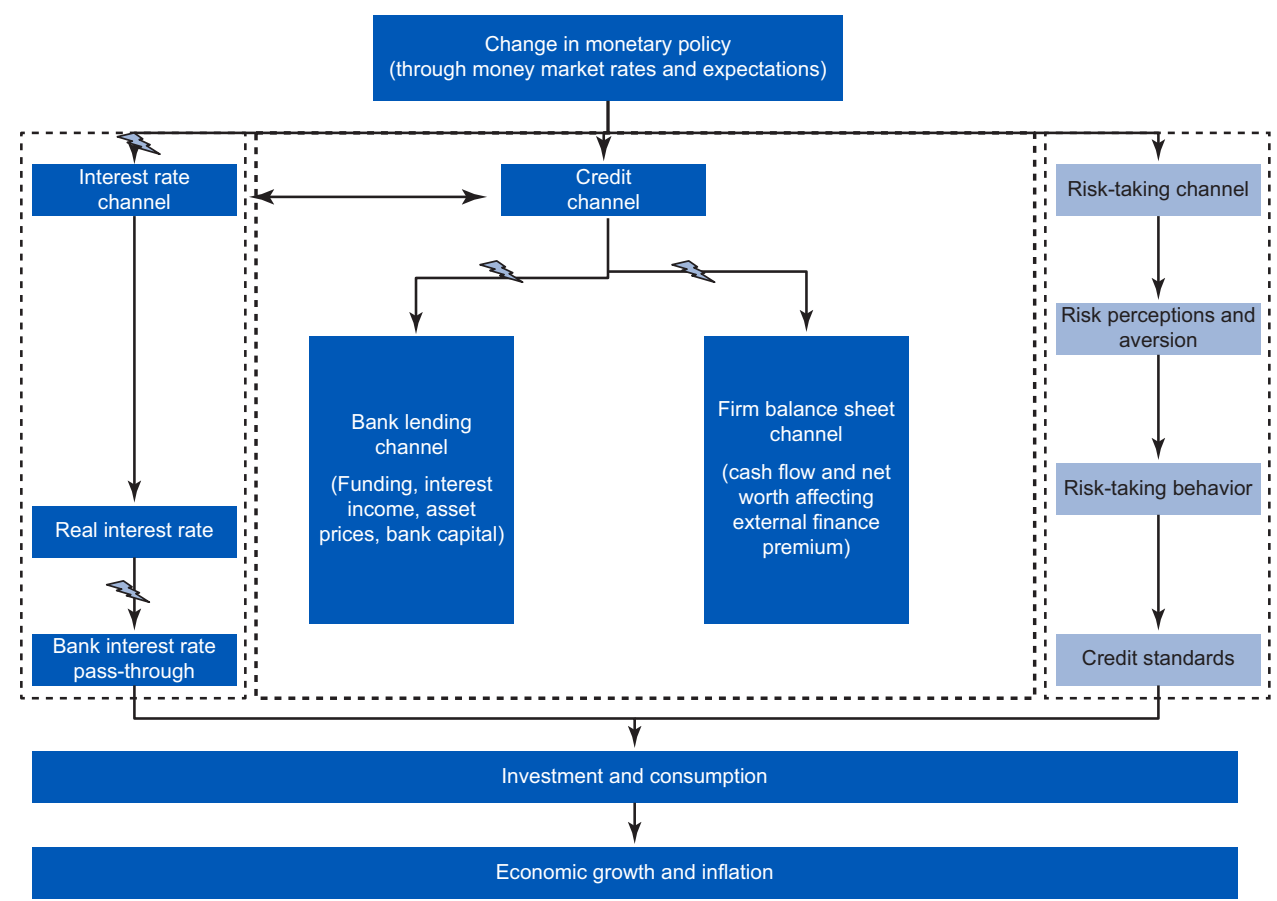

Annex 4.1 Monetary Policy Transmission Channels 


\section{REFERENCES}

Al-Eyd, A., and P. Berkmen. 2013. "Fragmentation and Monetary Policy in the Euro Area." Working Paper 13/208, International Monetary Fund, Washington, DC.

Bornhorst, F., and M. Ruiz-Arranz. 2013. "Indebtedness and Deleveraging in the Euro Area." Country Report No. 13/232, International Monetary Fund, Washington, DC.

Ciccarelli, M., A. Maddaloni, and J. Peydro. 2013. "Heterogeneous Transmission Mechanism: Monetary Policy and Financial Fragility in the Euro Area." Working Paper No. 1527, European Central Bank, Frankfurt.

European Central Bank (ECB). 2009. Monthly Bulletin, August, Frankfurt.

. 2010. Monthly Bulletin, May, Frankfurt.

2012. Euro Money Market Study 2012. Frankfurt.

2013. Monthly Bulletin, May, Frankfurt.

Goretti, M. 2013. "Determinants of Lending Rates in Portugal." In Portugal, Seventh Review under the Extended Arrangement and Request for Modification of End-June Performance Criteria. Country Report No. 13/160, International Monetary Fund, Washington, DC.

International Monetary Fund (IMF). 2013a. "United Kingdom: 2013 Article IV Consultation.” Country Report No. 13/210, International Monetary Fund, Washington, DC.

. 2013b. "United Kingdom: 2013 Article IV Consultation.” Country Report No. 13/231, International Monetary Fund, Washington, DC.

Zoli, E. 2013. "Italian Sovereign Spreads: Their Determinants and Pass-Through to Bank Funding Costs and Lending Conditions." Working Paper No. 13/84, International Monetary Fund, Washington, DC. 


\title{
Possible Subordination Effects of Eurosystem Bond Purchases
}

\author{
Nico Valckx, Kenichi Ueda, And Manmohan Singh
}

The debt restructuring in Greece in February-March 2012 effectively extended senior creditor status to Eurosystem bond purchases. By mid-February 2012, the European Central Bank (ECB) and the national central banks of the euro area, collectively, the Eurosystem, swapped their Greek bonds acquired under the Securities Markets Program (SMP) for new bonds of identical structure and nominal value, with different serial numbers. This transaction provided the Eurosystem an exemption from the subsequent private sector debt swap under so-called private sector involvement (PSI), effected through retroactive collective action clauses. ${ }^{1}$ By swapping its debt purchases in advance of the PSI announcement, the Eurosystem effectively received preferential (senior) creditor status on its Greek bond holdings. ${ }^{2}$

According to the ECB, this exemption from PSI was "special" because Eurosystem bond market interventions were undertaken solely for monetary policy purposes. Treating Greece as a special case may indicate that the subordination of private debt holders will not be repeated in other contexts. At the same time, the ECB has cautioned against incurring losses on the SMP, which could-in an extreme case-require recapitalization of Eurosystem central banks and result in reduced financial independence.

In this context, a key question is whether the SMP has become less effective after the Greek PSI exemption — or had done so even earlier-because of subordination risk. This treatment of the Eurosystem may effectively have reshaped the seniority structure of all official holdings of sovereign bonds. From a market risk-return perspective, this treatment implied a possible mispricing of many euro area bond markets, leaving future SMP beneficiaries subject to rating downgrades because Eurosystem interventions reduce the private investor base and increase losses in the event of restructuring. Anecdotal market evidence confirms that the impact of SMP purchases has become controversial, although this controversy may already have been priced in before the Greek debt exchange in February 2012. Indeed, after the euro area summit of heads of state and government on July 21, 2011, when PSI for Greece was first announced, subordination effects were already under consideration. ${ }^{3}$

This chapter is based on Euro Area Policies: 2012 Article IV Consultation-Selected Issues, IMF Country Report 12/182, 2012.

Comments from Tommaso Mancini-Griffoli and Christian Mulder of the IMF Monetary and Capital Markets Department and ECB counterparts are gratefully acknowledged.

${ }^{1}$ The PSI invited Greek debt holders to exchange their existing holdings for new debt at a face amount of 31.5 percent and cash-equivalent European Financial Stability Facility notes with a two-year maturity at 15 percent of the face amount. In contrast, the ECB received the full face (par) value of the Greek bonds that it had purchased in the markets at a discount on the face value (about $€ 40$ billion versus $€ 55$ billion face value) and would also benefit from future coupon payments on these new bonds.

${ }^{2}$ In addition, Greek bonds purchased by Eurosystem central banks for investment purposes and European Investment Bank holdings were exempt from PSI.

${ }^{3}$ ECB President Trichet stated in an interview in the Süddeutsche Zeitung on July 22, 2011, on PSI, "It goes without saying that the governments will have to redeem their bonds that are on the balance sheet of the Eurosystem without any 

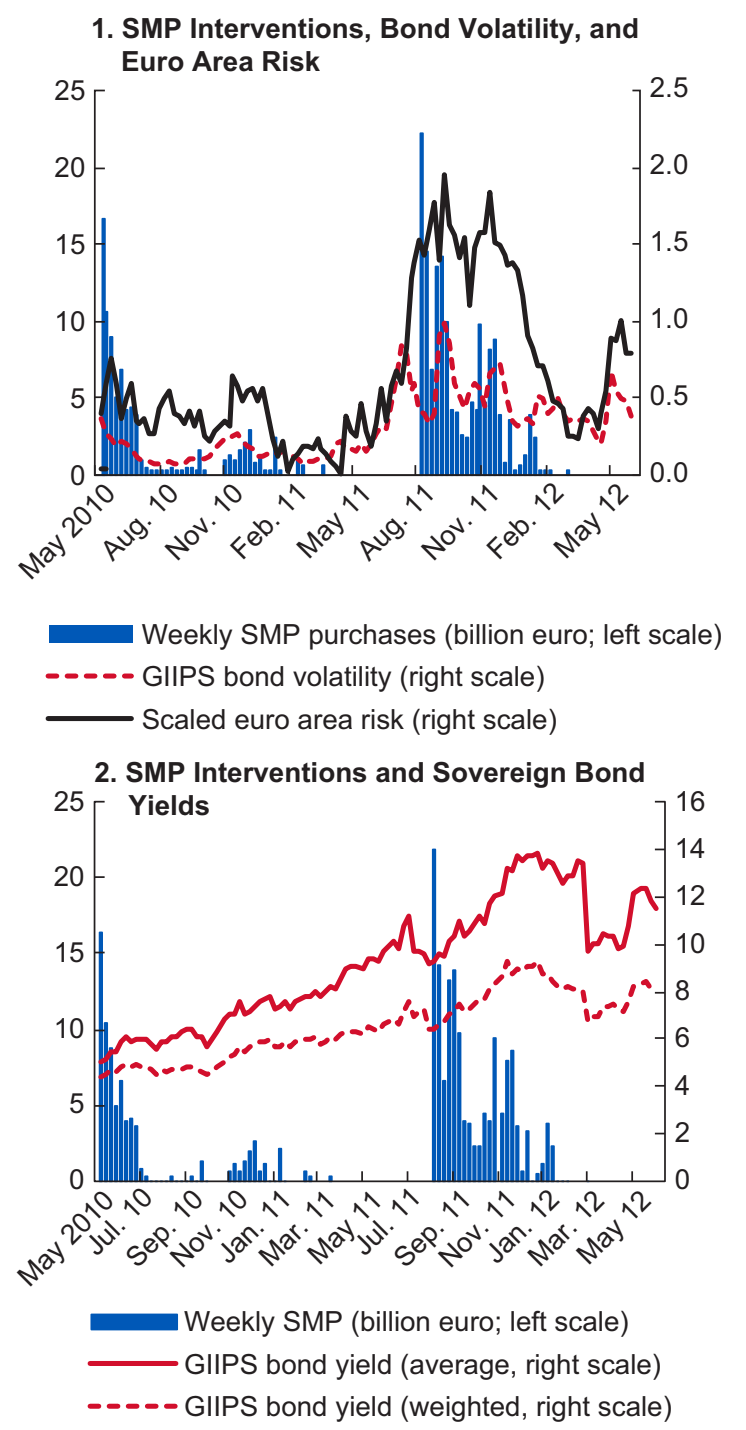

Sources: Bloomberg, L.P.; and IMF staff calculations.
Note: GIIPS = Greece, Ireland, Italy, Portugal, and Spain. Bond yields refer to
10-year benchmark yields. Weighted series take government debt as weights.
Bond volatility follows a GARCH $(1,1)$. Scaled euro area risk is the principal
component score of 13 euro area interbank market spreads, corporate credit
default swap (CDS) spreads, euro area equity risk premium, SovX and EMBIG
CDS, and euro exchange rate implied volatility.

Figure 5.1 Securities Markets Program (SMP) Interventions

At the same time, although the SMP helped to reduce stress in government bond markets temporarily, because of the limited scale and time horizon of its effective use, it did not appear to be fully effective (Figure 5.1). Especially after its launch in May-June 2010 and after reactivation in August 2011, interventions were sizable and helped stem the rise in stressed country sovereign yields (Figure 5.1, panel 2) and the escalation of bond market volatility. ${ }^{4}$ Purchases amounted to

change. Of course, being part of the official sector, we will not be participating in the voluntary private sector involvement mentioned on Thursday as regards Greece." http://www.ecb.int/press/key/date/2011/html/sp110722_1.en.html.

${ }^{4}$ Stressed countries refers to those which experienced sharp rises in sovereign bond yields during the period covered by this study. 
$€ 36$ billion in the first month and $€ 21$ billion in the second month of the program but dropped to less than a few billion afterward. However, as purchases were scaled back, volatility and broad euro area financial market risks increased again, and SMP interventions were scaled up again in November and December 2010. Similarly, as sovereign market stresses increased again during the summer of 2011, the reactivation of the SMP in August and September 2011 with purchases of $€ 51$ billion and $€ 37$ billion led to a reduction in broad market stresses. However, as stress in some debt markets reemerged, SMP purchases increased again to $€ 40$ billion in November 2011 before the Eurosystem adopted other measures to help stressed economy banks in need of funding.

This chapter examines various ways to quantify the extent of subordination arising from Eurosystem debt purchases. It first looks at illustrative empirical evidence, aimed at documenting developments in government bond prices and credit default swap (CDS) risk premiums during and after the Eurosystem debt swap. Next, it looks at theoretical models to quantify and illustrate the potential effect of subordination on bond prices and CDSs. Finally, it offers some tentative policy conclusions. The main finding is that the impact of Eurosystem seniority is primarily related to perceived probability of default and the proportion of outstanding debt already in the hands of the central bank. Moreover, credibility of SMP interventions matters.

\section{EMPIRICAL EVIDENCE ON EUROSYSTEM SUBORDINATION RISK}

Insufficient data makes directly quantifying the subordination risk from Eurosystem debt purchases difficult. Eurosystem debt purchases under the SMP were largely put on hold after the PSI exemption. Only one SMP intervention took place afterward, in the week of March 5-9, 2012, for $€ 27$ million, the fifth-smallest intervention since the start of SMP purchases in May 2010, based on weekly Eurosystem financial statements. Hence, there is insufficient quantitative evidence to establish empirically the relationship between subordination risk from Eurosystem debt purchases and sovereign yields.

However, an event study analysis of news on its senior status can provide some gauge of subordination risk. ${ }^{5}$ Innovations in bond yields and CDS premiums in the days surrounding the July 22, 2011, statement by President Trichet and the Eurosystem debt swap on February 16, 2012, are examined. Following MacKinlay (1997), standardized cumulative abnormal yields and CDS spreads are estimated (in first differences). The underlying model is

$$
\begin{gathered}
\Delta Y_{i}=a_{i}+b_{i} \Delta Y_{L C H}+c_{i} \Delta \operatorname{Sov} X \\
\text { and } \\
\Delta C D S=d_{i}+e_{i} \Delta \operatorname{Sov} X,
\end{gathered}
$$

in which $Y_{i}$ denotes the government bond yield in country $i, C D S$ is the sovereign credit default swap spread, $Y_{L C H}$ is the LCH Clearnet benchmark 10-year yield on AAA countries, and SovX is the SovX Western Europe CDS index. Standardization makes it easier to compare cumulative abnormal yields and spreads. The models are estimated using 70 daily observations with data up until one month ahead of the event, to avoid coefficient bias due to the events.

The results show little impact of the Eurosystem debt swap on stressed country yields, but the initial PSI announcement and the Eurosystem's nonparticipation did have substantial short-term

\footnotetext{
${ }^{5}$ In addition, one could analyze the spread between subordinated and senior bank debt CDS premiums, given the close comovement between bank CDSs and sovereign CDSs, as a proxy for sovereign subordination risk. Such an analysis would show that the introduction of PSI under the draft European Stability Mechanism Treaty in November 2010 and its effective use in Greece as agreed in July 2011 and reaffirmed in October 2011 raised subordination substantially, more so than the actual ECB debt swap in February 2012. However, this spread may be confounded by bank-specific conditions (for example, shares of subordinated debt) and country-specific legal considerations related to bail-in and resolution regimes, which will be overhauled following proposals by the European Commission $(2011,2012)$.
} 
1. Ten-Year Bond Yield

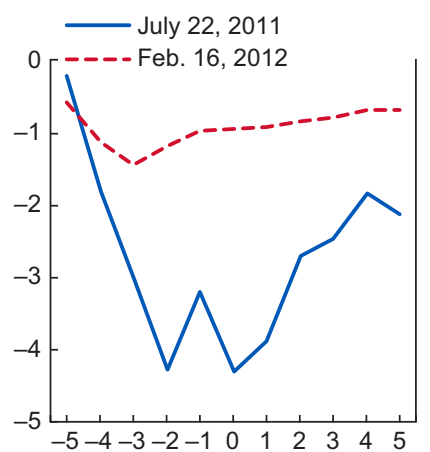

2. Two-Year Bond Yield

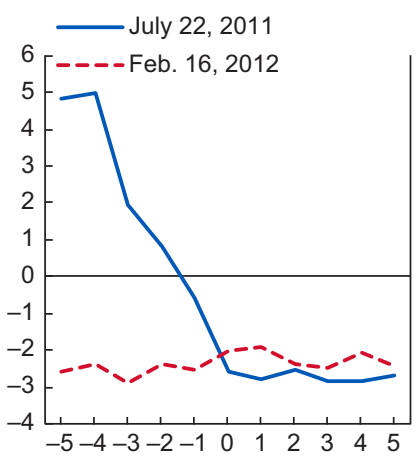

3. Five-Year Sovereign CDS

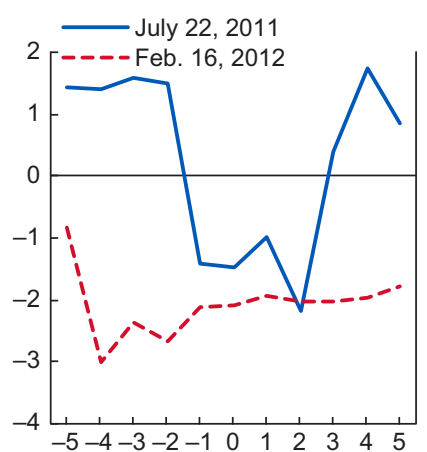

Sources: Bloomberg, L.P.; and IMF staff calculations.

Note: Figure shows the changes in selected euro area (Italy, Portugal, and Spain) bond yields and sovereign credit default swap (CDS) spreads. Scales are standard normal, that is, values exceeding +/- 1.96 are statistically significant at the 5 percent level.

Figure 5.2 Event Study Analysis of European Central Bank Subordination on Bond Yields and Credit Default Swap Spreads

negative effects. The market effect of the Eurosystem, as a large creditor, shifting to preferred debtor status did not seem significant when evaluated around the time of the debt swap announcement (Figure 5.2). However, this lack of a significant impact appears to reflect that the market may have anticipated the event and already priced it in. Longer-dated stressed country bond yields and CDS default risk premiums seem to have risen unexpectedly following President Trichet's public statement on July 22, 2011, that the Eurosystem would not be participating in the voluntary Greek PSI—one day after an important euro area summit had agreed on modalities of additional support for Greece (including PSI) and on greater flexibility of European Financial Stability Facility loans to the other program countries (Ireland, Portugal). In the days ahead of the summit, bond yields and CDS default risk premiums had fallen substantially, but these declines were reversed after the ECB President's statement, although it cannot be excluded that markets may have been disappointed by some other summit-related news (for instance, the realization that the size of the European Financial Stability Facility had not been increased and large implementation risks).

\section{THEORETICAL APPROACHES TO QUANTIFYING SUBORDINATION RISKS}

It is possible to incorporate the subordination effect in a closed-form bond price model or in a reduced-form CDS model. In both models, the subordination effect depends on three factors: probability of default, loss given default (one minus the recovery rate), and the share of Eurosystem bond holdings.

\section{Sovereign Bonds, Closed-Form Model}

Eurosystem seniority matters when the recovery rate is not close to zero or to 100 percent. For example, suppose a country's debt trades at 60 percent of par before establishment of the Eurosystem's senior creditor status (Figure 5.3). This rate could reflect market estimates of 40 percent default probability with 100 percent loss given default (zero recovery value) and 60 percent (nondefault) probability of full repayment. In this case (case I), seniority does not matter because upon default, no single bondholder is repaid. However, a preannouncement price of 60 cents on the euro is also consistent with another case: 80 percent default probability with 50 percent recovery (case II). In case II, seniority matters. For example, if the Eurosystem's share 

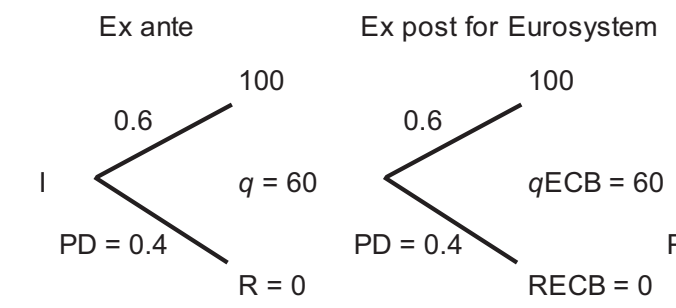

Ex post for private sector
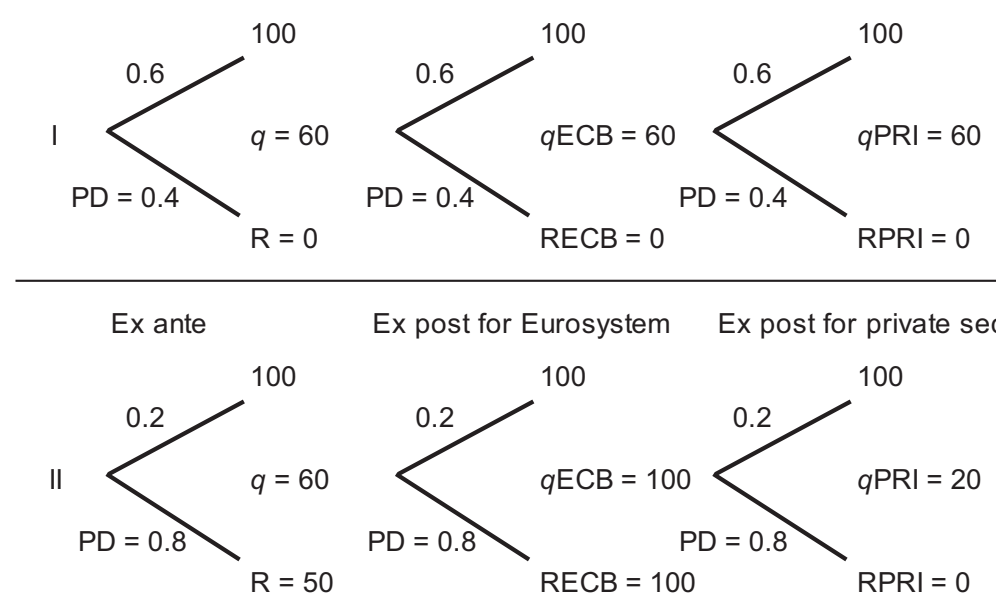

Source: IMF staff calculations.

Note: See text for explanation of case I and case II. "Ex ante" and "ex post" refer to before and after establishment of the Eurosystem's senior creditor status. PD = probability of default; PRI = private bondholder; $q=$ market price of debt before Eurosystem seniority; $q \mathrm{ECB}=$ shadow price of debt for Eurosystem bondholder after establishment of Eurosystem debt seniority; $q \mathrm{PRI}=$ shadow price of debt for private bondholder after establishment of Eurosystem debt seniority; $R$ = recovery rate upon default before establishment of Eurosystem seniority; RECB (RPRI) = recovery rate upon default for Eurosystem (private) bondholders after.

Figure 5.3 Illustration of Closed-Form Model under Differing Probabilities of Default and Recovery Rates

is 50 percent of the country's debt, the Eurosystem can recover all its claims at face value because the country will repay the first 50 percent of the total debt to senior creditors. For the Eurosystem, the after-the-fact (shadow) price of the bond becomes the full face value. After repaying the Eurosystem, the country that defaulted will have nothing left with which to repay private bondholders. The after-the-fact market price of the bond reflects this zero recovery and the bond will be traded at 20 percent of face value because there is still a 20 percent probability of nondefault with full repayment of 100. Annex 5.1 develops this model more formally.

The net impact of subordination thus depends on three major factors:

- Probability of default (PD)—The PD increases linearly with the subordination effect, that is, the difference between the original price and ex post price (after subordination). Figure 5.4 (panel 1) plots this effect for various default probabilities for a range of Eurosystem debt market shares. Evidently, the larger the Eurosystem market share, $b$, the lower the market price after subordination for any given PD.

- Loss given default (LGD)_-If the LGD is large, then having senior status does not translate into a large advantage. Also, for a small LGD, senior status is not valued much because even junior creditors could recover a large portion of the face value. The overall effect-the difference between the original price and ex post price-is thus not monotonic. Figure 5.4 (panel 2) illustrates this effect for an 80 percent default probability and various Eurosystem market shares for various LGD values.

- The Eurosystem's ownership share of sovereign bonds - As long as the Eurosystem's ownership of sovereign bonds, acquired through the SMP, is small relative to the original recovery rate, even with the Eurosystem expecting full repayment, the loss on private sector holdings will be limited. Therefore, the difference between the original price and the ex post price will be small.

\footnotetext{
${ }^{6}$ Note that this is not an independent third factor, but rather an attribute of LGD: the higher the Eurosystem's holdership share, the lower the recovery rate (or higher LGD) for private bondholders.
} 

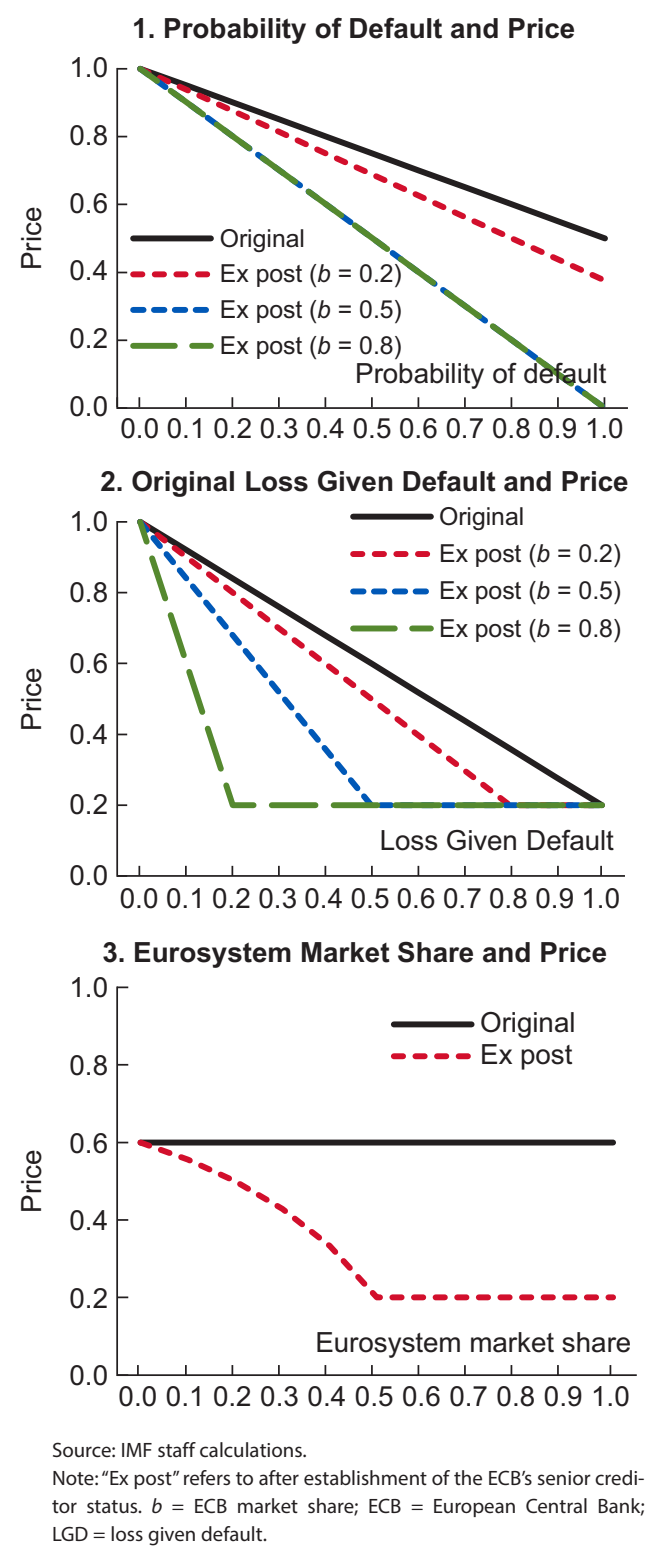

Figure 5.4 Bond Prices and Securities Markets Program Determinants

In contrast, when the Eurosystem holds a large share of sovereign bonds relative to the recovery rate, the Eurosystem's senior status will lower the (ex post) recovery rate for the private sector dramatically. Figure 5.4 (panel 3) shows that this effect is monotonic but not linear. In particular, when the Eurosystem's share is larger than the original recovery rate, there is a kink, above which private bondholders will not receive anything (ex post) in bad states of nature. Note that what is important in pricing the bonds is the expectation of the Eurosystem's share including future acquisitions under the SMP. Increases in the expected Eurosystem share (or related uncertainty) can create further negative effects. 
SMP purchases thus have two main effects on bond prices and yields:

- Raising subordination risk-The rise in yields for distressed sovereigns at the time of announcement of a debt swap (in favor of the Eurosystem) reflects a net expected transfer of value from private bondholders to the Eurosystem. This subordination will also undermine the effects of any future SMP purchases because sovereigns will face higher issuance cost on any bonds not purchased by the Eurosystem.

- Improving liquidity-To the extent that the SMP improves liquidity conditions, it would reduce the probability of default and thereby increase the value of residual bonds. This increase in value happens when the Eurosystem provides vital liquidity to the market, and ultimately to stressed country governments. Investors would be reassured that the Eurosystem is willing to smooth out temporary liquidity shocks. Also, a lower interest rate could decrease the default probability by improving debt sustainability. This beneficial effect would be enhanced by a credible and clearly communicated SMP intervention strategy.

Therefore, the net impact on bond prices of the subordination effect versus the liquidity support effect is ambiguous a priori.

\section{CDS, Reduced-Form Model}

Along the same lines, CDS pricing implicitly reflects liquidity and seniority effects. CDS and bonds should be perfectly cointegrated because they are assets with exactly the same cash flow and thus the same price. ${ }^{7}$ At the same time, the CDS model allows the role of SMP interventions to be illustrated somewhat differently and shows the role of credibility in SMP interventions (although the latter is also implicit in bond prices).

- Liquidity effect: Starting from a standard CDS pricing formula, SMP interventions-by lowering sovereign yields, assuming the intervention is credible and sustained (see below) reduce the cumulative probability of default $(P D)$, which has a nonlinear (but less than proportional) impact on CDS spreads $(C D S)$ :

$$
C D S=L G D \times\left(1-(1-P D)^{1 / n}\right),
$$

in which $n$ denotes the number of periods (years). The subsequent analysis abstracts from realworld versus risk-neutral PDs, which are analyzed, for example, in Bilal and Singh (2012). ${ }^{8}$

- Subordination risk: Because of perceived senior creditor status, SMP purchases may increase private sector LGD and possibly offset the lower probability of default.

LGD for private bondholders increases with debt restructuring needs and the size of Eurosystem holdings. Intuitively, for a debt restructuring, the LGD will depend on the necessary reduction in the debt-to-GDP ratio $(\triangle D / G D P)$ and on the participation rate. Hence, official sector holdings have a nonlinear impact on expected private sector loss given default or haircut. ${ }^{9}$ If the Eurosystem is expected to be exempt from PSI, as in Greece, a higher Eurosystem share of debt holdings, $b$, will increase the private sector haircut or LGD.

Combining these elements gives equation (5.4):

$$
L G D=(\Delta D / G D P) /(1-b) .
$$

\footnotetext{
${ }^{7}$ Note, however, that the CDS-bond basis may widen as the result of credit tightness or relative margin requirements (see, for example, Garleanu and Pedersen 2011).

${ }^{8}$ Note that the use of PDs abstracts from the debate on real-world versus risk-neutral probabilities. As shown in Bilal and Singh (2012), there may be substantial differences between the two.

${ }^{9}$ This point is also made in Lin and Mutkin (2012).
} 

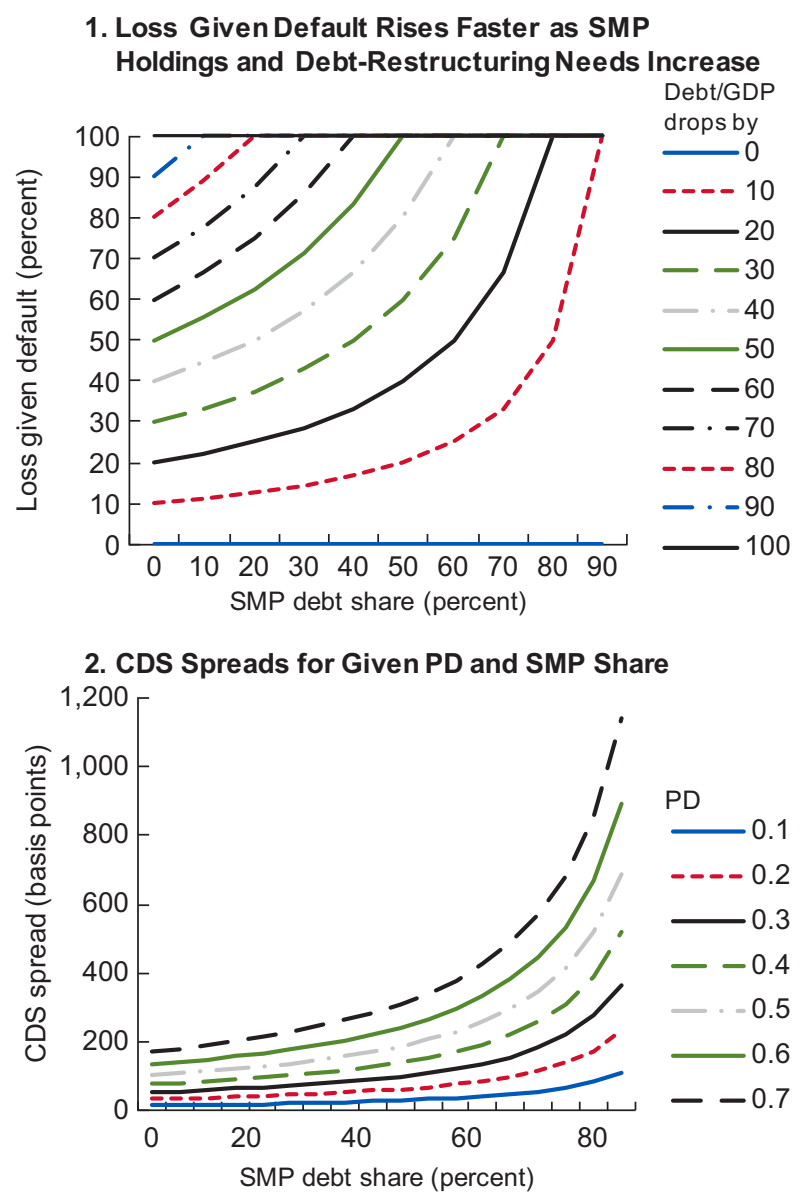

Source: IMF staff calculations.

Note: $C D S=$ credit default swap; PD = probability of default; SMP = Securities Markets Program.

Figure 5.5 Role of Securities Markets Program Purchases in a Credit Default Swap Model

Equation (5.4) makes it clear that the negative effect of SMP purchases rises progressively with an increase in debt because it entails larger haircuts (panel 1 of Figure 5.5).

Substitution in equation (5.4) yields

$$
C D S=(\Delta D / G D P) /(1-b) \times\left(1-(1-P D)^{1 / n}\right) .
$$

Equation (5.5) shows that an increase in the share of SMP purchases, $b$, increases CDS spreads but more strongly so when CDS prices are already high (that is, when $P D$ is more elevated) and to a limited extent when CDS premiums are low, that is, only when default or restructuring fears come into play (see panel 2 of Figure 5.5). When putting this in a dynamic context (although not explicitly done in this model), the beneficial effect of SMP interventions can be shown to hinge on the credibility of the Eurosystem's SMP intervention strategy: 
subordination may lead to self-fulfilling default dynamics (upward shift of the $P D$ line), if, similar to models of currency crises, the central bank's purchases are not able to offset the increased private sector LGD owing to the Eurosystem subordination effect. This effect may prevail when the Eurosystem is not able to lower spreads (or yields), which would otherwise help improve debt sustainability and contribute to lowering the PD (or at least keep the PD unchanged).

\section{CONCLUSION}

This discussion illustrates that the SMP may have a subordination effect, but this effect will be important only at the margin, as was the case in Greece, and depends on the program's credibility. The rise in yields for the most distressed sovereigns at the time of announcement of the Eurosystem's exemption from the Greek PSI reflected a net expected transfer of value from private sovereign bondholders to the Eurosystem. This de facto subordination may undermine future SMP interventions because sovereigns may face higher issuance cost on any bonds not purchased by the Eurosystem. As shown theoretically, this subordination effect depends on three factors: probability of default, loss given default, and the share of Eurosystem bond holdings. At low PD levels, when LGD is relatively low and the sovereign debt ownership share of the Eurosystem is not too high, subordination risk plays a limited role. This conclusion is also borne out by the analysis in a CDS model, in which further SMP interventions have a negative effect only when adjustment needs are very high or CDS spreads are already extremely high. The latter analysis also helps illustrate the importance to the SMP of the Eurosystem's credibility: if credibility is low, SMP interventions may be unable to stop self-fulfilling debt default dynamics. This effect may occur when the Eurosystem is not able to reduce sovereign spreads or yields, which would otherwise support debt sustainability and be conducive to lowering the PD.

Should anything be done to accommodate market fears about subordination inherent in SMP purchases? SMP subordination currently does not seem to play a large role in pricing and markets. However, in principle, it is possible to attenuate market fears about SMP subordination (beyond what is captured in these stylized models) by transferring some of the benefits accruing to the Eurosystem back to private sector bondholders.

\section{ANNEX 5.1. VALUATION OF SOVEREIGN BONDS WITH EUROSYSTEM SENIOR CREDITOR STATUS}

\section{Eurosystem Ranked Equally with Private Bondholders}

Suppose a country's debt is trading at 60 cents on the euro $\left(q_{0}\right)$. This could, for instance, reflect market estimates of 80 percent probability of default (PD) with 50 percent loss given default (LGD); that is, upon default, the country can repay half of the total face value of bonds. The overall discount is 40 percent more than the risk-free discount, which is assumed to be zero. Therefore, if the total face value $F$ is $€ 100$ million, the total market value $V_{0}$ is $€ 60$ million. These relationships can be captured by the following simple valuation equation:

$$
V_{0}=(1-P D \times L G D) \times F,
$$

and the price the bond trades at is $q_{0}=V_{0} / F$ 
Assume that the Eurosystem's share is $b$ percent of the total outstanding. Then, $b$ percent of the market value is held by the Eurosystem and the rest is held by the private sector. The values of the Eurosystem's holding, $V_{E 0}$, and the private sector's holding, $V_{P 0}$, are

$$
\begin{array}{ll}
V_{E 0}=b \times \mathrm{V}_{0}, & \text { and } \\
V_{P 0}=V_{0}-V_{E 0}, & \text { respectively. }
\end{array}
$$

For example, if the Eurosystem holds 20 percent, the value of the Eurosystem's holding is just 20 percent of the original market valuation $V_{0}$. The price $\left(q_{0}\right)$ is unchanged to any level of $b$.

\section{Eurosystem as Senior Creditor}

What if the Eurosystem becomes a senior creditor? As shown below, the effect on existing debt depends on the Eurosystem's share $(b)$. Note, however, that what is important is the expectation of $b$ from the future SMP. And, uncertainty about $b$ can create further distress.

When the Eurosystem was shielded from the Greek bond exchange, private sector claims suddenly became subordinated, which lowered the value of bonds left in the hands of the private sector. Amid expectations that senior status would be granted to the Eurosystem for other euro area government bonds, their prices should also fall (that is, yields should go up). The degree of price decline varies with three factors: the probability of default $P D$; the loss given default $L G D$; and the Eurosystem's holding share, $b$, of the outstanding bonds.

The reason the Eurosystem's claim depends on the share it holds is that its $b$ percent holdings of bonds are now repaid before the private sector's claim. The private sector's claim is only the residual:

$$
V_{P 1}=V_{0}-V_{E 1}
$$

The Eurosystem's claim would be fully guaranteed if its face value claim is less than what the country can repay; that is, its loss given default $\left(L G D_{E 1}\right)$ would be zero. Otherwise, the Eurosystem would take all the repayments, although it only owns $b$ percent of total outstanding.

$$
\begin{aligned}
L G D_{E 1} & =0, \quad \text { if } b \leq(1-L G D) ; \\
& =1-(1-L G D) / b, \quad \text { otherwise. }
\end{aligned}
$$

The Eurosystem's holding is theoretically valued at $V_{E 1}$ by using the $L G D$ that the Eurosystem faces:

$$
V_{E 1}=\left(1-P D \times L G D_{E 1}\right) \times b \times F \text {. }
$$

And the shadow price that the Eurosystem faces is

$$
q_{E 1}=1-P D \times L G D_{E 1}
$$

The price that the private sector pays is now changed to the ratio of its valuation to the face value of the bonds that it possesses,

$$
q_{P 1}=V_{P 1} /(1-b) F
$$




\section{REFERENCES}

Bilal, Mohsan, and M. Singh. 2012. "CDS Spreads in European Periphery: Some Technical Issues to Consider." Working Paper 12/77, International Monetary Fund, Washington, DC.

European Commission (EC). 2011. "Technical Details of a Possible EU Framework for Bank Recovery and Resolution.” Directorate-General Internal Market and Services Working Document, Luxembourg.

. 2012. "Proposal for a Directive of the European Parliament and of the Council Establishing a Framework for the Recovery and Resolution of Credit Institutions and Investment Firms.” Luxembourg.

Garleanu, Nicolae, and Lasse Heje Pedersen. 2011. "Margin-Based Asset Pricing and Deviations from the Law of One Price.” Review of Financial Studies 24 (6): 1980-2022.

Lin, Elaine, and Lawrence Mutkin. 2012. "SMP Subordination Is Overstated." European Interest Rate Strategist, April, Morgan Stanley.

MacKinlay, A. Craig. 1997. "Event Studies in Economics and Finance.” Journal of Economic Literature 35 (March): $13-39$. 
This page intentionally left blank

CInternational Monetary Fund. Not for Redistribution 


\section{An Early Assessment of Quantitative Easing}

\section{S. Pelin Berkmen And AndReAs (Andy) Jobst}

The European Central Bank (ECB) has taken a series of easing steps since mid-2014, including a negative deposit facility rate and targeted longer-term refinancing operations to support new lending. In September 2014 the ECB announced a private asset purchase program comprising asset-backed securities and covered bonds and began purchases in the fourth quarter of 2014 to directly lower private borrowing costs. While private asset purchases have had a significant price impact, they fell short of reversing the contraction of the ECB's balance sheet and the trend decline in inflation expectations.

In January 2015 the ECB announced the addition of sovereign assets to its asset purchase programs (Annex 6.1). The expanded asset purchase program is effectively open-ended and is larger than expected (i.e., purchases are intended to be carried out until end-September 2016, and will in any case be conducted until the ECB sees a sustained adjustment in the path of inflation consistent with its objective). The scale of additional sovereign asset purchases (about $€ 840$ billion in market value terms $)^{1}$ under the public sector asset purchase program (PSPP) signaled a substantial expansion of the ECB's balance sheet. This underscored the ECB's commitment to meet its price stability mandate and helped anchor inflation expectations. Since the start of sovereign quantitative easing $(\mathrm{QE})^{2}$ in March 2015, the ECB has expanded its balance sheet by 18 percent (as of end July 2015). Combined purchases of public sector securities, covered bonds, and asset-backed securities under the asset purchase program amount to $€ 324$ billion, with the split heavily skewed toward sovereign assets (€216 billion).

The ECB also took steps to strengthen transparency and communications. Starting in 2014 it extended its staff projection horizon by one year to better guide market expectations and began publishing accounts of monetary policy meetings. This, with the ECB's regular press conferences after monetary policy meetings, has increased transparency regarding the Governing Council's view. In March 2015, the Governing Council clarified its intention to continue the purchases until it sees a sustained adjustment in the path of inflation and at least until September 2016; and to concentrate on trends in inflation, looking through transient factors that do not affect the medium-term inflation outlook. In June the Governing Council reiterated the importance of fully implementing QE and was unanimous in its intent to "look through" the recent bond market volatility, unless financial conditions endanger medium-term price stability.

\footnotetext{
This chapter is based on Euro Area Policies: 2015 Article IV Consultation-Selected Issues, IMF Country Report 15/183, 2015. Research support was provided by Jesse Siminitz.

${ }^{1}$ This implies a lower nominal volume of asset purchases if bonds trade above par value on average.

${ }^{2} \mathrm{QE}$ is the commonly used term to describe the ECB's expanded asset purchase program (APP). APP includes the purchase of public sector securities issued by euro area governments, agencies, and supra-national organizations, in addition to pre-existing programs to purchase private asset-backed securities and covered bonds. Public sector-issued securities make up the bulk of APP purchases (more than 80 percent) and constitute more than two-thirds of asset holdings under QE (as of mid-July).
} 


\section{Change of Key Indicators Relative to Pre-Jackson Hole ${ }^{1}$ (Standard deviations)}

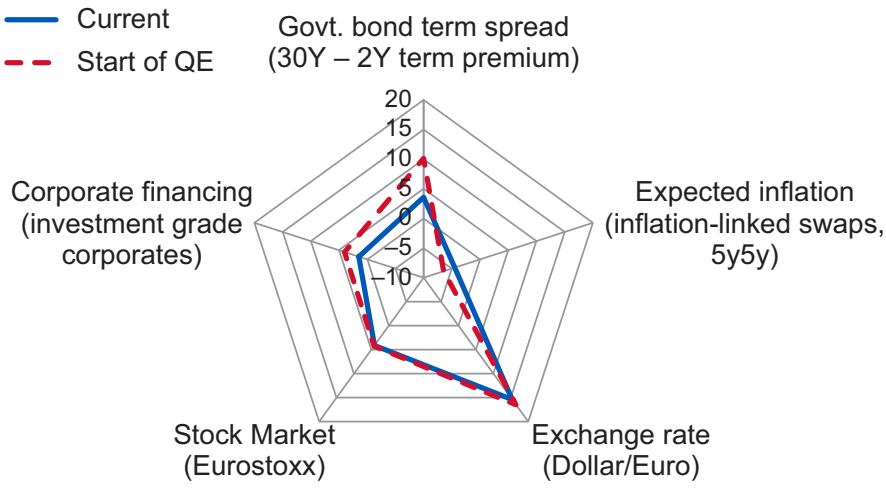

2. Change of Key Indicators Relative to Pre-QE Announcement ${ }^{2}$ (Standard deviations)

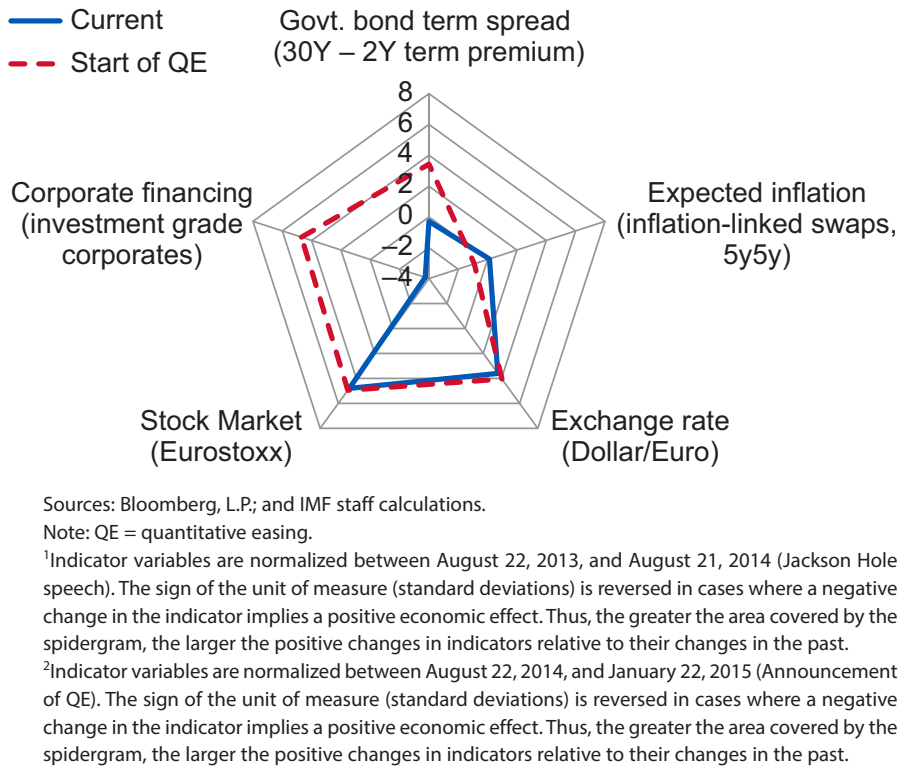

Figure 6.1 Monitoring the Aggregate Effect of Sovereign QE on the Financial Sector, as of July 13, 2015

This chapter assesses the effectiveness and implementation of quantitative easing to date. It explores the various transmission channels and their impact on macrofinancial conditions and examines the design and implementation of asset purchases and their influence on the effectiveness of QE. The chapter concludes with policy recommendations.

\section{QE'S TRANSMISSION CHANNELS AND INITIAL ASSESSMENT}

The ECB's QE had an immediate impact on financial conditions and expectations (Figure 6.1 and Figure 6.2). The initial market impact was stronger and broader than expected, lower term spreads across the euro area (portfolio rebalancing and signaling channels), with higher inflation 


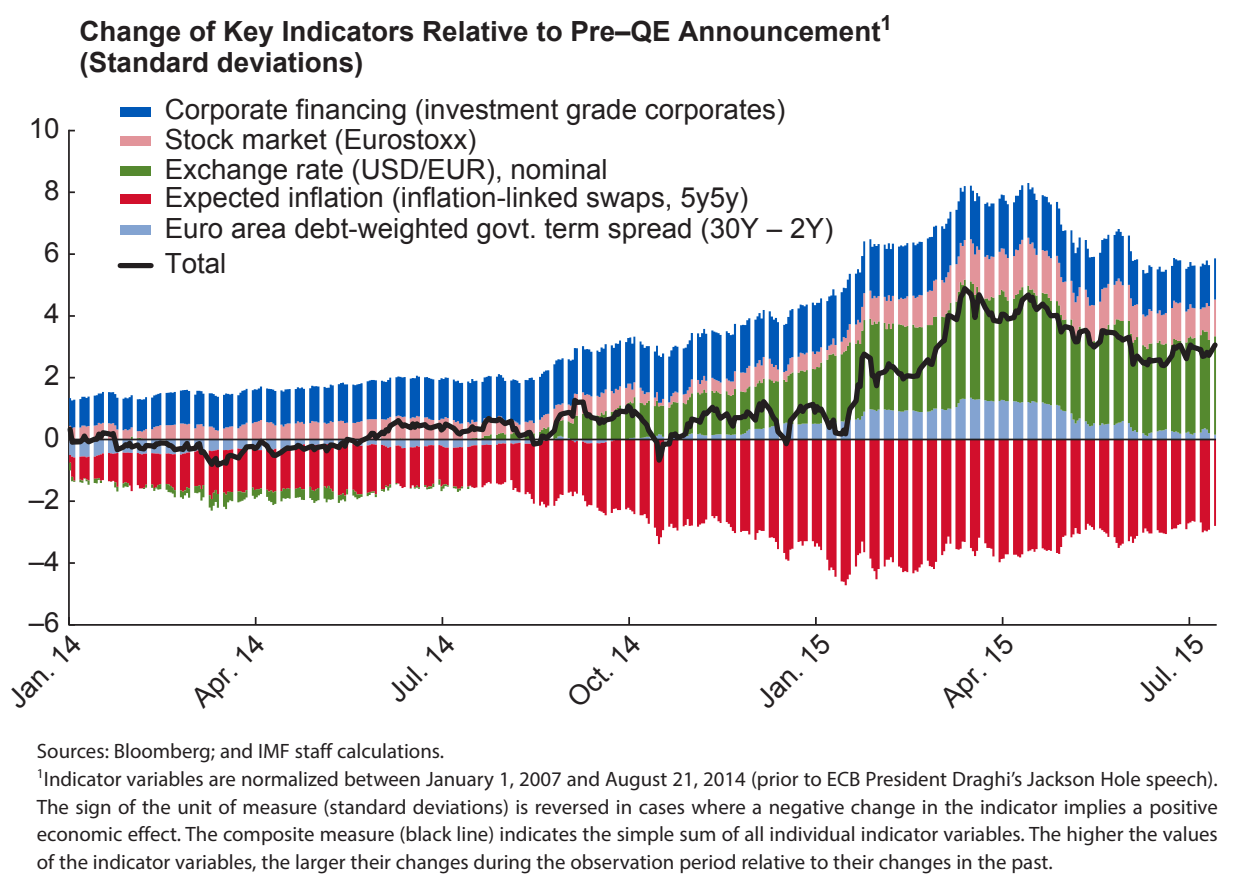

Figure 6.2 Composite Aggregate Effect of Sovereign QE

expectations (expectations channel), a weaker euro (exchange rate channel), higher equity prices (asset price channel), an improvement in consumer and business confidence (broader confidence channel), and easier lending conditions (credit channel) (Figure 6.3). While the surge in bond market volatility since April 21, 2015, has unwound some earlier gains in asset prices, financial conditions are still easier than before (Kapetanios and others 2012).

The full impact on the real economy will take time to materialize. International experience with QE suggests that peak effects on growth could take between two to eight quarters, and from three to 16 quarters for inflation (IMF 2013a and 2013b). Engen, Laubach, and Reifschneider (2015) estimate that the response of unemployment and inflation to the Federal Reserve's QE policies since early 2009 is expected to peak only in 2015 and 2016, respectively. In particular, as the IMF's April 2015 Global Financial Stability Report noted, a credit recovery typically takes more time, especially if banks' asset quality is still weak.

\section{Portfolio Rebalancing and Signaling}

Despite recent market corrections, term spreads remain low in selected countries-including Ireland, Italy, Portugal, and Spain — and in the euro area as a whole. Term spreads in core countries, however, have reverted to near their levels since the ECB announced its private asset purchase program in September 2014. Initial declines were sizable across the board (Figure 6.4), particularly given already low yields (relative to those of the United States and United Kingdom government bonds) (Banarjee 2012; Glick and Leduc 2013) (Figure 6.5). Given the price cap on negative rates, purchases initially focused on the longer end, ${ }^{3}$ which strengthened the decline in term spreads. This decline reflected a combination of factors, including expected short-term

\footnotetext{
${ }^{3}$ The size-weighted average maturity of Eurosystem holdings under the PSPP was 8.1 years after three months of purchases (as of end-June 2015).
} 
The start of sovereign QE in March 2015 reversed the contraction of the Eurosystem's balance sheet...

1. Eurosystem Funding to Banks and Securities Holdings ${ }^{1}$ (EUR billion)

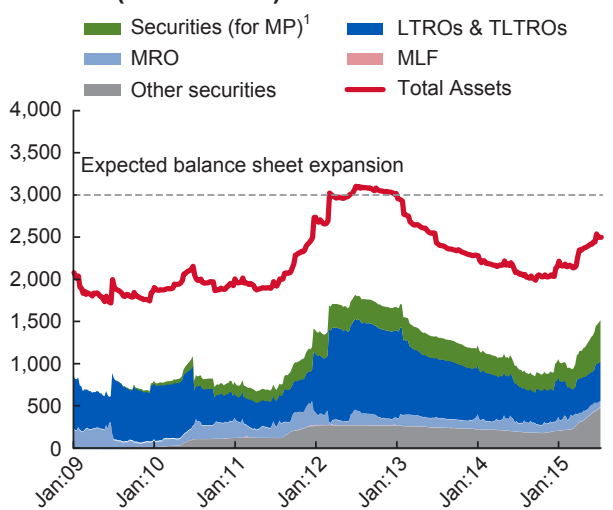

After six weeks, cumulative purchases under sovereign QE surpassed the total amount of private asset purchases over six months.

3. ECB APP: Recent Asset Purchase Programs $^{2}$

(EUR billion, cumulative)

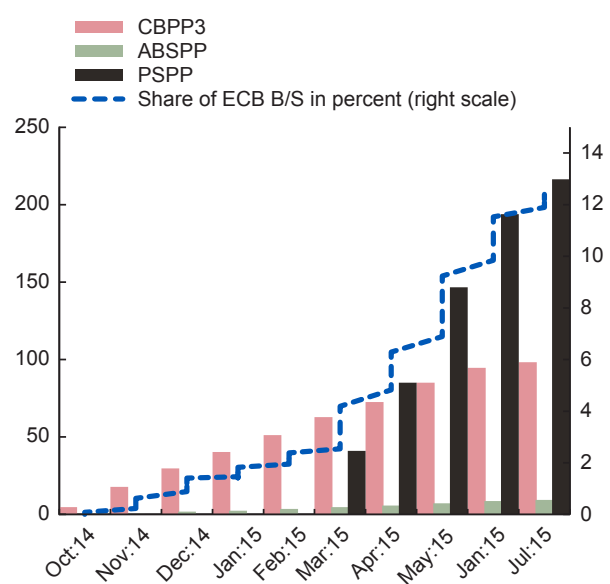

... after a successful implementation of two private asset purchase programs of covered bonds and asset-backed securities.

\section{ECB Asset Purchase Programs ${ }^{1}$} (EUR billion)

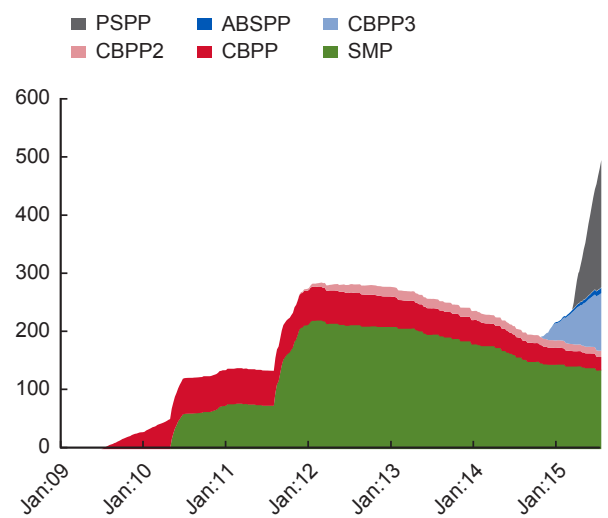

Sovereign QE added further momentum to improved liquidity conditions.

\section{ECB: Excess Liquidity and Base Money ${ }^{3}$} (EUR billion)

EONIA 1-week (percent, left scale)

Excess liquidity (abs. change, y-o-y)

M1 (abs. change, y-o-y)

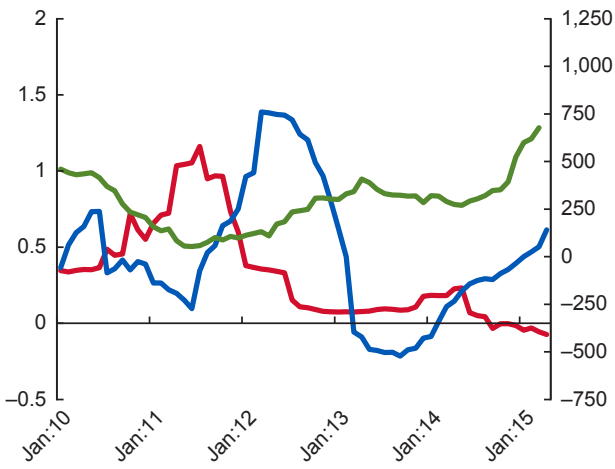

Figure 6.3 Monitoring Sovereign Quantitative Easing—Scale of Purchases and Liquidity Conditions 
Sovereign QE has a large impact on aggregate liquidity due to a low encumbrance of government debt securities.

\section{Collateral Utilization for ECB Repo, 2007-14 \\ (Percent, left scale; EUR billion, right scale)}

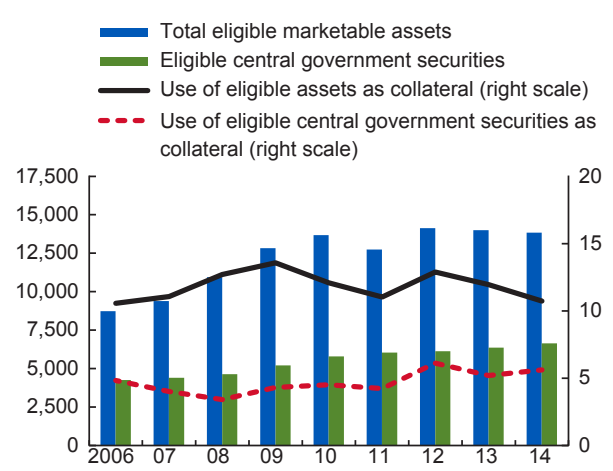

The implicit price cap for asset purchases (via the prevailing rate of the deposit facility) reduces the eligible amount of outstanding euro area government debt by about 7 percent (or €313 billion).

\section{Euro Area: Sovereign Debt with Negative Yields as of July 6, 2015 \\ (Percent)}

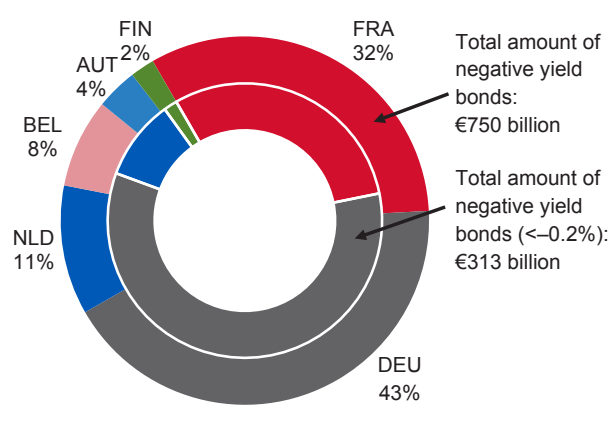

Sources: Bloomberg, L.P.; Eurostat; ICAP; Markit; and IMF staff calculations.

Note: $A B S P P=$ asset-backed securities purchase program; $A P P=$ asset purchase program; $B / S=$ balance sheet; $C B P P=$ covered bond purchase program; $E C B=$ European Central Bank; EONIA = Euro OverNight Index Average; $L$ TRO = Long-Term Refinancing Operation; $M L F=$ margin lending facility; $\mathrm{MP}=$ monetary policy; $\mathrm{MRO}=$ main refinancing operations; $\mathrm{PSPP}=$ public sector purchase program; $\mathrm{QE}=$ quantitative easing; SMP = securities market program; TLTRO = targeted longer-term refinancing operations. Data labels in panel 6 use International Organization for Standardization (ISO) country codes.

${ }^{1}$ Securities held for monetary policy purposes (SMP, CBPPs, ABSPP, and PSPP).

${ }^{2}$ Securities held for monetary policy purposes (without SMP and other CBPPs).

${ }^{3}$ Excess liquidity $=$ current account + overnight deposits - minimum reserve requirement - MLF.

Figure 6.3 (Continued)

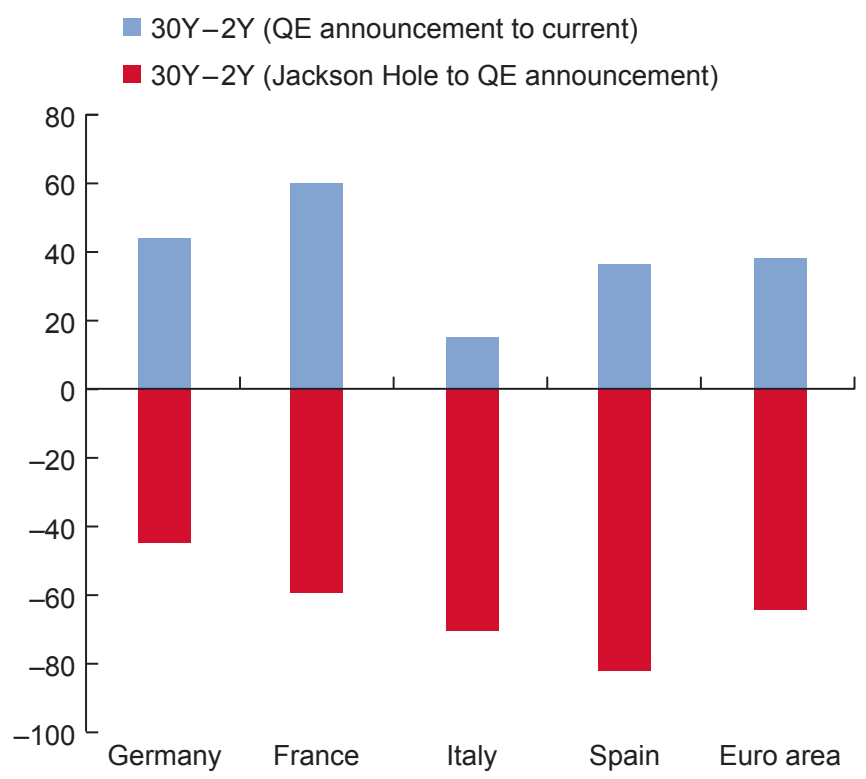

Sources: Bloomberg, L.P.; and IMF staff calculations.

Note: $\mathrm{AAA}=$ euro area countries with triple-A credit ratings; $\mathrm{EA}=$ euro area; $\mathrm{QE}=$ quantitative easing.

Figure 6.4 Change in Term Spread (Basis points) 


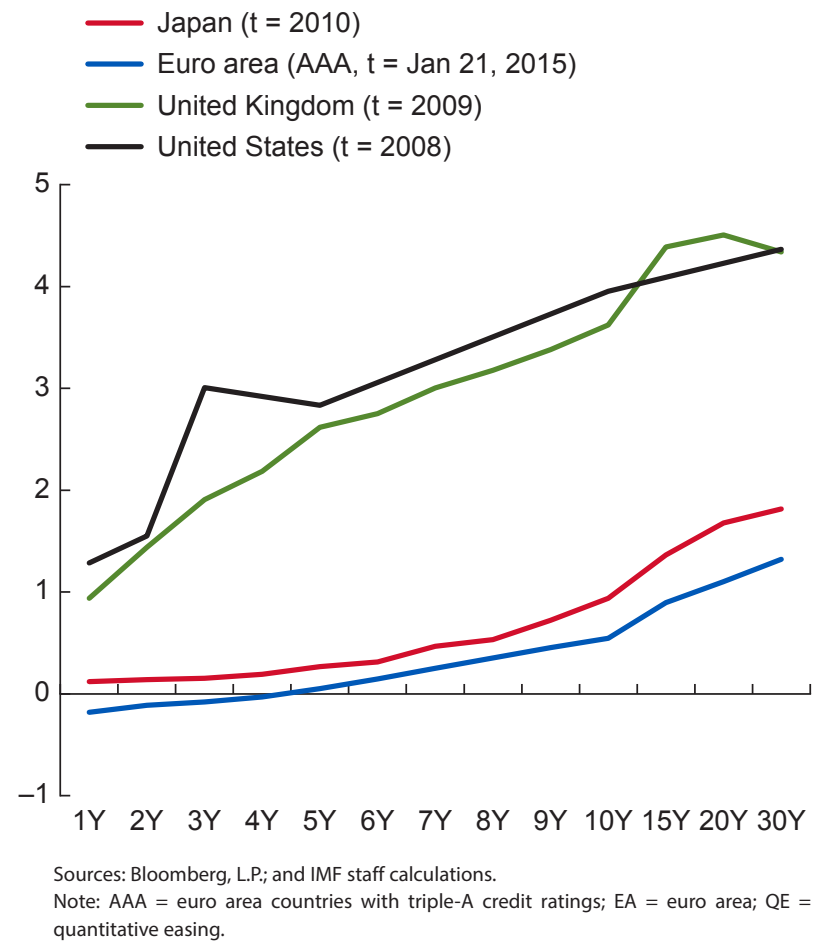

Figure 6.5 Sovereign Yield Curves (Percent, last day of month preceding the start of $Q E$ )

interest rates (signaling) and term premiums (as a result of both the duration and scarcity effects, given the long maturity of purchases).

QE has also successfully signaled lower expected short-term interest rates (Christensen and Rudebusch 2012; Krishnamurthy and Vissing-Jorgensen 2011). The announced program was larger than expected and practically open-ended, signaling the ECB's willingness to keep monetary policy accommodative until price stability is achieved. This has strengthened forward guidance and pushed short-term interest rates deeply into negative territory for maturities up to three years (Figure 6.5. and Figure 6.6).

Looking ahead, portfolio rebalancing in Europe will likely depend on the reaction of different types of sellers (Figure 6.7). As of mid-2014, domestic private sector investors in the euro area held about 40 percent of their own government's debt securities, compared to about 60 percent in the United Kingdom and the United States and about 82 percent in Japan at the start of their QE episodes (Benford and others 2009; Joyce, Tong, and Woods 2011; Saito, Hogen, and Nishiguchi 2014). There is wide variation across countries in Europe, with domestic residents holding about 25-30 percent of their own bonds in France and Germany, and about 60 percent in Italy and Spain. The euro area aggregation, however, treats intra-euro area holdings as foreign investment. After controlling for cross-country holdings within the euro area, non-euro area private sector investors held about 9 percent of the total, while other central banks account for most of non-euro area holdings (see Figure 6.23, panel 5). Several factors could prompt these players to change their portfolios:

- Global reserve management changes could generate large flows-Since the global financial crisis, the euro's share in global reserves has been declining (22 percent in 2014). If negative rates prompt central banks and the private sector to further reduce their euro allocations, this could lead to additional euro weakening (Figure 6.8). 
Term spreads narrowed sharply...

\section{AAA Euro Area Term Spread (Basis points)}

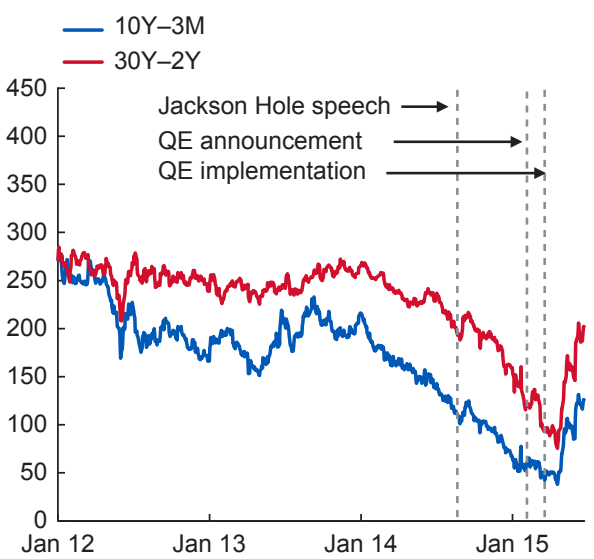

The risk of an unexpected increase in policy rates has significantly declined.

\section{Major Reserve Currencies: Carry-to- Risk Ratio ${ }^{1}$ \\ (10Y-3M Govt. Yields)}

Difference (US minus EA)

- EA

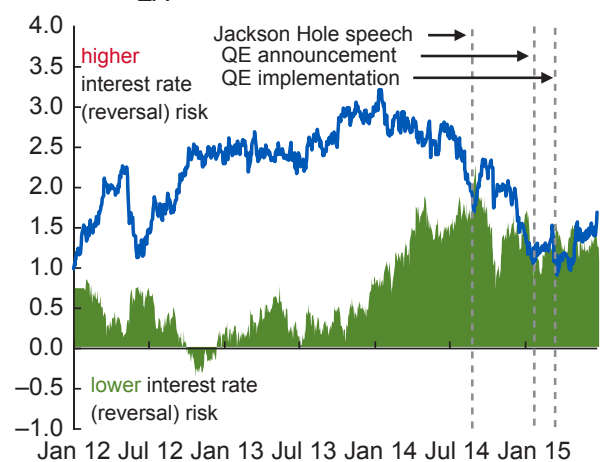

... partly reflecting a large decline in expected interest rates, which have slipped into negative territory even at relatively long horizons.

2. Euro OverNight Index Average (Effective yield in bps, since September 2014)

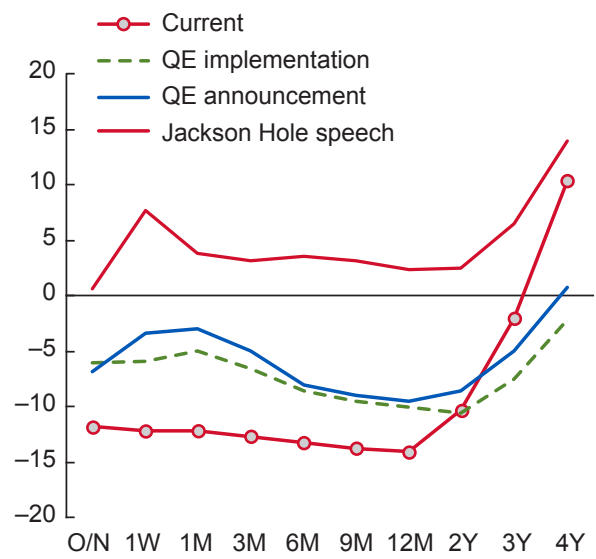

While it is too early to assess how these translate into portfolio rebalancing by the private sector, banks are already reducing their bond holdings.

4. Euro Area: Bank Holdings of Domestic Government Debt (Percent of total assets)

Core economies ${ }^{2}$

-.-- Selected economies ${ }^{3}$

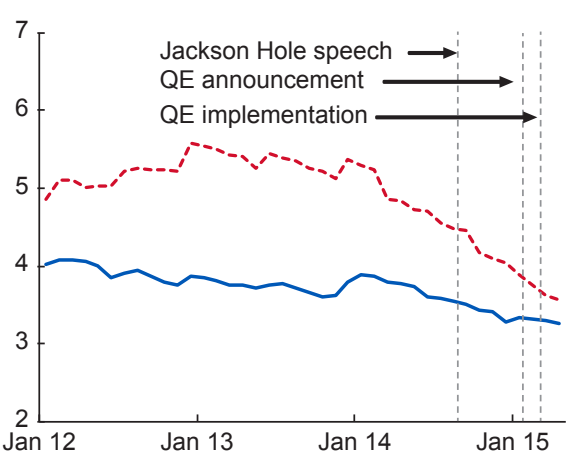

Sources: Bloomberg, L.P.; IMF 2013b; and IMF staff calculations.

Note: $\mathrm{AAA}=$ euro area countries with Triple-A sovereign credit rating; bps = basis points; $\mathrm{QE}=$ quantitative easing

${ }^{1}$ The carry-to-risk ratio is defined as the ratio of the spread difference between the 10-year and the 3-month risk-free rate (that is the term spread) to the implied volatility of the 3-month/10-year swaption; the lower the carry-to-risk ratio, the lower the risk of a reversal in the interest rate path towards monetary tightening.

${ }^{2}$ Core economies include Germany, France, and Netherlands

${ }^{3}$ Selected economies include Spain, Italy, and Portugal.

Figure 6.6 Portfolio Rebalancing and Signaling Effects 


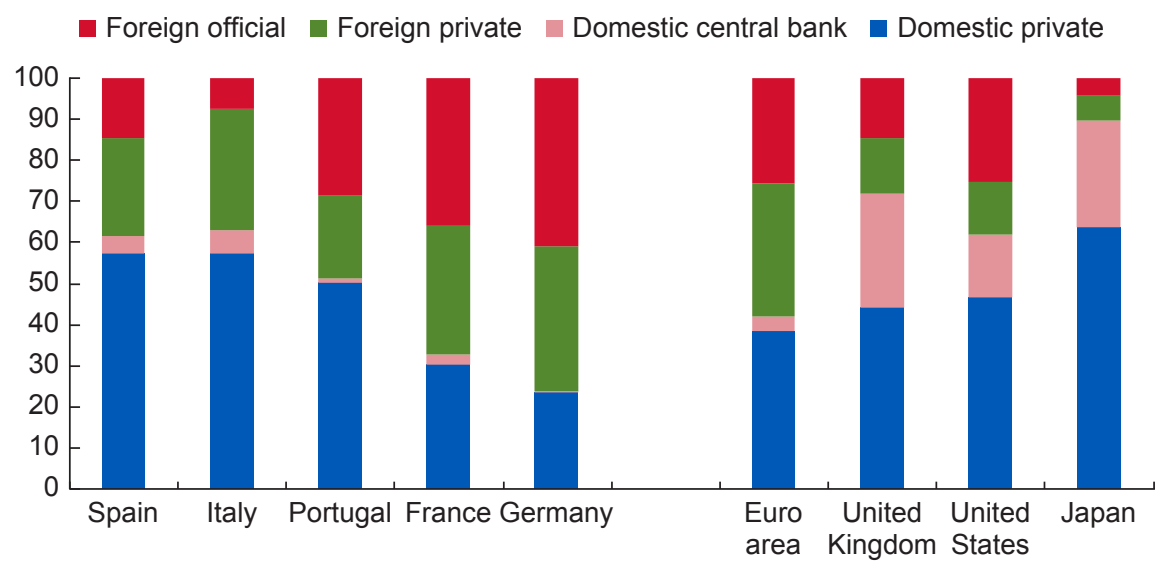

Source: Based on BIS data as of mid-2014 and using the methodology of Arslanalp and Tsuda (2012).

Figure 6.7 Investor Base of Euro-Area Government Debt Securities at the Start of QE Episodes (Percent of total)

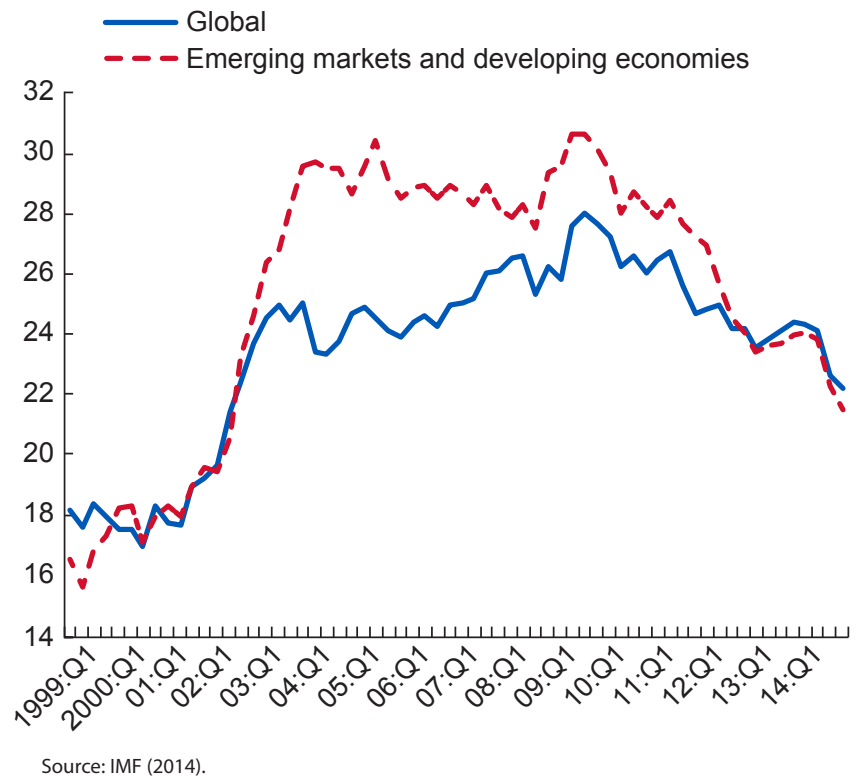

Figure 6.8 Euro Share in Foreign Exchange Reserves (Percent of all allocated reserves)

- Domestic nonbank resident holders, such as pension funds, mutual funds, and insurance companies, could diversify into foreign safe assets or other riskier domestic assets-Given statutory and regulatory requirements, European pension funds and insurance companies, which currently account for roughly 14 percent of total securities holdings, could opt for safe foreign assets (that is, U.S. government bonds), contributing to further weakening of the euro. Alternatively, a shift to riskier domestic assets would lower the private cost of borrowing.

- Since the beginning of 2015, euro area banks have sold about 4 percent of domestic government and other euro area government debt, accounting for roughly 16 percent of securities holdingsIf banks continue to sell, they could increase lending, as indicated by the ECB's April 2015 Bank Lending Survey, or find other investments (Figure 6.17). According to the survey, banks indicated that they have used the additional liquidity mainly for granting loans, 


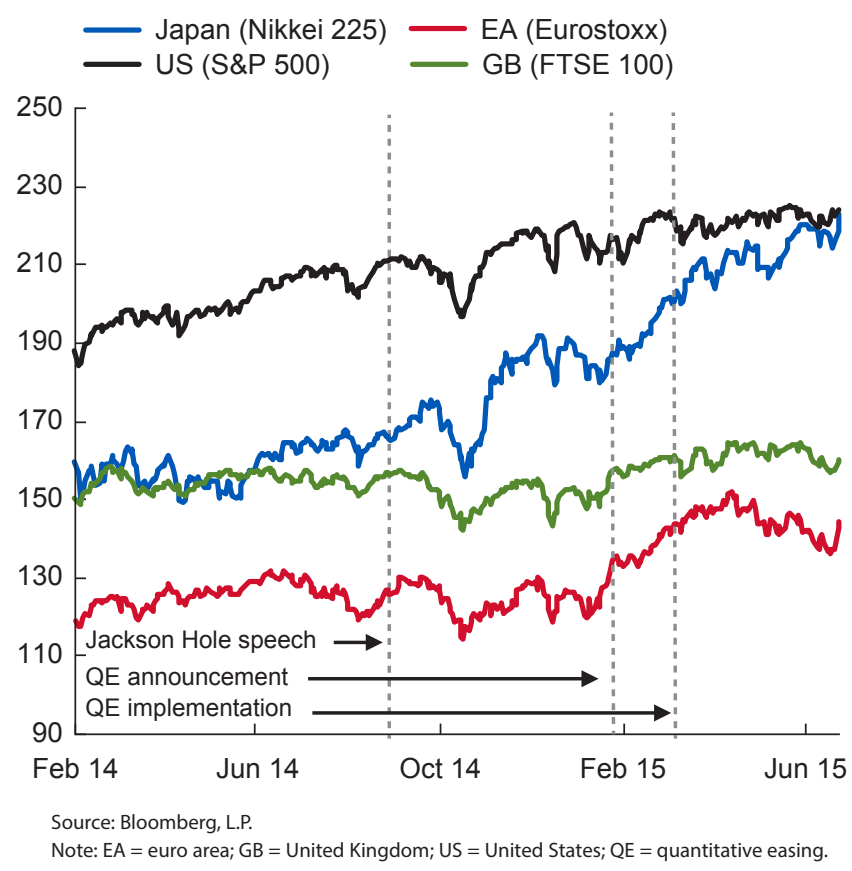

Figure 6.9 Stock Market Indices in Advanced Economies (Index, $2009=100)$

particularly to nonfinancial corporations and for refinancing both maturing debt and Eurosystem funding. Only a small percent of banks indicated that they have purchased other marketable assets. In both cases, this would comprise portfolio balancing toward greater risk taking, which would support growth and ultimately inflation.

\section{Asset Price Channel}

With the announcement of QE, European stock prices surged, catching up with other advanced economies (Figure 6.9). The initial surge, driven by declines in risk premiums and the weaker euro, was partly reversed, with inflows to equity markets slowing during the second quarter of 2015. Looking ahead, equity prices could rise further if QE generates higher inflation, confidence, and growth. In other QE episodes, equity prices continued to rise well after the QE launch, in some cases, more than doubled (Joyce and others 2011).

Higher asset prices support spending by boosting wealth and collateral values:

- Wealth effects - The generally low share of equity holdings by households is likely to limit the initial wealth effects stemming from higher stock prices (less so for households in Belgium and Germany given their larger holdings of bonds and equities) (Figure 6.10). The overall impact on consumption will also depend on house prices, with households in countries with higher real estate ownership rate (Spain, Portugal, Italy) benefiting more than core countries (Slacalek 2009). However, these wealth effects might be mitigated by cyclical weaknesses in the demand for housing and oversupply in some countries. Overall, empirical evidence suggests that while financial wealth effects are large, their impact on the economy is limited given their limited share in wealth (ECB 2013; Sousa 2009).

- Increased collateral values-Higher asset values mean lower leverage, stronger corporate balance sheets, and better assessment of credit risks by banks. Higher real estate prices would also increase collateral valuations, supporting the credit channel. 


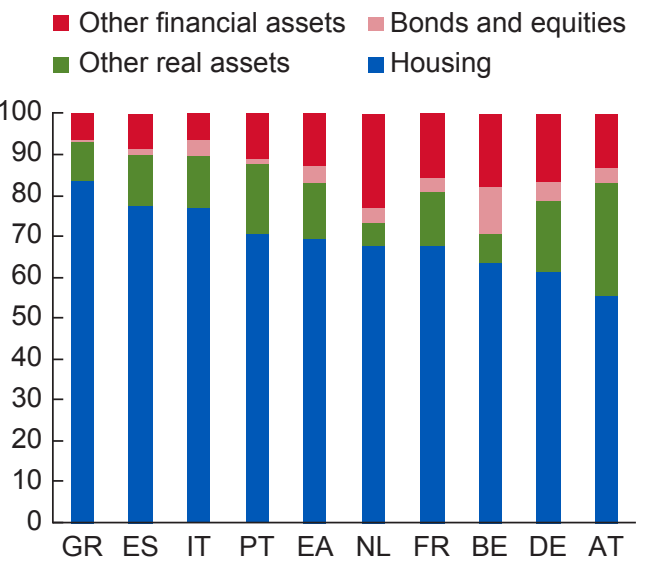

Source: ECB (2013)

Note: $\mathrm{EA}=$ euro area. Data labels in the figure use International Organization for Standardization (ISO) country codes.

Figure 6.10 Household Total Assets, 2013 (Percent of total assets)

— Dollar/Euro — Yen/Euro (right scale)

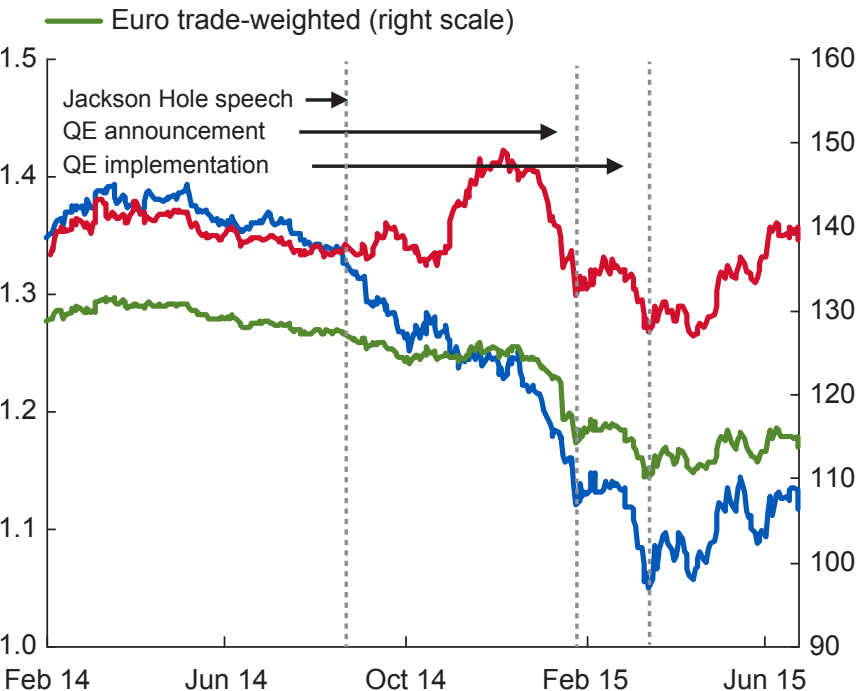

Source: Bloomberg, L.P.

Figure 6.11 Nominal Exchange Rates in Advanced Economies

\section{Exchange Rate Channel}

The euro has also depreciated substantially since mid-2014, despite recent corrections (Figures 6.11). As of May 2015, the euro has declined by 7 percent in nominal effective terms since September 2014. Factors affecting this include: (1) the divergent outlook for the monetary policy stance among advanced economies, (2) possible shifts to U.S. assets by European long-term investors in 


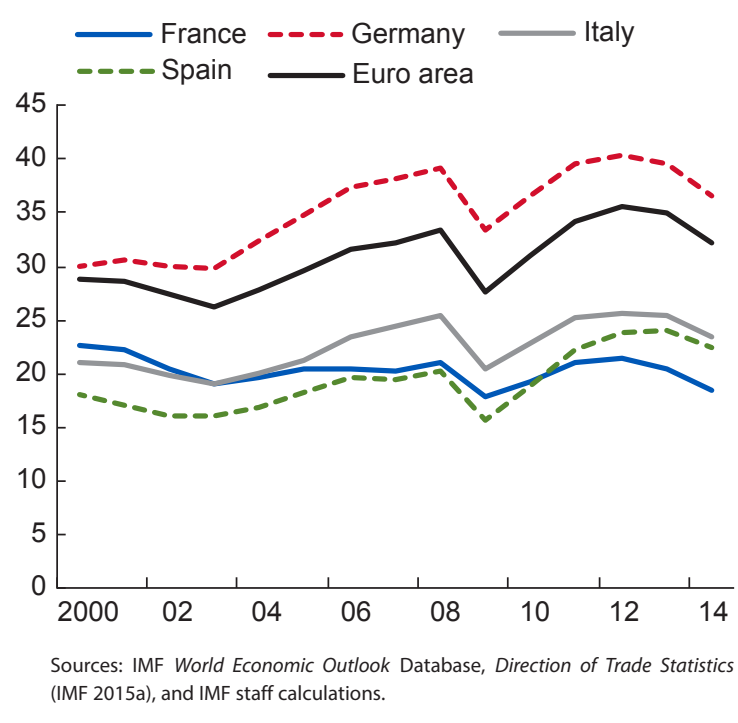

Figure 6.12 Openness Excluding Intra-Euro Area Trade (Percent GDP)

response to changing differences in real interest rates (possibly in combination with euro-funded carry trades), and (3) asset sales and shifts in reserve allocation away from the euro area. Overall, market expectations based on various indicators, including euro risk reversals, ${ }^{4}$ speculative positions, and correlation-weighted currency indices, suggest that the euro could weaken further.

A weaker euro will support exports and inflation but the impact will differ across the euro area (Figure 6.12). Broadly, the strength of the impact would depend on the degree of openness and trade elasticities. Excluding intra-euro area trade, exports and imports are about 30 percent of euro area GDP (similar to the United States and Japan, but lower than the United Kingdom). There is, however, cross-country heterogeneity, with Germany relatively more open than Italy, Spain, and France. On the other hand, according to the European Commission's estimates, elasticities of exports with respect to the exchange rate are higher for countries with negative external debt positions, such as Italy, Portugal, and Spain (European Commission 2015).

\section{Inflation Expectations and Confidence Channels}

Inflation expectations for all time horizons have improved (Figure 6.13). Before the announcement of QE on January 22, 2015, inflation expectations across the board were on a declining trend. With QE, the secular decline in inflation expectations has been reversed, and the inflation outlook has improved, with the distribution of the consensus forecast for 2016 inflation narrowing and shifting to the right. This is similar to the effect that QE has had elsewhere in anchoring inflation expectations. In the United States and the United Kingdom, QE was launched early on during the global financial crisis, helping keep inflation expectations anchored. In Japan, inflation expectations picked up only after the Bank of Japan's QE was combined with a comprehensive package of fiscal and structural policies (Figure 6.14).

Confidence has also improved (Figure 6.15). As expectations of QE intensified in late 2014 and oil prices fell, the decline in confidence indicators since early 2014 was reversed. These

\footnotetext{
${ }^{4}$ The risk reversal can be interpreted as the market view of the most likely direction of the spot exchange rate over a specific period of time. It is calculated as the difference between the implied volatility of out-of-the-money call options minus the implied volatility of out-of-the-money put options at the same distance to the strike price for a given maturity date.
} 


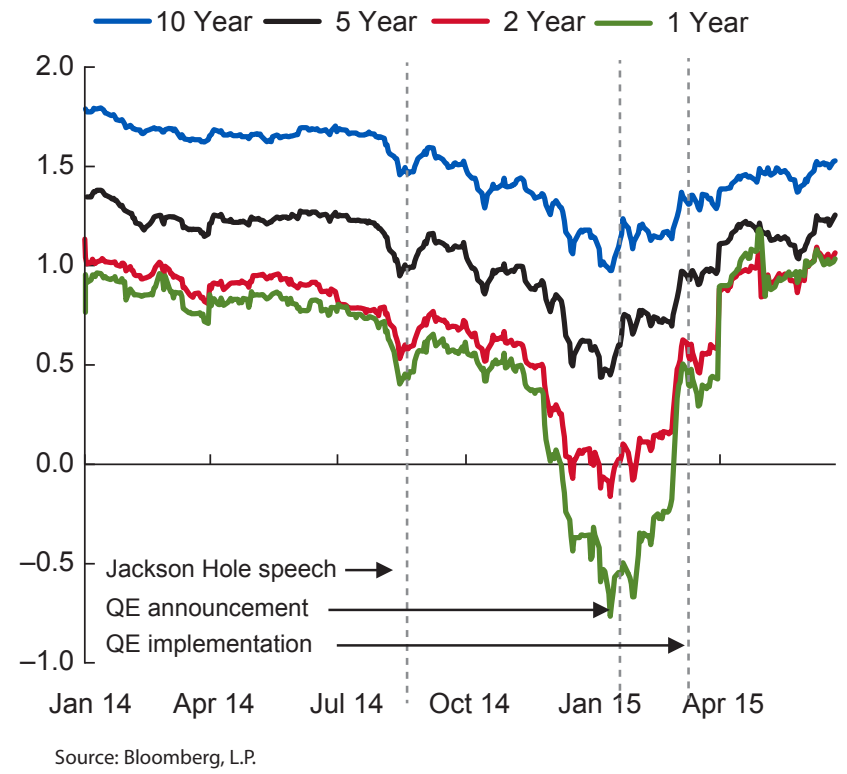

Figure 6.13 Inflation-Linked Swap Rates in Euro Area (Percent)

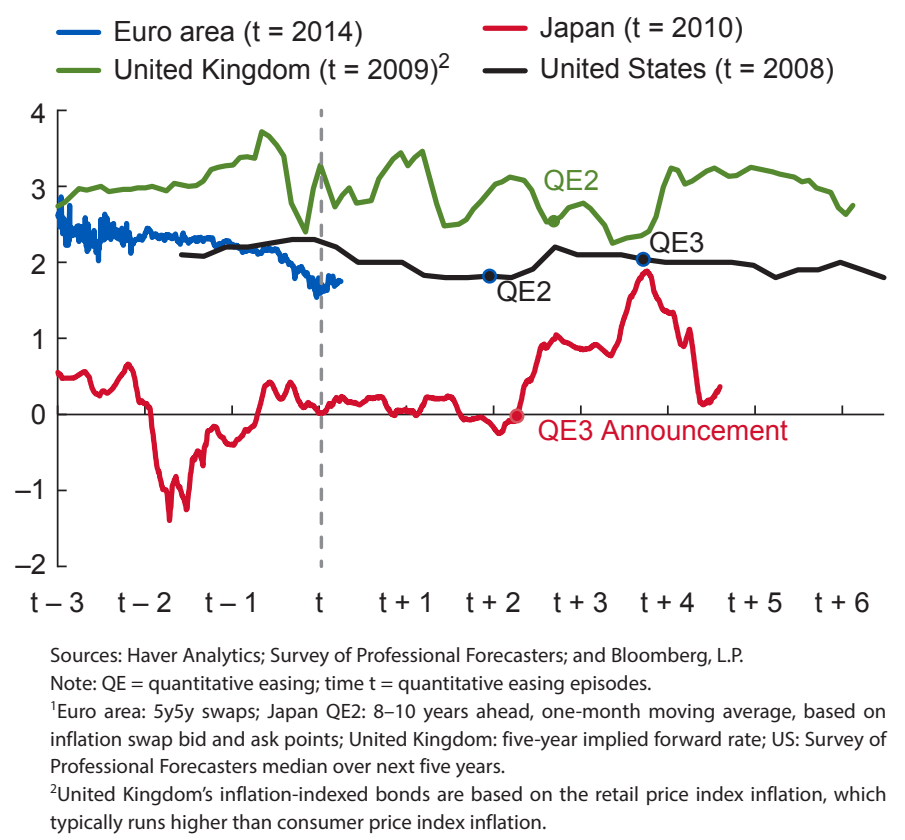

Figure 6.14 Medium- to Long-Term Inflation Expectations' (Percent, year-over-year inflation rates) 
With the introduction of QE, the trend decline in inflation expectations was reversed...

\section{Euro Area Inflation-Linked Swap Rates (Percent)}

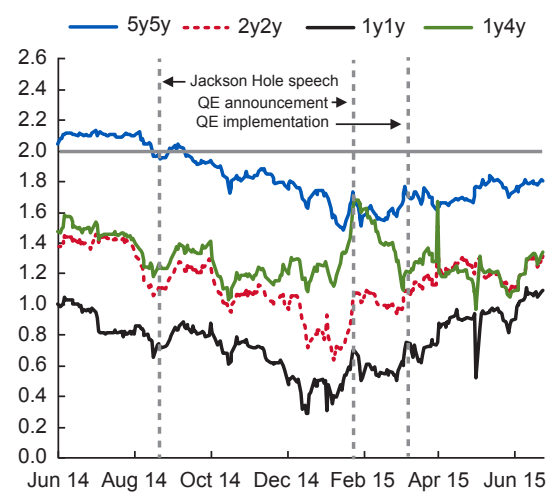

The distribution of inflation expectations has also tightened.

3. Euro Area Consensus Forecast Distribution of Inflation Expectations for 2016 (Percent)

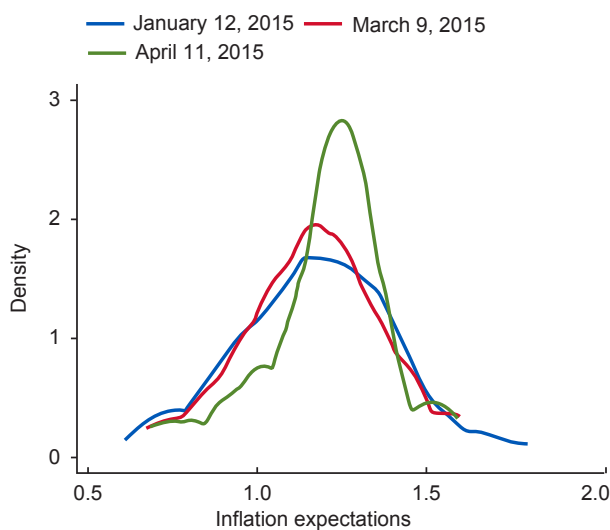

... which was captured by a wide range of measures, including survey-based ones.

\section{Euro Area Consensus Forecast Inflation Expectations (Percent, year-over-year)}

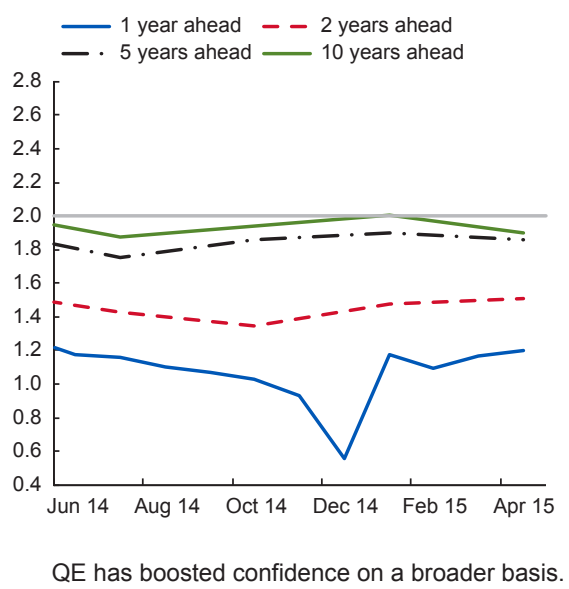

\section{Euro Area Confidence Indicators}

- Business confidence (ESI, long-term average $=100)$ -- - - Household confidence (percent balance, right scale)

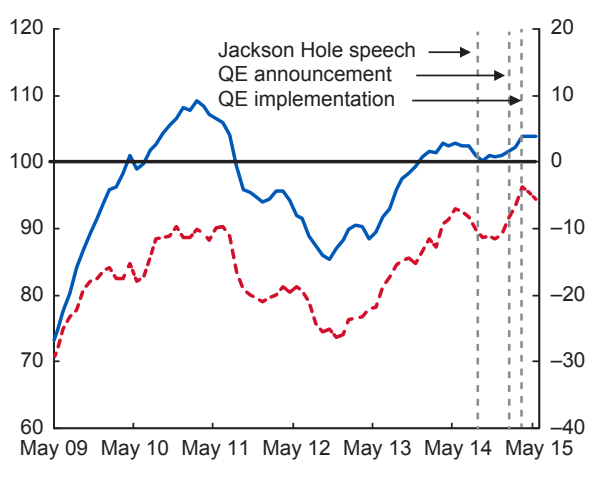

Figure 6.15 Inflation Expectations, Confidence, and Exchange Rate Effects (Continued) 
Following the increase real term spread with the United States...

\section{Real Term Spread Difference to the US} (Basis points)

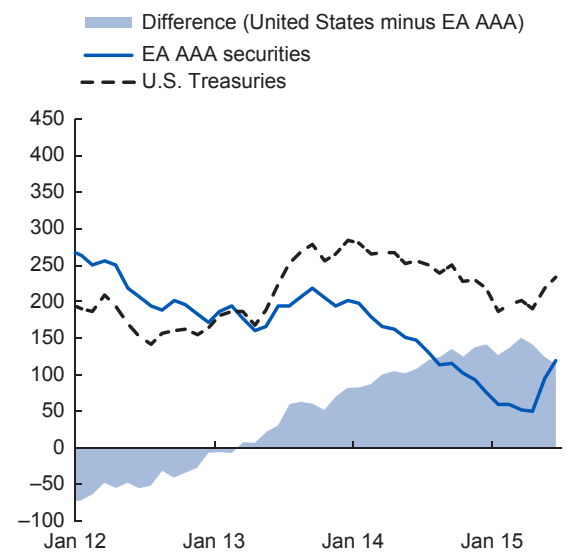

... the euro has weakened substantially, and markets expect it to remain weak

\section{Euro Risk Reversal and Speculative} Positions $^{1}$

_ Net speculative long position (percent of total, left scale)

_ 3-month risk reversal (right scale)

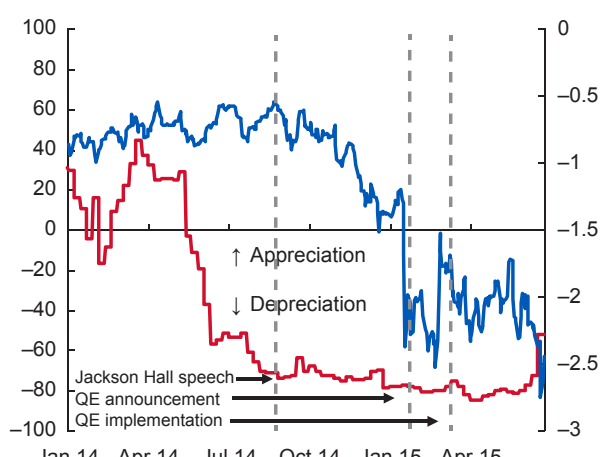

Jan 14 Apr 14 Jul 14 Oct 14 Jan 15 Apr 15

Sources: Bloomberg, L.P.; European Central Bank (ECB); Consensus Forecast; and IMF staff calculations.

Note: $\mathrm{ESI}=$ economic sentiment indicator; $\mathrm{QE}=$ quantitative easing.

${ }^{1}$ The risk reversal can be interpreted as the market view of the most likely direction of the spot exchange rate over a specific maturity date based on the skew in the demand for call options at high strike prices. It is calculated as the difference between the implied volatility of out-of-the-money call options minus the implied volatility of out-of-the-money put options at the same distance to the strike price for a given maturity date.

Figure 6.15 (Continued)

broader confidence effects could be quite powerful. For example, to the extent that QE leads to an improved economic outlook, it might release pent-up demand and bring forward spending, creating a positive feedback loop. Some of this more general improvement in confidence may also push up asset prices by reducing risk premiums.

\section{Credit Channel}

Financial conditions have improved, while fragmentation has declined. QE has reduced wholesale funding costs as portfolio rebalancing effects have led to a compression of bank bond yields (Figure 6.16 and Figure 6.18). The improvement in bank funding conditions since 2012 has recently translated into declines in deposit and lending rates. In particular, the dispersion between the core and selected countries has disappeared for deposit rates and shrunk considerably for lending rates. In addition, the divergence in deposit flows to banks has diminished, Target 2 imbalances have narrowed, and the decline in cross-border banking flows has slowed down. Nevertheless, it is still more expensive to borrow in selected countries, particularly in real terms, and deposit and bank flows have not recovered to precrisis levels.

Credit constraints have eased (Figure 6.16). Credit demand has picked up and the contraction of credit to the private sector has nearly ended. The ECB's asset purchases have led to an easing of credit standards and terms as banks expect a boost to profitability due to capital gains, according to the Bank Lending Survey in April 2015 (Figure 6.17). Furthermore, with declining corporate bond yields, overall borrowing costs for firms have also fallen. Nevertheless, low inflation continues to keep real rates high, affecting more indebted countries in particular.

With the euro area largely a bank-based economy, the credit channel has been the main transmission channel of monetary policy to the real economy. The euro area is not, however, exceptional in its bank financing. Both the United Kingdom and Japan have a very large share of financial intermediation through banks, but QE has worked there through a combination of channels. 
Credit is picking up . .

1. Euro Area Credit (Percent, year-over-year)

- - - Households — Nonfinancial corporations

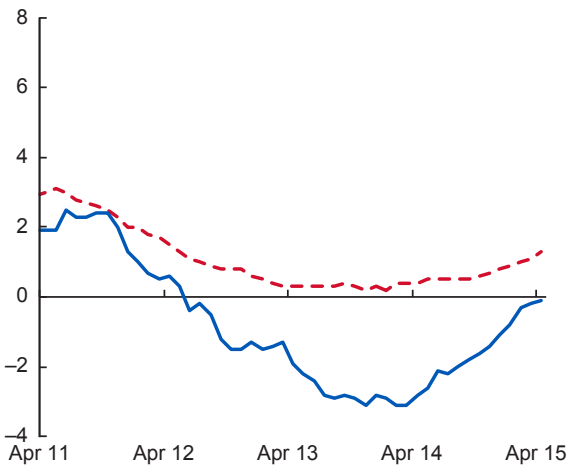

Bank lending standards are easing...

3. ECB Survey: Credit Standard to Private Sector (Percent balance in past $3 \mathrm{M}$, positive implies tightening)

- EA: Change in credit standards for business loans

- EA: Change in credit standards: approved house purchase loans

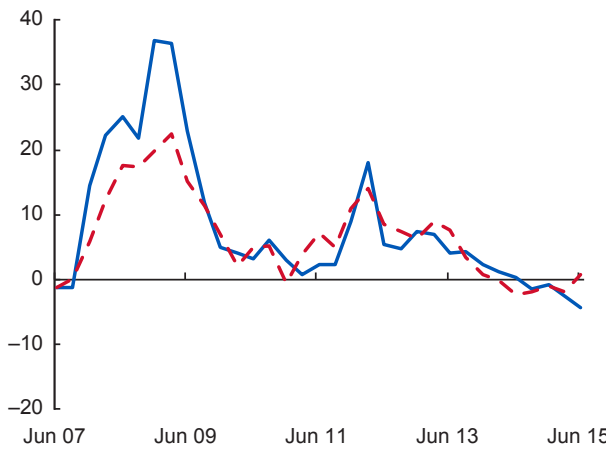

Lending rates across the board are declining . .

5. Nominal Lending Rates for Small Loans (Percent)
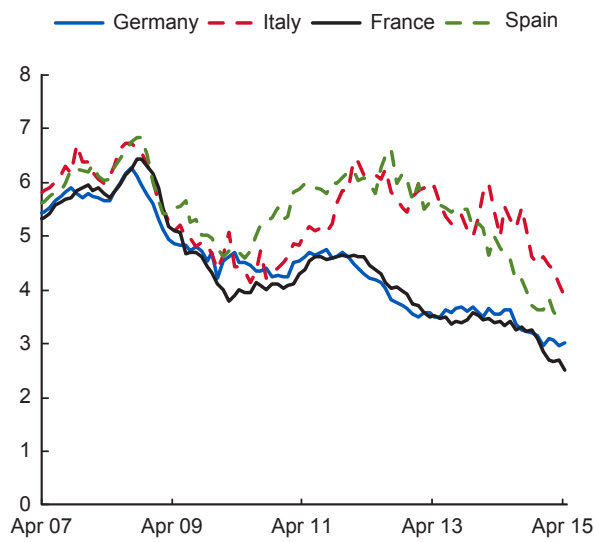

Sources: ECB; Haver Analytics; and IMF staff calculations. Note: $\mathrm{EA}=$ euro area; $\mathrm{ECB}=$ European Central Bank.

Figure 6.16 Credit Developments in Euro Area
... as accommodative monetary policy finally pass through to financial conditions.

\section{ECB Monetary Aggregates}

(Percent, year-over-year)

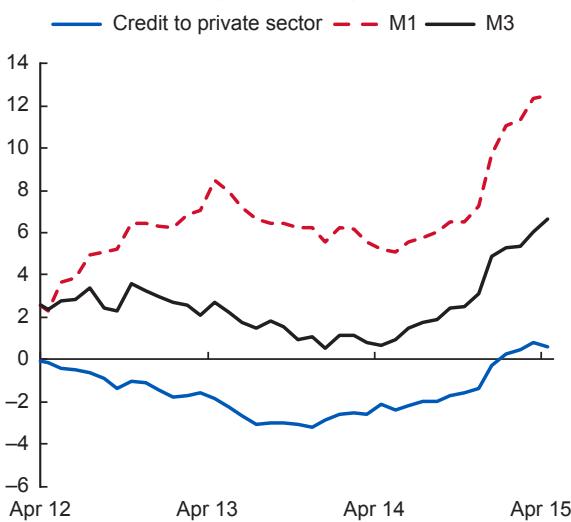

$\ldots$ and credit demand is picking up.

4. ECB Survey: Credit Demand from Private Sector (Percent balance in past $3 \mathrm{M}$, positive implies increase)

LA: Change in business loan demand

_ _ EA: Change in household demand for housing

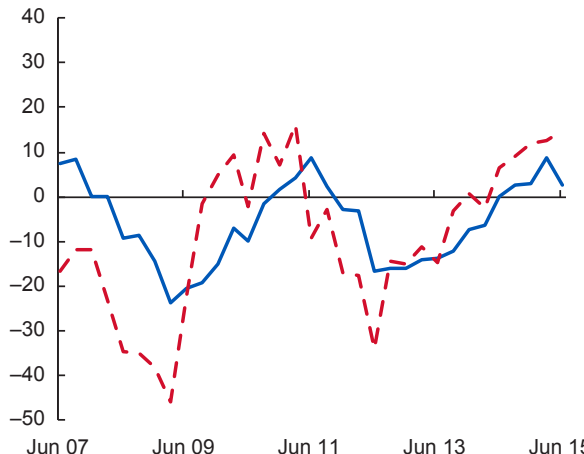

and the real cost of funding has also been declining.

6. Euro Area: Corporate Bond Yields (Basis points)

_ Investment grade corporates _ - High-yield corporates

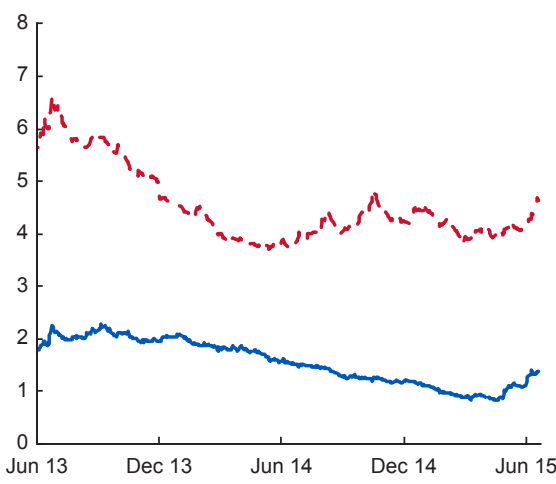




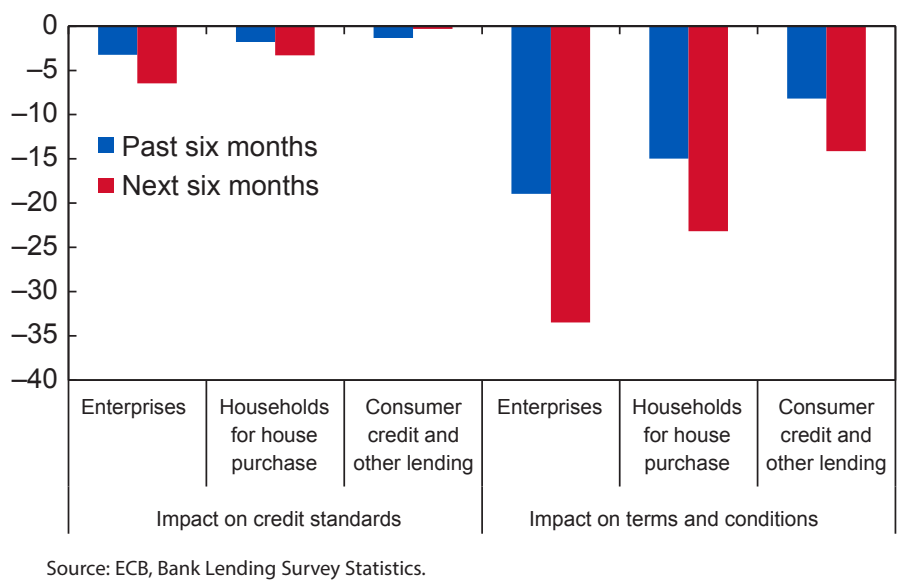

Figure 6.17 Impact of Expanded Asset Purchase Program on Bank Lending Conditions (Net percentage of respondents)

In addition to channels discussed earlier, the ECB's asset purchases support bank lending through lower lending rates, improved bank balance sheets and the corporate balance sheet channel through improved collateral values, higher expected growth, and lower leverage.

However, credit recoveries after QE typically take more time. In Japan in 2001 and the United States in 2008, credit picked up only two to three years after financial sector problems were dealt with. Even with sounder financial systems, credit could still respond slowly (for example, Japan in 2010 and the United Kingdom in 2009), mainly due to weak investment demand (Figure 6.19).

In the euro area, high nonperforming loans (NPLs) remain an obstacle to a credit recovery (Figure 6.20). The ECB's Comprehensive Assessment, which concluded in October 2014, revealed high NPLs in several banking systems, with considerable variation among countries. High nonperforming loans result in lower profitability and tie up substantial amounts of capital that could otherwise be used for new lending (Aiyar and others, forthcoming). Rising asset prices and an improved outlook are likely to increase credit demand, including through higher collateral values and higher expected earnings, providing an opportunity for banks to restart lending. But weak bank balance sheets and the large private sector debt overhang will likely hold back investment.

\section{IMPLEMENTATION AND DESIGN OF ASSET PURCHASES}

\section{Addressing Potential Asset Scarcity}

The transmission channels of QE are also affected by the design and the implementation of asset purchases. These relate to (1) the scale and scope of the target market, (2) the willingness of different financial institutions to sell assets, and (3) the functioning of markets in distributing excess liquidity and market making.

The potential scarcity of sovereign bonds may pose challenges for implementation. Staff analysis (Table 6.1 and Figure 6.21) suggests that based on current trends, some national central banks (NCBs) might have difficulty meeting their target purchases due to the combined effect of the price cap on purchases (that is, no purchase of securities with a yield less than the deposit rate of 0.2 percent), a shrinking net supply of government debt, and purchases of longer-dated debt securities held predominantly by long-term investors that are less inclined to sell. More specifically, the following factors could raise challenges for meeting the target volumes: 
Banks are issuing bonds at very low rates.

\section{Bank Bond Issuance (Percent)}

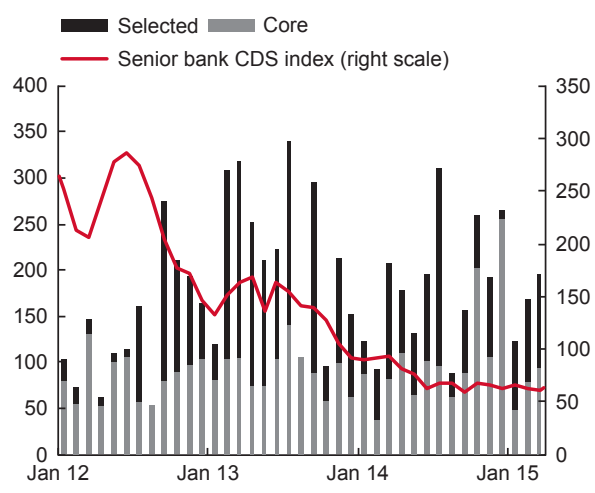

The dispersion in deposit rates has disappeared.

2. Euro Area Deposit Rates (Percent)

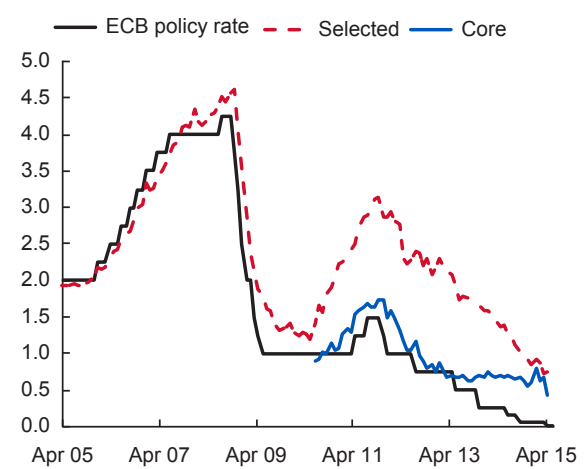

Deposit flows to selected countries picked up, but still remain lower than in the core.

Target 2 imbalances have been improving steadily, but they still remain high relative to precrisis.

3. Cumulative Deposit Flows Since 2008 (Households and nonfinancial corporations, EUR billion)

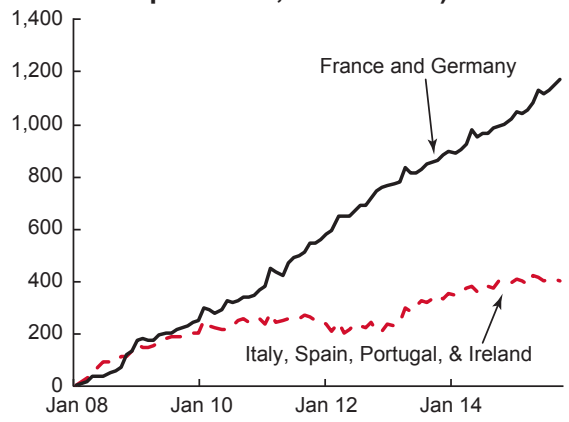

Fragmentation on the lending side also declined substantially with lending rates converging.

\section{Euro Area Nominal Corporate Lending Rates (Percent)}

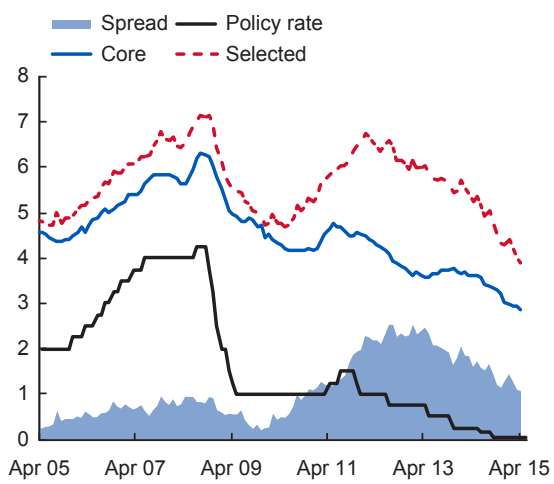

\section{Target 2 Balance (EUR billion)}

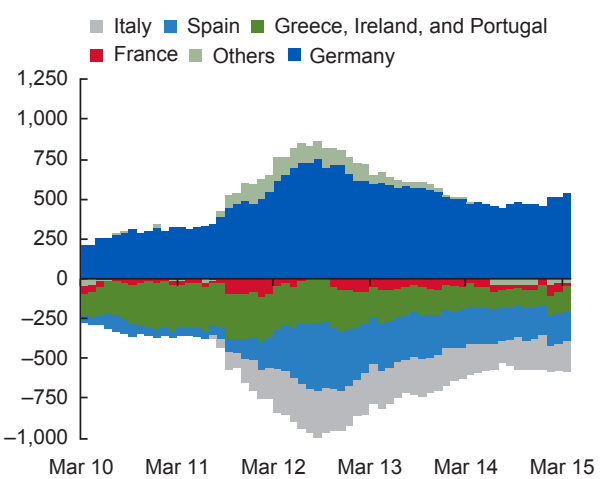

Differences in real lending rates also declined, but mainly because of the increase in the core due to lower inflation.

\section{Euro Area Real Lending Rates (Percent, deflated by CPIs)}

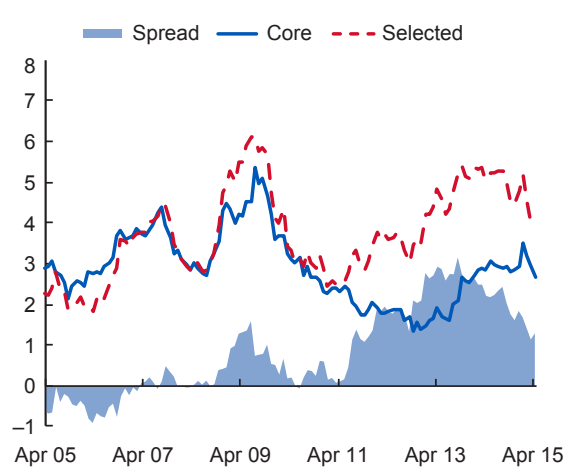

Sources: Haver Analytics; Dealogic; Eurostat; ECB; and IMF staff calculations.

Note: $\mathrm{CDS}$ = credit default swap; $\mathrm{CPI}$ = consumer price index; $\mathrm{ECB}=$ European Central Bank. Core countries include Germany, France, and the Netherlands; selected countries include Spain, Italy, and Portugal.

Figure 6.18 Financial Fragmentation 
— United Kingdom $(\mathrm{t}=2009)$ - United States $(\mathrm{t}=2008)$

— Japan $(\mathrm{t}=2001)$ - - - Japan $(\mathrm{t}=2010)$

- Euro area $(\mathrm{t}=2014)$

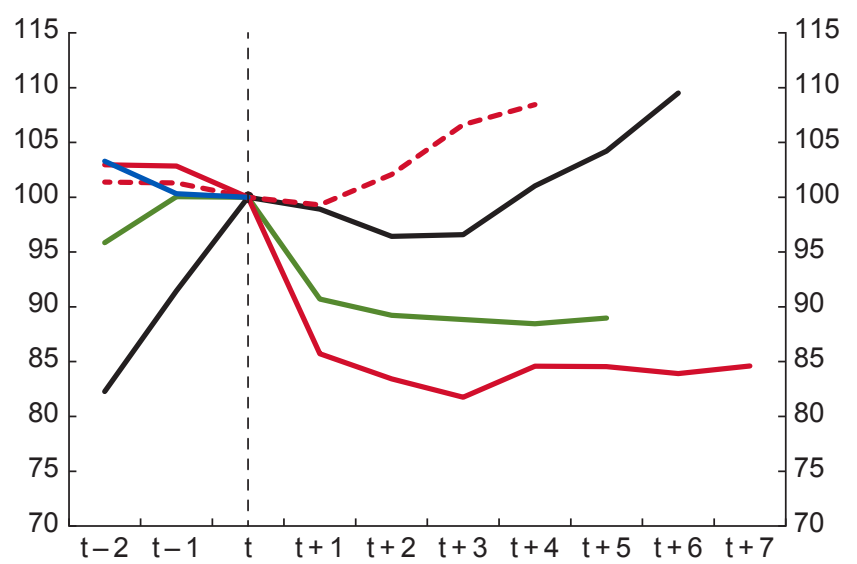

Sources: Haver Analytics; IMF, World Economic Outlook database; and World Bank, World Development Indicators.

Note: United States—Commercial bank credit to the private sector; Japan-Domestic monetary and financial institutions credit to the private sector; Euro area-Monetary and financial institutions loans to private sector; United Kingdom - M4 monetary and financial institutions sterling net lending to private nonfinancial corporations and households.

Figure 6.19 Loans to Private Sector in Advanced Economies (Indexed to time $t=$ start of $Q$ E episodes)

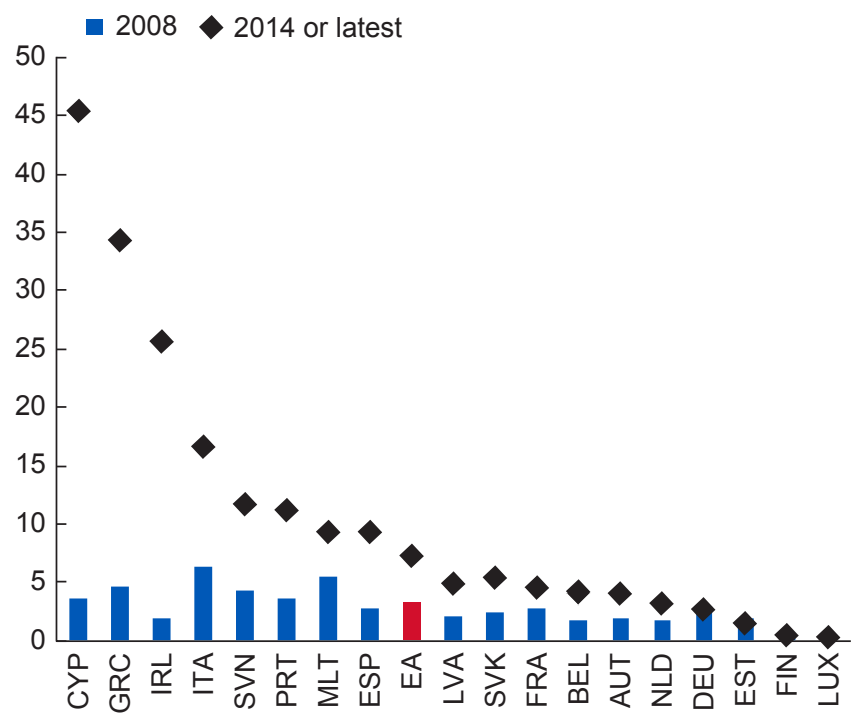

Source: IMF, Financial Soundness Indicators.

Note: $\mathrm{EU}=$ euro area. Data labels in the figure use International Organization for Standardization (ISO) country codes.

Figure 6.20 Nonperforming Loans in the Euro Area (Percent of total loans) 
TABLE 6.1

\begin{tabular}{|c|c|c|c|c|c|c|c|c|c|c|c|}
\hline \multirow[b]{3}{*}{ Country } & \multirow[b]{3}{*}{$\begin{array}{c}\text { ECB Target } \\
\text { Purchase Amount } \\
\text { (market value) }\end{array}$} & \multirow[b]{3}{*}{$\begin{array}{l}\text { Implied ECB } \\
\text { Target Purchase } \\
\text { Amount }^{1}\end{array}$} & \multicolumn{6}{|c|}{ Government and Agency Debt Securities } & \multirow{2}{*}{\multicolumn{2}{|c|}{$\begin{array}{c}\text { Supranational Debt } \\
\text { (potential) }\end{array}$}} & \multirow[b]{3}{*}{$\begin{array}{c}\text { Total } \\
\text { Reduction }\end{array}$} \\
\hline & & & \multicolumn{2}{|c|}{$\begin{array}{l}\text { Government Debt } \\
\text { (current) }\end{array}$} & \multicolumn{2}{|c|}{ Agency Debt (current) } & \multicolumn{2}{|c|}{ Agency Debt (potential) } & & & \\
\hline & & & $\begin{array}{c}\text { Eligible } \\
\text { Amount }^{2}\end{array}$ & $\begin{array}{c}\text { Share of } \\
\text { Purchases }\end{array}$ & $\begin{array}{l}\text { Eligible } \\
\text { Amount }^{3}\end{array}$ & $\begin{array}{c}\text { Share of } \\
\text { Purchases }\end{array}$ & $\begin{array}{l}\text { Max. Eligible } \\
\text { Amount }^{3}\end{array}$ & $\begin{array}{c}\text { Share of } \\
\text { Purchases }\end{array}$ & $\begin{array}{l}\text { Potential } \\
\text { Amount }^{4}\end{array}$ & Share of Purchases & \\
\hline & & [a] & [b] & $\mathbf{p}_{1}=\mathrm{a} / \mathrm{b}$ & [c] & $p_{2}=(b+c) / a$ & [d] & $p_{3}=(b+c+d) / a$ & [e] & $p_{4}=(b+c+d+e) / a$ & $\operatorname{sum}\left(p_{1}-p_{4}\right)$ \\
\hline Austria & 23.5 & 18.4 & 37.3 & 49.3 & - & 49.3 & 5.3 & 43.2 & 2.5 & 40.9 & -8.5 \\
\hline Belgium & 29.6 & 22.4 & 65.8 & 34.1 & - & 34.1 & - & 34.1 & 3.1 & 32.6 & -1.5 \\
\hline Finland & 13.9 & 11.9 & 19.8 & 60.1 & 0.3 & 59.2 & 0.3 & 59.2 & 1.5 & 55.2 & -4.9 \\
\hline France & 169.4 & 132.4 & 282.8 & 46.8 & 30.3 & 42.3 & 41.8 & 40.8 & 17.8 & 38.7 & -8.1 \\
\hline Germany & 244.4 & 195.6 & 195.3 & 100.2 & 41.4 & 82.6 & 47.3 & 80.7 & 22.6 & 73.8 & -26.4 \\
\hline Greece & $24.7^{*}$ & $44.5^{*}$ & 57.5 & 43.0 & - & 43.0 & - & 43.0 & 2.6 & 41.1 & -1.8 \\
\hline Ireland & 15.0 & 11.7 & 28.3 & 41.3 & - & 41.3 & - & 41.3 & 1.6 & 39.1 & -2.2 \\
\hline Italy & 147.1 & 118.3 & 326.8 & 36.2 & 1.6 & 36.0 & 1.9 & 36.0 & 15.5 & 34.4 & -1.8 \\
\hline Netherlands & 47.8 & 38.5 & 65.8 & 58.5 & 10.3 & 50.6 & 10.3 & 50.6 & 5.0 & 47.5 & -11.0 \\
\hline Portugal & 20.8 & 17.1 & 21.3 & 80.4 & - & 80.4 & 0.6 & 80.4 & 2.2 & 71.0 & -9.4 \\
\hline Spain & 105.6 & 83.8 & 165.3 & 50.7 & 4.2 & 49.5 & 7.9 & 48.4 & 11.1 & 45.5 & -5.2 \\
\hline All Others & 22.6 & 22.1 & 29.2 & 75.8 & - & 75.8 & - & 75.8 & 2.5 & 69.7 & -6.0 \\
\hline Total & 839.6 & 672.2 & 1,294.7 & 51.9 & 88.1 & 48.6 & 115.2 & 47.7 & 87.9 & 44.9 & -7.0 \\
\hline
\end{tabular}

Sources: Bloomberg L.P.; ECB; and IMF staff calculations.

Note: - = data not available: $E C B$ = European Central Bank

${ }^{1}$ Applies market value of eligible bonds at end of April 2015 to infer the actual purchase amount in nominal terms.

${ }^{2}$ Considers net issuance, subject to issue/issuer limits (including securities market program), but includes bonds trading below the deposit rate cap.

${ }^{3}$ Subject to issue limit but includes bonds trading below the deposit rate cap, and based on ECB capital key.

${ }^{4}$ Subject to issue limit but includes bonds trading below the deposit rate cap, and based on ECB capital key, assuming that ECB purchases of supra-national debt are conducted by national central banks (without risk sharing).

*Currently no purchases of Greek debt under the expanded asset purchase program. 
1. ECB PSPP: Average Maturity of Bonds (Outstanding vs. Purchases) and Past Yield Changes, as of May 1, 2015 (In years, weighted by notional amounts/percentage points)

- Average maturity of current ECB holdings ${ }^{2}$

- Difference in maturity between outstanding debt and ECB holdings

Change in effective yield since Sep. 2014 at key rate duration of outstanding debt (Percentage points, scales to right axis)

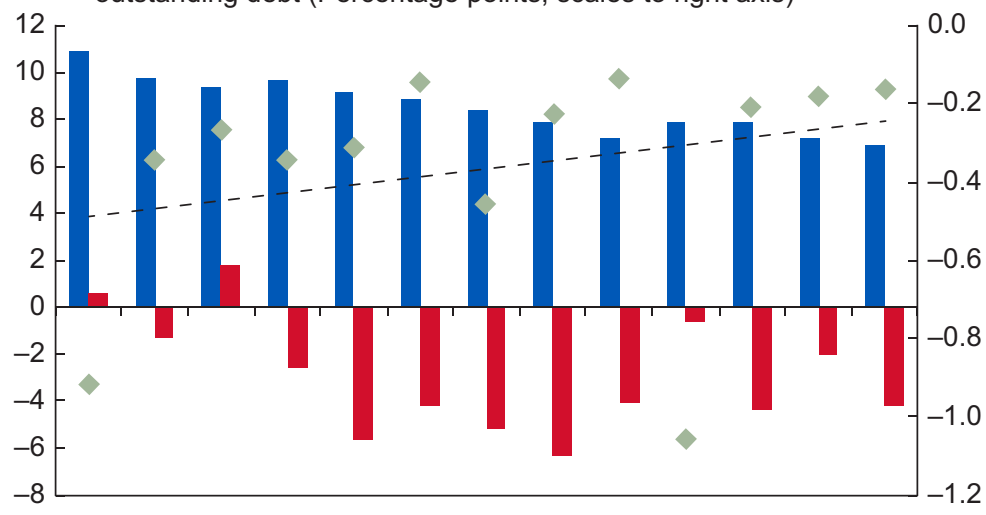

PRT ESP SVK IRL BEL MLT ITA AUT DEU SLV FRA FIN NLD

2. ECBP SPP: Eligible Outstanding Amount and Target Purchase Volumes (until Sep. 2016), Nominal Amounts, as of June 15, 2015 (EUR billion)

- Total eligible (after deposit rate cap) ${ }^{1,5}$

- Total eligible (after issue/issuer limits) ${ }^{6}$

- Implied target purchase amount ${ }^{7}$

$\times$ Share of eligible amount to be bought (govt. and agency debt) ${ }^{8}$

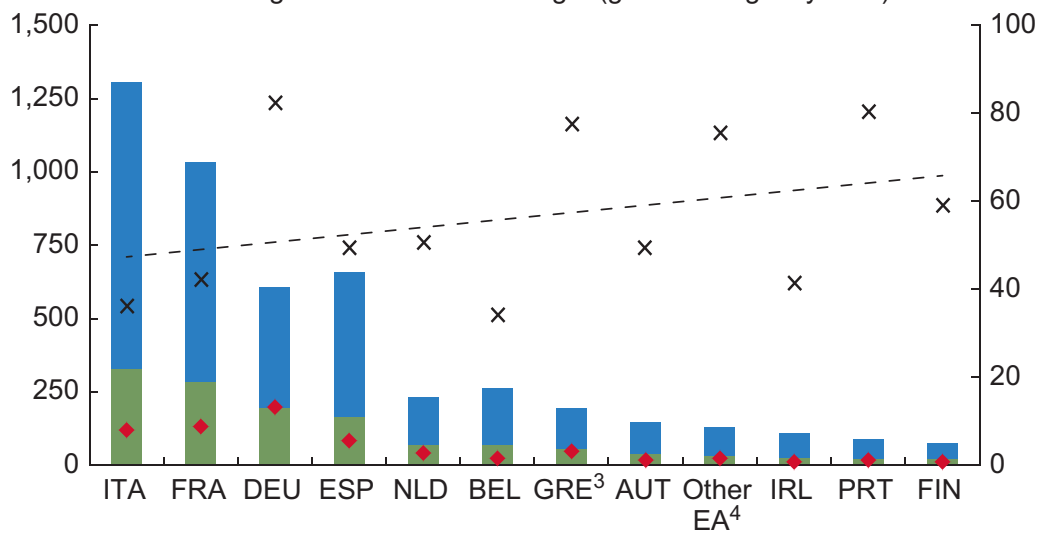

Sources: Barclays; Bloomberg, L.P.; ECB; EBA (Oct.2014); J.P. Morgan; and IMF staff calculations.

Note: $\mathrm{EA}=$ euro area; $\mathrm{ECB}=$ European Central Bank; $\mathrm{PSPP}=$ public sector purchase program.

${ }^{1}$ Excludes purchases of public securities from Greece and Cyprus due to collateral restrictions and purchasing limits as well as other euro area countries. The Eurosystem also did not buy any government debt securities in Estonia as of May 1, 2015.

${ }^{2}$ Average maturity weighted by monthly purchases between March 9 and May 1, 2015.

${ }^{3}$ Greece and Cyprus are currently excluded from the PSPP.

${ }^{4}$ Includes Estonia, Latvia, Lithuania, Luxembourg, and Malta.

${ }^{5}$ Excludes bonds ineligible due to nominal yield below deposit facility rate ( -20 basis points).

${ }^{6}$ Includes bonds ineligible due to nominal yield below deposit facility rate ( -20 basis points).

${ }^{7}$ Purchases based on ECB capital key in market value terms, converted into nominal amounts.

${ }^{8}$ Calculations include eligible agency debt as per amended implementation details of April 15, 2015, and weighted according to the ECB capital key; eligible stock includes amount of net issuance (until 2016).

Figure 6.21 Size of Target Market and Maturity Term of Purchase under the PSPP, as of June 15, 2015 
- Nominal limits restrict the overall scale of the target market-The impact of the nominal security issue and issuer limits of 25 and 33 percent, respectively, is offset somewhat as the Eurosystem's purchase targets refer to settled amounts (in market value terms). This implies lower nominal amounts of purchases of bonds that trade above par. Targeting purchases in market value terms makes it easier to comply with nominal purchasing limits, and even more so at longer durations (where bonds trade at a higher price premium) (Annex 6.1). However, for some countries, even lower (implied) nominal target volumes come very close to the maximum eligible amount after applying nominal limits (Figure 6.21).

- The target market is likely to shrink due to low net supply of government debt-The Eurosystem is expected to purchase a nominal amount of government bonds that will exceed net new issuance by $€ 239$ billion annually (or about 5 percent of the eligible stock) (Figure 6.22). A shrinking target market enhances the effectiveness of portfolio rebalancing, but also reduces the amount of securities available for purchase over time. However, targeting purchases in market value terms lowers the nominal amount of purchases (if bonds trade above par), and thus could mitigate the extent to which asset purchases further diminish a declining stock of outstanding government debt.

- Price cap on asset purchases varies with market conditions - The cap on purchases of securities with nominal yields below the current -0.2 percent deposit rate reduces the pool of eligible sovereign assets subject to changes in market. This currently affects about 5 percent of the total eligible stock and about 14 percent of German government debt (as of June 21, 2015). The price cap could lengthen the average maturity of purchases, which benefits countries that issue longer-dated bonds, but also risks overweighting purchases at longer maturities in smaller markets.

- The scope for substitute purchases by NCBs is limited - The shrinking pool of eligible securities raises the importance of other eligible nongovernment debt securities, such as agency and supranational debt (Annex 6.1). ${ }^{5}$ However, the list of eligible agency debt remains restrictive even after recent amendments, suggesting a possible constraint on agency purchases in noncore countries. With approval from the Governing Council, substitute purchases could also include other national public nonfinancial entities which are not currently eligible, and European Union agencies. ${ }^{6}$ Also, purchases of marketable debt instruments issued by supranational organizations are possible if $\mathrm{NCB}$ sun out of eligible central government and national agency debt. However, purchases of supranational debt are undertaken exclusively by two designated NCBs on behalf of the ECB under full risk sharing (and are capped at 12 percent of purchases) so any substitute purchases by NCBs would raise the overall purchases of supranational debt. This adds to the overall importance of the near-term supply of supranational debt and is particularly relevant in countries with smaller government debt markets relative to target purchase amounts. In addition, the eligibility criteria for private sector asset purchases are slightly more stringent than those for public sector purchases. ${ }^{7}$

- Weighting asset purchases by nominal outstanding amounts along the term structure shifts purchases toward longer maturities - Since the market value of longer-dated bonds is on average higher than shorter-dated bonds, this implies a greater share of purchases of longer-dated securities in market value terms. However, banks' asset holdings decline dramatically at maturities

\footnotetext{
${ }^{5}$ The volume of eligible outstanding agency and supranational debt for potential "substitute purchases" is about $€ 756$ billion. Recognizing all issuers categorized as euro area agencies would increase the total volume from $€ 357$ billion to $€ 430$ billion.

${ }^{6}$ Increased buying of debt in other jurisdictions does not seem to be explicitly ruled out.

${ }^{7}$ Whereas the best available credit rating determines eligibility ("first-best rule") under the PSPP, the ECB requires assetbacked securities and covered bonds to have two ratings at the maximum achievable rating level ("second-best rule").
}

\section{CInternational Monetary Fund. Not for Redistribution}


1. Euro Area Government Debt' (Nominal amounts, EUR billions)

\begin{tabular}{|c|c|c|c|c|c|c|c|c|c|c|c|c|c|c|c|}
\hline \multirow[b]{3}{*}{ Country } & \multicolumn{7}{|c|}{ Bank Holdings of EA Government Debt ${ }^{1}$} & \multicolumn{6}{|c|}{ ECB's Purchase Program (PSPP) } & \multirow{2}{*}{\multicolumn{2}{|c|}{$\begin{array}{c}\begin{array}{c}\text { Memo Item: } \\
\text { Agency Debt }^{2}\end{array} \\
\text { Total Eligible Amount }\end{array}$}} \\
\hline & \multirow[b]{2}{*}{$>2 \mathrm{Y}$} & \multirow[b]{2}{*}{$2 \mathrm{Y}-3 \mathrm{Y}$} & \multirow[b]{2}{*}{$3 Y-5 Y$} & \multirow[b]{2}{*}{$5 Y-10 Y$} & \multirow[b]{2}{*}{$>10 Y$} & \multirow[b]{2}{*}{ Total } & \multirow[b]{2}{*}{$\begin{array}{c}\text { Total } \\
\text { (Eligible } \\
\text { for ECB } \\
\text { purchases, } \\
\left.2 Y_{+}\right)\end{array}$} & \multirow[b]{2}{*}{$\begin{array}{c}\text { Share of } \\
\text { Eligible } \\
\text { Amount } \\
\text { under PSPP } \\
\text { (Percent) }\end{array}$} & \multicolumn{3}{|c|}{ Total Eligible Amount } & \multirow[b]{2}{*}{$\begin{array}{c}\text { ECB Target } \\
\text { Purchase } \\
\text { Amount } \\
\text { (market } \\
\text { value) }^{1}\end{array}$} & \multirow[b]{2}{*}{$\begin{array}{l}\text { Implied } \\
\text { ECB Target } \\
\text { Purchase } \\
\text { Amount }^{1,4}\end{array}$} & & \\
\hline & & & & & & & & & $\begin{array}{c}\text { Only } \\
\text { Eligible } \\
\text { Maturity } \\
\text { Tenor } \\
\text { (30Y-2Y) }\end{array}$ & $\begin{array}{c}\text { After } \\
\text { Accounting } \\
\text { for Net } \\
\text { Issuance }\end{array}$ & $\begin{array}{l}\text { Applying } \\
\text { the Issue/ } \\
\text { Issuer } \\
\text { Limit }^{3}\end{array}$ & & & $\begin{array}{c}\text { Only } \\
\text { Eligible } \\
\text { Maturity } \\
\text { Tenor } \\
(30 Y-2 Y)\end{array}$ & $\begin{array}{c}\text { Applying } \\
\text { the Issue } \\
\text { Limit } \\
(25 \%)\end{array}$ \\
\hline Austria & 11.8 & 2.4 & 9.7 & 18.3 & 23.3 & 65.5 & 53.7 & 35.3 & 152.0 & 149.0 & 37.3 & 23.5 & 18.4 & - & - \\
\hline Belgium & 20.5 & 12.7 & 23.6 & 31.2 & 24.6 & 112.7 & 92.1 & 35.0 & 263.0 & 263.0 & 65.8 & 29.6 & 22.4 & - & - \\
\hline Finland & 3.0 & 0.8 & 3.0 & 7.7 & 2.0 & 16.5 & 13.4 & 18.9 & 71.0 & 79.0 & 19.8 & 13.9 & 11.9 & 1.2 & 0.3 \\
\hline France & 142.0 & 17.8 & 38.6 & 64.0 & 20.9 & 283.3 & 141.3 & 13.2 & $1,068.0$ & $1,131.0$ & 282.8 & 169.4 & 132.4 & 121.4 & 30.3 \\
\hline Germany & 170.4 & 37.8 & 68.7 & 95.8 & 110.9 & 483.6 & 313.2 & 39.8 & 786.0 & 781.0 & 195.3 & 244.4 & 195.6 & 165.8 & 41.4 \\
\hline Greece & 12.7 & 0.0 & 0.0 & 0.2 & 8.3 & 21.2 & 8.5 & 4.7 & 180.3 & 194.3 & 57.5 & $24.7^{5}$ & $44.5^{5}$ & - & - \\
\hline Ireland & 6.3 & 3.7 & 6.9 & 10.0 & 1.3 & 28.1 & 21.8 & 21.6 & 101.0 & 113.0 & 28.3 & 15.0 & 11.7 & - & - \\
\hline Italy & 151.7 & 40.1 & 60.3 & 45.3 & 62.8 & 360.3 & 208.6 & 16.8 & $1,239.0$ & $1,307.0$ & 326.8 & 147.1 & 118.3 & 6.3 & 1.6 \\
\hline Netherlands & 23.4 & 7.5 & 26.6 & 44.4 & 21.2 & 123.0 & 99.7 & 39.7 & 251.0 & 263.0 & 65.8 & 47.8 & 38.5 & 41.0 & 10.3 \\
\hline Portugal & 16.1 & 2.1 & 5.3 & 4.9 & 3.2 & 31.5 & 15.4 & 17.7 & 87.0 & 85.0 & 21.3 & 20.8 & 17.1 & - & - \\
\hline Spain & 95.5 & 38.2 & 40.6 & 70.1 & 38.5 & 283.0 & 187.4 & 34.5 & 543.0 & 661.0 & 165.3 & 105.6 & 83.8 & 16.9 & 4.2 \\
\hline All others ${ }^{6}$ & 12.2 & 4.3 & 6.1 & 9.0 & 4.1 & 35.6 & 23.5 & 18.8 & 124.8 & 128.8 & 29.2 & 22.6 & 22.1 & - & - \\
\hline Total & 665.6 & 167.5 & 289.4 & 400.8 & 320.9 & $1,844.2$ & $1,178.6$ & 24.2 & $4,866.0$ & $5,155.0$ & $1,294.7$ & 839.6 & 672.2 & 352.5 & 88.1 \\
\hline
\end{tabular}

Figure 6.22 Monitoring Sovereign Quantitative Easing (Continued) 
2. Bank Holdings at Yield Thresholds

(Nominal amounts, EUR billion)

\begin{tabular}{lrrr}
\hline & \multicolumn{2}{c}{$\begin{array}{c}\text { Nominal Yield Below } \\
\text { Threshold }{ }^{7} \text { (Percent): }\end{array}$} \\
\cline { 2 - 4 } & \multicolumn{1}{c}{$\mathbf{0 . 2}$} & \multicolumn{1}{c}{$\mathbf{0 . 1}$} & \multicolumn{1}{c}{$\mathbf{0 . 0}$} \\
\hline Austria & 0.0 & 14.2 & 9.7 \\
Belgium & 0.0 & 0.0 & 16.6 \\
Finland & 3.0 & 0.8 & 6.9 \\
France & 74.2 & 67.8 & 8.9 \\
Germany & 170.4 & 37.8 & 34.3 \\
Greece & 0.0 & 0.0 & 0.0 \\
Ireland & 0.0 & 0.0 & 0.0 \\
Italy & 0.0 & 0.0 & 0.0 \\
Netherlands & 23.4 & 7.5 & 13.3 \\
Portugal & 0.0 & 0.0 & 0.0 \\
Spain & 0.0 & 0.0 & 0.0 \\
\hline Total & $\mathbf{2 7 1 . 0}$ & $\mathbf{1 2 8 . 0}$ & $\mathbf{8 9 . 7}$ \\
\hline
\end{tabular}

3. PSPP Net Displacement of Euro Area Government Debt (Nominal amounts, EUR billion)

\begin{tabular}{ccccc}
\hline $\begin{array}{c}\text { Avg. Gross } \\
\text { Issuance per } \\
\text { Month }\end{array}$ & $\begin{array}{c}\text { Avg. Net } \\
\text { Issuance } \\
\text { per Month }\end{array}$ & $\begin{array}{c}\text { Implied } \\
\text { ECB Buying } \\
\text { per Month }{ }^{1}\end{array}$ & $\begin{array}{c}\text { Avg. Monthly } \\
\text { Displacement } \\
\text { Impact }\end{array}$ & $\begin{array}{c}\text { Avg. Annual } \\
\text { Displacement } \\
\text { Impact }\end{array}$ \\
\hline 1.5 & -0.2 & 1.0 & -1.1 & -13.5 \\
3.3 & 0.0 & 1.2 & -1.2 & -14.2 \\
1.0 & 0.4 & 0.6 & -0.2 & -2.4 \\
17.3 & 3.3 & 7.0 & -3.7 & -43.9 \\
13.3 & -0.3 & 10.3 & -10.6 & -126.7 \\
0.9 & 0.7 & $2.3^{5}$ & $-1.6^{5}$ & $-19.2^{5}$ \\
1.0 & 0.6 & 0.6 & 0.0 & 0.2 \\
20.6 & 3.6 & 6.2 & -2.6 & -31.8 \\
4.0 & 0.6 & 2.0 & -1.4 & -16.7 \\
1.1 & -0.1 & 0.9 & -1.0 & -12.1 \\
11.8 & 6.2 & 4.4 & 1.8 & 21.6 \\
\hline $\mathbf{7 5 . 8}$ & $\mathbf{1 5 . 0}$ & $\mathbf{3 4 . 2}$ & $\mathbf{- 2 0 . 0}$ & $\mathbf{- 2 3 9 . 4}$ \\
\hline
\end{tabular}

4. Euro Area: Eligible Marketable Assets at end of 2014 (Percent of total euro area market) Other marketable assets (incl. agency and supranational debt)

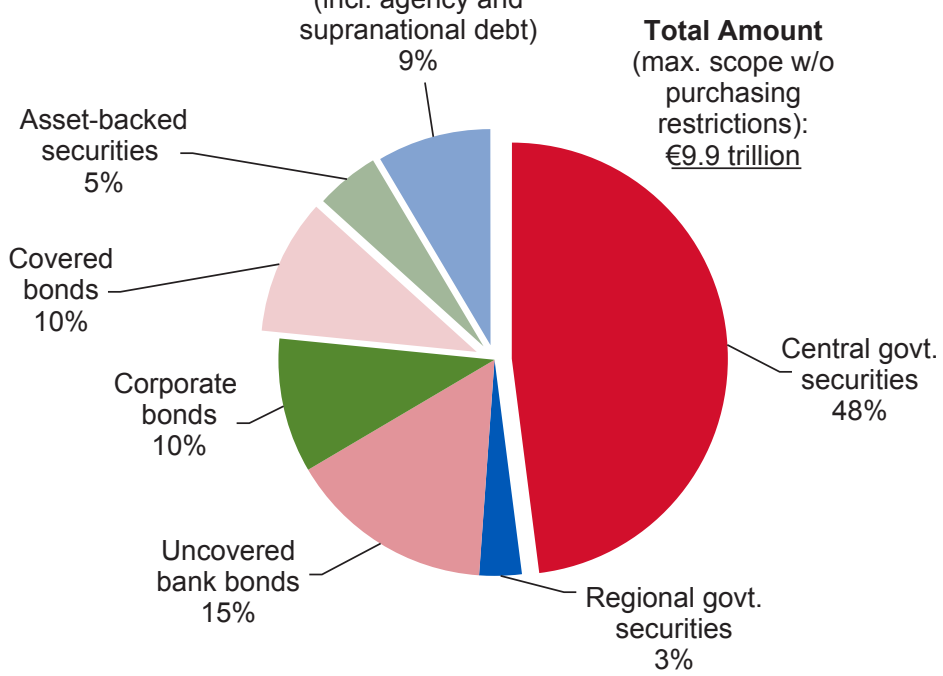

Sources: Barclays; Bloomberg, L.P.; ECB; EBA (Oct. 2014); J.P. Morgan; and IMF staff calculations.

Note: $\mathrm{EA}=$ euro area; $\mathrm{ECB}=$ European Central Bank; $\mathrm{PSPP}=$ public sector purchase program; $-=$ data not available.

${ }^{1}$ Excludes purchases of public securities from Greece and Cyprus due to collateral restrictions and purchasing limits as well as other EA countries. The Eurosystem also did not buy any government debt securities in Estonia as of May $1,2015$.

${ }^{2}$ Calculations include eligible agency debt as per amended implementation details of April 15, 2015, and weighted according to the ECB capital key; eligible stock includes amount of net issuance (until 2016).

${ }^{3}$ Includes bonds ineligible due to nominal yield below deposit facility rate (-20 bps).

${ }^{4}$ Purchases based on ECB capital key in market value terms, converted into nominal amounts.

${ }^{5}$ Greece (and Cyprus) are currently excluded from the PSPP.

IIncludes Estonia, Latvia, Lithuania, Luxembourg, and Malta.

${ }^{7}$ Non-cumulative.

Figure 6.22 Monitoring Sovereign Quantitative Easing 
beyond 10 years (Figure 6.22 and Figure 6.24), and especially so in the more selected economies. Since the share of purchases is higher for low-yielding debt issued in core economies, it further strengthens the duration effect of purchases, but it also increases demand for longdated assets to a point where the security issue limit may become more binding.

- The pool of "willing" sellers shrinks at longer maturities - Nonbank financial institutions, such as insurance companies and pension funds, hold long-dated sovereign debt for asset-liability matching, and account for about 20 percent of the investor base in the euro area (Figure 6.23). Regulatory requirements, such as asset-liability matching, and accounting standards, such as hold-to-maturity valuation, discourage nonbank financial institutions from selling debt securities. In addition, rising reinvestment risk in a low-interest rate environment, disproportionately higher capital charges for riskier investments, and the lack of substitutes for sovereign debt as a liquidity buffer also serve as disincentives. For banks, yields on their government debt holdings ( $€ 271$ billion) have fallen below the deposit facility rate (Figure 6.22), limiting their incentive to sell. At the same time, incentives to sell sovereign debt and reinvest in highly-rated foreign assets (such as U.S. government bonds) have increased as the difference between the U.S. and euro term spreads continues to widen in real terms (Figure 6.15).

\section{Improving Collateral Availability}

Sovereign debt purchases may also impair market functioning (so-called financial plumbing) if they significantly diminish the availability of debt securities for securities lending. Assets purchased by the Eurosystem are also valued by market participants for their collateral services (Cœuré 2015; Singh 2014). Unlike the order-book ${ }^{8}$ model of price formation in equity markets, government bond markets are mostly over the counter and rely predominantly on market makers, who compete for customer order flow through buy and sell quotations ("two-way prices"). These market makers optimize their inventory of bonds by selling short and carrying open positions, which requires liquid hedging markets and efficient securities financing transactions, that is, repos and securities lending. Most government debt securities serve as liquid, fixed-duration, and high-quality collateral for these activities.

A decrease in the available debt securities that can be used as collateral in repo markets may adversely affect market making for government bond markets. ${ }^{9}$ And since most sellers of sovereign assets are also important securities lenders, asset purchases could reduce the stock held by those that are more likely to engage in securities lending. Data on the current volume of securities lending and the utilization of government bonds suggest that the aggregate lendable collateral value has already declined by almost 12 percent (or $€ 78$ billion) since the end of August 2014 (with the utilization rate of available collateral increasing), and is expected to further contract (Figure 6.23).

The importance of the Eurosystem's securities lending activities varies across countries. Similar to portfolio rebalancing as transmission channel for asset purchases, the availability of collateral for market making is influenced by the size of market, the composition of the investor base, the net issuance by governments, and the maturity of government bonds for securities lending. The interaction between monetary conditions and the willingness of investors to lend securities is an important consideration in this regard:

- Excess liquidity could diminish supply of collateral in the core economies-Banks, which tend to be more active lenders of collateral (Figure 6.23), generally hold a liquidity surplus in the core economies. They also face limited incentives to engage in cash-based securities lending

\footnotetext{
${ }^{8} \mathrm{An}$ order book is the list of orders (manual or electronic) that a trading venue (in particular stock exchanges) uses to record the interest of buyers and sellers in a particular financial instrument.

${ }^{9}$ Collateral scarcity raises the cost of short selling, which would curtail the ability of market makers to generate two-way flows that are essential to efficient price discovery in government bond markets.
}

\section{CInternational Monetary Fund. Not for Redistribution}


The availability of government bonds for securities lending has been contracting since the second half of 2013.

1. Euro Area: Availability of Government Bonds for Securities Lending ${ }^{1}$ (EUR billion, left scale; percent, right scale)

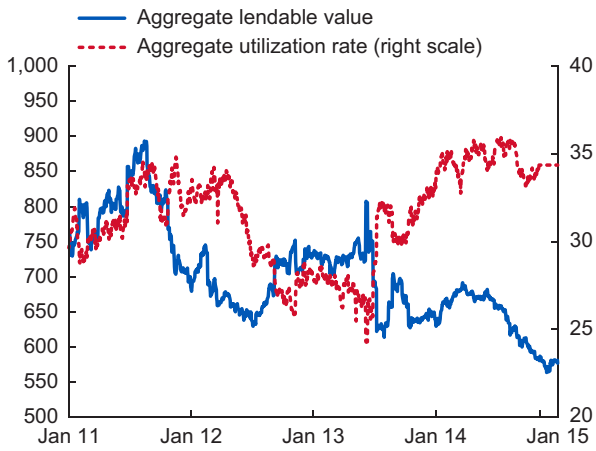

Market making in government debt securities has become less attractive as the cost of borrowing collateral has dropped below the effective money market rate. .

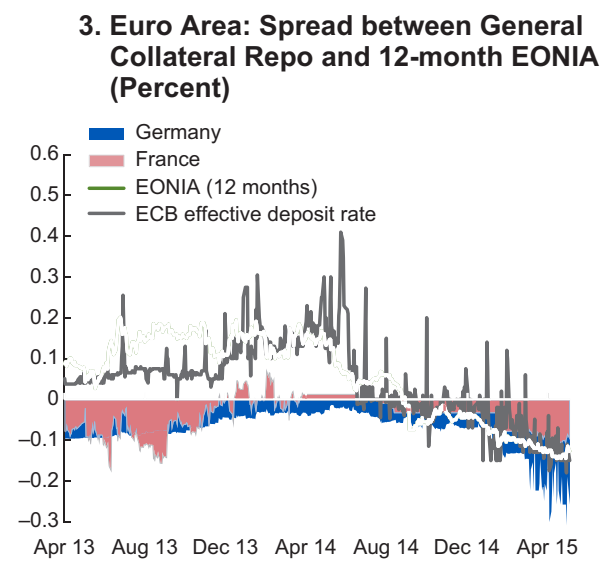

Banks represent a significant share of potential lenders of securities to offset a potential scarcity of collateral in the market.

2. Euro Area: Distribution of Unencumbered Amount of Government Debt for Securities Lending, End-2014

(Percent)

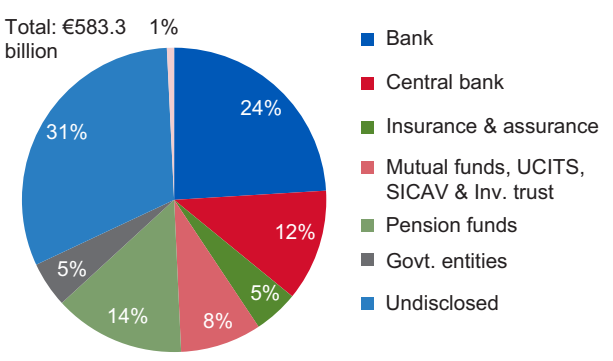

... which also shows in a reduced willingness to reuse collateral for secured funding, pushing down repo rates.

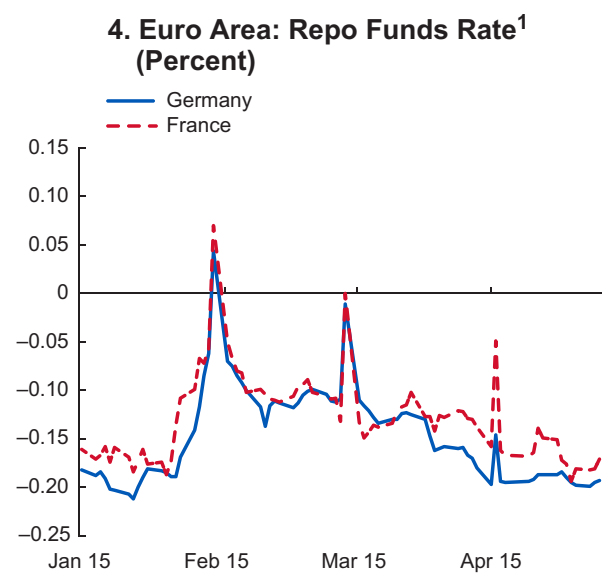

5. Composition of Investor Base in Euro Area Countries' Debt Securities, End-2014 ${ }^{1}$ (Nominal amounts, EUR billion and percent)

\begin{tabular}{|c|c|c|c|c|c|c|c|c|c|c|}
\hline \multirow[b]{3}{*}{ All Euro Area } & \multicolumn{4}{|c|}{ EUR Billion } & \multirow[b]{3}{*}{ Total } & \multirow[b]{3}{*}{ Domestic } & \multicolumn{3}{|c|}{ Percent } & \multirow[b]{3}{*}{ Tota } \\
\hline & \multirow[b]{2}{*}{ Domestic } & \multicolumn{3}{|c|}{ Nondomestic } & & & & Nondomesti & & \\
\hline & & Euro & Non-Euro & Total & & & Euro & Non-Euro & Total & \\
\hline Central Banks & 270 & 236 & 1,500 & 1,736 & 2,006 & 4 & 3 & 20 & 23 & 27 \\
\hline Banks & 1,216 & 427 & 300 & 727 & 1,943 & 16 & 6 & 4 & 10 & 26 \\
\hline Insurance Companies & 802 & 300 & 120 & 150 & 952 & 11 & 4 & 2 & 2 & 13 \\
\hline Pension Funds & 242 & 125 & 100 & 80 & 322 & 3 & 2 & 1 & 1 & 4 \\
\hline Investment Funds & 380 & 432 & 50 & 482 & 862 & 5 & 6 & 1 & 6 & 12 \\
\hline Others & 620 & 218 & 90 & 308 & 928 & 8 & 3 & 1 & 4 & 12 \\
\hline Total & 3,530 & 1,738 & 2,160 & 3,898 & 7,429 & 48 & 23 & 29 & 52 & 100 \\
\hline
\end{tabular}

Sources: Barclays; Bloomberg, L.P.; ECB; ICAP; J.P. Morgan; Markit; and IMF staff calculations.

Note: $\mathrm{EA}=$ euro area; EONIA = Euro OverNight Index Average; SICAV = investment company with variable capital; UCITS = undertakings for the collective investment of transferable securities.

${ }^{1}$ Includes the following EA countries: Austria, Belgium, Finland, France, Germany, Netherlands, Italy, Portugal, and Spain.

Figure 6.23 Monitoring Sovereign Quantitative Easing 


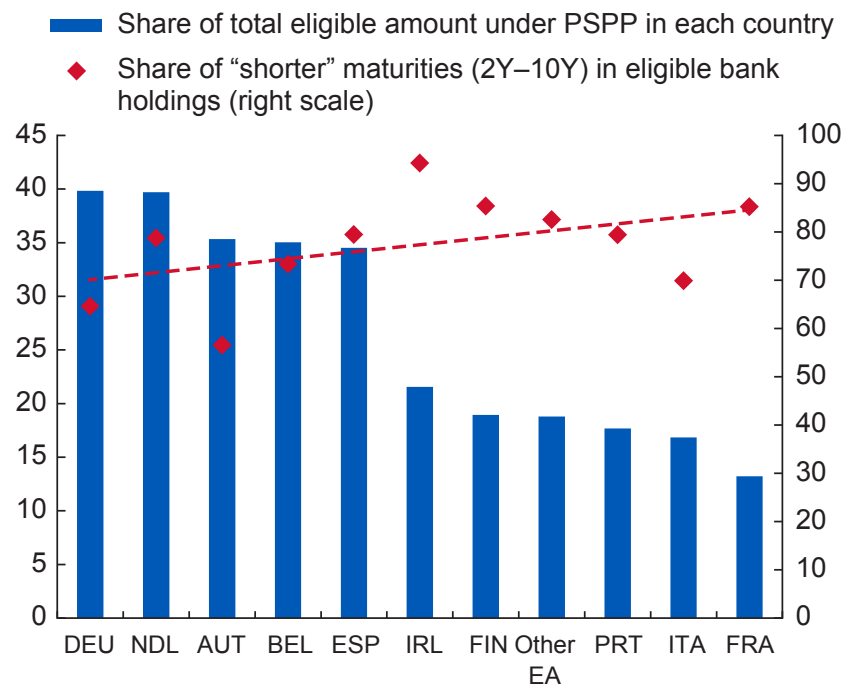

Sources: Barclays; Bloomberg LP; ECB; J.P. Morgan; and IMF staff calculations. Note: $\mathrm{EA}$ = euro area; PSPP = public sector purchase program. Data labels in the figure use International Organization for Standardization (ISO) country codes.

Figure 6.24 Bank Holdings of Government Debt in Euro Area (Percent)

due to the lack of attractive investment opportunities. ${ }^{10}$ Instead, much like in Eurosystem's securities lending, they are likely to prefer lending out government bonds in return for other government bonds with higher yields and/or longer maturities (as "collateral swaps" via mutually offsetting repo and reverse repo transactions) — but this does not expand available collateral for market making. In addition, most NCBs in the core economies, which account for a large amount of PSPP purchases, do not accept nondomestic government debt as collateral, preventing a net release of highly sought-after collateral, such as German government debt by the Deutsche Bundesbank.

- Strong incentives to securities lending by banks in non-core economies-Negative deposit rates reduce incentives for banks to hold excess liquidity and encourage lending (or investment). In the case of Italy and Spain, for instance, the amount of government debt securities held by domestic investors has risen substantially since 2011 - and over 60 percent by the end of 2014. In addition, most investment securities held by euro area banks are valued on either a mark-to-market for trading or fair value basis for assets for sale, with generally less than 20 percent being held to maturity. This suggests strong incentives for securities lending when interest rates decline, which bodes well for the availability of collateral.

- Shrinking pool of "willing" securities lenders-Collateral scarcity is more likely to arise at longer maturities and in countries where the net supply of government bonds is small (or even negative). Banks tend to hold government bonds at the front end of the eligible range of maturities (for example, more than 80 percent of government debt holdings of European banks have a residual maturity of less than 10 years) (Figures 6.22 and 6.24), and are less likely to engage in securities lending at longer maturity tenors. Moreover, nonbank financial

\footnotetext{
${ }^{10}$ This might push repo rates below the levels set by the ECB and NCBs in their securities lending program (which is already becoming apparent as general collateral repos on German and French government bonds), which trade at spreads of more than -20 bps to the 12-month Euro OverNight Index Average (EONIA) rate (Figure 6.23).
} 
institutions with long-term liabilities face supervisory standards that discourage active collateral management. Insurance companies and pension funds are generally less active in repo markets, and in most countries are barred from engaging in securities lending and liquidity swaps with banks or asset managers. Similarly, the high foreign official sector holdings of government debt of some core economies (outside the Eurosystem) remove collateral from securities lending within the euro area.

Based on these considerations, current securities lending by NCBs might be insufficient. ${ }^{11}$ Securities lending aims to ease the reduced availability of collateral for market making while avoiding sterilizing the impact of asset purchases on aggregate liquidity. The ECB's securities lending works well and has established clear and effective standards that helped build confidence in the availability of collateral (Annex 6.2). The ECB operates a centralized securities lending program of own bonds bought under the PSPP without maturity restrictions, but at very small amounts per issue (of up to 2.5 percent of the notional amount). Although the ECB's securities lending allows collateral access to a wide range of market participants, it provides only a small backstop against potential collateral scarcity, since most of its securities lending remains decentralized under NCBs. Some 80 percent of the PSPP's current stock is held by NCBs, whose securities lending is marked by considerable cross-country variation in conditions on pricing, haircuts, and eligibility. This could undermine transparency and limit equitable access to collateral for market makers across the euro area. In the absence of sufficient centralized securities lending, purchases by NCBs could reduce access to collateral for market-making activities outside their domestic market. In addition, cash (or equity) cannot be posted straight in exchange for bonds, which excludes market makers who often use these assets when borrowing securities. ${ }^{12}$

\section{CONCLUSION AND POLICY RECOMMENDATIONS}

Given the risks of prolonged low inflation, the ECB should stay the course until inflation is on a sustained adjustment path. Despite recent market corrections, various channels, particularly the expectations channel, likely play a significant role in transmitting an ECB balance sheet expansion into higher inflation. If inflation and inflation expectations fail to pick up after a reasonable period of QE, the ECB should stand ready to extend the asset purchase program beyond September 2016. The Governing Council should look through current market volatility and transient changes in inflation in signaling its monetary policy stance. Continued clear communication of the Governing Council's intentions will help mitigate excessive market volatility and reinforce its commitment to meeting the ECB's aim of achieving inflation rates below, but close to, 2 percent over the medium term (Praet 2015).

Dealing with bank and corporate balance sheet problems would increase the effectiveness of QE. Reducing NPLs is a policy priority, not only to restore the health of the banking sector, but also to strengthen monetary transmission via the bank lending channel. It also remains essential that the accommodative monetary stance be supported by comprehensive and timely policy actions in other areas, not least structural reforms to boost potential growth.

\footnotetext{
${ }^{11}$ Other major central banks that have completed a QE program adopted a centralized and active securities lending program. The Federal Reserve used the System Open Market Accounts Program of up to 90 percent per issue (http://www. newyorkfed.org/markets/soma/sysopen_accholdings.html). The Bank of England adopted a three-stage process of lending to market counterparts, which comprised (1) direct lending by the HM Treasury's Debt Management Office of own inventory, (2) the bank's standard repo facility (since 2009) if the office's inventory is exhausted, and (3) making a portion of their purchases available to the Debt Management Office for lending with a negotiated borrowing fee. The Bank of Japan lent Japanese government bonds via auction-based repo agreements (using the New Gensaki trade type) to provide a temporary and secondary source of these instruments to the market to enhance liquidity.

${ }^{12}$ Also, most NCBs do not use specialized agents for securities lending, which creates legal uncertainty regarding netting provisions due to sovereign immunity clauses.
} 
Potential implementation challenges could be overcome by expanding the flexibility of the current asset purchase program, and enhancing access to collateral for market makers within a common securities lending framework:

- Expand flexibility of asset purchases-The Eurosystem could widen the eligibility of agency debt, increase purchases of supranational debt (Table 6.1), ${ }^{13}$ and relax the eligibility criteria for private sector assets, which are slightly more stringent than those for public sector purchases with the same risk. This would help NCBs meet purchasing targets in their home markets without breaching the single issue and issuer limits imposed by the PSPP. Measured deviations from the capital key-based allocation of purchases might be warranted if purchases risk diminishing market liquidity at certain (longer) maturity terms. Substitute purchases of sovereign and agency debt in other jurisdictions do not seem to be explicitly ruled out by the implementation guidelines of the purchase program and should be considered if necessary.

- Enhance market making through harmonized securities lending-The ECB should develop high-level principles to harmonize procedures for securities lending and encourage a common active lending solution for all $\mathrm{NCBs},{ }^{14}$ for example, joint securities lending with specialized agents and coordinated by the ECB (Figure 6.25). The aim would be to improve transparency, pricing, and the availability of collateral for market making, and so support sufficient market liquidity. ${ }^{15}$ This would enhance the effectiveness of the Eurosystem's asset purchases, especially for securities in smaller markets or at maturities with low trading activity. The NCBs' acceptance of nondomestic government debt as collateral and price-based incentives could help ensure that dealers only access the ECB's centralized securities lending facility as a last resort.

\footnotetext{
${ }^{13}$ On July 1, 2015, the ECB added corporate bonds issued by 13 government-owned entities from across the euro area to the list of assets eligible for purchase.

${ }^{14}$ This approach would ideally be supplemented with accessing the lending infrastructure of international central securities depositories. It would also require introducing a minimum fail charge (to prevent opportunistic settlement fails) and creating a legal arrangement that leverages the concept of the Global Master Repurchase Agreement Protocol to create legal certainty in NCB-sponsored securities lending.

${ }^{15}$ As part of alleviating pressures on the availability of collateral, both the ECB and NCBs could also reduce the valuation haircuts for bond collateral, raise the limit on securities lending per issue, extend standard maturity terms (or reduce extra charge for rollovers), and accept equity as noncash collateral.
}

\section{CInternational Monetary Fund. Not for Redistribution}




\section{Direct Lending Facility}

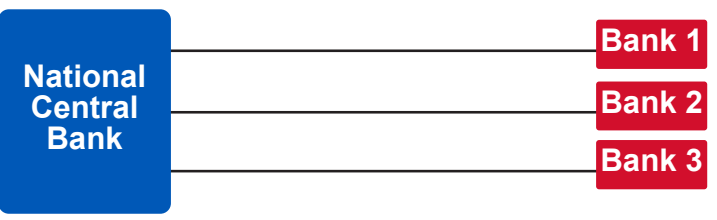

Security Lender as Principal Model

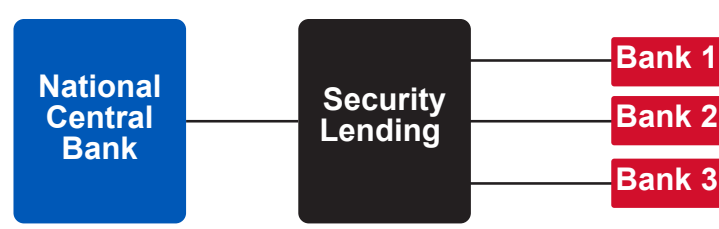

Security Lender as Agent Model

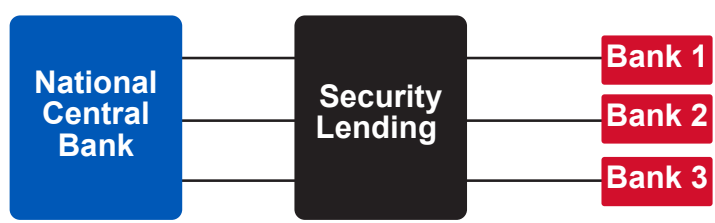

Source: ECB.

Note: $\mathrm{ECB}=$ European Central Bank; RWA = risk-weighted assets.

Figure 6.25 Solutions for Active Securities Lending

\section{Advantages}

\section{Cost and Scale}

Bonds released to the market

Potential term borrowing

No security lender fee

Source of market intelligence

for the central bank

Lower RWA impact on banks

\section{Speed, Access, and Flexibility}

Bonds released to the market

Shorter time-to-market of

program implementation

Available to nonprimary

dealers

Possible transparency via lending feeds

Greater collateral flexibility

Same as in the case of Principal Model

plus:

No credit line limit between the central bank and security lender

\section{Disadvantages}

Speed, Access, and Flexibility

$x$ Long lead time for implementation

* May be limited to primary dealers

* Noncash collateral (and maybe like-for-like) causing net drain of "high-quality collateral"

* Slow inquiry response time

* Punitive fee structure

\section{Cost and Scale}

* Credit line limitation between central bank and lender, thus restricting supply

$x$ Borrows on open and subject to daily rerates

$x$ Punitive haircut schedule

$x$ Higher RWA impact for banks

x Security lender balance sheet availability could limit supply

$x$ Security lender fees may increase cost

$\times$ Same as in the case of Principal Model plus:

$x$ Requires agency lending disclosure support/integration

* Cost of indemnification could limit supply and increase cost 


\section{ANNEX 6.1. THE EXPANDED ASSET PURCHASE PROGRAM (APP)}

The expanded asset purchase program (APP) was announced on January 22, 2015, and started on March 9. It consists of combined monthly purchases of $€ 60$ billion in public and private sector securities with a residual maturity of at least two years (but not greater than 30 years) in the secondary market.

The public sector assets purchase program (PSPP) represents more than 80 percent of the volume generation under the APP and comprises euro-denominated marketable debt instruments issued by euro area central governments, certain agencies located in the euro area, or certain international or supranational institutions in the euro area. It complements existing private asset purchases under the $\mathrm{CBPP} 3$ and ABSPP (Annex Figure 6.1.1). Purchases are conducted by both the ECB and national central banks in their home market, with the possibility of purchasing marketable debt instruments issued by agencies and international or supranational institutions located in the euro area if needed to meet each country's allocation based on the ECB's capital key ("substitute purchases").

Several restrictions are placed on asset purchases. The ECB introduced a cap on purchases of securities with yields below the -0.2 percent deposit rate (which does not apply to inflationlinked securities). Moreover, asset purchases are subject to a 25 percent limit on the notional amount of each issue ("issue share limit") together with a 33 percent limit on the total outstanding amount per issuer ("issuer limit"). The issue share limit covers existing Eurosystem holdings of securities used for monetary operations (that is, stock under the securities markets program) and any other portfolios owned by Eurosystem central banks.

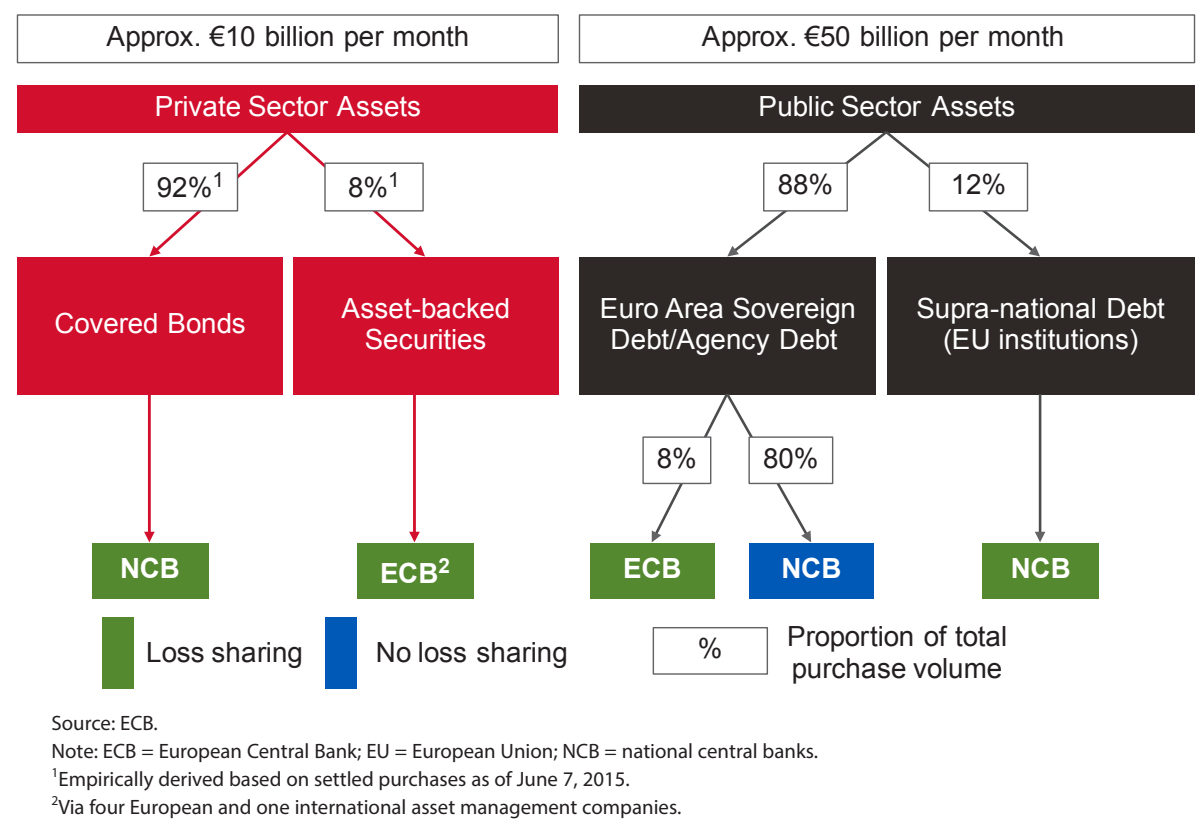

Annex Figure 6.1.1 Overview of the Expanded Asset Purchase Program 


\section{ANNEX 6.2. SECURITIES LENDING UNDER THE EXPANDED ASSET PURCHASE PROGRAM (APP)}

On April 2, 2015, the European Central Bank (ECB) and several Eurosystem national central banks (NCBs) began making available securities purchased under the public sector purchase program (PSPP) and asset holdings under the securities market program. Holdings of securities purchased under the program are eligible for securities lending to facilitate bond and repo market liquidity. Securities are made available in a decentralized manner, mirroring the organization of the PSPP by replicating existing private sector solutions, with a small amount of securities purchases by the ECB itself under the PSPP being provided centrally via the existing settlement system for failed trades. The program primarily targets market-making institutions. Lending of PSPP-securities holdings takes place on a "cash neutral basis" (that is, repo transactions against cash collateral are accompanied by a fully offsetting reverse repo transaction and typically with the same counterparty).

More specifically, the Eurosystem follows a two-pronged securities lending program:

- Centralized securities lending - The ECB offers securities that it has directly purchased at a fixed fee of 40 basis points for one week, which can be rolled over up to three times at an incremental cost of 10 basis points per additional week. The amount lent for each bond cannot exceed the lower of $€ 200$ million or 2.5 percent of the outstanding notional amount. Lending is funded via a noncash repo at a collateral haircut of 4 percent. All securities that fulfill the PSPP requirements are accepted as collateral, even if their residual maturity is lower than two years. This allows borrowers to "upgrade" collateral by posting short-dated government debt in exchange for longer-dated, higher-yielding government debt, which offers a potential pricing benefit in an environment of continued spread compression. This should support collateral rates in selected economies; for instance, as a result of swapping five-year German Bunds against a 30-year Italian treasury bond. It might also contribute to reduced fragmentation of lending rates between core and selected economies. However, these conditions apply only to bonds bought directly by the ECB, which represents a maximum of 20 percent of all asset purchases under the risk-sharing arrangement of the asset purchase program.

- Decentralized securities lending-NCBs, which complete most of the purchases under the PSPP (80 percent, Annex 6.1), conduct their own securities lending programs, and are able to set different conditions and use different channels of lending securities to the market. They employ the channels for securities lending available under their existing infrastructure for mitigating settlement failures. This includes bilateral securities lending and lending relying on specialized securities lending agents ("agency lending") or on the lending infrastructure of international central securities depositories (ICSDs). NCBs lend acquired bonds using collateral swaps or fails mitigation programs by ICSDs, and some NCBs make their securities available in Euroclear's automated securities lending and borrowing program for the purpose of mitigating settlement fails caused by the lack of specific collateral. Bonds are lent at more expensive levels compared to general collateral, which are influenced by market conditions. ${ }^{16}$ Several NCBs have added some restrictions to securities lending on the maturity of the operation as well as on the size of transactions. They might also apply their own risk management framework, which determines, for instance, collateral eligibility, pricing, haircuts, and term, and counterparty eligibility.

\footnotetext{
${ }^{16}$ While unsecured lending prices for Eurosystem banks cannot drop below the rate offered by the ECB's deposit facility, repo rates can, and do. Despite the recent market correction, even general collateral repos of French and German government debt securities still trade at more than 20 basis points below the EONIA rate (Figure 6.25).
} 


\section{REFERENCES}

Aiyar, S., W. Bergthaler, J. M. Garrido, A. Ilyina, A. A. Jobst, K. Kang, D. Kovtun, Y. Liu, D. Monaghan, and M. Moretti. Forthcoming. "A Strategy for Resolving Europe's Problem Loans," Staff Discussion Note, International Monetary Fund, Washington.

Arslanalp, S., and T. Tsuda. 2012. "Tracking Global Demand for Advanced Economy Sovereign Debt.” Working Paper 12/284, International Monetary Fund, Washington.

Banarjee, R., D. Latto, and N. McLaren. 2012. "Using Changes in Auction Maturity Sectors to Help Identify the Impact of QE on Gilt Yields." Bank of England, Quarterly Bulletin Q1.

Benford, J., S. Berry, K. Nikolov, and C. Young. 2009. "Quantitative Easing." Bank of England, Quarterly Bulletin Q2.

Christensen, J. H. E., and G. D. Rudebusch. 2012. "The Response of Interest Rates to US and UK Quantitative Easing." The Economic Journal 122 (564): 385-414.

Cœuré, B. 2015. "Embarking on Public Sector Asset Purchases." Speech at the Second International Conference on Sovereign Bond Markets, March 10, Frankfurt am Main.

Engen, M. E., T. T. Laubach, and D. Reifschneider. 2015. "The Macroeconomic Effects of the Federal Reserve's Unconventional Monetary Policies." Finance and Economic Discussion Series, 2015-005, Federal Reserve, Washington.

European Central Bank (ECB). 2013. "The Eurosystem Household Finance and Consumption Survey: Results from the First Wave." Statistics Paper Series 2, April, Frankfurt.

European Commission. 2015. "Putting the Spring Forecast into Perspective: The ECB's Quantitative Easing and the Euro Area Economy.” In European Economic Forecast, Spring. Brussels: European Commission.

Glick, R., and S. Leduc. 2013. "The Effects of Unconventional and Conventional U.S. Monetary Policy on the Dollar.” Working Paper, Federal Reserve Bank of San Francisco.

International Monetary Fund. 2013a. "Unconventional Monetary Policies-Recent Experience and Prospects." Monetary and Capital Markets and Strategy and Policy Review Departments, Background Paper, October 18, Washington.

. 2013b. "Global Impact and Challenges of Unconventional Monetary Policies." Monetary and Capital Markets and Strategy and Policy Review Departments, Policy Paper, October 18, Washington.

_. 2014. "Appendix I: International Reserves." Annual Report 2014, Washington. Available at www.imf.org/ external/pubs/ft/ar/2014/eng/pdf/a1.pdf.

- 2015a. Direction of Trade Statistics. Annual Yearbook. International Monetary Fund, Washington.

Joyce, M., A. Lasaosa, I. Stevens, and M. Tong. 2011. "The Financial Market Impact of Quantitative Easing in the United Kingdom.” International Journal of Central Banking 7 (3): 113-61.

Joyce, M., M. Tong, and R. Woods. 2011. "The United Kingdom’s Quantitative Easing Policy: Design, Operation, and Impact.” Bank of England, Quarterly Bulletin Q3.

Kapetanios, G., H. Mumtaz, I. Stevens, and K. Theodoridis. 2012. "Assessing the Economy-Wide Effects of Quantitative Easing." The Economic Journal 122 (November): 316-47.

Krishnamurthy, A., and A. Vissing-Jorgensen. 2011. "The Effects of Quantitative Easing on Interest Rates: Channels and Implications for Policy." Working Paper 17555, National Bureau of Economic Research, Cambridge, Massachusetts.

Praet, P. 2015. “The APP Impact on the Economy and Bond Markets." Speech at the European Central Bank's Bond Market Contact Group, June 30, Frankfurt am Main.

Saito, M., Y. Hogen, and S. Nishiguchi. 2014. "Portfolio Rebalancing Following the Bank of Japan's Government Bond Purchases: A Fact Finding Analysis Using the Flow of Funds Accounts Statistics." Bank of Japan Review 2 (June): $1-5$.

Singh, M. 2014. "Financial Plumbing and Monetary Policy." Working Paper 14/111, International Monetary Fund, Washington.

Slacalek, J. 2009. "What Drives Personal Consumption? The Role of Housing and Financial Wealth.” Working Paper Series 1117, European Central Bank, Frankfurt am Main.

Sousa, R. M. 2009, "Wealth Effects on Consumption: Evidence from the Euro Area.” Working Paper Series 1050, European Central Bank, Frankfurt am Main. 


\title{
Fiscal Consolidation under the Stability and Growth Pact: Some Illustrative Simulations
}

\author{
Derek Anderson, Marialuz Moreno Badia, Esther Perez Ruiz, \\ STEPHEN SNUDDEN, AND FRANCIS VITEK
}

The Stability and Growth Pact (SGP) continues to be at the core of European Union (EU) fiscal governance (Figure 7.1). The SGP was put in place to avoid excessive deficits and debt levels. However, fiscal slippages during the first decade of the Economic and Monetary Union (EMU) led to high vulnerabilities during the global economic and financial crisis (Pérez Ruiz 2011). To remedy past flaws, EU fiscal governance is being upgraded around a number of reforms focusing on intertwined objectives. These reforms include tighter national enforcement of EU fiscal rules (implementation of the Directive on National Fiscal Frameworks under the Six-Pack and automatic correction mechanisms under the Fiscal Compact); expanded surveillance over internal and external imbalances (through the Excessive Imbalances Procedure introduced under the SixPack); and enhanced EU oversight of national budgetary processes (under the Two-Pack). Underpinned by these complementary processes, the SGP occupies a central role in the EU fiscal framework.

Both the scale and speed of consolidation in EMU countries are influenced by SGP rules. Bringing debt ratios down to safer levels will require a sustained period of adjustment. The key question is whether the pace of consolidation driven by the SGP is appropriate in the face of a weak outlook.

This chapter quantifies the output effects from fiscal consolidation as required by the SGP. To this aim, it proposes a conceptual framework in three steps. First, the analysis takes the April 2012 World Economic Outlook (WEO) as the baseline for fiscal consolidation. ${ }^{1}$ Second, the gap between fiscal plans under this baseline and the SGP targets (in structural terms) is quantified, keeping GDP at WEO levels (that is, no multiplier effects are at play). Third, using the IMF's dynamic stochastic general equilibrium model-the Global Integrated Monetary and Fiscal model (GIMF) — the output effects of that fiscal shock are simulated. In short,

Step 1: The April $2012 \mathrm{WEO}$ is used as the baseline scenario.

Step 2: The fiscal shock is quantified as

$$
\alpha_{t}=\frac{S b_{t, S G P}}{G D P_{t, W \in U}}-\frac{S b_{t, W E U}}{G D P_{t, W \in U}},
$$

\footnotetext{
This chapter is based on Euro Area Policies 2012 Article IV Consultation—Selected Issues, IMF Country Report 12/182, 2012. The authors are grateful for comments from the Directorate-General for Economic and Financial Affairs staff during the seminar held in Brussels, June 4, 2012.

${ }^{1}$ The shock and simulation results presented in this chapter take into account the fiscal plans adopted or specified in sufficient detail at the time of the elaboration of the April 2012 WEO forecasts. Since then, some countries have announced additional measures.
} 


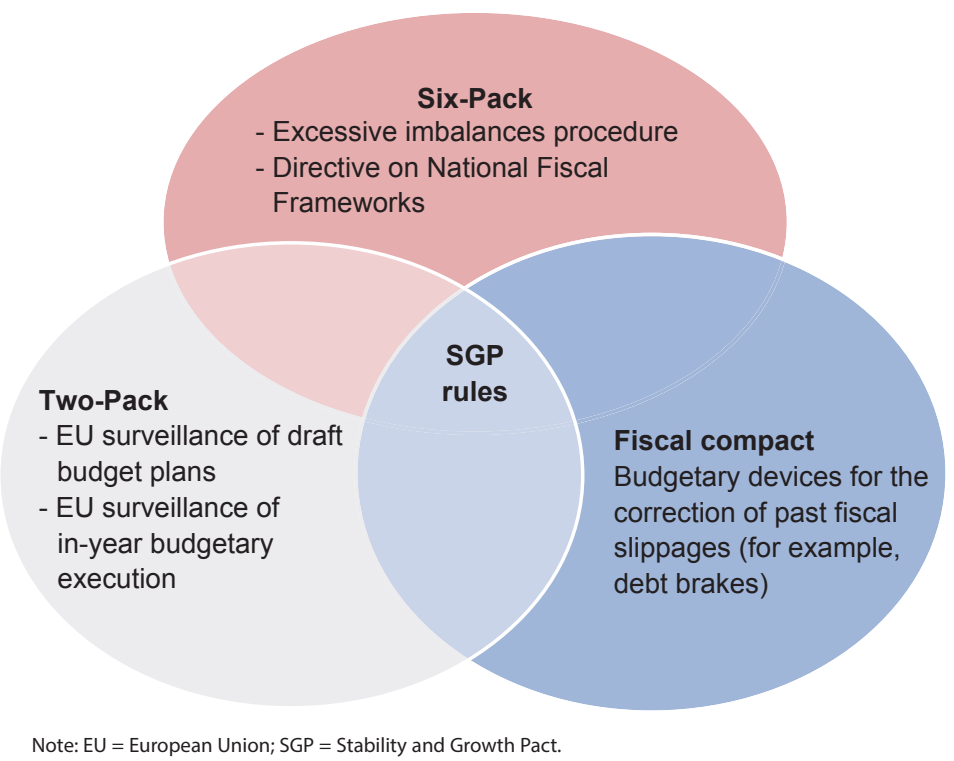

Figure 7.1 Recent European Union Fiscal Governance Reforms

in which, $\alpha_{t}$ represents the change in the structural-balance $(S b)$-to-GDP ratio relative to the fiscal consolidation path projected in the WEO, for a given GDP (at WEO values).

Step 3: The model economy is shocked with $\alpha_{t}$ and the output decline $G D P_{t, S G P}-G D P_{t, W E O}$ is quantified when multiplier effects are at work.

The rest of this chapter is organized as follows: Building on EU legislation and discussions with the European Commission during the 2012 Article IV Consultation, the second section outlines the order of prevalence between the various SGP benchmarks and quantifies fiscal consolidation needs relative to the April 2012 WEO. The third section presents the associated output loss under different sets of assumptions. The different scenarios demonstrate that the effects of fiscal consolidation depend largely on the composition and credibility of fiscal packages, as well as on the ability of monetary policy to cushion the fiscal tightening. The chapter concludes with a number of policy recommendations.

\section{A CHARACTERIZATION OF SGP REGIMES}

Since its introduction, the SGP system has become increasingly complex (Table 7.1). Countries are required to converge to the 60 percent of GDP debt benchmark; prohibited from breaching the 3 percent of GDP deficit threshold; and mandated to improve the structural-deficit-to-GDP ratio at an average rate of 0.5 percent per year. In addition, government spending is constrained to grow in line with trend GDP. These requirements raise the question of the order of prevalence between the existing rules, complicating the task of quantifying the fiscal shock implied by the SGP.

To disentangle the order of prevalence between rules, this analysis assumes the strictest criteria apply. EU regulations and discussions with the Commission suggest that where rules overlap, countries would be subject to the strictest benchmark. This direction rules out the possibility of overdetermination and makes it possible to calculate SGP consolidation paths in an unambiguous manner. 
TABLE 7.1

\begin{tabular}{|c|c|c|c|c|}
\hline \multicolumn{5}{|c|}{ EU Fiscal Rules from Maastricht to the Fiscal Compact } \\
\hline Type & Maastricht (SGP.1) & 2005 Reform (SGP.2) & 2011 “Six-Pack” Reform (SGP.3) & Fiscal Compact \\
\hline Debt rule & $\begin{array}{l}\text { Debt/GDP is reduced } \\
\text { to below } 60 \text { percent }\end{array}$ & $\rightarrow$ & $\begin{array}{l}\text { Yearly reduction in Debt/GDP equal to } 1 / 20 \text { th of } \\
\text { distance between current level and target }\end{array}$ & $\rightarrow$ \\
\hline Deficit rule & $\begin{array}{r}\text { Deficit/GDP below } 3 \\
\text { percent at any time }\end{array}$ & $\rightarrow$ & $\rightarrow$ & $\rightarrow$ \\
\hline $\begin{array}{l}\text { Structural } \\
\text { balanced } \\
\text { budget rule }\end{array}$ & $\begin{array}{l}\text { Medium-term budget } \\
\text { positions of "close to } \\
\text { balance or in surplus" }\end{array}$ & $\begin{array}{l}\text { Structural deficit/ } \\
\text { GDP to remain } \\
\text { below } 1 \text { percent }\end{array}$ & $\rightarrow$ & $\begin{array}{l}\text {...below } \\
0.5 \text { percent }\end{array}$ \\
\hline $\begin{array}{l}\text { Expenditure } \\
\text { rule }\end{array}$ & & & $\begin{array}{l}\text { Primary expenditure (excluding unemployment } \\
\text { benefits and tax discretionary increases) grows } \\
\text { less than medium-term GDP growth }\end{array}$ & $\rightarrow$ \\
\hline
\end{tabular}

Sources: IMF staff, based on the European Union treaty, Stability and Growth Pact secondary legislation, and the Fiscal Compact intergovernmental treaty.

\begin{tabular}{ll} 
TABLE & 7.2 \\
\hline \multicolumn{2}{l}{ Excessive Deficit Procedure Deadlines } \\
\hline 2012 & Belgium, Cyprus, Italy \\
2013 & Austria, France, Germany, Netherlands, Portugal, Spain \\
2014 & Greece \\
2015 & Ireland \\
\hline
\end{tabular}

Source: European Commission.

Note: Excessive Deficit Procedure deadlines by April 2012.

For the WEO horizon, this exercise assumes that compliance with the rules follows a three-stage process. All fiscal commitments are translated into deviations from the WEO for the structuraldeficit-to-GDP ratio. ${ }^{2}$ Two regime switches operate during the WEO projection period: first, from the overall to the structural deficit benchmark; and second, from the structural deficit benchmark to the debt-reduction criterion. The relevant fiscal regimes can be summarized as follows:

- Excessive Deficit Procedure (EDP) phase-Countries under the EDP by April 2012 are expected to deliver structural adjustments needed to meet the 3 percent of GDP deficit target by the requested deadlines (between 2012 and 2015; see Table 7.2).

- Grace period-An exemption from the one-twentieth debt reduction rule will apply during the three-year period following the closure of the EDP for each country. During this period, each country is expected to improve its structural balance by at least 0.5 percent of GDP each year until it reaches its medium-term objective (MTO). ${ }^{3}$

- One-twentieth debt benchmark-Beginning three years after exiting the EDP, structural balances will improve by 0.5 percent of GDP per year or more, if required by the one-twentieth debt benchmark. This benchmark ensures an annual pace of debt reduction of no less than 5 percent of the gap between the observed debt level and the 60 percent of GDP target. EU authorities will first verify compliance with the debt rule in a backwardlooking manner and then in a forward-looking manner for countries breaching the first criterion (Figure 7.2).

\footnotetext{
${ }^{2} \mathrm{GDP}$ is kept at WEO levels and Organisation for Economic Co-operation and Development budgetary semi-elasticities are used to break down the overall deficit into its structural and cyclical components.

${ }^{3}$ MTOs are country specific and updated every three to four years. MTOs applying to the 2012 EDP are 0.5 of debt for Belgium, Finland, and Luxembourg; 0 for Austria, Cyprus, Estonia, Greece, France, Italy, Malta, and Spain; -0.5 for Germany, Ireland, Netherlands, Portugal, and Slovak Republic; and -1 for Slovenia.
} 
1.

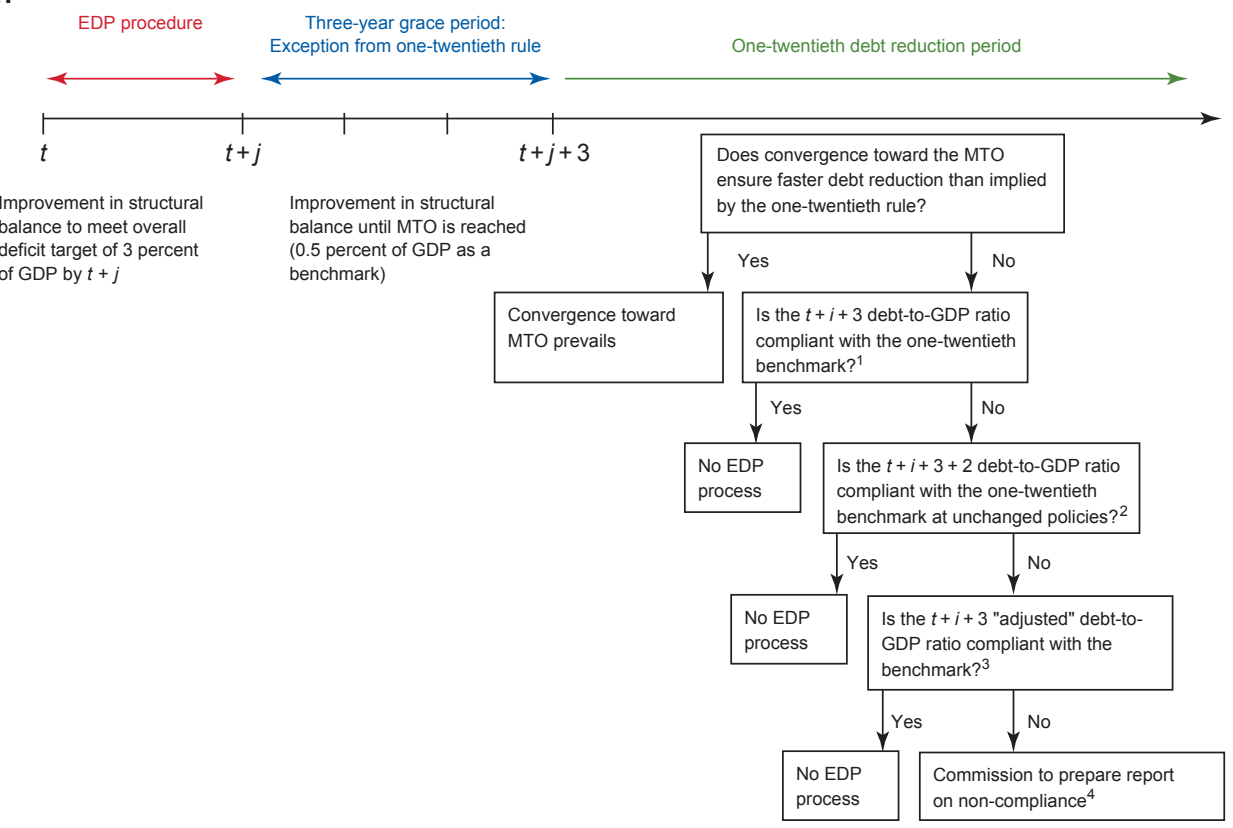

2.

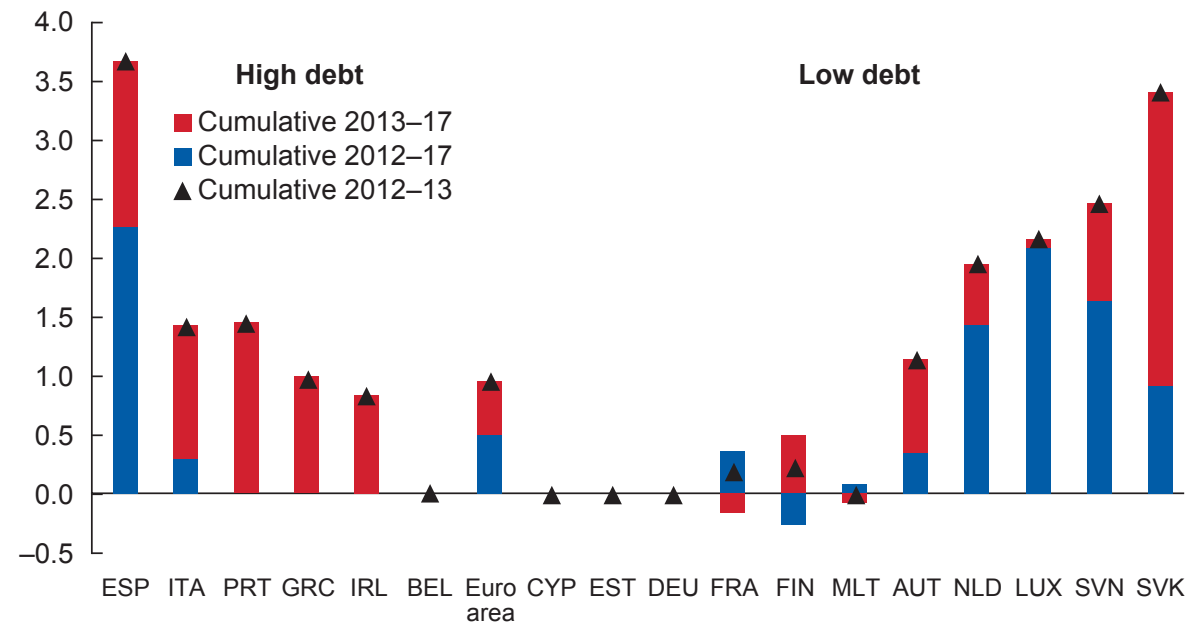

Sources: IMF, World Economic Outlook April 2012; Stability and Growth Pact regulations; and IMF staff calculations.

Note: EDP = Excessive Deficit Procedure; MTO = medium-term objective; SGP = Stability and Growth Pact; WEO = World Economic Outlook. Data labels in the figure use International Organization for Standardization (ISO) country codes.

${ }^{1}$ The benchmark is given by $\left.B_{t} / Y_{t}=60+(0.95 / 3) \times\left(B_{t-1} / Y_{t-1}-60\right)+\left(\left(0.95^{2}\right) / 3\right)\right) \times\left(B_{t-2} / Y_{t-2}-60\right)+\left(\left(0.95^{3}\right) / 3\right) \times\left(B_{t-3} / Y_{t-3}-60\right)$.

${ }^{2}$ The formula specified in footnote 1 is applied to projected debt-to-GDP ratio up to $t+i+3+2$.

${ }^{3}$ The "adjusted debt measure" is given by $B_{i} / Y_{i}=B_{t}+\sum_{0}^{2} C_{t-1} / Y_{i-3} \prod_{0}^{2}\left(1+Y_{t-1}^{*}\right)$, with $C$ the cyclical budget and $Y^{*}$ the growth rate of nominal potential GDP.

${ }^{4}$ To place a country under EDP, the report assesses risk factors such as the structure of debt, implicit liabilities related to aging, or private indebtedness.

${ }^{5}$ The High Debt group comprises Belgium, Greece, Ireland, Italy, Portugal, and Spain. The Low Debt group includes the rest of euro area countries.

Figure 7.2 Translating Stability and Growth Pact into a Fiscal Shock

\section{(C) International Monetary Fund. Not for Redistribution}


Overall, planned fiscal efforts in the euro area fall significantly short of SGP requirements. For the euro area as a whole, the additional consolidation amounts to 1 percent of GDP during 2012-17, nearly half of which would be front-loaded during 2012-13 (Figure 7.2). For the analysis in this chapter, the euro area countries are split into two blocs: those countries with acute fiscal sustainability issues (high-debt ${ }^{4}$ or $\mathrm{HD}$ ), comprising Belgium, Greece, Ireland, Italy, Portugal, and Spain, and those countries with less acute fiscal sustainability issues (low-debt or LD), comprising the rest of the euro area. Additional consolidation needs in the HD bloc (at about 2.2 percent of GDP for the WEO horizon) are five times as large as in the LD bloc (at 0.4 percent of GDP for 2012-17). Across countries, the additional fiscal effort is highest in Spain, mainly as a result of requirements under the EDP. In contrast, Belgium, Cyprus, Estonia, and Germany have no additional adjustment because the WEO path is consistently more demanding than requirements under the SGP. Among the larger euro area countries, additional consolidation is particularly front-loaded in the Netherlands and Spain.

\section{THE OUTPUT EFFECTS FROM FISCAL CONSOLIDATION UNDER THE SGP}

The output effects from fiscal consolidation requirements under the SGP vary depending on key assumptions such as the composition of the fiscal adjustment, the monetary policy stance, and the credibility of fiscal policy. To illustrate this, a number of scenarios are conducted and simulation results are inspected based on the GIMF model (country groupings) and the G35 model (country specific results).

\section{Assumptions}

The impact of fiscal tightening on economic activity will depend on the underlying simulation assumptions. First, the composition of the fiscal adjustment makes a big difference, with multipliers typically being larger for spending-based consolidations. Second, the monetary policy reaction function is an important factor because multipliers are higher when interest rates are constrained by the zero lower bound. Finally, the credibility of fiscal packages also affects multipliers through anticipation of the future benefits of consolidation. This last effect may be substantial in some cases.

In practice, however, considerable uncertainty surrounds these assumptions. Information on the composition of the adjustment on a country basis is not readily available, and predicting the time horizon over which monetary policy in the euro area will be constrained by the zero lower bound is difficult. Also, governments' credibility in delivering fiscal commitments is at stake, and risk-premium effects are inherently difficult to quantify when spreads are volatile and an increasing number of countries face punitive yields.

In the face of these uncertainties, a number of illustrative simulations are carried out. These alternatives are intended to illustrate the possible response of the economy under three different scenarios rather than aiming to accurately represent the economic reality (Table 7.3):

- Scenario 1: Myopia and growth-friendly consolidation-Under this scenario, the consolidation package is tilted toward measures that have strong effects on households' current disposable income, but little negative impact on factor supply and potential output. It is further assumed that fiscal plans are not credible per se, but rather that credibility needs to be established by action. In particular, agents do not perceive the government's commitment

\footnotetext{
${ }^{4}$ For the purposes of the simulation, the HD group includes countries with debt projected to be greater than 85 percent of GDP by 2017.
} 
TABLE 7.3

\begin{tabular}{|c|c|c|c|c|c|c|}
\hline \multicolumn{7}{|c|}{ Assumptions Underlying Stability and Growth Pact Simulations } \\
\hline Assumptions & Explanation & $\begin{array}{l}\text { Scenario 1: } \\
\text { Myopia and } \\
\text { Growth-Friendly } \\
\text { Consolidation }\end{array}$ & $\begin{array}{l}\text { Scenario 1A: } \\
\text { Scenario } 1 \\
\text { plus ZIF }\end{array}$ & $\begin{array}{l}\text { Scenario 1B: } \\
\text { Scenario } 1 \\
\text { plus Joint } \\
\text { Consolidation }\end{array}$ & $\begin{array}{c}\text { Scenario 2: } \\
\text { Credibility } \\
\text { and Growth- } \\
\text { Friendly } \\
\text { Consolidation }\end{array}$ & $\begin{array}{l}\text { Scenario 3: } \\
\text { Credibility } \\
\text { and Growth- } \\
\text { Unfriendly } \\
\text { Consolidation }\end{array}$ \\
\hline \multicolumn{7}{|c|}{ Composition of adjustment } \\
\hline $\begin{array}{l}\text { 1. Growth-friendly } \\
\text { consolidation }\end{array}$ & $\begin{array}{l}1 / 4 \text { transfers, } 1 / 3 \text { government } \\
\text { consumption, } 1 / 4 \text { labor } \\
\text { income tax, } 1 / 6 \text { consumption } \\
\text { tax }\end{array}$ & $\mathrm{x}$ & $x$ & $\mathrm{x}$ & $\mathrm{x}$ & \\
\hline $\begin{array}{l}\text { 2. Growth- } \\
\text { unfriendly } \\
\text { consolidation }\end{array}$ & $\begin{array}{l}\text { 1/4 targeted transfers, } 1 / 3 \\
\text { government investment, } 1 / 4 \\
\text { labor income, } 1 / 6 \text { corporate } \\
\text { tax }\end{array}$ & & & & & $\mathrm{x}$ \\
\hline \multicolumn{7}{|l|}{ Spillovers } \\
\hline $\begin{array}{l}\text { 3. Joint } \\
\text { consolidation }\end{array}$ & $\begin{array}{l}\text { High Debt and Low Debt } \\
\text { groups jointly consolidate }\end{array}$ & & & $\mathrm{x}$ & $\mathrm{x}$ & $\mathrm{x}$ \\
\hline $\begin{array}{l}\text { 4. Individual } \\
\text { consolidation }\end{array}$ & $\begin{array}{l}\text { Only one of the blocs consoli- } \\
\text { dates (euro area calculated } \\
\text { by simple addition disregard- } \\
\text { ing spillovers) }\end{array}$ & $\mathrm{x}$ & $x$ & & & \\
\hline \multicolumn{7}{|l|}{ Monetary policy reaction } \\
\hline $\begin{array}{l}\text { 5. Interest rates } \\
\text { unconstrained by } \\
\text { zero interest floor } \\
\text { (ZIF) }\end{array}$ & $\begin{array}{l}\text { Unconstrained reaction of } \\
\text { nominal interest rates }\end{array}$ & & $\mathrm{x}$ & $\mathrm{x}$ & $\mathrm{x}$ & $\mathrm{x}$ \\
\hline $\begin{array}{l}\text { 6. Interest rates } \\
\text { constrained by ZIF }\end{array}$ & $\begin{array}{l}\text { Nominal interest rates } \\
\text { unchanged over first } 5 \text { years }\end{array}$ & $\mathrm{x}$ & & & & \\
\hline \multicolumn{7}{|l|}{ Credibility of fiscal plans } \\
\hline 7. Myopia & $\begin{array}{l}\text { Agents do not perceive as } \\
\text { permanent the government's } \\
\text { commitment toward consoli- } \\
\text { dation; they only change } \\
\text { their beliefs ex post, once } \\
\text { they verify past fiscal mea- } \\
\text { sures remain in place }\end{array}$ & $\mathrm{x}$ & $\mathrm{x}$ & $\mathrm{x}$ & & \\
\hline $\begin{array}{l}\text { 8. Partial Ricardian } \\
\text { behavior }\end{array}$ & $\begin{array}{l}\text { Changes in the structural } \\
\text { balance are perceived as } \\
\text { permanent as of the year } \\
\text { of implementation }\end{array}$ & & & & $x$ & $\mathrm{x}$ \\
\hline
\end{tabular}

Source: IMF staff.

Note: ZIF = zero interest rate floor.

to consolidation to be permanent but rather expect measures to revert back to baseline levels in each period. However, they change their beliefs once they verify past fiscal measures remain in place. This version is meant to portray an economy in which, because of a general lack of confidence in the future, agents base their decisions on short-term considerations. With regard to monetary policy, the zero interest floor is assumed to bind during the 2012-17 period. To gauge the magnitude of spillovers, two variants of this scenario are run featuring joint and stand-alone consolidation (that is, undertaken separately by the HD and LD groups).

- Scenario 2: Credibility and growth-friendly consolidation-The assumptions mimic scenario 1 except that agents are not myopic, that is, changes in the structural balance are perceived

\section{(C) International Monetary Fund. Not for Redistribution}


to be permanent as of the year of implementation. As a result, agents incorporate the longterm benefits of the consolidation already undertaken (lower real interest rates and future debt-service costs) into their expectations. However, fiscal changes are not anticipated and do not affect behavior until they actually occur (absence of full Ricardian equivalence).

- Scenario 3: Credibility and growth-unfriendly consolidation-A variant of scenario 2, this scenario is intended to illustrate the sensitivity of the results to the composition of the fiscal consolidation, with a package biased toward high-multiplier measures. In particular, fiscal efforts are switched (1) from consumption to corporate taxes, (2) from government consumption to public investment, and (3) from general transfers to transfers targeted to households with high marginal propensities to consume. As empirical evidence shows (for example, OECD 2010 and the references therein), corporate taxes have the highest distortionary effects among revenue measures. Government investment shrinks potential output, and cuts in targeted transfers reduce the income of households whose marginal propensity to consume is equal to one.

\section{Simulation Tools and Output Effects from Additional Fiscal Consolidation}

The simulations are conducted for the two euro area country groupings using the GIMF model. ${ }^{5}$ The analysis uses a general equilibrium framework applying a six-region version of the GIMF, with the euro area split into the HD and LD blocs, the United States, Japan, emerging Asia, and a bloc encompassing the rest of the world. The GIMF models both liquidity-constrained and finite-planning-horizon households. This setup provides nonneutrality in both spending- and revenue-based measures, which makes the model particularly appropriate for analyzing the stabilization role of fiscal policy in the short term.

Country-specific effects are examined using the G35 model. ${ }^{6}$ The G35 model is an estimated structural macroeconometric model of the world economy, disaggregated into 35 national economies, including 11 euro area countries. ${ }^{7}$ Within this framework, each economy is represented by interconnected real, external, monetary, fiscal, and financial sectors. Spillovers are transmitted across economies via trade, financial, and commodity price linkages.

Even with a growth-friendly consolidation package, the output effects are sizable (Figure 7.3). Under scenario 1, output in the euro area is 1 percent lower than baseline by 2017 (Figure 7.3, panel 1). This result implies a cumulative output loss of $3 \frac{1}{2}$ percent between 2012 and 2017. The fairly large multiplier stems from negative spillovers (about 40 percent of the loss) and the inability of monetary authorities to ease the policy rate (20 percent of the loss). As expected, the HD bloc experiences the largest losses (Figure 7.3, panel 2)-1.4 percent of GDP by 2017 (cumulatively 5 percent during 2012-17) - mainly reflecting the scale of the additional fiscal adjustment required. Losses among the LD bloc of 0.8 percent by 2017 (cumulatively 3 percent during 2012-17) are largely caused by spillovers from the HD bloc (given their relatively high propensity to import from the LD countries) (Figure 7.3, panel 3). The aggregate results conceal considerable cross-country heterogeneity (Figure 7.3, panel 4). Because of contractions in domestic demand, cumulative output losses are highest in Spain (at about 10 percent), closely followed by Portugal (at almost 8 percent), largely caused by substantial spillovers from fiscal tightening in its neighboring country. Negative spillovers are also sizable in small open economies like Belgium, Finland, and Ireland. Somewhat surprisingly, Greece experiences positive spillovers from fiscal adjustment in other euro area countries. This occurs because a joint consolidation in the euro area reduces world demand for commodities and improves Greece's terms of trade. Because Greece is

\footnotetext{
${ }^{5}$ For further details on this model, see Kumhof and others (2010).

${ }^{6}$ For further details, see Vitek (2012).

${ }^{7}$ Austria, Belgium, Finland, France, Germany, Greece, Ireland, Italy, Netherlands, Portugal, and Spain.
} 
1. Euro Area: Loss in GDP (Percent deviations from WEO, 2012-17)

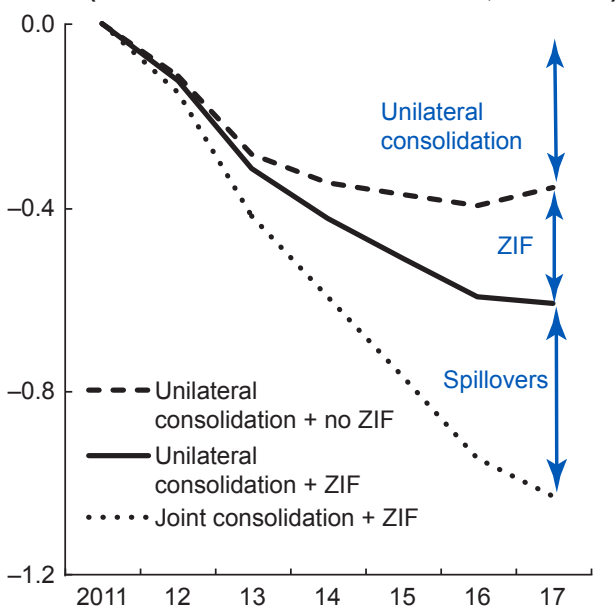

3. Low Debt: Loss in GDP ${ }^{1}$ (Percent deviations from WEO, 2012-17)

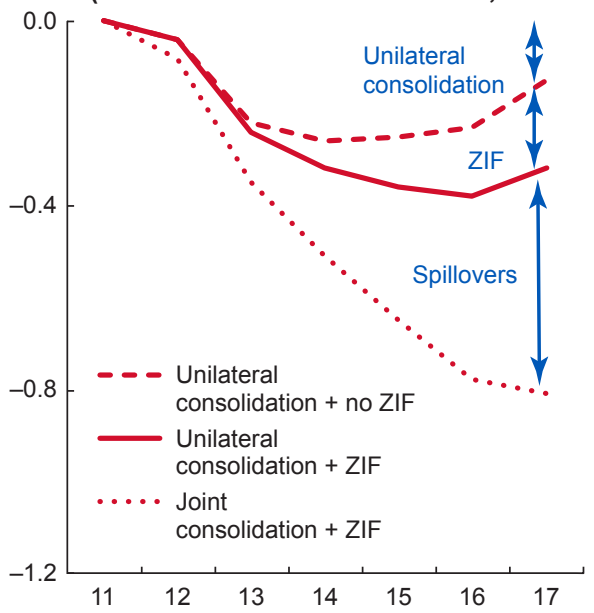

2. High Debt: Loss in GDP ${ }^{1}$ (Percent deviations from WEO, 2012-17)

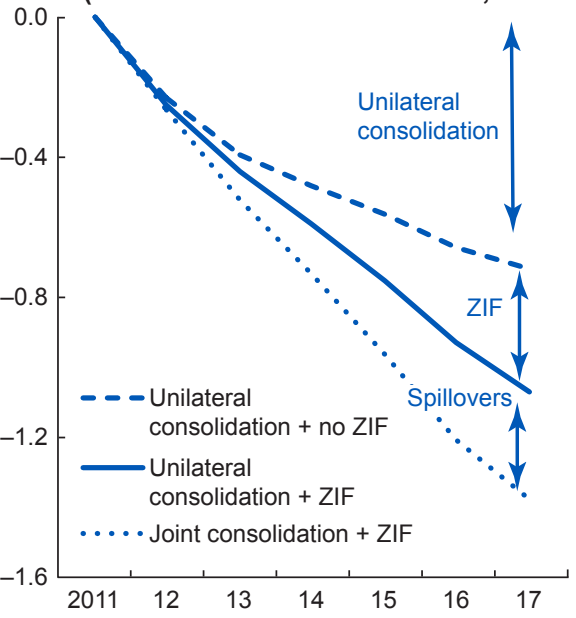

\section{Cumulative Output Losses in Selected} Countries (Percent, 2012-17)

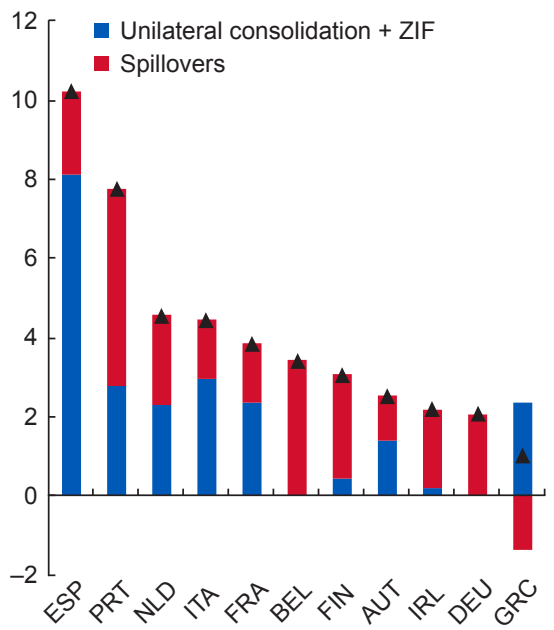

Sources: IMF, April 2012 World Economic Outlook; and IMF staff simulations carried out using the Global Integrated Monetary and Fiscal model (panels 1-3) and the G35 model (panel 4).

Note: SGP = Stability and Growth Pact; WEO = World Economic Outlook; ZIF = Zero interest floor. Data labels in the figure use International Organization for Standardization (ISO) country codes.

${ }^{1}$ The High Debt bloc comprises Belgium, Greece, Ireland, Italy, Portugal, and Spain. The Low Debt bloc includes the rest of euro area countries.

Figure 7.3 Output Effects from SGP Rules: Myopia and Growth-Friendly Consolidation

a relatively closed economy, this improvement in the terms of trade outweighs the reduction in its external demand, yielding a positive net spillover.

Multiplier effects dramatically change with credibility and fiscal composition assumptions (Figure 7.4). With myopia (scenario 1), private households and firms are so concerned with the short-term impact of fiscal retrenchment that they neglect the positive income effects arising from future lower tax liabilities when making their consumption, employment, and investment choices. For a given composition of adjustment and the zero lower bound constraint, the 2017 GDP loss in the euro area is considerably reduced if fiscal plans are credible (scenario 2), falling 


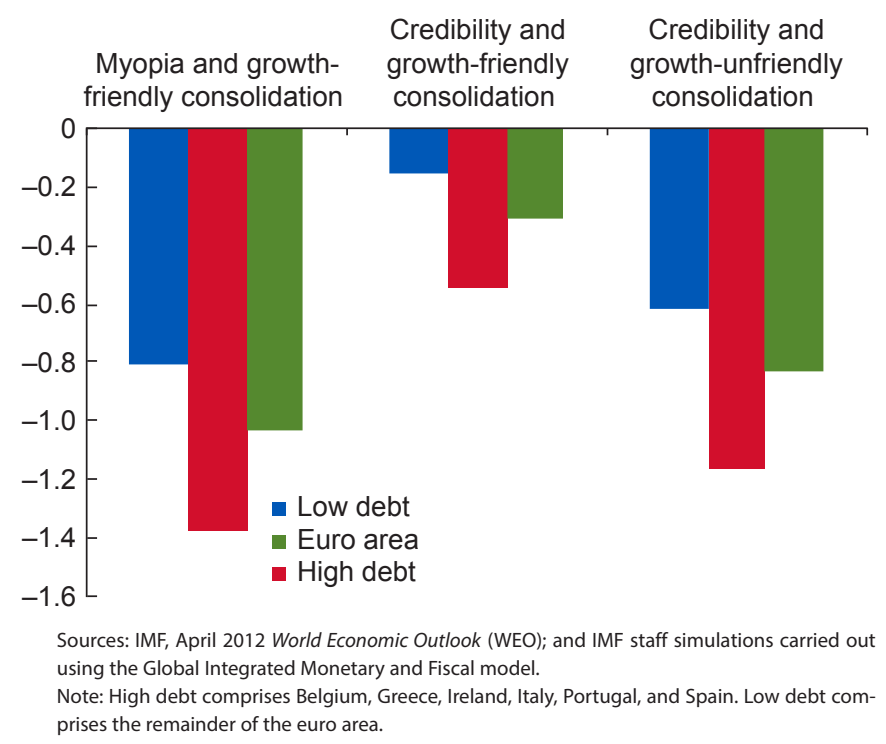

Figure 7.4 Comparing Output Losses across Scenarios (Percent deviations from WEO, 2017)

from 1 percent to 0.3 percent of GDP. However, the multiplier effect is more than doubled when consolidation remains credible but becomes growth unfriendly (scenario 3). In this case, the 2017 GDP loss in the euro area relative to the WEO amounts to 0.8 percent, compared with 0.3 under credible but growth-friendly consolidation. Cumulative losses in the euro area throughout 2012-17 amount to 1.5 percent under scenario 2 and 3.1 percent under scenario 3 .

The output decline might be higher than implied by these simulations because of the state of the economy during the crisis. Empirical work suggests that fiscal multipliers are larger when there is excess capacity (for example, Batini, Callegari, and Melina 2012; and Baum, PoplawskiRibeiro, and Weber 2012). This situation could arise from tighter credit constraints, the need to repair balance sheets, and higher precautionary savings.

\section{POLICY PERSPECTIVES: HOW CAN THE OUTPUT LOSS FROM ADDITIONAL FISCAL CONSOLIDATION BE MITIGATED?}

The SGP rules should be applied flexibly to accommodate unexpected events. The appropriate pace of consolidation should depend on the state of public finances and growth, and the monetary policy stance. Given uncertainties surrounding these developments, consolidation strategies that adjust for new information can be welfare improving. Thus, the shift of focus toward structural targets under the SGP during the crisis is appropriate.

Where financing conditions permit, the pace of fiscal consolidation should take into account adverse economic conditions. With limited scope for monetary policy to mitigate output losses from fiscal tightening, negative output gaps, and joint consolidation efforts, multipliers are likely to be larger than normal. Furthermore, multipliers might increase with the size of consolidation (Stehn and others 2011; Erceg and Lindé 2010). Therefore, to the extent that market financing remains available at reasonable rates, adjustment should occur at a steady pace defined in cyclically adjusted terms and should avoid heavy front-loading.

The composition of fiscal adjustment should be tilted toward growth-friendly measures. Where adjustment needs are very large, countries will have to act on both the revenue and the 
spending sides. However, given the high spending levels prevailing in many European countries, consolidation should focus on the spending side, targeting in particular those areas in which multipliers are low or spending is most inefficient.

Reforms that underpin credibility are essential to limiting output losses from fiscal tightening. The findings in this chapter suggest that by raising agents' expectations about the positive future income effects of consolidation, credible policies can reduce multipliers in the short term and act as a substitute for heavy front-loading. Anchoring adjustment in well-specified medium-term plans is crucial. Responsible implementation of automatic correction mechanisms under the Fiscal Compact will be important to safeguarding durable fiscal efforts.

Finally, monetary policy should accommodate the consolidation. The simulations suggest significant output losses if monetary policy does not provide support. When the zero bound is binding or if conventional interest rate cuts are less effective than normal, unconventional monetary policy stimulus may be needed.

\section{REFERENCES}

Batini, N., G. Callegari, and G. Melina. 2012. "Successful Austerity in the United States, Europe and Japan." Working Paper No. 12/190, International Monetary Fund, Washington, DC.

Baum, A., M. Poplawski-Ribeiro, and A. Weber. 2012. "Fiscal Multipliers and the State of the Economy." Working Paper No. 12/286, International Monetary Fund, Washington, DC.

Erceg, Christopher J., and J. Lindé. 2010. "Asymmetric Shocks in a Currency Union with Monetary and Fiscal Handcuffs." In NBER International Seminar on Macroeconomics 2010, ed. by R. Clarida and F. Giavazzi, 95-135. Chicago, Illinois: University of Chicago Press.

Kumhof, Michael, D. Laxton, D. Muir, and S. Mursula. 2010. "The Global Integrated Monetary and Fiscal Model (GIMF)_Theoretical Structure.” Working Paper No. 10/34, International Monetary Fund, Washington, DC.

Organisation for Economic Co-operation and Development (OECD). 2010. "Tax Policy Reform and Economic Growth.” Tax Policy Study No. 20, Paris.

Pérez Ruiz, Esther. 2011. "Strengthening Governance in the Euro Area." In "Euro Area Policies: 2011 Article IV Consultation: Lessons from the European Financial Stability Framework Exercise, and Selected Issues Paper." Country Report No. 11/186, International Monetary Fund, Washington, DC.

Stehn, S. J., J. Hatzius, D. Wilson, and S. Carlson. 2011. "The Speed Limit of Fiscal Consolidation.” Global Economics Paper No. 207, Goldman Sachs, New York.

Vitek, Francis. 2012. "Policy Analysis and Forecasting in the World Economy: A Panel Unobserved Components Approach.” Working Paper No. 12/149, International Monetary Fund, Washington, DC. 


\title{
Fiscal Governance in the Euro Area: Progress and Challenges
}

\author{
LUC EYRAUD AND TAO WU
}

The Stability and Growth Pact (SGP) is at the core of the European fiscal governance framework. The SGP's origin dates back to the 1992 Maastricht Treaty, which launched the Economic and Monetary Union (EMU). Because of the unique structure of euro area integration-with a common monetary policy but decentralized fiscal policies-fiscal rules were introduced to prevent national fiscal policies from producing negative spillovers on other countries and on the conduct of monetary policy (EC 2013a). These fiscal spillovers may take several forms, including unwanted monetary tightening to contain inflation fueled by fiscal expansion in a particular country, higher euro area-wide interest rates caused by crowding out, contagion effects, and bailout costs.

The euro area crisis has revealed gaps in the effectiveness of the fiscal governance framework and in the functioning of the monetary union. In a context of a severe economic downturn and large private sector imbalances, fiscal institutions could not prevent a dramatic surge in public debt, which was, in part, due to national public support provided to the impaired financial sector. Fiscal rules were put to the test, in particular those that did not explicitly foresee how to deal with exceptional economic circumstances (IMF 2013b). The crisis also showed that sovereigns could be priced out of the market or even lose market access altogether. It highlighted how contagion could set in, with deep recessions and fiscal stress in some member states spilling over to the rest of the membership.

Yet, weak fiscal governance is not a recent development. Most countries had built insufficient fiscal buffers in good times before the crisis hit. The windfall from lower interest and debt payments had not been saved in the early years of the EMU, and higher budget revenues generated by unsustainable domestic demand booms were wrongly deemed permanent (Allard and others 2013). In the precrisis years, individual member states did not fully take into account the potential spillovers from their idiosyncratic policies on other countries. Moreover, the European fiscal governance framework was too loosely implemented to ensure the appropriate management of public finances over the cycle. Governance failures and political interference became particularly apparent when the European Council decided to hold in abeyance the SGP's procedures in 2003.

This chapter aims to contribute to the ongoing discussions on fiscal governance in Europe. It takes stock of recent reforms, identifies areas for further progress, and presents a menu of policy options. The first section briefly reviews the underlying drivers of the public debt increase in euro area countries during the crisis. The second and third sections examine past reforms and the track record of the framework. The fourth section identifies remaining gaps in the areas of rule design and implementation. The fifth section discusses options for future reforms. The final section concludes with some considerations on reform priority and sequencing.

\section{THE SETTING: PUBLIC DEBT ON AN UPWARD TREND}

Public finances have deteriorated significantly since 2008. The average public-debt-to-GDP ratio soared to 95 percent in 2013, almost 30 percentage points higher than the precrisis level.

This chapter is based on “Playing by the Rules: Reforming Fiscal Governance in Europe," IMF Working Paper 15-067, 2015. 
TABLE 8.1

\begin{tabular}{|c|c|c|}
\hline \multicolumn{3}{|c|}{ Decomposition of Debt Changes in the Euro Area, End-2007 to End-2013 } \\
\hline & \multicolumn{2}{|c|}{ Total Changes } \\
\hline & Percentage Points & Proportion (percent) \\
\hline Increases in debt-to-GDP ratio & 28.8 & 100 \\
\hline Stock-flow adjustment & 9.4 & 33 \\
\hline Overall deficit & 19.4 & 67 \\
\hline Interest rate-growth differential & 11.6 & 40 \\
\hline Nominal GDP growth & -5.0 & -17 \\
\hline Interest rate ${ }^{1}$ & 16.6 & 58 \\
\hline Primary deficit & 7.8 & 27 \\
\hline Cyclical component & 5.3 & 18 \\
\hline CAPB & 2.5 & 9 \\
\hline One-offs & 1.3 & 5 \\
\hline Structural balance & 1.1 & 4 \\
\hline
\end{tabular}

Source: IMF staff calculation.

Note: $\mathrm{CAPB}=$ cyclically adjusted primary balance. The decomposition is applied to EA18 aggregate data. See the Abbreviations section for composition of EA18.

${ }^{1}$ Cumulative interest payments over the period.

The debt increase during the crisis was due to a combination of cyclical and discretionary factors, as illustrated by a decomposition (Table 8.1) that uses the Debt Sustainability Analysis framework (IMF 2013c).

Stock-flow adjustment residuals accounted for about one-third of the total debt increase in the euro area during the crisis. To a large extent, these residuals reflected financial sector intervention and rescue packages in the early stages of the crisis, as well as the realization of contingent liabilities (Blanchard, Dell'Ariccia, and Mauro 2013).

Fiscal deficits in European countries were another important factor behind the rapid debt increase. About two-thirds of the debt surge can be attributed to the accumulation of fiscal deficits. In particular, the interest bill was the largest contributor to the increase in debt.

The economic slowdown during the crisis added to the debt problem. In normal times, a continued economic expansion should offset the effect of interest payments and thus reduce the debt-to-GDP ratio over time (other factors being equal). However, the sharp decline in economic activity and the very sluggish recovery thereafter led to minimal increases in nominal GDP during 2008-13. As a result, the interest component dominated the changes in the interest rate-growth differential term, with a net contribution of 11.6 percentage points, or 40 percent of the total increases in the debt-to-GDP ratio.

One-fourth of the debt increase resulted from the accumulation of primary deficits over time, although the discretionary part was limited. Of the 28.8 percentage point increase in the debtto-GDP ratio since end-2007, 8.8 percentage points can be accounted for by cumulative primary deficits, more than half of which were due to changes in cyclical conditions (18 percent). The remainder reflected the accumulation of cyclically adjusted primary deficits. Further analysis reveals that a substantial part of the accumulated cyclically adjusted primary deficit can be attributed to one-off (idiosyncratic) items. The contribution of the accumulated structural balance to debt increases since 2008 was modest-about 11 percentage points for the euro area or slightly higher than 4 percent of the total debt increase.

An important lesson of this exercise is that countries should build sufficient fiscal buffers in good times to accommodate cyclical and exogenous shocks in bad times. As shown above, most of the deterioration in public finances during the crisis was not due to discretionary fiscal stimulus. It was the effect of automatic stabilizers (as revenues fell and expenditures rose in the recession) and exogenous factors (like the bailout of the banking sector or the interest bill). In essence, countries did not enter the crisis with strong enough fiscal positions to withstand such large shocks. The 3 percent of GDP nominal deficit ceiling did not prevent countries from spending

\section{(C) International Monetary Fund. Not for Redistribution}


their revenue windfalls in the mid-2000s. Partly to address this issue, the European authorities have introduced several changes in the European Union (EU) fiscal and economic governance framework since its inception.

\section{PAST REFORMS OF THE FISCAL FRAMEWORK}

The European fiscal governance system is established by a number of legal texts. The main principles are defined in the two EU treaties (the Treaty on European Union and the Treaty on the Functioning of the European Union) that lay the groundwork for the surveillance and coordination of the member states' fiscal policies. The SGP refers to the secondary legislation that implements the treaties' requirements.

Since 1997, the secondary legislation governing the SGP has been reformed several times. The first major revision, in 2005, introduced more flexibility in the procedures while improving the economic underpinning of fiscal rules. In the context of the sovereign debt crisis, the SGP was further amended in 2011 with five new regulations and one directive (the "Six-Pack") that brought numerous modifications to the framework, including new rules, new and earlier sanctions, and additional escape clauses. In 2013, fiscal governance was again strengthened. The "Two-Pack" reinforced budgetary surveillance and coordination for euro area countries, reflecting the higher risk of spillovers within the single currency area. Additional commitments were made by 25 member states through the intergovernmental Treaty on Stability, Coordination and Governance, whose fiscal provisionsreferred to as the "Fiscal Compact" - transpose elements of the SGP into national legislation.

On the whole, successive revisions of the framework have pursued five primary objectives:

- To provide stronger economic underpinnings to the framework-Fiscal rules have increasingly focused on fiscal actions rather than fiscal outcomes, the latter being affected by economic circumstances beyond the control of governments. The 2005 reform put the concepts of structural balance at center stage under both the preventive and corrective arms. In 2011, the European Commission improved the measurement of the structural effort with the introduction of the expenditure benchmark and the concept of "adjusted fiscal effort."

- To better align fiscal targets with the final debt objective - The idea, present in the initial version of the SGP, that focusing on the fiscal deficit would be sufficient to contain debt and that the debt criterion could be overlooked, proved incorrect for two reasons. First, in the absence of correction mechanisms, past fiscal slippages on the deficit were not subsequently offset and therefore piled up over time. Second, a large portion of the debt increase resulted from stockflow adjustments (such as bank recapitalization) that were not captured by the deficit target. These elements led to a renewed focus on public debt, with the one-twentieth debt-reduction benchmark becoming a possible trigger of the Excessive Deficit Procedure (EDP) in 2011.

- To strengthen enforcement mechanisms-Successive reforms have stepped up enforcement in several ways: (1) by fostering ownership of the supranational framework by transposing some rules at the national level and better integrating supranational surveillance within the national budget calendar to ensure that the European Commission's recommendations could be incorporated into national budgets and policies; (2) by introducing earlier and stronger sanctions-late sanctions were found to be not credible and counterproductive; and (3) by entrusting independent institutions such as fiscal councils to monitor fiscal rules.

- To implement fiscal rules with more flexibility-Another lesson from past experience is that rules that are too rigid and do not foresee how to deal with exceptional economic circumstances are often disputed and quickly suspended. To mitigate this risk, some flexibility was brought to the initial framework by extending the scope of escape clauses and allowing deviations from targets when structural reforms are adopted, provided that these reforms entail short-term budgetary costs and long-term gains. 
- To bring more specificity to the definition of the rules—Rules that are vague or ambiguous are difficult to implement. This was a major criticism of the initial debt criterion, which did not include any metric to assess whether debt was "sufficiently diminishing." Successive reforms improved the measurability and specificity of the rules, including the definition of medium-term objective (MTO), the quantification of annual fiscal effort, and the pace of debt reduction. Another important step was the recognition that some rules needed to be differentiated across member states to reflect diverse debt sustainability concerns. In 2005, the MTO became country specific, with the formula taking into account the debt level and prospective population aging costs of the country.

\section{TRACK RECORD UNDER THE SGP}

Although successive reforms have brought many positive elements to the framework, they have not been sufficient to prevent a steady deterioration in public accounts. Under the SGP, noncompliance has been the rule rather than the exception. Nearly all euro area economies have breached at least one of the fiscal rules. Figure 8.1 compares fiscal outturns with SGP targets or ceilings since the adoption of the euro. ${ }^{1}$
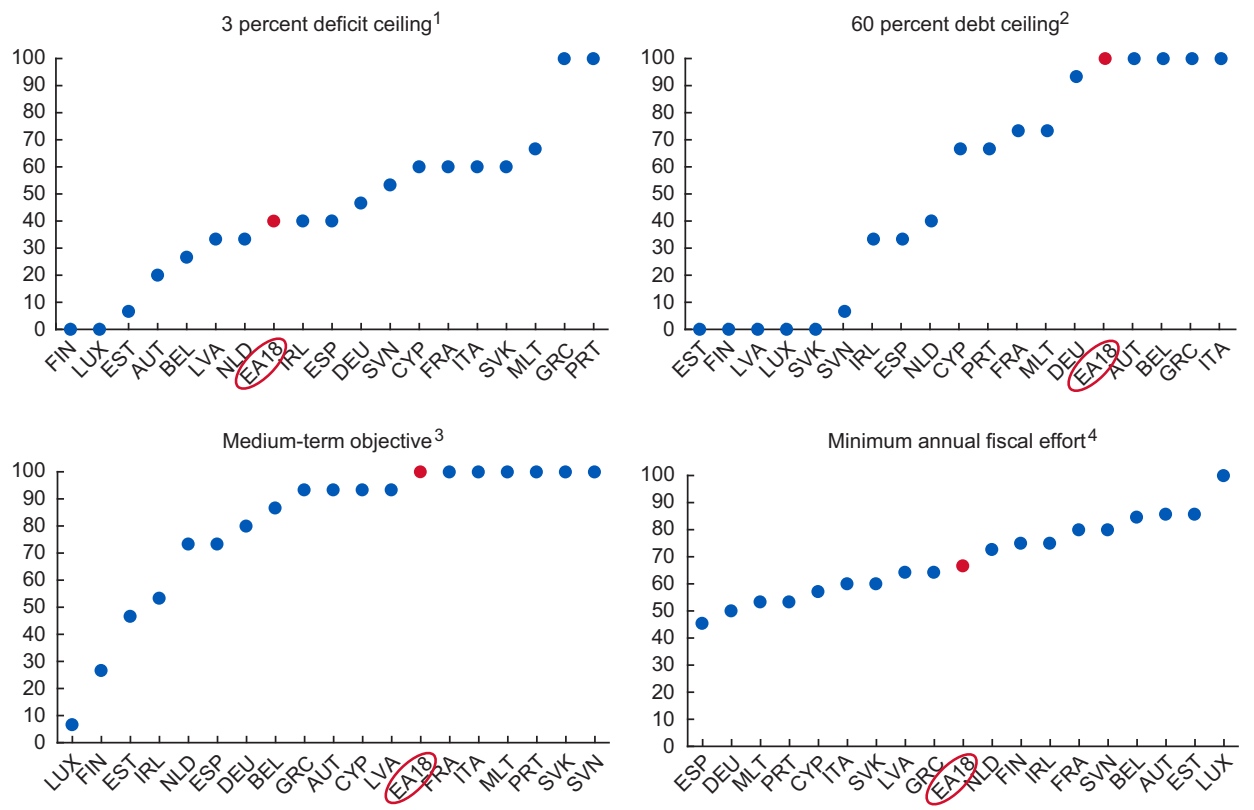

Source: European Commission Annual Macroeconomic Database.

Note: Not all member states had to comply with the rules over the whole period, because some countries joined the Economic and Monetary Union after 1999. See Abbreviations section for countries and composition of EA18.

${ }^{1}$ Number of years with fiscal deficit greater than 3 percent divided by total number of years.

${ }^{2}$ Number of years with debt greater than 60 percent divided by total number of years.

${ }^{3} \mathrm{Number}$ of years with structural deficit greater than 0.5 percent divided by total number of years.

${ }^{4}$ In the subset of years with structural deficit greater than 0.5 percent, share of number of years with annual fiscal effort less than 0.5 percent of potential GDP. Fiscal effort is defined as the change in the structural balance.

Figure 8.1 Noncompliance with European Fiscal Rules

\footnotetext{
${ }^{1}$ This simplified exercise should not be considered a formal test of compliance because (1) it is based on ex post data, (2) targets are assumed to be similar across countries and constant over time, and (3) the comparison is carried out for all 18 euro area countries, including those that adopted the euro after 1999.
} 


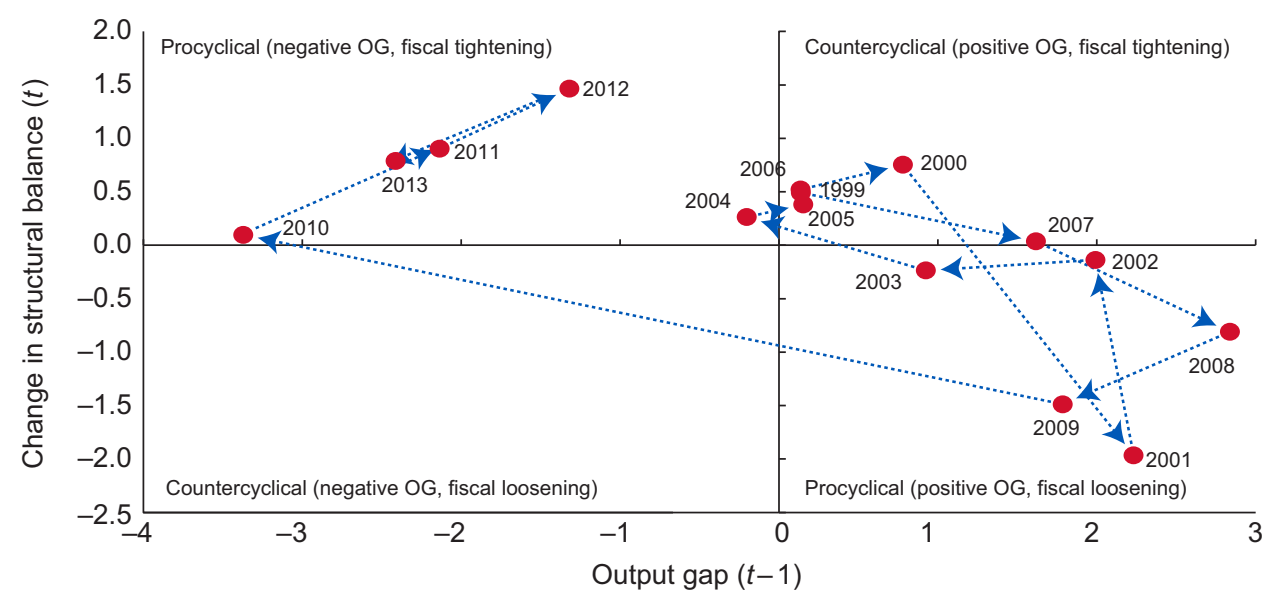

Source: European Commission Annual Macroeconomic Database.

Note: $\mathrm{OG}=$ output gap. The figures uses the previous year output gap to mitigate the feedback effect from the fiscal stance to the output gap. Using the current output gap, which is directly impacted by the fiscal actions taken in the same year, would complicate the results' interpretation. For instance, the 2009 data point relates the 2008 output gap to the change in the structural balance in 2009 relative to 2008.

Figure 8.2 Structural Balance and Output Gap (Euro area aggregate; ex post output gap data)

Compliance has been the highest with the 3 percent deficit ceiling. Most countries have complied with this target during the pre-crisis period (1999-2007). Based on ex post data, Greece and Portugal have failed to keep their deficits to less than 3 percent of GDP every year since they joined the euro.

About half of the countries have missed the 60 percent debt ceiling target more than half of the time. At the member state level, compliance with the 60 percent rule has been uneven, with smaller countries being, on average, more compliant. At the level of the euro area as a whole $\left(\mathrm{EA} 12\right.$ or EA $18^{2}$ ), public debt has been higher than 60 percent of GDP every year since 1999.

Structural deficits have been persistent, reflecting difficulties in building buffers in good times. Compliance with the "close to balance position" has been extremely rare, except in Finland and Luxembourg. In the EA18 as a whole, there has not been a single year with a structural deficit of less than 1 percent of potential GDP. The preventive arm has failed to encourage the buildup of sufficient buffers in good times. Although the output gap was positive or close to zero from 1999 through 2008, the structural balance recorded, on average, a deficit of 2.5 percent in the euro area. Beyond the absolute level, what is striking is the response of the structural position to the output gap (Figure 8.2). During the period 1999-2013, the euro area as a whole had a tendency to tighten (loosen) the structural stance by about 1 percentage point following a year with a negative (positive) output gap. ${ }^{3}$ At the member state level, the correlation between the change in the structural balance and the initial output gap is also negative (except in Finland and Luxembourg), suggesting that the fiscal stance was procyclical over the period. ${ }^{4}$

Had the euro area pursued a more countercyclical fiscal stance in the first decade of the EMU, it would have entered the crisis in a far stronger position. Figure 8.3 presents the results of a simulation assuming that the euro area follows a simple countercyclical rule from 1999 to 2008 - with the structural position improving (decreasing) by 0.5 percent of GDP when the

\footnotetext{
${ }^{2}$ See Abbreviations section for composition of euro area 12 (EA12) and EA18.

${ }^{3}$ Years with a small output gap (between -1 and +1 ) are excluded from the average.

${ }^{4}$ The negative correlation is also observed with real-time output gap data (extracted from stability programs).
} 


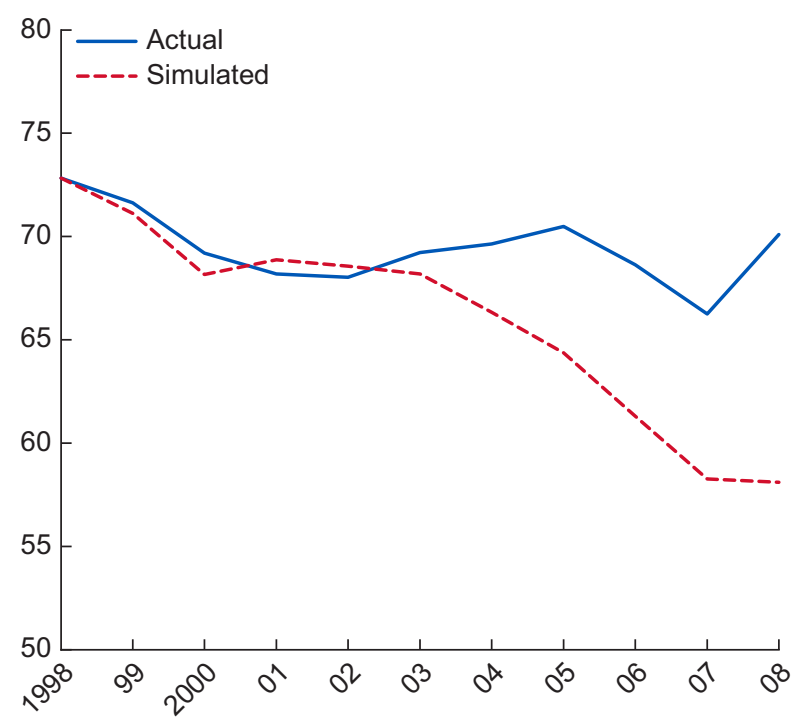

Sources: European Commission Annual Macroeconomic Database; and IMF staff calculations.

Note: Calculations based on ex post output gap data.

Figure 8.3 Public Debt (Percent of GDP; 1998-2008)

previous year's output gap is positive (negative). ${ }^{5}$ The simulation is based on EA18 aggregate data. A fiscal multiplier of 1 (declining to 0 in five years) is used to estimate the GDP effect of the implicit fiscal shock corresponding to the difference between the structural positions in the baseline and in the scenario. The main finding is that the euro area would have entered the crisis with a neutral (that is, balanced) structural position and with a debt ratio of about 60 percent of GDP_about 10 percentage points below the actual 2008 level. ${ }^{6}$

\section{PENDING ISSUES AND AREAS FOR FURTHER PROGRESS}

The implementation of the SGP has exposed gaps in both the design of the rules and enforcement mechanisms. The first three parts of this section identify and discuss design-related issues; the last part focuses on key dimensions of implementation.

\section{The Growing Complexity of the Framework}

By successively layering new constraints and procedures on top of old ones, the European framework has become very complicated with a greater risk of overlaps and inconsistencies between rules.

\footnotetext{
${ }^{5}$ The simulation assumes that the structural stance is unchanged when the output gap is small (between -1 and +1 percent).

${ }^{6}$ Using real-time output gap data would not fundamentally change this result. The downward bias of the output gap concerns its level rather than its first difference (Balassone and Kumar 2007). There is little reason to think that the annual structural effort would be reduced if countries based their fiscal decisions on real-time (rather than ex post) output gap data.
} 
Constraint

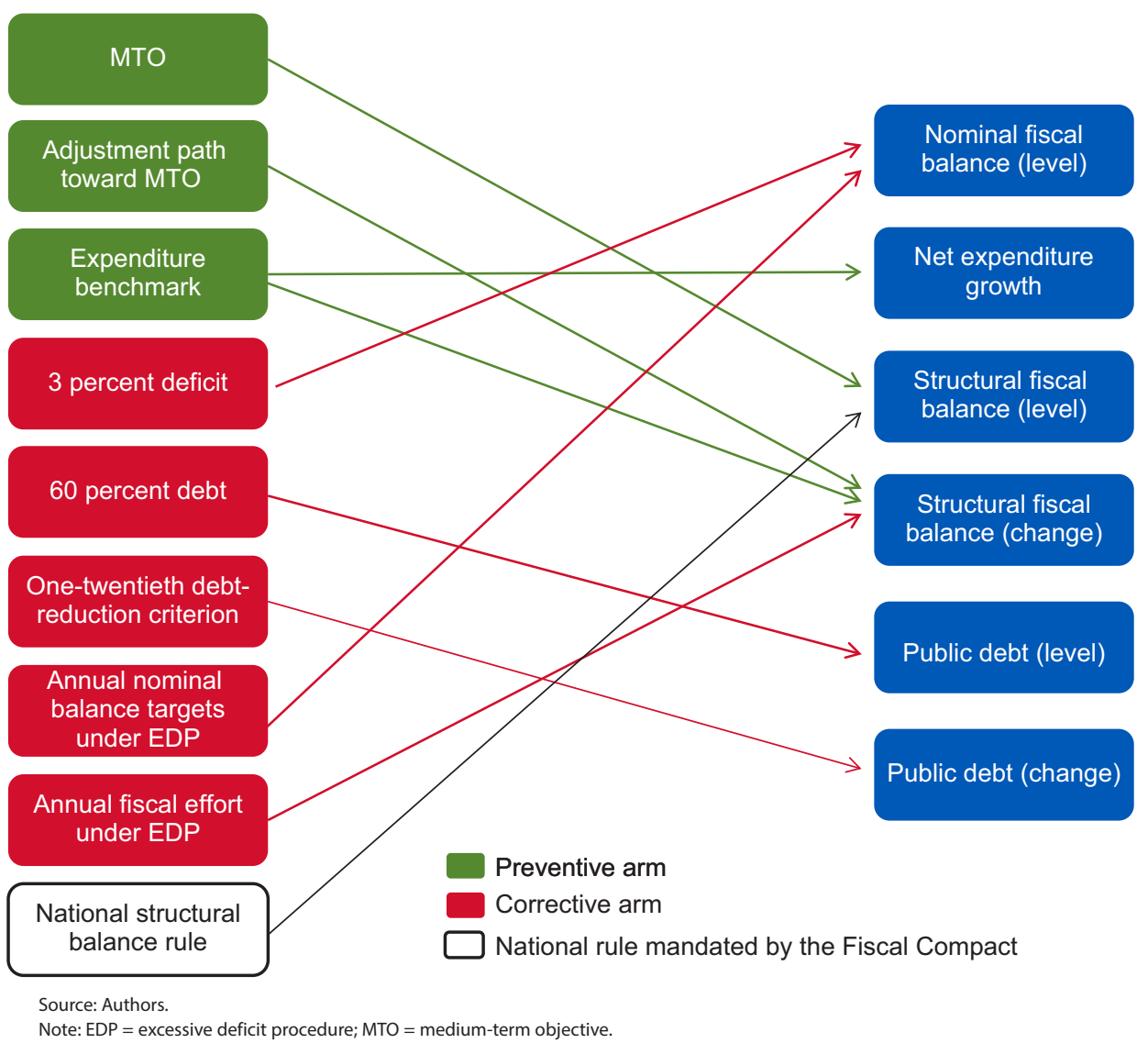

Figure 8.4 Supranational Constraints and Rules on Fiscal Aggregates

\section{Successive legislative changes have made the SGP increasingly complex}

The growing complexity of the system is rooted in the history of the SGP. The initial pact only included three supranational rules, of which only one was truly binding. ${ }^{7}$ Later, the fiscal crisis and the unsuccessful experience with a small set of constraints prompted the adoption of additional rules-some of them to address the shortcomings of previous ones (for example, the structural balance supplementing the nominal deficit ceiling). More complex rules were also introduced as a way to ensure enforcement in a wide range of circumstances; for instance, the structural balance rule and expenditure benchmark were seen as effective tools to prevent lax policies in good times. Another explanation for the proliferation of supranational rules is the relative paucity of self-imposed national rules, particularly in the initial years. ${ }^{8}$ Finally, political factors also played a role, with the mutual lack of confidence leading member states to overspecify rules and procedures.

As of 2014, fiscal aggregates are tied by an intricate set of constraints, which makes the monitoring and communication of the rules more difficult. Both the preventive and corrective arms impose constraints on member states' fiscal targets (Figure 8.4). Countries are required to

\footnotetext{
${ }^{7}$ The initial rules were the 60 percent debt cap, the 3 percent deficit ceiling, and the requirement that medium-term budget positions should be "close to balance or in surplus."

${ }^{8}$ In the mid-1990s, there was, on average, only one national rule per country in the European Community.
} 
converge toward the 60 percent of GDP debt target at a sufficient pace; prohibited from breaching the 3 percent of nominal GDP deficit threshold; and mandated to improve the structuraldeficit-to-GDP ratio at an average rate of 0.5 percent per year until they reach their MTO. In addition, government spending (net of new revenue measures) is constrained to grow in line with trend GDP. When countries are under EDP, they are also subject to specific nominal and structural balance targets. Finally, the Fiscal Compact, signed by 25 member states, requires contracting parties to ensure convergence toward their MTOs by means of a national rule, whose specification and scope may be slightly different from the MTO's.

\section{The high number of rules and subrules creates risks of overlap and inconsistency}

Compared with most federations, the EU imposes a larger set of constraints on subnational governments. In a sample of 13 federations, Eyraud and Gomez (2014) find that the federal level imposes, on average, two constraints on subcentral governments (states and substate entities), compared with five in the euro area. ${ }^{9}$ In Canada, the United States, and Switzerland, no federal restrictions are placed on subcentral fiscal targets. In addition, most European rules include restrictions on both the level and the first difference of fiscal targets, the second restriction being conditioned on the breach of the first one. Fiscal rules are, thus, implemented in stages. For instance, when countries do not comply with the 60 percent debt ceiling, a constraint on debt changes-the one-twentieth rule-applies. Similarly, if a member state's structural deficit is higher than its MTO, it has to improve its fiscal position by 0.5 percent of GDP per year in structural terms. Corrective actions and sanctions are also progressive, becoming more stringent when the target in level is breached and efforts to correct the imbalance are deemed insufficient. This multistep approach-probably motivated by the relative weakness of enforcement tools and the desire to make peer pressure more effective-is nonexistent in the federations reviewed by Eyraud and Gomez (2014). Overall, the large number of primary and secondary rules may result in redundancy and inconsistency.

Specifically, the complexity of the framework creates a number of policy risks:

- Revisions to medium-term growth have weakened the link between deficit and debt ceilings. The 3 percent nominal deficit rule was initially set to stabilize and cap public debt at 60 percent of GDP (under the assumption of 5 percent nominal growth); however, downward revisions to potential growth, which is currently estimated to be about 3 percent in nominal terms in many euro area countries, suggest that debt would actually converge toward 100 percent of GDP. ${ }^{10}$

- A second issue is the overlap and potential redundancy between structural and nominal targets. Provided that it is measured accurately, the MTO, which is a structural balance target, is generally more binding than the other rules (abstracting from the distinction between preventive and corrective arms). It does not come as a surprise that the MTO dominates the 3 percent nominal deficit rule, given that the output gap rarely deteriorates beyond 5 percent ${ }^{11}$ - a situation that would, in any case, lead to a temporary suspension of the fiscal rule framework. Also, the MTO typically brings the fiscal balance above the

\footnotetext{
${ }^{9}$ Given the complexity of the European framework, the counting of rules is a matter of judgment. In this chapter's authors' view, the framework has four main supranational rules - the 3 percent deficit rule, the 60 percent debt rule, an expenditure benchmark, and MTOs defined in structural terms. It also requires countries to enshrine a structural balance rule in national legislation.

${ }^{10}$ The debt-stabilizing overall balance is computed as $d \times g /(1+g)$, in which $d$ denotes the debt-to-GDP ratio and $g$ the potential growth in nominal terms (Escolano 2010).

${ }^{11}$ With a budget semi-elasticity of 0.5 and a structural deficit of up to 0.5 percent of potential GDP, a 3 percent nominal deficit appears if the output gap deteriorates to 5 percent: $-0.5 \approx-3-0.5 \times(-5)$.
}

\section{(C)International Monetary Fund. Not for Redistribution}


debt-stabilizing level, resulting in a steady reduction in the debt ratio. ${ }^{12}$ Simulations show that this pace of reduction is sufficient to either reduce public debt to less than 60 percent by the end of the forecast period or, if the debt is greater than 60 percent, comply with the one-twentieth debt benchmark in its backward-looking version. ${ }^{13}$

- Another form of inconsistency may arise between national and supranational rules. The Fiscal Compact requires some supranational requirements — in particular the MTO — to be transposed into national legislation to strengthen compliance and ownership. This may create inconsistencies if a target or procedure is defined differently by the national and supranational legislation (although the latter can generally be amended). A similar issue may arise with the path toward the MTO, because the preventive arm requires a minimum annual effort of 0.5 percent of potential GDP, which may differ from the correction mechanism imposed by national rules. Deadlines for achieving the targets and escape clauses may also not match exactly.

\section{The Difficult Migration from Nominal to Structural Balance Targets}

Nominal balance rules have serious shortcomings. Although the 3 percent deficit ceiling leaves sufficient room for automatic stabilizers to operate under normal circumstances, ${ }^{14}$ it does not prevent and may even encourage a procyclical fiscal stance. During the past decade, the deficit ceiling allowed for fiscal expansion during the precrisis boom (for example, in Spain) and called for politically difficult tightening when the global economy weakened in 2011-13. The drawbacks of the nominal deficit ceiling are particularly apparent when the economy is booming-it is compatible with very large structural deficits. For instance, when current output is 4 percent above potential, ${ }^{15}$ a 3 percent deficit would translate into a structural deficit of 5 percent, which would be seen as unsustainable in most countries. A second issue is that the deficit ceiling does not prevent a structural medium-term drift of public finances. As discussed previously, a 3 percent deficit would bring public debt toward 100 percent of GDP (under the assumption of 3 percent nominal growth). Other shortcomings of the rule are that the ceiling is identical for all countries - unrelated to their debt levels and growth potential; it creates incentives for creative accounting and idiosyncratic measures; and it does not capture stock-flow adjustments, which accounted for about 33 percent of the euro area debt increase during the recent crisis (see Section "The Setting: Public Debt on an Upward Trend").

The structural balance, which has been central in the EU framework since the 2005 reform, addresses some of these issues. Its computation entails decomposing the fiscal position into two parts: one representing the fiscal response to economic activity and other transitory factors, and another measuring the policy stance. A first advantage of the structural balance is that this indicator is a tractable fiscal target, which is more directly under the control of governments than the nominal balance. Its changes should, in principle, be mapped directly to discretionary fiscal measures. In addition, the structural balance helps policymakers take a more medium-term perspective rather than attempting to fine-tune fiscal policy; if a country pursues a predetermined structural position, it does not have to offset cyclical factors and can let automatic stabilizers operate. For this reason, the structural balance entails a more binding fiscal stance in good

\footnotetext{
${ }^{12}$ With an initial debt of 95 percent of GDP (average of the euro area in 2013) and nominal growth of 3 percent, the debt-stabilizing nominal deficit is about 3 percent of GDP. Because a structural deficit of less than 0.5 percent would generally translate into a nominal deficit of less than 3 percent, the debt ratio would decline.

${ }^{13}$ Simulations are not reported in the chapter but are available from the authors upon request.

${ }^{14}$ Provided that the country's structural position is close to balance and the negative output gap is not excessively large.

${ }^{15}$ Current output 4 percent above potential corresponds to the average of the peak output gaps in euro area countries since 1995 (excluding Estonia and Latvia, which are outliers).
} 


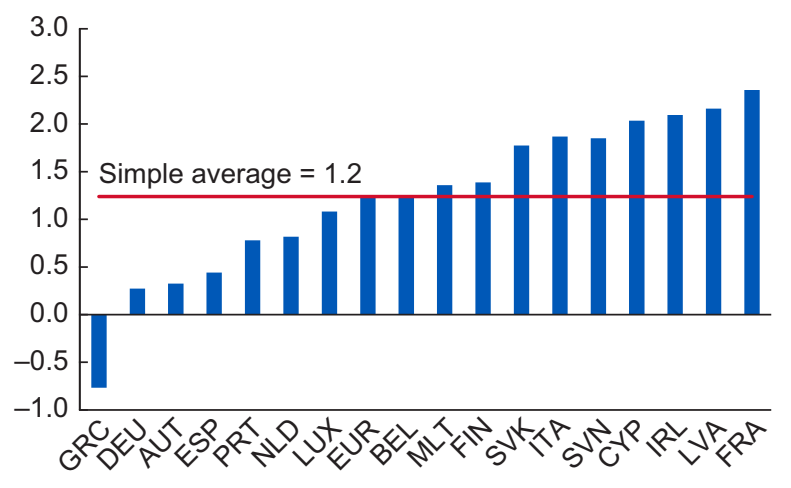

Sources: European Commission Annual Macroeconomic Database for after-the-fact data; and stability programs for real-time estimates.

Note: Data labels in the figure use International Organization for Standardization (ISO) country codes.

Figure 8.5 Real-Time Estimation Error of the Output Gap (Difference between ex post and real time data; 2003-13)

economic times (relative to the overall balance), while allowing some room for maneuver when the economy is weak. This feature is particularly important in Europe, where countries struggled to save revenue windfalls before the crisis (Lemmer and Stegarescu 2009). A third advantage of the structural balance target (as defined in the European framework) is that the MTO is country specific and takes into account debt levels and population aging costs. The formula for the MTO "reference value" is designed to ensure that member states are on course toward sustainable debt positions (EC 2013b).

However, computing structural budget balances is difficult and subject to significant errors. Specifically, the structural balance is prone to ex post revisions resulting from the measurement bias of potential GDP. Even when it is measured on the production side, potential output calculations typically involve the use of statistical filters that give excessive weight to the most recent observations and result in frequent revisions - an issue described as the "end-point bias." In the euro area, real-time output gaps are found to be underestimated, on average, by about 1 percent compared to ex post data (Figure 8.5). ${ }^{16}$ These revisions suggest that the structural balance is initially overestimated by half a percent of potential output - under the assumption of a budget semi-elasticity of 0.5 . In other words, a structural balance rule relying on real-time estimates would tend to allow deficits exceeding ex post their targeted values by about 0.5 percentage point per year. Without a correction mechanism, relying on this rule would produce a permanent drift of public finances. This problem affects all structural stance indicators of the European framework, including the expenditure benchmark.

Another issue is the difficulty of extracting the nondiscretionary component of revenue. The standard methodology filters out cyclical movements by using constant elasticities of revenue to the output gap. However, this method is not always sufficient to remove all cyclical factors. The business cycle is the most prominent source of macroeconomic fluctuations, but such fluctuations can arise from other disturbances, such as boom-and-bust cycles of asset or commodity prices and changes in the composition of output. To address this issue, the calculation of the structural balance has evolved in two distinct directions. The first approach adjusts the structural balance formula beyond the output gap. New structural balance indicators have been developed

\footnotetext{
${ }^{16}$ This result is consistent with Kempkes (2012), who finds that in the EU15 sample, the output gap was underestimated by 1 percent, compared with final estimates for 1996-2011. (See Abbreviations section for composition of EU15.)
} 
to correct for a broader range of macroeconomic fluctuations, but they add further complexity to the concept (Bornhorst and others 2011). In this vein, the "adjusted fiscal effort" used in the corrective arm explicitly corrects for revenue windfalls or shortfalls unrelated to the economic cycle. The second approach, which is pursued with the expenditure benchmark, ${ }^{17}$ consists of measuring discretionary revenues through a bottom-up approach that uses budget estimates of tax measures mandated by law. Although this second approach is conceptually more appealing, the estimation faces practical difficulties, in particular in the definition of the unchanged policy scenario.

Despite these issues, the focus on the structural balance remains appropriate. Although this indicator imperfectly filters out asset and commodity price cycles, it is still more "accurate" than the nominal balance, which does not extract these factors at all. In addition, the output measurement error is usually significantly lower than the "noise" created by the cyclical component of the nominal balance. An empirical analysis shows that, if the nominal balance is used to measure the underlying fiscal position, the error is about 25 percent higher than with the real-time structural balance. The gap is particularly large at the peaks and troughs of the cycle. Finally, the output gap measurement error is less of an issue when structural indicators are expressed in first-difference (see section "Should the Current System of Fiscal Rules Be Simplified (and if So, How)?").

Measurement issues point to the need to further improve the methodological underpinnings of the concept. They may also explain the proliferation of structural indicators in the European framework. Currently, the European Commission maintains four alternative measures of the structural stance (the structural balance and expenditure benchmark in the preventive arm; and the observed and adjusted fiscal efforts in the corrective arm) and has recently proposed a fifth one-discretionary fiscal effort (EC 2013c). All these indicators differ in their specification and purpose, reducing the transparency of the system and creating risks of conflicting messages and assessments.

\section{Reconciling Fiscal Sustainability and Growth Objectives}

As its name suggests, one purpose of the SGP is to foster growth. In a difficult balancing exercise, the European framework tries to achieve two potentially conflicting goals: leaving sufficient space for member states to offset asymmetric shocks with fiscal instruments, while ensuring that they do not take advantage of the single currency to free ride on collective discipline and build unsustainable fiscal positions. In light of the lackluster growth performance of the euro area since the 1990s, some have argued that the balance has tilted toward sustainability at the expense of growth. For instance, the focus on fiscal sustainability may have fostered adjustment strategiessuch as cuts in public investment or tax hikes-that are detrimental to long-term growth.

A first question is whether the SGP leaves sufficient room for macroeconomic stabilization. Stabilization may take the form of automatic stabilizers or discretionary fiscal policy. Regarding the first type, it seems that the SGP provides adequate margins. With a budget semi-elasticity of 0.5 and a structural deficit of 0.5 percent, a deficit ceiling of 3 percent is compatible with full operation of automatic stabilizers in downturns up to a negative output gap of 5 percent. In other words, the SGP does not compel countries to offset cyclical variations in spending and revenue unless the crisis is exceptionally severe-in which case the escape clause would probably be triggered and fiscal rules held in abeyance. The second issue is more difficult and controversial because not all agree that stabilization should involve discretionary fiscal policy. It is often argued that the SGP impairs the ability to conduct countercyclical policy, in particular in downturns. Admittedly, the lower limit of the MTO $(-0.5$ percent as a general rule, and -1.0 percent in

\footnotetext{
${ }^{17}$ The expenditure benchmark, which is net of revenue measures, is conceptually equivalent to the structural balance (EC 2013b).
} 


\section{BOX 8.1. The Trade-Off between Fiscal Consolidation and Structural Reforms}

Structural reforms are generally successfully implemented in countries with healthy initial fiscal positions or that implement fiscal stimulus (IMF 2004; Beetsma and Debrun 2004; Høj and others 2006). Conversely, fiscal consolidation tends to coexist with a slower pace of structural reforms.

Several explanations have been advanced to explain why consolidation and reforms rarely coexist in practice:

- Political capital is limited and governments that are too ambitious in pursuing reforms are not reelected.

- Some structural reforms have large short-term budgetary costs. These costs can be direct, such as funding a public research and development program. But there are also indirect costs-in particular the cost of compensating the losers. These costs make it more difficult to simultaneously reform and consolidate.

- Structural reforms tend to yield fewer benefits when the economy is weak. For instance, when demand is depressed, relaxing employment protection may not stimulate job creation. Or increasing the retirement age may just raise the number of unemployed. For this reason, Barkbu, Rahman, and Valdés (2012) recommends that structural reforms be complemented by policies to boost aggregate demand.

- The combination of structural reforms and fiscal consolidation should be avoided when it is likely to produce hysteresis effects.

low-debt countries) leaves little room for fiscal relaxation if the initial position is balanced. However, the preventive arm includes two economic downturn escape clauses, which authorize temporary deviations from the MTO or the path toward it. ${ }^{18}$ Therefore, a more relevant question is whether the 3 percent deficit ceiling (rather than the MTO) constrains the scope for fiscal stimulus. In a "normal" downturn corresponding to an output gap of -2 percent, a 3 percent deficit would correspond to a structural deficit of 2 percent, leaving some room for discretionary actions if the initial position is close to balance.

By focusing on annual or short-term constraints, the SGP may reduce incentives to introduce structural reforms and foster long-term growth. The experience of past fiscal adjustments suggests that there may be a trade-off between fiscal adjustment and structural reforms (Box 8.1). The 2005 reform of the SGP explicitly recognized this trade-off, by allowing temporary deviations from the MTO in the preventive arm and flexibility in the EDP for countries introducing some reforms. However, in practice, the current framework only applies to pension reforms, whose short-term budgetary cost and long-term impact on public finances are well understood and estimated. Going beyond pension reforms is a matter of current debate. The literature on the budgetary impact of structural reforms does not provide much guidance. Empirical studies do not find significant effects of broad reforms on the cyclically adjusted deficit (Giorno, Hoeller, and van den Noord 2005; Heinemann 2005; Deroose and Turrini 2006). Nonetheless, some evidence suggests that some specific reforms have large and measurable short-term costs. For example, the budgetary cost of active labor market policies, as estimated by the OECD databases, exceeds 1 percent of GDP in some countries. ${ }^{19}$ In light of the mixed evidence, further research should be conducted, perhaps focusing on particular structural measures and trying to address measurement issues. Another issue is that many structural reforms remain little more than policy announcements.

\footnotetext{
18 "In the case of an unusual event outside the control of the Member State concerned which has a major impact on the financial position of the general government or in periods of severe economic downturn for the euro area or the Union as a whole, Member States may be allowed temporarily to depart from the adjustment path towards the medium-term budgetary objective referred to in the third subparagraph, provided that this does not endanger fiscal sustainability in the medium term" (EC, 2013b).

${ }^{19}$ The OECD database on Public Expenditure and Participant Stocks on LMP is available at www.oecd.org/els /employment/almp.
}

\section{CInternational Monetary Fund. Not for Redistribution}




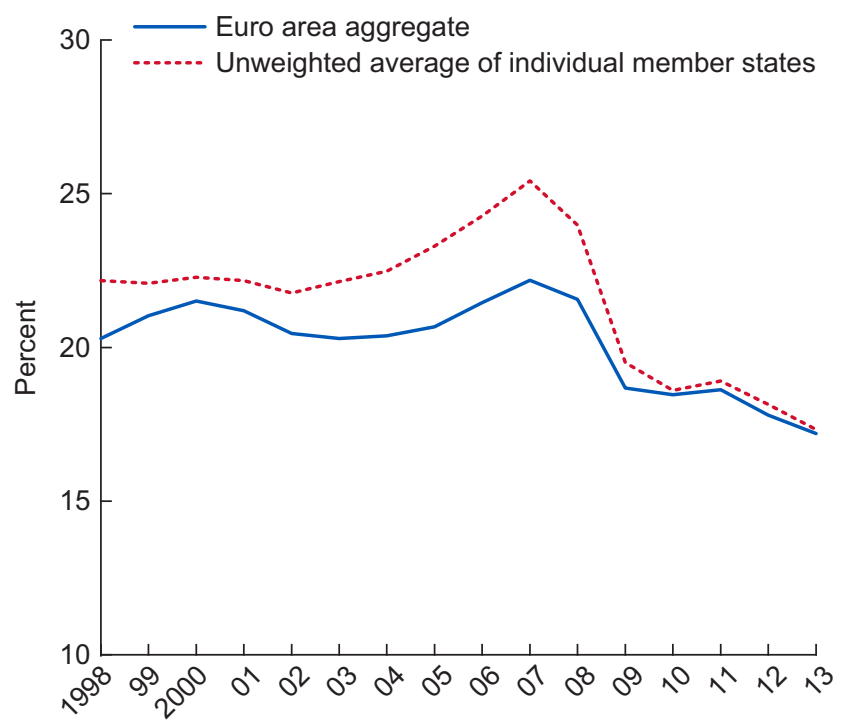

Source: European Commission Annual Macroeconomic Database.

Figure 8.6 Investment in the Euro Area (Share of potential GDP; total economy)

Any flexibility provided by the framework should therefore be tied to the implementation of reforms, going beyond the promise stage.

A related question is whether the MTO and, to a lesser extent, the 3 percent deficit cap may discourage public investment. This is an old debate, but the question has recently come to the fore again because the financial crisis prompted politically easier cuts in government investment in many advanced economies, reinforcing a long-term declining trend (Figure 8.6). With private investment also falling in many countries, medium- and long-term growth prospects could be affected. The public investment deceleration was particularly pronounced in the countries hit hard by the crisis, such as Greece, Ireland, and Portugal (IMF 2014). Although this problem extends beyond the fiscal governance framework, the SGP should set the right incentives to avoid further depletion of capital.

A fundamental question is whether the fiscal framework should exclude capital outlays from targeted fiscal balances (the "golden rule") on the grounds that such spending contributes to growth in the long term. This type of rule has some intuitive appeal ${ }^{20}$ but raises concerns because it weakens the link between fiscal targets and gross debt. In addition, capital expenditure is not necessarily productive, while other items such as expenditures on health and education may raise productivity and potential growth even more. Thus, the exclusion of capital expenditure needs to be weighed against the risks of lower transparency, "creative accounting," and weaker links to sustainability. Another direction that the SGP could take is to induce member states to better internalize the benefits of domestic investment. For instance, EDP targets and deadlines could be adjusted when fiscal consolidation protects capital expenditure. Nonetheless, this would further complicate the framework and raises practical difficulties, which are, to a large extent, similar to those previously described.

A better approach could be to boost the ability of the center to fund pan-European public infrastructure. Such investments could include cross-border projects with network externalities,

\footnotetext{
${ }^{20}$ The main argument in favor of the golden rule is that, as in the case of a private company, a government should not attribute the full cost of a project that is expected to yield gains over several periods to a single year's account.
}

\section{(C) International Monetary Fund. Not for Redistribution}


in particular in the energy sector. As national budgets have to be kept within the bounds of the fiscal framework, other sources of financing should be considered, such as, for example, the European Investment Bank (EIB) and other forms of common borrowing to promote publicprivate partnerships. Although difficult, this option should not be lightly discarded, at least in a medium-term perspective, given that low public investment is a serious issue in the euro area, with implications for potential growth and debt sustainability.

\section{Enforcement: The Limits of Peer Pressure}

Both rule design problems and governance failures have contributed to the poor enforcement of the SGP. First, compliance may be at risk when SGP targets are too demanding or rigid, particularly in a low-growth environment. Although recent reforms have strengthened the economic underpinnings of the framework, greater complexity is likely to create new loopholes. Second, the unique surveillance and coordination procedures within the EMU create new challenges to enforcement. The textbook model of supranational surveillance relies on a strict separation of powers between the monitoring entity of the rules and the executing entity to minimize the risk of moral hazard. In practice, this separation has been incomplete in the European Union-the European Council has the final word on monitoring decisions, while the Commission, guardian of the SGP, makes recommendations. In other words, the Commission has the right and duty to monitor SGP implementation without having full power to take actions in cases of noncompliance. As such, the system falls between the peer pressure model and complete supranational control, reflecting the absence of a full-fledged political and fiscal union.

This incomplete separation of powers has long been seen as a weakness of the pact. Finance ministers make the ultimate judgment on whether excessive deficits exist and penalties should be imposed. In assessing the fiscal performance of other member states, Council members may have incentives to be lenient and avoid actions that are politically costly for other members because they might find themselves in a position of fiscal distress in the future. This makes collusion more likely than strict application of the sanctions and correction mechanisms. In addition, enforcement could be tainted by political considerations. Otmar Issing, former chief economist of the $\mathrm{ECB}$, described the situation as one in which potential sinners pass judgment on actual sinners. As a result, the credibility of the EDP as a tool for safeguarding fiscal discipline has been questioned. However, recent reforms may have, nonetheless, mitigated this problem (see end of this section).

The crisis has further highlighted the limits of moral suasion. Peer pressure is less effective when the number of fiscal delinquents rises, as observed during the global crisis (Figure 8.7). This ineffectiveness occurs because reputation costs decline, the "sinners judging sinners" incentive problem becomes more acute, and the difficulty of imposing sanctions increases with the number of delinquent countries.

Another issue is that the SGP enforcement mechanisms are not as strong as in other federations. Although the unique structure of the EMU and the relative weakness of the supranational level would call for strong enforcement tools, sanctions and corrective actions are, on the contrary, relatively mild in Europe. Sanctions usually consist of opportunity costs from financial deposits. ${ }^{21}$ The conditions for converting these deposits into outright fines are very strict and have, so far, never been applied. In addition, the EU framework does not provide for administrative sanctions, whereas they exist and are applied in other federations. In some federations, individual officials are held liable for fiscal slippages. In addition, sanctions only apply

\footnotetext{
${ }^{21}$ If the Council adopts a decision on noneffective action under the preventive arm, the euro area member state in question can be asked to lodge an interest-bearing deposit, which can then be turned into a non-interest-bearing deposit if an EDP is opened (EC 2013b).
} 


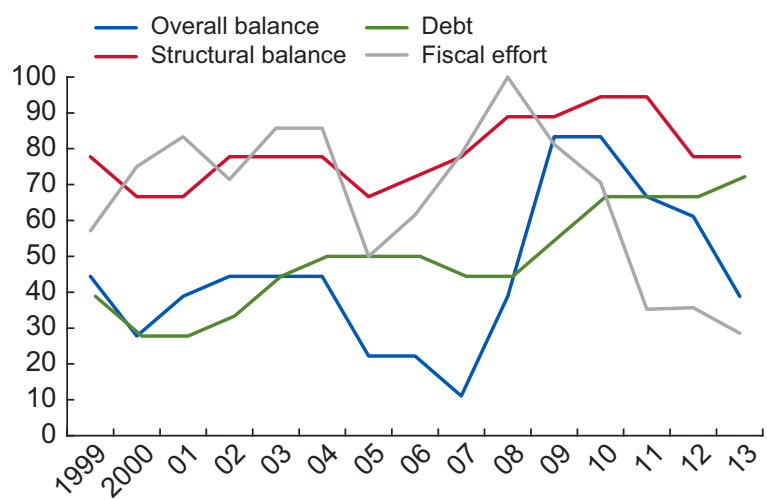

Sources: European Commission Annual Macroeconomic Database; and IMF staff calculations.

Note: Fiscal effort compliance defined as those countries that failed to comply with the structural balance rule but had a change in structural balance larger than 0.5 percent of GDP. The "share of noncompliers" refers to the share of euro area countries that did not comply with fiscal rules. See Abbreviations section for composition of EA18.

Figure 8.7 Euro Area: Share of "Noncompliers," 1999-2013 (Percent, EA18)

to euro area member states. For instance, countries under the EDP that are not part of the euro area are neither required to hold deposits at the EU, nor liable for fines for insufficient progress. By contrast, in federations, central constraints usually bear on all subnational governments in a nondiscriminatory way (Eyraud and Gomez 2014). Finally, corrective actions required for noncompliance are also relatively weak, in part because the European authorities do not have the ability to impose direct controls on national budgets. For instance, borrowing restrictions imposed by the federal level do not exist in the European framework, whereas they do exist in some federations.

Recent reforms to EU fiscal governance have strengthened enforcement. The Fiscal Compact requires countries to introduce structural balance rules in national legislation (preferably in the constitution); these rules should be monitored by independent institutions and incorporate correction mechanisms for deviations. In addition, sanctions for euro area countries have become more automatic because they are now adopted by the "reverse qualified majority" procedure. This new voting system gives more power to the Commission by ensuring that its recommendation or proposal is approved by the Council unless a qualified majority of member states vote against it. It is now more difficult for the Council to go against the Commission's advice.

Nonetheless, political interferences are unlikely to disappear entirely. Commissioners continue to be nominated by member states and the EC staff has constant interactions with national authorities (including at the technical level), creating a risk that political constraints be internalized by the Commission. In this case, additional safeguards would be needed. For instance, independent and public reviews of the EC recommendations and technical work may strengthen its legitimacy and provide further guarantees of evenhandedness.

\section{ISSUES FOR DISCUSSION AND POLICY OPTIONS}

This section presents options for future reforms. Its main argument is that it is possible to simplify the system of rules while keeping some flexibility against shocks and strengthening enforcement mechanisms. 


\section{Should the Preventive and Corrective Arms Be Consolidated?}

In federations, fiscal targets are generally constrained by rules that follow a standardized design. This design includes three main features. A rule delineates a numerical target for a fiscal variable (often the overall balance) over a long period. A number of provisions deal with noncompliance when targets are not attained. Subcentral governments failing to abide by the rules may be subject to sanctions and corrective actions. ${ }^{22}$ Finally, escape clauses allow for temporary suspension of these provisions for a predetermined set of events.

The corrective arm of the SGP broadly fits into this standard model, whereas the preventive arm is more specific to the EU governance system. Similar to existing federations, the corrective arm defines numerical targets for certain fiscal variables (deficit and debt) and foresees procedures (such as EDP) in cases of noncompliance, as well as escape clauses. By contrast, the preventive arm has no clear equivalent outside Europe. Its surveillance and coordination procedures are meant to prevent the emergence of fiscal imbalances and ensure that member states achieve sound fiscal positions in the medium term.

Successive reforms have blurred the distinction between the two arms of the pact. Although the preventive arm was initially thought of as a surveillance and peer pressure mechanism, reforms have added many features of the standard rule model, including a fiscal target (structural deficit of less than 0.5 percent), a convergence path toward this target in case of deviation, escape clauses, and, more recently, sanctions. The fact that the Fiscal Compact requires the transposition of the MTO into national law creates another bridge between the preventive and corrective concepts- the MTO has become an annual target for fiscal policy rather than simply a "mediumterm objective" used for the multilateral assessment of member states' fiscal plans.

While maintaining the gradual approach of the SGP, there may be beneficial ways to integrate the two arms of the pact. The strengthening of the preventive arm is a welcome development (early corrections and sanctions are more likely to be effective). However, the conceptual distinction between the two arms has weakened over time, creating potentially redundant and conflicting fiscal targets. The fact that the most elaborate set of corrective actions and sanctions- the EDP - is triggered by the 3 percent deficit rule, which has a weaker economic rationale than the structural balance rule of the preventive arm, creates certain problems. It is very difficult to justify, on economic grounds, that a country at the MTO be placed under EDP if it breaches the 3 percent ceiling (this procedure has happened in the past).

A range of options for consolidating the two arms of the pact are available. A minimal approach could be to enhance the consistency of the two arms-in the same spirit that recent reforms set similar benchmarks for the annual fiscal effort. A more ambitious approach, which raises legal difficulties, would merge the two arms into a two-step procedure based on a common set of rules, possibly with the MTO as the overarching target. Minor slippages would trigger mild corrective actions; the EDP would be used exclusively for serious cases of noncompliance. Along these lines, IMF (2010) proposes tying EDP exit to fulfillment of the MTO.

\section{Should the Current System of Fiscal Rules Be Simplified (and if So, How)?}

The ultimate objective of preserving debt sustainability suggests a two-pillar approach to the design of the fiscal framework, with a fiscal anchor and an operational target. By analogy with monetary policy, a fiscal rule framework should set targets for both intermediate and final objectives. Because the final objective of the framework is to preserve fiscal sustainability, a natural

\footnotetext{
${ }^{22}$ Corrective actions can be defined as a set of measures intended to put finances back on a sound footing, and that entail some temporary loss of autonomy for subnational entities. Sanctions are financial and administrative penalties imposed on the subcentral government or its officials; contrary to corrective actions, they only have a disciplinary function and do not contribute to restoring fiscal soundness (financial sanctions may, in fact, aggravate fiscal stress).
} 
anchor for expectations is the debt ratio, which creates an upper limit to repeated (cumulative) fiscal slippages. In addition to the anchor, the framework should also include an operational target, which would be under the direct control of governments, while also having a close link to debt dynamics. To the extent possible, the operational target should be easy to monitor, and serve to communicate the fiscal stance to the public.

The choice of an operational target is difficult and controversial. Public debt cannot play this role given that factors other than policy decisions affect public debt changes, including belowthe-line operations and valuation effects. Available options include a revenue rule, an expenditure rule, a nominal balance, a structural balance target-in level or in first difference-or some combination. Currently, the European framework includes too many operational targets. Reducing their number and focusing on the most economically relevant should be a priority. If the consolidation of indicators raises too many legal obstacles in the short term, a first step could be to give more attention and prominence to the preferred target(s) in the fiscal analysis and advice of the Commission.

From a policy standpoint, the most natural operational target is the "fiscal effort" variable. The fiscal effort is defined as the change in the fiscal stance resulting from discretionary fiscal actions taken during the year on the spending and revenue sides. By definition, the fiscal effort should be directly impacted by discretionary budgetary policy actions. Using this variable as a main policy target would define a structural path for future fiscal balances and, implicitly, allow automatic stabilizers to operate fully along this path (in case of cyclical surprises).

The fiscal effort variable can be measured in different ways. Specifically, it can be estimated (1) by identifying and aggregating budget measures in percent of potential GDP ("bottom-up approach"); (2) or by calculating the change in the structural fiscal balance ("top-down approach"); (3) or through other structural indicators such as an annual expenditure growth ceiling linked to potential output growth. ${ }^{23}$ While these concepts are theoretically equivalent, they often return different amounts of fiscal effort (see Bi, Qu, and Roaf 2013). One of the reasons is that the change in the structural balance calculates the fiscal effort relative to the previous year, while expenditure and tax measures are typically estimated relative to an unchanged-policy scenario at a given point in time. Of the three fiscal effort variables, the expenditure growth ceiling may seem the most appealing. This indicator is tractable (constraining directly the budget), easy to communicate to the public, and conceptually sound provided that it is linked to some measure of long-term output growth.

A difficult question is whether a structural balance target in level should also be maintained in the framework. The ceiling chosen for the public debt anchor determines implicitly a steady-state level for the structural balance, which suggests that setting targets for both variables could be redundant (and potentially inconsistent). That is not to say that the structural balance indicator (in level) is useless and should be eliminated from the framework altogether. It fulfills a function, which is to monitor the progress toward the steady-state- that is the distance between the current structural position and the level consistent with the debt anchor.

From a measurement point of view, the structural balance (in level) creates greater issues than its first-difference version. This is mainly because ex post revisions of the output gap generally affect the series level rather than its slope (Balassone and Kumar 2007). A wide range of options are available for addressing the shortcomings of the structural balance (Box 8.2). Each of these options has advantages and disadvantages. The methodology should be further improved until the risk of misjudging the fiscal stance and the resulting policy errors are sufficiently contained.

\footnotetext{
${ }^{23}$ Conceptually, certain expenditure growth rules are equivalent to first-difference structural balance rules. Indeed, the structural fiscal balance declines (improves) when expenditure grows above (below) potential GDP_other things being equal. In addition, expenditure rules can incorporate the effect of revenue measures (see the design of the European expenditure benchmark).
} 


\section{BOX 8.2. How to Move Forward with the Structural Balance Indicator}

Methodological improvements can contribute to reducing measurement errors of the output gap. Recent research shows that multivariate filters, which extract information about the cycle from additional observable variables (such as capacity utilization) are less exposed to the end-point problem (see Benes and others 2010; IMF 2013a). In 2010, the European Commission introduced a new method for computing the output gap (d'Auria and others 2010), which uses capacity utilization data to help identify supply.

Another possibility could be to explicitly account for the bias ex ante. Bias could be accounted for in advance by including an ad hoc adjustment factor in the structural balance formula or by conducting a study about the predictability of revisions to the output gap. However, if the bias is not rooted in exogenous technical flaws but in strategic behavior of a political economy nature, introducing an adjustment may result in a larger bias to compensate for the adjustment. Moreover, the bias is unlikely to affect all countries equally. Thus, the adjustment would have to be tailored to each member country and possibly readjusted over time.

The structural rule could include a notional account recording ex post deviations between real-time and mature estimates (in the vein of the Swiss debt brake). When cumulative deviations exceed a threshold, correction measures would have to be taken, for instance, by cutting spending to realign it with the lower than initially estimated potential GDP.

Some have proposed replacing the structural balance with an indicator mimicking its properties without relying on output gap estimates. For instance, the "augmented growth-based balance rule" extracts cyclical effects from the nominal balance by using the difference between economic growth and trend (IMF 2009). However, this indicator does not have strong theoretical underpinnings and may incorporate a procyclical stance.

More radical options suggest abandoning the structural balance altogether. For instance, Debrun, Epstein, and Symansky (2008) propose replacing it with an expenditure rule that includes a correction mechanism associated with the debt level.

Some of the existing rules do not fit well in this simple framework. The 3 percent deficit rule has weak economic rationale and entails large costs when it fosters a procyclical fiscal stance. Dominated by the structural balance rule, the one-twentieth debt-reduction benchmark would become redundant if the structural balance were used to determine the necessity of an EDP, as suggested in the previous section. ${ }^{24}$

\section{How Can Enforcement Be Further Strengthened?}

Two main directions can be followed to improve compliance. ${ }^{25}$ The first approach reinforces the existing supranational framework by strengthening procedures, correction mechanisms, and sanctions, while making them more automatic. The second approach relies on alternative mechanisms to promote fiscal discipline, such as stronger market oversight or transfer of fiscal powers to the center.

Existing enforcement mechanisms can be made stronger. More automaticity could be introduced in moving up steps after a rule is breached and the breach is acknowledged. In some cases, procedural steps could be accelerated in well-defined circumstances, such as misreporting. The imposition of sanctions should nevertheless remain the result of a discretionary decision based on sound economic judgment.

\footnotetext{
${ }^{24}$ Nonetheless, measurement errors and uncertainties affecting the estimates of potential output and the structural budget balance could argue in favor of maintaining the one-twentieth debt rule-as an objective and simple benchmark for consolidation progress.

${ }^{25}$ National fiscal frameworks have a key role to play in strengthening the overall fiscal architecture. Reliance on national fiscal rules and fiscal councils is a central part of the efforts to foster compliance with supranational requirements. In essence, enforcement is likely to be more credible if it takes place at the level at which fiscal sovereignty is exerted. This important issue, which goes beyond the scope of the chapter, is not discussed here.
} 
A broad set of sanctions could be envisaged. Financial sanctions in bad times lack credibility because they exacerbate the financial difficulties of distressed governments. Hence, these sanctions (for example, reduced access to structural funds and other EU subsidies ${ }^{26}$ ) could be imposed only in good times, while nonpecuniary sanctions could also be considered in bad times. Administrative sanctions (such as personal sanctions or constraints on new staff hire) exist in other federations. Political sanctions (for example, limitation of voting rights) are another option.

A key question is whether past deviations from supranational fiscal targets should be offset subsequently. ${ }^{27}$ Currently, countries breaching the 3 percent rule or the MTO are required to bring the deficit back below the ceiling. But the effect of past deviations on debt does not need to be corrected subsequently, creating a risk that debt ratchets up over time until it reaches 60 percent of GDP. ${ }^{28}$ The debt-brake model addresses this issue by requiring compensation for past slippages. For instance, the Swiss debt-brake rule specifies a one-year-ahead ceiling on central government expenditure equal to predicted cyclically adjusted revenue, which effectively corresponds to maintaining a structural budget balance every year. Differences between budget targets and outcomes are recorded in a notional account. If the negative balance in the account exceeds a threshold, the authorities are required to take measures sufficient to reduce the balance to less than this level within three years. Debt brakes have been criticized for imposing unrealistic adjustments following large slippages given that the fiscal position should not only get back to the targeted level in the following year but also overshoot it because of the correction. However, never offsetting past deviations is misguided because debt eventually increases to a point that the debt ceiling becomes binding. A more balanced approach would be to target a gradual correction for countries with debt of less than 60 percent of GDP. This approach could be achieved by proper calibration of the fiscal rule formulas (IMF 2009).

Better compliance with fiscal rules may also come from stronger market oversight and discipline. Enforcement is stronger when financial markets penalize countries that breach fiscal rules. The provision enshrined in the Maastricht Treaty to ensure that member states do not assume other member states' fiscal commitments (Article 125 of the Treaty on the Functioning of the European Union)—often referred to as the "no-bailout" clause-was meant to give financial markets an incentive to discriminate among countries and price each member state's default risk. However, market discipline has not worked properly in the EMU because the no-bailout provision has lacked credibility; the scale of the crisis has warranted some risk sharing through the European Stability Mechanism and other instruments, and the sovereign-bank link has distorted the pricing of risk by markets (Allard and others 2013). Restoring market discipline and mitigating moral hazard are long-term endeavors. Some conditions should be fulfilled, including clear rules for the involvement of private creditors in bailouts of sovereigns and banks. The transition to such a regime would have to be carefully managed and implemented in a gradual and coordinated fashion, so as to not trigger sharp readjustments in investors' portfolios and abrupt moves in bond prices.

Another possibility would be to rely more extensively on central controls. Restoring market discipline is an important element for fostering compliance and fiscal discipline, but doing so will take some time. Therefore, in the interim—and possibly as a long-term solution, too-enforcement will have to be imposed more directly by the center. This enforcement may

\footnotetext{
${ }^{26}$ As of January 2014, structural funds can be suspended if a country does not comply with the EDP recommendations under the corrective arm.

${ }^{27}$ Strictly speaking, correction mechanisms exist at the national level (they are mandated by the Fiscal Compact), but not at the supranational level.

${ }^{28}$ For countries with public debt greater than 60 percent of GDP, the one-twentieth debt-reduction criterion functions de facto as a debt-brake correction mechanism.
} 
have to come at the expense of a permanent loss of fiscal sovereignty for euro area members (for instance, if veto power of the center on national budgets were to be introduced). A thorough analysis of options to deepen fiscal integration in the euro area goes beyond the scope of this chapter (see Allard and others 2013 for an assessment of the costs and benefits of a fiscal union).

\section{CONCLUSION}

Despite recent improvements, the European fiscal governance system faces a number of challenges. The remaining gaps are most apparent in the complex design of fiscal rules and poor enforcement mechanisms. Public debt is approaching unsafe territory in several member states, meaning that the fiscal framework has a key role to play to put public finances back on sound footing. Fiscal governance needs to be particularly strong ahead of time-preventing the emergence of fiscal imbalances is more effective and sometimes easier than correcting them ex post. In this regard, the preventive arm of the SGP has to become more effective in enforcing structural balance targets and limiting the ability of member states to spend revenue windfalls in good times-a challenge given the uneven track record of countries in sustaining healthy structural positions for long periods.

Fiscal reforms have to be properly sequenced, while taking into account the trade-offs between priority and practicability. The most important reforms-those tackling the complexity of the framework and its enforcement-are probably the most difficult to implement (in part because of the legal constraints) and constitute medium-term objectives. Simplifying the framework may require rethinking its overall structure, including by consolidating the preventive and corrective arms and eliminating some redundant or ill-designed rules. Enhancing enforcement mechanisms is also complicated because compliance failures are partly rooted in the unique governance structure of the EU.

Going beyond the fiscal framework, better economic governance can play an important role in reducing future imbalances. The global crisis showed that there is no clear-cut separation between private and public sector balance sheets (Moghadam 2014). In particular, the original framework neglected the risks associated with excessive private leverage and divergence in competitiveness. Another lesson from the crisis is that there is no clear-cut separation between private and public sector balance sheets. Private imbalances can eventually end up as public sector liabilities - either through a direct bailout of the banking system (as in Ireland) or the lost revenue and increased spending required by deep and prolonged declines in output (as in Spain). Conversely, public imbalances can aggravate private imbalances. For instance, a weak sovereign may increase private sector stress if banks have large exposures to domestic public debt or if the government's ability to honor financial safety net obligations is impaired (Goyal and others 2013). Therefore, improvements in fiscal and economic governance should be pursued together to minimize the occurrence of internal imbalances (both private and public), as well as their scope for disruption to the economy. Some recent reforms are positive steps in this direction. The Macroeconomic Imbalance Procedure goes beyond fiscal metrics to consider private debt, external current accounts, and net international investment positions. The banking union, especially the bail-in regime, better aligns incentives in the financial sector and should reduce taxpayer exposure to banking sector losses. 


\section{REFERENCES}

Allard, C., P. Koeva Brooks, J. C. Bluedorn, F. Bornhorst, K. Christopherson, F. Ohnsorge, and T. Poghosyan. 2013. "Towards a Fiscal Union for the Euro Area." Staff Discussion Note 13/09, International Monetary Fund, Washington, DC.

Balassone, F., and M. Kumar. 2007. "Addressing the Procyclical Bias.” In Promoting Fiscal Discipline, edited by M. Kumar and T. Ter-Minassian. Washington, DC: International Monetary Fund.

Barkbu, B., J. Rahman, and R. Valdés. 2012. "Fostering Growth in Europe Now." Staff Discussion Note 12/07, International Monetary Fund, Washington, DC.

Beetsma, R., and X. Debrun. 2004. "Reconciling Stability and Growth: Smart Pacts and Structural Reforms." IMF Staff Papers 51 (3): 431-56.

Benes J., K. Clinton, R. Garcia-Saltos, M. Johnson, D. Laxton, P. Manchev, and T. Matheson. 2010. “Estimating Potential Output with a Multivariate Filter." Working Paper No. 10/285, International Monetary Fund, Washington, DC.

Bi, R., H. Qu, and J. Roaf. 2013. "Assessing the Impact and Phasing of Multi-year Fiscal Adjustment: A General Framework." IMF Working Paper WP/13/182, International Monetary Fund, Washington, DC.

Blanchard, O., G. Dell'Ariccia, and P. Mauro. 2013. "Rethinking Macro Policy II: Getting Granular." Staff Discussion Note 13/03, International Monetary Fund, Washington, DC.

Bornhorst, F., G. Dobrescu, A. Fedelino, J. Gottschalk, and T. Nakata. 2011. "When and How to Adjust Beyond the Business Cycle? A Guide to Structural Fiscal Balances." IMF Technical Notes and Manuals 11/02, International Monetary Fund, Washington, DC.

D’Auria, F., C. Denis, K. Havik, K. McMorrow, C. Planas, R. Raciborski, W. Röger, and A. Rossi. 2010. "The Production Function Methodology for Calculating Potential Growth Rates and Output Gaps." Economic Paper No. 420, European Commission, Brussels.

Deroose, S., and A. Turrini. 2006. "The Short-Term Budgetary Implications of Structural Reforms: Evidence from a Panel of EU Countries." In Proceedings from the ECFIN Workshop "The Budgetary Implications of Structural Reforms"-Brussels, 2 December 2005, edited by S. Deroose, E. Flores, and A. Turrini. Brussels: European Commission.

Debrun, X., N. Epstein, and S. Symansky. 2008. “A New Fiscal Rule: Should Israel Go Swiss?” Working Paper No. 08/87, International Monetary Fund, Washington, DC.

Escolano, J. 2010. "A Practical Guide to Public Debt Dynamics, Fiscal Sustainability, and Cyclical Adjustment of Budgetary Aggregates.” Technical Notes and Manuals 10/2, International Monetary Fund, Washington, DC.

European Commission (EC). 2013a. "Building a Strengthened Fiscal Framework in the European Union: A Guide to the Stability and Growth Pact." Occasional Paper 150, European Commission, Brussels.

2013b. "Vade Mecum on the Stability and Growth Pact." Occasional Paper 151, European Commission, Brussels.

2013c. 2013 Report on Public Finances in EMU. Brussels: European Commission.

Eyraud, L., and R. Gomez. 2014. "Constraints on Subnational Fiscal Policy." In Designing a European Fiscal Union: Lessons from the Experience of Fiscal Federations, edited by C. Cottarelli and M. Guerguil. New York: Routledge.

Giorno, C., P. Hoeller, and P. van den Noord. 2005. "Nothing Ventured, Nothing Gained: The Long Run Fiscal Reward of Structural Reform." Proceedings from the ECFIN Workshop "The Budgetary Implications of Structural Reforms"-Brussels, 2 December 2005, edited by S. Deroose, E. Flores, and A. Turrini. Brussels: European Commission.

Goyal R., P. Koeva Brooks, M. Pradhan, T. Tressel, G. Dell'Ariccia, R. Leckow, and C. Pazarbasioglu. 2013. "A Banking Union for the Euro Area," Staff Discussion Note 13/01, International Monetary Fund, Washington, DC.

Heinemann, F. 2005. "How Distant Is Lisbon from Maastricht? The Short-Run Link between Structural Reforms and Budgetary Performance." In Proceedings from the ECFIN Workshop "The Budgetary Implications of Structural Reforms"-Brussels, 2 December 2005, edited by S. Deroose, E. Flores, and A. Turrini. Brussels: European Commission.

Høj J., V. Galasso, G. Nicoletti, and T. Dang. 2006. "An Empirical Investigation of Political Economy Factors behind Structural Reforms in OECD Countries." OECD Economic Studies No. 41, OECD, Paris. 
International Monetary Fund (IMF). 2004. "Fostering Structural Reforms in Industrial Countries." In World Economic Outlook, Washington, DC, April. . 2009. "Fiscal Rules-Anchoring Expectations for Sustainable Public Finances." IMF Policy Paper, Washington, DC. www.imf.org/external/np/pp/eng/2009/121609.pdf. . 2010. "Gaps in the Euro Area Fiscal Framework: Options for a New Fiscal Contract." Euro Area Policies: Selected Issues, IMF Country Report 10/222, Washington, DC. . 2013a. France Article IV Report. Country Report No. 13/251, Washington, DC. . 2013b. "Reassessing the Scope and Modalities of Fiscal Policy in Advanced Economies." IMF Policy Paper, Washington, DC. http://www.imf.org/external/np/pp/eng/2013/072113.pdf.

_. 2013c. "Staff Guidance Note for Public Debt Sustainability Analysis in Market-Access Countries." Washington, DC.

- 2014. Fiscal Monitor: Public Expenditure Reform-Making Difficult Choices, Washington, DC, April.

Kempkes, G. 2012. "Cyclical Adjustment in Fiscal Rules: Some Evidence on Real-Time Bias for EU-15 Countries.” Discussion Paper 15/2012, Deutsche Bundesbank, Frankfurt.

Lemmer, A., and D. Stegarescu. 2009. "Revenue Windfalls and Expenditure Slippages: Disappointing Implementation of the Reformed Stability and Growth Pact." Intereconomics 44 (3): 159-65.

Moghadam, R. 2014. "Maastricht and the Crisis in Europe: Where We've Been and What We've Learned." Speech at the ECB/NBB Conference: "Progress through Crisis?" Brussels, February 12, 2014. http://www.imf.org/exter$\mathrm{nal} / \mathrm{np} / \mathrm{speeches} / 2014 / 021214 . \mathrm{htm}$. 


\section{Completing the Economic and Monetary Union (EMU)}


This page intentionally left blank

CInternational Monetary Fund. Not for Redistribution 


\title{
A Banking Union for the Euro Area
}

\author{
Rishi Goyal, Petya Koeva Brooks, Mahmood Pradhan, \\ THIERRY TRESSEL, GIOVANNI DELL'AricCiA, ROSS LeCKOW, \\ and CeYla Pazarbasioglu
}

\begin{abstract}
A banking union-a single supervisory and regulatory framework, resolution mechanism, and safety net - for the euro area is the logical conclusion of the idea that integrated banking systems require integrated prudential oversight. The case for a banking union for the euro area is both immediate and longer term. Moving responsibility for potential financial support and bank supervision to a shared level can reduce fragmentation of financial markets, stem deposit flight, and weaken the vicious circle of rising sovereign and bank borrowing costs. In steady state, a single framework should bring a uniformly high standard of confidence and oversight, reduce national distortions, and mitigate the buildup of concentrated risk that compromises systemic stability.
\end{abstract}

\section{CONTEXT}

The fiscal and financial crisis in the euro area has exposed critical gaps in the architecture of stability in the region. In the years preceding the crisis, large capital flows within the euro area fueled the buildup of sovereign and private sector imbalances. The subsequent deterioration of balance sheets and reversal of flows has forced very sharp economic contractions and financial market fragmentation (Figure 9.1). Borrowing costs of sovereigns and national private sectors have diverged widely and persistently, cuts in monetary policy rates have had limited or no effect in several economies, and adverse sovereign-bank-real-economy dynamics have been prevalent across the region (Figures 9.2 and 9.3). The monetary union, in short, is malfunctioning.

Important measures-for near-term crisis management and longer-term architecture-have been undertaken. Adjustment programs are being implemented and progress is being made to unwind fiscal and external imbalances that developed over several years. Regional firewalls - the European Financial Stability Facility and the European Stability Mechanism (ESM)—have been created and strengthened to smooth adjustment. The framework for fiscal and economic governance has been enhanced through the "Six-Pack" and the Treaty on Stability, Coordination, and Governance. The European Central Bank (ECB) has provided substantial liquidity to banks, stepped in to address market strains through government bond purchases, and announced its framework for Outright Monetary Transactions. The Eurosystem has recycled part of the capital flight from stressed economies to the core through the TARGET2 payments balances.

In this comprehensive policy response, the role of a banking union for the euro area is twofold. As part of crisis management, it can reduce fragmentation of European banking markets. Direct bank recapitalization by the ESM can help restore the health of bank balance sheets and remove tail risks and potential contingent liabilities affecting sovereigns under stress. A precondition for direct recapitalization of banks by the ESM is the creation of an effective single supervisory mechanism (SSM), called for by euro area leaders in June 2012. In steady state, an integrated architecture for financial stability in the euro area would bring a uniformly high standard of enforcement, remove

This chapter is based on “A Banking Union for the Euro Area," IMF Staff Discussion Note 13/01, 2013. 

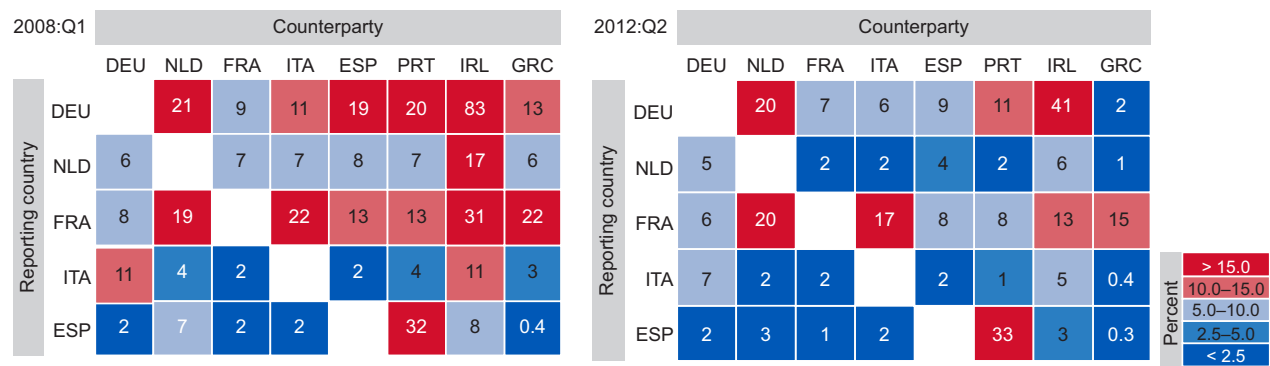

Sources: Bank for International Settlements (BIS); and IMF staff calculations.

Note: Data labels in the figure use International Organization for Standardization (ISO) country codes.

Figure 9.1 Euro Area: Financial Market Integration and Fragmentation (BIS cross-border bank claims; percent of reporting country's GDP)

\section{NFC Lending Rates and ECB Policy Rate} (1-5 yr. maturity, up to $€ 1$ million)

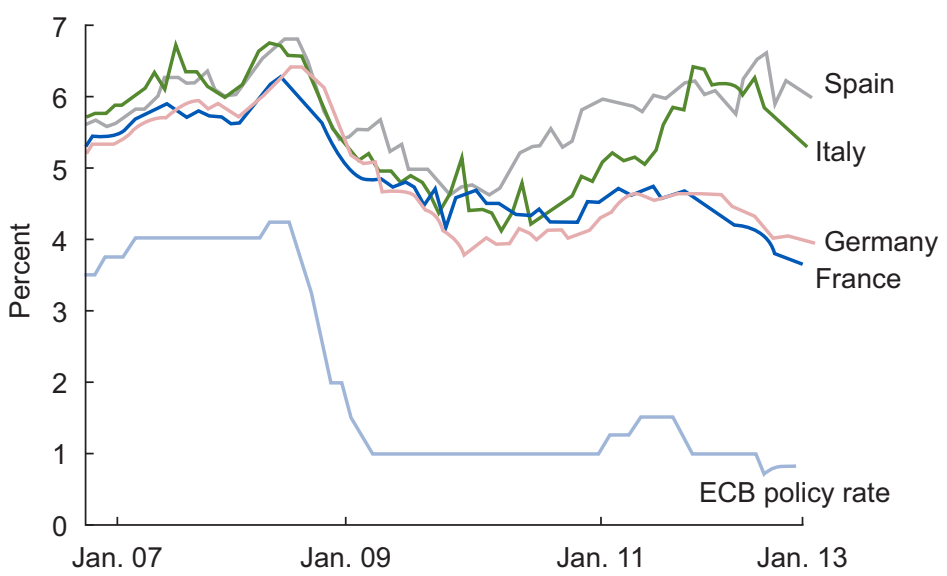

Source: European Central Bank.

Note: $\mathrm{ECB}=$ European Central Bank; NFC = nonfinancial corporations.

Figure 9.2 Euro Area: Diverging Funding Costs

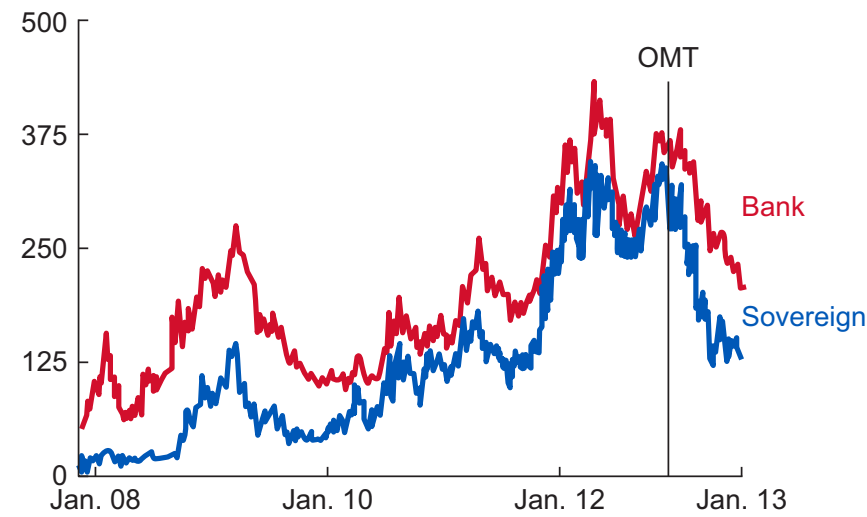

Source: Bloomberg L.P.

Note: OMT = Outright Monetary Transactions.

Figure 9.3 Euro Area: Sovereign-Bank Loops (Credit default swap spreads; basis points weighted by gross debt) 
national distortions, and mitigate the buildup of risk concentrations that compromise systemic stability. Moving responsibility for potential financial support-and the associated banking supervision - to a shared level would reduce financial fragmentation and weaken the vicious circle experienced by many countries of rising sovereign and bank borrowing costs.

The European Commission presented a plan on September 12, 2012, on the elements of a new SSM that could begin operating in 2013. It called for adoption by end-2012 of European Union (EU) legislative proposals establishing a harmonized regulatory setup, harmonized national resolution regimes for credit institutions, and standards across national deposit insurance programs. On December 13-14, 2012, the European Council agreed that the SSM would come into operation in March 2014 or one year after the SSM legislation enters into force, whichever is later. Once the SSM legislation is adopted, ESM direct recapitalization could occur, with the ECB supervising the bank in need of assistance. The Council noted that adoption of a harmonized regulatory setup (the Capital Requirements Regulation/Capital Requirements Directive IV, or CRR/CRD IV) is "of the utmost priority," and called for the adoption of the draft directive for bank recovery and resolution and for harmonization of deposit guarantee programs by June 2013. It affirmed that a single resolution mechanism with adequate powers and tools is required. This mechanism will be based on financial sector contributions and backstop arrangements that recoup taxpayer support over the medium term. The Commission made a proposal for such a mechanism in 2013, and a final agreement was reached at the end of 2014.

Although agreement has been reached on the SSM, different views on the modalities of the other elements of a banking union remain. These differences partly reflect concerns about the potential mutualization of liabilities and asymmetric cost sharing across members, as well as on the desirability of separating near-term crisis resolution, such as needed fiscal solutions and backstops for bank recapitalization, from longer-term architecture issues. They also reflect the complexities and difficulties of setting up a banking union in a relatively compressed period.

This chapter elaborates the case for, and the design of, a banking union for the euro area. This chapter discusses the benefits and costs of a banking union, presents a steady state view of the banking union, elaborates transition issues, and briefly discusses broader EU issues. The background technical notes analyze in depth the various elements of the banking union: a single supervisory framework, a single resolution mechanism and common safety net, and urgent issues related to ESM direct recapitalization of banks.

\section{HOW WOULD A BANKING UNION HELP?}

Although finance spans the euro area in a dense network of cross-border banks and obligations, the current architecture of stability is based largely on national supervision, national resolution, and national safety nets. This architecture-outlined in Box 9.1-has several implications, including the following:

- Bank-sovereign-real-economy links-Absent the ability to control local interest rate conditions, the existing architecture strengthens the link between a country's banking and real sectors and the health of its public finances. In good times, banks may grow to overwhelm national supervisory capacity. In bad times, they may overwhelm national fiscal resources. Similarly, if a sovereign's finances are sound, its backstop for its banks is credible. But if they are weak, then its banks are more vulnerable and will face higher funding costs. As a result, private borrowing costs rise with the sovereign's, imparting procyclicality (costs rise as conditions deteriorate and capital flows out), impairing the transmission of monetary policy (because rate cuts have limited or no effect), and amplifying fragmentation of financial markets and volatility.

- Skewed incentives - National authorities may unduly favor the national banking system and economy, regardless of outward spillovers, which lie beyond their mandates. In good times, they may not be stringent or capable enough to limit the buildup of excesses. In bad times,

\section{CInternational Monetary Fund. Not for Redistribution}




\section{BOX 9.1. European Union: Existing Framework for Financial Stability}

\section{Regulation and supervision}

Regulatory framework. Most financial rules in Europe originate from European Union (EU) directives and regulations. A minimum standard has been set in harmonized legislation. In May 2012, the European Council approved the "Danish compromise" legislative package-the Capital Requirements Regulation (CRR) and Capital Requirement Directive (CRD IV) - which transposed Basel III in the EU and harmonized prudential rules that would apply to all banks in the EU. National options and discretion would be the exception, although flexibility is envisaged for financial stability risks that differ across jurisdictions and institutions. National authorities may impose "systemic risk buffers" without the European Commission's preapproval up to a limit, and above the limit with prior approval. They may temporarily impose stricter requirements, for example, in relation to risk weights for certain sectors, large exposure limits, and liquidity requirements. They also retain the flexibility to impose stricter requirements on individual institutions through Pillar 2 reviews.

National supervision. Banking supervision in the EU is the prerogative of national authorities. Although EU directives have set minimum internationally agreed-on standards, supervisory handbooks and approaches vary across member states. The CRR/CRD IV aims to strengthen elements of supervision (such as supervisory planning, on-site inspections, and more robust and intrusive supervisory assessments) and harmonize sanctions.

Cross-border cooperation. Given the high degree of financial integration in the EU, home-host cooperation is essential for effective supervision. Since 2010, guidance has been provided on the supervision of crossborder banks, and supervisory colleges provide a forum for discussions, but it is not clear that these are altogether effective. The EU directive on bank resolution and recovery clarifies nonbinding home-host relations and responsibilities in colleges, in particular in relation to the provision of intragroup liquidity provision.

\section{Resolution}

National regimes. Many EU countries have relied on general corporate insolvency proceedings to deal with bank failures, an approach that has resulted in complex and lengthy windups or, more commonly, nationalization, with significant costs for the economy. Although some national frameworks have been strengthened through special resolution powers to facilitate the quick resolution of failing banks, they remain largely untested and may not, in all cases, be fully in line with international best practice (for example, the Financial Stability Board Key Attributes).

Harmonization. The Commission's draft directive on bank recovery and resolution seeks to ensure that national authorities have strong preventive powers, including in relation to recovery planning; early intervention powers (for example, power to impose capital-raising and conservation measures, restrictions on activities, and implementation of recovery plans); and resolution tools (for example, the possibility to set up bridge banks, perform asset separations, override shareholders' rights, replace management, divest nonessential businesses, or write down or "bail in" debt).

Member states are also required to set up resolution funds, built over 10 years and prefunded to a target ratio of 1 percent of total liabilities excluding own funds. The draft directive proposes after-the-fact levies; access to a credit line from the central bank; and borrowing arrangements among funds across countries, subject to safeguards.

Cross-border resolution. The draft directive also offers principles for early intervention and resolution of cross-border banks, such as liquidity provision within groups and the creation of resolution colleges to develop nonbinding, crisis-planning mechanisms. The absence of binding, burden-sharing agreements put in place in advance of any crisis, however, leaves unresolved the issue of coordination. It is not clear, therefore, that least-cost resolution would be achieved quickly and effectively. Nevertheless, implementation of the directive would set the stage for a more integrated EU resolution framework.

\section{Safety nets}

Lender of last resort (LOLR). Banks can place deposits and refinance eligible assets with the Eurosystem and, if collateral constraints bind, resort to emergency liquidity assistance from their national central banks. Although the ECB's Governing Council has authority to ensure that LOLR activities by national central banks do not interfere with common monetary policy, losses arising on emergency liquidity assistance remain the responsibility of the national central banks, exacerbating sovereign-bank linkages.

Deposit insurance. Existing deposit insurance programs are national, with varying coverage limits, contributions, and fund sizes. Most programs are underfunded. The EU Directive on Deposit Guarantee Schemes has set minimum standards on coverage $(€ 100,000$ per depositor per bank) and the payout period. The Commission has proposed harmonizing national programs (for example, introducing common standards

\section{CInternational Monetary Fund. Not for Redistribution}




\section{BOX 9.1. (continued)}

on financing and setting a target fund size of 1.5 percent of eligible deposits) and clarifying responsibilities (for example, improving insurance payments for cross-border banks), with the possibility of borrowing arrangements across national programs and with adequate safeguards.

\section{The European System of Financial Supervisors (ESFS)}

ESFS. Following the 2009 de Larosiere Report recommendations, elements of an EU supervisory structure were established in 2011. Although regulation remains the prerogative of the Commission, technical standards on sectoral microprudential regulation are tasked to the European Supervisory Authorities-the European Banking Authority (EBA), the European Securities and Markets Authority, and the European Insurance and Occupational Pensions Authority-and macroprudential oversight to the European Systemic Risk Board (ESRB). As EU agencies, these agencies have limited powers (including because of fiscal safeguards) and resources, with ultimate decisions remaining at the national level.

EBA. The EBA is a cooperative body for EU bank supervisors. It is tasked with issuing technical standards in regulatory and supervisory areas (subject to fiscal safeguards). It can organize and conduct peer reviews of competent authorities, including issuing recommendations and identifying best practices, to strengthen consistency in supervisory outcomes, promote supervisory convergence, address breaches of EU law, limit scope for regulatory arbitrage, foster a level playing field, and support consumer protection. It coordinates and ensures consistency of EU-wide stress tests.

ESRB. The ESRB's role includes establishing macroprudential frameworks and ensuring effective coordination and internalization of cross-border spillovers. Its main instrument is the issuance of nonbinding risk warnings and recommendations through a "comply or explain" mechanism.

they may encourage the reduction of their banks' cross-border activities, exacerbating financial fragmentation. Delays in resolving stresses would only increase the eventual cost. And because a bank's distress may have adverse cross-border externalities, other countries may have no choice but to support those economies whose banking systems run into trouble.

A single regulatory and supervisory framework would help contain systemic risks and curb the moral hazard that accompany common backstops and safety nets; a single resolution mechanism with adequate backstops would isolate and address pockets of weakness; and a common safety net would help prevent retail deposit runs that could overwhelm the capacity of any one economy:

- Regulation and supervision-Regulation involves rules to prescribe what banks must or may not do, while supervision verifies and enforces such rules and adds broad discretionary powers to control undue risk-taking and ensure adequate capitalization. Both seek to complement market discipline imposed by bank creditors and shareholders. The SSM would facilitate a systemic approach to supervision of risk management across all countries and help identify and prevent the buildup of excessive risk concentrations. It would enforce regulations consistently across the banking union, reduce national distortions, and better address cross-border issues and fragmentation. It could be less subject to capture by local interests (if not to broader ones); for example, Agarwal and others (2012) show that, in the United States, federal regulators are significantly less lenient than state regulators (although the United States also has federal backstops in place).

- Resolution and safety nets-An effective resolution mechanism would facilitate timely intervention to address weak banks and prevent contagion across the system. A single resolution authority would support market discipline and should minimize the costs of failing individual banks, although cost minimization needs to be considered at the system level for systemically important institutions. Together with a common safety net that comprises deposit insurance (to provide certainty to retail depositors) and a lender of last resort (LOLR) (for emergency liquidity), it would enhance the capacity to cope with shocks that may overwhelm any individual economy. A credible single resolution framework and safety net would address coordination and burden-sharing problems related to cross-border

\section{CInternational Monetary Fund. Not for Redistribution}




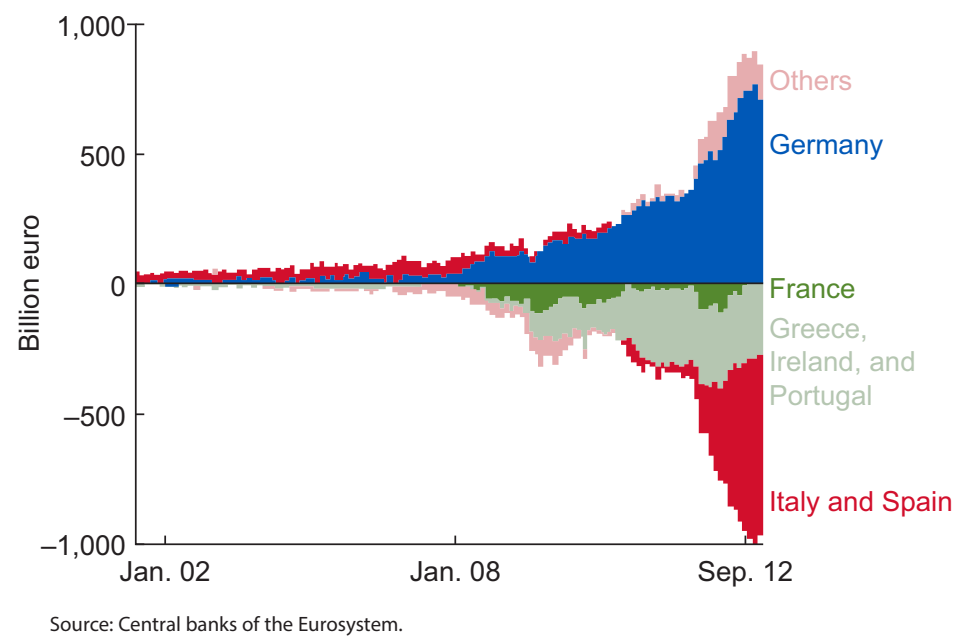

Figure 9.4 Euro Area: Central Bank's TARGET2 Balances

failures and internalize associated externalities. By moving responsibility for potential financial support from the national to the supranational level, they would decouple banks' prospects from those of sovereigns with weak finances, and protect individual sovereigns from banking sector weaknesses. They would also limit the potential burden on taxpayers, including by "bailing in" creditors as necessary.

In these ways, a banking union would narrow gaps in the design of the monetary union, enhance confidence, and strengthen the basis for financial stability, sound credit, and sustainable growth.

Would a banking union have prevented this crisis? Arguably, it would not have halted the sovereign debt crisis in some countries. But a well-functioning banking union could have substantially weakened, if not broken, the adverse sovereign-bank-growth spirals, maintained depositor confidence, and attenuated the liquidity and funding freezes that followed. The ECB's rate cuts would more likely have fed through to lower borrowing costs for the private sector. A strong banking union would also have limited the concentrated exposures of banks to certain risks. For example, euro area-wide supervisors would arguably not have allowed size, structure, and concentration risks to grow as they did in countries such as Cyprus, Ireland, and Spain, or general banking weaknesses to have accumulated in some other places. However, as experience in the United States and other economies suggests, supervision would have had to strive toward a high standard. Merely reorganizing supervisory structures would not have addressed the buildup of systemic risk or the too-big-to-fail problem.

Differences of views on cost sharing for resolution and deposit insurance and the legacy problems of the crisis could delay progress. But the cost of delaying resolution is likely to be far higher for everyone. Some member states remain exposed to potentially large costs, including through claims accumulated via Eurosystem exposures (Figure 9.4). To restore stability, agreement is needed on burden sharing for losses that occur in the future. These costs could be made more manageable by raising resources from the financial sector.

- Resolution funds-Resolution and deposit insurance funds are meant to cover individual bank failures, not systemic crises. As such, prefunded programs (in the steady state) could be fairly small. Funds could be raised over time from the financial sector to reach the target size and should be risk based (see the section "What Should the Banking Union Look Like?"). Together with a least-cost resolution mechanism and common backstops for systemic crises, the funds should be sufficient to ensure that bank failures are dealt with in an orderly fashion.

\section{(C) International Monetary Fund. Not for Redistribution}


- Backstops - In systemic crises, resolution and deposit insurance funds would likely be inadequate. Therefore, the assurance of fiscal and monetary backstops - the availability of common public resources for resolving banks and restoring confidence in the financial sector-is required to halt disorderly dynamics, such as deposit flight. A credible joint backstop, with governance safeguards, could substantially weaken bank-sovereign links and prevent inefficient cross-border resolutions along national lines. What is the fiscal cost, defined as bank recapitalization by the sovereign and other types of support?

- Gross versus net costs - It is important to distinguish gross from net fiscal costs. Net costs are invariably much smaller because recovery of asset values over time allows some of the cost of up-front support to be recouped. According to Laeven and Valencia (2012), the gross fiscal cost of a median systemic crisis is 7 percent of GDP. For the current crisis, gross costs have thus far ranged from about 4 percent of GDP in Spain to about 40 percent of GDP in Ireland. Many countries have resorted to recapitalization programs, as well as guarantees of existing or new bank liabilities (for example, blanket guarantees of all liabilities or of deposits, and guarantees of unsecured debt) or of the value of assets to forestall the possibility of a run, but these measures have reinforced sovereign-bank links. However, the net costs are expected to decline as economies stabilize.

- Credibility - The existence of common backstops does not mean that they will necessarily be tapped. Ideally, credibility would be sufficient to deter bank runs and capital flight; common backstops can prevent self-fulfilling panics that might occur if a national program is not credible. Actual costs to taxpayers could be relatively small, particularly if the need for subsequent sovereign bailouts is reduced. That said, when solvency issues arise, resources would need to be disbursed.

- On balance-In the steady state, the costs and benefits across member states would be symmetric (relative to the size of the respective banking systems). All would benefit from a betterfunctioning financial system, and insurance would be available for everyone (given that it is not clear where future problems may arise). In the interim, resolving the current crisis will require recapitalizing banks and ensuring credible common backstops. Absent progress toward a well-functioning resolution mechanism and credible backstops, sovereign-bank spirals would be prolonged, exacerbating deleveraging, worsening the recession, and causing negative spillovers. Sovereign bailouts or the failure of a systemically important institution early in the new supervisory regime would raise costs and adversely affect the credibility of the new regime.

\section{WHAT SHOULD THE BANKING UNION LOOK LIKE?}

The challenge for European policymakers is to halt the crisis while ensuring that actions dovetail seamlessly into the future steady state. Progress is required on all elements, and the governance of the banking union must provide the right incentives and promote timely decision making, lest national interests prevail and effectiveness is compromised.

- A single supervisory mechanism (SSM) without a common resolution and safety net framework will do little to break the vicious circle between banks and sovereigns and stabilize the euro area. In particular, lack of a credible resolution framework would hamper the effectiveness of the SSM, and impede timely decision making by leaving national authorities to deal with the fiscal consequences of others' supervisory decisions.

- Bank recapitalization as well as resolution and deposit insurance mechanisms would lack credibility without the assurance of fiscal backstops and burden-sharing arrangements.

- Conversely, common safety nets and backstops without effective supervision and resolution would break sovereign-bank links, but risk distorting incentives, reinforcing tendencies for regulatory forbearance, and shifting losses to the euro area level. Effective control must accompany, or precede, risk or burden sharing. 
A banking union is necessary for the euro area, given the financial fragmentation, stresses, and deposit flight from one part of the currency union to another. An EU banking union, while desirable, raises more complex issues, not least the interaction of multiple central banks. Such interaction has consequences for the LOLR function and the relationship between monetary and macroprudential policies. Potentially different access to backstops or safety nets, such as the ESM that is currently available only to euro area members, adds to the complexities. It is, therefore, prudent to proceed first with a euro area banking union, albeit with an option to "opt in" for non-euro area EU members and with adequate governance safeguards for those who wish to stay out (see Section "Dealing with the Outs").

Should all banks be covered, regardless of size, complexity, and cross-border reach? Or given potential administrative and resource limitations, should the approach be focused on systemically important banks and those that urgently need or may potentially require recapitalization? As experience has shown, systemically important banks require tailored solutions for oversight and resolution. Equally, however, larger numbers of small banks with correlated exposures (for example, Spanish cajas) can threaten systemic stability, especially when policy buffers are low. The ultimate goal should therefore be to supervise all banks, not just systemically important or vulnerable ones, because doing so would allow for complete and evenhanded treatment and limit the scope for regulatory arbitrage or capture. A phasing in of coverage, a risk-based use of scarce supervisory resources, and an appropriate level of decentralization would, in practice, need to be considered, with greater delegation initially to national authorities, and subsequent adjustment as capacity at the center is built.

This section presents considerations for a banking union in the longer term. Near-term transition and crisis management issues are elaborated in the next section. Box 9.2 briefly describes and analyzes the Commission's proposal and EU Council agreement for an SSM and road map to a banking union.

\section{Single Supervisory Mechanism}

An SSM offers many potential advantages. It would facilitate a more systemic approach to tracking the buildup of risk concentrations and contribute to achieving comprehensive macroprudential oversight of the euro area. It would allow the coordination of supervisory actions across countries, and ensure consistent application of prudential norms. It would foster convergence of best practices across members, partly alleviate concerns of regulatory capture at the local level, and promote integration of the single market for financial services. In concrete terms, higher standards of supervision in place before the crisis might have meant a swifter identification of an unsustainable buildup of risk (for example, in Ireland or Spain) and a more timely and effective intervention to diffuse such risk (for example, by applying higher capital buffers or restricting excessive concentrations).

An SSM that involves the ECB has merit. The ECB has access to supervisory skill sets given that many Eurosystem national central banks are also national supervisors. Involving the ECB would give it access to supervisory information in support of its monetary policy and LOLR duties. However, housing both banking oversight and monetary policy under one roof could potentially lead to difficult trade-offs between the two, for example, when monetary policy decisions affect bank solvency, or when the need to safeguard financial stability may call for liquidity provision to insolvent banks. As a creditor, the ECB may also face conflicts of interest when, as a supervisor, it is required to withdraw a license and trigger resolution, resulting in losses to bank claimants. These potential trade-offs call for appropriate checks and balances, such as transparency in the decisions made and implemented by the supervisory board.

Designing a system involving many countries is complex. With more than 6,000 banks in the euro area, an appropriate division of labor would be needed between the center and the national agencies, because no single new body could supervise all banks with full effect. The ECB would

\section{(C)International Monetary Fund. Not for Redistribution}


BOX 9.2. The European Commission Proposal and the Council of the European Union Agreement

European Union (EU) agreement. The September 12, 2012, Commission proposal and December 13-14, 2012, Council agreement covered the design of a single supervisory mechanism (SSM), the passage of three pieces of draft EU legislation, and the role of the European Banking Authority (EBA). According to the agreement, the European Central Bank (ECB) would start carrying out supervisory tasks in March 2014 or one year after the SSM legislation takes effect, whichever is later. Banks receiving or requesting public financial assistance would be targeted first; at the European Stability Mechanism's request and as a precondition for direct recapitalization, the ECB could begin directly supervising these banks, regardless of the starting date of the SSM. The Council further called for adoption of the Capital Requirements Regulation/Capital Requirements Directive IV, or CRR/CRD IV, as of the utmost priority, and for adoption by June 2013 of draft EU legislation harmonizing and strengthening national resolution regimes and deposit guarantee programs. The powers of the EBA were confirmed as the regulatory and supervisory standard setter and the mediator of cross-border supervision and resolution issues arising in the EU.

Supervision. The agreement specified a clear mandate for bank safety and soundness to the ECB, and its accountability to the European Parliament and the Eurogroup. The ECB would directly supervise banks accounting for about 80 percent of euro area banking assets, including banks with more than $€ 30$ billion in assets or 20 percent of national GDP, or if otherwise deemed systemically important (for example, given crossborder reach). At least the three largest banks in each member state would be directly supervised, with the ECB retaining the power to bring any bank under its supervision if deemed necessary by the supervisory board. At the ECB, a supervisory board and a steering committee are being created to prepare and implement decisions and give voice to non-euro area members that opt in (because the Governing Council remains ultimately responsible).

Operational details. The agreement appropriately conferred broad investigatory and supervisory powers on the ECB, which is responsible for the effective and consistent functioning of the SSM (although national authorities are also responsible for the banks remaining under their direct supervision). The challenges of effective implementation must not be underestimated. Operational arrangements now need to be specified, which must make incentives compatible between national authorities and the ECB, ensure an adequate division of labor, and provide for appropriate information sharing within the SSM to underpin effective supervisory decision making. The ECB has adopted a detailed framework for the practical modalities of supervisory cooperation within the SSM. The governance setup is complex, but must seek to promote, not hinder, timely decision making. Moreover, to be effective, it is essential to appropriately and urgently staff the ECB. The Council agreement provided both national authorities and the ECB with powers to make use of macroprudential instruments specified in the relevant EU directives, although accountability must be clarified. In practice, close cooperation will be critical to ensure coherence and effectiveness of measures.

Resolution and safety nets. A single resolution mechanism is an indispensable supplement to effective supervision, ideally centered on a single resolution authority, deposit insurance, and common backstops. The Council recognized the importance of a single resolution mechanism with adequate powers and tools. This mechanism is to be based on financial sector contributions and backstop arrangements that recoup taxpayer support in the medium term. The Commission made a proposal in this regard in in 2013. Though the immediate priority is to strengthen and harmonize national regimes, funds raised over time from financial institutions could cover individual small to medium-sized bank failures. Common backstops are essential to handle systemic failures. A time-bound road map to common safety nets-needed for depositor confidence and to break sovereign-bank links - would limit the risks of an incomplete banking union.

need to rely partly on the competencies and resources at the national level, with clarity on the allocation of tasks and powers as well as strong oversight and accountability to ensure compatibility of incentives and contain risks of slippages. The ECB must also be adequately resourced to ensure that it has the capacity to perform key and strategic tasks while it is able to supervise systemically important banks and those that require, or may potentially require, public support. In this regard, the challenge of developing the requisite competence at the ECB and building credibility in supervision should not be underestimated.

Guidance on the design of an effective mechanism is provided in the Basel Core Principles (the "Core Principles for Effective Supervision"). According to these principles, a number of preconditions and prerequisites must be met at the euro area level.

\section{CInternational Monetary Fund. Not for Redistribution}




\begin{tabular}{|lc|}
\hline \multicolumn{2}{|c|}{ Number of Banks } \\
\hline \multicolumn{2}{|c|}{7,246} \\
\hline United States FDIC insured & 6,027 \\
Number of banks regulated by: & 26 \\
Federal Reserve & 4,551 \\
$\quad$ of which assets > US $\$ 100$ billion & 2,036 \\
Federal Deposit Insurance Corporation (FDIC) & 7,094 \\
Office of the Comptroller of the Currency (OCC) & 6,180 \\
National Credit Union Administration (NCUA) & $>30$ \\
\hline Euro area credit institutions & \\
\hline of which assets > $€ 100$ billion &
\end{tabular}

Sources: European Central Bank; FED; FDIC; and NCUA.

Figure 9.5 Banks under Supervision

- Preconditions for sound banking include (1) the implementation of coherent and sustainable macroeconomic policies, (2) a clear framework for financial stability policy, (3) an effective crisis management and resolution framework to deal with bank failures and minimize disruptions, (4) an adequate safety net to deal with a crisis of confidence while minimizing distortions, (5) a well-developed public infrastructure, and (6) effective market discipline.

Clearly, some of these preconditions are beyond reach in the immediate future, but they are essential for the effectiveness of the new system in the longer term.

- Prerequisites to establish a sound basis for the SSM include (1) operational independence of the SSM; (2) clear objectives and mandates; (3) legal protection of supervisors; (4) transparent processes, sound governance, and adequate resources; and (5) accountability. The Commission proposal and EU Council agreement by and large meet these prerequisites. Clarity is required on resources, and aspects of the governance mechanism and legal robustness, for example, delegation, may require strengthening.

Supervisors at the national and supranational levels must have clear responsibilities and the powers necessary to perform their tasks. Having formal responsibility but no real enforcement power (as could occur at the ECB level) would carry serious risks, whereas having the power but no clear responsibility or accountability (as could occur at the national level) could lead to misaligned incentives and distorted outcomes. A monitoring mechanism thus becomes important. The ECB should have the ability to conduct joint inspections and peer reviews and establish cross-country teams of supervisors with an ECB-appointed head (drawing lessons from EBA's experience with peer review could be helpful). Along with operational independence, accountability, and governance, joint inspection teams would provide safeguards to further align national interests with the interests of the center.

Although the euro area has more than 6,000 banks (a similar order of magnitude as in the United States; see Figure 9.5), the 150 largest banks account for about 80 percent of banking system assets. Thus, some degree of delegation is necessary. Full centralization is neither practical nor desirable because supervisory knowledge and resources remain at the national level. Full decentralization in which the center merely validates decisions is not desirable either, particularly when common resources are at stake (for example, ESM direct recapitalization of banks or future common backstops). The goal should be to create a coherent and consistent supervisory mechanism with adequate information flow and final significant decisions made at the center. To ensure 
incentives are compatible, the degree of delegation should be clarified. The extent of delegation would depend on the ECB's supervisory classification of risks for each bank, and factors such as the importance of local knowledge and know-how, the systemic dimension of banks and tasks, and the amount of discretion required in decision making. For example, institutions with systemic implications should be subject to more intrusive supervision from the center, as should functions that are more subject to discretion, capture by the industry, or political influence. Consolidated supervision of financial groups would involve interagency coordination to oversee nonbank financial institutions as well.

To facilitate identification of, and action on systemic risks, including information sharing and home-host coordination, and internalization of cross-border externalities, some shift in macroprudential mandates and tools - away from member states and toward the ECB-should be considered. The ECB should be given binding powers to be able to use macroprudential instruments if it deems doing so to be necessary. Given the ECB's established expertise on financial stability, the setup costs should be limited. The framework should involve national authorities and be sufficiently flexible to tailor solutions to local conditions. Therefore, national authorities should also be able to make use of macroprudential tools within the parameters and guidelines set by the ECB, and mechanisms are needed to resolve conflicts of interest that may arise between national authorities and the ECB. The ECB should also coordinate with the ESRB.

The regulatory framework would largely build on existing and upcoming regulations designed at the EU level, in close coordination with non-euro area EU members.

\section{Single Resolution Mechanism}

A single authority as presumptive receiver of failed banks can facilitate timely resolution, including of banks that operate across borders. Such an authority provides a mechanism for internalizing home-host concerns and reaching agreement on resolution and burden sharing. It can thus help to avoid the protracted and costly resolutions that occurred, for instance, in the cases of Fortis and Dexia (Box 9.3). A single authority is also necessary for aligning incentives for leastcost resolution-because a common backstop in the context of a decentralized mechanism would provide mal-incentives to shift residual losses from national taxpayers to those in the euro area. Pooling bank resolution capacity in a single body would achieve economies of scale, avoid incoherence and duplication, and accumulate expertise for the preparation and implementation of recovery and resolution plans, in particular for systemically important institutions. At the same time, there are important complexities. If a common approach to resolution is based on national legislation, significant resources may be needed at the national level to deal with different legal regimes. A single resolution authority, the preferred approach, would be based on supranational legislation, but any treaty change would require time.

Emerging best practices are laid out in the "Key Attributes of Effective Resolution Regimes for Financial Institutions," according to which the resolution authority should seek to resolve financial institutions without disrupting financial stability (Financial Stability Board 2011). It should minimize costs to taxpayers; protect insured depositors; and ensure that shareholders and unsecured, uninsured creditors absorb losses. There are prerequisites and preconditions of effective resolution:

- Preconditions for effective bank resolution include (1) a well-established framework for financial stability; (2) an effective system of supervision, regulation, and oversight of financial institutions; (3) safety nets and protection programs; (4) a robust accounting, auditing, and disclosure regime; and (5) a well-developed legal framework.

- Prerequisites for a strong authority include (1) operational independence consistent with statutory responsibilities; (2) transparent processes; (3) legal protection; (4) sound governance and rigorous evaluation and accountability mechanisms; and (5) adequate resources.

\section{CInternational Monetary Fund. Not for Redistribution}




\section{BOX 9.3. Resolutions of Fortis and Dexia}

Fortis. In the aftermath of the Lehman Brothers collapse, an agreement was reached on September 28, 2008, to save the troubled Fortis group with taxpayer support from Belgium, Luxembourg, and the Netherlands. The agreement, however, fell apart soon thereafter as liquidity pressures mounted. Subsequently, the Belgian parent company sold the shares of the Dutch parts of Fortis to the Netherlands government, while Belgium and Luxembourg sought a common solution for their parts of Fortis, eventually agreeing to sell the banking arm to BNP Paribas. This breakup along national lines was a setback to financial integration in the Benelux and was likely more costly than a first-best joint solution for the group.

Dexia. Dexia failed in 2011 after losing access to wholesale funding and facing increased collateral demands on interest rate derivatives. The resulting breakup was segmented along national lines. On October 10, it was announced that the Belgian operations would be purchased by the Belgian government; foreign subsidiaries in Canada, Italy, Luxembourg, Spain, and Turkey would be put up for sale; and parts of the French operations would be purchased by two French public sector banks. The remaining troubled assets, including a $€ 95$ billion bond portfolio, would remain in a bank runoff (Dexia SA) that would receive funding guarantees of up to $€ 85$ billion provided severally but not jointly by the governments of Belgium, France, and Luxembourg and recapitalization of $€ 5.5$ billion. At end-2012, the Commission approved the resolution plan for Dexia Group.

A single authority would need a mandate, alongside the supervisor, to develop resolution and recovery plans well ahead of, and to intervene before, insolvency using well-defined quantitative and qualitative triggers. The authority would need strong powers to take early intervention measures (for example, to require capital conservation measures or restrictions on activities), restructure banks' assets and liabilities (for example, apply a "bail-in tool" to subordinated and senior unsecured creditors, transfer assets and liabilities - "purchase and assumption" - to a sound acquirer, and separate bad assets by setting up an asset management vehicle), override shareholder rights (subject to them being no worse off), establish bridge banks to maintain essential financial services, and close banks.

Because resolution involves sensitive choices about the distribution of losses, clear burdensharing mechanisms would need to be established in advance to realize least-cost resolution. At the same time, a systemic risk exception is needed (Box 9.4).

- Hierarchy-Respecting the hierarchy of creditor claims, the resolution authority should be able to haircut or extinguish unsecured liabilities, starting with equity and potentially extending to senior unsecured debt, according to a clear creditor priority list. This ability would reduce uncertainty in the capital structure and any eventual resort to taxpayer funds. Given their explicit taxpayer backing, insured depositors would need to be given clear priority among unsecured bank liabilities to maximize recovery of deposit payouts from failed banks in resolution. Depositor preference provisions should be included in EU legislation, possibly in the draft recovery and resolution directive.

- Contributions - Contributions from the industry - held in a fund—should be used first to finance resolution. Insofar as private sector contributions and loss allocation across uninsured and unsecured claimants might be insufficient in a systemic crisis, a common backstop would need to be tapped. Contributions could follow specific rules established in advance, for example, based on the ECB or ESM capital keys.

The resolution fund would build resources over time through levies on the industry. It would be prefunded through premiums. These premiums should be risk based, which would help capture national specificities in risk parameters. Use of funds could be complemented by arrangements to recoup net losses through levies on the industry after any crisis. In the event a systemically important institution is under stress, common backstops, including temporary funding support from the ECB, with safeguards, would ensure adequate liquidity. The EU draft directive on bank recovery and resolution states explicitly that, under the new EU regime, national resolution authorities will have the possibility to borrow from the central bank.

\section{CInternational Monetary Fund. Not for Redistribution}




\section{BOX 9.4. A Systemic Risk Exception for Europe}

Europe's bank-sovereign conundrum is intertwined with the issue of systemic risk. In many countries, national authorities are supporting banks that would otherwise fail, including those considered too big to fail. Fiscal authorities have plugged negative equity, topped up capital, provided guarantees, and set up stateowned asset management companies or asset protection programs-in some cases hurting sovereign credit standing in the process. National central banks, in turn, have extended vast volumes of emergency liquidity assistance to plug structural funding gaps in the wake of funding runs-financing this lender-of-last-resort liquidity through TARGET2.

Systemic risk creates legitimate concerns. Policymakers perceive, often correctly, that bank closure followed by least-cost resolution will trigger contagion, bank runs, and asset fire sales-including of government securities - threatening damaging wealth effects, loss of market access, and worse. In such situations, bailouts may present the lowest-cost option. However, in some countries with particularly oversized banking systems relative to their domestic tax bases-for example, Ireland-loss of market access by both banks and the sovereign has proved unavoidable.

The U.S. system, with its statutory "systemic risk exception," may be instructive. In the United States, the default option for failed banks is resolution at least cost to the Deposit Insurance Fund. However, the statutes also include a systemic risk exception to the least-cost resolution requirement. Given evident moral hazard, the law sets a high bar to invoke the exception: a "three keys" approach requiring support by two-thirds of the Federal Deposit Insurance Corporation (FDIC) and Federal Reserve Boards and concurrence by the secretary of the treasury after consultation with the president. The exception was invoked four times in 2008:Q4, once to justify the FDIC's blanket guarantee, and three times to rescue failing U.S. systemically important financial institutions-with each of the latter three operations combining fiscal support and large Federal Reserve funding commitments.

Europe, too, needs procedures to analyze the possibility of systemic risk in bank failure. A systemic risk exception for the euro area would lend needed clarity and credibility to the bank resolution process. Formal vetting procedures would limit moral hazard and protect resolution funds (aided by indicative criteria giving shape to unacceptable systemic risk). Recognition will be needed, however, that because of financial fragmentation the case for intervention can be made not only for a few European systemically important financial institutions, but also for "domestically systemic" banks. Thus, systemic risk determinations should include a concern for local credit conditions even for banks whose failure would have little direct impact at the euro area level.

A systemic risk exception for the euro area would be a unique construct. The triggering procedure would need to balance national and collective concerns, and recognize that systemic bank resolutions typically require both fiscal and central bank backstops. Findings of unacceptable systemic risk could, for instance, require two-thirds majorities of the national central bank and European Stability Mechanism boards (the latter later replaced by the single resolution authority) with concurrence by the ECB's Governing Council. This or some similar arrangement would help ensure proper and credible vetting of bank failures, sorting banks into those warranting least-cost windup and those requiring support.

The resolution mechanism should specify clear exit strategies that maximize the value of participations acquired and prohibit national preference.

The resolution authority should manage the resolution and deposit insurance fund. Given the complex fiscal decisions involved, and the need for checks and balances, the resolution authority should be set up independently of, but on par with, the ECB supervisory mechanism. Coordination and information sharing between the two, with due attention to incentives compatibility, is essential. For instance, consideration could be given to the creation of a committee comprising the head of the supervisory function of the ECB and the chairman of the resolution authority. Alternatively, the ECB head of supervision could serve on the board of the resolution authority, together with national representatives and representatives of other EU bodies.

\section{Common Safety Nets}

Once uniform prudential oversight across euro area countries is effectively in place, it becomes feasible to contemplate the pooling of risk. By pooling risk, common safety nets-common deposit insurance and centralized LOLR - will not only help countries avoid disruptions that

\section{CInternational Monetary Fund. Not for Redistribution}


may overwhelm their individual capacities but also form a key pillar in the incentives compatibility of the banking union. If a weak sovereign is perceived not to be able to honor its safety net obligations, losses of confidence can quickly follow, triggering capital flight and deposit outflows. A pooled mechanism with credible backstops would more effectively protect confidence and diversify risks across banks. But without common safety nets and backstops, the banking union would remain an incomplete and risky construct that fails to delink the funding costs of weak sovereigns from that of their banks. It would also risk jeopardizing the credibility of the ECB and the SSM by leaving the system vulnerable to financial fragility.

The resolution and deposit insurance fund could be relatively small and cover some individual bank failures, with fiscal and central bank backing to be used in the event of a systemic crisis. The fund could, in practice, cover both resolution and deposit insurance; if the ranking of claimants is clear and adequate, the objectives of the two functions would be aligned. Although there is no well-established good practice, the typical target size of resolution and deposit insurance funds could range from about 1-2 percent of total liabilities (excluding equity) in large systems (as in the Commission proposal, or as in the United States) to 4-5 percent in smaller systems, where the aim is to cover two or three midsized banks and four to six small banks. The target size also varies with the quality of the institutional environment and resolution regime, including the presence of prompt corrective actions and early structured intervention mechanisms.

The idea of creating a common resolution fund, administered by the single resolution authority, while harmonizing deposit insurance programs but allowing them to remain at the national level has also been discussed. Such a model would enhance the effectiveness of the SSM while providing common financing for resolution, although without common backstops its impact would be limited. Under this model, it will be essential that national deposit insurance funds are available to contribute to resolution, up to the amount available for payout. Even so, the disadvantages would be less efficient risk pooling, which would not effectively decouple sovereigns and banks; complexities in cost allocation and implementation for cross-border failures, requiring close coordination between national deposit guarantee programs and the single resolution authority; and duplication of costs and administrative resources because the same banks would be assessed for both funds.

The LOLR makes liquidity support available to solvent yet illiquid banks. Centralizing all LOLR functions at the ECB would, in the steady state, eliminate bank-sovereign linkages present in the current emergency liquidity assistance (ELA) program (see Box 9.1). Centralization would require changes to the ECB's collateral policy because by definition euro area banks that tap ELA cannot access Eurosystem liquidity owing to collateral constraints. Until such time as all banks are brought under the ECB's supervisory oversight, ELA would be sourced through both the ECB (for banks brought under its purview) and national central banks (for banks that remain under national supervision, albeit with adjustments made to the national ELA limits).

\section{HOW DO WE GET THERE?}

A firm plan of key deliverables toward a full banking union should anchor execution. In normal times, a gradual sequencing might start with first harmonizing rules governing national regulation, supervision, resolution, and safety nets, a process that may take some years as EU directives are fully adopted at the national level. This step would be followed by gradual development of new common institutions. Eventually, once there is agreement on burden sharing, the process would culminate in a full banking union, with an SSM, a single resolution authority, a common resolution and deposit insurance fund, and common backstops. After all, a decade elapsed between the European Council decision to realize the monetary union in 1989 and the launch of the euro in 1999. 
But times are not normal. Critical to addressing the crisis is the repair of the financial sector, including through bank recapitalization that weakens the damaging bank-sovereign dynamic and creates more favorable conditions for stabilization. In the context of private and public sector deleveraging, raising resources domestically to recapitalize banks is challenging (impossible in some jurisdictions). At the same time, closing domestic systemically important banks continues to pose a risk of uncontrollable consequences. Shared support for recapitalization would facilitate financial and economic stabilization at the national level, and thus for the monetary union as a whole, although it raises questions about burden sharing and moral hazard.

In June 2012, euro area leaders affirmed, "it is imperative to break the vicious circle between banks and sovereigns.... When an effective single supervisory mechanism is established, involving the ECB, for banks in the euro area the ESM could, following a regular decision, have the possibility to recapitalize banks directly" (Council of the European Union 2012). The Council agreed on December 13-14, 2012, that, at the request of the ESM, the ECB may start directly supervising a bank as a precondition for direct recapitalization, once the SSM regulation takes effect (that is, even before March 2014). The Council also called for agreement on an operational framework for direct recapitalization, including the definition of legacy assets, by June 2013.

To be clear, the core purpose of ESM recapitalization of domestically systemically important banks undergoing restructuring must be to remove the residual risk from the balance sheet of a sovereign whose finances are already strained. Unviable, nonsystemic banks should be wound down at least cost, and systemically important banks should be resuscitated by shareholders, creditors, the sovereign, and the ESM as the quintessential patient, deep-pocket investor. By delinking the sovereign from future unexpected losses on bank balance sheets, ESM direct recapitalization would remove future tail risks from the sovereign balance sheet; ensuring that the banks have an owner of unquestioned financial strength would improve bank funding conditions. Thus, the ESM would attack the sovereign-bank link from both sides. In all cases, ESM involvement should be conditional on a determination of systemic risk, which could be as basic as a finding that the bank is too large for the sovereign alone to wind up, given the state of public finances. A robust mechanism for the systemic risk determination will be critical (Box 9.4).

Sequencing the key steps toward a banking union while implementing crisis resolution measures raises at least four issues: (1) what is essential for "effective" supervisory control? (2) how should steps toward a full banking union be phased in? (3) how should burden sharing in ESM direct recapitalization of banks be accomplished in practice? and (4) what are the risks? Each of these issues is taken up in turn.

\section{Effective Supervision}

How should the SSM be judged as having become effective?

- Basel Core Principles-One approach would be to apply the Basel Core Principles. Full supervisory capacity would need to be set up, and the various prerequisites and preconditions met, including establishing an adequate safety net and crisis management and resolution frameworks. The approach demands completeness, and could take years to achieve. In effect, the present crisis resolution efforts should be viewed as stepping stones to the longerterm task of building a robust architecture for financial stability. The Basel Core Principles are therefore the internationally recognized standard for use in the new steady state.

- Pragmatic approach-A more modest and pragmatic approach for the near term was adopted by the EU Council at its December 2012 meeting: as soon as the SSM regulation is adopted, the ECB could, at the request of the ESM, start to directly supervise a bank, as a precondition to it receiving ESM direct recapitalization. If pursued, this approach opens the door to the critical task of repairing weak, systemically important banks, while ensuring 
that the ECB has the powers and tools needed to supervise these banks. It is thus critical to swiftly secure legislative agreement and adoption, establish a single rule book, and begin preparation both for supervision at the ECB and for ESM direct recapitalization (including finding common ground on remaining issues in the first half of 2013).

\section{Sequencing Banking Union}

An agreement on burden sharing and common backstops at the outset would both pave the way to a full banking union and facilitate current crisis management. It would set the stage for a single resolution authority that would coordinate corrective actions with the SSM. Absent centralized resolution, the SSM would need to coordinate with multiple national resolution authorities, especially for banks operating across borders. As a result, conflicts over the distribution of losses could arise because the fiscal consequences of coordinated supervision remain national. The incentives would be to shift the costs of resolution, delaying action and jeopardizing the achievement of least-cost resolution. Therefore, sequencing in which the SSM is set up alongside an agreement on burden sharing and common backstops would ensure that decision making at all levels of the banking union is incentives compatible. Following that, a common resolution fund and deposit guarantee program could be set up to provide a risk-sharing mechanism.

The elements above-an SSM, single resolution mechanism with common backstops, and common safety nets—are necessary for a successful banking union. Missing elements would result in an incoherent banking union and, at worst, an architecture that is inferior to the current national-based one. Therefore, ideally, progress would be made on each of the elements. Given the need to resolve outstanding differences of views on the details and timing, however, it may not be possible to make progress on all the elements now. This lack of simultaneous progress could result in a different sequencing than ideally warranted. In any event, it is crucial that all the elements of a successful banking union are included eventually. A well-defined timetable at the outset would remove uncertainty, bolster confidence in the political willingness to build a robust financial stability architecture, and anchor execution. A possible approach could be as follows:

- Harmonized legislation-As noted, adoption of the single rule book-CRR/CRD IV, the recovery and resolution directive, and the deposit insurance directive-needs to proceed urgently. Agreed-on drafts of these pieces of EU legislation should be submitted to the EU Parliament as soon as possible, with approval during the first half of 2013 and adoption in national legislations starting in the course of 2013.

- Implementing the SSM-A phased rollout of the SSM could seek to make it "effective" for troubled systemically important banks over the course of 2014. The emphasis should be on establishing a strong SSM in which the ECB has formal powers, the decision-making processes, and the capability to perform essential supervisory tasks in an intrusive delegated monitoring model. The ECB must be able to request and receive all necessary information, conduct off-site diligence, field on-site inspections, and pursue further action on any bank in the euro area. A well-functioning information and evaluation infrastructure must be established quickly so that the ECB can serve as a central supervisor.

- The ECB would need to put in place adequate resources and organizational capacity to commence selected supervisory tasks, which will be a complex and demanding exercise. Based on information to be provided by national authorities on their banks' supervisory histories and risk profiles, the ECB could then start off-site stocktaking of the banks under its supervision, to prioritize institutions in need of deeper diagnostics based on risk.

- Once essential capacity is in place, the ECB could start, say by end of 2014, actively supervising banks receiving state aid, with an appropriate degree of delegation to national authorities but with the key decisions made at the center. Reaching agreement before this 
date on ESM direct recapitalization would allow for direct recapitalization to occur soon thereafter.

- With the largest 150 banks accounting for about 80 percent of banking system assets in the euro area, the supervision of most banks could remain the responsibility of national authorities, although the ECB should have the prerogative to step in wherever needed (as indeed provided for by the EU Council agreement). This would allow an initial focus on the banks at the heart of the current crisis, such as the Spanish cajas, where correlated exposures fueled systemic risks. In all these cases, appropriate delegation to national authorities would be essential, with accountability and governance arrangements, but with key decisions made at the center. Delegating also provides flexibility, particularly during the transition when the ECB builds resources, but caution is needed to not lock in an imperfect delegation practice in the SSM. Adequate early intervention powers for the ECB provide incentives for cooperation, and are essential for the effectiveness of the SSM.

- Implementing single resolution and common safety nets-

- It is essential that the EC commit to a firm timeline for implementing a single resolution mechanism, including burden-sharing arrangements. The Commission is to present a proposal in the course of 2013.

- When agreement on adequate resolution (and deposit insurance) funding and backstops is in place, the single resolution authority could begin operating. Meanwhile, resolutions would be handled by the national authorities under strengthened regimes (and, as needed, support from the sovereign with borrowing from the ESM).

The ECB-centered SSM would have powers of early intervention. It would work with national resolution authorities to resolve or restructure weak institutions, until a single resolution authority with common backstops is established. To facilitate the process, there may be merit to establishing a temporary body or rapidly creating an EU agency tasked with the coordination of bank crisis management and resolution among national authorities and the ECB.

Steps should also be taken toward common safety nets. A reinsurance program, for instance, could be created from national deposit guarantee programs, funded at the euro area level through industry levies and contributions from member states. It would pool risk and weaken sovereignbank links. Agreement beforehand on the shares of national and supranational funding in depositor payouts would limit moral hazard. Over time, the fund would build administrative capacity, and could be a step toward a permanent euro area program and resolution fund.

Finally, although working under the existing treaty framework is the swiftest way to begin, gradually strengthening the legal framework would minimize implementation and litigation risks (Box 9.5).

\section{ESM Direct Recapitalization}

Mobilizing the ESM direct bank recapitalization tool in a forceful and timely manner is critical to developing a path out of the current crisis, and would complement other measures such as the ECB's Outright Monetary Transactions. Recapitalization of frail, domestically systemically important banks in the euro area, including some migration to the ESM of existing public support to such banks, can help break the vicious circle between banks and sovereigns, reduce financial fragmentation, repair monetary transmission, prepare for banking union, and thus help complete the economic and monetary union. To be sure, failing nonsystemic banks should be resolved at least-cost to national resolution funds and taxpayers. Equally, systemically important banks benefiting from ESM support will need effective supervision and reform to be returned to full viability and private ownership, with state aid rules mandating formal restructuring plans. In some 


\section{BOX 9.5. Legal Considerations}

Legal basis of the banking union. Under Article 127(6) of the Treaty, the European Central Bank (ECB) is able to take on specific supervisory tasks without treaty change, upon a unanimous decision of the European Council and after consultation with the European Parliament and the ECB. The EU Council agreement vests in the ECB exclusive authority for a wide range of supervisory tasks. Article 127(6) provides a legal basis, and has been interpreted expansively to establish the single supervisory mechanism (SSM). The draft SSM regulation carefully attempts to specify the ECB's remit, but litigation risks may, in principle, not be excluded-any financial institution confronted with a supervisory decision by the ECB could bring a case before the European Court of Justice $(E C J)$ on grounds of lack of competence. In the medium term, providing explicit legal underpinning for financial stability arrangements in the Treaty would further strengthen their legal soundness. This would allow financial stability to be anchored as a key objective under the Treaty and for the roles and powers of all the safety net players to be defined, including a full-fledged resolution authority with a common backstop.

Shared competences and responsibilities. Under Article 127(6) and the regulation that is based upon it, supervision will remain a shared competence between the ECB and member states. The ECB will be responsible for certain supervisory measures, while member states retain their powers with respect to any aspect that is not covered by the draft SSM Regulation (for example, anti-money laundering, consumer protection, and some macroprudential tools). For the tasks conferred to it, the ECB would make the final decisions vis-à-vis "significant" banks, while the national competent authorities (NCAs) would assist the ECB with the preparation and implementation of such decisions, pursuant to the ECB's instructions. For other banks, NCAs will formally make supervisory decisions, but still under ECB instructions. The ECB will be responsible for the effective and consistent functioning of the SSM, and both the ECB and the NCAs will be subject to a duty of cooperation. The overall division of tasks and responsibilities will need to be clarified to remove any remaining uncertainties as to who, as a legal matter, will be ultimately accountable for supervisory decisions.

ECB governance. The Governing Council is the ultimate decision-making body of the ECB, as enshrined in the Treaty, including for any supervisory tasks conferred upon the ECB under Article 127(6). Several challenges may arise from this setup. First, because the supervisory board can only prepare the supervisory decisions to be made by the Governing Council, it is only the latter that will formally be responsible for supervision, in addition to monetary policy. Therefore, the separation of monetary and supervisory responsibilities can only be implemented at an operational level because the legal mandate of the ECB, pursued by the Governing Council as the ultimate decision-making body, remains unaltered. Second, the existence of multiple layers of governance arrangements, coupled with the impossibility of delegating decisions to the supervisory board, may create a burdensome process; legal risks may arise from the need to align daily supervision practices with the legal requirements dictated under the Treaty and the SSM regulation. Last, because non-euro area SSM participants cannot be represented on the Governing Council of the euro area, taking part in the SSM decision-making process would require alternative arrangements for their voices to be heard, such as through the supervisory board, with mediation channels to resolve differences.

EU banking laws. The EU's banking laws have significant weaknesses in both form and substance. On form, the current approach based on directives implemented in national laws must swiftly be replaced by a directly applicable single rule book. On substance, current weaknesses in EU banking law will also have to be remedied, for example, weak fit-and-proper criteria and the absence of restrictions on related-party lending.

Legal actions at the national level. Whether the EU regulation conferring supervisory tasks on the ECB also requires legal changes at the national level is unclear. However, amendments to national legislation seem to be inevitable, to provide the legal clarity that will ensure the smooth functioning of the SSM. Absent a single, directly applicable rule book, such amendments to domestic legislation may also be necessary to improve national supervisory regimes.

cases, the sovereign itself may need an adjustment program, providing an enabling environment for asset price recovery.

The mobilization of the ESM direct recapitalization tool should ensure that frail, domestically systemically important banks have adequate capital, access to funding at reasonable cost, and positive profits-in short, a viable business model. To this end, asset valuations are critical, as are the roles of shareholders, creditors, and the domestic sovereign in bearing costs.

- In principle, there would be significant advantages to breaking the vicious bank-sovereign circle if all the capital needed to ensure a systemically important bank was adequately capitalized was ultimately provided by a central fiscal authority. This would especially be the case

\section{CInternational Monetary Fund. Not for Redistribution}


if the scenario were to play out in a small jurisdiction, and even more so if it also had to internalize spillovers to others (that might result, for example, if external creditors did not share in losses, for fear of triggering wider problems). More generally, pooling risk would provide protection to all in advance of any crisis, because any country could, in theory, find itself in a similar position in the future.

- In practice, although the treaty establishing the ESM provides for the possibility of losses, such losses are not expected in its financial operations, including bank recapitalization. As a bank investor, the expectation is that the ESM must be careful to take balanced risk positions. It likely could not provide capital that a patient investor would not expect to recover over time. Thus, capital needed to bring a systemically important bank out of insolvency (that is, to bring it from negative to nonnegative equity) would in the first instance need to be provided by shareholders and creditors, and then by the national government, with any remaining shortfall covered by the ESM. Fortunately, there are unlikely to be large, insolvent banks currently in most economies.

- A balanced approach would prudently internalize the benefits of ESM capital support by looking ahead over a time horizon sufficiently long to realize the benefits. As a patient, deeppocket investor, the ESM should take a long-term perspective in its investment decisions, recognizing that gross up-front crisis outlays tend to dwarf ultimate costs net of recoveries or capital gains and, in many instances, generate positive financial returns.

- Asset valuation-The implications for asset valuation, which determines the size of recapitalization needs as well as investors' upside or downside risks, are twofold. First, asset values should be neither too high (which would imply mutualization through the back door) nor too low (in which case, the private sector could simply buy the assets, and there would be limited benefit to having an official investor). Second, because the ESM is a patient investor willing to give the banks the necessary time to restructure, assets should be priced at values that give due consideration to the positive effect of recapitalization on asset values. This effect includes not just the direct positive effect of recapitalization (including more favorable funding costs) and recovery, but also the removal of tail risk events (see next bullet point).

- Risk sharing-As a patient, deep-pocket investor, the ESM provides assurance to creditors that, in the event of a negative surprise, potential future capital needs can be met. In other words, although the ESM would not take on expected losses, it would shoulder the risk of unexpected future losses. This approach is in line with efficient risk sharing, wherein the patient investor bears the residual risk. In this regard, it should be noted that, conditional upon the ESM standing ready to take material losses in a downside scenario, the ESM would be unlikely to actually incur those losses, because the investment would minimize the risk of the adverse scenario occurring.

- No first loss guarantees-ESM investments should not benefit from loss protection provided by the sovereign. Such approaches would preserve sovereign-bank links, undermining the purpose of ESM direct recapitalization. But there should be safeguards for the ESM (for example, built into the sales contract) against domestic policies that could directly harm the viability or profitability of the recipient banks (for example, onerous taxes imposed after the crisis or stiff resolution levies).

- Exit strategy - Incentives should be provided for an early ESM exit and private investor entry. The timing would be built around the EU-approved restructuring plans. Mandatory sunset clauses should be avoided because they could affect negotiating power ahead of the deadline.

- Adequate resources - Direct equity injections into banks could absorb significant amounts of ESM capital. It would be important to ensure that the ESM has adequate capital to not only allay any investor concerns about ESM credit quality, and thereby limit any rating implications, but also play its potential role as a common backstop for bank recapitalization.

\section{CInternational Monetary Fund. Not for Redistribution}


This term has been very controversial, reflecting concerns that creditor countries could be expected to put capital into unviable banks. This is not what is being suggested above. Rather, losses on impaired "legacy" assets should be recognized through up-front provisioning and proper (long-term, postcrisis) valuation. It is not recommended that all impaired assets be segregated from the bank before ESM direct recapitalization and placed into recovery vehicles ultimately backed by the national taxpayer; such an approach would greatly reduce the effectiveness of the tool in addressing bank-sovereign links. Rather, bank health should be restored with shareholders, including the sovereign, bearing the expected loss of past excesses by being subjected to an independent valuation exercise consistent with the shared commitment to restore full viability after the restructuring period.

To further support balance sheet clean up, certain classes of legacy assets could be transferred to asset runoff vehicles such as asset management companies (AMCs) under ESM ownership. Expected losses would remain with the sovereign, given the terms of the foregoing recapitalization. But to limit further contingent fiscal liabilities and harness efficiencies, consideration could be given to allowing the ESM to set up and own AMCs. Possible roles for the ECB in supporting AMC operations could also be considered (although concerns regarding the prohibition on monetary financing may also be raised). ECB funding, if possible under its statute, would help smooth over time the warehousing and disposal of hard-to-value and hard-to-sell assets. An alternative would be for the ECB to support AMC operations indirectly by accepting ESM-guaranteed AMC bonds issued to banks in Eurosystem refinancing operations.

\section{Risks in Transition}

The move toward a banking union must not stop prematurely with an SSM. If it does, although the benefits of coordinated supervision would accrue, the costs derived from coordinating resolution across national authorities - with limited incentives for least-cost and rapid action, and no common backstops - could undermine effectiveness. Therefore, critical design aspects must not be deferred far into the future. Agreement on burden sharing and ESM direct recapitalization must also not be delayed, lest the costs of the crisis keep mounting. For example, the lack of common backstops could lead to a slower pace of restructuring or resolving problem banks. Policy paralysis or backsliding in the current environment could derail confidence and the recovery. Still, progress under constraints may be better than no progress at all, as long as all the essential elements of the banking union come together in time.

Pragmatism would need to govern decisions related to SSM resources. Mobilizing the necessary resources, building the requisite capacity, and putting in place effective and incentives-compatible structures will inevitably involve iteration. In the meantime, supervisory drift could occur. To contain these risks, clarity is essential on the responsibilities and accountability of the various supervisory authorities. The ECB must move swiftly to put in place cross-country teams for the supervision of the most systemically important or fragile banks. It will also need to set up the capacity to interact frequently and effectively with national resolution authorities.

Conflicts of interest could arise between the ECB's monetary policy function and its supervisory responsibilities - for example, when monetary policy decisions affect bank solvency, or when the need to safeguard financial stability may call for liquidity provision to insolvent banks. These risks would be exacerbated by the lack of a robust resolution (and early intervention) regime and safety nets. Besides completing the architecture, consideration could be given to strengthening the governance of the decision-making process and accountability of supervision at the same level as the central banking functions. The Council agreement on the SSM strengthened the governance arrangements relative to the Commission proposal. The supervisory board will draft decisions that will be deemed adopted unless the Governing Council objects within 10 days in normal times and 2 days in stressful times. In practice, it will be important to balance the 
representation of national interests and public officials from the ECB in the governance structure of the SSM.

A banking union could change the very structure of finance. Further consolidation of banks could occur and new banks could enter (for example, as country-level rules give way to uniform union-wide ones), and interconnections may strengthen across the banking union. More banks could become too systemically important to fail at the union level-the banking union does not solve the too-big-to-fail problem — and the associated moral hazard might not be resolved (the SSM may help contain incentives to grow excessively, including, for example, through capital surcharges for systemically important financial institutions). These and other issues would raise new challenges for financial stability, requiring renewed vigilance and decisive action against identified risks. In this respect, some of the recommendations of the EU High-Level Expert Group on structural bank reforms (the Liikanen report) could prove useful.

\section{DEALING WITH THE “OUTS"}

This chapter argues that a banking union is necessary for the euro area. What is the benefit to non-euro area EU members of a euro area banking union? It should be recognized that, by enhancing stability and removing financial market fragmentation, a well-functioning euro area banking union generates positive spillovers and enhances the functioning of the EU single market for financial services. Therefore, other EU members have a legitimate interest in ensuring that the new system is set up properly. A single euro area supervisory mechanism can also solve coordination problems related to the supervision of cross-border banks.

But a euro area banking union raises a number of issues for the "outs": (1) how can the interests of the "outs" be protected in decisions made by the SSM, for example, in the EBA and supervisory colleges in which the SSM would be represented by the ECB, on the integrity of the single market, and on issues such as the fiscal consequences of decisions on banks with cross-border operations; and (2) how can the interests of those who wish to join the banking union but keep their own currency be represented, given that they would not have a voice in the ECB Governing Council? Some also want the banking union to be made more attractive to join, for instance, by facilitating access to backstops and safety nets, albeit with commensurate contributions.

Strengthening the EBA provides an avenue not only for protecting the interests of the "outs" but also for coordinating action. In this regard, the Commission proposal and EU Council agreement confirming the role of the EBA as the mediator of cross-border supervision and resolution issues and the regulatory and supervisory standard setter in the EU is helpful. Non-euro area EU members should retain an adequate voice within the EBA. The Council agreement modified voting procedures within the EBA board with double majority voting to balance the interests of the "outs." It will be important that the EBA be an effective and credible force in the single financial market, including limiting concerns about regulatory arbitrage. Likewise, the ESRB's role as the main macroprudential oversight body in the EU would need to be strengthened further, and it should cooperate closely with the ECB, once the ECB takes on greater macroprudential responsibilities.

The Council agreement seeks to allow non-euro area EU countries to opt in, through representation and procedures on the supervisory board (since these members cannot be represented on the ECB's Governing Council). As noted, draft decisions prepared by the supervisory board are deemed adopted unless the Governing Council objects within 10 days in normal times or 2 days in stressful ones. A mediation panel and a steering committee would also be created. These structures seek to aid decision making and resolve disagreements, and to reinforce cooperation between the ECB and national authorities. However, it will also be important to ensure that the complexity of the setup does not undermine effective and prompt supervisory decision making. 
Over time, some EU countries may want to be part of the banking union even if they do not join the euro area. A strong banking union that offers risk sharing (while avoiding the mutualization of legacy issues) and ensures least-cost bank resolution could be an attractive proposition. Moving supervision to the ECB could improve supervisory quality in some countries, reduce compliance costs for cross-border banks, limit scope for regulatory arbitrage, eliminate host-home coordination issues, and increase the congruence between the market for financial services and the underlying prudential framework. Once in place, a single resolution authority and common safety nets, with backstops, would provide further risk-sharing benefits. However, there are also drawbacks and complications, including the interaction of multiple central banks (with implications for the LOLR function and the conduct of macroprudential policies), difficulties in ensuring adequate participation of the "opt-ins" in SSM decisions, a loss of sovereignty, and potentially less flexibility to deal with country specificities. These costs are likely to be less for those whose currencies are pegged to the euro, have high levels of foreign currency liabilities, or have a sizable presence of euro area banks in their financial systems. If these members adopt the euro at the same time as they join the banking union, the benefit would likely outweigh the cost, just as it does for current euro area members.

\section{CONCLUSION}

The crisis has forced a reconsideration of the underlying institutions needed to sustain the euro as a common currency. The extension of the discussion on common fiscal frameworks and institutions to the banking sector is an important move. Banking union is obviously not a panacea, but it can be pivotal in fighting the current crisis by breaking the vicious circle between sovereign and bank costs and by fixing the broken transmission mechanism from ECB policy rates to final borrowing and lending rates across the full span of the euro area. A common supervisor, resolution mechanism, and safety net would also lay the foundation for long-term stability and reverse the fragmentation into subzones of greater or lesser confidence.

Many issues must be tackled, but critical design aspects must not be deferred, and strong euro area-wide bank supervision and safety net measures must be implemented quickly-not least because the cost of dwindling confidence accumulated silently in the massive payments imbalances brought on by the flight of deposits and capital across the euro area, which has been reflected in the rapid rise in the ECB's TARGET2 balances. These potential costs can be reversed and minimized by early and credible action on banking union. Although speed is important, reformers will need to be mindful that wrong sequencing and a piecemeal approach could actually worsen outcomes.

\section{REFERENCES}

Agarwal, Sumit, David Lucca, Amit Seru, and Francesco Trebbi. 2012. "Inconsistent Regulators: Evidence from Banking." Working Paper 17736, National Bureau of Economic Research, Cambridge, Massachusetts.

Council of the European Union. 2012. "Euro Area Summit Statement.” June 29.

European Commission. 2012. "EU High-Level Expert Group on Reforming the Structure of the EU Banking Sector." Chaired by Erkki Liikanen, Brussels, October 2012.

Financial Stability Board. 2011. "Key Attributes of Effective Resolution Regimes for Financial Institutions.” Basel. Laeven, Luc, and Fabian Valencia. 2012. "Systemic Banking Crises Database: An Update.” IMF Working Paper No. 12/163, International Monetary Fund, Washington. 


\title{
Toward a Fiscal Union for the Euro Area
}

\author{
imF Staff Team Led by Céline Allard
}

The global economic and financial crisis has exposed a critical gap in the Economic and Monetary Union (EMU): the capacity for country-level shocks, whether exogenous or home grown, to spread across the euro area, calling into question the viability of the common currency. This chapter explores the role that deeper fiscal integration can play in correcting architectural weaknesses in the system, reducing the incidence and severity of future crises, and lending long-term credibility to the crisis measures currently in progress. Europe has already taken important measures to improve economic and fiscal governance, and steps toward further fiscal integration have been proposed. Country-level adjustment, euro area-wide support via the European Financial Stability Facility, European Stability Mechanism (ESM), and the Outright Monetary Transactions backstop, and progress toward a banking union are also substantial achievements, adopted despite the difficult political issues raised by cross-border fiscal oversight and transfers. The chapter's argument is that a clearer ex ante approach to fiscal discipline and transfers in the future will further strengthen the architecture of EMU, ensuring the stability of the euro area. This chapter complements Chapter 9 that investigates the role of a banking union for the euro area.

\section{CONTEXT}

The euro area crisis has revealed critical gaps in the functioning of the monetary union. It has shown how sovereigns can be priced out of the market or lose market access altogether, and how private borrowing costs can differ widely within the union, despite a common monetary policy. It has also highlighted how contagion can set in, with deep recessions in some member states spilling over to the rest of the membership.

Addressing gaps in the Economic and Monetary Union's (EMU) architecture could help prevent crises of such magnitude in the future, while supporting current crisis resolution efforts. To that effect, fiscal and economic governance has been strengthened, including through the "Six-Pack" legislation, "Two-Pack" regulation, and the Fiscal Compact. In addition, the European Council, at their June 2012 summit, asked both the European Commission and the president of the European Council to issue detailed proposals "to develop, in close collaboration with the President of the Commission, the President of the Eurogroup and the President of the ECB, a specific and time-bound road map for the achievement of a genuine Economic and Monetary Union" (Van Rompuy 2012, 2), including greater fiscal integration, so as to ensure

\footnotetext{
This chapter is based on "Toward a Fiscal Union for the Euro Area," IMF Staff Discussion Note 13/07, 2013.

The chapter was prepared by a staff team led by Céline Allard, under the guidance of Mahmood Pradhan, Petya Koeva Brooks, and Helge Berger, comprising Jochen Andritzky, Fabian Bornhorst, Esther Perez Ruiz (European Department); John C. Bluedorn, Davide Furceri, Florence Jaumotte (Research Department); Franziska Ohnsorge (Strategy, Policy and Review Department); Xavier Debrun, Luc Eyraud, Tigran Poghosyan (Fiscal Affairs Department); Atilla Arda, Katharine Christopherson, Geerten Michielse (Legal Department); and Aleksandra Zdzienicka (African Department). Olivier Blanchard, Carlo Cottarelli, Lorenzo Giorgianni, and Martine Guerguil provided valuable comments and advice. Janyne Quarm provided excellent research assistance.
} 


\section{BOX 10.1. European Actions and Proposals for Furthering Fiscal Integration} and Governance

Actions so far. European policymakers have taken important steps to strengthen economic and fiscal governance. The Six-Pack went into force in December 2011; the Fiscal Compact, agreed upon in December 2012, has been ratified by all euro area member states; and the Two-Pack regulation, approved by the European Parliament in March 2013, applied to the 2014 budgeting period.

Road map going forward. The European Commission and the president of the European Council, in close collaboration with the presidents of the European Commission, the Eurogroup, and the European Central Bank, both issued their proposals for a road map toward fiscal integration at the end of 2012, responding to a request from European leaders at their June 2012 summit. The proposals have in common that they spell out different stages of action, depending on the legal requirements to implement them.

The European Commission's blueprint

- Short term (next 18 months, actions within the current treaty framework): Full implementation of the governance reforms in progress (European Semester, Six-Pack, and Two-Pack); single resolution mechanism for the banking union funded by the industry; and creation of a "Convergence and Competitiveness Instrument" to promote ex ante coordination of major structural reforms.

- Medium term (18 months to 5 years, actions requiring treaty changes): Stronger control on national budgets, including a right by the center to request changes in national fiscal decisions; a central fiscal capacity with dedicated resources; and borrowing under joint and several liabilities, namely a European Redemption Fund to coordinate the reduction in public debt and Eurobills to foster the integration of financial markets.

The President of the Council's Report

- Stage 1 (end-2012 and 2013): Completion of a stronger framework for fiscal governance (Six-Pack, Fiscal Compact, Two-Pack); agreement on the harmonization of national resolution and deposit guarantee frameworks with funding from the industry; and the setting up of the operational framework for direct bank recapitalization through the European Stability Mechanism.

- Stage 2 (2013-14): Completion of an integrated financial framework with a common resolution authority and an appropriate backstop; and the setting up of a mechanism to coordinate structural policies through contractual arrangements with potentially temporary financial support.

- Stage 3 (post 2014): Establishment of a well-defined and limited fiscal capacity to improve shock absorption capacities, through an insurance system set up at the central level, with built-in incentives for participating countries to continue to pursue sound fiscal and structural policies.

the irreversibility of EMU (Box 10.1). ${ }^{1}$ The idea of deeper fiscal integration for Europe is not a new concept; it had been developed in the 1970s in the famous MacDougall report (Commission of the European Communities 1977).

Yet, political backing for a clear road map remains elusive, with views on the contours of a fiscal union differing widely among euro area members. ${ }^{2}$ Some argue in favor of greater solidarity between member states, while others point to the need to strengthen national fiscal policies as a first priority to prevent further stress. There is also a concern that any debt mutualization would lead to moral hazard, sapping members' motivation to undertake prudent domestic policies in the future.

\footnotetext{
${ }^{1}$ The terms EMU and euro area are used synonymously throughout-even though, in legal terms, EMU refers to the economic and monetary union chapter in the European Union (EU) Treaty, which applies to all EU members, albeit to different extents. In practice, not all EU members have introduced the euro as their legal tender in accordance with the procedures laid down in the EU treaties.

${ }^{2}$ The scope of a fiscal union can vary significantly. For the purposes of this chapter, we consider fiscal union to be a set of fiscal rules and arrangements, including possibly cross-country transfers, commonly agreed on by euro area member states to deepen fiscal integration.
}

\section{CInternational Monetary Fund. Not for Redistribution}


As a contribution to this ongoing debate, this chapter and two companion background notes (Bluedorn and others 2013; Bornhorst, Pérez Ruiz, and Ohnsorge 2013) outline a conceptual framework for assessing the case for further fiscal integration for the euro area and present new empirical analysis on the level of risk sharing at play in the euro area. To do so, this chapter analyzes the critical gaps in EMU architecture exposed by the crisis, derives from that the minimal elements of a fiscal union to address them, and discusses the immediate priorities in the current crisis context. The companion notes elaborate on the rationale for fiscal risk sharing and the institutional arrangements underpinning fiscal unions in international experience.

\section{WHAT CRITICAL GAPS HAS THE CRISIS EXPOSED?}

While country-specific shocks have remained more prevalent than initially expected, the high degree of trade and, even more important, financial integration has created the potential for substantial spillovers. Furthermore, weak fiscal governance and the absence of effective market discipline have compounded these problems. Finally, sovereign and bank stresses have moved together, setting off a vicious circle with markets starting to price in both bank and sovereign default.

Although it was recognized that countries joining the euro area had significant structural differences, the launch of the common currency was expected to create the conditions for further real convergence among member countries. The benefits of the single market were to be reinforced by growing trade and financial links-making economies more similar and subject to more common shocks over time (Frankel and Rose 1998). In that context, these common shocks would be best addressed through a common monetary policy. Instead, country-specific shocks have remained frequent and substantial (Pisani-Ferry 2012; Figure 10.1). Some countries experienced a specific shock with a dramatic decline in their borrowing costs at the launch of the euro, which created the conditions for localized credit booms and busts. The impact of globalization was also felt differently across the euro area, reflecting diverse trade specialization patterns and competitiveness levels. These country-specific shocks have had lasting effects on activity. And differences in growth rates across countries have remained as sizable after the creation of the euro as before (Figure 10.2).

The consequences of these shocks have been compounded by weak fiscal policies in some countries. In some cases, the shocks themselves were the result of idiosyncratic policies (for example, Greece). More generally, the windfall from lower interest and debt payments was not saved, and higher revenues generated by unsustainable domestic demand booms were wrongly deemed permanent. By the time the crisis hit, countries had insufficient buffers to enable countercyclical support at the national level. Moreover, the European fiscal governance framework was too loosely implemented to ensure the appropriate management of public finances over the cycle. Government failure and political interference became especially evident when the Council decided to hold the Stability and Growth Pact's excessive deficit procedure in abeyance for the two largest countries of the euro area in 2003.

While country-specific shocks remained more frequent than expected, and imprudent national policies were pursued by some, there were few market forces to correct growing fiscal and external imbalances:

- Labor market and price rigidities-Unlike what would have been expected in an optimal currency area, prices and wages continued to display strong downward rigidities in many euro area countries, standing in the way of the timely real exchange rate adjustment that may be required after a negative shock (Jaumotte and Morsy 2012). This rigidity allowed 


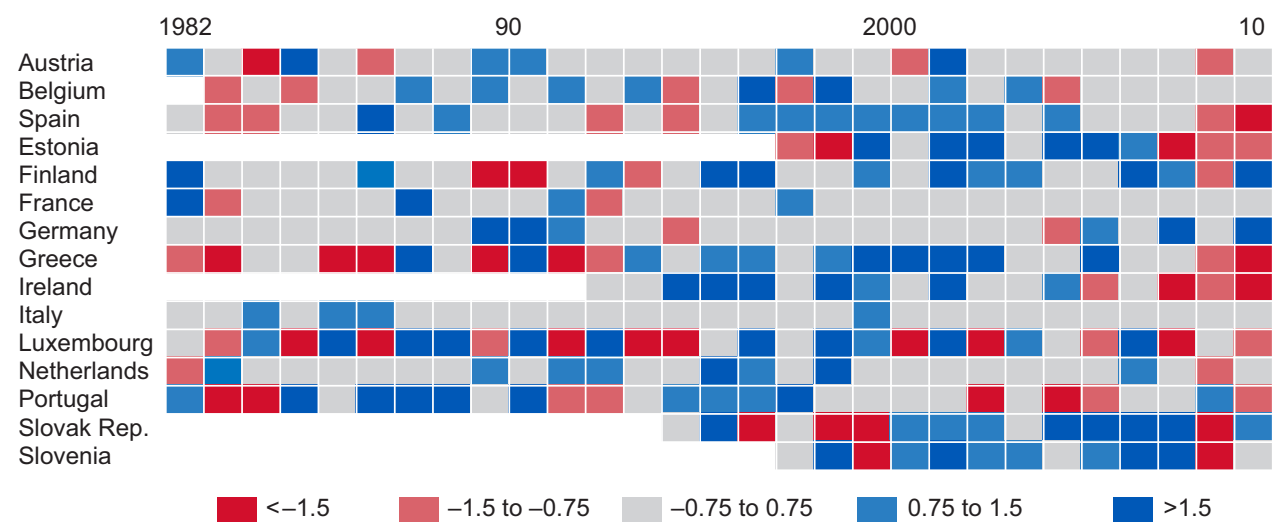

Sources: Organisation for Economic Co-operation and Development; and IMF staff calculations.

Note: The idiosyncratic growth shocks are derived as the part of the country-specific growth shocks that are not explained by euro area-wide growth shocks. Growth shocks (both for the euro area and individual countries) are computed as the residuals from a regression of the country's (or euro area's) growth rate over two lags.

Figure 10.1 Country-Specific Growth Shocks (Percent)

\section{Euro Area: Standard Deviation of Member States GDP Growth (Percent)}

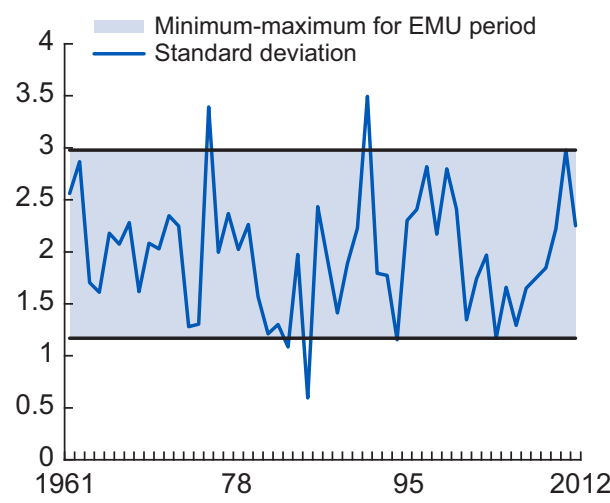

Sources: European Commission Annual Macroeconomic Database; and IMF staff calculations.

Note: EA11 until the end of 2000; includes new member states thereafter. See Abbreviations section for composition of EA11. $\mathrm{EMU}=$ Economic and Monetary Union.

Min-Max EMU Period indicates the minimum and maximum annual standard deviation of growth across euro area countries since the start of EMU in 1999.
2. Euro Area: Growth Rate Dispersion (Percent, quarter over quarter, annualized)

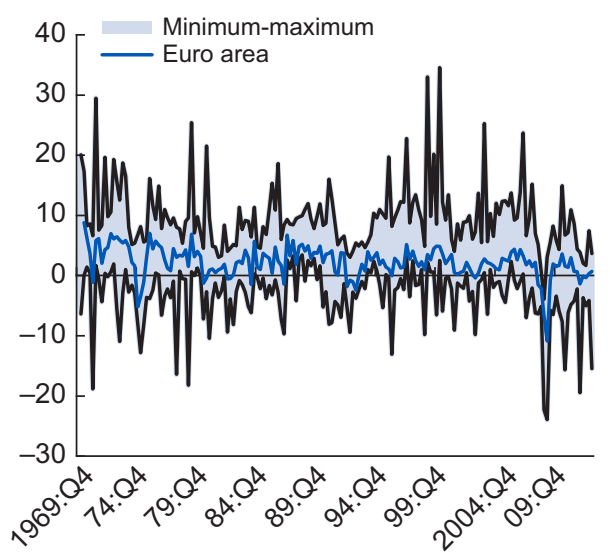

Sources: Organisation for Economic Co-operation and Development; and IMF staff calculations.

Note: EA11 until the end of 2000; includes new members thereafter as they join, with the exception of Malta and Cyprus. See Abbreviations section for composition of EA11. EMU = Economic and Monetary Union.

Figure 10.2 Persistent Growth Divergence within the Euro Area

the accumulation of large intra-euro area imbalances that have been at the heart of the crisis. Likewise, labor mobility — even though increasing — continued to be lower than in other common currency areas (for example, in federations such as the United States), both because of language and cultural barriers and because of institutional constraints, such as the inability to port pensions or unemployment benefits across borders, inhibiting rebalancing through migration. 


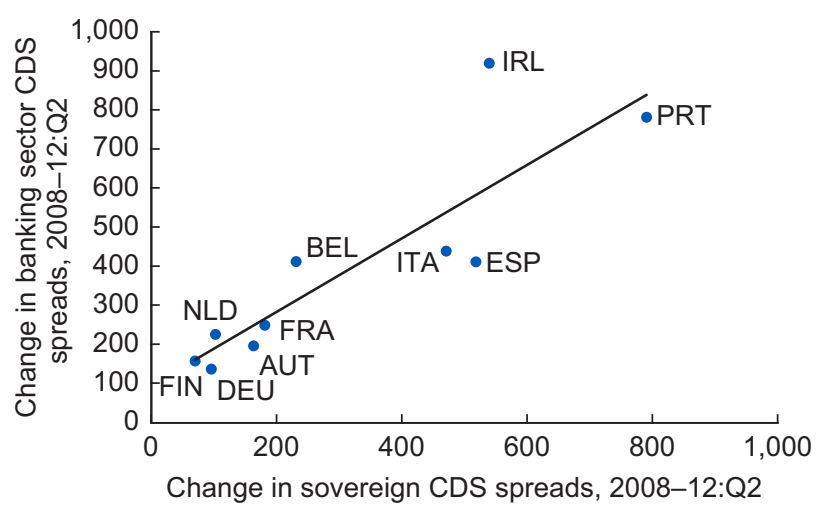

Sources: Bloomberg, L.P.; Datastream; and IMF staff calculations.

Note: $\mathrm{CDS}=$ credit default spread. Data labels in the figure use International Organization

for Standardization (ISO) country codes.

Figure 10.3 Sovereign-Bank Feedback Loops (Basis points)

- Missing incentives for markets to enforce discipline-A corrective mechanism against unsustainable national fiscal policies could have come from capital markets. In fact, the provision enshrined in the Maastricht Treaty to ensure that no member ends up assuming another member state's fiscal commitments (Article 125 of the Treaty on the Functioning of the European Union, TFEU)—-hereafter referred to as the "no-bailout" clause-was meant to give financial markets an incentive to price default risk in a differentiated way across the euro area. However, general optimism about the region's growth prospects at the euro's inception blunted markets' scrutiny of national fiscal policies. Moreover, it also did not help that the clause lacked credibility; with few automatic mechanisms in place ex ante to support individual members in distress, markets could extrapolate that the crisis in the affected countries would be deep and that spillovers would be substantial enough for policymakers to prefer to bail out a member country ex post rather than let it default. In other words, market discipline failed ex ante because the no-bailout option was not ex post credible. In turn, because ex ante market discipline was missing — and fiscal rules were not strictly enforced-some members borrowed excessively, taking on more debt than they would have if risks had been priced appropriately.

When, eventually, large adverse shocks hit at the end of the 2000s, they were left unmitigated, increasing the probability and impact of sovereign and bank distress. Domestic fiscal buffers were rapidly depleted. Meanwhile, although the launch of the euro did not foster as much real convergence as had been expected, financial market integration increased greatly in the first 10 years of EMU, and some banks had extended themselves well beyond the capability of their national sovereigns to rescue them. Yet, many banks continued to hold a sizable share of the debt issued by their domestic sovereigns. This combination set the stage for an escalation of domestic stress, with problems in banks raising doubts about sovereign creditworthiness, and sovereign stress aggravating the pressure on banks' balance sheetscreating severe negative feedback loops between sovereigns and domestic banks (Figure 10.3). With no clear circuit-breaker in the system, markets could start pricing in default in a selffulfilling way.

In a highly integrated union, the deleterious impacts of these shocks could travel across borders quickly. Spreading through interconnected euro area banks, localized points of stress in 2010 were quickly amplified to a systemic level (Figure 10.4). 
1.

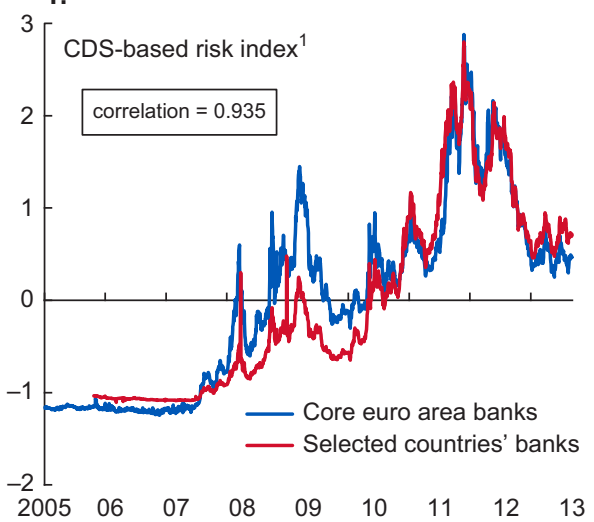

2.

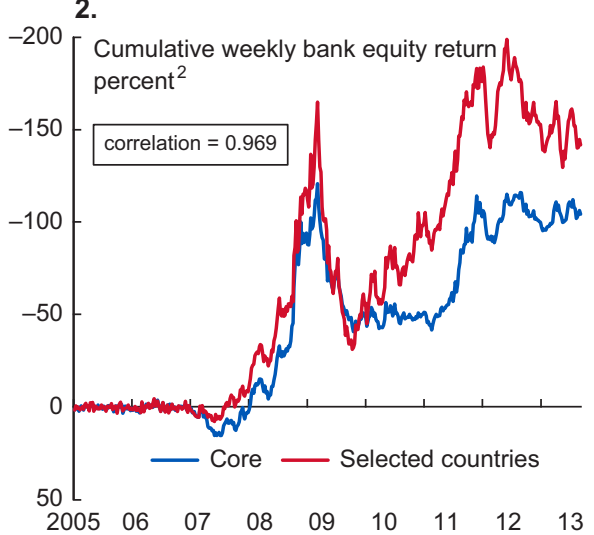

Sources: Bloomberg, L.P.; Datastream; and IMF staff calculations.

Note: $C D S=$ credit default swap. GIIPS = Greece, Ireland, Italy, Portugal, and Spain

${ }^{1}$ Normalized score from a principal component analysis on five-year senior bank credit default swap spreads, estimated using daily data (Jan. 2005-Sep. 2013). The core risk index comprises CDS spreads of 23 banks and the selected countries risk index 22 banks (Greece, Ireland, Italy, Portugal, Spain). The first principal component captures 86 percent of the common variation across core country banks and 85 percent across selected country banks.

${ }^{2}$ Based on country indices of weekly banking sector equity returns, cumulated since January 2007 (equally weighted returns; inverted scale). Selected countries comprise Greece, Ireland, Portugal, and Spain. Core euro area consists of other euro area countries except Estonia and Slovak Republic (which do not have banking equity indices).

Figure 10.4 Financial Sector Interconnectedness: Banking Sector Risk Indices

\section{ADDRESSING GAPS FOR THE FUTURE: RISK REDUCTION AND RISK SHARING}

Risk reduction - through a more robust fiscal governance framework-would guide national governments toward more prudent behavior, while some fiscal risk sharing at the euro area level would help smooth the impact of adverse country-specific shocks. Common backstops for euro area banks would dampen the spillover effects of sovereign and bank distress. Borrowing from the center, by providing a safe asset, could also, to some extent, limit portfolio shifts between sovereign bonds. Taken together, these steps would contribute to reducing the severity of future crises.

\section{Risk Reduction: Addressing Government Failures}

The euro area cannot afford to repeat the imprudent fiscal and financial policies undertaken by some countries in the first decade of EMU. Debt levels are at dangerously high levels in some places, and confidence in the existing enforcement mechanisms embedded in the SGP is low. Steps toward improving fiscal governance and restoring the commitment to fiscal discipline should be guided by the following principles:

- Smarter fiscal rules at the national level-Although a structural medium-term objective is also pursued, the binding target in the SGP applies to the headline fiscal balance and is therefore defined independently of the position in the cycle. This has proved suboptimal, with countries easily hitting an unambitious deficit of 3 percent of GDP under favorable economic conditions, but forced to unduly tighten during downturns to meet that same target. Medium-term targets need more prominence to establish the credibility of fiscal plans, allowing for some flexibility to spread consolidation efforts over time, with more consideration for the position in the business cycle. 


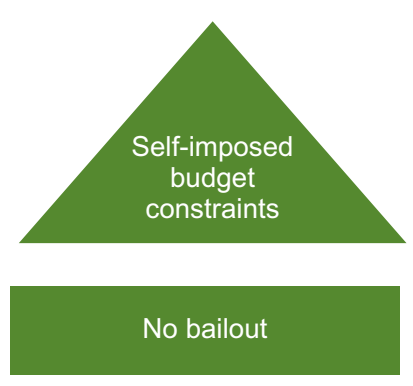

Strong market discipline

High subnational fiscal autonomy

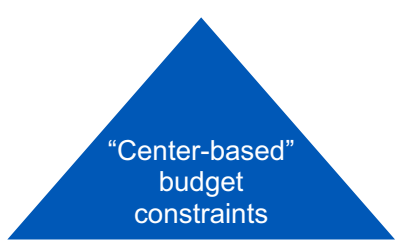

Bailout

Strong oversight from center

Less subnational fiscal autonomy

Source: Authors.

Figure 10.5 Arrangements for Fiscal Discipline: Stylized Setups for Hard Budget Constraints

- Robust corrective mechanisms - The first decade of EMU has shown that, when left to the Council-which is composed of national ministers - the temptation remains to underenforce fiscal rules and delay adjustment, as evidenced in 2003 when the Council decided to suspend the Excessive Deficit Procedure against Germany and France-a decision that was later reversed by the European Court of Justice. When policy slippages occur, countries should have the incentive to take corrective measures systematically, and potential for political interference should be kept to a minimum.

- Coordination -A stronger centralization of budget oversight would allow the negative spillovers of imprudent national fiscal policies on the other member states to be internalized. Although greater centralization would result in less national sovereignty on fiscal issues, such a loss would be offset by (1) the benefits of not risking being priced out of markets or losing market access in times of stress as a result of imprudent policies or contagion stemming from imprudent policies elsewhere in the union, and (2) the benefits of belonging to a monetary union that is functioning properly.

\section{Risk Reduction: Fostering Fiscal Discipline}

Various arrangements have emerged in existing federations, with distinct disciplining mechanisms:

- Different arrangements - In a first group of countries, market discipline at the subnational level is underpinned by a credible "no-bailout" rule and self-imposed budget constraints (Canada, the United States). ${ }^{3}$ At the other extreme, where subnational governments have been bailed out in the recent past, discipline emerges from stronger central oversight (Brazil and, more recently, Germany) (Figure 10.5). In intermediate systems, the federal government's authority over lower jurisdictions has been supported by a culture of dialogue and intergovernmental coordination (Australia, Belgium) or by direct democracy (Switzerland) features that have proved effective at instilling sound fiscal subnational policies.

\footnotetext{
${ }^{3}$ The mobility of workers and firms across states can also increase competitive pressures at subnational levels to maintain fiscal discipline, while ensuring low taxation and high-quality public services.
} 


\section{BOX 10.2. International Experiences with Resolutions of Subnational Crises in Federations}

A stronger center after bailout episodes. In the United States in 1790, the central government under Treasury Secretary Alexander Hamilton assumed liabilities of states that became bankrupt after the Revolutionary War. In the process, the central government secured dedicated revenues-customs duties in that case-marking the beginning of a federal budget (Henning and Kessler 2012). In Brazil in the 1990s, the central government bailed out a number of states in exchange for strict centralized spending and borrowing controls. These controls took the form of bilateral contracts between the central government and the states, and important elements of these contracts were enacted in the Fiscal Responsibility Law in 2000.

Reinstating market discipline after local defaults. When in the 1830 s and 1840 s many U.S. states faced bankruptcy following the end of an investment boom in railroads, canals, and state banks, the federal government withheld direct financial support. In light of these episodes, many states imposed fiscal rules in their constitutions to signal commitment to sound fiscal policies and to prevent future defaults. Today, 49 U.S. states have some form of balanced budget rule. At the same time, federal institutions provide significant fiscal support and risk sharing across the United States even for financial distress at the state level (for example, through federal programs or the Federal Deposit Insurance Corporation; see Bornhorst, Pérez Ruiz, and Ohnsorge 2013).

- Evolution after crisis episodes - The interplay between hard budget constraints and central control evolves, with crisis episodes not unlike the one currently experienced by the euro area tending to lead-at least for a time-to more central control. Following periods of stress involving subnational bailouts, fiscal discipline often increases through bailout conditionality or a strengthening of the central authority (as in the United States at the end of the eighteenth century, or in Brazil after the bailouts of states in the 1990s). The return to market discipline typically occurs after a transitional period when private risk sharing again becomes a possibility, and, in some cases, after a regional bankruptcy has tested the nobailout rule (as in the United States in the 1840s) (Box 10.2). Intermediate arrangements usually exist in federations that have not been tested by severe fiscal crises.

Cooperative approaches to fostering fiscal discipline have demonstrated their limits in the first decade of EMU. On that basis, and in light of international experience, two options emerge to foster fiscal discipline in the euro area in the longer term. One could be to aim to restore the credibility of the no-bailout clause, including through clear rules for the involvement of private creditors when support facilities are activated. But the transition to such a regime would have to be carefully managed and would have to be implemented in a gradual and coordinated fashion so as to not trigger sharp readjustments in investors' portfolios and abrupt moves in bond prices. Another option would be to rely extensively on a center-based approach and less on market price signals. This approach would, however, have to come at the expense of a permanent loss of fiscal sovereignty for euro area members. In practice, the steadystate regime might have to embed elements of both options, with market discipline complementing stronger governance.

For market discipline to function properly, certain conditions would have to be fulfilled, including conditions minimizing the spillover effects of sovereign financial distress:

- A minimum of fiscal risk sharing - With a minimum of fiscal risk sharing in place, a country facing severe financial distress would not be deprived of essential government services, social security, and financial stability. This safeguard would contain the social and economic costs of the crisis. Country-specific shocks would then be less likely to damage the economies of other members of the euro area, alleviating the need for ex post financial support and hence making the no-bailout clause more credible. Approaches to achieving greater risk sharing are the focus of the next section. 
- Ex ante rules involve private actors in bailouts-A complementary approach should be to combine the existing crisis support facilities for distressed sovereigns with predictable resolution mechanisms when these facilities are activated. This approach would help markets better assess, and therefore price, sovereign risks, and would strengthen incentives for borrower and creditor countries to avoid excessive sovereign borrowing, even in the presence of bailout arrangements. The requirement in the ESM treaty for all new euro area government bond issuances with maturity greater than one year to include aggregated collective action clauses as of January 2013 is a step in that direction.

\section{Risk Sharing: Insuring against Country-Specific Risks}

Larger fiscal buffers at the national level would help smooth the impact of country-specific shocks, but given their magnitude and the potential for contagion, some insurance mechanisms at the euro area level would be beneficial. These mechanisms would give individual countries the means to smooth demand in the face of negative income or activity shocks—and, as a consequence, better insulate fellow euro area members from damaging spillovers. Such mechanisms take on an added importance in a currency union, in which countries operating under fixed nominal exchange rates cannot use monetary policy tools to respond to country-specific shocks.

Cross-country risk sharing can be provided by both markets and governments. In the first case, smoothing is provided by cross-border credit markets, allowing countries to save in good times and borrow when a crisis hits. Private capital markets can also provide insurance against income shocks in that they allow households or governments to hold diversified portfolios of euro area and international investment assets, and hence to diversify their income streams. In the second case, intergovernmental fiscal arrangements can allow for temporary transfers of resources across member states. A central budget with dedicated revenues to finance the common provision of public services can also play that role (see Bluedorn and others 2013).

An international comparison shows that the euro area lacks the degree of risk sharing seen in other federations (Figure 10.6): ${ }^{4}$

- Little overall insurance-Whereas federations such as the United States, Canada, and Germany manage to smooth about 80 percent of local shocks, the euro area only manages to insulate half that amount-in other words, when GDP contracts by 1 percent in one of the euro area countries, household consumption in that country is depressed by as much as 0.6 percent (as opposed to 0.2 percent in the United States, Canada, or Germany).

- Little market-based insurance-Capital markets in the euro area play much less of an insurance role than elsewhere, in part because cross-border ownership of assets within the euro area remains more limited than, for example, across U.S. states or across German Länderdespite the single market. To the extent that there is insulation from negative shocks in the euro area, it occurs through cross-border saving and borrowing. Yet, this channel tends to break down in periods of severe downturns and financial crisis, when risk sharing is most needed as international credit markets become unwilling to grant loans (Furceri and Zdzienicka 2013). The global financial crisis was no exception, as evidenced by the plunge in cross-border credit flows in the euro area.

- Little fiscal risk sharing-Cross-country fiscal risk sharing is almost nonexistent, both in the European Union (EU) and the euro area. This is not surprising given the small size of the EU budget, its focus on harmonizing living standards (through the Structural and Cohesion

\footnotetext{
${ }^{4}$ Although the euro area is not a federal state itself and legal arrangements differ from existing federations, the degree of economic and financial integration between member states is of the same order of magnitude as that of the different regions of many federal states. This suggests that, on economic grounds, federal states offer the closest benchmark for the euro area (see Bornhorst, Pérez Ruiz, and Ohnsorge 2013).
} 


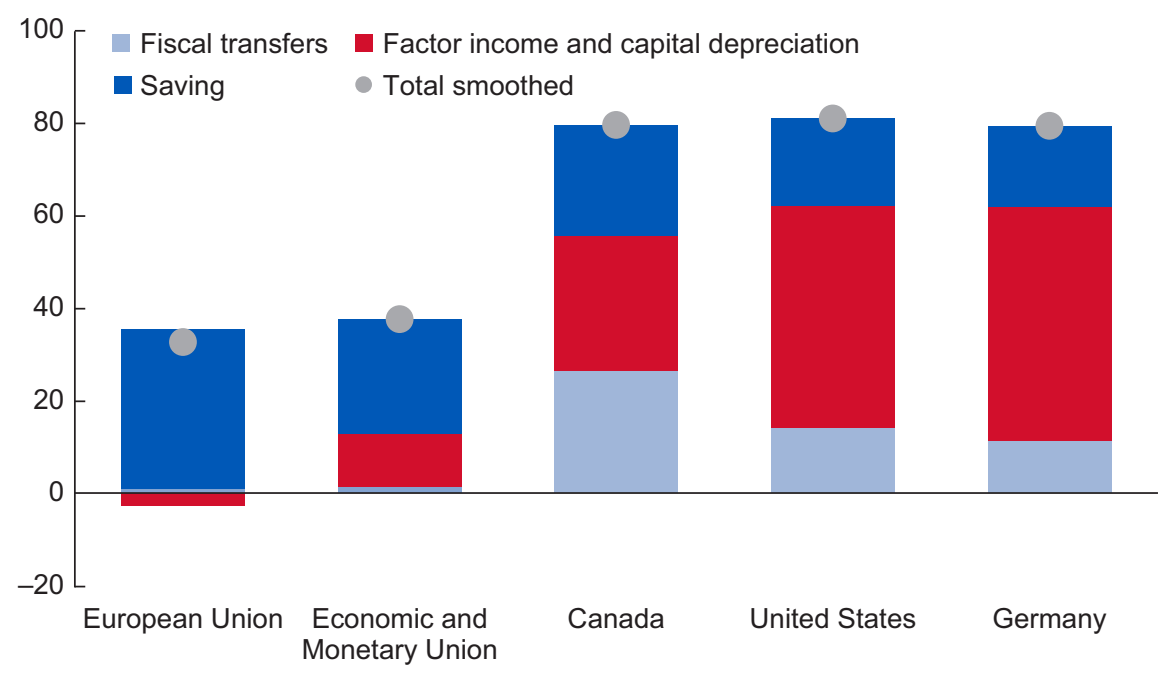

Sources: Hepp and von Hagen (2013) for Germany; Sorensen and Yosha (1998) for the United States; Balli, Basher, and Rosmy (2011) for Canada; and Afonso and Furceri (2008) for the Economic and Monetary Union and the European Union. Note: Time period covered differs across studies.

Figure 10.6 Risk Sharing across Constituent Units (Percent of regional income shock smoothed by channel)

Funds) as opposed to providing risk sharing, and the overall limited transfer of fiscal authority to the EU level.

The euro area would benefit from larger overall smoothing of these country-specific income shocks through the following means:

- Crisis management measures-Financial support through the European Financial Stability Facility (EFSF) and the ESM has provided some elements of fiscal risk sharing, and the TARGET2 system has cushioned against the sharp reversal in private capital outflows since the beginning of the crisis. However, these measures only came ex post, after the crisis had already severely affected the economy, with a high cost in lost output.

- Banking union-The creation of a banking union would help reinforce the role of credit markets in providing risk sharing. In particular, it would help develop banking services in a truly integrated way and prevent financial market fragmentation along national borders, especially in times of stress (IMF 2013a).

- Capital market (re)integration - Although the widening in TARGET2 positions has prevented a sudden stop, the impact of the shocks has still been exacerbated, rather than smoothed, by capital market movements. A reversal of the recent financial deintegration, let alone further capital market integration, will take time. The functioning of capital markets in the euro area could also be improved through common financial market reporting standards and further harmonization of financial market regulations.

- A role for fiscal risk sharing-Fiscal risk sharing can play a complementary role beyond crisis mechanisms, both by providing a minimum amount of smoothing when other channels break down, and also by serving as a catalyst for investors' behavior (Farhi and Werning 2012). Knowing that there is a floor to the impact of negative shocks, private markets would view countries under stress as less risky than they do currently and hence be more willing 


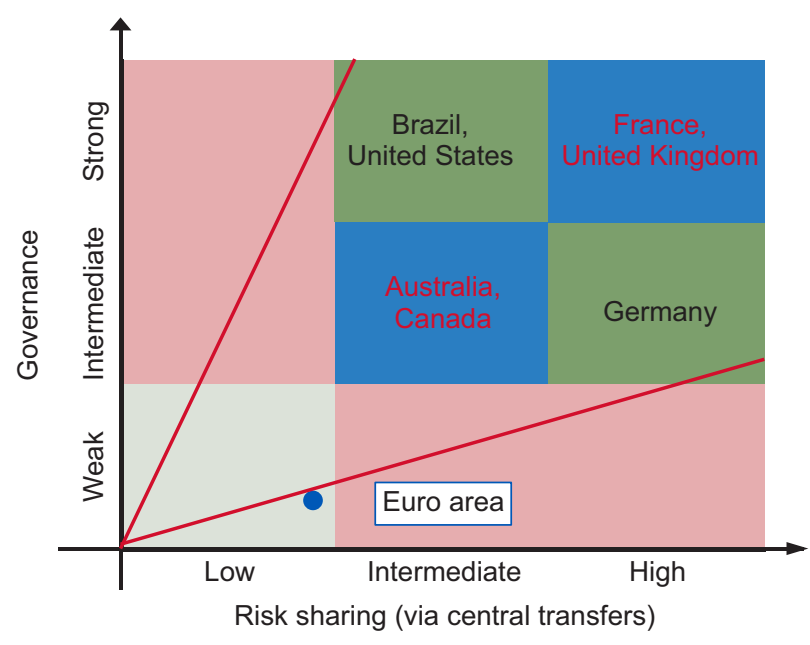

Note: France and the United Kingdom are unitary countries, where administrative units are defined by the central government and exercise powers at the central government's discretion. The remaining countries (Australia, Brazil, Canada, Germany, the United States) are federations, where the subnational states' existence and powers cannot be changed unilaterally by the central government. The risk sharing classification is based on estimates from the literature of the share of income shocks to subnational entities that are absorbed by central transfers. The governance classification is based on a review of each country's codified rules and an assessment of their effectiveness in constraining subnational budgets.

Figure 10.7 Nexus between Risk Sharing and Governance

to support them through market-based mechanisms. In other words, the existence of a credible form of government insurance would catalyze the provision of market insurance.

If the union provides a safety net against unexpected bad outcomes, countries may be tempted to implement riskier policies (thus "free-riding"), which calls for reinforced governance. Indeed, international experience shows that stronger risk sharing and stronger governance typically go hand in hand to mitigate this "moral hazard" problem (Figure 10.7). Therefore, as a prerequisite for any increase in fiscal risk sharing in the euro area, governance and enforcement provisions should be further strengthened.

\section{Dampening Spillovers, Stemming Contagion}

An effective common macroprudential supervisory framework would help prevent imbalances from building up in the financial sector, while a single resolution mechanism, covering all banks regardless of nationality, would provide a powerful tool to sever the adverse feedback loop between sovereigns and domestic banks at play in times of stress. Some of the insurance against banking accidents should be funded by the industry. But common backstops for the recapitalization and resolution of, and deposit insurance schemes for, all banks within the jurisdiction of the single supervisory mechanism would contribute to reducing the risk of contagion. They would in particular limit the extent to which sovereign distress in any one country is transmitted to another through the banking system.

Large reversals in capital flows going to sovereign bonds can also amplify and propagate shocks. With very few sovereign bonds still considered to be safe assets, the risk of sharp portfolio shifts between sovereigns will persist. The existence of common debt (debt incurred by euro area bodies) could provide some relief against this channel of contagion, and act as a more stable source of funding. 


\section{MINIMAL ELEMENTS FOR A FISCAL UNION}

The ultimate scope and shape of further fiscal integration will remain a matter of social and political preferences. However, to make any future crisis less severe, four elements seem essential: (1) better oversight of national fiscal policies and enforcement of fiscal rules to build buffers and ensure common concerns are addressed; (2) subject to strong oversight and enforcement of fiscal discipline, some system of temporary transfers or joint provision of common public goods or services to increase fiscal risk sharing; (3) credible pan-euro area backstops for the banking sector; and (4) some common borrowing to finance greater risk sharing and stronger backstops and provide a common—albeit limited in size—safe asset.

\section{Better Oversight of Fiscal Policies}

Ex ante fiscal policies, with essential commonly agreed-on rules, can be better organized. In that respect, the Fiscal Compact usefully complements the existing framework, given that it requires national authorities to transpose into national legislation these commonly agreed-to rules. However, enforcement capability will remain a key test. Critical oversight ingredients include the following:

- Structural fiscal targets - The flexibility introduced in the 2005 reform of the SGP (through the "effective action" clause) and the Fiscal Compact allows for the focus to be put more on structural-instead of headline-fiscal balance targets; however, that concept should be applied more systematically.

- Independent forecasts -Assessing the position in the cycle in real time will always be a difficult exercise. Switching to structural targets will therefore require careful estimates of the output gap. Furthermore, governments have tended to rely on overly optimistic forecasts to build their budgets. For these reasons, relying on independent national agencies-in coordination with central oversight- to assess fiscal policy design and implementation would improve the process, as is foreseen in the Two-Pack regulation.

- Binding medium-term fiscal plans-Flexibility in the fiscal rules will only be credible if fiscal policy is anchored in medium-term fiscal plans that clearly state the path back to lower debt levels. In particular, any accommodation for the cycle during downturns needs to be accompanied by plans to offset this accommodation in the medium term, possibly in an automatic way. Although such corrective mechanisms have, in principle, been agreed to in the Fiscal Compact, they still have to be designed at the national level and made consistent across countries.

- Increased transparency-Fiscal transparency and accountability could be enhanced by entrusting fiscal councils or other national independent agencies with the task of assessing the credibility of medium-term plans and any corrective measures. Harmonization of budget presentation, fiscal reporting, and accounting at all levels of government, as well as timely reporting of fiscal outturns, would all improve the functioning of the fiscal oversight framework.

To ensure that the agreed-on fiscal rules are implemented, countries need to be provided with the proper incentives to comply, but also with a credible threat if they do not.

- "Center-based" approach-As argued previously, although market discipline could be an important mechanism for preventing future fiscal imbalances from emerging, it cannot be restored overnight, and certainly not until this crisis is resolved. Therefore, in the interimand possibly as a long-term solution-enforcement will have to be imposed more directly by the center. 
- Clear bailout rules for now - While the other elements underpinning deeper fiscal integration are put in place, ESM support to sovereigns under market stress will continue to be the best line of defense against further systemic shocks. Still, credible rules in the form of conditionality will be needed to preserve the incentives to reform and to ensure decisive implementation of adjustment measures at the country level.

In a center-based approach, stronger involvement in national fiscal decisions could take various forms, along the following lines:

- Legal challenges at the national level-With fiscal rules soon to be enshrined in national legislation, enforcement will also become a national matter, making it possible to bring cases of infringement to domestic courts, depending on the domestic legal tradition of the member, and on the specific provisions of the domestic legal instruments implementing the fiscal rules. EU court jurisdiction over compliance with national domestic rules could also be considered. However, this approach would likely require treaty changes and whether such a deterrent would be effective in generating enforcement in real time remains to be seen.

- Leverage to sanction with a larger central budget-The case for controls on national fiscal policies would be even stronger if there were greater risk sharing among the euro area members. For example, if a larger euro area budget were to emerge (see next sub-section), member states could be under threat of losing some transfers from the center for noncompliance with relevant rules or policy recommendations. Such a mechanism, in triggering more systematic sanctions, possibly deferred over time, could act as a more credible device for generating compliance with the rules. In the same vein, some in Europe have suggested that targeted transfers to countries that implement beneficial structural reforms should be introduced. Conditions could also be applied for access to a rainy day fund or to existing crisis mechanisms like the ESM. Although this approach has merit in encouraging reforms, by making such support or transfers contingent on compliance, the main drawback would be to reduce the automatic stabilization effect of these transfers.

- Veto power from the center-The Two-Pack envisages that national authorities may be requested to revise their budgets if plans are not deemed to be in accord with common principles for the euro area. However, the center has no power to enforce compliance. Consideration should be given to stronger powers for the center, either to set national spending or borrowing plans or to veto national fiscal decisions when they breach commonly agreed-on rules. Although intrusive, such an arrangement would provide timely and preemptive intervention when budget plans are clearly inconsistent with the targets derived from fiscal rules. However, it would also require treaty changes and a significant loss of national sovereignty. To mitigate this concern, a gradation in the loss of sovereignty could be considered, depending on the degree of noncompliance with the fiscal rules. Significant loss of fiscal autonomy and extensive fiscal custody would be reserved to the most extreme cases of rule violation and when financial support is being extended-variations of which can be found in countries such as Brazil and Germany.

A larger role for the center raises difficult questions about political and democratic accountability for European and euro area decision bodies. Existing fiscal unions are also political unions, and moving toward deeper fiscal integration in the euro area may not be possible without changes in the political organization of the union. Although the issue of the steady-state political regime for the euro area is beyond the scope of this chapter, ensuring that the political bodies implementing and enforcing fiscal rules at the central level are mandated to do so with the euro area's collective interest in mind - rather than individual members' national interests - will be essential.

\section{CInternational Monetary Fund. Not for Redistribution}




\section{Temporary Transfers or Common Provision of Public Services}

There are a number of options for ensuring better common insurance against country-specific shocks, with varying degrees of centralization and requirements for legislative changes. They include a rainy-day fund, common unemployment insurance, and a euro area budget.

The simplest way to organize temporary transfers to deal with adverse shocks at the country level would be through a common, dedicated rainy-day fund, similar to the one suggested by the report from the Tommaso Padoa-Schioppa Group (2012).

- General features - Such a fund would collect revenues from euro area members at all times and make transfers to countries when they experience negative shocks. With a dedicated and guaranteed flow of revenues, the fund might even be able to borrow at low cost to smooth the impact of downturns throughout the union.

- Size of the fund-Although any such evaluation comes with numerous caveats, if the fund had existed since the inception of the euro, annual contributions of about $1 \frac{1}{2} 2$ to $2 \frac{1}{2} 2$ percent of GNP would have been sufficient to provide a level of overall income stabilization comparable to that found within Germany-where 80 percent of regional income shocks are smoothed, as compared with the 40 percent currently smoothed in the euro area (see Bluedorn and others 2013). Although still limited, these amounts are larger than the resources transferred under the existing EU budget, and could be underestimated if the risk of contagion has increased. Any misidentification of the nature of shocks (see next section) would also lead to higher transfers. In comparison, the total resources devoted to the euro area firewalls (ESM and EFSF), at their maximum, will amount to about $71 \frac{1}{2}$ percent of GNP (€700 billion).

- Pros-Unlike the ESM, the rainy-day fund would provide ex ante support before the shocks have turned into funding crises. But like the ESM, it would be easier to manage than a fullfledged euro area budget and would not involve any ceding of spending responsibilities to the center. Furthermore, in addition to providing cross-country insurance against idiosyncratic shocks, the fund would allow for region-wide countercyclical fiscal policy responses, with contributions saved in good times and paid out to the contributing countries in tough times - in times of common shocks, or when idiosyncratic shocks have spilled over to other euro area countries.

- Cons-The main practical challenge in such a scheme would be to correctly detect the events warranting the activation of the insurance scheme, and hence transfer payments. Although technical methods exist to identify negative growth shocks, they are not free of errors and are complex to implement in real time, making it hard to disentangle temporary from permanent shocks, and exogenous shocks from policy shocks. The parameters of intervention could also be hard to communicate to the public, raising challenging issues of transparency and accountability. As with any insurance scheme-that is, without any conditionality-free-riding would remain a risk, especially if the scheme ends up delivering more permanent transfers than warranted; countries could be less inclined to build fiscal buffers at the national level or implement difficult adjustment measures, knowing that ultimately, the rainy-day fund would provide support.

Social protection could also be a candidate for more fiscal risk sharing. More specifically, moving a minimum level of provision of unemployment benefits to the euro area level would naturally provide insurance against individual income risk across the union. Indeed, in most existing federations, unemployment insurance is highly centralized; and even in the United States, where states also finance part of unemployment benefits, the role of the federal government typically increases in the event of severe negative shocks (see IMF 2014; Bornhorst, Pérez Ruiz, and 
Ohnsorge 2013). Such a scheme should go hand in hand with efforts to enhance and harmonize labor market arrangements across countries.

- Pros-The funding (via social security contributions) and provision of unemployment benefits are highly related to the cycle. A common scheme would also require a minimum amount of harmonization in labor taxation as well as, potentially, pension rights - a beneficial step on its own toward a single labor market. Finally, by focusing on unemployment, which is a highly identifiable variable, a common social security fund would be more understandable and acceptable to the public than a rainy-day fund. With parameters defined ex ante, transfers in the form of unemployment benefits would also have the advantage of automaticity.

- Cons-Unemployment reacts with lags to activity shocks, so the transfers may not be sufficiently timely. In addition, given the wide variation in long-term unemployment levels across the euro area, the focus should be restricted to short-term unemployment benefits, which are directly connected to negative shocks, as opposed to long-term unemployment, which is more closely linked to labor market and other structural rigidities. Providing insurance against long-term unemployment from the center would immediately give rise to permanent transfers from low-unemployment regions to high-unemployment regions. This process would be akin to redistribution, not risk sharing, and could provide disincentives to reform labor markets in recipient countries. Focusing on short-term unemployment insurance would, however, reduce the amount of smoothing, although it would still enable the immediate mitigation of adverse shocks to employment.

A full-fledged budget at the euro area level would allow for risk sharing both through revenues, because countries hit by negative shocks would automatically contribute less, and through spending, because countries hit by negative shocks and in compliance with relevant rules and policy recommendations would still benefit from the same amount of centrally provided public services. An example of such jointly provided services is public infrastructure, for which the central government retains an important role in many existing federations, often using such outlays as a countercyclical tool.

- Pros-The extent of risk sharing would increase with the extent of centralization of fiscal revenue and spending responsibilities. Along that dimension, a euro area budget would therefore be superior to the other options explored previously in this chapter. In addition, it would facilitate the coordination of the fiscal stance at the euro area level and foster some fiscal harmonization for those taxes that are dedicated to funding the common budget and spending responsibilities moved to the center.

- Cons-Setting up a dedicated full-fledged euro area budget would require more extensive loss of fiscal sovereignty at the national level than other options given that it would require transferring some taxation and spending responsibilities to the center. At this stage, such a move is unlikely to have the support of the constituent electorates.

\section{A Common Backstop for the Banking Union}

A single resolution mechanism, including a common backstop, covering all banks regardless of their nationality can provide a powerful tool to sever the adverse feedback loop between sovereigns and domestic banks at play in times of stress. It can also provide a mechanism to internalize home-host concerns and reach agreement on cross-border resolution and burden sharing. As such, it would naturally complement the single supervisory mechanism and prevent protracted and costly resolutions. 
Because resolution involves sensitive choices about the distribution of losses, clear ex ante burden sharing mechanisms - as agreed between European ministers of finance in the context of the Bank Resolution and Recovery Directive (BRRD) — are necessary to achieve least-cost resolution, while they also help provide the right incentives for investors and foster market discipline. At the same time, when systemic risks prevail, exceptional treatment may require recourse to taxpayer money, and hence a fiscal backstop from the center (IMF 2013a). Indeed, in no existing federation has the responsibility for resolving or providing deposit insurance for troubled banks - especially systemically important ones-fallen on the subnational level in this crisis. ${ }^{5}$ And even when no national bank resolution fund existed before the crisis, such funds have been put in place, with public means, as ad hoc crisis responses (see Bornhorst, Pérez Ruiz, and Ohnsorge 2013).

- Funding from the industry - Contributions from the banking industry-in the form of a resolution fund-should be used first to finance resolution. The fund could build resources over time through levies on the industry, as is common for existing national deposit insurance schemes or resolution funds. Use of the funds could also be complemented by arrangements to recoup net losses through ex post levies on the industry.

- Fiscal backstop-However, to the extent that private sector contributions and loss allocation across uninsured and unsecured claimants would be insufficient in a systemic crisis, a common backstop would need to be tapped, including through a credit line from the European Central Bank (ECB)—with appropriate safeguards — to ensure adequate liquidity. Even if such a backstop would only be tapped in exceptional circumstances, the mere existence of a common backstop would help anchor confidence in the euro area banking system. The ESM can provide a bridge to such permanent fiscal backstops, as under ESM direct bank recapitalization. Ultimately, however, a credit line from pooled fiscal resources would provide the best insurance against financial risks.

In the spring of 2014, the EU adopted legislation establishing a single resolution mechanism for the banking union that would follow the rules laid out in the BRRD for resolution. The mechanism can also draw upon an industry-funded single resolution fund that was set up under an intergovernmental agreement between member states participating in the banking union. The single resolution mechanism came into existence in January 2015, although the resolution fund will only be available from January 2016 and even then, it will take eight years to reach its final size of about $€ 55$ billion. A full-fledged fiscal backstop, however, is still missing.

\section{Borrowing at the Center}

Provided the appropriate governance structure is in place and fiscal revenues have been assigned to the center-either in a dedicated fund or through a full-fledged budget - a euro area debt instrument backed by those revenues could help finance the temporary transfers and spending responsibilities moved to the center, or provide a credible common backstop to the banking union, or both. Such debt issued by the center would also help in developing a new safe asset for investors-although it should be recognized that, at least initially, common debt would only contribute marginally to reducing the scope for portfolio shifts between sovereign bonds driven by safe haven motives. Finally, although any spending responsibility at the center would have to be backed by revenue, borrowing from the center could increase the countercyclical nature of these instruments by also providing intertemporal risk sharing. However, any common bonds

\footnotetext{
${ }^{5}$ Even in Germany where the presumption was that support to banks would come from the Länder, bailouts were provided on an ad hoc basis by the federal government.
} 
would require the creation of entities at the center able to issue debt on their own behalf (for example, a euro area stabilization fund, a euro area unemployment fund, or an entity managing the euro area budget).

\section{PROS AND CONS OF A FISCAL UNION, AND IMMEDIATE CONSIDERATIONS}

Although the elements outlined so far could prevent future crises from reaching the systemic levels seen following the global financial crisis, progress in this direction faces serious political hurdles. The current approach is already stretching the political fabric of the euro area, however, and the collective cost of the crisis continues to rise. As of 2013, the immediate priority was to put in place adequate and credible fiscal backstops for the banking union while making progress on a road map for the other elements underpinning further fiscal integration.

The benefits from further fiscal integration would accrue in both the short and long terms. In the steady state, with these elements in place, the likelihood of future crises will decrease, and when they occur, they would be less severe and less prone to systemic spillovers. And spelling out today a road map for further fiscal integration would have immediate effects by raising confidence in the viability of the union, which would support current crisis management efforts. In addition, a shared approach with some elements of centralized fiscal policy would allow for better fiscal coordination. It would expand the scope of available countercyclical tools when national policies are constrained by limited market access or fiscal rules-for example, avoiding excessively restrictive fiscal stances during severe recessions. In these circumstances, integration would more than offset the loss of some stabilization capacity at the country level resulting from stronger control of national budgets and the transfer of some fiscal responsibility to the center.

There are also costs to deepening fiscal integration.

- Political costs - Political hurdles to ceding any national sovereignty over budgets are considerable, and they would require extensive public debate. Many steps may require legal changes. In some cases, where existing EU treaties provide only a limited legal basis for euro area-specific reforms, gradually strengthening the legal framework would help clarify the role of euro area versus EU members-but it would require approval by all EU countries. Alternatively, intergovernmental treaties outside the EU framework could be considered, where feasible, as was done with the Fiscal Compact (Box 10.3).

- Operational challenges-The mechanisms suggested in this chapter could be complex to put in place. Mistakes in the identification of temporary shocks could lead to more permanent transfers than desirable. A fiscal union could also result in financial costs if centralized fiscal oversight proves ineffective in curbing moral hazard and instilling policy discipline. In addition, fiscal risk sharing would have a headline cost in revenues transferred to central institutions - although deeper fiscal integration would also mean transferring some spending responsibilities to the center.

- Costs of union versus the costs of ex post crisis measures - The current approach to dealing with the crisis ex post instead of ex ante also has a substantial cost, even though creditor countries have indirectly benefited from safe haven flows that have kept their cost of funding at record low levels. First, there has been a cost in lost output and increased unemployment because ex post measures are implemented only with a lag. Second, there has also been a cost in providing subsidized financial support to countries under stress through programs (Box 10.4). In addition, contingent TARGET2 liabilities would not have increased as much in the presence of ex ante fiscal risk sharing. 


\section{BOX 10.3. Legal Considerations}

Missing euro area framework. Although the European Union (EU) legal framework allows for key elements of a fiscal union (for example, a small central budget with own resources, a system of allocation and redistribution of resources, and the Stability and Growth Pact to support fiscal discipline), the Treaty on the Functioning of the European Union (TFEU) does not envisage common elements of fiscal policy specifically at the euro area level. In addition, it does not recognize the euro area as a separate entity, and the currency union lacks a legal personality. Some of the reforms considered in this chapter could be introduced as EU secondary legislation, but strengthening the legal framework might be required in the long term to anchor deeper fiscal integration in the euro area as an objective under the TFEU. Alternatively, euro area countries could enter into an intergovernmental treaty outside the EU framework, as they did with the Fiscal Compact.

Fiscal policy design. The current EU framework provides flexibility to assess fiscal targets in structural terms, alongside headline targets. Secondary legislation could be used to introduce independent agencies responsible for fiscal forecasting (Articles 121 and 136 of the TFEU), as was recently decided as part of the so-called Two-Pack. Automatic correction mechanisms are being introduced in national legislation, as required by the Fiscal Compact.

Enforcement mechanisms. Options to veto national budgets when national policies are deemed noncompliant with common fiscal rules would require treaty changes. Changes to national legislation and constitutionsand possibly referendums-could be required as well.

Increased fiscal risk sharing. Secondary legislation could be used to introduce a rainy-day fund (Articles 122, 136 , and 352 of the TFEU), and a euro area budget could be established as part of the larger EU budget, but a euro area unemployment benefit scheme would be more complex to accommodate in the current legal framework. In the long term, treaty changes may be necessary to clarify the role of euro area versus EU members, given that the current framework would continue to involve the full Council and European Parliament in all decisions. Alternatively, an intergovernmental treaty among euro area countries could be considered along with the creation of a euro area entity to manage the fund, scheme, or budget.

Fiscal backstop to the banking union. An intergovernmental agreement establishing a euro area resolution fund with industry contributions collected at the national level has been adopted. In the medium term, providing an explicit legal underpinning in the EU treaties for financial stability arrangements, including for the introduction of a fiscal backstop for the banking union, would strengthen their legal soundness. Alternatively, the Board of Governors of the European Stability Mechanism (ESM) could decide to provide a more general ESM backstop for the banking union-in addition to direct recapitalization of banks (Article 19 of the ESM Treaty).

\section{BOX 10.4. The Implicit Cost of Existing Crisis Management Measures}

Crisis financing. Euro area countries have disbursed about $€ 277$ billion out of $€ 390$ billion in program commitments from European Stability Mechanism, European Financial Stability Facility, European Financial Stabilization Mechanism, and the Greek Loan Facility (see Figure 10.4.1). The Eurosystem has an additional exposure of about $€ 1,137$ billion to countries with liquidity needs, including through the European Central Bank (ECB) balance sheet and TARGET2 payment system.

Implicit transfers. The rates charged on most crisis financing reflect the average cost of funding of creditor countries and the ECB's lending rate and fall well below the market rates faced by crisis countries. In particular, liquidity provision through the Eurosystem has allowed the reduction in foreign investors' exposures to occur without a generalized liquidity or currency crisis. To give a sense of the magnitude of the implicit transfer, actual interest expenses for crisis financing are compared with the hypothetical costs if (1) similar amounts had been raised by crisis countries at current long-term yields, or alternatively, at rates reflecting fundamentals (derived from a model, because market rates might have overshot in the current context); or (2) creditor countries had hedged their exposures at prevailing credit default swap rates to insure against the risks taken on their balance sheets.

The implicit transfer is estimated to be between $€ 44$ billion and $€ 75$ billion per year for Greece, Ireland, Italy, Portugal, and Spain (see Table 10.4.1). Netting out the contributions by these countries to crisis financing, the implicit transfer by euro area net creditors ranges between $3 / 4$ percent and 11/4 percent of their GDP. These are

\section{CInternational Monetary Fund. Not for Redistribution}




\section{BOX 10.4. (continued)}

rough estimates of the magnitudes involved. It is important to note, however, that they do not capture the potentially very large costs (longer crisis duration, lower output, and higher unemployment) that could be associated with the current approach of ex post burden and risk sharing.

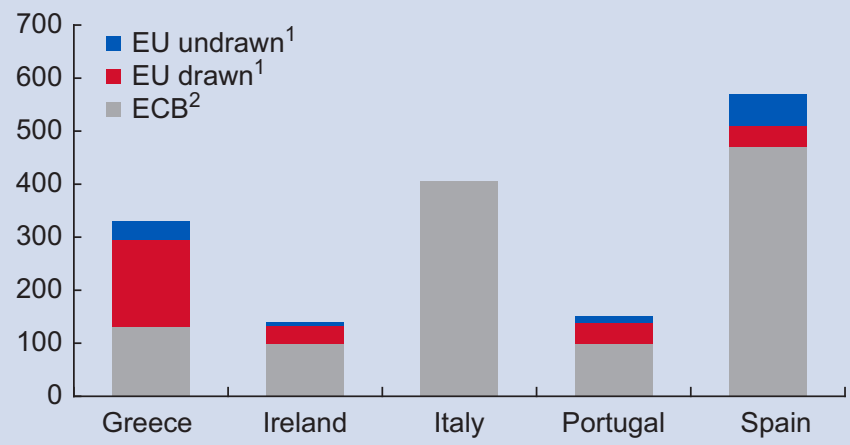

Sources: IMF staff calculations.

${ }^{1}$ Includes European Financial Stability Facility, European Stability Mechanism, European Financial Stabilization Mechanism, and Greek Loan Facility as of January 2013.

${ }^{2}$ Includes change in TARGET2 debts and excess banknote allocation accumulated since

December 2007, as well as Securities Market Program holdings.

Figure 10.4.1 Current Exposure to Selected Euro Area Countries (Billions of euro)

TABLE 10.4.1

\begin{tabular}{|c|c|c|c|c|c|c|c|}
\hline \multicolumn{8}{|c|}{$\begin{array}{l}\text { Implicit Transfers to Selected Euro Area Countries } \\
\text { (Billions of euro, as of February 2013) }\end{array}$} \\
\hline & \multicolumn{3}{|c|}{ Cost Paid Cost Derived from Market Rates } & \multicolumn{4}{|c|}{ Implicit Transfer Per Year } \\
\hline & (a) & $\begin{array}{l}\text { Bonds } \\
\text { (b) }\end{array}$ & $\begin{array}{c}\operatorname{CDS}^{1} \\
\text { (c) }\end{array}$ & $\begin{array}{l}\text { Model }^{2} \\
\text { (d) }\end{array}$ & $\begin{array}{l}\text { Bonds } \\
\text { (b)-(a) }\end{array}$ & $\begin{array}{c}\text { CDS } \\
\text { (c) }-(\mathrm{a})\end{array}$ & $\begin{array}{l}\text { Model } \\
\text { (d)-(a) }\end{array}$ \\
\hline European Union arrangements ${ }^{3}$ & 5.8 & 20.5 & 20.1 & 31.0 & 14.7 & 14.3 & 25.2 \\
\hline European Central Bank ${ }^{4}$ & 20.3 & 49.7 & 48.1 & 70.2 & 29.3 & 27.7 & 49.9 \\
\hline $\begin{array}{l}\text { Gross total } \\
\text { (percent of euro area GDP) }\end{array}$ & $\begin{array}{r}26.1 \\
0.3\end{array}$ & $\begin{array}{r}70.2 \\
0.7\end{array}$ & $\begin{array}{r}68.1 \\
0.7\end{array}$ & $\begin{array}{r}101.2 \\
1.1\end{array}$ & $\begin{array}{r}44.1 \\
0.5\end{array}$ & $\begin{array}{r}42.0 \\
0.4\end{array}$ & $\begin{array}{r}75.1 \\
0.8\end{array}$ \\
\hline $\begin{array}{l}\text { Net total }{ }^{5} \\
\quad \text { (percent of net contributors' GDP) }\end{array}$ & $\begin{array}{r}24.7 \\
0.4\end{array}$ & $\begin{array}{r}67.5 \\
1.1 \\
\end{array}$ & $\begin{array}{r}66.0 \\
1.0 \\
\end{array}$ & $\begin{array}{r}98.4 \\
1.5 \\
\end{array}$ & $\begin{array}{r}42.8 \\
0.7\end{array}$ & $\begin{array}{r}41.3 \\
0.6\end{array}$ & $\begin{array}{r}73.7 \\
1.2 \\
\end{array}$ \\
\hline \multicolumn{8}{|c|}{$\begin{array}{l}\text { Source: IMF staff estimates. } \\
\text { Note: CDS = credit default swap. } \\
\text { 'Germany bond yield plus CDS spread; } 10 \text {-year bond yield for Greece. } \\
\text { 'Estimates for } 10 \text {-year yields; see IMF Fiscal Monitor, October 2012, p. } 40 . \\
\text { IIncludes European Financial Stabilization Facility, European Stability Mechanism, European Financial Stabilization Mechanism, and } \\
\quad \text { Greek Loan Facility. }\end{array}$} \\
\hline
\end{tabular}

It is often assumed that greater risk sharing would invariably evolve into a system of permanent transfers, with financial costs systematically falling on those countries with stronger traditions of fiscal prudence. So would risk sharing mean redistribution? With appropriate safeguards, the answer is no.

- All benefit in the long run-Deeper integration would provide insurance from fellow euro area members against bad events, thereby also preventing worse outcomes for the membership at large. However, although support could span several years if shocks are persistent-as 


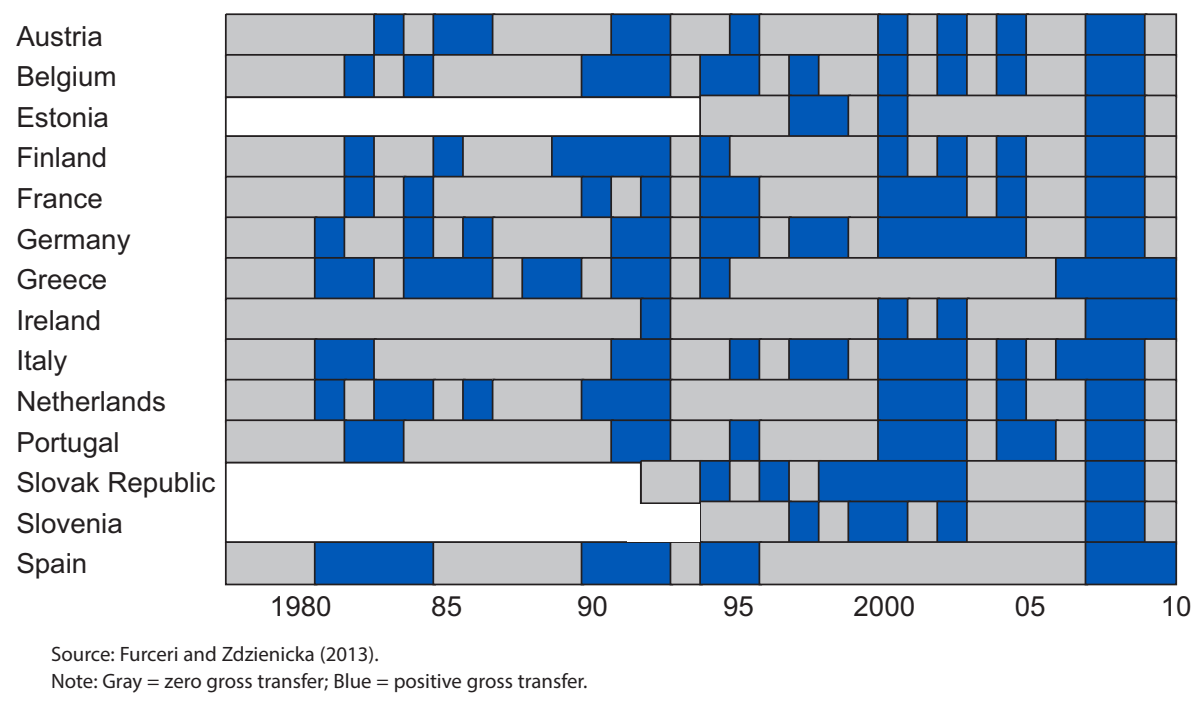

Figure $\mathbf{1 0 . 8}$ Transfers over a Longer Horizon

they appear to be in the current crisis—no system should provide permanent transfers to compensate for a permanent lack of competitiveness or enduringly low income levels. Put differently, risk sharing means that at any given time countries facing relatively better economic circumstances would support countries facing less favorable outcomes. This does not mean, however, that the same countries would always be on the receiving end. In fact, analysis for this chapter shows that the net beneficiaries would have varied greatly year to year, had a risk-sharing mechanism been in place during the past 30 years. Using the example of a rainy-day fund described earlier, the analysis finds that since the late 1970s, all countries would have benefited from transfers at some point (Figure 10.8).

- Small versus large countries-However, the support afforded by centralized stabilization mechanisms may vary between small and large countries. On the one hand, activity in smaller countries might be more volatile than in larger ones. Their economies might also be more prone to idiosyncratic shocks if their business cycles are less synchronized with the euro area-for example, if they trade relatively more with non-euro area countries. If so, there could be instances in which they resort to fiscal risk sharing mechanisms more frequently than do larger euro area members. On the other hand, when larger countries are affected by country-specific shocks, to the extent that inflation evolution in these countries weighs relatively more on euro area-wide price indices, some stabilization is also provided through monetary policy support. Fiscal-risk-sharing mechanisms at the euro area level would thus naturally complement other policy instruments in fostering macroeconomic stability.

Crisis management measures taken since 2010 must remain in place to accompany the ongoing adjustment at the country level. Progress toward a banking union is also occurring. The current proposals to strengthen fiscal governance (see Box 10.1) are a major step in the right direction, and any element of fiscal risk sharing will have to be preceded by further strengthening in that framework and a stronger role for the center. However, deeper fiscal integration need not and will not occur overnight, but defining a clear road map and beginning the journey will help anchor expectations, and thereby contribute to instilling confidence in the resolve to strive toward a more stable monetary union. 
- Progress on fiscal backstop for the banking union-A euro area common fiscal backstop for the region's systemic banks should be put in place to fully sever the negative sovereign-bank feedback loop and anchor confidence in the banking system. The banking union's single resolution mechanism and the associated industry-funded single resolution fund are important steps in the right direction, but a common fiscal backstop remains essential as insurance against a systemic crisis.

- A road map now for future fiscal integration-Meanwhile, the momentum for longer-term reforms needs to be maintained. Agreeing on the details of the above elements, alongside a time-bound road map for implementation, will help anchor confidence in EMU viability. Governance reforms in progress should proceed. Once the road map is agreed on, legal requirements to support stronger central oversight, fiscal risk sharing, and eventually borrowing at the center should be assessed in a comprehensive manner.

The proposals laid out in this chapter are for future crises. They will not resolve the existing debt overhang. Dealing with this overhang will remain a delicate issue, pertaining more to burden sharing rather than risk sharing.

- Striking the appropriate balance-On the one hand, relying entirely on national adjustment could trigger debt-deflation dynamics in fiscally constrained countries with large debt overhangs, dragging the entire region into a period of prolonged stagnation, with a heightened risk of financial instability. On the other hand, debt mutualization at this stage would be akin to selling insurance after the fact and could even reduce the incentives to restore competitiveness.

- Conditioning support-One compromise could be to transform part of the sovereign debt where it is excessive to common debt- that is, euro area entities would hold the debtagainst a commitment from participating countries to repay that debt over time, and conditional on fiscal medium-term plans and structural reforms. The Debt Redemption Fund proposal, as put forward by the German Council of Economic Experts (2011), could be one such option.

- Linking legacy issues to the road map-More generally, resolving the legacy issues and providing a common fiscal backstop to a banking union could provide an embryonic framework for stronger fiscal risk sharing. It could also be a window of opportunity to generate momentum for some of the more ambitious reforms to strengthen fiscal governance and central oversight.

\section{REFERENCES}

Afonso, A. and D. Furceri. 2008. "EMU Enlargement Stabilization Costs and Insurance Mechanisms.” Journal of International Money and Finance 27: 169-187.

Balli, F., S. Basher, and J. Rosmy. 2011. "Channels of Risk Sharing Among Canadian Provinces: 1961-2006." MPRA Paper No. 30876, University Library of Munich, Germany.

Bluedorn, J., D. Furceri, F. Jaumotte, F. Ohnsorge, T. Poghosyan, and A. Zdzienicka. 2013. "Fiscal Risk Sharing: New Evidence for the Euro Area." Staff Discussion Note No. 13/09, International Monetary Fund, Washington. Bornhorst, F., E. Perez Ruiz, and F. Ohnsorge. 2013. "Fiscal Union: Common Practices in Federal States." Staff Discussion Note No. 13/09, International Monetary Fund, Washington.

Commission of the European Communities. 1977. Report of the Study Group on the Role of Public Finances in European Integration (MacDougall Report), Volumes 1 and 2. Brussels. http://ec.europa.eu/economy_finance /emu_history/documentation/chapter8/19770401en73macdougallrepvol1.pdf and http://ec.europa.eu/econ omy_finance/emu_history/documentation/chapter8/19770401en517macdougallrepv2_a.pdf.

European Commission. 2012. "A Blueprint for a Deep and Genuine Economic and Monetary Union—Launching the Debate," November 30, Brussels.

\section{CInternational Monetary Fund. Not for Redistribution}


European Council. 2012. "Towards a Genuine Economic and Monetary Union, Report by the President of the European Council, in collaboration with the Presidents of the Commission, the Eurogroup and the ECB," December 5, Brussels.

Farhi, E., and I. Werning. 2012. "Fiscal Unions.” Working Paper No. 18280, National Bureau of Economic Research, Cambridge, Massachusetts. http://www.nber.org/papers/w18280.

Frankel, J., and A. Rose. 1998. “The Endogeneity of the Optimal Currency Area Criterion.” Economic Journal 108 (449, July): 1009-25.

Furceri, D., and A. Zdzienicka. 2013. "The Euro Area Crisis: Need for a Supranational Fiscal Risk Sharing Mechanism?” Working Paper 13/198, International Monetary Fund, Washington, DC.

German Council of Economic Experts. 2011. "Euro Area in Crisis." Chapter 3 of the Annual Report 2011/2012. http://www.sachverstaendigenrat-wirtschaft.de/.

Henning C. R., and M. Kessler. 2012. "Fiscal Federalism: U.S. History for Architects of Europe's Fiscal Union.” Working Paper No. 12/1, Peterson Institute for International Economics, Washington, DC.

Hepp, R., and J. von Hagen. 2013. "Interstate Risk Sharing in Germany: 1970-2006." Oxford Economic Papers 65 (1): $1-24$.

International Monetary Fund (IMF). 2013. "A Banking Union for the Euro Area." Staff Discussion Note 13/01, Washington, DC.

. 2014. Designing a European Fiscal Union: Lessons from the Experience of Fiscal Federations? edited by C. Cottarelli and M. Guerguil. London: Routledge.

Jaumotte, F., and H. Morsy. 2012. "Determinants of Inflation in the Euro Area: The Role of Product and Labor Market Institutions.” Working Paper No. 12/37, International Monetary Fund, Washington, DC.

Pisani-Ferry, J. 2012. "The Known Unknown and Unknown Unknowns of EMU.” Bruegel Policy Contribution, Issue 2012/18, October.

Sorensen, B. and O. Yosha. 1998. "International Risk sharing and European Monetary Unification." Journal of International Economics 45: 211-238.

Tommaso Padoa-Schioppa Group. 2012. "Completing the Euro: A Roadmap toward Fiscal Union in Europe.” Studies and Reports 92, Notre Europe-Jacques Delors Institute, Paris. http://www.eng.notre-europe.eu /011-3317-Completing-the-EuroA-road-map-towards-fiscal-union-in-Europe.html.

Van Rompuy, Herman. 2012. "Towards a Genuine Economic and Monetary Union.” European Council. http://www.consilium.europa.eu/uedocs/cms_Data/docs/pressdata/en/ec/134069.pdf. 


\section{The Role of Structural Policies at the Euro Area Level}


This page intentionally left blank

CInternational Monetary Fund. Not for Redistribution 


\title{
Capital Market Development: Financing of Small and Medium-Sized Enterprises in the Euro Area
}

\author{
Ali Al-Eyd, Bergljot Barkbu, S. Pelin Berkmen, John Bluedorn, \\ ANDREAS (ANDY) JOBSt, AND ALEXANDER TIEMAN
}

The corporate sector in Europe is highly dependent on bank financing, which has constrained the recovery of credit supply in the wake of the crisis, particularly to small and medium-sized enterprises (SMEs). Developing alternative funding sources for SMEs would enhance the resilience of the financial system and help ensure lending to viable smaller firms. An expansion of the SME securitization market would move firmly in this direction while drawing upon a large existing pool of assets. It would also improve the transmission of monetary policy and the allocation of capital from surplus to deficit economies. The European securitization market performed relatively well through the crisis, likely reflecting more conservative origination and issuance standards. However, further development of these markets requires greater regulatory differentiation of structured finance, crosscountry harmonization of asset structures, and information disclosure, as well as official sector support as a catalyst to expand the market, including by underwriting riskier tranches.

\section{BACKGROUND}

Euro area nonfinancial corporations (NFCs) are more reliant on banks for financing than are their U.S. counterparts. About a third of euro area NFC liabilities are bank loans (Figure 11.1, panel 1). By contrast, in the United States, bank loans account for only about 7 percent of NFC liabilities; firms are much more reliant on capital markets for their financing. Equities also account for a larger share of firm financing in the United States. Focusing only on debt, the picture is similarly stark, with the euro area, Japan, and Europe more broadly all having about four-fifths of debt finance supplied by banks (Figure 11.1, panel 2).

Only the largest euro area NFCs are able to directly access capital markets. And even though concerns about sovereign risk in the euro area have abated significantly, the higher perceived borrower risk due to high levels of private sector debt have contributed to reduced lending to SMEs in vulnerable economies. In addition, real lending rates charged to small loans are higher than those charged for similar loans in core countries (Al-Eyd and Berkmen 2013) and have continued to rise as inflation has fallen, raising debt service burdens over the near term in countries in which firms face the highest funding constraints (Figure 11.1, panels 3 and 4).

SMEs are disproportionately affected by weak credit supply. The European Central Bank's SAFE survey shows that SMEs applying for loans are experiencing difficulties in obtaining credit from banks (Figure 11.1, panel 6). This is particularly the case in Spain and Italy, despite some recent improvement in approval rates (ECB 2014). ${ }^{1}$ In these countries, "finding customers" and "access to finance" are among the largest concerns.

This chapter is based on Euro Area Policies: Article IV 2014 Consultation-Selected Issues, "Capital Market Development: SME Financing in the Euro Area," IMF Country Report 14/199, 2014.

${ }^{1}$ The survey covers about 7,520 firms, of which 93 percent are SMEs. 


\section{Liabilities of Private Nonfinancial Corporations (Percent of aggregate balance sheet, end-2013)}

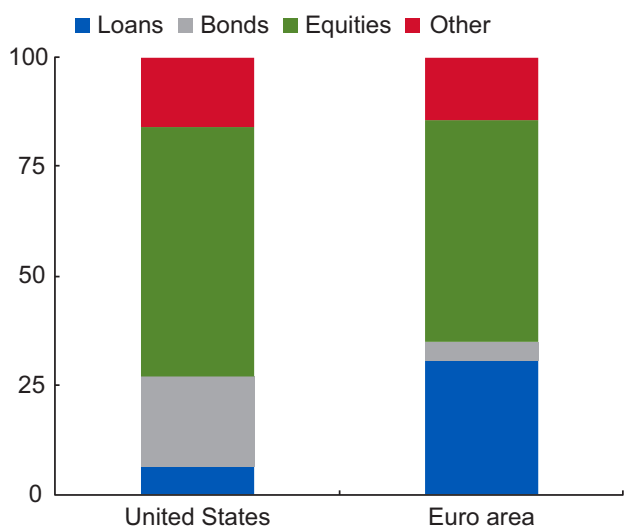

\section{Banking Lending to NFC} (Year-over-year percentage change)

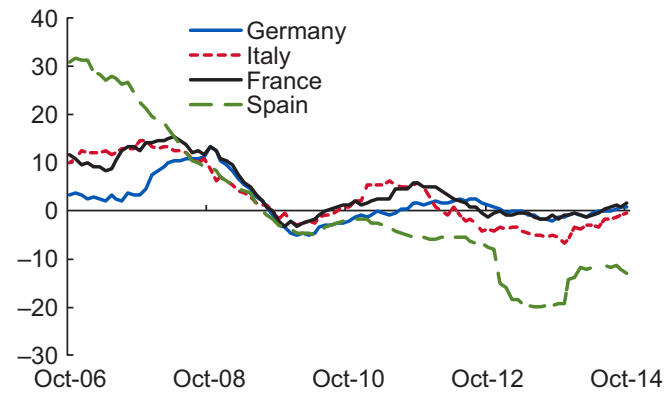

5. SME's Share in the Economy, 2012 (Percent)

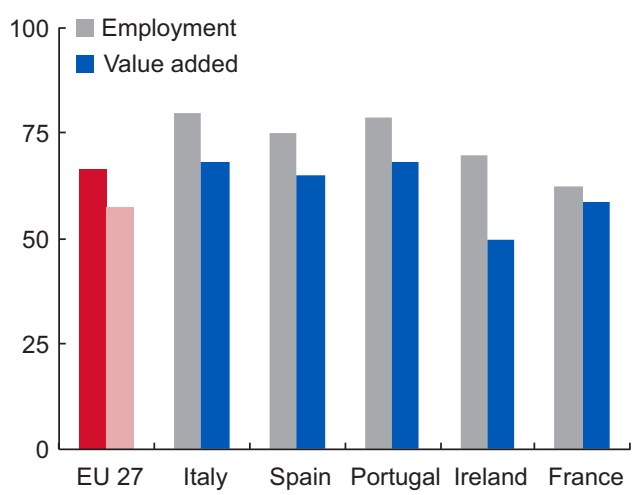

\section{Debt Financing Sources for Nonfinancial Corporations (Percent)}

Bank based $\square$ Securities

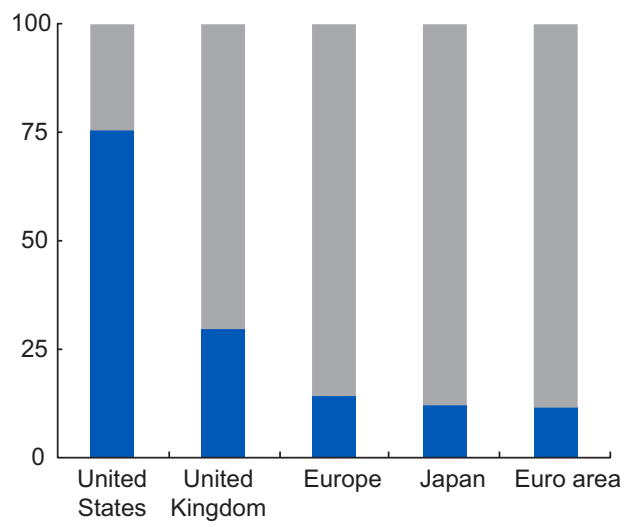

4. SME Real Corporate Lending Rates (Using HICP inflation, percent) ${ }^{1}$

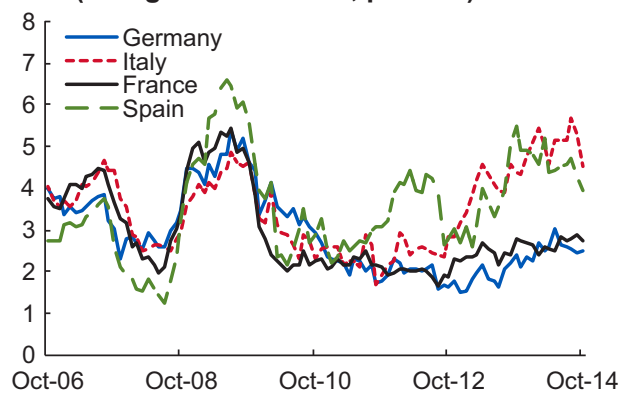

6. Outcome of Loan Application by Euro Area Firms, 2013: $\mathrm{H}^{2}{ }^{2}$ (Weighted percentages of responses)

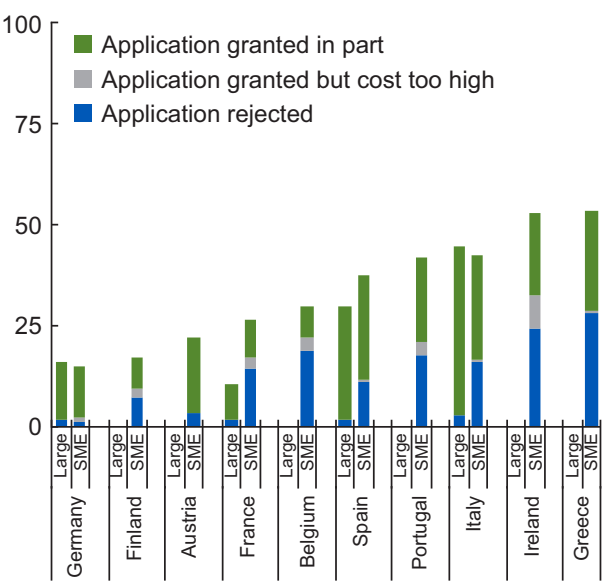

Sources: Bank of England; Bank of Japan; European Central Bank; and U.S. Federal Reserve.

Note: SME = small and medium-sized enterprises. Total private nonfinancial corporation liabilities were about 2 quadrillion yen in Japan, 34 trillion U.S. dollars in the United States, and 27 trillion euro in the euro area in 2013. Europe is the sum of the euro area and the United Kingdom. Data in right panel are end-2013:Q3, apart from Japan, which is end-2012.

${ }^{1}$ Monetary financial institution lending to corporations under $€ 1$ million, for one to five years. Real rates are calculated using realized Harmonized Index of Consumer Prices (HICP) inflation by country.

${ }^{2} \mathrm{Among}$ those firms that applied within the past six months.

Figure 11.1 Liabilities and Financing of Nonfinancial Corporations and Funding Conditions of SMEs 
Ensuring credit availability to viable SMEs is essential to supporting the recovery in the euro area. In 2012, more than 20 million SMEs in the European Union comprised 99.8 percent of all nonfinancial enterprises, employed 87 million people (67 percent of total employment), and generated 58 percent of total added value (Figure 11.1, panel 5). SMEs account for about 80 percent of employment and 70 percent of value added in Italy, Portugal, and Spain. ${ }^{2}$ In addition, SME sectors in these economies are dominated by micro-firms with fewer than 10 employees (about $90-95$ percent of total firms). ${ }^{3}$

\section{RATIONALE FOR SECURITIZATION OF SME LOANS}

Diversification of funding sources would enhance the resilience of the corporate sector. Broader access to finance would limit the exposure of firms to banking sector difficulties and help ensure the flow of credit to viable smaller firms, also reducing the vulnerability of the financial system to shocks. In this regard, a number of markets could be further developed. On the equity side, European venture capital and growth funding in SMEs amounted to about $€ 5$ billion in 2013 (which is less than one-half the size of the outstanding stock of actively traded, placed senior tranches of SME securitization transactions) (EVCA 2014). ${ }^{4}$ On the debt side, minibonds (Italy) and commercial paper markets exist, but are also relatively small. Given the dominance of bank lending, these markets tend to be small or nationally oriented. Starting with bank-intermediated SME securitization would develop the market, which could later facilitate direct asset securitization-i.e., more direct access of SMEs to capital markets (Jobst 2008).

A focus on promoting SME securitization would have several advantages, including the following:

- Readily drawing upon a large pool of existing bank assets (SME loans) to provide additional funding for SMEs;

- Boosting bank liquidity and releasing regulatory capital, thus providing incentives to banks to cleanse their balance sheets and lend to viable firms; ${ }^{5}$

- Helping SMEs rebalance their financial liabilities toward longer maturities; and

- Attracting nonbank investors to SMEs, particularly in a low-yield environment.

A more developed SME securitization market could also improve the monetary transmission mechanism through the bank lending channel (Jobst, Goswami, and Long 2009). In the context of banks' reducing their exposures to SMEs and fragmentation across countries, monetary easing has a limited impact on bank credit to SMEs. With SME securitization, SMEs and banks would be able to draw on more funding sources, with a smaller charge on capital for regulated investors, thereby making monetary easing through interest rates and standard liquidity facilities more effective. A more developed market could also boost the supply of collateral for liquidity provision in a crisis situation.

European securitization markets performed comparatively well during the financial crisis, likely reflecting more conservative origination standards. (See Box 11.1 for an overview.) The cumulative default rate on securitization products was relatively low, at about 2 percent; in

\footnotetext{
${ }^{2}$ SMEs are defined by the European Commission as having fewer than 250 employees. They should also have an annual turnover of up to $€ 50$ million or a balance sheet total of no more than $€ 43$ million (Gagliardi and others 2013).

${ }^{3}$ See Darvas (2013) for more information on SME finance in Europe.

${ }^{4}$ For the purposes of venture capital and growth funding, SMEs are defined solely by the number of employees in the EVCA data set. See also Kraemer-Eis, Lang, and Gvetadze (2014).

${ }^{5}$ Many large European banks depend on either a large deposit base or rely on wholesale funding for large parts of their balance sheets. Securitization of SME loans would increase secured funding for lending over longer terms, creating highquality collateral and transferring credit risk to nonbank investors.
} 


\section{BOX 11.1. Overview of the European Securitization Market}

The European securitization market is relatively small and concentrated, making securitized instruments a limited alternative for firm financing. The outstanding stock of transactions is about $€ 1.5$ trillion-slightly larger than the U.S. market (US\$1.38 trillion) excluding residential mortgage-backed securities (RMBS) issued by the housing agencies Fannie Mae and Freddie Mac (Galizia and Gentili 2014; IMF 2009, 2011) (Figure 11.1.1, left panel 1). The European market is dominated by bank-sponsored RMBS, which amounted to around $€ 820$ billion at end-Q2 2014. SME asset-backed securities (ABS) constitute less than one-tenth of the total market ( $€ 104$ billion), broadly comparable with the share of other securities. Moreover, the euro area securitization market is concentrated, with only a handful of countries accounting for the majority of the market. Together, transactions from Belgium, Germany, Italy, the Netherlands, and Spain accounted for about 84 percent of the securitization market in the euro area at end-Q2 2014 (Figure 11.1.1, right panel 2).

The securitization market in Europe has contracted by about one-third since the start of the crisis. New placements peaked in 2008 (Figure 11.1.1, panel 5) but dropped to about one-fourth their earlier volume, hovering around $€ 100$ billion for 2013. The bulk of the decline in these markets reflects the approximately $€ 500$ billion (or about one-third) fall in the RMBS segment since 2009. In relative terms, however, the

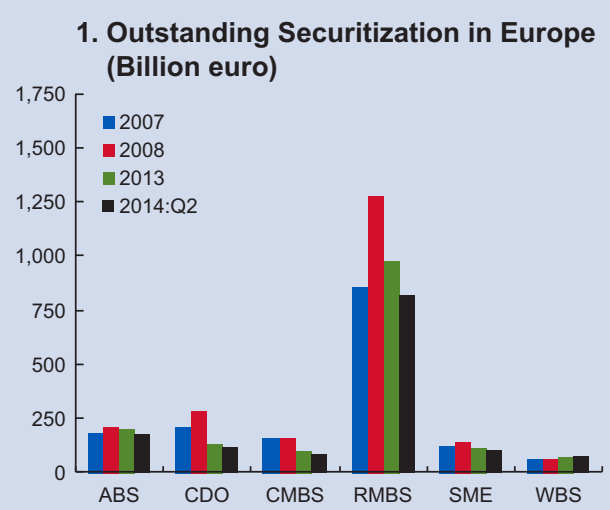

3. Outstanding European Securitization, 2006-14 (Billion euro and percent of total ECB eligible assets)

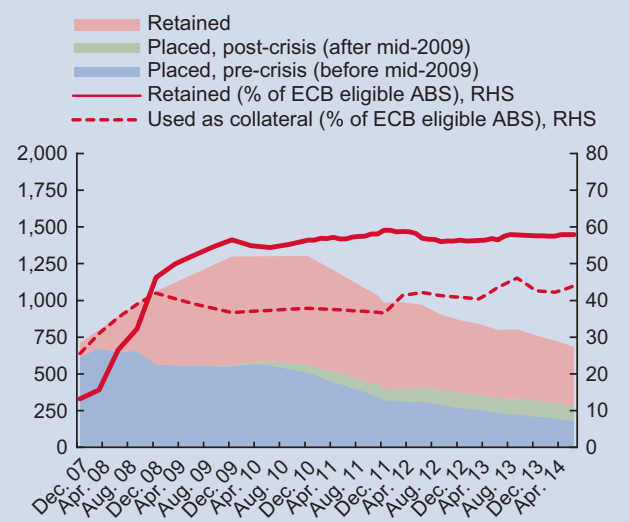

\section{Outstanding Securitization in Europe (Billion euro)}

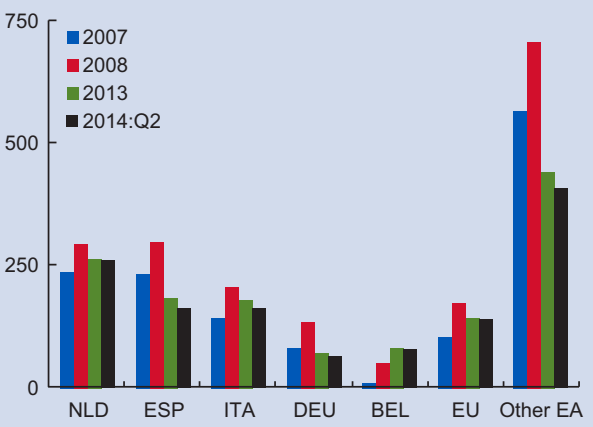

\section{Collateral Utilization for ECB Repo, 2007-14}

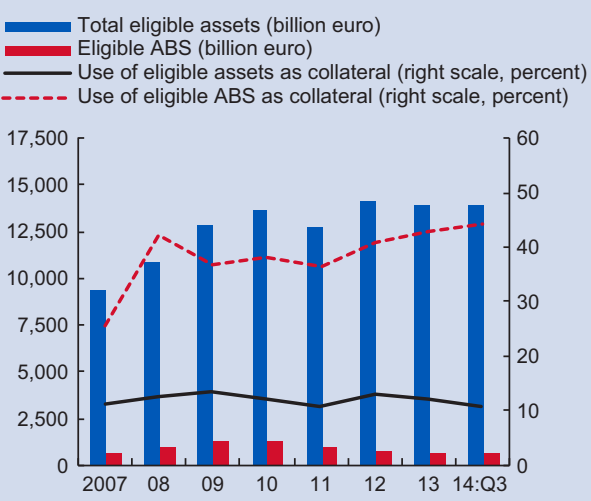

Sources: Association for Financial Markets in Europe; European Central Bank; Royal Bank of Scotland estimates; and IMF staff calculations. Note: $\mathrm{ABS}=$ asset-backed securities; $\mathrm{CDO}=$ collateralized debt obligations; $C M B S=$ commercial mortgage-backed securities; $\mathrm{RMBS}=$ residential mortgage-backed securities; SME = SME asset-backed securities; WBS/PFI = whole business securities/project finance initiatives. Europe is a geographic designation, including EU member states and non-EU countries (panel 1). Other EA is the sum of other euro area members' outstanding securitization for which separate data are available. It includes Austria, Finland, France, Greece, Ireland, and Portugal (panel 2). Europe includes EU and non-EU countries (panels 5-6). Data labels in the figure use International Organization for Standardization (ISO) country codes.

Figure 11.1.1 The European Securitization Market 


\section{BOX 11.1. (continued)}
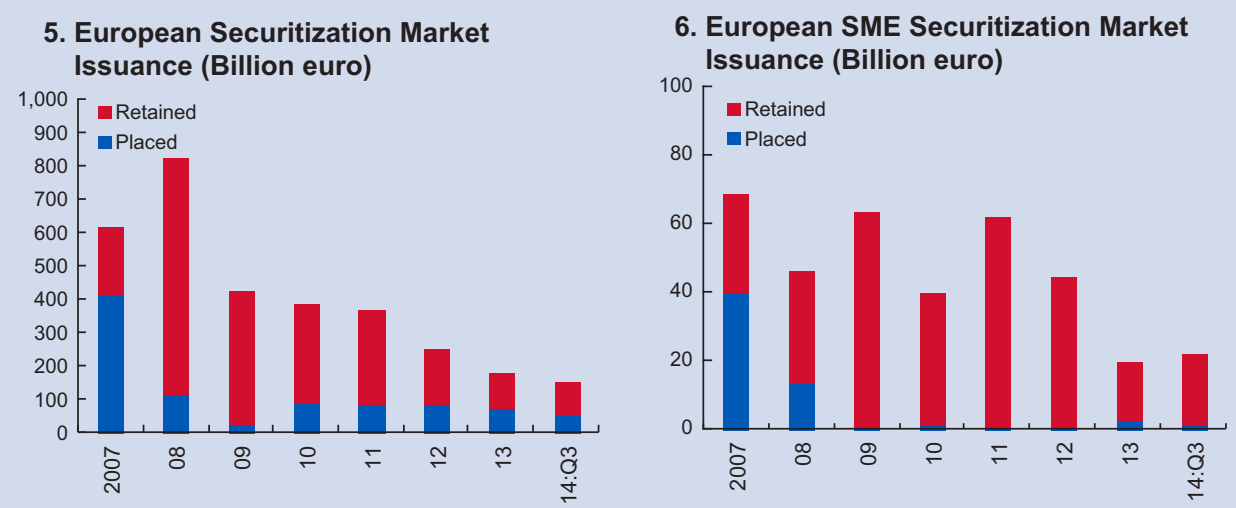

Figure 11.1.1 (continued)

collateralized debt obligation and commercial mortgage-backed securities markets experienced larger declines, shrinking by almost half, while the SME market similarly fell by about one-third.

As securitization issuance has fallen, its use for refinancing at the Eurosystem has increased. At the peak, the market was evenly split between retained and placed securitization (Figure 11.1.1, panel 3). However, since then, placed securitization has fallen by about a half, mostly reflecting the amortization of contracts before 2009 that have not been fully offset by new placements (Figure 11.1.1, panel 5). Of new issuances, about two-thirds remain on bank books, while for SME securitizations, nearly 90 percent are retained. These retained securities can often be used as collateral for short-term funding from the Eurosystem (Figure 11.1.1, panel 4). Although the size of the eligible asset pool for Eurosystem collateral has increased, the pool of eligible ABS has actually dropped, likely reflecting the attrition of these (and the high redemption rates over the recent past) rather than a tightening of Eurosystem collateral standards (which have been relaxed for some asset classes in the recent past).

contrast, the cumulative default rate for U.S. securitization products was about 18 percent. However, the comparison of U.S. and European securitization markets is not straightforward because the underlying assets for these securities differ in their riskiness (Bank of England and ECB 2014b). About one-third of European securitization transactions are rated "AAA" (which is the mode), and more than half are rated "A" or higher (Figure 11.2, panel 1). SME securitization shows a slightly lower average rating, with the modal rating of A. However, almost one-third of SME securitizations are unrated, possibly reflecting their higher likelihood of being retained (Figure 11.2, panel 2). There is also a greater tendency of retained tranches to be lower rated.

Given the high reliance on bank lending in the euro area, this chapter focuses on developing SME loan securitization-intermediated through banks as opposed to direct asset securitization-as a readily available source of finance and a means to overcome the allocation problem that is reflected in divergent private borrowing costs for similar firms across the euro area.

\section{IMPEDIMENTS TO SME SECURITIZATION}

Several challenges must be addressed to further develop SME securitization in Europe. In particular, structural market factors, including unfavorable economic terms (for example, high cost of issuance), adverse cyclical factors (such as ongoing economic weaknesses), and inefficient and fragmented national insolvency regimes reduce the incentives for issuance. In addition, regulatory 
All Placed

1. Credit Rating Distribution of Outstanding European Securitization, 2013 (Percent)

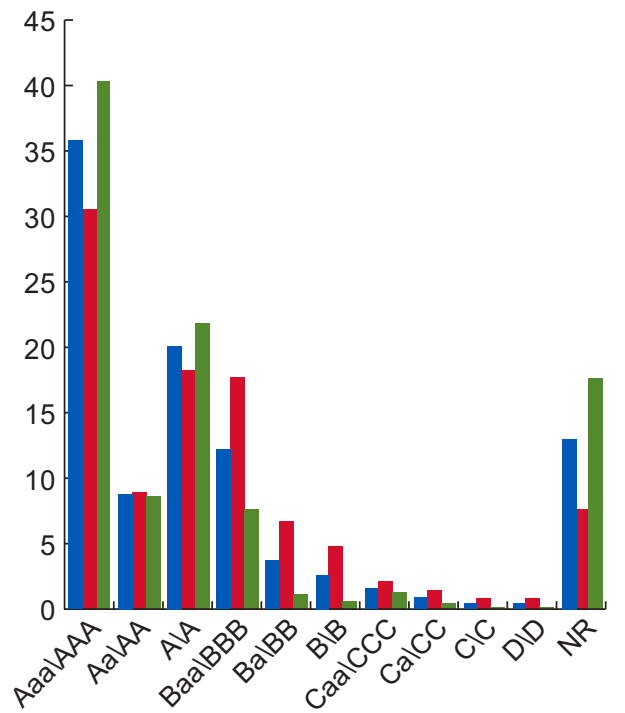

Retained

\section{Credit Rating Distribution of Outstanding European SME Securitization, 2013 (Percent)}

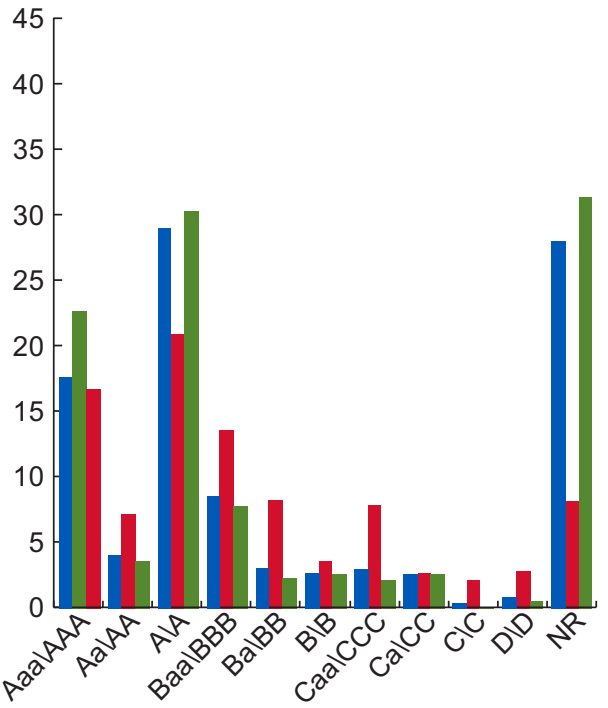

Sources: Securities Industry and Financial Markets Association; and IMF staff calculations.

Note: $\mathrm{NR}=$ not rated; $\mathrm{SME}=$ small and medium-sized enterprises. Figure includes both European Union and non-European countries. The value of total outstanding European securitization was about $€ 1.5$ trillion in 2013. Of this, about 46 percent was placed and 54 percent retained. SME securities accounted for 8 percent of total outstanding European securitization in 2013. Of this, 14 percent was placed, while 86 percent were retained.

Figure 11.2 Distribution of Credit Ratings for Outstanding European Securitization, 2013

factors, including pending regulatory changes that raise the capital intensity of holding less risky asset-backed securities (ABS), weaken the investor base.

\section{Structural Market Factors}

The economic cost of issuance is high, and a bank must balance this cost against the potential capital relief from securitization and the cost of alternative sources of funding. Higher issuance costs reflect lower net interest margins (and thus difficulty in pricing attractive yields), a high cost of structuring SME-backed transactions (for instance, legal costs, due diligence, pooling, ratings, and credit enhancements), ${ }^{6}$ and the lack of a sufficiently large investor base (due to regulatory burdens and stringent internal risk guidelines, for example).

High sunk costs can also be involved in securitizing SME loan portfolios. In particular, setting up information technology systems to handle the granular information and variety of collateral related to SME loan portfolios, and operational constraints, such as a lack of uniform reporting standards and credit scoring, make securitization of SME-related claims more costly than, for example, mortgages. Both the significant heterogeneity of SME portfolios across country loan pools and differences in national insolvency frameworks limit the scope for broader securitization markets on the supply and demand sides alike. Also, insufficient volumes of long-term loans

\footnotetext{
${ }^{6} \mathrm{Up}$-front costs related to the due diligence process required to securitize assets can be significant. Credit enhancements (for example, high subordination levels for senior tranches, overcollateralization, and interest reserve accounts) may also often be required by ratings agencies, especially if many reference assets in the securitized portfolio are unrated.
} 
(which complicate the estimation of the cash flow pattern of SME portfolios) continue to hamper faster market growth.

- Pooling - Certain conditions must be satisfied to ensure a loan's suitability for pooling, raising the cost of due diligence. Among these conditions, a few are crucial: a clean credit history, sufficient tenor with a predictable cash stream (that is, an amortizing loan rather than a bullet loan), clarity on collateral and its availability, and sufficient sectoral diversification. From a bank's perspective, achieving a critical mass of loans with such characteristics is more difficult in the SME sector than, for example, in the residential mortgage sector in which there is more uniformity of loans, longer maturity tenors, and regularity of payment streams due to amortization.

- Securitizing-Once a pool of loans is identified, legal documentation must be drawn up, and ratings must be assigned by a commercial agency. Regarding the latter, SME securitization issuances typically require a compromise on the part of issuers, for example, by providing greater credit enhancement than comparable securitization of other assets. Overall, these costs provide a degree of transparency (or reduce riskiness), but they must be balanced against the size of the pool to ensure an adequate cost ratio. Typically, the larger the pool, the less costly are such considerations, except perhaps for credit enhancements.

- High yields-Investors require a favorable risk-to-return profile. Such a profile can be achieved through a sufficiently high-yielding asset (relative to risk), an inherently less risky asset (relative to yield), or a combination of these. However, it can be difficult for a bank to ensure a high-yielding asset with adequate differentiation between tranches from a heterogeneous pool of SME loans given that such assets are costly to securitize and command relatively low returns. This situation contrasts, for example, with the scope for high-yielding securitization from credit card payments given their high relative interest rates. As a result, low returns on SME loans make for low-yielding securitized assets.

- Investor base-More stringent internal risk metrics for institutional investors, reflecting the combination of higher capital charges for securitization transactions and heightened risk aversion, have narrowed the investor base, which is mostly regulated in Europe (banks, reinsurance companies, and pension funds). Other types of investors, typically hedge funds, account for only a small portion of the market.

\section{Regulatory Hurdles}

Ongoing reforms tend to set high capital charges on securitization instruments relative to other funding instruments of similar risk. ${ }^{7}$ Under the proposed regulatory treatment for securitization, senior tranches of transactions compare unfavorably with other funding instruments such as senior unsecured debt or covered bonds. In particular, the proposed revision to the definition of risk-weighted assets for securitization exposures by banks effectively raises the capital intensity of simpler (or less risky) assets to the level of complex (or more risky) assets, rendering differentiation of these instruments based on actual market performance irrelevant. ${ }^{8}$ Furthermore, the finalized capital charges under the Solvency II Directive for insurers investing in securitization transactions (European Commission 2014b) are higher than those for other assets with

\footnotetext{
${ }^{7}$ See Bank of England and European Central Bank (2014b) for a comprehensive discussion of regulatory impediments to securitization. See Segoviano and others (2013) for a general discussion on the reform process in securitization markets. ${ }^{8}$ Upon conclusion of the final consultation on the regulatory treatment of securitization exposures held in the banking book, the Basel Committee (BCBS 2014) proposes higher risk weights for exposures rated "BB+" or higher, yet a lower and more risk sensitive approach for securitization tranches rated "BB" or lower. For instance, the risk weighting on "AAA"-rated tranches will increase from 7 percent to 25 percent in the five-year tenor under the standardized approach.
} 
comparable risks. Although the capital charge on these assets has recently been lowered, ${ }^{9}$ it is unlikely to be sufficient to draw institutional investors. ${ }^{10}$ Under current market conditions, the proposed regulatory capital charges for highly rated structured finance instruments (securitization and covered bonds) on SME-related debt would reduce balance sheet leverage to a point that insurance companies (and to a lesser extent banks) can no longer achieve a sufficient return on equity based on current profitability. (Box 11.2 illustrates how capital charges affect potential returns.)

Preferential treatment of high-quality securitization (HQS) instruments in the forthcoming European liquidity standards would increase investor appetite for these assets. The Basel definition of the liquidity coverage ratio (LCR) mostly excludes securitization instruments from the measure of liquid assets, apart from some limited types of RMBS, but will allow the inclusion of highly-rated covered bonds up to 70 percent of high-quality, liquid assets (HQLA). Failure to broaden the pool of eligible assets to a wider range of securitization structures of sufficient credit quality will reduce investor appetite for such instruments. ${ }^{11}$ However, the pending LCR under the Capital Requirements Regulation (CRR) is likely to include a wider range of HQS (see Annex 11.2) in the definition of liquid assets.

Recent EU retention rules help ensure that issuers have "skin in the game," but may also put a burden on investors to fund retained portions once transaction structures for genuine risk transfer replace the current "securitization to repo" issuance. In 2013, more than half of all issuances (and far more than what would be required under the existing skin-in-the-game rule of 5 percent under the Capital Requirements Directive II) were retained by the originators, that is, the current retention rule is nonbinding. Steps are being taken at the EU level to improve access to information to enhance investors' confidence in the quality of the instrument and the underlying asset portfolio. Under the CRR, the European Banking Authority has drafted Regulatory Technical Standards that specify requirements for due diligence for institutions becoming exposed to a securitization position as well as for originators, sponsors, and lenders to retain an economic interest.

\section{RELATIVE PERFORMANCE}

Simple structures and limited, targeted official support have enhanced the relative performance of European securitization. Unlike some other jurisdictions, most transactions in Europe showed remarkable resilience during the recent crisis. ${ }^{12}$ This performance might be explained by many features of HQS that have developed as a result of both bank-based issuance and established public sector programs, including traditionally conservative loan origination standards, with high equity participation of the originator; servicing being retained by the originator (servicer continuity) together with issuer due diligence; adequate post-issuance performance monitoring; and treatment of securitization as part of ongoing balance sheet operations (see Annex 11.2).

\footnotetext{
${ }^{9}$ The European Commission has recently proposed further lowering the currently proposed capital charge of 4.3 percent per year of duration to be assigned to the highest-quality ABS instruments as an attempt by the European Insurance and Occupational Pensions Authority to differentiate such assets from lower-quality ones.

${ }^{10}$ Note that Solvency II assigns a lower capital charge for covered bonds compared with other nongovernment or unsecured assets. Furthermore, covered bonds will be exempted from "bail-in" that would subject unsecured senior debt of failed banks to forced write-downs or conversion into equity in resolution.

${ }^{11}$ However, it is currently being debated at the European level whether exposures that are consistent with the concept of HQS could be included in the EU liquidity coverage ratio under the CRR.

${ }^{12}$ Note, however, that some SME-loan-backed transactions with nongranular reference portfolios, especially those including unsecured (mezzanine) loans, did experience significant downgrades and defaults during the financial crisis. These transactions represented only a small part of the market and did not exhibit the properties of HQS listed in Annex 13.2.
} 


\section{BOX 11.2. Regulatory Hurdles}

A simple cost-benefit analysis can illustrate how proposed capital charges under the standardized regulatory approaches affect banks' and insurance companies' trade-off between investing in either securitized or nonsecuritized SME loans. For these investors, which are subject to regulatory standards for capital adequacy, the interaction of their desired return on equity $(\mathrm{RoE})$ and the degree of leverage implied in the economic cost of capital for any given asset return determines whether the proposed capital charges under the relevant regulatory regime (Basel III-Securitization Framework and Solvency II-Capital Charges for Long-Term Investment) are binding. ${ }^{1}$

At current market prices, insurance companies (and to a lesser extent, banks) have a much greater incentive to hold SME loans rather than invest in highly-rated securitization transactions backed by the same credit risk. The solid curves in Figure 11.2.1 depict feasible combinations of the regulatory capital charge and the RoE for any given market return on an asset. Higher capital charges are associated with lower implied leverage, which decreases the potential RoE for a given asset return and vice-versa (all else equal). The intersection of these curves with the dotted horizontal lines showing the proposed capital charges under the Basel III and Solvency II regimes illustrate that investment in highly-rated senior tranches ("ABS (SME) AAA") would result in a RoE of less than 13.0 percent for banks and 4.5 percent for insurers. This rate is only slightly above the current benchmark RoE that banks would earn by simply holding the SME loan on their books (with the intersection, or asymptotic convergence, of the blue curve and line occurring to the right of the current RoE).

\section{European Securitization: Market-Implied Regulatory Capital Charge for Banks at Current Yields for Different Levels of Return on Equity (As of end-May 2014, in percent)}

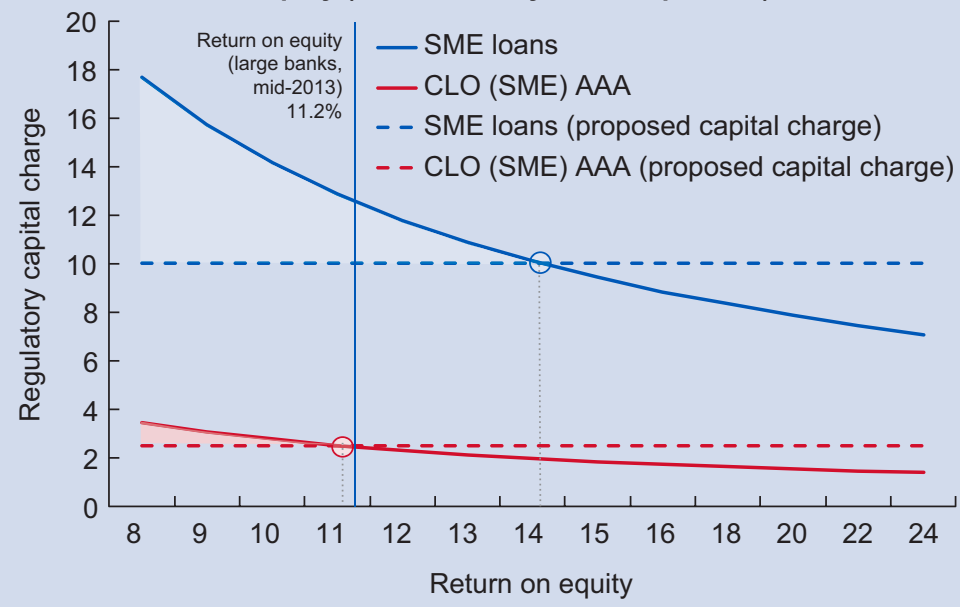

Sources: Basel Committee on Banking Supervision; Bloomberg, L.P.; European Insurance and Occupational Pensions Authority; and IMF staff calculations.

Note: $\mathrm{CLO}=$ collateralized loan obligation; RoE = return on equity; SME = small and medium-sized enterprises. Current yields for benchmark deals of AAA-rated CLOs and covered bonds as well as average net interest margin of SME lending in the euro area after provisioning (20 percent); return on equity after taxes. For the capital charge of insurers, a maturity tenor of three years was assumed for the CLO to derive the solvency capital requirement (EIOPA 2013); for banks, the calculation of the regulatory capital charge assumes the capital adequacy ratio $=10$ percent based on given risk weightings according to BCBS (2013). This analysis reflects the standardized approach under the proposed regulatory regimes for banks and insurers. For an assessment of internal model-based approaches in banking, for instance, one would need to apply the so-called ratings-based approach to rated tranches and the supervisory formula approach to unrated tranches retained by originators. For investing banks, unrated tranches would need to be fully deducted from capital unless the application of the supervisory formula approach is granted by the national supervisor.

Figure 11.2.1 European Securitization: Market-Implied Regulatory Capital Charge for Banks and Insurance Companies at Current Yields (As of end-May 2014)

\footnotetext{
${ }^{1}$ Sophisticated investors are likely to use approved internal models; however, given the overall consistency between internal model-based estimates and standardized approaches, the results presented provide broad guidance regarding firms' sensitivity to changes in capital charges.
} 


\section{BOX 11.2. (continued)}

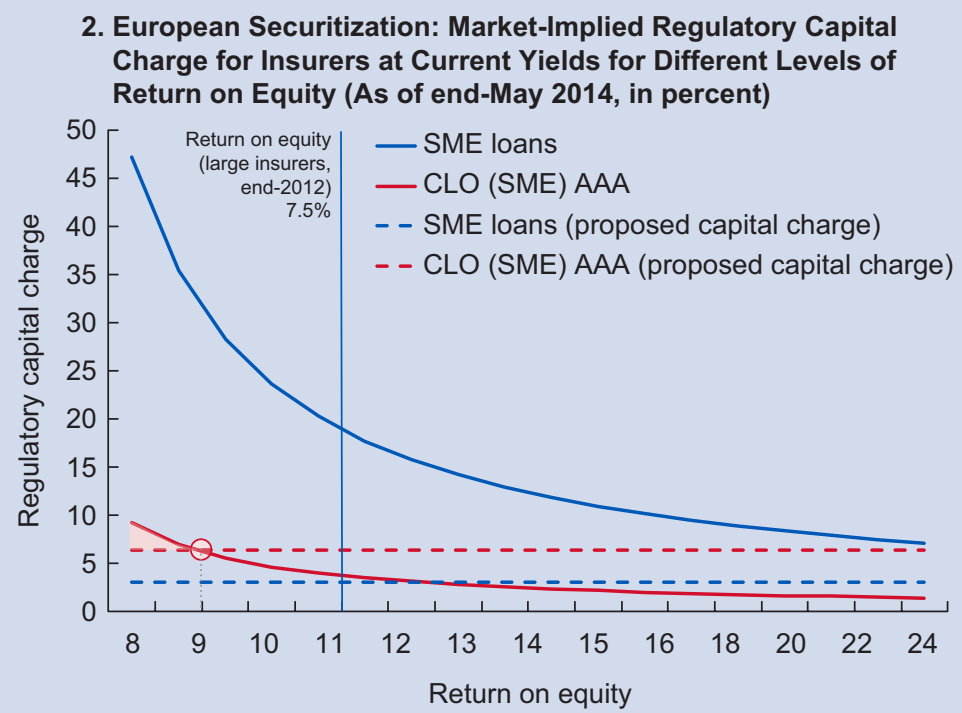

Figure 11.2.1 (continued)

Moreover, for insurers, the RoE from holding the security is far below the (current) benchmark RoE of 7.5 percent. Note that investing in (or not securitizing) SME loans remains profitable for both banks and insurers, with the intersection (or asymptotic convergence) of the curves and lines with markers occurring to the right of the (current) benchmark RoEs.

These observations highlight that current regulatory incentives are stacked against securitization. In particular the regulatory treatment of nonbanks in the area of capital adequacy impedes the broadening of the potential investor base. The impact of current monetary easing on risk premia (and the current yield/net interest margin) influences these results but is unlikely to affect the overall outcome.

Moreover, in some countries, such as Germany and Spain, successful platforms for banksponsored SME securitization are in operation.

\section{LESSONS FROM PREVIOUS SME SUPPORT PROGRAMS}

Most SME securitization transactions in Europe have benefited from public sector-sponsored programs, which have enhanced their relative performance. However, the customized and nationally oriented nature of these programs has limited the potential scope for broadening capital market access for SMEs (see Annexes 11.1, 11.3, and 11.4). The most significant national programs in Europe are the Asset Securitization Funds for SMEs (Fondos de Titulización de Activos para Pymes or FTPYME) in Spain and Kreditanstalt für Wiederaufbau (KfW)'s PROMISE (Program for Mittelstand-loan Securitisation) platform, which provide cost-efficient funding support to bank-originated loans to SMEs. Such support has generally been motivated by the cost implications of recent structural and regulatory changes for banks' SME lending, such as the shift toward fee-generating business, the greater risk sensitivity of capital standards, and more competitive pricing of SME loans. 
In some cases, the European Investment Fund (EIF) has acted as credit guarantor for public sector programs or banks' own securitization vehicles. These actions help facilitate credit risk transfer and improve the market liquidity of SME securitization transactions by widening the investor base. The EIF typically covers tranches rated in the range of BB to A (mezzanine tranches), for which the secondary market is particularly illiquid. ${ }^{13}$ Such guarantee schemes are very effective in providing market access to smaller banks with low issuer ratings and mitigating the influence of "sovereign ceilings" in deficit countries, which cap the highest rating issuers can achieve because of the general level of sovereign default risk. During the financial crisis, the EIF also provided "wrappers" for senior tranches issued by banks in stressed economies, making their placement possible with a wider investor base.

Schemes also exist at the European level, but their use has been limited to supporting onlending rather than SME securitization (Annex 11.3). The SME Guarantee Facility was set up under the EU's 2007-13 Multiannual Financial Framework (MFF) to improve SMEs' access to finance, including through co-, counter- and direct guarantees to banks. Although the facility was used in 21 countries, generating $€ 15$ billion in lending to more than 275,000 SMEs, there was only one agreement under the securitization window. ${ }^{14}$ The SME Guarantee Facility was closed at the end of the 2007-13 MFF, but its activities, including a securitization instrument, are expected to be continued under the European Commission's Competitiveness of Enterprises and Small and Medium-Sized Enterprises (COSME) program for the 2014-20 MFF.

There are also private sector initiatives, such as True Sale International GmbH (TSI). The TSI platform was created in 2004 by a consortium of 13 German commercial banks to promote the German securitization market. It provides issuers of transactions with a cost-efficient, standardized issuance process that complies with national competition law and regulatory requirements. The TSI platform allows participating banks to securitize loans through a specially created limited-liability special purpose vehicle (SPV) owned by three charitable foundations (Jobst 2006). ${ }^{15}$ In 2010, the TSI created the German securitization certification standard (Deutscher Verbriefungsstandard), which establishes clear rules for transparency, disclosure, lending, and loan processing. The platform is heavily used by consumer loan and lease ABS structures; only two SME securitizations have been completed via the TSI so far.

\section{RECENT EFFORTS}

Current initiatives at the European and national levels are steps in the right direction, but are too small or too narrowly focused on bank lending to have a broad impact. These initiatives include the joint European Commission-European Investment Bank SME Initiative and the Banque de France's approval of securitized credit claims for collateralized refinancing by originating banks. Both proposals envisage greater official support to bank-sponsored SME lending, but fall short

\footnotetext{
${ }^{13}$ As opposed to credit insurance, an EIF guarantee also implies a substantial leverage effect. In structured transactions, the risk transfer can be achieved with a limited nominal EIF guarantee exposure that covers only a small portion of the loan portfolio but results in significant "rating uplift" for more senior investors.

${ }^{14}$ Under this agreement, the EIF took the second-loss risk, and Italian mutual guarantee funds (Confidi) took the first-loss tranche, reducing the capital requirement for the originating bank (Unicredit) and facilitating Italian SMEs' access to $€ 120$ million of new loans.

${ }^{15}$ These charitable foundations act as majority shareholders of the SPV to achieve tax-exempt status, and thus eliminate income taxation on funds managed by the SPV. The use of multiple foundations ensures the loans are "bankruptcy remote" from the originating banks. TSI Services GmbH, a limited-liability subsidiary of TSI, organizes and coordinates the establishment of the SPV.
} 
of mechanisms to solicit nonbank funding sources and schemes that would allow direct capital market access:

- Joint EC-EIB Initiative - This initiative aims to kick-start lending to SMEs by blending EU Structural Funds, EU funds, and EIB resources through guarantees and securitization, thereby offering more generous conditions than existing EU initiatives (Annex 11.3). However, the uptake among EU countries has been limited, with only a few countries participating so far, partly because of complex procedures governing the use of Structural Funds as well as funds having already been committed. The option of cross-country pooling of resources and risk, which would significantly leverage resources and reduce the effects of financial fragmentation, is unlikely to be used in the near term, reflecting the limited uptake and, possibly, concerns about adverse selection bias.

- Banque de France (BdF) proposal-The BdF developed a scheme for the standardization of securitized credit claims by allowing banks to bundle SME loans rated "BBB-" and higher (through a commonly owned SPV [Euro Secured Notes Issuer]) unrated as collateral for refinancing via the central bank or interbank repurchase agreements. ${ }^{16}$ This scheme draws on the experience of the Eurosystem in instituting greater transparency about collateral assets and their performance over time in "retained" securitization transactions via the ECB's loan-level data initiative. The first transaction was completed in April 2014. However, current implementation requires detailed supervisory information on loan characteristics, which may limit broader (pan-European) application.

The ECB's loan-level data initiative will help improve transparency of securitization instruments. The initiative establishes requirements for transparency and standardization as necessary preconditions for ABS, including SME ABS, to be considered eligible as Eurosystem collateral. The detailed information on borrower and loan characteristics can be used by current and potential investors to carry out their own credit analyses, and will help address information asymmetries. The benefits are likely to take some time to materialize and will require steadfast implementation of the standards and data requirements.

\section{SUGGESTED MEASURES TO FACILITATE THE DEVELOPMENT OF SME SECURITIZATION ${ }^{17}$}

Involvement of the official sector would help promote credit risk transfer. The official sector should support the development of ABS structures that facilitate the transfer of SME lending risks from banks to capital markets and take steps to align the underlying risks of these instruments with regulatory charges. Low bank funding costs have limited the supply of moreexpensive transactions that involve credit risk transfer and the inclusion of asset types that are generally more costly to securitize, such as SME loans. ${ }^{18}$ At the same time, higher regulatory capital charges and cumbersome operational requirements for investment have inhibited demand for SME securitization transactions (relative to other forms of investment). Moreover, risk-adjusted returns of senior tranches of such transactions are currently too low for institutional

\footnotetext{
${ }^{16}$ The acceptance of such assets as collateral for Eurosystem credit operations is still being assessed.

${ }^{17}$ These recommendations have been further developed in Aiyar and others (2015), and have been presented in a Joint EIB-IMF workshop on SME securitization in Europe on October 23, 2014, in Brussels/Belgium (Aiyar, Barkbu, and Jobst 2014).

${ }^{18}$ Any securitization transaction would require a structure under which issuers would not be parting with their assets without making some kind of return or gain on sale. Doing so depends on the spread payable to investors as well as on the asset yield and the size of the risk retention.
} 
investors (banks, insurance companies, and pension funds), while the nonbank investor base is limited.

Measures that would facilitate development of SME securitization include the following: ${ }^{19}$

- The regulatory regime should appropriately differentiate between high-and low-quality securitization transactions-The proposed revisions to the definition of risk-weighted assets by the Basel Committee and assigned capital charges for long-term investment under the implementation guidance under Solvency II will lead to a significant increase in capital requirements for institutional investors subject to the regulations in senior tranches of securitization transactions. Reducing the capital intensity of structures that qualify as HQS could encourage the supply of transactions that provide genuine risk transfer (rather than being used for funding purposes only). ${ }^{20}$

- SME securitization - as an asset class - is generally considered HQS in current policy proposals and monetary frameworks, but does not benefit from more favorable regulatory treatment (see Annex 11.1). HQS would place greater focus on structural characteristics that allow for better risk sharing between originators and investors who can assess the impact of changing economic conditions on the performance of securitization transactions.

- Demonstrable compliance with these characteristics should result in regulatory treatment that is commensurate with this proposition in contrast to the currently proposed catch-all regulatory treatment of securitization transactions.

- Greater disclosure of underlying loan quality and performance monitoring would aid compliance efforts. The operational implementation of HQS would be largely informed by central bank repo eligibility with a focus on transactions with simple structures, transparent underlying asset pools, and predictable performance (see Annex 11.2).

- Demand for SME securitization is also influenced by proposed regulatory standards for liquidity risk - The definition of the LCR mostly excludes securitization instruments from the measure of liquid assets, apart from some limited types of RMBS. Moreover, the pending liquidity coverage ratio under the CRR will include only highly-rated RMBS, but will allow the inclusion of highly-rated covered bonds up to 70 percent of the liquidity buffer. ${ }^{21}$ Broadening the pool of eligible assets to include HQS in the stock of high-quality liquid assets (HQLAs) will increase investor appetite for a wider range of securitization structures of sufficient credit quality.

- Capital markets for securitized SME loans could be developed further by revising the investment restrictions for institutional investors (insurance companies and pension funds, for example)— once the supervision and regulatory framework is strengthened-to encourage alternative investments that benefit SME financing, such as venture capital.

- Structural improvements could further facilitate market development-SME securitization instruments face particular challenges related to the heterogeneity of SME loan portfolios across countries. The complexity of information and different reporting requirements makes it difficult for investors to assess credit risk and creates a home bias.

\footnotetext{
${ }^{19}$ In May 2014, the Bank of England and the ECB (2014a, 2014b) published a comprehensive review of existing obstacles to the better functioning of the securitization market in the European Union, which includes some arguments that are also reflected in these recommendations.

${ }^{20} \mathrm{HQS}$ can, in principle, also help meet the increasing demand for high-quality collateral, providing a complement to government debt.

${ }^{21}$ However, there is discussion about the potential inclusion of a wider range (wider than RMBS) of highly rated ("AA-" or higher) securitization exposures, namely auto ABS, SME-backed collateralized loan obligations, and consumer ABS, as Level 2B (which are capped at 15 percent of HQLA) with a 25 percent valuation haircut.
}

\section{CInternational Monetary Fund. Not for Redistribution}


- National debt enforcement and insolvency frameworks should continue to be strengthened, with a view to cleaning up banks' balance sheets and boosting the quality, transparency, and accessibility of collateral. This effort would include policy measures that facilitate out-of-court settlements, reduce impediments to efficient debt restructuring, and introduce guidance on tax incentives and resolution procedures in line with international best practices.

- Greater harmonization of SME lending standards, loan reporting requirements (through the Single Supervisory Mechanism), and credit registries across countries would facilitate the establishment of a truly single market. ${ }^{22}$ Consideration could be given to broadening the coverage of credit registries through a centralized database. The harmonization of reporting requirements would not only enhance cross-border investor demand but create scope for developing securitization instruments that pool SME loans on an EU-wide basis. The single supervisory mechanism can help in this respect.

- Direct capital market access for SMEs should be improved by creating a mutual issuance platform. This platform would allow sufficient aggregation for minibond and structured finance issuance and could build on efforts to achieve greater harmonization of SME funding in line with recent recommendations by the European Commission's High-Level Expert Group on SME and Infrastructure Financing (European Commission 2013). Also, forms of nonbank-intermediated securitization (such as trade receivables via asset-backed commercial paper [ABCP] facilities) and equity finance should be explored in areas in which structural impediments to asset securitization are too high and cannot be overcome in the near term (European Commission 2014a).

- Official sector involvement would be essential in areas of SME finance in which information constraints and insufficient economies limit the effectiveness of market-based solutions-Supplyside impediments to a wider range of nonbank SME funding options are often found in the costs associated with higher standardization of both information disclosure and performance reporting. For SME securitization, existing public sector programs could be augmented and potentially supplemented by additional efforts:

- The various euro area institutions could initially act as guarantors or strategic investors in cost-efficient funding structures with genuine risk transfer to market investors, while guarding against long-term distortionary effects by time limiting any risk sharing. For instance, the European Investment Bank (EIB) and EIF could initially provide guarantees to lower tranches of fully marketable transactions, which would reduce the credit risk of strategic asset purchases of senior tranches by the Eurosystem. Such efforts could be combined with the EC-EIB SME initiative to create operational synergies and sufficient critical mass to address the funding needs of SMEs in stressed economies.

- Incorporating a more nuanced treatment of HQS in the Eurosystem collateral framework could benefit SME securitization by providing incentives to issuers to develop transactions irrespective of whether parts of them are retained for ECB repo funding. ${ }^{23}$

\footnotetext{
${ }^{22}$ In particular, the lack of long time series data on the default frequency of SMEs; the heterogeneity of SME portfolios that differ from each other in size, corporate form, business activity, and geographic location; and insufficient volumes of long-term loans (which complicate the estimation of the cash flows pattern of SME portfolios) continue to hamper SME securitization.

${ }^{23}$ Throughout the crisis, the ECB has widened the pool of eligible assets under its collateral framework for refinancing operations. Raw loans ("credit claims") are eligible collateral for refinancing at the ECB if they are rated "BBB" or higher. Assets rated "BB" can be used as collateral provided the national central bank of the Eurosystem underwrites the credit. The ECB last reviewed its haircuts on eligible assets in July 2013.
} 


\section{CONCLUSION}

The further development of securitization is an important step toward more integrated capital markets in Europe. Given the lack of diversified funding markets, with only the largest firms able to directly access capital markets, credit supply to the corporate sector is heavily influenced by the lending behavior of banks. Securitization of intermediated credit could help overcome the adverse effects of financial fragmentation, improve the allocation of liquidity, and support cross-border investment within the euro area. Restarting securitization would mitigate structural constraints on credit supply as many banks, especially those in vulnerable economies, continue facing considerable funding needs while unsecured funding remains impaired, especially at longer maturities - even though concerns about sovereign risks in the euro area have dissipated. An expansion of the SME securitization market would move firmly in this direction, while drawing upon a large existing pool of assets and providing a key nonbank funding channel.

However, structural and regulatory conditions are stacked against SME securitization. Unfavorable economic terms and adverse cyclical factors reduce the incentives for issuance. Moreover, pending regulatory changes-Basel III for banks and Solvency II for insurance companies-weaken the investor base by increasing the capital intensity of holding highly-rated securitization transactions and limiting their eligibility for liquidity purposes. Progress toward incubating a larger SME securitization market would require greater regulatory differentiation of HQS, cross-country harmonization of asset structures, and official sector support as a catalyst to greater activity.

\section{ANNEX 11.1. PUBLIC SECTOR SUPPORT FOR SME SECURITIZATION}

The most significant SME support programs in Europe are the Asset Securitization Funds for SMEs (Fondos de Titulización de Activos para Pymes or FTPYME) in Spain and Kreditanstalt für Wiederaufbau's (KfW's) PROMISE (Program for Mittelstand-loan Securitisation) platform, which provide cost-efficient funding support to bank-originated loans to SMEs. In PROMISE, the issuing bank sells credit protection (supported by third-party guarantees) to create partially funded and leveraged investments in SME exposures (without removing them from its balance sheet). Similarly, in FTPYME, banks receive guarantees that support the off-loading of SME loans. Although both programs have attracted repeat issuers and involve a considerable cost reduction for issuers, they tend to be very customized and focused on larger banks, with limited or no diversification effects across different SME loan portfolios or banks. Similar products (securitization of lease receivables) have been developed in Italy by arrangers and originators to achieve better funding costs. Given the high dependence of SMEs on bank lending, both programs aim to provide capital market access for smaller banks and reduce both the regulatory and economic cost of new lending. By helping financial institutions achieve regulatory capital relief for securitized SME lending, these programs have created more scope for future SME loan origination.

In the United States, SME loan securitization began in 1985 when the Small Business Administration (SBA), a U.S. government agency, launched its loan guarantee program. The SBA does not lend money directly to SMEs but offers government guarantees of up to US\$5 million on loans made by commercial lenders to SME borrowers that face challenges obtaining financing. The guarantee covers a portion of an SME loan originated by a local bank, credit union, or specialized lender, ranging from 50 percent to 85 percent, depending on the program, thereby limiting the lender's risk and exposure. The lender then provides the actual loan to the borrower and securitizes the "SBA-backed loan." During fiscal year 2012, lending volumes exceeded US\$14 billion. 
In addition to public guarantees, the Bank of Japan (BoJ) introduced measures to support SME financing and securitization during the late 1990s and early 2000s, also aiming to repair the monetary policy transmission mechanism. Given the importance of SMEs in Japanese economic activity, improving their access to credit was seen to be essential to restoring the monetary policy transmission mechanism. In 1999, the BoJ started accepting eligible ABS as collateral for banks' maintenance requirements. In 2003, the BoJ introduced a program to purchase ABS and asset-backed commercial paper backed by SME loans. ${ }^{24}$ The objective was to strengthen the transmission mechanism by circumventing the banking sector, while avoiding market distortions and limiting the risk to the BoJ. ${ }^{25}$ Accordingly, the BoJ started purchasing ABS with a broad range of underlying assets, including SME loans, receivables, and leases. ${ }^{26}$ However, other policy measures distorted the healthy development of the SME sector. Various credit support policies helped shelter existing firms from tighter credit conditions and limited the number of bankruptcies but also kept unviable SMEs afloat. The measures comprised public credit guarantees, safety net lending by government-affiliated financial institutions, and temporary relaxation of provisioning requirements for SME loans (Lam and Shin 2012).

\section{ANNEX 11.2. DEFINING HIGH-QUALITY SECURITIZATION (HQS)}

Three attempts have been made to define HQS within the broad securitization market: (1) the ECB with its collateral eligibility criteria; (2) the European Insurance and Occupational Pensions Authority (EIOPA) with its "Type 1" standard for long-term investment of insurers in securitization transactions; and (3) the Bank of England's eligibility criteria for repo collateral, which closely (but not fully) matches the eligible asset classes and eligibility requirements of the prime collateralized securities (PCS) standard related to sufficient portfolio diversity, no subordinated exposure of loans, risk retention, information about underwriting criteria, and servicer continuity. Together with residential mortgages and consumer loans, leases, and credit card debt, SME loans are commonly found as reference assets for HQS. Complex structures (for example, resecuritization, synthetic securitization, and single tranche securitization) are unanimously excluded from all lists. Typically, the qualification as HQS should involve additional criteria: (1) restriction to true sale structures (synthetic transactions are excluded); (2) minimum rating threshold (at least "BBB-" [or equivalent] by two credit rating agencies at any time since launch); ${ }^{27}$ (3) exclusion of nonperforming loans and loans to self-certifying borrowers or creditimpaired borrowers at the time of loan origination; (4) homogeneous underlying portfolio (securitizations of mixed pools are excluded); and (5) loan-by-loan-level data available at launch and on a regular basis.

Based on transparent characteristics, the identification of HQS would help distinguish simple and prudently structured transactions from transactions with more complex, opaque structures. Some of these characteristics reflect the reasons for the relatively stable performance of European securitization markets during the financial crisis: (1) a strong funding relation to real economic activity; (2) traditionally conservative loan origination standards, with high equity participation

\footnotetext{
${ }^{24}$ SMEs accounted for 80 percent of total employment (and about 70 percent at end-2013) and more than half of manufacturing value added in Japan.

${ }^{25}$ The program was ended in March 2006 together with the exit from quantitative easing.

${ }^{26}$ The BoJ set the maximum amount of purchases at 1 trillion yen (3/4 percent of the BoJ's assets). The total amount of outstanding securitized bonds in Japan was 44.5 trillion yen in 2007 (33 trillion yen in 2013). About half of this amount was trust beneficiary rights. The outstanding amount of asset-backed commercial paper remains small, especially after its decline from 4.4 trillion yen in 2007 to 1.8 trillion yen in 2013 .

${ }^{27}$ Note that limiting eligibility only to tranches with a very high rating would exclude most senior tranches of very high quality by issuers in stressed economies, whose ratings are capped by the sovereign ceiling of the respective country, which would contradict the intent of delinking the regulatory treatment of HQS from sovereign risk.
} 
by the originator under the same credit law as non-securitized loans ("skin in the game"); (3) servicing retained by the originator (servicer continuity) together with issuer due diligence; and (4) adequate post-issuance performance monitoring. Moreover, the conceptual treatment of securitization as part of ongoing balance sheet operations (with seasoned loans only) further reduces incentive problems (Jobst and Kiff 2011). In general, the concept of HQS should be applicable to all asset classes that support lending to the real economy (and especially SMEs), and is not limited to investment in senior tranches. ${ }^{28}$

\section{ANNEX 11.3. SELECTED OFFICIAL SECTOR SUPPORT FOR SECURITIZATION IN EUROPE}

\begin{tabular}{|c|c|c|c|c|}
\hline Country & Name of Program & Amount & Period & Description \\
\hline $\begin{array}{l}\text { European } \\
\text { Union }\end{array}$ & $\begin{array}{l}\text { EIB Group ABS } \\
\text { Initiative for } \\
\text { SMEs }\end{array}$ & $\sim € 10$ billion & since 2013 & $\begin{array}{l}\text { EIB Group provides facilities (funded and unfunded) to bank-spon- } \\
\text { sored securitization transactions via guarantees on mezzanine or } \\
\text { senior tranches with minimum rating requirement (EIF), and acts } \\
\text { as "structuring" investor in senior tranches (EIB). The initiative aims } \\
\text { to restart the SME securitization market by facilitating deal execu- } \\
\text { tion through increased underwriting capacity and provision of } \\
\text { credit enhancement to third-party investors. The ABS Initiative is } \\
\text { expected to be combined with the SME Initiative. }\end{array}$ \\
\hline $\begin{array}{l}\text { European } \\
\text { Union }\end{array}$ & $\begin{array}{l}\text { EIF-CIP } \\
\text { Securitisation } \\
\text { Window under } \\
\text { the SME } \\
\text { Guarantee } \\
\text { Facility }\end{array}$ & $\begin{array}{l}€ 17 \text { billion in } \\
\text { SME finance } \\
\text { for all CIP win- } \\
\text { dows (about } \\
€ 0.5 \text { billion in } \\
\text { guarantees) }\end{array}$ & $2007-13$ & $\begin{array}{l}\text { EIF provided unconditional and irrevocable guarantees on securiti- } \\
\text { zation tranches with little credit enhancement to facilitate access } \\
\text { to capital markets for unrated or low-rated issuers, such as smaller } \\
\text { banks. The aim was to generate additional funding for SMEs; } \\
\text { therefore, it combined guarantees on existing loan portfolios with } \\
\text { a separate undertaking to build up a new portfolio of SME loans } \\
\text { (under a separate "additional portfolio agreement"). The required } \\
\text { size and composition of this portfolio depended on the size and } \\
\text { the seniority of the guaranteed tranche. The CIP Securitization } \\
\text { Window was provided under the EU 2007-13 Multiannual } \\
\text { Financial Framework. }\end{array}$ \\
\hline $\begin{array}{l}\text { European } \\
\text { Union }\end{array}$ & $\begin{array}{l}\text { COSME } \\
\text { Securitization } \\
\text { Window }\end{array}$ & $€ 1.4$ billion & 2014-20 & $\begin{array}{l}\text { The COSME program includes a capped guarantee and securitiza- } \\
\text { tion support, which largely continues the activities of the EIF-CIP } \\
\text { Securitization Window under the EU 2014-20 Multiannual } \\
\text { Financial Framework. It envisages securitization of SME debt } \\
\text { finance portfolios, to mobilize additional debt financing for SMEs } \\
\text { under risk-sharing arrangements with the targeted financial insti- } \\
\text { tution. Support for the transactions is conditional upon an under- } \\
\text { taking by the financial intermediary to use a significant part of } \\
\text { the resulting liquidity or mobilized capital for new SME lending in } \\
\text { a reasonable period. Relative to the EIF-CIP Securitization Window } \\
\text { there will be some new elements with the aim of getting more } \\
\text { leverage and targeting regional, smaller banks. }\end{array}$ \\
\hline
\end{tabular}

\footnotetext{
${ }^{28}$ It is also important to support more junior tranches of safe and robust structures, especially via improvement of data and analytics, eventually allowing a broad investor base and risk transfer between bank and nonbank sectors.
} 


\begin{tabular}{|c|c|c|c|c|}
\hline Country & Name of Program & Amount & Period & Description \\
\hline Germany & $\begin{array}{l}\text { PROMISE } \\
\text { Program }\end{array}$ & $\begin{array}{r}€ 47.6 \text { billion } \\
\text { (until 2008) }\end{array}$ & since 2000 & $\begin{array}{l}\text { Securitization program created by national development bank } \\
\text { Kreditanstalt für Wiederaufbau to provide capital relief to SME } \\
\text { loan portfolios of sponsoring banks using a synthetic transaction } \\
\text { structure; EIF has acted as a swap counterparty for the junior } \\
\text { tranche (first-loss piece) and the mezzanine tranche in many } \\
\text { transactions. }\end{array}$ \\
\hline Spain & $\begin{array}{l}\text { FTPYME } \\
\text { Program }\end{array}$ & $€ 3$ billion & since 2000 & $\begin{array}{l}\text { Spanish Ministry of Economy established a budgetary endowment } \\
\text { for Programa de Fondos de Titulización de Activos para PYME } \\
\text { (FTPYME) guarantees from the kingdom of Spain; provides guaran- } \\
\text { tees for SME securitization if the originator commits to reinvest the } \\
\text { liquidity in new SME financing. The guarantee is limited in size and } \\
\text { contingent on rating of tranches: up to the } 80 \text { percent for tranches } \\
\text { rated "AA" and higher, up to } 50 \text { percent of tranches rated at least } \\
\text { "A. The asset portfolio transferred to the securitized fund must } \\
\text { comply with the following requirements: (1) portfolio structure } \\
\text { (only loans to domestic, nonfinancial firms; } 80 \text { percent of portfolio } \\
\text { should be SMEs according to European Commission definition; ini- } \\
\text { tial maturity of loans greater than one year); ( } 2 \text { ) use of funding } \\
\text { support (net funds obtained from securitization must be reinvest- } \\
\text { ed-50 percent within six months and remainder within one year); } \\
\text { and (3) placement (all guaranteed bonds must be listed). }\end{array}$ \\
\hline $\begin{array}{l}\text { United } \\
\text { Kingdom }\end{array}$ & $\begin{array}{l}\text { Special Liquidity } \\
\text { Scheme (SLS) }\end{array}$ & $\begin{array}{l}\text { No limit; } £ 185 \\
\text { billion at peak }\end{array}$ & $\begin{array}{l}\text { April } \\
\text { 2008- } \\
\text { January } \\
2012\end{array}$ & $\begin{array}{l}\text { The scheme allowed banks and building societies to swap their } \\
\text { high-quality mortgage-backed and other securities for U.K. } \\
\text { Treasury Bills for up to three years. Although the drawdown } \\
\text { period for the SLS closed on January 30, 2009, the scheme } \\
\text { remained in place for a further three years. }\end{array}$ \\
\hline $\begin{array}{l}\text { United } \\
\text { Kingdom }\end{array}$ & $\begin{array}{l}\text { Asset-backed } \\
\text { Securities } \\
\text { Guarantee } \\
\text { Scheme } \\
\text { (ABSGS) }\end{array}$ & No limit & $\begin{array}{l}\text { April 2009- } \\
\text { December } \\
2009\end{array}$ & $\begin{array}{l}\text { Under the scheme, the Treasury can provide two types of guaran- } \\
\text { tee to be attached to eligible "AAA"-rated ABS, initially in respect } \\
\text { of residential mortgages, issued under the sponsorship of U.K. } \\
\text { banks and building societies. The ABSGS offered a credit guaran- } \\
\text { tee and a liquidity guarantee, though an eligible instrument may } \\
\text { only benefit from one, not both of these. The credit guarantee } \\
\text { was issued as an unconditional and irrevocable guarantee of the } \\
\text { timely payment of all interest and principal due from an issuer } \\
\text { and payable in respect of the eligible instruments. The liquidity } \\
\text { guarantee covered the issuer's obligation to redeem or repur- } \\
\text { chase securities pursuant to an issuer's call option or a notehold- } \\
\text { er's put option under the terms of the eligible securities. }\end{array}$ \\
\hline
\end{tabular}

Sources: Australian Office of Financial Management; European Commission; European Investment Bank; European Investment Fund; HM Treasury; Spanish Ministry of Economy and Competition; Italian Ministry of Finance and Economic Affairs; and Kreditanstalt für Wiederaufbau.

Note: $\mathrm{ABS}=$ Asset-backed securities; CIP = Competitiveness and Innovation Framework Program; COSME = Competitiveness of Enterprises and Small and Medium-Sized Enterprises; PROMISE = Program for Mittelstand-loan Securitisation. 


\section{ANNEX 11.4. SELECTED OFFICIAL SECTOR SUPPORT FOR SME FINANCE IN EUROPE}

\begin{tabular}{|c|c|c|c|c|}
\hline Country & Name of Program & Amount & Period & Description \\
\hline Germany & $\begin{array}{l}\text { Kreditanstalt für } \\
\text { Wiederaufbau } \\
\text { SME Program }\end{array}$ & $>€ 3$ billion & since 1971 & $\begin{array}{l}\text { Credit facility for German banks for SME loans with } \\
\text { maturities up to } 20 \text { years; refinanced exclusively using } \\
\text { capital market funds, which enables Kreditanstalt für } \\
\text { Wiederaufbau to offer SMEs long-term investment } \\
\text { loans while maintaining the principle of subsidiarity } \\
\text { and on-lending through banks. }\end{array}$ \\
\hline Italy & $\begin{array}{l}\text { SMEs Lending } \\
\text { Facility (Fondo } \\
\text { Centrale di } \\
\text { Garanzia) }\end{array}$ & $\begin{array}{l}€ 17 \text { billion of issued } \\
\text { guarantees activat- } \\
\text { ing } € 32 \text { billion of } \\
\text { new loans (end-2011) }\end{array}$ & since 2000 & $\begin{array}{l}\text { The institution provides guarantees of up to } 80 \text { percent } \\
\text { of bank-originated credit facilities to SMEs. }\end{array}$ \\
\hline Ireland & $\begin{array}{l}\text { Strategic Banking } \\
\text { Corporate of } \\
\text { Ireland }\end{array}$ & $€ 4$ billion (until 2018) & since 2014 & $\begin{array}{l}\text { Initial funding of } € 500 \text { million (to rise to } € 4 \text { billion until } \\
2018 \text { ) provided by the Ireland Strategic Investment } \\
\text { Fund together with KfW and the EIF to support on- } \\
\text { lending (through commercial banks and other loan } \\
\text { originators) to SMEs, aiming to reduce costs and } \\
\text { improve flexibility of SME funding. }\end{array}$ \\
\hline Spain & $\begin{array}{l}\text { Instituto Crédito } \\
\text { Official SME } \\
\text { financing facility }\end{array}$ & $\begin{array}{l}\text { Annual limits ranging } \\
\text { between } € 2 \text { billion } \\
\text { and } € 7 \text { billion }\end{array}$ & since 1993 & $\begin{array}{l}\text { Credit facility for Spanish banks originating SME loans } \\
\text { with maturities up to } 10 \text { years (possibility of grace } \\
\text { period); for new and productive fixed assets only. }\end{array}$ \\
\hline $\begin{array}{l}\text { United } \\
\text { Kingdom }\end{array}$ & $\begin{array}{l}\text { Funding for } \\
\text { Lending Scheme } \\
\text { (FLS) }\end{array}$ & $\begin{array}{l}\text { No limit; } 5 \text { percent of } \\
\text { stock }=£ 80 \text { billion at } \\
\text { launch }\end{array}$ & $\begin{array}{l}\text { July } 2012- \\
\text { January } \\
2015\end{array}$ & $\begin{array}{l}\text { The scheme provides funding to banks and building } \\
\text { societies for an extended period, with both the price } \\
\text { and quantity of funding provided linked to their lend- } \\
\text { ing performance. The FLS allows participants to borrow } \\
\text { U.K. Treasury Bills in exchange for eligible collateral, } \\
\text { which consists of all collateral eligible in the Bank of } \\
\text { England's Discount Window Facility. The Bank and HM } \\
\text { Treasury announced an extension to the FLS on April } \\
\text { 24, 2013, with incentives to boost lending skewed } \\
\text { toward SMEs. }\end{array}$ \\
\hline
\end{tabular}

Sources: Australian Office of Financial Management; European Commission; European Investment Bank; European Investment Fund; HM Treasury; Spanish Ministry of Economy and Competition; Italian Ministry of Finance and Economic Affairs; and Kreditanstalt für Wiederaufbau.

\section{REFERENCES}

Aiyar, S., A. Al-Eyd, B. Barkbu, and A. Jobst. 2015. "Revitalizing SME Securitization in Europe," Staff Discussion Note, May, International Monetary Fund, Washington, DC.

Aiyar, S., B. Barkbu, and A. Jobst. 2014. "Seminar on SME Financing: Europe Needs to Revitalize Finance for Small and Medium Enterprises," IMF Survey Magazine, November 5, International Monetary Fund, Washington, DC. http://www.imf.org/external/pubs/ft/survey/so/2014/CAR110514A.htm.

Al-Eyd, A., and S. P. Berkmen. 2013. "Fragmentation and Monetary Policy in the Euro Area." Working Paper No. 13/208, International Monetary Fund, Washington, DC. http://www.imf.org/external/pubs/ft/wp/2013 /wp13208.pdf.

Al-Eyd, A., B. Barkbu, S. P. Berkmen, J. Bluedorn, A. Jobst, and A. Tieman. 2014. "Capital Market Development: SME Financing in the Euro Area," Euro Area Policies: Selected Issues, IMF Country Report No. 14/199, July 14, 43-66, International Monetary Fund, Washington, DC. http://www.imf.org/external/pubs/ft/scr/2014 /cr14199.pdf.

Bank of England and European Central Bank. 2014a. "The Case for a Better Functioning Securitisation Market in the European Union.” European Central Bank, Frankfurt. http://www.ecb.europa.eu/pub/pdf/other /ecb-boe_case_better_functioning_securitisation_marketen.pdf.

_ 2014b, "The Impaired EU Securitisation Market: Causes, Roadblocks and How to Deal with Them.” European Central Bank, Frankfurt. https://www.ecb.europa.eu/pub/pdf/other/ecb-boe_impaired_eu _securitisation_marketen.pdf.

Basel Committee on Banking Supervision (BCBS). 2014. "Revisions to the Securitisation Framework." Final Document, Bank for International Settlements, Basel. http://www.bis.org/publ/bcbs303.pdf

Darvas, Zsolt. 2013. "Banking System Soundness Is the Key to More SME Financing.” DG for Internal Policies, Policy Department A: Economic and Scientific Policy, IP/A/ECON/NT/2013, European Commission, Brussels. 
European Central Bank. 2014. "Survey on the Access to Finance of Small and Medium-Sized Enterprises (SAFE) in the Euro Area (October 2013-March 2014).” Frankfurt.

European Commission. 2013. "Finance for Growth." High-Level Expert Group on SME and Infrastructure Financing, Brussels. http://europa.eu/efc/working_groups/hleg_report_2013.pdf.

_. 2014a. "Commission Recommendation of 12 March 2014 on a New Approach to Business Failure and Insolvency.” Document 2014/135/EU, Brussels. http://eur-lex.europa.eu/legal-content/EN/TXT/?uri=uriserv :OJ.L_.2014.074.01.0065.01.ENG.

_. 2014b. "Commission Delegated Regulation Supplementing Directive 2009/138/EC of the European Parliament and of the Council on the Taking-up and Pursuit of the Business of Insurance and Reinsurance (Solvency II)," COM(2014) Provisional Version, October 10, Brussels, http://ec.europa.eu/internal_market /insurance/docs/solvency/solvency2/delegated/141010-delegated-act-solvency-2_en.pdf.

- 2014c. "Commission Delegated Regulation to Supplement Regulation (EU) 575/2013 with Regard to Liquidity Coverage Requirement for Credit Institutions." COM(2014) 7232 Final, October 10, Brussels. http://ec.europa.eu/internal_market/bank/docs/regcapital/acts/delegated/141010_delegated-act-liquidity -coverage_en.pdf.

European Insurance and Occupational Pensions Authority (EIOPA). 2013. "Technical Report on Standard Formula Design and Calibration for Certain Long-Term Investments.” EIOPA/13/513, Frankfurt. https:// eiopa.europa.eu/consultations/consultation-papers/2013-closed-consultations/april-2013/discussion-paper-on -standard-formula-design-and-calibration-for-certain-long-term-investments/index.html.

European Private Equity and Venture Capital Association (EVCA). 2014. "European Private Equity Activity, 2007-2013.” Brussels. http://www.evca.eu/media/165475/yearbook-2014-europe-country-tables-final.xlsx.

Gagliardi, D., P. Muller, E. Glossop, C. Caliandro, M. Fritsch, G. Brtkova, N. U. Bohn, D. Klitou, G. Avigdor, C. Marzocchi, and R. Ramlogan. 2013. A Recovery on the Horizon? Annual Report on European SMEs 2012/2013. PricewaterhouseCoopers Société coopérative, CARSA, The University of Manchester, Manchester Institute of Innovation Research, INNOVA SpA, London Economics, DIW Berlin, DIW econ. http://ec.europa.eu/enter prise/policies/sme/facts-figures-analysis/performance-review/files/sme-pr-final-annual-report_2012-13_en.pdf.

Galizia, F., and G. Gentili. 2014. "Management and Transfer Pricing of Collateral." In The Handbook of ALM in Banking: Interest Rates, Liquidity and the Balance Sheet, edited by A. Bohn and M. Elkenbracht-Huizing. London: RISK Books.

International Monetary Fund (IMF). 2009. "Restarting Securitization Markets: Policy Proposals and Pitfalls.” In Global Financial Stability Report, October. Washington, DC. http://www.imf.org/External/Pubs/FT /GFSR/2009/02/pdf/chap2.pdf.

. 2011. "Germany: Technical Note on the Future of German Mortgage-Backed Covered Bond (Pfandbrief) and Securitization Markets." Country Report No. 11/369, Washington, DC. http://www.imf.org/external $/ \mathrm{pubs} / \mathrm{ft} / \mathrm{scr} / 2011 / \mathrm{cr} 11369 . \mathrm{pdf}$.

- 2012. "Spain: Financial System Stability Assessment." Country Report No. 12/137, International Monetary Fund, Washington, DC. http://www.imf.org/external/pubs/ft/scr/2012/cr12137.pdf.

- 2013. "Belgium: Financial System Stability Assessment." Country Report No. 13/124, International Monetary Fund, Washington, DC. http://www.imf.org/external/pubs/ft/scr/2013/cr13124.pdf.

Jobst, A. A. 2006. "Asset Securitisation as a Risk Management and Funding Tool: What Small Firms Need to Know." Managerial Finance 32 (9): 731-60.

- 2008. "What Is Securitization?" Finance and Development 47 (3): $48 \mathrm{f}$.
, M. Goswami, and X. Long. 2009. "An Investigation of Some Macro-Financial Linkages of Securitization." Working Paper No. 9/26, International Monetary Fund, Washington, DC. http://www.imf.org/external/pubs /ft/wp/2009/wp0926.pdf.

— Bonds." Zeitschrift für das gesamte Kreditwesen 64 (19): 1004-7.

Kraemer-Eis, H., F. Lang, and S. Gvetadze. 2014. "European Small Business Finance Outlook.” Working Paper No. 2014/24, European Investment Fund, Luxembourg. http://www.eif.org/news_centre/publications/EIF _Working_Paper_2014_24.htm.

Lam, W. R., and J. Shin. 2012. “What Role Can Financial Policies Play in Revitalizing SMEs in Japan?” Working Paper No. 12/297, International Monetary Fund, Washington, DC. http://www.imf.org/external/pubs/ft /wp/2012/wp12297.pdf.

Segoviano, M., B. Jones, P. Lindner, and J. Blankenheim. 2013. "Securitization: Lessons Learned and the Road Ahead.” Working Paper No. 13/255, International Monetary Fund, Washington, DC. http://www.imf.org /external/pubs/ft/wp/2013/wp13255.pdf.

\section{CInternational Monetary Fund. Not for Redistribution}




\title{
Youth Unemployment in Europe: Okun's Law and Beyond
}

\author{
Angana BanerJi, Huidan Lin, Sergejs Saksonovs, \\ AND RODOLPHE BLAVY
}

Youth unemployment increased sharply in Europe in the aftermath of the global crisis in 2008-09 and remains at historic highs in the current weak recovery. A large proportion of these increases can be explained by output dynamics and the greater sensitivity of youth unemployment to economic activity compared with adult unemployment. Labor market institutions also play an important role, especially the tax wedge, minimum wages, and spending on active labor market policies (ALMPs). Youth unemployment has moved up the policy agenda in Europe, and policies to deal with this issue have been formulated at both the European Union (EU) (European Commission 2012, 2013b) and national levels.

This chapter assesses the youth unemployment problem in advanced European countries, especially the euro area. It documents the main trends in youth and adult unemployment before and after the crisis, identifies the cyclical and structural drivers of youth and adult unemployment, and outlines elements of a comprehensive strategy to address the problem.

\section{STYLIZED FACTS}

Youth unemployment rates were at unprecedented levels in the euro area in 2014. ${ }^{1}$ The global crisis has reversed a decade-long trend of modest declines in youth unemployment; the youth unemployment rate in the euro area in mid-2014 (some 23 percent) was well above the precrisis rate (15 percent in 2007).

Adult unemployment also ticked up after the crisis, but less so than youth unemployment. Although unemployment rates typically tend to be higher for youth than for adults, ${ }^{2}$ these differences increased sharply after the global crisis (Figure 12.1).

Youth unemployment rates vary widely across the euro area in magnitude as well as in trajectory. These cross-country differences were exacerbated during the crisis. The hardest hit euro area

This chapter is based on Euro Area Policies: Article IV 2014 Consultation-Selected Issues, IMF Country Report 14/199, 2014.

The authors thank Jesse Siminitz and Xiaobo Shao for excellent research assistance and Katherine Cincotta for general assistance. They also thank Ana Lamo of the European Central Bank and Alessandro Turrini of the European Commission, the participants of seminars at the European Central Bank and the European Commission, as well as IMF European Department country teams for helpful feedback and comments.

${ }^{1}$ Henceforth, youth refers to individuals ages 15-24 years old, and adults refers to individuals ages 25-64 years old. Unemployment refers to the unemployment rate.

${ }^{2}$ The youth labor force tends to be smaller than the labor force for other age cohorts because young individuals may choose to pursue full-time education, although participation in education does not necessarily exclude participation in the labor force (for example, through part-time work or apprenticeships). The youth labor market is also characterized by frequent search and matching as individuals look for better jobs, using intermediate stages for accumulating experience (and perhaps occasionally dropping out of the labor force). 

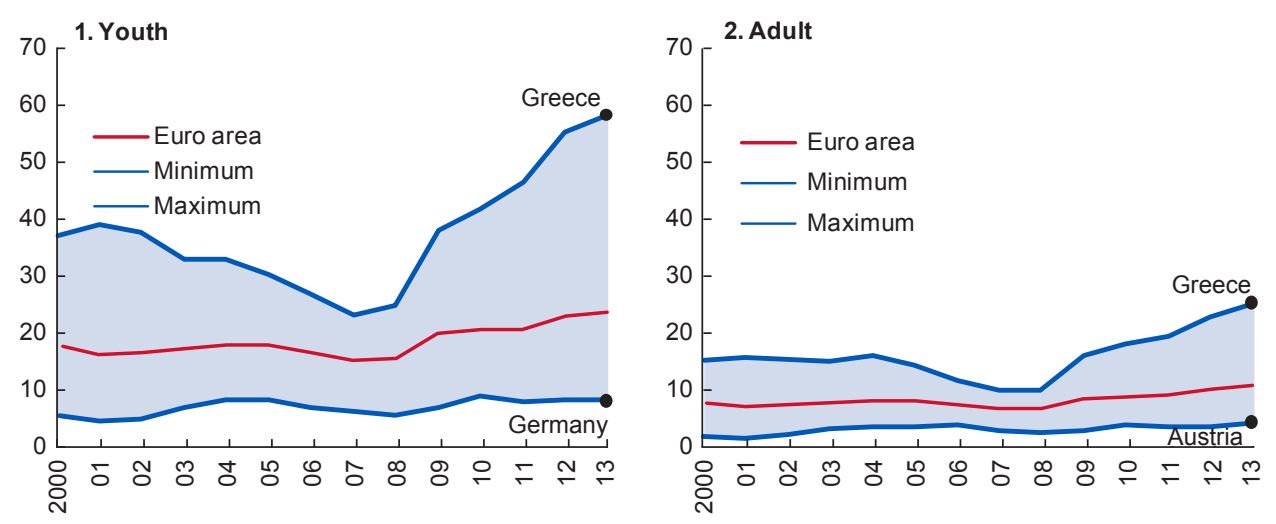

Source: Eurostat.

Figure 12.1 Euro Area Unemployment Rate (Percent)

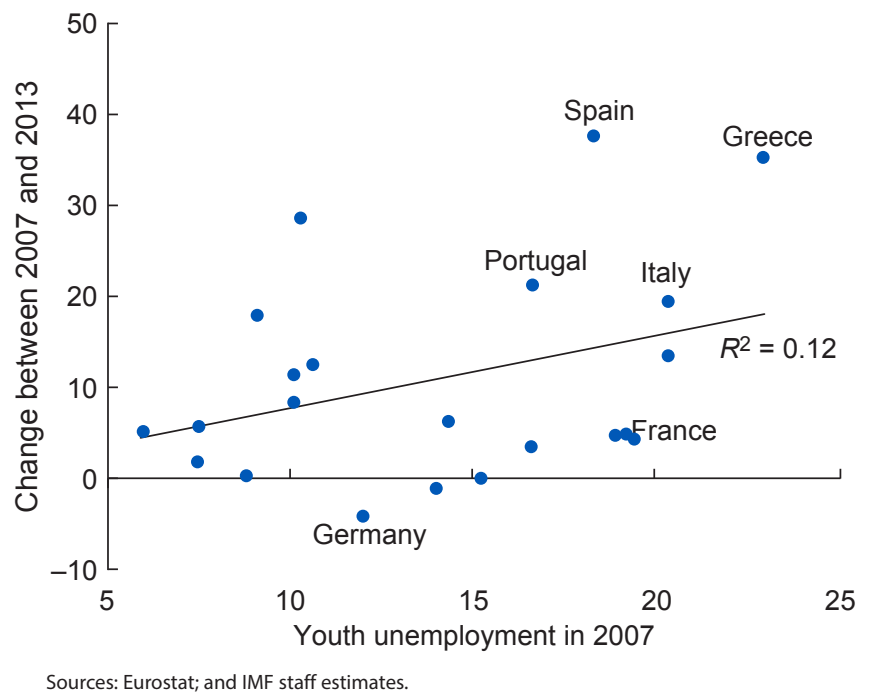

Figure 12.2 Changes in the Youth Unemployment Rate since 2007

countries had unprecedented increases in youth unemployment rates, ranging from 25 percent in Ireland to 43 percent in Spain, on average, during 2007-13 (Figure 12.2). In countries that fared better, youth unemployment rates increased only marginally (Austria, the Netherlands) or even fell (Germany). Precrisis youth unemployment rates, however, have had little bearing on youth unemployment dynamics since the crisis.

Large and persistent youth and adult unemployment rates lower potential output as the result of hysteresis effects (skill attrition and depreciated human capital) or the outward migration of skilled labor. Youth unemployment erodes social cohesion and institutions. For individuals it may lead to scarring — a lower probability of future employment and lower wages.

\section{DETERMINANTS}

This chapter analyzes the relative significance of two main drivers of youth unemploymentbusiness cycle fluctuations and the institutional setup and features of the labor market. It contrasts the impact of these factors on the youth versus the adult labor market. 
The analysis covers 22 advanced European countries-18 in the euro area, ${ }^{3}$ plus Denmark, Sweden, Norway, and the United Kingdom. It is based on annual data from 1980 through 2012, although the actual size of the sample varies depending on data availability, especially for labor market characteristics.

Labor market features are grouped into several interrelated categories: the opportunity cost of working, hiring costs, the role of collective bargaining, measures of labor market duality, education and training, and spending on ALMPs. A number of different measures are used in each category. Labor market features vary widely across countries but change slowly over time. (See Annex 12.1 for definitions.)

Data on labor market characteristics are usually not available for the full sample period, and are especially limited for new entrants to the euro area. Data gaps make it infeasible to produce country-by-country estimations to determine the country-specific effects of institutional variables and the business cycle. As a workaround for the data limitations, a two-pronged approach was adopted. One prong was to assume that the impact of labor market features was the same across countries while allowing the impact of the business cycle to vary. This approach was implemented using one labor market factor at a time as well as a combination of factors. The second prong also assumed common effects of labor market factors across countries; however, the model allowed the impact of labor market institutions to vary across countries via the interaction of labor market variables with the business cycle. To ensure robustness, only one institutional variable was considered at a time. (See Annex 12.2 for additional details on this methodology.)

\section{THE BUSINESS CYCLE}

Okun's Law, proposed by Arthur Okun in 1962, is the empirical regularity that changes in unemployment rates and output growth are negatively related. ${ }^{4}$ Many studies confirm this relationship for overall unemployment, but research on youth is less common. Some authors highlight the sensitivity of youth unemployment to the business cycle (OECD 2006; Scarpetta 1996; Scarpetta, Sonnet, and Manfredi 2010; European Commission 2013a).

Empirical analysis unambiguously confirms that Okun's Law holds (Figure 12.3), regardless of how the business cycle is measured-by real GDP growth or the output gap (that is, the difference between actual output and its potential). Cyclical factors explain about 50 percent of the changes in youth unemployment rates (and 70 percent of the increase in unemployment rates in stressed euro area countries) and about 60 percent of changes in adult unemployment rates across all advanced European countries.

The sensitivity of unemployment rates to the business cycle (Okun's coefficient) varies across countries (Figure 12.3). Estimates range from not significantly different from zero (Austria ${ }^{5}$ ) to -1.9 in Spain, that is, a 1 percent decline in growth increases the youth unemployment rate by almost 2 percentage points. Countries with the biggest increases in youth unemployment rates since the crisis tend to be those that are most affected by the business cycle (they have the largest Okun's coefficients).

In every country the estimated Okun's coefficient is higher for youth than for adults, almost three times as large on average. This may be due to both the nature of the youth labor force (described previously) and special features of youth employment, specifically concentration in cyclically sensitive industries and in small and medium-sized enterprises (SMEs).

\footnotetext{
${ }^{3}$ Euro area countries include Austria, Belgium, Cyprus, Estonia, Finland, France, Germany, Greece, Ireland, Italy, Latvia, Luxembourg, Malta, Netherlands, Portugal, Slovak Republic, Slovenia, and Spain.

${ }^{4}$ See Ball, Leigh, and Loungani (2013) for an extensive discussion on this topic.

${ }^{5}$ Even in those cases, some studies have found that Okun's Law holds for measures of hours worked.
} 


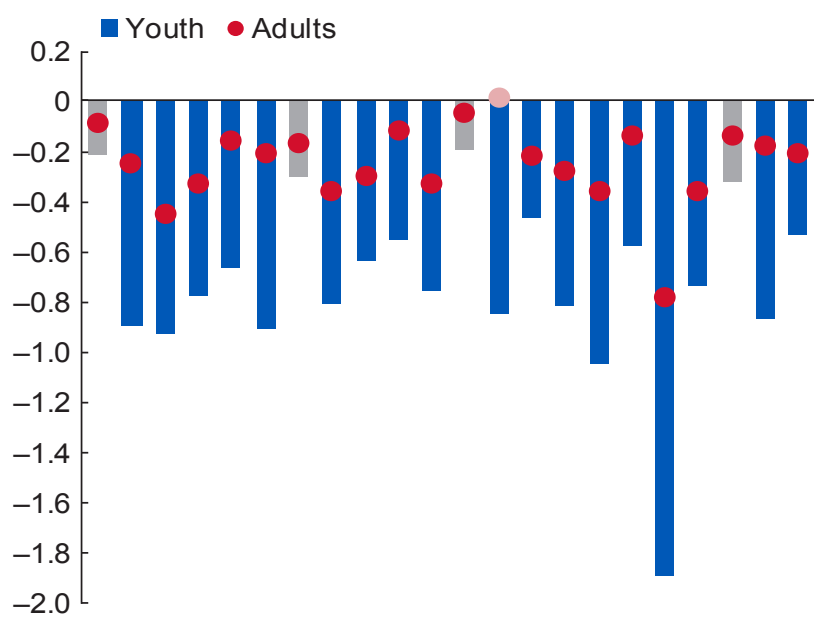

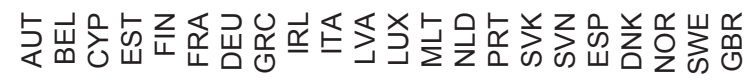

Sources: Eurostat; and IMF staff estimates.

Note: The gray shaded bars and dots indicate statistically insignificant results. Data labels

in the figure use International Organization for Standardization (ISO) country codes.

Figure 12.3 Euro Area: Okun's Coefficients

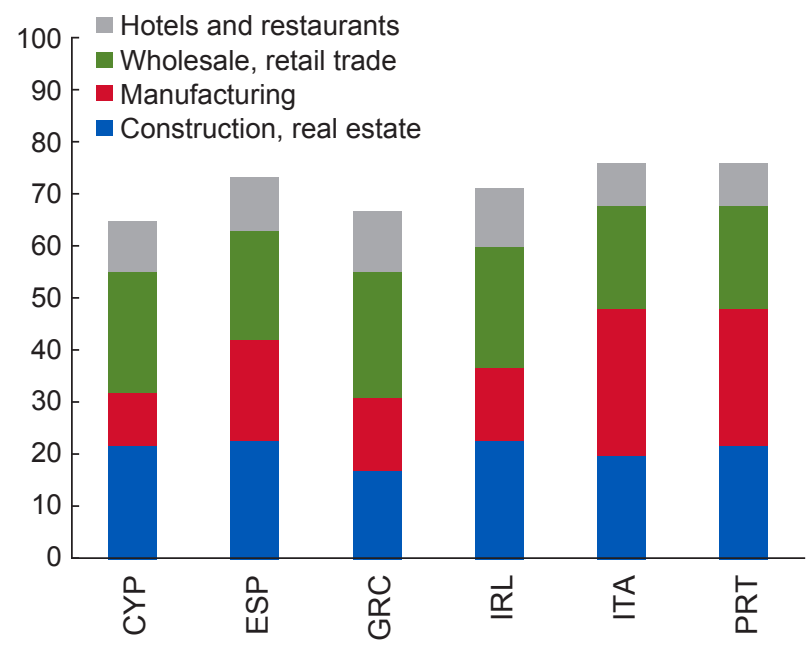

Sources: Eurostat; and IMF staff estimates.

Note: Data labels in the figure use International Organization for Standardization (ISO) country codes.

Figure 12.4 Youth Employment by Sector, 2000-07 (Percent)

Youth employment is concentrated in sectors that tend to be more sensitive to the business cycle: manufacturing, construction and real estate, wholesale and retail trade, and hotels and restaurants (Figure 12.4). Together these sectors comprise between 65 percent and 75 percent of youth employment in countries where youth unemployment increased the most after the global crisis. 


\section{BOX 12.1. Small and Medium-Sized Enterprises (SMEs): The Role of Financing} Constraints and Youth Unemployment

Methodology. The Okun's Law framework is augmented with the interaction of GDP growth and the average share of SMEs (Figure 12.1.1), or with financial constraints (Figure 12.1.1). Financing constraints are measured as the percentage of firms in the industry and services sectors that, in surveys, report financial constraints as a factor limiting production. The surveys do not separate SMEs as a separate category, but it is reasonable to assume that they are more affected by financial constraints than larger firms. ${ }^{1}$

Results.

- Greater financial constraints are associated with higher youth unemployment. Controlling for countryspecific fixed effects and output gaps, an additional percentage point of firms reporting financial constraints raises youth unemployment rates by 0.3 percentage point (industry) to 0.4 percentage point (services). The effect on adult unemployment rates is smaller ( 0.2 percentage point).

- A percentage point increase in the average employment share in SMEs (or the SME share of value added) lowers Okun's coefficient by 0.01 , making unemployment more procyclical.

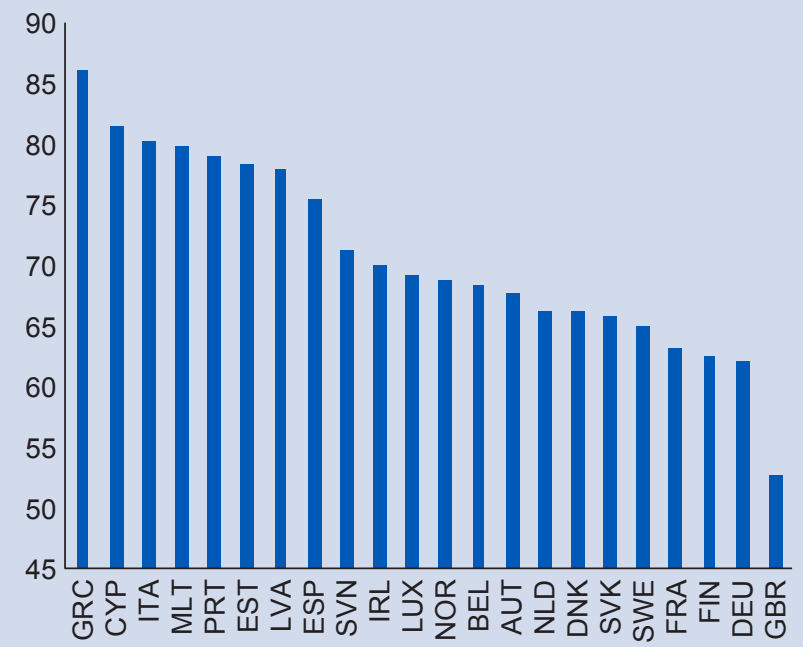

Source: European Commission.

Note: Data labels in the figure use International Organization for Standardization (ISO) country codes.

Figure 12.1.1 Small and Medium-Sized Enterprises' Share in Employment (Percent; average 2008-13)

${ }^{1}$ There are data limitations. The average SME share is used because the data are available only from 2008 and stay broadly constant. The percentage of firms reporting financial constraints is small (often zero) and relatively unchanged; for example, before the financial crisis only 2 percent of industrial firms reported financial constraints, on average, compared with 2012-13, when the average was 9.3 percent.

$\mathrm{SMEs}^{6}$ employ the majority of the labor force, with the average employment share especially high in some southern European countries - more than 75 percent for Italy, Portugal, and Spain, for example. SMEs face unique financial constraints in the current environment of financial fragmentation and private sector deleveraging. These constraints appear to increase the extent to which youth unemployment rates respond to growth (Box 12.1).

\footnotetext{
${ }^{6}$ SMEs are defined as firms with fewer than 250 employees, turnover of less than $€ 50$ million, or balance sheets of less
} than $€ 43$ million. 


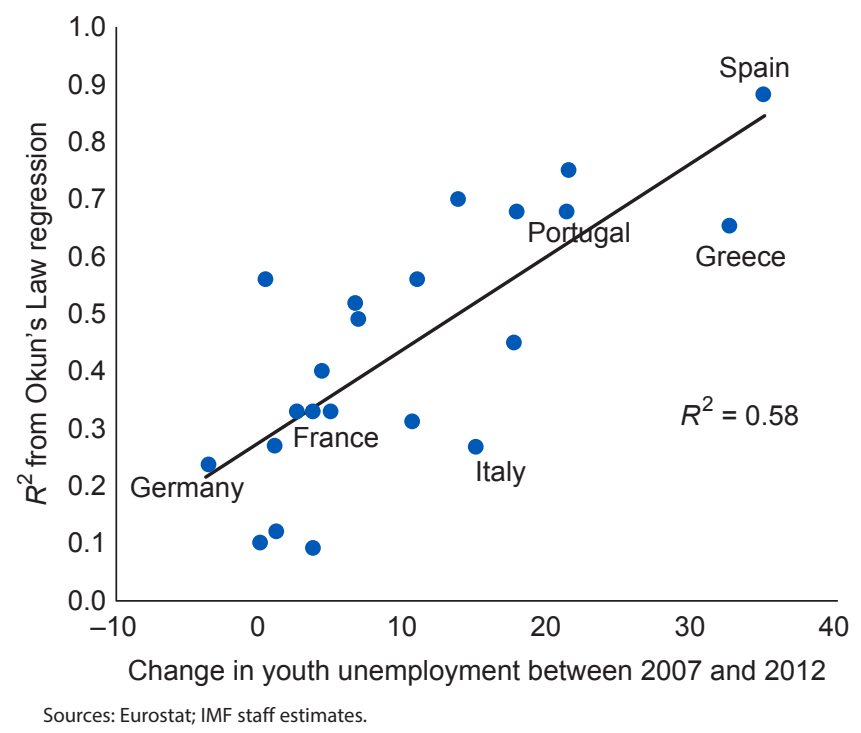

Figure 12.5 Proportion of Change in Youth Unemployment Explained by Growth

\section{LABOR MARKET FEATURES}

Output changes, on average, explain much of the increase in youth unemployment, but not in every country in Europe (Figure 12.5). Excluding countries worst affected by the crisis-Greece, Ireland, Latvia, Portugal, and Spain — cyclical factors explain, on average, about 35 percent of the changes in youth unemployment rates across advanced European countries (for example, 33 percent and 27 percent, respectively, in France and Italy, both of which have high youth unemployment rates). What are the other explanatory factors? In particular, to what extent do labor market institutions and skills play a role in explaining labor market outcomes across advanced European economies as well as within individual countries?

A large body of literature discusses the role of labor market characteristics in determining aggregate unemployment in Europe. Some of the labor market characteristics considered in the literature to have an impact on youth unemployment include unionization (Bertola, Blau, and Kahn 2007); hiring and firing regulations; minimum wages and hiring costs (Bernal-Verdugo, Furceri, and Guillaume 2012); and labor market flexibility (OECD 2006; Choudhry, Marelli, and Signorelli 2012).

Labor market features have significant effects on the levels of youth and adult employment and unemployment, but not on changes. ${ }^{7}$ Put simply, the rapid divergence of youth unemployment rates in the aftermath of the crisis has not been accompanied by dramatic changes in labor market features.

A number of labor market features have an impact on youth unemployment rates; in particular, lower hiring costs (tax wedge, minimum wages relative to the median wage) and higher spending on ALMPs per unemployed person, especially on training, reduce unemployment. The opportunity costs of working (for example, benefit replacement rates) and low skill levels tend to raise unemployment, whereas collective bargaining (for example, union density) and labor

\footnotetext{
${ }^{7}$ These results are robust to changes in specification. Results for changes in unemployment rates are available upon
} request. Results discussed in the text refer to the multivariate model unless otherwise specified. 

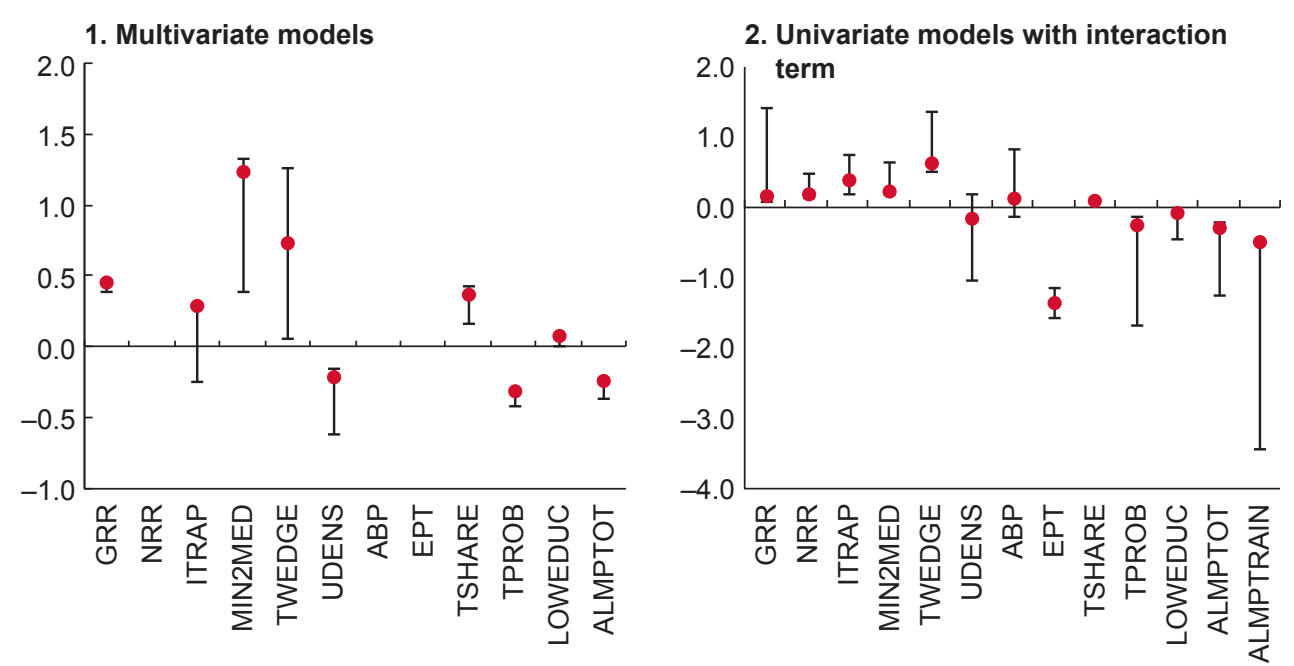

Sources: Eurostat; Organisation for Economic Co-operation and Development (OECD); IMF World Economic Outlook; and IMF staff estimates. Note: GRR = gross replacement rate; NRR = net replacement rate; ITRAP = inactivity trap; MIN2MED = ratio of minimum to median wage; TWEDGE = tax wedge; UDENS = union density; $A B P=$ adjusted bargaining power; $E P T=O E C D$ temporary employment protection index; TSHARE = share of temporary employees for a given age group; TPROB = share of temporary employees on probation in total temporary employees for a given age group; ALMPTOT = total spending on ALMP (thousand euro per unemployed); ALMPTRAIN = spending on ALMP training policies. See Annex 12.2 for model details. Only significant results are shown for the univariate model (panel 2).

Figure 12.6 Effects of Labor Market Features on Youth Employment (Percentage points)

market duality (for example, protection of workers) have mixed effects. These effects remain significant after controlling for several labor market features at a time (Figure 12.6, panel 1).

Allowing for interactions between labor market features and the business cycle reveals significant cross-country differences in the impact of labor market features on labor market outcomes (Figure 12.6, panel 2). For instance, a 1 percentage point increase in the tax wedge increases youth unemployment rates by between 0.6 and 1.4 percentage points in univariate models with the interaction term. ${ }^{8}$

\section{Higher Hiring Costs, Higher Unemployment}

Taxes on employers and employees, in combination with statutory minimum wage rates, affect both the supply of and demand for labor. High tax rates on labor income depress the supply of labor and drive a wedge between marginal productivity and the reward for work. If higher taxes translate into higher wages, then the increase in labor costs can reduce labor demand and increase unemployment. High payroll taxes and employers' social security contributions are even more likely to raise labor costs in the presence of wage floors generated by statutory minimum wages. If employers succeed in shifting the tax burden to employees in the form of lower wages, the labor supply could shrink, especially for low-wage earners (who would conceivably include youth). OECD (2012) shows that since 2007 young people have, on average, been at a big disadvantage in countries in which the minimum wage is relatively high as a percentage of median pay.

Hiring costs remain above average for several countries. The tax wedge declined in the Scandinavian countries and Germany, while either remaining unchanged or even increasing in other European countries (in particular, Greece and Spain) (Figure 12.7). The ratio of the minimum wage to the median wage has remained unchanged for the vast majority of advanced

\footnotetext{
${ }^{8}$ Several studies find that higher labor tax wedges raise unemployment, and the impact of the tax wedge is strengthened when combined with the impact of minimum wages and the strength of collective bargaining.
} 


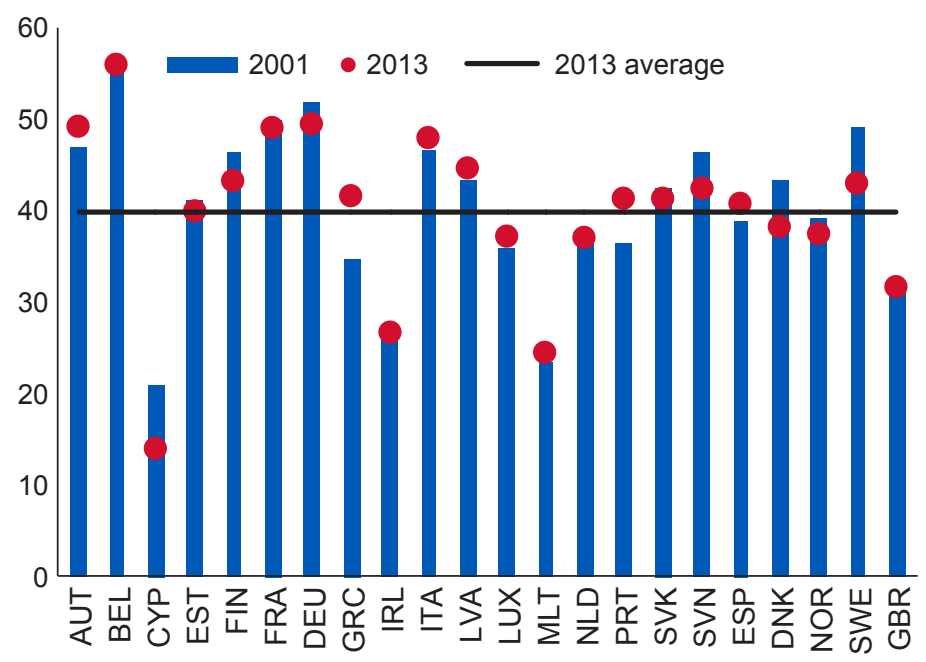

Source: European Commission.

Note: Latest data for Cyprus are for 2007. Data labels in the figure use International Organization for Standardization (ISO) country codes.

Figure 12.7 Tax Wedge (Percent)

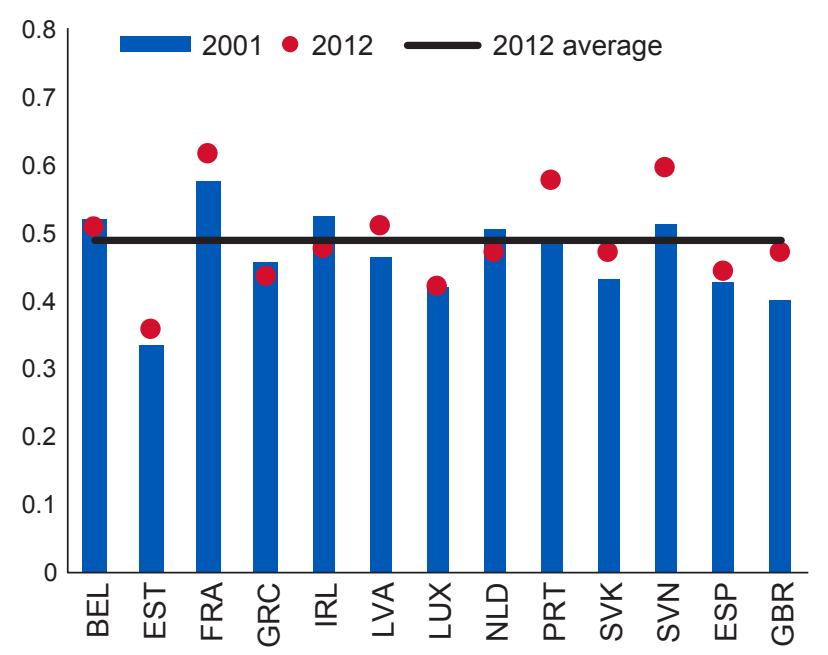

Source: European Commission.

Note: Data labels in the figure use International Organization for Standardization (ISO) country codes.

Figure 12.8 Ratio of Minimum to Median Wage

European countries while marginally increasing in France, Greece, Portugal, and Spain (Figure 12.8). ${ }^{9}$

This chapter's empirical analysis indicates that greater hiring costs-larger tax wedge, higher minimum wages relative to the median wage, or both-are associated with higher youth and adult unemployment rates and lower employment rates for both youth and adults. A 1 percentage point increase in the tax wedge raises youth unemployment rates $0.3-1.3$ percentage points.

${ }^{9}$ The minimum wage was frozen in Portugal in the second half of 2011 and cut in Greece in the second half of 2012 under the financial assistance programs. 
The effect on adult unemployment is smaller (about $0.4-0.5$ percentage point). Higher minimum wages (relative to median wages) raise youth unemployment by $0.4-1.2$ percentage points. Because many young people are hired at minimum wage jobs, they may be particularly vulnerable to increases in the cost of hiring.

\section{Higher Opportunity Cost of Working, Higher Unemployment}

High unemployment benefits raise unemployment by reducing the willingness to search intensively for jobs or to accept job offers, and by increasing the reservation wage, that is, the salary at which the unemployed would be willing to work instead of receiving unemployment benefits (both of which lower labor supply). Moreover, tax and benefit systems can interact to create an unemployment or inactivity trap that arises when individuals who qualify for social protection benefits have little financial incentive to work because the combined effects of increased tax payments and the withdrawal of income-tested benefits offset the potential gain in disposable income from increased earnings.

Overall, the picture remains largely unchanged during 2001-12, regardless of which indicators are used to capture the incentives of the unemployed to seek work (the net benefit replacement rate or the inactivity trap; Figures 12.9 and 12.10). Germany and some Scandinavian countries, which have reduced benefit replacement rates and indicators of the inactivity trap, provide the few exceptions. In contrast, these indicators have remained unchanged for the vast majority of advanced European countries while marginally increasing in the euro area countries under stress.

Higher opportunity costs of working are associated with higher youth and adult unemployment rates. In univariate models with the interaction term, a 1 percentage point increase in net replacement rates raises youth unemployment rate $0.1-0.5$ percentage point depending on the country, more than it does for adults (0.1-0.2 percentage point). Country-specific estimates find significant and positive effects of higher marginal tax rates on income (inactivity trap) on youth unemployment for most countries, with a stronger effect on youth unemployment than on adults. Youth may be more sensitive to net replacement rates because unemployment benefits allow them time to find a more desirable job. However, an aggregate indicator may mask

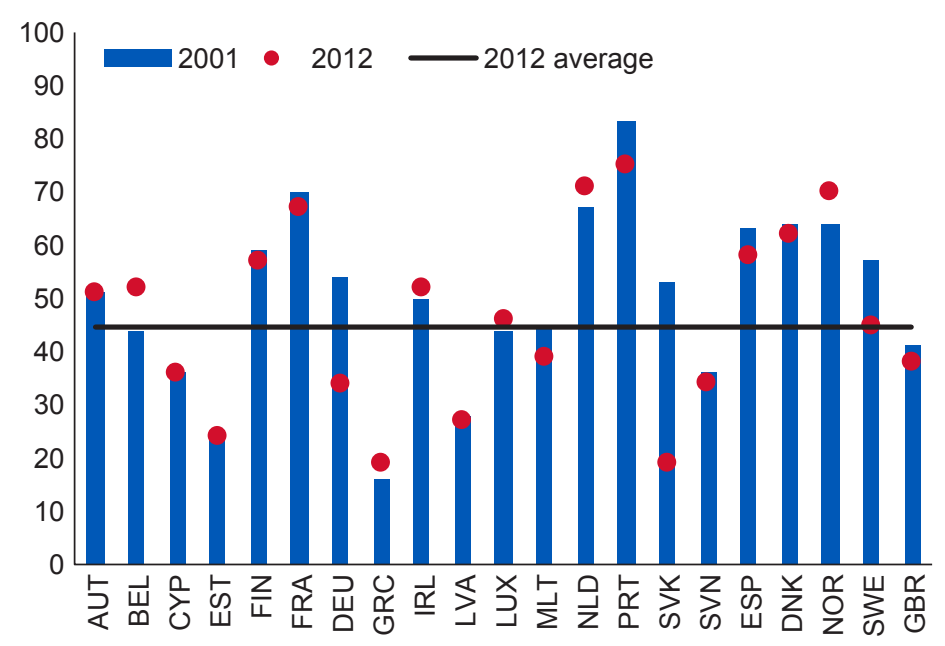

Source: European Commission.

Note: Data labels in the figure use International Organization for Standardization (ISO) country codes.

Figure 12.9 Net Replacement Rate (Percent) 


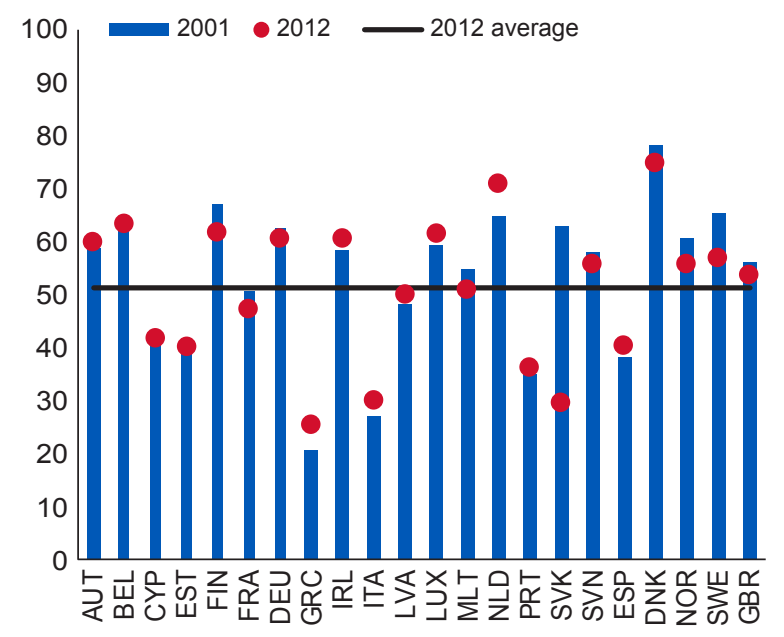

Source: European Commission.

Note: Data labels in the figure use International Organization for Standardization (ISO) country codes.

Figure 12.10 Inactivity Trap (Percent)

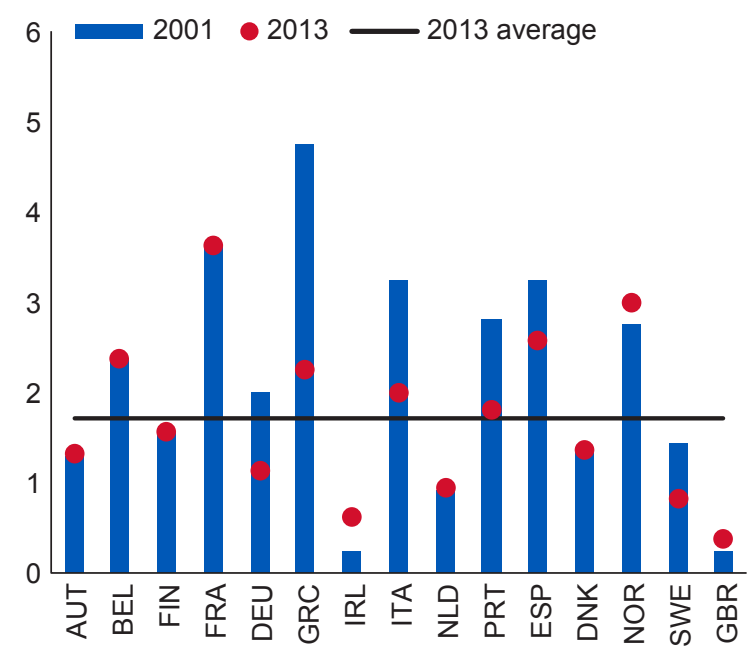

Source: Organisation for Economic Co-operation and Development. Note: Data labels in the figure use International Organization for Standardization (ISO) country codes.

Figure 12.11 Protection of Temporary Workers (Rating)

country-specific differences in eligibility for unemployment benefits; for example, in some countries, people who have never had a job may not be eligible for unemployment benefits.

\section{Dual Labor Markets, Shifting Composition of Unemployment}

Dual labor markets feature a high share of temporary employment contracts with lower employment protection (Figure 12.11). Studies show that the impact of employment protection legislation (EPL) — legislation governing the hiring and firing of employees — on labor market outcomes 


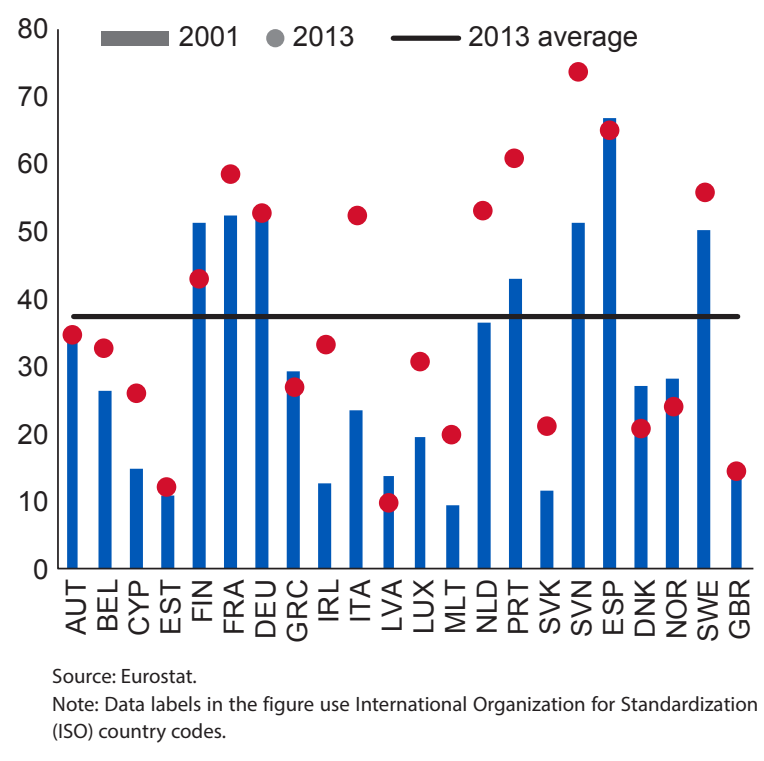

Figure 12.12 Share of Temporary Workers (Percent, 15-24 years)

is small and ambiguous. ${ }^{10}$ It can lower job separation rates by increasing the cost of firing, but also lower the job finding rate by increasing employers' reluctance to hire workers in the first place. Labor market duality has been associated with a lower youth employment rate in a sample of 17 OECD countries during 1960-96 (Bertola, Blau, and Kahn 2007).

Young workers tend to be employed on temporary contracts more so than adult workers. The disparity between adults and youth in this regard is particularly large in Italy, Portugal, and Spain, which have had some of the largest increases in youth unemployment. In Spain, labor market adjustments have focused on shedding workers on temporary contracts-mainly youth.

Higher protection for temporary contracts lowers unemployment rates for youth and adults, but the effects for youth are stronger because a higher share is employed on temporary contracts (Figure 12.12). A unit increase in the EPL rating ${ }^{11}$ lowers youth unemployment rates by $2.5-5.0$ percentage points and adult unemployment by $1.5-2.0$ percentage points. A higher share of youth on temporary contracts increases youth unemployment and lowers employment by 0.3-0.4 percentage point, but it has no significant effects on adult employment or unemployment rates. Hence stronger labor market duality can shift the composition of employment toward adults.

\section{Stronger Collective Bargaining, Limited Effect on Youth Unemployment}

A higher incidence of collective bargaining has the potential to lower employment, but the impact of collective bargaining depends on the level at which the bargaining occurs. Firm-level bargaining tends to limit wage increases beyond productivity levels, thereby having less of an impact on employment and unemployment rates. Very centralized or coordinated bargaining

\footnotetext{
${ }^{10}$ Labor market duality is measured by the Organisation for Economic Co-operation and Development's (OECD's) employment protection indicator for temporary and permanent workers, and the share of temporary workers as a percentage of total employees. In-sample variation in the data is larger for temporary employment protection indicators than for permanent employment protection indicators.

${ }^{11}$ The rating is on a scale from 1 to 6 .
} 


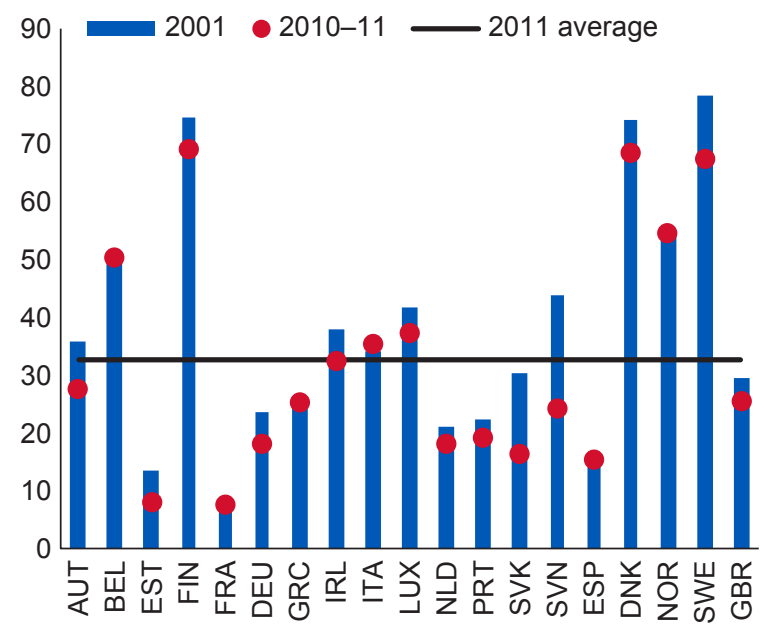

Source: Organisation for Economic Co-operation and Development. Note: Data labels in the figure use International Organization for Standardization (ISO) country codes.

Figure 12.13 Union Density (Percent)

systems may also be less detrimental to employment because the overall impact on the labor force can be explicitly incorporated into the bargaining process, thereby minimizing the effect on unemployment. Thus, the relationship between the strength of collective bargaining and unemployment tends to be hump shaped, having the worst effects on unemployment when collective bargaining systems are neither fully centralized nor fully decentralized.

Overall, higher union density has a limited (not significant) effect on youth unemployment. Some specifications indicate that a 1 percentage point increase in union density could lower youth unemployment rates $0.2-0.6$ percentage point. ${ }^{12}$ However, this finding is not robust to alternative specifications, including variations in control variables or allowing country-specific interactions. The results from some specifications suggest that higher union density may be associated with an altered employment composition as well, perhaps because employers prefer to hire nonunionized youth instead of unionized adults to preserve the flexibility to adjust the workforce as needed, leading to higher employment for youth and lower employment for adults.

\section{More Vocational Training, Less Unemployment}

Educational attainment may have a large impact on employability (OECD 2013). Vocational training and expanded access to training could play a significant role in reducing temporary work and contribute to making temporary jobs a stepping stone toward open-ended contracts (OECD 2004).

The share of workers in the population with low education has been declining steadily across all countries, but the level of formal education may not provide a complete picture of the skills of the young unemployed. Vocational training and apprenticeships are also important forms of attaining skills, but are difficult to measure. Survey data on the reasons for temporary contracts suggests that temporary contracts for youth are associated with education, training, or probation in countries with low youth unemployment rates such as Austria, Germany, and the Netherlands

\footnotetext{
${ }^{12}$ This result is based on the OECD's indicator on union density, which measures the incidence of unionization among the employed but does not measure the degree of centralization (Figure 12.13).
} 


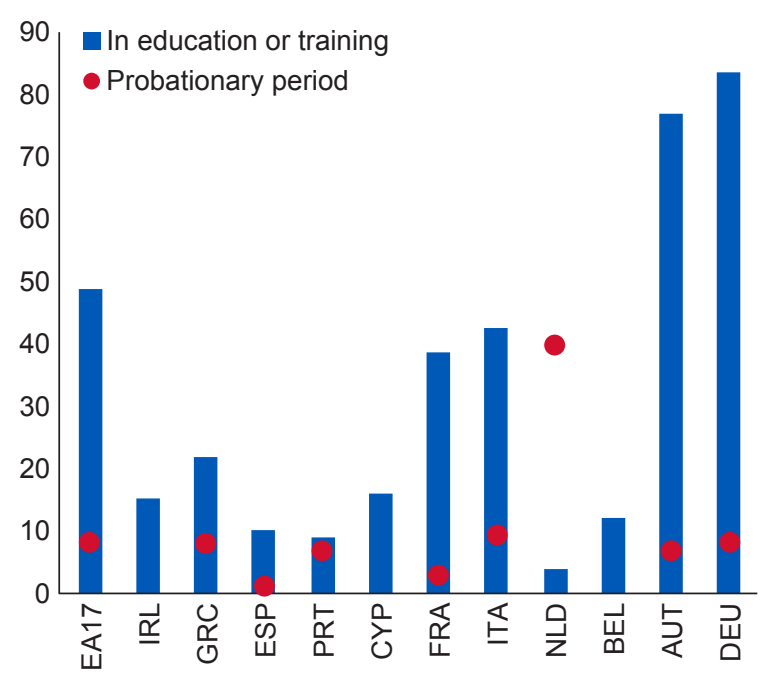

Source: Eurostat.

Note: See Abbreviations and Acronyms section for composition of EA17. Data labels in the figure use International Organization for Standardization (ISO) country codes.

Figure 12.14 Reason for Temporary Work Contract among Youth (Percent of unemployed, 2012)

(Figure 12.14). The share of those in education, training, and probation is relatively smaller in Cyprus, Greece, Portugal, and Spain.

Access to vocational training-measured by the share of temporary workers in probation or vocational training — significantly reduces youth unemployment, by about 0.3 percentage point, but has no significant effect for adults. A higher share of individuals with low education has generally no significant effects on youth unemployment or employment rates, but has a strong negative effect on adult unemployment and employment rates. Low education may be less of an obstacle for youth employment, perhaps because young workers can be more easily trained than adults.

\section{More Spending on Active Labor Market Policies, Lower Unemployment}

According to OECD (2006), most macroeconometric studies have found significant positive effects of spending on ALMP, especially spending on training, on aggregate unemployment. However, microeconomic evaluation studies of ALMPs find that the effectiveness of programs vary, and that apparently similar programs can yield very different outcomes (Card, Kluve, and Weber 2010; Kluve 2010). Studies also show that ALMPs that specifically target young people are not very effective regardless of the type of the program (that is, they have a lower probability of yielding positive results).

Spending on ALMPs varies widely across countries, and several countries have increased spending in this area since the crisis (Figure 12.15). Given dramatic increases in unemployment during the crisis, ALMP funds have had to be distributed across greater numbers of the unemployed.

Higher spending on ALMPs, especially training, is associated with significant reductions in youth unemployment rates. Additional ALMP spending of 1,000 euro per unemployed reduces youth unemployment by about 0.3 percentage point and adult unemployment by about 0.1 percentage point. It also raises employment rates by 0.2 percentage point for youth and 0.1 percentage point for adult. 


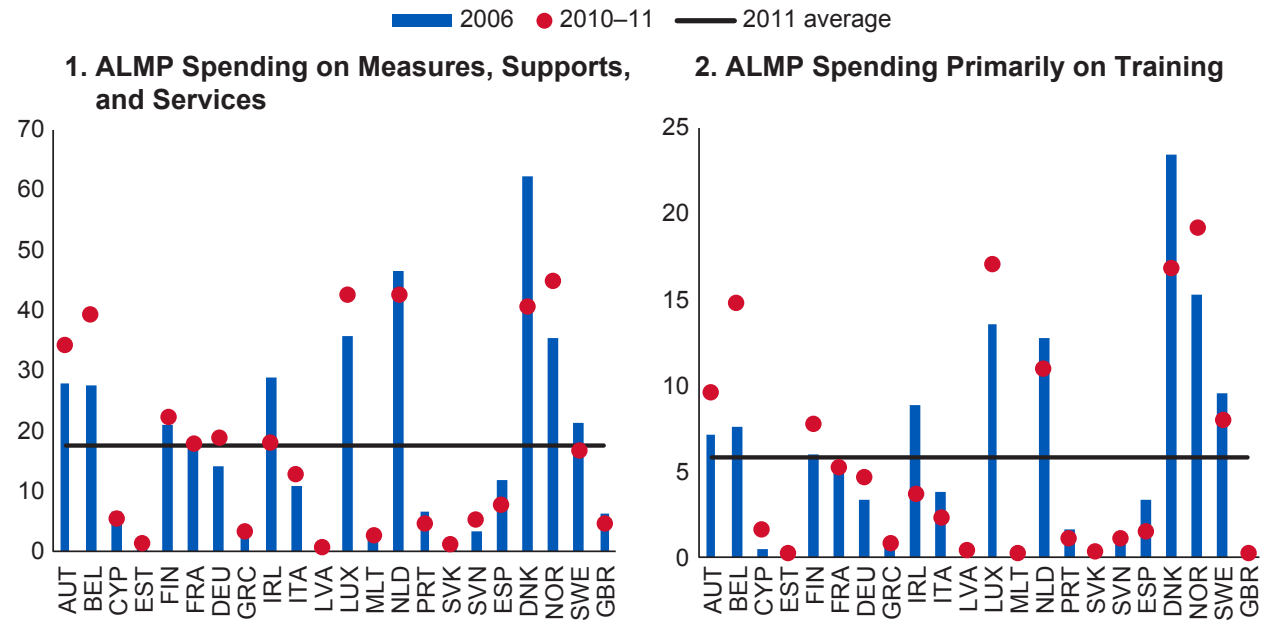

Figure 12.15 Spending on Active Labor Market Policies (ALMPs) (Thousand euros per unemployed)

\section{CONCLUSION}

The youth unemployment problem in the euro area is multifaceted and varies across countries. Substantial cross-country differences in the composition and dynamics of youth unemployment suggest that no single policy at the EU or national level is likely to solve the problem. The solution would need to target the country-specific factors affecting youth unemployment. Past experience indicates that there is no one-size-fits-all approach to tackling youth unemployment (ILO 2013).

A comprehensive strategy for tackling youth unemployment in the euro area should focus on creating conditions for sustainable growth, given the higher sensitivity of youth unemployment to the business cycle. In the short term, policies to restore the housing sector and improve competitiveness in trade and tourism activities would be particularly beneficial given that these are also sectors in which youth employment is concentrated. Historically, euro area countries have reduced youth unemployment rates by growing much more strongly than they are currently expected to (Box 12.2).

Labor market reforms will help. The empirical results show that growth explains about half the increase in youth unemployment overall, and about a third in some high youth unemployment countries (such as France and Italy). Therefore, growth alone cannot solve the youth unemployment problem. Empirical analysis also shows that labor market reforms would pay dividends. As the economic recovery solidifies and unemployment rates return closer to their historical averages, labor market institutions may play an increasingly large role in labor market dynamics. Reforms could include lowering hiring costs by reducing the tax wedge and reconsidering minimum wage policies (which largely affect youth) to increase labor demand; changing unemployment benefits to provide better incentives for moving from inactivity to work; improving skill levels and work-related training; and implementing ALMPs.

Reforms may complement business cycle effects. Labor market institutions affect the sensitivity of youth unemployment rates to the business cycle in Greece, Ireland, Italy, and Spain (Figure 12.16). For example, an increase in the tax wedge increases the cyclical responsiveness of youth unemployment in both Greece and Spain. Similarly, ALMP spending seems to significantly reduce the effect of cyclical changes on youth unemployment in Ireland, Italy, and Spain. Thus, a reduction in ALMP spending per unemployed in Ireland and Spain in the aftermath of 


\section{BOX 12.2. A Historical Perspective on Growth and Youth Unemployment}

Youth unemployment rates have been very high in the euro area after the global economic and financial crisis, but such unemployment levels are not unprecedented (Figure 12.2.1). In Spain, for example, youth unemployment rates are close to (about 90 percent of) the previous peaks (1986 and 1994). Youth unemployment rates remain below their historical peaks for France and Italy.

Euro area countries succeeded in reducing high youth unemployment rates in the past, but they have done so in the context of stronger growth than currently envisaged (Figure 12.2.2). In some cases, growth rates would have to be double or even triple the current forecasts.

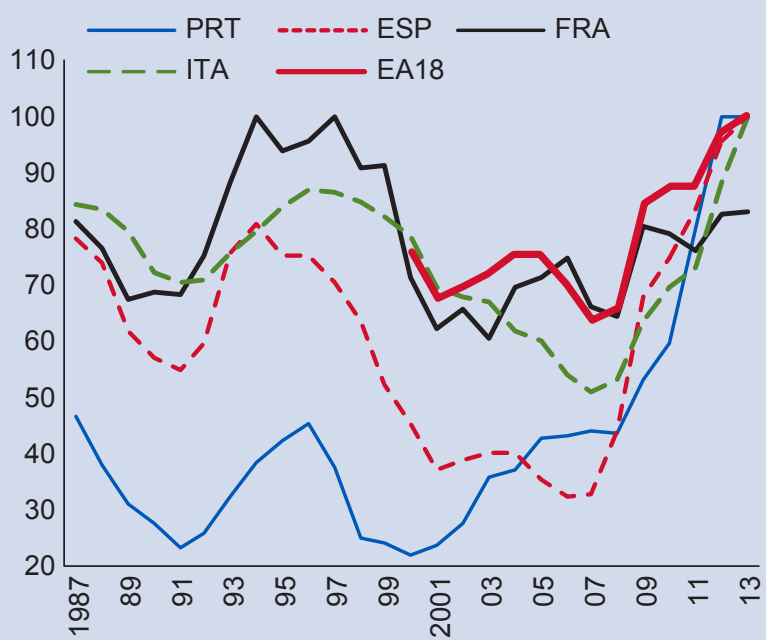

Source: Eurostat.

Note: See Abbreviations and Acronyms section for composition of EA18. Data labels in the figure use International Organization for Standardization (ISO) country codes.

Figure 12.2.1 Euro Area: Youth Unemployment Rate (Peak=100)

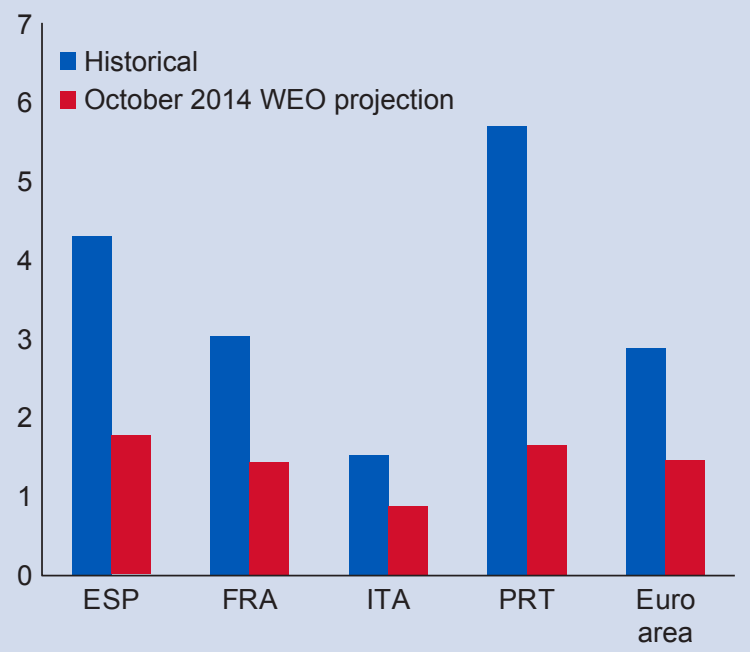

Sources: Eurostat; IMF World Economic Outlook (WEO); and IMF staff estimates.

Figure 12.2.2 Average Growth during Unemployment Reduction and Current Projections (Percent) 

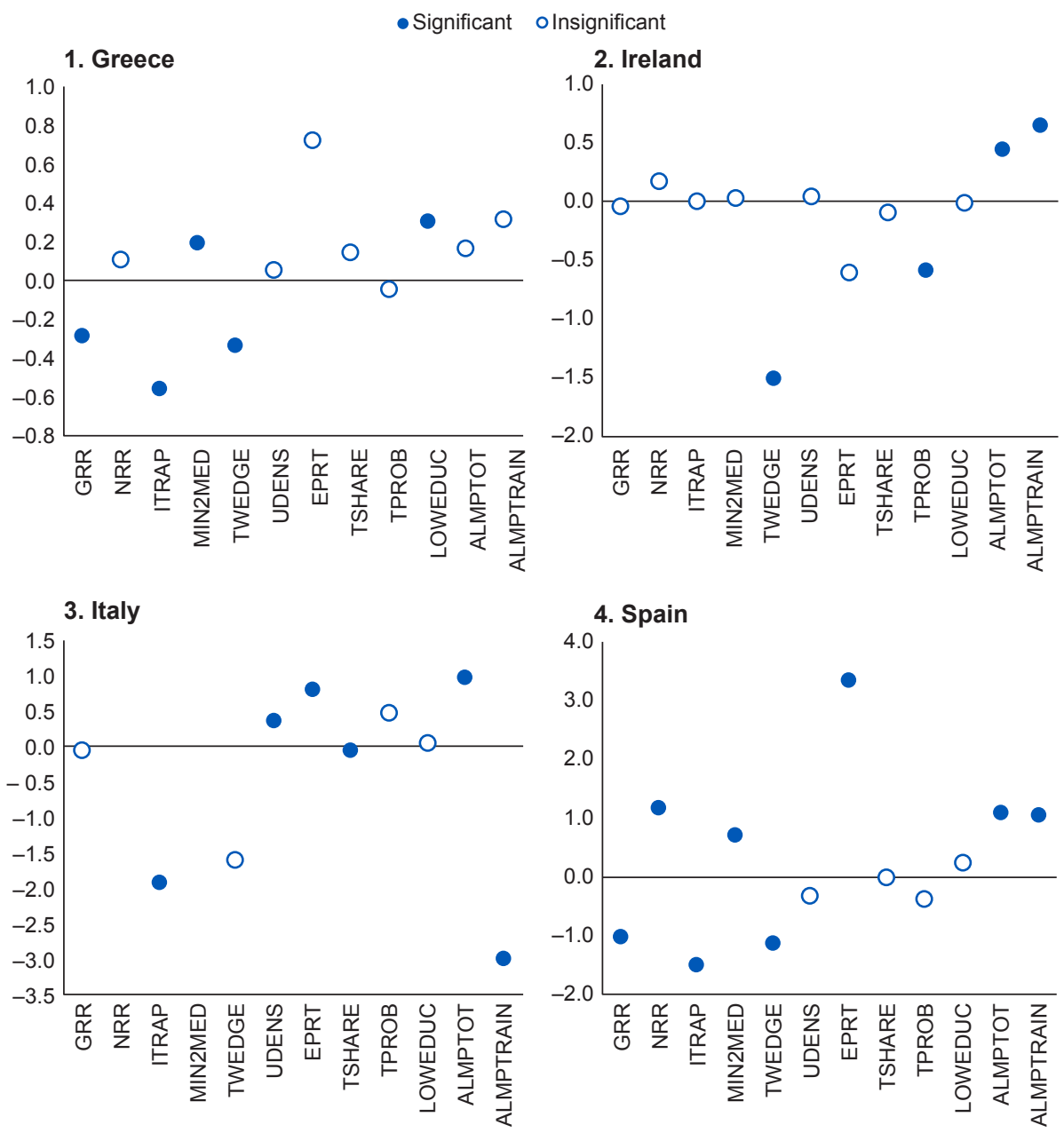

Source: IMF staff estimates.

Note: $\mathrm{GRR}=$ gross replacement rate; $\mathrm{NRR}=$ net replacement rate; ITRAP = inactivity trap; MIN2MED = ratio of minimum to median wage; TWEDGE = tax wedge; UDENS = union density; EPRT = OECD temporary employment protection index; TSHARE = share of temporary employees for a given age group; $\mathrm{TPROB}$ = share of temporary employees on probation in total temporary employees for a given age group; LOWEDUC = share of population with lower secondary education; ALMPTOT = total spending on ALMP (thousand euro per unemployed); ALMPTRAIN = spending on ALMP training policies.

Figure 12.16 Coefficients for Interaction between Labor Market Features and Output Gap

the crisis may have aggravated the effect of the sharp drop in growth on youth unemployment rates.

Given the estimated effects on youth unemployment, the amounts of ALMP spending required to make a sizable dent in historically high youth unemployment rates would be too large to be feasible. Thus, ALMP spending will need to be complemented by growth and other labor market reforms to yield the maximum effect. Empirical analysis shows that ALMPs are likely to be more effective if they are part of a broader, comprehensive strategy to address structural impediments to greater youth employment; for example, higher tax wedges reduce the effectiveness of ALMP spending in Austria and Germany.

However, ALMP is not a panacea. ALMP programs need to be designed and monitored properly-meta analysis of such programs show that the impact and cost-effectiveness of ALMPs vary significantly based on their design. 
ANNEX 12.1. DATA DEFINITIONS

\begin{tabular}{|c|c|c|}
\hline Variable & Definition & Source \\
\hline Output gap & (Real GDP - Real potential GDP) as a percentage of real potential GDP. & WEO \\
\hline GDP growth & Year-over-year growth of GDP, constant price. & WEO \\
\hline Unemployment rate & Unemployed population as a percentage of labor force in corresponding age cohort. & Eurostat \\
\hline Net replacement rate & $\begin{array}{l}\text { Net benefits replacement rate is defined as the ratio of net income while out of work (mainly unemployment benefits if } \\
\text { unemployed, or means-tested benefits, if on social assistance) divided by net income while in work. A lower net replace- } \\
\text { ment rate is associated with a greater incentive to search for and take up a job when unemployed. }\end{array}$ & $\begin{array}{l}\text { European Commission Tax and } \\
\text { Benefits Indicators Database }\end{array}$ \\
\hline Gross replacement rate & $\begin{array}{l}\text { Average of the gross unemployment benefit replacement rates for two earnings levels, three family situations, and three } \\
\text { durations of unemployment. }\end{array}$ & OECD \\
\hline Inactivity trap & $\begin{array}{l}\text { The implicit tax on returning to work for inactive persons; measures the part of additional gross wage that is taxed away } \\
\text { when an inactive person (not entitled to receive unemployment benefits but eligible for income-tested social assistance) } \\
\text { takes up a job. This indicator measures the financial incentive to move from inactivity and social assistance to } \\
\text { employment. }\end{array}$ & $\begin{array}{l}\text { European Commission Tax and } \\
\text { Benefits Indicators Database }\end{array}$ \\
\hline Minimum wage/Median wage & $\begin{array}{l}\text { Minimum wage relative to median wage for full-time workers. This ratio is set to zero for countries without a national mini- } \\
\text { mum wage. }\end{array}$ & OECD \\
\hline Protection of temporary workers & Strictness of employment protection for temporary contracts. & OECD \\
\hline Share of temporary workers & Temporary employees as a percentage of the total number of employees. & Eurostat \\
\hline Tax wedge & $\begin{array}{l}\text { The tax wedge is defined as the proportional difference between the costs of a worker to their employer (wage and social } \\
\text { security contributions, that is, the total labor cost) and the amount of net earnings that the worker receives (wages minus } \\
\text { personal income tax and social security contributions, plus any available family benefits). The tax wedge measures both } \\
\text { incentives to work (labor supply side) and to hire persons (labor demand side). }\end{array}$ & $\begin{array}{l}\text { European Commission Tax and } \\
\text { Benefits Indicators Database }\end{array}$ \\
\hline Union density & $\begin{array}{l}\text { Trade union density corresponds to the ratio of wage and salary earners that are trade union members, divided by the total } \\
\text { number of wage and salary earners (OECD Labour Force Statistics). Density is calculated using survey data, wherever possi- } \\
\text { ble, and administrative data adjusted for nonactive and self-employed union members otherwise. }\end{array}$ & OECD \\
\hline Adjusted bargaining power & $\begin{array}{l}\text { Employees covered by wage bargaining agreements as a percentage of all wage and salary earners in employment with the } \\
\text { right to bargaining, adjusted for the possibility that some sectors or occupations are excluded from the right to bargain } \\
\text { (removing such groups from the employment count before dividing the number of covered employees over the total } \\
\text { number of dependent workers in employment). }\end{array}$ & $\begin{array}{l}\text { The Quality of Government } \\
\text { Institute, University of } \\
\text { Gothenburg }\end{array}$ \\
\hline Share of temporary workers on probation & $\begin{array}{l}\text { Proportion of total temporary workers on probation (other reasons for being on temporary contracts include "could not find } \\
\text { a permanent job," "did not find a permanent job," "in education or training"). }\end{array}$ & Eurostat \\
\hline Share of low-educated workers & Persons with lower secondary education attainment. & Eurostat \\
\hline ALMP total spending per unemployed & Total ALMP spending per unemployed. & Eurostat \\
\hline ALMP spending per unemployed on training & ALMP spending on training per unemployed. & Eurostat \\
\hline
\end{tabular}




\section{ANNEX 12.2. METHODOLOGY}

\section{Estimating Okun's Coefficient}

The estimation of Okun's coefficient for individual countries was conducted using the following specifications:

$$
\begin{gathered}
\text { Urate }_{i t}-\text { Urate }_{i t-1}=\text { Constant }^{22}+\sum_{i=1}^{22} b_{i} \times \text { Growth }_{i t} \times \text { Country dummy }_{i}+\text { Country }_{i}+\varepsilon_{i t}, \text { and } \\
\text { Urate }_{i t}-\text { Urate }_{i t}^{*}=\text { Constant }+\sum_{i=1}^{22} b_{i} \times \text { Output gap }_{i t} \times \text { Country dummy }_{i}+\text { Country }_{i}+\varepsilon_{i t}
\end{gathered}
$$

in which

Urate $_{i t}$ : Unemployment rate for the youth and adult age groups in country $i$, year $t$

Urate $_{i t}^{*}$ : Structural (equilibrium) unemployment rate in a certain age group in country $i$, year $t$ (estimated by using Hodrick-Prescott filter, with $\lambda=100$ )

Growth $_{i t}$ GDP growth rate in country $i$, year $t$

Output gapit: Output gap in country $i$, year $t$

Country: Country fixed effect

The estimated $b_{i}$ is the Okun's coefficient.

\section{Impact of Labor Market Institutions}

Economists have advanced a number of models for the unemployment rate that are consistent with using the unemployment rate in levels as a dependent variable in reduced-form equations. For example, Nickell and Layard (1999) develop a wage-bargaining model with numerous identical firms, showing that the equilibrium level of the unemployment rate will be decreasing in any exogenous factor that increases the job separation rate (represented in this case by the output gap), increases the search effectiveness of the unemployed (represented by ALMPs), lowers the benefit replacement ratio, lowers the strength of workers in wage bargaining (union density), or raises the elasticity of product demand facing the firm. The latter argument even suggests scope for including variables associated with product market regulation into unemployment equations. Other examples of similar models include Scarpetta (1996) and Bassanini and Duval (2006), who estimate a specification very similar to the one in this chapter. ${ }^{13}$

The univariate model with interaction terms assumes that (1) the effects of the business cycle may depend on labor market features, (2) this dependence may be different across countries, and (3) the effect of the structural variable itself does not depend on the country, except indirectly via the business cycle. These assumptions, together with data limitations, mean that structural variables can only be considered one at a time; otherwise the high number of parameters to estimate relative to the size of the sample prevents efficient estimation of the coefficients.

We consider the following specification:

$$
u_{i, i}=\beta_{0}+\beta_{1, i} c_{i}+\beta_{2} x_{i, t}+\beta_{3, i} c_{i} y_{i, t}^{*}+\beta_{4, i} c_{i} x_{i, t} y_{i, t}^{*}+\varepsilon_{i, t},
$$

\footnotetext{
${ }^{13}$ Bassanini and Duval (1996) estimate a reduced-form equation $\left(u_{i, t}=\sum_{j} \beta_{j} X_{j}+\chi G_{i, t}+\alpha_{i}+\lambda_{t}+\varepsilon_{i, t}\right)$ consistent with a variety of theoretical models of the labor market equilibrium (job search, wage setting), in which unemployment is regressed on a series of structural variables (in vector $X$ ), an output gap measure $(G)$, as well as country and time fixed effects. The analysis in this chapter departs from this specification by including interaction terms and excluding time fixed effects.
} 
in which $u_{i, t}$ is one out of six dependent variables (youth and adult unemployment and long-term unemployment rates, as well as employment rates), $c_{i}$ is a dummy variable equal to 1 if the dependent variable is from country $I ; y_{i, t}^{*}$ is the and $x_{i, t}$ is a given labor market feature. Finally $\varepsilon_{i, t}$ is the error term with standard assumptions.

The marginal impact of the change in labor market feature $x_{i, t}$ on the level of unemployment or employment is given by the following partial derivative:

$$
\frac{\partial u_{i, t}}{\partial x_{i, t}}=\beta_{2}+\beta_{4, i} c_{i} y_{i, t}^{*}
$$

That is, the impact of a change in a labor market feature differs depending on the country considered and its output gap. Crucially, therefore, the marginal effects of the change in the structural variable will depend on the value of the output gap $y_{i, t}^{*}$ at which they are evaluated. In this chapter, this point is the country-specific average output gap (average growth rate for the specification in differences). The standard errors for the marginal effects are computed using the delta method.

The second specification considers several labor market features at a time and assumes that the impact of labor market features, if any, is common across all countries. It allows the impact of the business cycle (output gap) to vary across countries.

$$
\text { Urate }_{i t}=\text { Constant }+\sum_{j} \gamma_{j} X_{i j t}+\sum_{i=1}^{22} b_{i} \times \text { Output gap } p_{i t} \times \text { Country dummy }_{i}+\text { Country }_{i}+\varepsilon_{i t}
$$

In which

Urate $_{i t}$ : Unemployment rate for the youth and adult age groups in country $i$, year $t$ $X_{i j t}$ : Labor market institution $j$, in country $i$, year $t$

A variety of robustness checks are performed, for example, including time effects, using different measures of the output gap and youth unemployment, and others. These results are available upon request.

\section{REFERENCES}

Ball, L. M., D. Leigh, and P. Loungani. 2013. “Okun's Law: Fit at Fifty?” Working Paper 18668, National Bureau of Economic Research, Cambridge, Massachusetts.

Bassanini, A., and R. Duval. 2006. "The Determinants of Unemployment across OECD Countries: Reassessing the Role of Policies and Institutions." Economic Studies 42, Organisation for Economic Co-operation and Development, Paris.

Bernal-Verdugo, L. E., D. Furceri, and D. Guillaume. 2012. "Labor Market Flexibility and Unemployment: New Empirical Evidence of Static and Dynamic Effects." Comparative Economic Studies 54 (2): 251-73.

Bertola, G., F. D. Blau, and L. M. Kahn. 2007. "Labor Market Institutions and Demographic Employment Patterns." Journal of Population Economics 20 (4): 833-67.

Card, D., J. Kluve, and A. Weber. 2010. "Active Labor Market Policy Evaluations: A Meta-Analysis.” Economic Journal 120 (548): F452-77.

Choudhry, M., E. Marelli, and M. Signorelli. 2012. "Youth and Total Unemployment Rate: The Impact of Policies and Institutions.” Unpublished. http://www.eco.unibs.it/ - emarelli/CMS_unemp_instit.pdf.

European Commission. 2012. "Moving Youth into Employment." Communication from the Commission to the European Parliament, the Council, the European Economic and Social Committee and the Committee of the Regions, 727, Brussels.

_. 2013a. “Labor Market Developments in Europe 2013.” European Economy 6/2013, Brussels.

2013b. "Working Together for Europe's Young People: A Call to Action on Youth Unemployment." Communication from the Commission to the European Parliament, the Council, the European Economic and Social Committee and the Committee of the Regions, 447, Brussels. 
International Labor Organization (ILO). 2013. Global Employment Trends for Youth 2013: A Generation at Risk. Geneva: International Labour Office. http://www.ilo.org/wcmsp5/groups/public/---dgreports/---dcomm/documents /publication/wcms_212423.pdf.

Kluve, J. 2010. “The Effectiveness of European Active Labor Market Programs.” Labour Economics 17 (6): $904-18$. Nickell, S., and R. Layard. 1999. "Labor Market Institutions and Economic Performance." In Handbook of Labor Economics, Vol. 3C, edited by O. Ashenfelter and D. Card. Amsterdam: North-Holland.

Organisation for Economic Co-operation and Development. 2004. Employment Outlook. Paris: OECD Publishing.

- 2006. OECD Employment Outlook: Boosting Jobs and Growth. Paris: OECD Publishing.

. 2012. "Under Shock: How to Spread Macroeconomic Risks More Fairly." In Economic Policy Reforms 2012: Going for Growth. Paris: OECD Publishing.

. 2013. Education at a Glance 2013: OECD Indicators. Paris: OECD Publishing. http://dx.doi.org /10.1787/eag-2013-en.

Scarpetta, S. 1996. "Assessing the Role of Labour Market Policies and Institutional Settings on Unemployment: A Cross-Country Study." OECD Economic Studies 26: 43-98.

, A. Sonnet, and T. Manfredi. 2010. "Rising Youth Unemployment during the Crisis: How to Prevent Negative Long-Term Consequences on a Generation?” OECD Social, Employment and Migration Working Paper No. 106, OECD Publishing, Paris. doi:10.1787/5kmh79zb2mmv-en. 
Note: Page numbers followed by $b$ indicate box, $f$ figure, and $t$ table.

A

Accelerator model of private investment, 9, 10-11, $11 f, 19 t, 20 f$

Active labor market policies, 239, 244, 251, 252-254, $252 f$

Asset-backed securities, 90-91b, 93f, 222b, 223-224, 230

ECB purchase program, 88, 107, 110f, 136

Asset management companies, 192

Asset price shocks, economy-wide transmission of, 25-27

Asset Securitization Funds for SMEs, 228, 233

Austria, youth unemployment, 249, 250-251

\section{B}

Banking Union, ix

benefits for non-euro area members of European Union, 193-194

common safety nets, $185-186,189,209-210$

current architecture of stability, 175-177

design of, 180-186

for European Union, 180

implementation, 179-180, 186-187, 188-193, 194

legal considerations in establishment of, $190 \mathrm{~b}$

progress toward, 175

rationale, 173-175, 177-179, 194, 204

resolution mechanism, 183-185, 184b, 186,

189,210

supervision mechanism, 180-183, 187-189

Bank Recovery and Resolution Directive, ix, 210

Banque de France, 230

Basel rules and principles, 176b, 181, 187, 226, $2276,231,233$

Belgium

euro area fiscal consolidation effects, 145

fiscal consolidation, 143

Bond markets

ECB asset purchase program, 107

future prospects, 114-115

Greek debt restructuring, 95

impact of Outright Monetary Transactions program, 75, 76-77b

monetary transmission mechanism problems and, $81-82$

ownership of government securities, 112, 113f, $114 f$

private investment performance and, 9-10, 13-14
Securities Markets Program subordination risk and, $97-101,98 f, 99 f, 100 f$

securitized, 93, $94 f$

Brazil, $202 b$

C

Capital flows

cross-border bank holdings, 78, $78 f$

in global financial crisis, 173

Capital markets

corporate financing in, 219

future challenges, ix, xii

growth of credit to private sector, 9, $10 f$

impact of Outright Monetary Transactions

program, 75

insurance role, 203

integration, 204

recommendations for, xii

See also Cost of capital; Securitization markets

Collective bargaining, 249-250, $250 f$

Corporate bonds

spread over government bond yields, investment and, 14

yields, $121 f$

Corporate debt

deleveraging patterns and trends, 40-41, $42 f$

economic growth and, 42, 43-44, $44 f$

financing sources, 219, $220 f$

insolvency framework reform, 45

insolvency patterns and trends, 30, 30f, $31 f$

intermediation, 81

international comparison, $27-28,28 f$

patterns and trends, 29-31, 30f, $82 f$

policies to support deleveraging, 45

vulnerabilities of indebted firms, 30-31

Cost of capital

lending rates, $6,8 f, 14,77 f, 79 f, 80 f, 123 f, 174 f$, 219, $220 f$

modeling technique, 16-17

pass-through of policy rates to lending rates, $83-88,85 f, 86 f$

postcrisis investment trends and, 11-13, 16 postcrisis trends, $6,12,12 f, 13 f, 17,18 f$

Covered bond purchase program, ECB, 107

Credit access

breakdown of monetary transmission mechanism in stressed countries, 81-83

lending rates, $6,8 f, 14,77 f$

loan application outcomes, $83 f$ 
Credit access (Continued)

postcrisis investment trends and, $6-9,8 f$

for small and medium enterprises, $81,88,89$,

219, 221

Credit default swaps, 75, 80

Securities Markets Program subordination risk and, 97-98, 98f, 101-103, $102 f$

sovereign-domestic bank spreads, 199, $199 f$

Current account balances

adjustment goals, 67

components, $51 f$, $52 f$

determinants of, $50,51 f, 70-71$

determinants of postcrisis export performance, 60-65, $63 f$

effects of global financial crisis, $\mathrm{x}$

export patterns and trends, 57-59, 58f, 59f, $62 f$

future challenges, 49-50

growth and, 49, $50 \mathrm{f}$

patterns and trends, 49

postcrisis patterns and trends, 50-59, 51-53f

strategies for rebalancing, 67-70, 71-72

structural and cyclical determinants of

adjustments, 65-67, 67f, 67t

variation within euro area, 49

Cyprus, 143, 251

\section{D}

Debt. See Private debt; Public debt

Debt Redemption Fund, 215

Deflation, $\mathrm{x}$-xi

Demand

credit, $80,83,88,92 b, 120,121 f, 122$

current account balance and, $\mathrm{x}, 49,50,58,59$, $61,63 f, 64,65 f, 70,71$

feedback loops from balance sheet effects, 26

for labor, 245, 252

output losses from contraction in, 145

postcrisis investment and, 3

for small and medium-size enterprise

securitization, 230, 231, 232

smoothing to reduce risk from shocks, 203

structural reforms and, 160

support for, in postcrisis recovery, ix

Deposit insurance, 176-177b, 185-186, 188

Dexia, $184 b$

Dual labor markets, 248-249, 248f, $249 f$

\section{E}

ECB. See European Central Bank

Economic and Monetary Union, v, ix, 149

fiscal governance shortcomings, xi-xii

obstacles to deeper integration, 196

proposals for deeper integration, 1966

rationale, $\mathrm{xi}$ rationale for deeper integration, 195-196

risk sharing in, $204 f$

structural variation among members of, 49

vulnerability to shocks, 195, 197

weaknesses exposed by global financial crisis,

195, 197-199

See also Fiscal union

Educational attainment, 250

Employment protection legislation, 248-249

Estonia, 143

Euro area

balance sheet stress in, 25-36

challenges to current account rebalancing, 49-50

current account balance, 50

cyclical and structural factors in current account adjustment, 65-67

determinants of youth unemployment, 240-251

drivers of growth in, $50 \mathrm{f}$

drivers of investment in, 10-16

financial market integration and fragmentation, $173,174 f$

global financial crisis outcomes, $\mathrm{x}$

historical episodes of deleveraging, 39-44

IMF and, v, ix

policy responses to recent economic

challenges, ix

policy support for private sector deleveraging, 44-46

postcrisis current account, 50-59

postcrisis export performance, $60-65$

postcrisis investment trends, 3-10, $161 f$

public debt trends, 149-151

recent economic challenges in, ix

recent reforms of fiscal framework, 151-152

recommendations for current account adjustment, 67-72

reforms to promote youth unemployment, 252-254

salient economic issues in, $\mathrm{x}$-xii

youth unemployment patterns and trends, 239-240

See also Banking Union; Fiscal union; specific country; specific governance institution

European Banking Authority, 177b, 193

European Central Bank (ECB), v

base money, $110 f$

Comprehensive Assessment, 122

in establishment of banking union, 1906, 192-193

Eurosystem collateral framework and, 90-91b

future challenges for, 75

lending rates, $6,8 f$

liquidity conditions, $110 f$

liquidity support for weak banks from, 88-89, 186 
pass-through of policy rates to lending rates,

83-88, 85f, $86 f$

recommendations for monetary policy reforms, $\mathrm{x}$ responses to global financial crisis, $\mathrm{x}-\mathrm{xi}, 75,173$ strategies for improving monetary transmission mechanism, 88-92

supervision, ix, 180-181, 181b, 182-183, $187-188$

targeted asset purchases, 89-91

transparency, 107, 133

See also Outright Monetary Transactions;

Quantitative easing, ECB

European Commission, 140, 151, 159, 162, 163, 229-230

European Council, 162, 175, 201

European Financial Stability Facility, 173, 195, $204,212 b$

European Financial Stabilization Mechanism, $212 b$

European Insurance and Occupational Pension $s$ Authority, 234-235

European Investment Bank, 88, 91-92, 162, 229-230, 232

European Investment Fund, 229, 232

European Stability Mechanism, 49, 167, 173, 195, 204, 208, $212 b$

direct recapitalization, 189-192

European Systemic Risk Board, $177 b$

European System of Financial Supervisors, $177 b$

European Union, 175

banking union, 180, $181 \mathrm{~b}$

non-euro area members of, benefits of banking union for, 193-194

risk sharing in, $204 f$

See also Fiscal governance, European Union

Eurosystem

balance sheet, $110 f$

collateral framework, 90-91b, 130, 132, 232

crisis financing, $79 f, 212 b$

flexibility in asset purchases, 134

government bond purchases, 127

Greek debt restructuring, 95

securities lending, 137

senior creditor status, sovereign bond valuation and, 98-99, 104

share of securities market, 99-100, 103

See also Securities Markets Program

Excessive deficit procedure, 141, 141t, 151, 162, 163, 201

Exchange rates

consumer price index-based, 50, $53 \mathrm{f}$

export performance and, 61, 62, 63, $64 f$

gross domestic product-based, $53 f, 55$

postcrisis patterns and trends, $50,53 f$

quantitative easing and, 116-117, $116 f$ recent euro depreciation, 116-117

trade elasticities and, 117

unit labor cost-based, 50, 51, $53 \mathrm{f}$

Exports

demand, 61, $62 f$

determinants of postcrisis performance, 60-65, 63f, $64 f$

exchange rates and, 61, 62, 63, $64 f$

goods and services, 68, $68 f$

labor cost adjustments and, 57

nonprice competitiveness, 58-59, 59f, $70 \mathrm{~b}$

postcrisis patterns and trends, 57-59, 58f,

$59 f, 62 f$

price competitiveness, 57-58, $59 f$

services sector, $68,68 f, 69 f$

strategies for rebalancing and enhancing

competitiveness, 68

trade correlation index, $64 f$

External indebtedness, 36, $38 f$

F

Financial sector

balance sheet stress, 80

bank bond issuance rates, $123 f$

breakdown of monetary transmission mechanism in stressed countries, 81-83

cross-border bank flows, 78, $78 f$

deposit rates, $123 f$

encumbered assets, 90-91b

Eurosystem collateral framework, 90-91b, 232

impact of Outright Monetary Transactions program, 75

interest rate divergence, $77 f, 78-80,79 f, 174 f$

intermediation system, 81

liquidity support from European Central Bank, 88-89

monetary policy transmission channels, $93 f$, 221

nonperforming loans, $35,35 f, 80,122,124 f$,

133

number of credit institutions, $182,182 f$

pass-through of policy rates to, $83-88,85 f, 86 f$

policies to support deleveraging, 45

quantitative easing effects in credit channel,

$120-122,121 f, 122 f$

resolution regimes, ix, 176b, 177-178, 183-185,

$184 b, 186,205,210$

return on equity, $35 f$

safety nets, 176-177b, 177-178

strategies for improving monetary transmission

mechanism, 88-92, 221

transmission of global financial crisis shocks, 199, $200 f$

See also Banking Union 
Fiscal Compact, 139, 140f, 141t, 151, 156, 157, 163, 164, 195, 196b, 206

Fiscal consolidation mitigating output losses from, 147-148 output effects from Securities Markets Program requirements, 143-147

recommendations for, $x i$ under Stability and Growth Pact, 139

Fiscal governance, European Union current challenges, xi, 168 current framework, 175-177, 176-177f effects of no-bailout clause on, 199 impact of global financial crisis and, 149, 153-154, 154f, 195, 197-199

lessons from global financial crisis, 150-151, 168

medium-term plans, 206

recent reforms, $140 f, 141 t$

recommendations for improving, $x i$ response to global financial crisis, 139, $140 f$ shortcomings of euro area, 149, 168 treaties and legislation, 151

vulnerability to cross-border transmission of shocks, xi-xii

See also Fiscal union; Securities Markets Program

Fiscal union

benefits of, 211

center-based approach, 206-207

as common backstop for banking union, 209-210

costs of, 211

essential elements of, 206

fiscal policy oversight, 206-207

implementation, 214-215

legal considerations, $212 b$

movement towards, 195-196, 1966

obstacles to, 196, 211

rationale, 195, 197-199

risk reduction in, 200-203

risk sharing in, 203-205, 213-214

to stem contagion, 205

transfers and social protection spending, 208-209

Forecasting, 206

Foreign exchange reserves, 112, $114 f$

Fortis, $184 b$

France

ownership of government bonds, 112

private investment in, 14

trade, 57, 58, 61

unit labor costs, 51

wages, 246

youth unemployment, 244
G

Germany

fiscal consolidation, 143

government debt, 127

hiring costs, 245

private investment in, $12,13,14$

private ownership of government bonds, 112

real effective exchange rate, 50

risk sharing in, $204 f$

trade, $57,58,61,117$

unemployment benefits, 247

unit labor costs, 51, 57

youth unemployment, 249, 250-251

Global financial crisis, ix, $\mathrm{x}$

banking union rationale, 178

effects on private investment, 3-10, 4-9f

effects on securitization market, 221-223, 222-223b

effects on youth unemployment, 239-240, $240 f$

euro's share in global reserves since, 112

lessons from, 150-151, 168, 173

outcomes, $\mathrm{x}$

policy responses to, 173

public debt and, 149-151, 150t, 153-154, $154 f$

shortcomings of euro area financial governance

and, 149, 153-154, 168, 195, 197-199

Government bonds

collateral availability issues in quantitative easing, 130-133

corporate bond spreads over, investment and, 14

future prospects, 114-115

investor base, 112, 113f, 114f, $131 t$

potential scarcity of, quantitative easing and, 122-130, $131 f$

Greece

crisis financing, 212-213b

current account balances, 50, 66

debt restructuring, 95

euro area fiscal consolidation effects, 145-146

fiscal consolidation, 143, 153

hiring costs, 245

housing investment, 3

private investment in, 12, 14

subordination risk in exemption from private

sector debt swap, 95, 98

trade, $57,58,61,70$

unit labor costs, 57

wages, 246

youth unemployment, 244, 251, 252

Greek Loan Facility, 212-213b

Growth

country-specific growth shocks, 197, $198 f$

debt levels and, $x, 42-44$

divergence within euro area, $198 f$ 
domestic and external contributions to, $49,50 f$

future challenges and opportunities, ix importance of small and medium enterprises, $79 f$ investment and, $3,5 f$

postcrisis trends, $3,5 f$

private sector debt levels and, 25, 26-27, 36

public debt increase during global financial crisis and lack of, 150

recovery from global financial crisis and, $\mathrm{x}$

Securities Markets Program objectives for sustainability and, 159-162, $160 \mathrm{~b}$

significance of small and medium enterprises, 221 youth unemployment and, 241-243, 244, $244 f$,

252-253

\section{H}

Household debt

deleveraging patterns and trends, 39-40, $40 f$

economic growth and, 42, 43-44, $44 f$

international comparison, 27-28, $28 f$

patterns and trends, 31-32, 32f, 35f, 39

policies to support deleveraging, 45-46

vulnerability to stress and, 32-35

Household savings, 33-34b

Household wealth, 115, $116 f$

Housing bubble, 31

Housing investment, 3

\section{I}

Income tax, unemployment patterns and, 247

Inflation

course of recovery from global financial crisis, $\mathrm{x}$-xi

ECB asset purchase program and, 107

quantitative easing and, xi, 117-120, 118-120f, 133

Insolvencies, 30, 30f, 31f, 45

Interest rates

breakdown of monetary transmission mechanism, 81

divergences between core and stressed country banks, $77 f, 78-80,79 f$

impact of Outright Monetary Transactions program, 75

pass-through of policy rates to lending rates, 83-88, 85f, $86 f$

quantitative easing, 109-112

response to global financial crisis, xi

for small and medium enterprise loans, 83

International Monetary Fund euro area Article IV consultations, v, ix Ireland

corporate debt, 40-41

crisis financing, 212-213b

current account balances, 50, 66 debt patterns and trends, 28-29

fiscal consolidation, 143

household debt, 31-32

housing investment, 3

private investment in, 12,14

trade, $57,58,70$

unit labor costs, 57

youth unemployment, 244, 252-254

Italy

access to credit, 83

crisis financing, 212-213b

employment patterns, 243

fiscal consolidation, 143

government debt securities, 132

labor productivity, 57

lending rates, 85, 87

nonperforming loans, 80

private investment in, 14

private ownership of government bonds, 112

trade, 57, 58, 61, 117

unit labor costs, 51

youth unemployment, 244, 249, 252

J

Japan, 234

loans to private sector, $124 f$

postcrisis credit market, 122

public debt securities, 112

quantitative easing program, xi, 117

L

Labor mobility in euro area, 198

Labor productivity

current account balance and, 66

postcrisis patterns and trends, 55-57, $57 f$

Latvia, youth unemployment, 244

Long-Term Refinancing Operation, 75, 80, 88-89, 90b, $91 f$

\section{M}

Macroeconomic Imbalance Procedure, 168

Manufacturing sector, 242, $242 f$

Minimum wage rates, 245-246, 252

Monetary policy

effects of global financial crisis, $\mathrm{x}$

prospects for recovery, $\mathrm{x}$

strategies for improving policy transmission, 88-92

transmission mechanism problems, 81-83

$\mathbf{N}$

Net foreign asset positions, 70, $71 f$

Netherlands

housing prices, 35

youth unemployment, 249, 250-251 
No-bailout clause, 167, 199, 201, 202

Nonfinancial corporations balance sheet stress and unemployment, $38 \mathrm{f}$ debt-to-equity ratio, $9 f$

deposit flows, $123 f$

lending and borrowing patterns, 28f, 30f, 37f, $82 f, 121 t$

liabilities, $220 f$

outcomes of loan applications, $220 \mathrm{f}$

sources of financing for, $81,219,220 f$

Nonperforming loans, 35, 35f, 80, 122, $124 f$, 133

\section{O}

Okun's Law, 241, 256

Outright Monetary Transactions, 49, 173, 195 effectiveness, 75

euro redenomination risk and, 75, 76-77b purpose, 75

\section{$\mathbf{P}$}

Portugal

access to credit, 83

corporate profitability, 30-31

crisis financing, 212-213b

current account balances, 50

debt patterns and trends, 28-29

employment patterns, 243

fiscal consolidation, 143, 153

household debt, 32

private investment in, 12,14

trade, $57,58,61,70,117$

unit labor costs, 57

wages, 246

youth unemployment, 244, 249, 251

Price adjustments in euro area

current account balances and, $\mathrm{x}$ patterns and trends, 51-53

Price rigidities in euro area, 197-198

Private debt

in advanced economies, $124 f$

assessing vulnerability of, 27

future challenges, ix, 25

global financial crisis outcomes, $\mathrm{x}, 25$

growth and, 42, 43-44

international comparison, $27-28,28 f$

policies to support deleveraging, 44-46

postcrisis trends, $9,9 f$

private investment and, 14, 16

public debt and, 35-36, $37 f$

transmission of economy-wide stresses from, $25-27,36,38 f$

variation within euro area, 28-29, $29 f$

See also Corporate debt; Household debt
Private investment

accelerator model of output dynamics, 9, 10-11,

$11 f, 19 t, 20 f$

bond market model of output dynamics, 9-10,

$13-14,15 f, 22 t, 23 f$

corporate leverage and, 14, 16

cost of capital and, 11-13, 16

credit access and, 6-9, $8 f$

differences across euro area, 3

drivers of nonresidential, 10-16

effects of global financial crisis, $x, 3-10,4-9 f$,

$15,15 f$

effects of historical financial crises, 3, 4f, 5-6, $5 f, 7 f$

future challenges and opportunities, $x, 3$

neoclassical model of output dynamics, 9 ,

$11-13,21 t$

uncertainty effects, 14, 16

Private sector involvement for Greece, 95

PROMISE program, 228, 233

Public debt

bank holdings, $129 t$, $132 f$

compliance with Securities Markets Program rules, $152 f, 153$

decomposition, 150, 150t

ECB quantitative easing and, $111 f, 125 t, 129 t$, 136

economic growth and, 42, 43-44, $44 f$

future challenges, ix

global financial crisis outcomes, $\mathrm{x}, 149-151$, 153-154, $154 f$

household deleveraging and, $40.41 f$

international comparison, 27, $28 f$

as operational target of Securities Markets

Program rules, 165

patterns and trends, $37 f, 129 t$

private sector debt and, 35-36, 37f, $129 t$

Securities Markets Program rules, 151

variation within euro area, 28-29, $29 f$

See also Government bonds

Public investment

cross-border projects, 161-162

differences across euro area, 3

postcrisis trends, 3

trends, 161, $161 f$

Public sector asset purchase program, 107

Q

Quantitative easing, ECB, ix asset prices and, $115,115 f$

collateral availability and, 130-133

covered bond purchases, 107

credit markets and, $120-122,121 f, 122 f$

effectiveness of, $\mathrm{x}$-xi, 107, $108 f$ 
exchange rate and, 116-117

expanded asset purchase program, 136, 136f, 137

Governing Council's commitment to, 107

harmonization of securities lending, 134

impact on financial conditions, 108-109, 109f,

110-111f

inflation expectations and, xi, 108, 109f,

117-120, 118-120f, 133

inflation goals, 107, 133

international comparison, $\mathrm{xi}$

potential scarcity of assets and, 122-130

price cap on asset purchases, 127

private asset purchases, 107, $110 f, 126 f$

projected effects, 109

prospects for portfolio rebalancing, 112-115, $113 f$

recommendations for, 133-134, $135 f$

scope of, 107

sovereign asset purchases, 107, 110f, 125t

subordination concerns, $\mathrm{x}$

term spreads and, 109-112, 111f, $113 f$

transmission channels, 108-109

See also Asset-backed securities purchase

program, ECB

\section{R}

Regional integration, ix

Regulation, securitization market, 225-226, $227-228 b, 231$

Repo funds rate, $131 f$

Resolution of banks, ix, 176b, 177-178, 183-185, $184 b, 186,189,205,210$

\section{S}

Securities Markets Program, $\mathrm{x}$

bond market yields and subordination risk from, 98-101

complexity of rules and procedures, 154-157, 164-166, 168

compliance, 152-153, 152f, $163 f$

credit default swap pricing and subordination risk from, 101-103, $102 f$

current weaknesses and shortcomings of, 154-163

effectiveness of interventions, 96-97, 96f, 152-154

effects of Greek debt restructuring, 95

empirical evidence of subordination risk, 97-98, $98 f$

enforcement mechanisms, 151, 162-163, 166-168

Eurosystem credibility and, 193

exclusion of capital outlays from fiscal balances, 161

fiscal effort as operational target, 165 flexibility in enforcement, 151

medium-term objective, 152, 156-157, 159-

$160,161,164$

mitigating output losses from fiscal consolidation under, 147-148

nominal balance rules, 157

origins, 149

output effects from fiscal consolidation under, 143-147

oversight, 162, 163

preventive and corrective arms, 164

principle reforms, 151-152

purchases, 96, 96f, 97

purpose of, 149

reform options, 163-168

rules on fiscal aggregates, 155-156, $155 f$

significance of subordination effects, 193

structural balance computation, 157-159, 165, $166 b$

subordination of private debt holders under, 95

sustainability and growth objectives, 159-162, $160 \mathrm{~b}$

Securitization markets

benefits of expanded funding for small and medium enterprises, 219, 221

credit rating, 223, $224 f$

defining high-quality securitization, 234-235

effects of global financial crisis, 91b, 219, 221-223, 222-223b

impediments to small and medium enterprise access to, 223-226, 233

overview, $222 b$

performance, 226-228

regulation, 225-226, 227-228b, 231

strategies for enhancing small and medium enterprise access, 230-233

support programs for small and medium enterprises, 228-230, 233-234, 235-237t

See also Securities Markets Program

Service sector exports, 68, 68f, $69 f$

youth employment in, 242, $242 f$

Single Supervisory Mechanism, ix, 173-175. See also Banking Union, 180-183, 181b, 188-189

Six-pack legislation, 139, 140f, 141t, 151, 173, 195,1966

Small and medium enterprises, ix access to credit, 81, 88, 219

economic benefits of expanded securitization market for, 219, 221-223

effects of broken monetary transmission mechanism, 83

effects of global financial crisis, $\mathrm{x}$

employment in, 221

impediment to securitization, 223-226, 233 
Small and medium enterprises (Continued)

lending rates for, $79 f, 83,219,220 f$

loan application outcomes, 83f, 219

public programs to support securitization funds

for, 228-230, 233-234, 235-237t

share of economy, $79 f, 83,220 f, 221$

share of securitized bond market, 93, $94 f$

strategies for improving credit access for, 89

strategies for improving securitization for,

230-233

youth employment in, 241, 243, 2436

Social protection spending, 208-209

unemployment benefits, 247-248

Spain

access to credit, 83

corporate debt, 30, 40-41

crisis financing, 212-213b

current account balances, 50, 66

debt patterns and trends, 28-29

employment patterns, 243

fiscal consolidation, 143

government debt securities, 132

hiring costs, 245

household savings and debt, 31-35, 346

housing investment, 3

labor productivity, 57

lending rates, 85

nonperforming loans, 80

private investment in, $11,11 f, 12,14,15,15 f$

private ownership of government bonds, 112

trade, 57, 58, 61, 70, 117

wages, 246

youth unemployment, 244, 249, 251, 252-254

youth unemployment and, $253 \mathrm{~b}$

Stability and Growth Pact, ix, 200

current compliance with requirements of, 143

in European Union fiscal governance, 139, $140 f$

fiscal consolidation under, xi, 139

fiscal regimes, $140-141$

order of prevalence between rules of, 140

output effects of fiscal consolidation under,

139-140

projected structural balance improvements, 141

purpose, 139

Stock market, quantitative easing and, 115, $115 f$

Stressed economies

bank holdings of government debt, $113 f, 132$

bank issuance, $79 f$

borrowing patterns, $82 f$

credit default swaps, $81 f$, $200 f$

current account balances, 49

deposit flows, $123 f$

financial sector risks and challenges, 80

foreign asset positions, $71 f$ interest rate divergence from core, $\mathrm{x}, 12,75,78$, 109

investment patterns, 3

lending rates, $8 f, 77 f, 79 f, 84,85,120,137$

monetary transmission mechanism breakdown

in, $81-83$

unit labor costs, $53 f$

Subnational fiscal governance, 201, 201f, $202 b$

Supervision, ix, 176b, 177, 177b, 187-189

Surveillance, $v, 162$

Systemic risk, 185b, 189-191, 210

T

TARGET2, 173, 178f, 185b, 204, 211

Tax wedge, youth unemployment and, 245-247, $246 f$

Trade openness and elasticity, 117, $117 f$

Transparency and accountability, 206

ECB, 107, 133

Treaty on European Union, 151

Treaty on Stability, Coordination, and Governance, 151,173

Treaty on the Functioning of the European Union, 151,167

True Sale International GmbH, 229

Two-Pack legislation, 139, 140f, 151, 195, 196b, 207

U

Unemployment, youth access to vocational training and, 250-251 active labor market policies and, 251, 252-254, $252 f$

business cycle effects, 241-243, 244, 244f, 252-253

collective bargaining incidence and, 244-245, 249-250, $250 f$

determinants of, xii, 239, 240-241

future challenges, ix, xii

growth and, 252, 2536

hiring costs and, 245-247, 252

hiring costs as factor in, 244

labor market duality and, 248-249, 248f, $249 f$

labor market features and, 244-245, 245f, $254 f$

opportunity costs of working and, 244, 247-248

postcrisis patterns and trends, 239-240, $240 f$

replacement rate, $247,247 f$

sectoral differences, $242,242 f$

in small and medium-sized enterprises, 241, 243,

2436

strategies for reducing, xii, 252-254

temporary work contracts, 250-251, $251 f$

unemployment benefits and, 247-248

variation within euro area, 239-240, 240f, 241,

252 
Unemployment insurance, 208-209, 247-248

Unions, 249-250, $250 f$

United Kingdom

loans to private sector, $124 f$

private debt in, 27-28, $28 f$

public debt securities, 112

quantitative easing program, xi, 117

United States

corporate financing, 219

household deleveraging, 39

loans to private sector, $124 f$

loan support for small and medium enterprises, 233

postcrisis credit market, 122

postcrisis investment trends, 3, $6 f$

private debt in, 27-28, $28 f$

public debt securities, 112

quantitative easing program, xi, 117

resolution of subnational economic crises, $202 b$ risk sharing in, $204 f$

securitization market, 223

Unit labor costs

contributions to changes in, $56 f$

postcrisis patterns and trends, 51, 53f, 54-55b,

$55-57,57 f, 59$

real effective exchange rate based on, 50

V

Venture capital, 221

Vocational training, 250

W

Wages

collective bargaining impact, 249-250

postcrisis patterns and trends, 55, $55 f$

rigidities in euro area, 197-198

youth unemployment and, 245-246, $246 f$ 
The euro area has experienced an unprecedented economic downturn and exceptional financial market turmoil in the past few years. These events threw into sharp relief underlying structural weaknesses that were masked by the earlier benign economic and financial environment.

Policymakers in Brussels, Frankfurt, and national capitals faced enormous challenges. Not only did they face the conventional task of smoothing the business cycle, but the much less conventional assignment of fixing the architecture of the currency union.

The IMF remained deeply engaged with euro area policymakers throughout this time. This book focuses on the analytical underpinnings of Fund policy advice during four cycles of the IMF's annual Article IV consultations (2012-15) with euro area authorities. It examines the legacies of the crisis and discusses the role of macroeconomic policies in supporting the recovery and the importance of completing the Economic and Monetary Union architecture.

The International Monetary Fund (IMF) is an organization of 188 countries working to foster global monetary cooperation, secure financial stability, facilitate international trade, promote high employment and sustainable economic growth, and reduce poverty around the world.

The Mechanics of a Strong Euro Area: IMF Policy Analysis

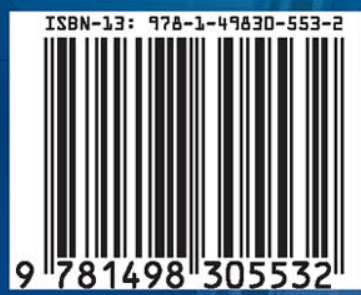

